\title{
O GRUPO CAMAQUÃ \\ (TRANSIÇÃO PROTEROZÓICO-FANEROZÓICO) NA REGIĀO DAS MINAS DO CAMAQUÃ, RS: ANÁLISE ESTRATIGRÁFICA DE FÁCIES, PROVENIÊNCIA E PALEOCORRENTES
}

Gelson Luís Fambrini

Orientador: Prof. Dr. Antonio Romalino Santos Fragoso Cesar

DISSERTAÇÃO DE MESTRADO

Programa de Pós-Graduação em Geoquímica e Geotectônica 


\section{UNIVERSIDADE DE SÃO PAULO INSTITUTO DE GEOCIENNCIAS}

\section{O GRUPO CAMAQUÃ (TRANSIÇÃO PROTEROZÓICO-FANEROZÓICO) NA REGIÃO DAS MINAS DO CAMAQUÃ, RS: ANÁLISE ESTRATIGRÁFICA DE FÁCIES, PROVENIÊNCIA E PALEOCORRENTES}

\section{GELSON LUÍS FAMBRINI}

Orientador: Prof. Dr. Antonio Romalino Santos Fragoso Cesar

DISSERTAÇÃO DE MESTRADO

COMISSÃO JULGADORA

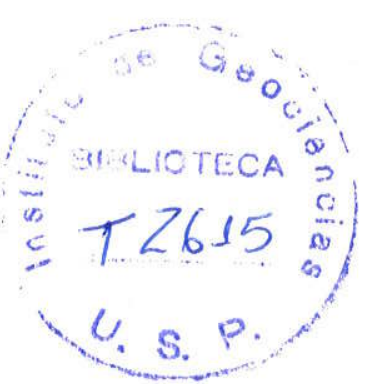

Nome

Assinatura

Presidente: Prof. Dr. Antonio Romalino S. F. Cesar

Examinadores: Prof. Dr. Claudio Riccomini

Prof. Dr. Paulo Sergio Gomes Paim

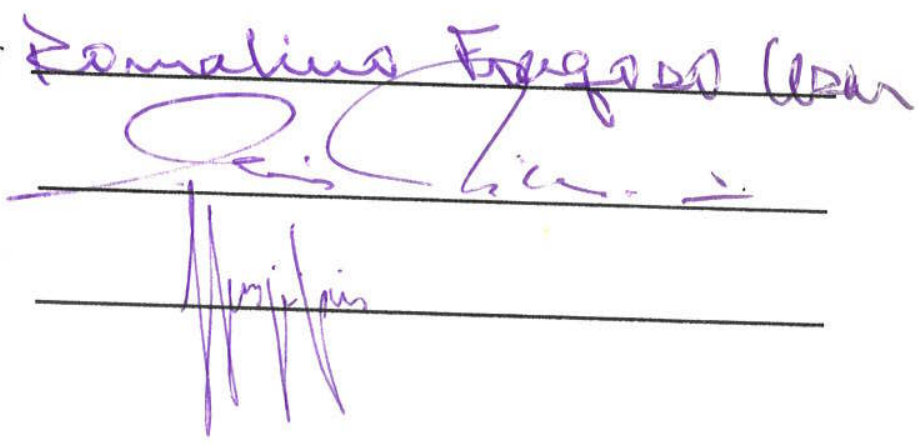




\title{
UNIVERSIDADE DE SÃO PAULO INSTITUTO DE GEOCIÊNCIAS
}

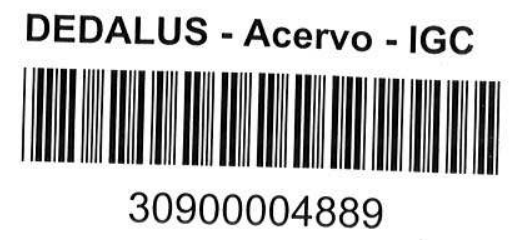

\section{O GRUPO CAMAQUÃ (TRANSIÇÃO PROTEROZÓICO- FANEROZÓICO) NA REGIÃO DAS MINAS DO CAMAQUÃ, RS: ANÁLISE ESTRATIGRÁFICA DE FÁCIES, PROVENIÊNCIA E PALEOCORRENTES}

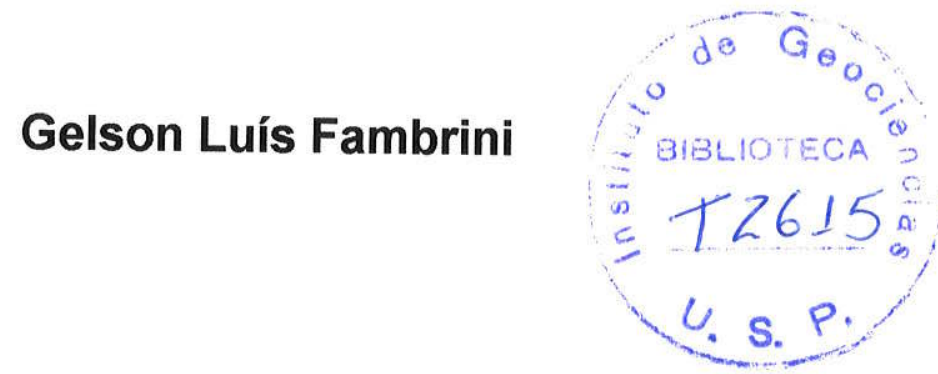

Orientador: Prof. Dr. Antonio Romalino Santos Fragoso Cesar

\author{
DISSERTAÇÃO DE MESTRADO
}

Programa de Pós-Graduação em Geoquímica e Geotectônica

SÃO PAULO

1998 


\section{UNIVERSIDADE DE SÃO PAULO INSTITUTO DE GEOCIÊNCIAS}

\section{O GRUPO CAMAQUÃ (TRANSIÇÃO PROTEROZÓICO- FANEROZÓICO) NA REGIÃO DAS MINAS DO CAMAQUÃ, RS: ANÁLISE ESTRATIGRÁFICA DE FÁCIES, PROVENIÊNCIA E PALEOCORRENTES}

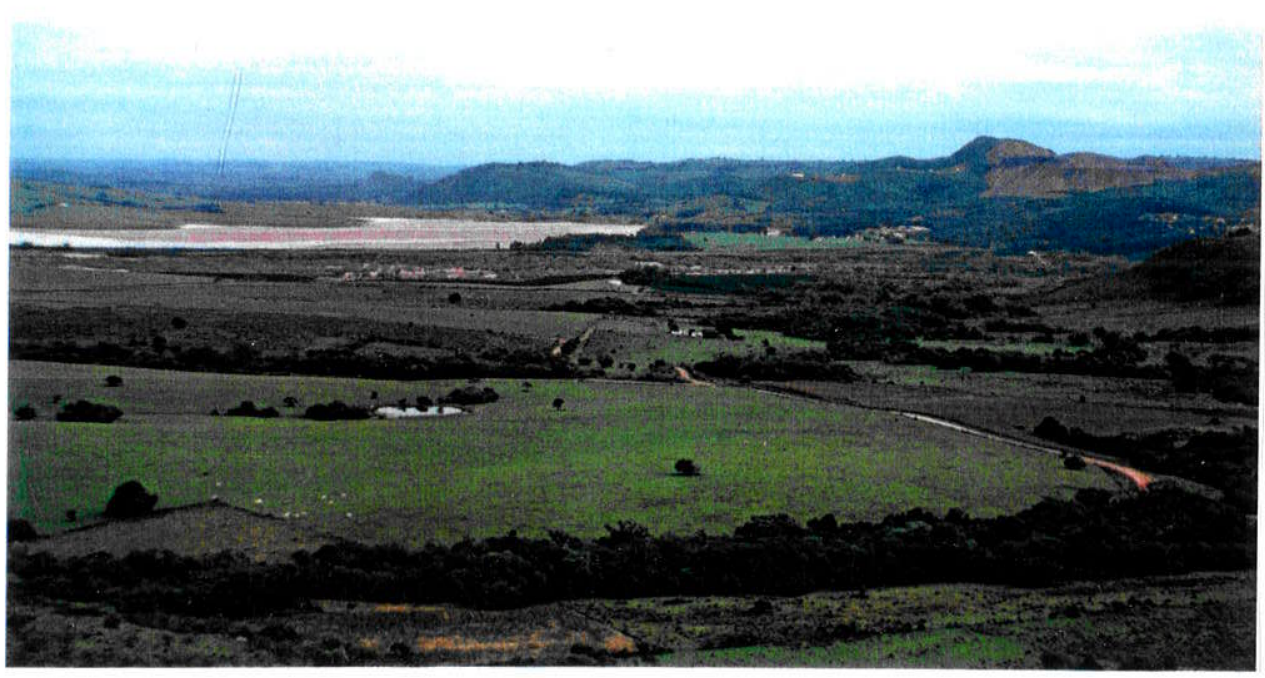

Gelson Luís Fambrini

Orientador: Prof. Dr. Antonio Romalino Santos Fragoso Cesar

\section{DISSERTAÇÃO DE MESTRADO}

Programa de Pós-Graduação em Geoquímica e Geotectônica 
À memória de meu avô materno, Paulo Jorge Küchler (1913-1983), que me estimulou na busca pelo conhecimento e pela curiosidade cientifica 


\section{RESUMO}

O objetivo principal deste estudo foi a análise estratigráfica do Grupo Camaquã (transição Proterozóico-Fanerozóico) através de análises litofaciológicas, de paleocorrentes, petrográficas, de proveniência e de ambientes de sedimentação na região das Minas do Camaquã, na porção sudeste do estado do Rio Grande do Sul. O Grupo Camaquã preenche a Bacia do Camaquã, feição tectônica que cobre o Escudo Gaúcho. O Escudo Gaúcho, que se estende para o Uruguai, é caracterizado como uma colagem de terrenos suspeitos, sendo que os depósitos da Bacia do Camaquã situam-se preferencialmente ao longo dos limites destes terrenos condicionados à instalação e reativação de zonas de cisalhamento NE-SW.

Considerando a movimentação tectônica dos terrenos em relação ao Cráton Rio de La Plata, dois grupos são identificados: (1) terrenos transportados de oeste (terrenos Rio Vacacai e Valentines), refletindo o fechamento de um oceano proterozóico ocidental - Oceano Charrua -, e (2) terrenos transportados de sul (terrenos Tijucas, Cerro da Árvore, Serra dos Pereira, Encruzilhada, Pelotas e Rocha), possivelmente relacionados ao fechamento do Oceano Adamastor. As unidades destes terrenos e de suas coberturas anteriores à instalação do Grupo Camaquã serviram de áreas fontes.

Embora controvertida quanto às denominações formais, a estratigrafia na área de estudos pôde ser separada em três conjuntos: inferior, médio e superior, correlacionados à litoestratigrafia do Grupo Camaquã como um todo: (i) inferior (CI) formado por ritmitos psamo-pelíticos (depósitos de turbiditos, tempestitos e inunditos caracterizando corpo aquoso marinho da Formação Mangueirão; (ii) médio (CM) constituído por depósitos rudáceos de fan deltas da Formação Vargas, progradantes sobre a unidade subjacente e (iii) superior (CS) transicional (marinha a flúvio-deltaica) da Formação João Dias. A aplicação do conceito de fácies à área de estudos possibilitou individualizar associações de fácies que registram o empilhamento estratigráfico em cada formação, sendo equiparáveis à classificação de membros na litoestratigrafia formal.

A Formação Mangueirão foi dividida em cinco associações de fácies compreendendo $2000 \mathrm{~m}$ de espessura: (i) CI1 representada por depósitos de turbiditos essencialmente arenosos; (ii) CI2 constituída por depósitos rudáceos de leques costeiros subaquáticos relacionados aos turbiditos; (iii) CI3 significando depósitos provavelmente de tempestitos; (iv) CI4 formada por depósitos de águas rasas (inunditos) definidos como uma planície de maré e (v) CI5 englobando já a porção subaérea do corpo aquoso representada por depósitos de frente deltaica. As paleocorrentes obtidas na Formação Mangueirão apresentam dispersão inicialmente para NNE na Associação CIl, indicando que a associação proveio de sul e sudoeste. Na Associação $\mathrm{Cl} 2$ as paleocorrentes indicaram que seus detritos vieram de sudoeste e, nas associações de fácies $\mathrm{Cl} 3, \mathrm{CI} 4$ e CI5, que os clastos provieram de sul. A análise dos fragmentos indica fontes no Terreno Valentines situado a SW.

A Formação Vargas compõe-se de três associações de fácies granocrescentes para o topo perfazendo espessura de cerca de $500 \mathrm{~m}$ : (i) CM1 formada por arenitos conglomeráticos e paraconglomerados de leques subaquáticos de fan deltas; (ii) CM2 composta de ortoconglomerados polimíticos de fácies canalizadas de depósitos de leques aluviais (sheet-flood e stream flow) e (iii) CM3, restrita à porção NE da unidade, formada de depósitos de brechas e conglomerados de leques aluviais proximais. $\mathrm{O}$ conjunto da Formação Vargas representa depósitos de fan deltas que colmataram o corpo aquoso da Formação Mangueirão.

As paleocorrentes obtidas na Formação Vargas indicaram (i) dispersão para N e NE na Associação $\mathrm{CM} 1$, indicando que as áreas fontes situar-se-iam a S e SW da região das Minas do Camaquã. Atualmente, a sul e a sudoeste da área de estudos encontra-se o Terreno Valentines; (ii) a Associação CM2 refletiu paleotransporte para NW revelando áreas fontes a S e, principalmente, SSE.

A análise de proveniência na Associação CM1 sugere fontes no Terreno Valentines (coberturas vulcano-sedimentares do Grupo Crespos e leucogranitos róseos de textura rapakivi no Uruguai), mas também do Terreno Rio Vacacai, que exibe as mesmas associações de rochas. A análise de proveniência na Associação CM2 sugere fontes no Terreno Valentines, mas principalmente, no Terreno Serra das Encantadas a SSE, comprovada pelo domínio de clastos de milonitos e mármores relacionados a este terreno presentes no topo da
associação.

A Formação João Dias engloba três associações de fácies perfazendo espessura de cerca de $1500 \mathrm{~m}$ : (i) CS1 formada por arenitos finos com estratificações hummocky de paleoambiente provavelmente marinho; (ii) CS2 constituída de arenitos médios de planície deltaica e CS3 de arenitos médios e grossos fluviais, estas compondo um sistema flúvio-deltaico.

$\mathrm{Na}$ Formação João Dias as poucas medidas de paleocorrentes obtidas indicaram fontes a SW representadas possivelmente pelo Terreno Valentines. 


\section{ABSTRACT}

The main aim of this study was stratigraphic analysis of the Camaquã Group at the ProterozoicPhanerozoic transition using petrographic, facies, paleocurrent, provenance and sedimentary environment analyses of the Camaquã Mines region in the southeastern part of the State of Rio Grande do Sul. The Camaquã Group filled the Camaquã basin, an important tectonic feature of the Gaucho Shield. This shield, which extends into Uruguay, is the result of amalgamation of suspect terranes, while the deposits of the Camaquã basin are preferentially located along the terrane limits which are the result of installation and reactivation of NE-SW oriented shear zones.

Two groups of terranes are separated according to their moviment relative to the Rio de La Plata craton: (1) the Vacacai and Valentines terranes which were transported eastwards during the closing of the (eastern) Charrua Ocean; and (2) the Tijucas, Cerro da Árvore, Serra dos Pereira, Encruzilhada, Pelotas and Rocha terranes, transported northwards, possibly during the closing of the Adamastor Ocean. Units of these
terranes and cover rocks older than the Camaquã Group were source areas.

Although there is controversy concerning formal definitions, the stratigraphy of the studied area can be separated into lower, middle, and upper units which are correlated to the global lithostratigraphy of the Camaquã Group. The lower group (CI) is composed of psammo-pelithic rhythmites which include turbidites, tempestites and inundites formed in the marine body of the Mangueirão Formation. The middle group (CM) is The upper group delta rudaceous deposits of the Vargas Formation which prograde over the earlier group. Application of (CS) is the João Dias Formation which is transitional between marine and fluvial-deltaic. sucession in each facies concept allowed the separation of facies associations which define the stratigraphic of $2000 \mathrm{~m}$

are equivalent fo the members classified in formal lithostratigraphy.

(1) CI1 - essentially arenaceous turbidites

(2) CI2 - rudaceous deposits of subaqueous coastal fans related to the turbidites

(3) CI3 - possible tempestites

(4) CI4 - shallow water inundites of tidal plains

(5) CI5 - the subaerial part of a delta front

Paleocurrent analysis showed NNE-wards dispersion in CIl, indicating provenance from the south and southwest. In $\mathrm{Cl} 2$ the paleocurrents are from the southwest, while in the remaining facies associations they were from the south. Fragment analyses shows that the source area was in the Valentines terrane. about $500 \mathrm{~m}$ :

Three upward-coarsening facies associations comprise the Vargas Formation with a total thickness of

(1) CMl - conglomeratic arenites and paraconglomerates of submarine fans formed in fan deltas

(2) CM2 - polymict orthoconglomerates of the channel facies (sheet flood and stream flow) deposits of
alluvial fans northeastern part of the unit

The Vargas Formation as a whole represents fan deltas which filled the water body of the Mangueirão Formation. Paleocurrents show northwards to northeastwards dispersion in CM1, suggesting that the source areas were southwards and southwestwards of the Camaquã Mines region where the Valentines terrane is presently situated. Northwestwards transport was found in CM2, with sources to the south and, principally, to the south-southeast. CM3 indicates some data showing transport to the southwestwards.

Provenance analysis for CM1 revealed not only the Valentines terrane, including volcanosedimentary cover rocks of the Crespos Group and rapakivi-textured leucogranites from Uruguay, but probably also the Rio Vacacai terrane, which has similar rock associations. Sources of CM2 are also in the Valentines terrane,

but also in the Serra das Encantadas terrane to the south-southeast, as show by the predominance at the top of
the association of clasts of mylonites and marbles derived from this terrane. associations:

(1) CS1 - fine hummocky cross stratified arenites of marine association

(2) CS2 - fine to medium arenites of delta plain and

(3) CS3 - fine to pebbly coarse arenites of fluvial system

The few paleocurrent measurements indicated sources to the southwest, possibly in the Valentines terrane. 


\section{AGRADECIMENTOS}

Para a concecução deste trabalho várias pessoas e entidades participaram efetivamente, as quais sou imensamente grato. Gostaria de expressar meus sinceros agradecimentos nomeando as principais.

Ao Prof. Dr. Antonio Romalino Santos Fragoso Cesar, meu orientador, que me abriu as portas do Rio Grande do Sul e sempre incentivou a atuação na pesquisa. Pela paciência e dedicada atenção nos momentos derradeiros, pela orientação correta, pelo apoio e companheirismo e pelas valiosas sugestões ao trabalho, expresso meus protestos de estima e consideração. Muito obrigado, mestre Roma!

Outra pessoa tem sido fundamental nesses anos, Prof. Dr. Rômulo Machado (DGG), pelo apoio, companheirismo, por ter sido co-orientador em muitos aspectos e por ter sido orientador já na Iniciação Cientifica, quero externar meus sinceros agradecimentos. Valeu.

Ao Prof. Dr. Claudio Riccomini (DPE) pelos valiosos ensinamentos nesses longos anos desde a graduação e a quem devo a escolha da área de Geologia Sedimentar na qual finalizo este trabalho.

Uma das pessoas que mais auxiliaram neste trabalho, seja nos trabalhos de campo, ou nos laboratórios, ou ainda em discussões, ou na cessão de fotos e figuras, foi o colega e amigo, grande parceiro, Prof. Msc. Wellington Ferreira da Silva Filho (UFC), a quem sou profundamente grato. Aos amigos geólogos Heitor Siqueira Sayeg e Prof. Msc. Fernando Machado de Mello (UFRRJ) agradeço as sugestões propostas e aos quais devo a oportunidade do convite de trabalhar nas bacias "eopaleozóicas" do RS já em 1990, onde tudo se iniciou. Ao Heitor sou grato, ainda, pela ajuda no campo e na confecção de algumas das imagens digitais TM-Landsat utilizadas neste trabalho, e também pela revisão crítica do texto e por fotos cedidas. Aos colegas geólogos e amigos de longas jornadas desde a graduação Marco Aurélio Bonfá Martin (o Agrô), Alexandre Patrício Chiarini (Chapinha) e Tadeu R. Godoy Pereira (Gaúcho) pelo prestimoso auxílio nos trabalhos de campo e pelas discussões posteriores. Ao Agrô, sou especialmente grato, ainda, pela inestimável ajuda na finalização do mapa geológico no AutoCad 14. Valeu mesmo, amigão!

Ao Prof. Dr. Teodoro Isnard Ribeiro de Almeida (DGE) que colaborou imensamente para a orientação no tratamento digital de imagens TM-Landsat, base para a cartografia dos mapas e na leitura crítica do capítulo a esse tema destinado, sou muito grato. Grande Teco!

Quero agradecer o colega e amigo Prof. Dr. Jorge Hachiro (LENEP/UENF) pela inestimável colaboração na leitura crítica do capítulo de geologia da área estudada.

Não fosse o imprescindível socorro de meu amigo Marlei Antonio C. Chamani, o Trilô, muitas das figuras que ilustram a dissertação não estariam a contento. Pelo companheirismo nesses longos anos (de muitas cervejas!) e, sobretudo, pelos profundos conhecimentos de Corel, eu o agradeço ternamente.

Os mapas se devem ao trabalho de Isabel A. A. Santos (Panzer). Sem o providencial auxílio do Prof. Dr. Caetano Juliani (DMP) cedendo o microcomputador de uso próprio de sua sala o mapa geológico não teria ficado pronto. Por esse gesto e por todos esses anos meu muito obrigado. 
Aos colegas e amigos do Curso de Pós-Graduação do IGc-USP que colaboraram sejam em frutíferas discussões, ou apenas acompanhando o autor nos momentos de relaxamento no happy-hour, em especial Luiz Antonio Teixeira, Mauro Cesar Geraldes, Ana Lúcia D. Gesicki, Renata P. X. Moro, Prof. Dr. Paulo Cesar Boggiani (UFMS), Sérgio L. F. de Matos, Francisco William da Cruz Jr., Fernando Laureano, Alexandre Magno Feitosa Sales, Prof. Msc. André Ferrari (UERJ), Nolan Maia Dehler, Irena Sparrenberger, Maria da Glória Motta Garcia, Prof. Msc. Egberto Pereira (UFRJ), William Salun Filho, Werner Weber, bem como o Prof. Msc. Gerson S. Saes (UFMT) pelo auxílio com seus conhecimentos sólidos de estratigrafia nos trabalhos de campo.

Ao mais novo membro de nossa equipe, o amigo Renato Paes de Almeida (o Ninguém), quero agradecer a gentileza da leitura crítica e consistente do capítulo de geologia e pelas sugestões formuladas.

Gostaria de expressar meus profundos agradecimentos à Companhia Brasileira do Cobre (CBC), cujo apoio logístico, na forma de acesso às dependências da Companhia, auxílio para os trabalhos de campo, cessão de mapas e consulta de relatórios internos, mostrou-se de fundamental importância na execução e desenvolvimento deste trabalho, em especial nas figuras de seu presidente Dr. Enrique Anawate e dos diretores José Luis Reischl e Nílson Torres Dornelles, dos geólogos Gilson Teixeira e Júlio Gros, e da tema e incansável Dona Betinha, uma verdadeira mãe, bem como a toda população da região das Minas do Camaquã pela calorosa recepção e companheirismo despendidos. Sem tal apoio, esta dissertação não teria chegado ao seu final. Sou particularmente grato também à Prefeitura do Município de Caçapava do Sul pelo apoio logístico para os trabalhos de campo nas pessoas do atual prefeito Sr. José Erli Pereira Vargas e do secretário de Coordenação e Planejamento Sr. Ibucaçara Rosa de Miranda.

À UNISINOS através do Centro de Estudos Avançados de Caçapava do Sul nas pessoas dos coordenadores Profs. Drs. Antonio Jorge Vasconcelos Garcia, Heraldo Campos e Henrique C. Fensterseifer. Agradeço as agências financiadoras FAPESP (Processo Geologia 93/03228-7) e CNPq pelo auxílio financeiro aos trabalhos de campo e pela bolsa de pesquisa concedidos, respectivamente.

Aos professores e funcionários do IGc-USP que colaboraram em várias etapas deste trabalho: Profs. Drs. Ian McReath (DGG), Thomas R. Fairchild e Paulo R. dos Santos (DPE), Jorge Silva Bettencourt (DGE), os funcionários Claudio Hopp (laminação), Dalton M. da Silva, Edemir de Oliveira, Claudionor Barbosa, José Neto e Henrique Martins (gráfica), Rita Parisi Conde e Márcia C. da Ponte, Maria Aparecida Bezerra (Biblioteca) e às incansáveis secretárias do DGG Nícia M. Brandão Zalaf e Sônia Gomes C. Vieira.

À coordenação do Curso de Pós-Graduação em Geoquímica e Geotectônica (DGG), nas pessoas dos profs. Dr. Rômulo Machado, Dra. Maria Cristina Motta de Toledo (ex-coordenadores) e Dr. Marcos Egydio da Silva (atual), agradeço pelo apoio logístico e incentivos à finalização deste trabalho.

À minha querida Elaine agradeço a convivência nestes anos e a paciência e o amor dispensados nesses momentos finais muito estafantes. Dedico-lhe com todo o carinho este trabalho.

Por último, como não poderia deixar de ser, gostaria de expressar a minha gratidão à minha família, em especial na figura de minha incansável mãe, pela paciência com minha ansiedade e nos momentos de angústia quando o tempo parecia esvair-se como as águas da correnteza. 
"Os sedimentos da série Camaquam são interessantíssimos, tanto sob o ponto de vista genético como seu caráter parcialmente conglomerático. Um estudo detalhado dos seixos deste conglomerado devia dar grandes esclarecimentos à litologia da superficie post-algonquiana".

Viktor Leinz (1939), a respeito dos problemas geológicos da Série Camaquan 
I.1 Objetivos.

I.2 Localização e Vias de Acesso.

I.3 Aspectos fisiográficos da região.

\section{CAPÍTULO I.2 - MATERIAIS E MÉTODOS DE TRABALHO, REVISÃo} DE CONCEITOS

I.2.1 ETAPAS DE TRABALHO. 06

I.2.1.1 Trabalhos Prévios de Gabinete

I.2.1.2 Trabalhos de campo.

I.2.1.3 Trabalhos de laboratório e estatísticos.

I.2.1.4 Trabalhos finais de gabinete.

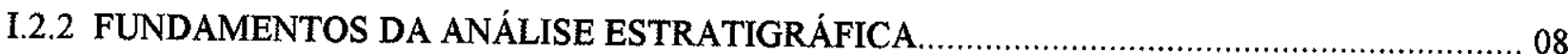

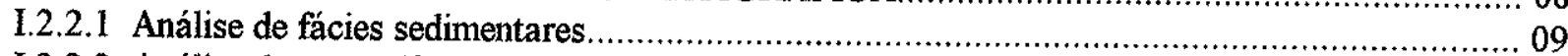

I.2.2.2 Análise de proveniência

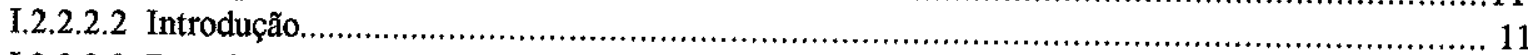

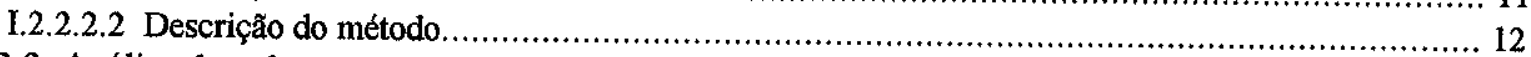

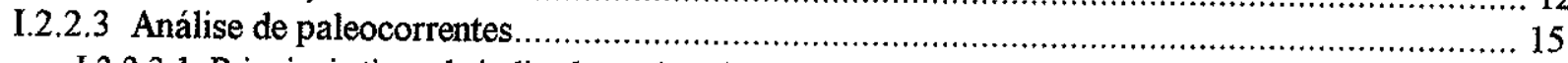

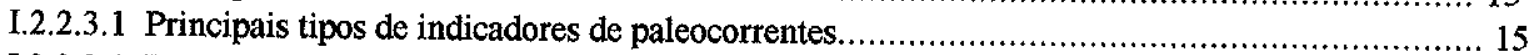

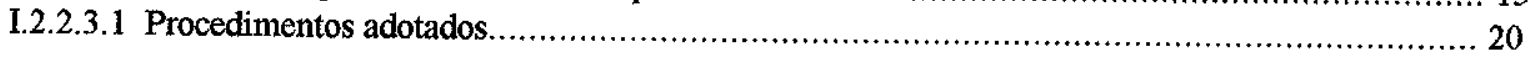

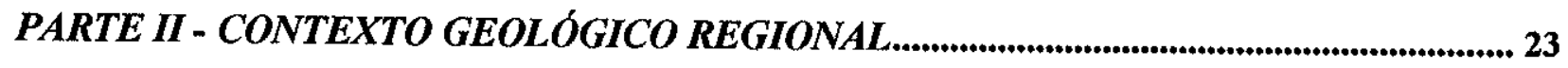

CAPÍTULO II.1 - O ESCUdO GAÚCHO NO RS E URUGUAI..................................................... 24

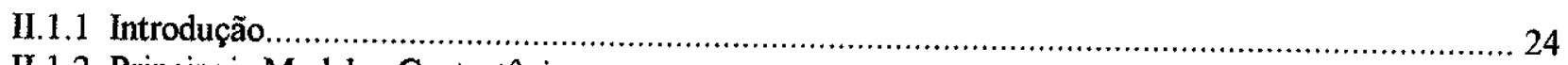

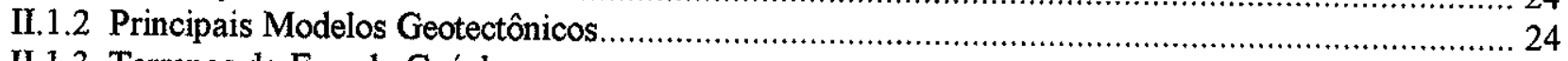

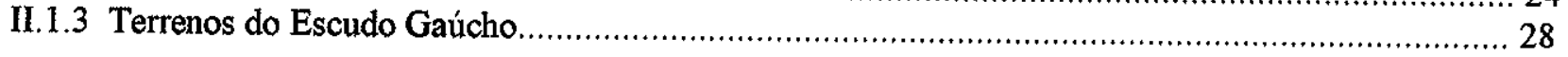

CAPÍTULO II.2 - EVOLUÇ̃̃O DOS CONHECIMENTOS SOBRE AS

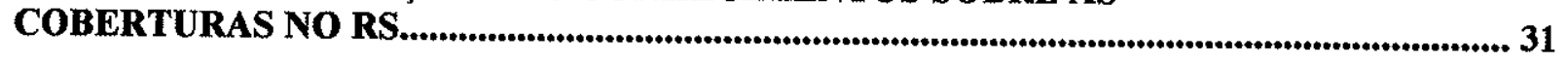

CAPÍTULO II.3 - ESTRATIGRAFIA DAS COBERTURAS.......................................................... 39

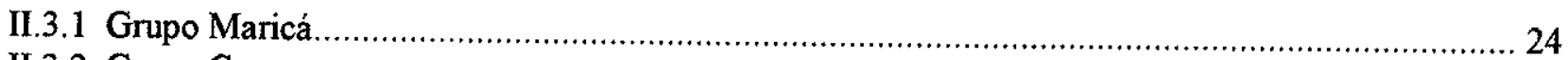

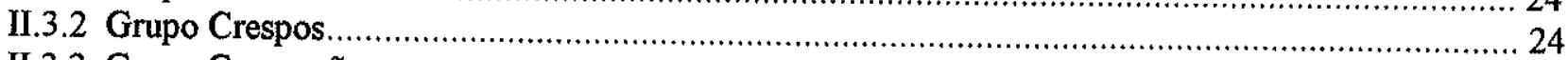

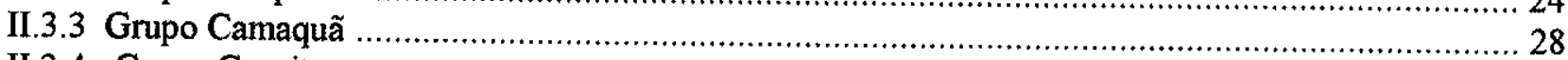

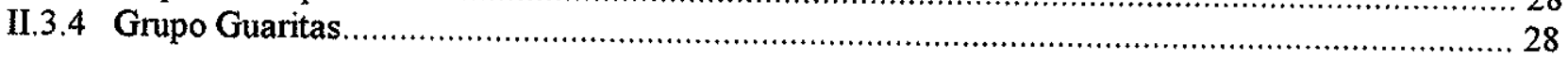

\section{PARTE III - O GRUPO CAMAQUÃ NA REGIAOO DAS MINAS DO} CAMAQUÃ.

CAPÍTULO III.1 - ESTRATIGRAFIA DA REGIÃO DAS MINAS DO CAMAQUÃ..................... 46

III.1.1 Introdução.

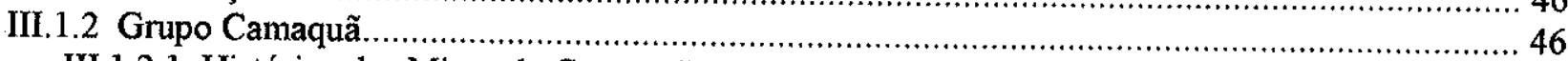

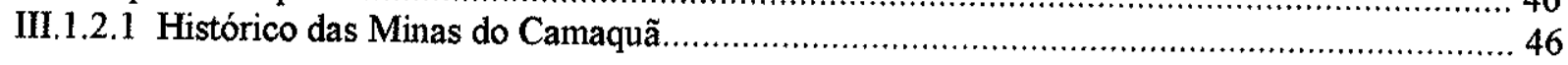


III.1.2.2 Trabalhos Anteriores na Região das Minas do Camaquã ............................................ 46

CAPÍTULO III.2 - ANÁLISE DE FÁCIES SEDIMENTARES....................................................... 50

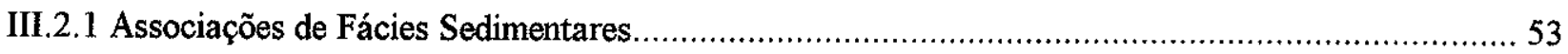

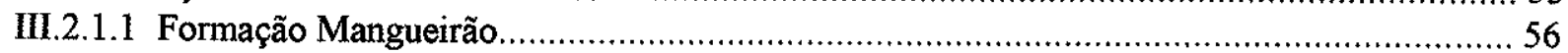

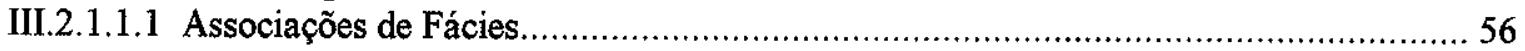

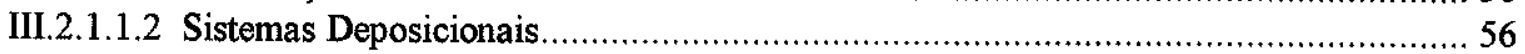

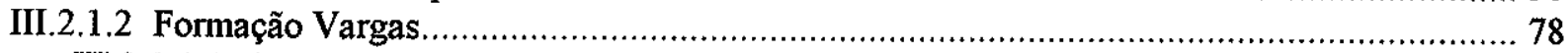

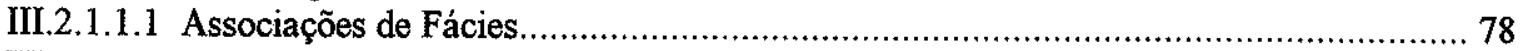

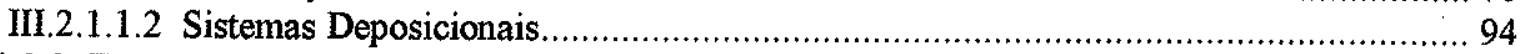

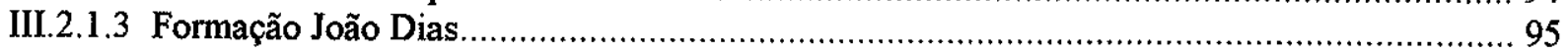

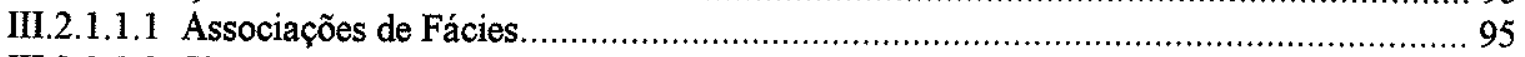

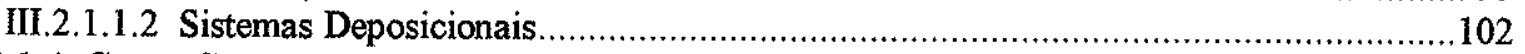

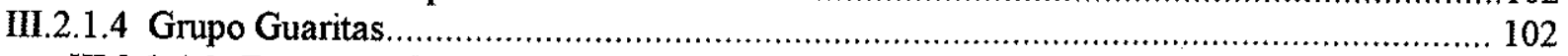

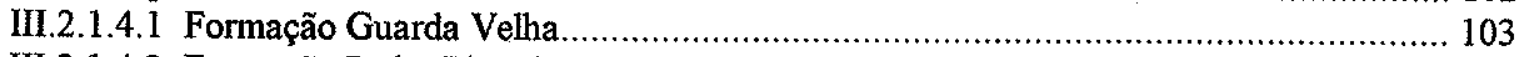

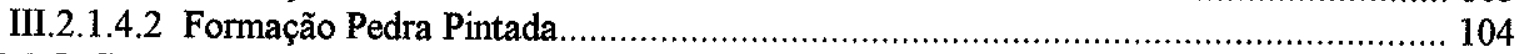

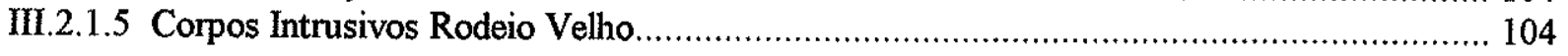

\section{CAPÍTULO III.3 - PROCESSAMENTO DIGITAL DE IMAGENS}

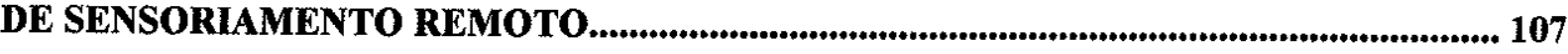

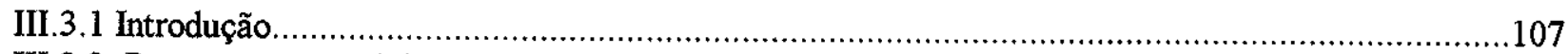

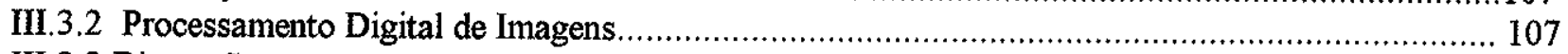

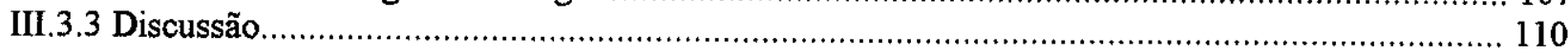

CAPÍTULO III.4 - ANÁLISE DE PALEOCORRENTES................................................................. 118

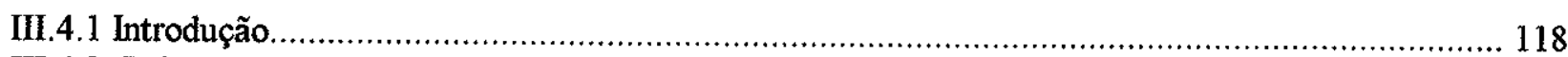

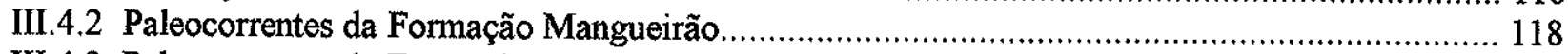

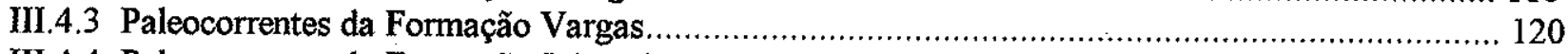

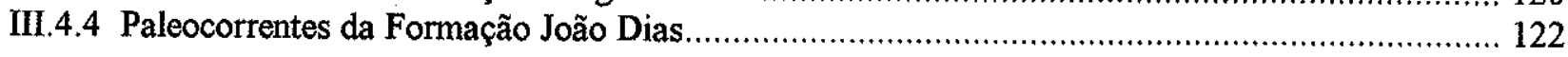

CAPÍTULO III.5 - ANÁLISE PETROGRÁFICA DO GRUPO CAMAQUÃ.................................... 124

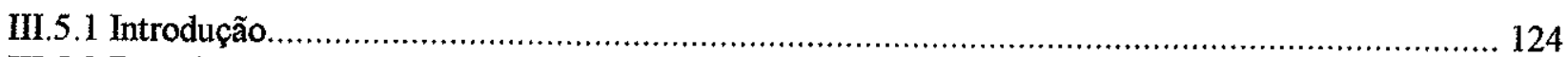

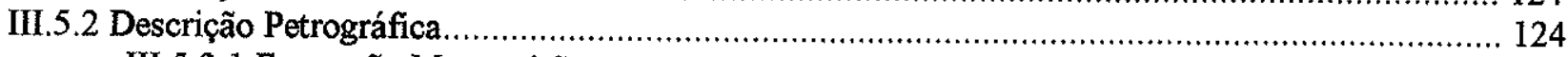

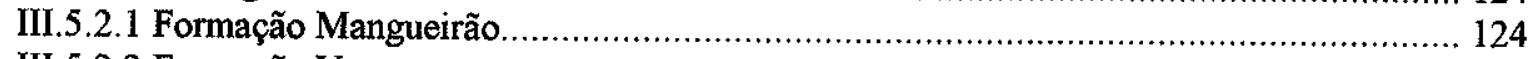

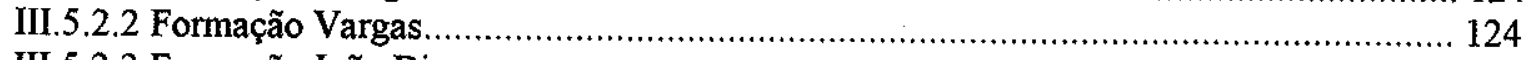

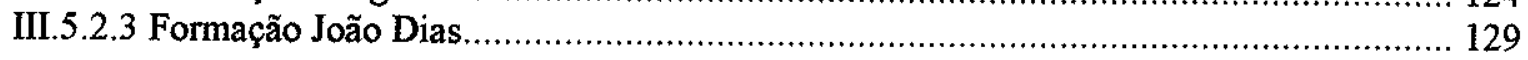

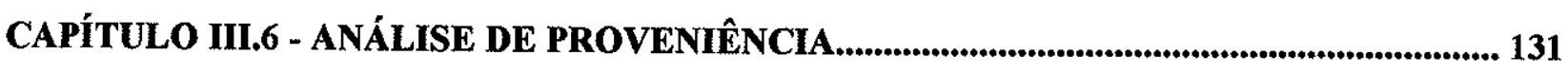

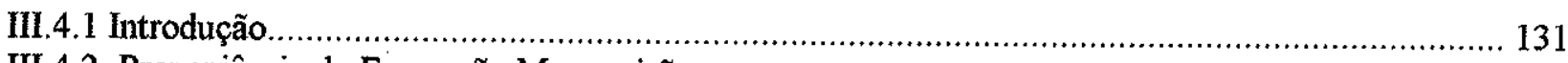

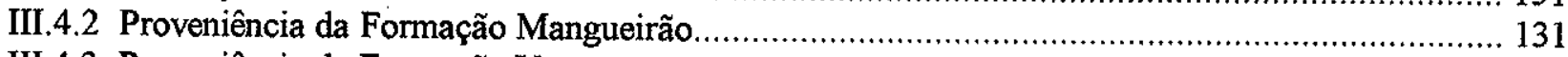

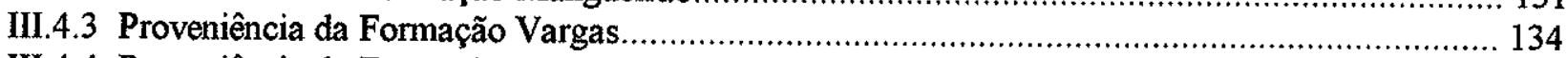

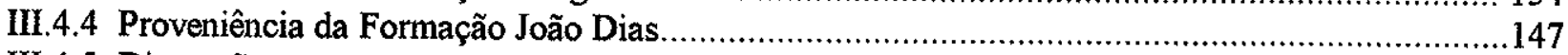

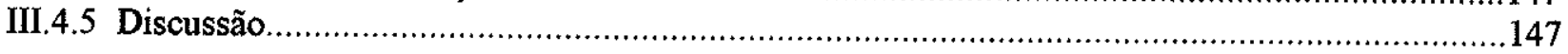

PARTE IV - CONSIDERAÇÕES FINAIS........................................................................ 149

IV.1 Evolução paleogeográfica da Bacia do Camaquã ........................................................... 150

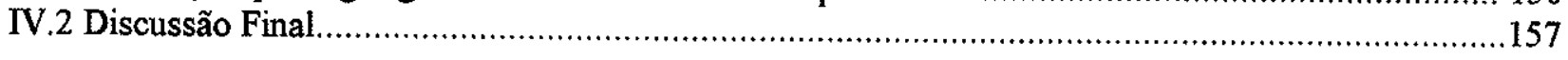

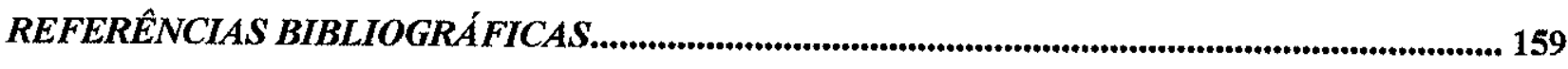




\section{LISTA DE FIGURAS}

\section{PARTE I}

I.1 - Localização da área de estudos.....

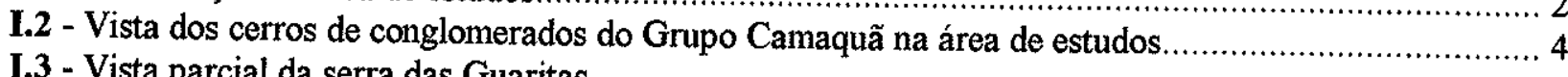

I.4 - Método de estimativa visual de va

45 - Blocos de clastos no campo................................................. 13

I.6 -

I.6 - Método de estimativa visual de volumes de clastos no campo ........................................................ 13

I.7 - Padrões de orientação preferencial de clastos em conglomerados.................................................... 18

I.8 - Modelo de comportamento de clastos durante o transporte por correntes fluviais.............................. 19

1.9 - Procedimentos para a correção de paleocorrentes em camadas basculadas........................................ 21

\section{PARTE II}

II.1 - Esquema de compartimentos tectônicos do Escudo Gaúcho. 2

II.2 - Mapa tectônico esquemático do Escudo Gaúcho com ênfase nos terrenos............................................ 29

II.3 - Mapa tectônico e geológico esquemático do Escudo Gaúcho no RS com destaque para as unidades de cobertura e os limites entre terrenos.

\section{PARTE III}

III.1 - Coluna estratigráfica do Grupo Camaquã na região das Minas do Camaquã

III.2 - Mapa geológico regional da porção central da Bacia do Camaquã.

III.3 - Seções geológicas do Grupo Camaquã.

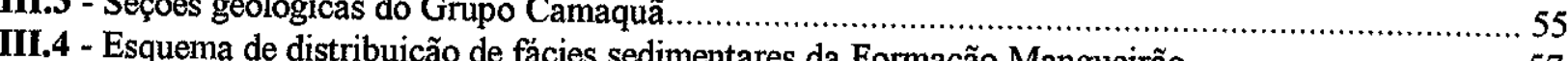

III.5 - Seção estratigráfica ḑão de fácies sedimentares da Formação Mangueirão .................................. 57

II.5 - Seção estratigráfica de detalhe da Associação CIl na localidade MC-37................................... 59

III.6 - Seção estratigráfica de detalhe da Associação CI1 na localidade MC-98......................................... 61

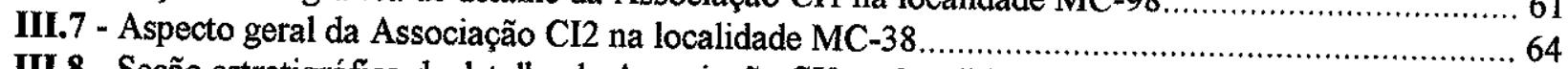

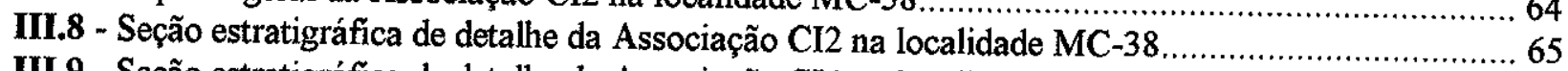

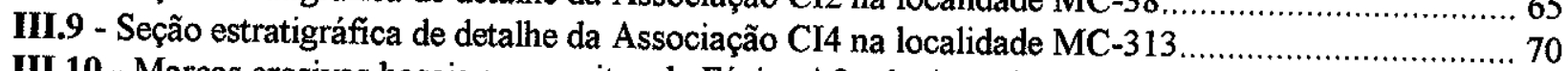

III.10 - Marcas erosivas basais em arenitos da Fácies Afm da Associação CI4 no local MC-124........... 72

III.11 - Estrutras sedimentares da Associação CI4 no local MC-124 ................................................ 73

III.12 - Arenitos sigmoidais (Fácies Ams) da Assoiação CI5 na localidade MC-145 ................................ 76

III.13 - Arenitos conglomeráticos da Assoiação CM1 na Mina Uruguai (local MC-40) ............................. 81

III.14 - Fendas de ressecação em argila na interface entre conglomerados da Associação CM1 ............... 81

III.15 - Estratificação cruzada em arenitos conglomeráticos da Fácies Aca da Associação CM1 .............. 82

III.16 - Conglomerados estratificados (Fácies Cp) da Associação CM1 ........................................... 82

111.17 - Aspecto geral da Associação CM2 no local MC-195 ............................................................... 84

III.18 - Seção estratigráfica de detalhe da Associação CM2 no local MC-195 ............................................ 85

III.19 - Fácies Aca da base da Associação CM2 no local MC-195...................................................... 86

III.20 - Vista parcial dos conglomerados da Associação CM2 na cava da Mina Uruguai (MC-40).......... 87

III.21 - Conglomerados estratificados da Fácies Cs da Associação CM2 (local MC-40) ....................... 88

III.22 - Visão da base do Cerro da Cruz (MC-44) salientando a passagem de CM1 para CM2 ................ 90

III.23 - Seção estratigráfica de detalhe da Associação CM2 no local MC-144 ..................................... 91

III.24 - Brechas da Associação CM3 no ponto MC-224 ................................................................. 92

III.25 - Detalhe do arcabouço da brecha da Associação CM3 no ponto MC-224 ….................................. 93

III.26 - Seção estratigráfica completa da Associação CS1 (Formação João Dias).......................................... 97

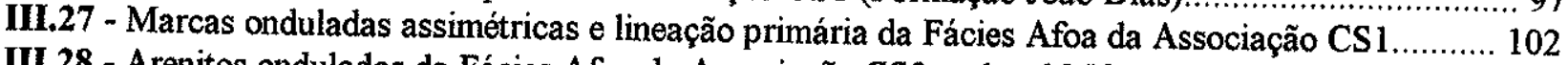

III.28 - Arenitos ondulados da Fácies Afoa da Associação CS3 no local MC-225 ............................. 102

III.29 - Nível de intraclastos da Fácies Afoa da Associação CS3 no local MC-272 ................................. 103

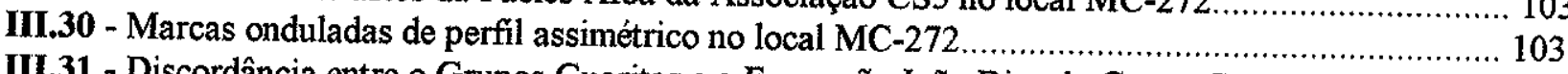

III.31 - Discordância entre o Grupos Guaritas e a Formação João Dias do Grupo Camaquã................... 105 
III.32 - Imagem Pci mostrando os padrões texturais da superficie da cena e lineamentos.

III.33 - Divisão entre as bandas TM4/TM3

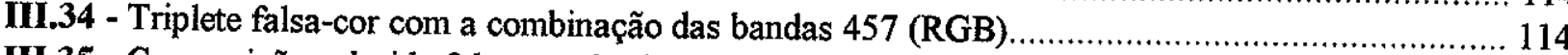

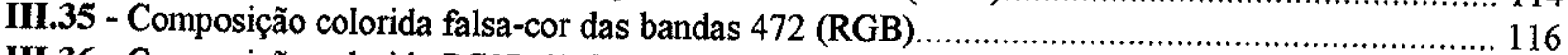

III.36 - Composição colorida PC1Pc2PC3 (RGB) por Análise por Principais Componentes.................. 117

III.37 - Diagramas de roseta com a dispersão de paleocorrentes da Formação Mangueirão.................... 119

III.38 - Diagramas de roseta mostrando padrão de paleocorrentes da Associação CI4 …..................... 120

III.39 - Diagramas de roseta mostrando padrão de paleocorrentes da Associação CM1 da Formação Vargas.

III.40 - Diagramas de roseta mostrando padrão de paleocorrentes da Associação CM2 da Formação Vargas.

III.41 - Diagramas de roseta mostrando padrão de paleocorrentes da Associação CM1 da Formação Vargas no local MC-195

III.42 - Diagramas de roseta mostrando padrão de paleocorrentes da Formação João Dias.

III.43 - Histogramas de freqüência de clastos da Associação CI2 da Formação Mangueirão

III.44 - Histogramas de freqüência de clastos da Associação CM1 da Formação Vargas no local MC-111....

III.45 - Histogramas de freqüência de clastos da Associação CM1 no local MC-40

III.46 - Histogramas de freqüência de clastos da Associação CM2 no local MC-40

III.47A - Matacão de rocha granitóide milonitizada

III.47B - Matacão de rocha pegmatóide.

III.48 - Histogramas de freqüência de clastos da base da Associação CM1 no local MC-40.

III.49 - Histogramas de frequiência de clastos da Associação CM2 no local MC-111.

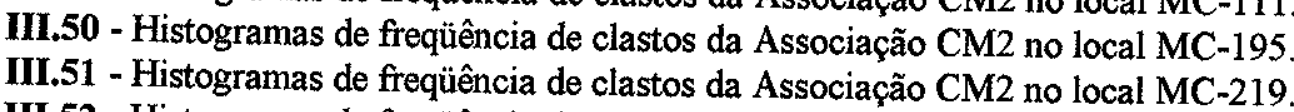

III.52 - Histogramas de frequiência de clastos da Associação CM2 no local MC-220.

III.53 - Histogramas de frequiência de clastos da Associação CM2 no local MC-392.

III.54 - Histogramas de freqüência de clastos da Associação CM2 nos locais MC-238, 239

III.55 - Histogramas de freqüência de clastos da Associação CM2 no local MC-244.

III.56 - Histogramas de freqüência de clastos da Associação CM2 no local MC-245.

III.57 - Histogramas de freqüência de clastos da Associação CM2 no local MC-269.

III.58 - Mapa de distribuição dos tamanhos máximos de clastos da Formação Vargas

\section{PARTE IV}

IV.1 - Esquema de evolução paleogeográfica do Grupo Camaquã na área de estudos

\section{LISTA DE TABELAS}

II.1 - Propostas estratigráficas para as coberturas do Escudo Gaúcho

III.2 - Fácies de psefitos do Grupo Camaquã.

III.3 - Fácies psamíticas do Grupo Camaquã.

III.4 - Fácies pelíticas do Grupo Camaquã

III.5 - Relação dos atributos do terreno das i.....................

III.6 - Médias aritméticas dos valores des imagens com as características fisiográficas .................... 108

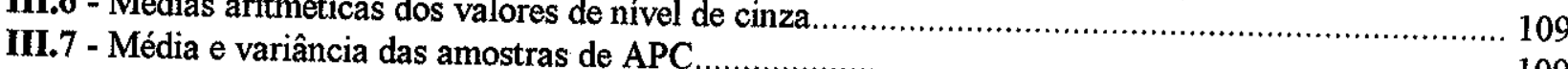

III.8 - Auto-vetores e auto-valores das PCs.

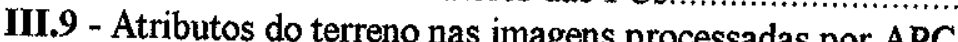

III.10 - Análise modal de 30 amostras do Grupo Camaquã

III.11 - Análise de proveniência da Aso

\section{LISTA DE QUADROS}

III.1 - Litoestratigrafia do Grupo Camaquã na região das Minas do Camaquã. 


\section{PARTE I}

\section{CONSIDERAÇÕES INICIAIS}


Os depósitos de cobertura da transição Neoproterozóico-Cambriano, particularmente bem expostos no Escudo Gaúcho no RS, têm sido objeto de interesse progressivamente maior de inúmeros pesquisadores desde os trabalhos clássicos de Carvalho $(1929,1932)$. Almeida $(1967,1969)$ atribuiu caráter "molássico" aos sedimentos, vinculando-os à erosão de uma cadeia de montanhas ao término do Ciclo Brasiliano. Esta interpretação sofreu profundas alterações ao longo das duas últimas décadas, porém a interpretação de sua origem por movimentações tectônicas tem sido preservada e ampliada. Dada sua posição cronológica e tectônica, representam possíveis remanescentes de uma outrora bacia (ou conjunto delas) que se estendia pelo Uruguai e pelos estados de RS, SC, PR e SP no Brasil, razão de sua importância científica.

Destes depósitos, estudamos aqueles aflorantes na região das Minas do Camaquã (RS), objeto de diversos estudos desde Paulino Franco de Carvalho (Leinz, 1939; Robertson, 1966; Ribeiro et al., 1966; Bettencourt, 1972; Ribeiro, 1978; Teixeira et al., 1978a, b; Gonzalez \& Teixeira, 1980; Fragoso Cesar et al., 1985; Lavina et al., 1985; Faccini et al., 1987; Paim et al., 1992), sendo localidade referencial de várias colunas litoestratigráficas, adiante discutidas. Destas, a mais recente, está sendo proposta por nossa equipe, sendo aqui adotada, onde na região é separada em dois grupos: Camaquã e Guaritas, além de intrusões de corpos ígneos tardios (Sills Máficos Rodeio Velho e Diques de Diabásio Serra Geral), tendo sido o primeiro - Grupo Camaquã - tema preferencial da presente dissertação.

\section{I.1 Objetivos}

Os objetivos deste trabalho foram conduzir investigações com base em dados estratigráficos, sedimentológicos, petrográficos, de sensoriamento remoto para o estudo geológico do Grupo Camaquã na região clássica das Minas do Camaquã. $O$ tema central foi o estudo da tectônica e sedimentação do Grupo Camaquã através de análises de fácies, proveniência e paleocorrentes com vistas a uma interpretação dos paleoambientes deposicionais.

\section{I.2 Localização e Vias de Acesso}

Os depósitos do Grupo Camaquã na região das Minas do Camaquã apresentam forma aproximadamente rombóide, com um espichamento para oeste (FIGURA I.1). A área de estudos localiza-se na porção central do Escudo Gaúcho no RS, entre os paralelos $30^{\circ} 50^{\prime} 88^{\prime \prime}$ e $31^{\circ} 00^{\prime} 00^{\prime \prime}$ de latitude sul e os 


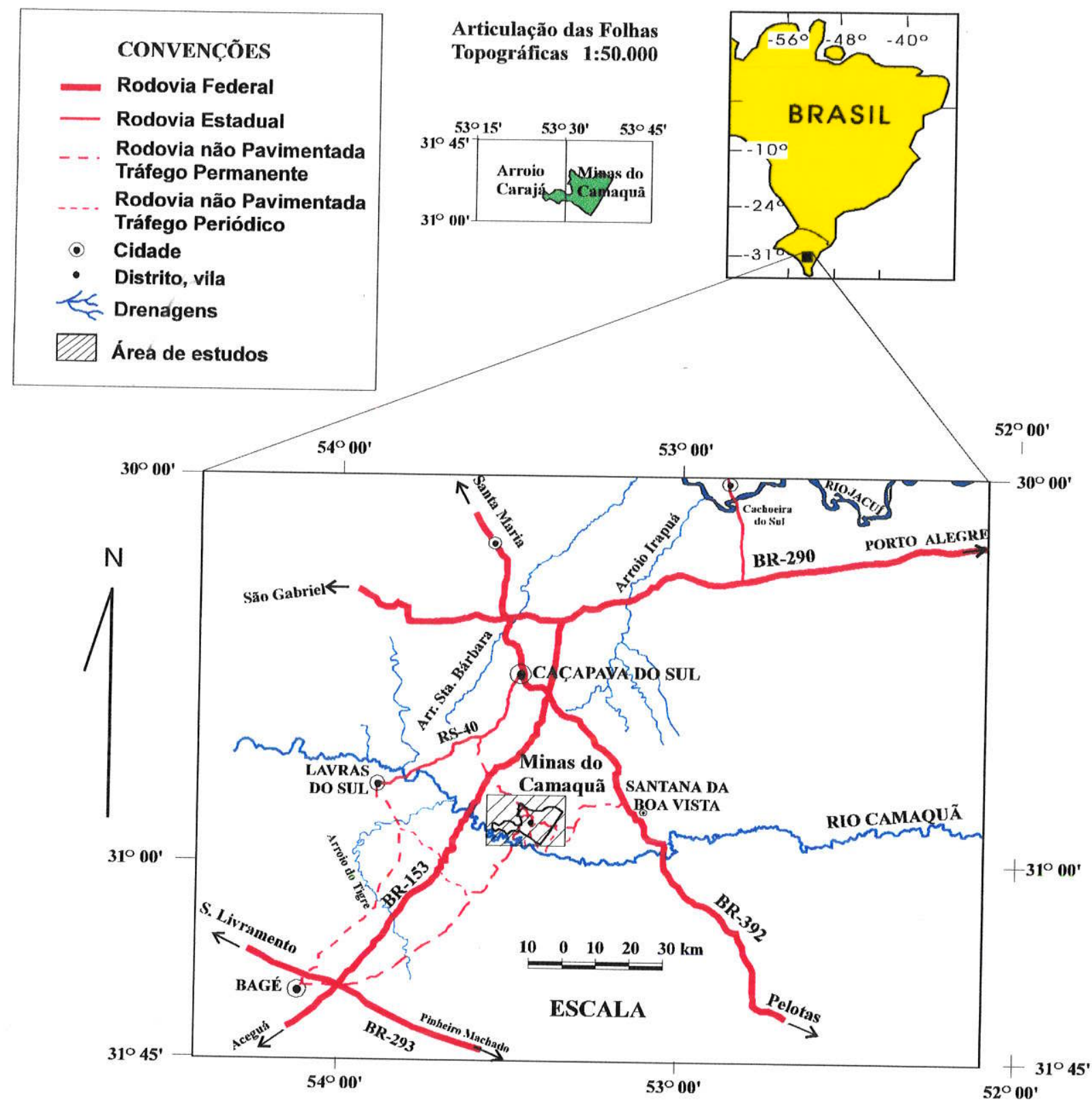

FigURA I.1- Localização da área de estudos e principais vias de acesso.

meridianos $53^{\circ} 40^{\prime} 44^{\prime \prime}$ e $53^{\circ} 20^{\prime} 29^{\prime \prime}$ de longitude oeste, situando-se na região limítrofe dos municípios de Caçapava do Sul, a oeste e norte, e de Santana da Boa Vista, a leste, separados pelo arroio João Dias que cruza a área de estudos de norte para sul desaguando nas águas do rio Camaquã. Circunscreve-se às folhas topográficas Minas do Camaquã (SH.22-Y-A-V-3) e Arroio Carajá (SH.22-Y-A-IV-4), editadas pela Diretoria de Serviço Geográfico do Ministério do Exército (DSG), na escala de 1:50.000. O acesso de Porto Alegre faz-se pela rodovia federal BR-290, da qual, a norte de Caçapava do Sul, pode-se optar pela BR-153, em direção a Bagé, ou pela BR-392, que conduz a Pelotas. Destas rodovias partem estradas 
vicinais com destino às Minas do Camaquã. Uma delas, a partir da BR-153 (região da Boa Vista) atravessa a porção norte da área de estudos. A outra, corta exposições do Grupo Guaritas atingindo a região pelo lado leste. Várias outras estradas cruzam a área de estudos, interligando-a a esses acessos principais.

\section{I.3 Aspectos Fisiográficos}

A exposição sul-riograndense do Escudo Gaúcho tem área de aproximadamente $50.000 \mathrm{~km}^{2} \mathrm{e}$ formato aproximadamente triangular, circunscrita a $\mathrm{N}, \mathrm{W}$ e $\mathrm{S}$ pela denominada Depressão Central composta pelo vale do Vacacai-Jacuí (Azevedo, 1980, p. 66) que precede o planalto sustentado pelas rochas basálticas da Bacia do Paraná (Formação Serra Geral) e, a leste, pela planície costeira (onde se situa a Lagoa dos Patos). O relevo de rochas pré-cambrianas é muito dissecado e engloba o Planalto Rebaixado Marginal (Projeto Radam, 1986).

A área de estudos possui topografia ligeiramente acidentada, com porções suavizadas (vale do Arroio João Dias), sobressaindo-se alguns altos controlados por falhamentos ou por erosão diferencial. As maiores cotas situam-se nos cerros de conglomerados do Alto Estrutural das Minas do Camaquã (Silva Filho, 1997), onde as altitudes máximas atingem $338 \mathrm{~m}$ (morro da cava a céu aberto da Mina Uruguai da $\mathrm{CBC}$ ) e $340 \mathrm{~m}$, no qual os sedimentos do Grupo Guaritas ocorrem em discordância angular e erosiva com os arenitos e conglomerados do Grupo Camaquã, formando monoclinal com caimento geral para NW. Cotas relativamente mais elevadas encontram-se no limite leste da área no topo de morros sustentados pelos arenitos do Grupo Guaritas e em morros suportados pelos conglomerados do Grupo Camaquã (FIGURA 1.2), bem como nas ocorrências dos Sills Máficos Rodeio Velho a S e ESE da área. Os segmentos mais rebaixados de relevo correspondem predominantemente às áreas de ocorrência dos ritmitos psamopelíticos do Grupo Camaquã.

A paisagem de relevo escarpado a noroeste, localmente denominada de serra das Guaritas, é esculpida em sucessões onde predominam os arenitos grossos e conglomerados fluviais do grupo homônimo, muito resistentes à erosão. Ressaltam-se nesta paisagem escarpas e encostas separadas por vales encaixados em fraturas e diáclases, donde o relevo reliquiar proporciona formas tabulares íngremes assemelhando-se a torres, origem do termo Guaritas (FIGURA I.3).

O padrão de drenagem é de alta densidade, com morfologia retilínea/ortogonal com angularidade média, bidirecional (NW-NE), com formas em cotovelo, bem evidente pelo entalhamento de vales encaixados em fraturas nos arenitos e conglomerados do Grupo Camaquã. Nas unidades psamo-pelíticas o padrão de drenagem é menos denso, e menor o controle das anisotropias geológicas, com padrões dendríticos a retilíneos, embora persistam as formas em cotovelo. $O$ próprio rio Camaquã é exemplo disso. 
NE

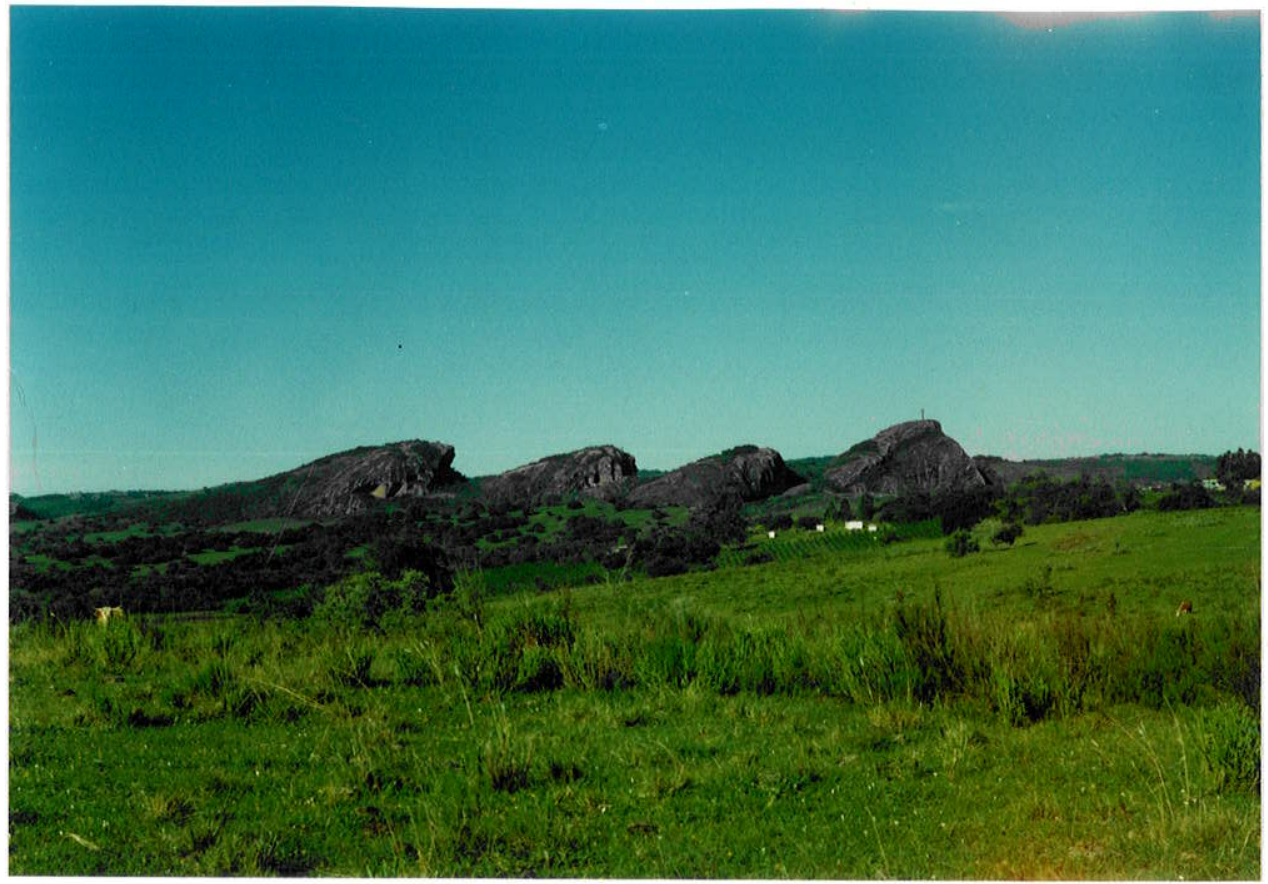

Figura I.2 - Vista de NW dos cerros de conglomerados do Grupo Camaquã na região das Minas do Camaquã a partir da estrada vicinal Minas-BR153. O $1^{\circ}$ da esquerda é a Pedra do Bagual e, o último, o cerro da Cruz. Note a forma de relevo abrupta causada por falhamentos normais de direção NW, as camadas mergulham cerca de $35-40^{\circ}$ para N20-30W.

NNE

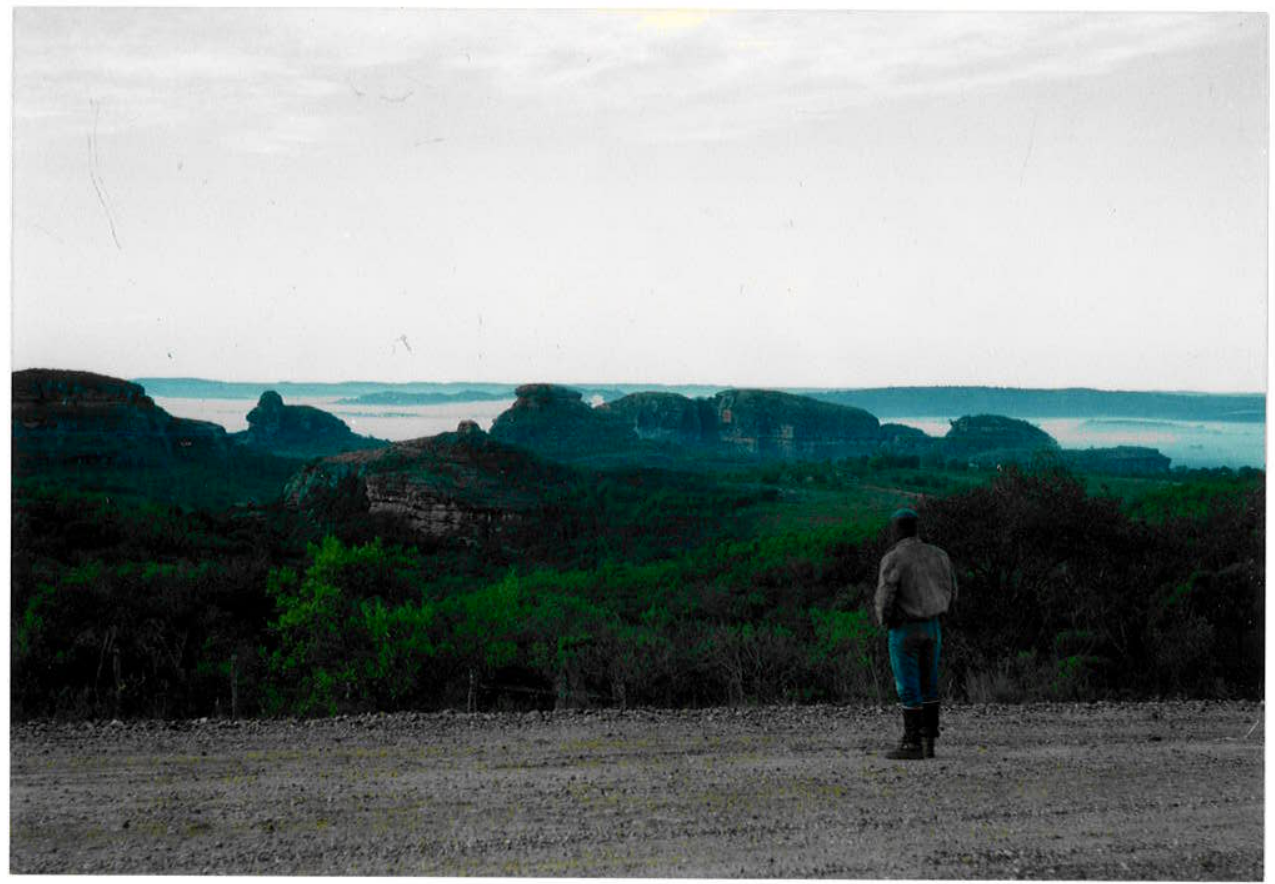

FIGURA I.3 - Vista parcial da serra das Guaritas mostrando a peculiar forma de relevo em torres, motivo da denominação da toponímia, fruto da erosão diferencial originando escarpas tabulares e vales profundos encaixados em arenitos fluviais fraturados do Grupo Guaritas. Limite NW da área de estudos. 
A temperatura média anual oscila entre $16^{\circ}$ e $18^{\circ}$, com média máxima de $22^{\circ}$ a $24^{\circ}$ no verão alto $\mathrm{e}$ média mínima (julho) de $11^{\circ}$ a $13^{\circ}$. Os índices pluviométricos variam anualmente de 1300 a $1500 \mathrm{~mm}$, com mais de $1500 \mathrm{~mm}$ nas regiões mais elevadas (Galvão, 1986; in Silva Filho, 1997). As precipitações concentram-se no inverno, sobretudo nos meses de maio a julho. A estiagem se dá no período de verão.

A cobertura vegetal domina a superficie do terreno como associações herbáceo-arbóreas do tipo savana. As áreas com menor densidade de cobertura vegetal (predomínio de gramíneas e rocha exposta) coincidem com cristas de conglomerados e a planície do vale do João Dias onde dominam litologias psamopelíticas do Grupo Camaquã, altos tabulares de arenitos do topo do Grupo Guaritas a NW e no limite leste, e alguns setores das ocorrências dos corpos ígneos Rodeio Velho a $\mathrm{S}$ da área de estudos. A vegetação arbórea concentra-se em matas ciliares no fundo de vales, em setores dos conglomerados (onde se situam as minas) e em porções mais setentrionais do Grupo Camaquã, em exposições dos Sills Máficos Rodeio Velho em áreas imediatamente a S e ESE das Minas do Camaquã. Já a vegetação de predominância herbácea ocupa áreas planas ou mais deprimidas do relevo, sob a forma de campos abertos com árvores e arbustos esparsos, coincidindo em sua maior parte com áreas de ocorrência das intercalações psamo-pelíticas do Grupo Camaquã, arenitos do Grupo Guaritas e em porções limitadas das ocorrências das rochas ígneas Rodeio Velho. Aí se desenvolve a ovinocultura. A cobertura de solo é pouco espessa, preferencialmente tendo-se o horizonte A situado diretamente sobre a rocha ou sobre o delgado horizonte C (Projeto Radam, 1986). 


\section{I.2.1 - ETAPAS DE TRABALHO}

\section{I.2.1.1 Trabalhos prévios de gabinete}

Como trabalhos iniciais visando o reconhecimento da área investigada destacaram-se levantamentos bibliográficos e cartográficos. Na análise da documentação cartográfica utilizou-se de mapas regionais (escalas 1:1.000.000 de Carraro et al., 1974; 1:1.000.000 e 1:600.000 de Santos et al., 1986; 1:250.000 de Ribeiro et al., 1966; Tessari \& Giffoni, 1970 e Camozzato et al., 1984; 1:100.000 de Ribeiro \& Carraro, 1971), de semi-detalhe na escala 1:50.000 de Teixeira et al. (1978a) e de detalhe na escala 1:25.000 de Gonzalez \& Teixeira (1980), além de diversos mapas e relatórios internos da extinta Companhia Brasileira do Cobre (CBC). Para a localização dos pontos descritos foram manuseadas as cartas topográficas Minas do Camaquã (SH.22-Y-A-V-3) e Arroio Carajá (SH.22-Y-A-IV-4), editadas pela Diretoria de Serviço Geográfico do Ministério do Exército (DSG), na escala 1:50.000.

Procedeu-se à fotointerpretação prévia de produtos de sensoriamento remoto tais como: fotografias aéreas nas escalas 1:25.000 e 1:60.000 e imagens TM-Landsat 5 nas escalas regionais aproximadas de 1:300.000 (cobrindo praticamente toda a área do Escudo Gaúcho no RS) e 1:100.000, e de semi-detalhe (1:50.000). Para tanto, manipulou-se composições coloridas falsa-cor, principalmente 457 (RGB) e 435 (RGB); composições coloridas de Principais Componentes (PCs), principalmente PC1PC2PC4 (RGB), e imagens branco e preto (PCs isoladas e bandas originais isoladas). Nas imagens coloridas buscou-se a delimitação de contatos litológicos e a separação de fácies sedimentares internamente às unidades litoestratigráficas.

Para realce de contraste serviu-se de ALCs (Aumento Linear de Contraste) e AMCs (Aumento Multilinear de Contraste). As composições coloridas tiveram o emprego de LUT (Look-up Table) para o destaque das cores, conforme Crosta (1992). Foram realizadas operações aritméticas como subtração e divisão sobre bandas originais separadas somente com Correção Atmosférica.

Como forma de se obter um destaque das unidades focalizadas empregou-se a Análise por Principais Componentes (APC), em imagens sem qualquer tratamento prévio, descrita em Loughlin (1991) e Crosta (1992). Esta técnica foi implementada através da (i) amostragem das cinco bandas utilizadas para cada unidade litológica distinguível, sejam individualizadas em trabalhos de mapeamento ou nas inagens; (ii) cálculo dos valores de variância e média para cada banda; (iii) ALC para cada PC e, por fim, (iv) combinação em tripletes usando-se filtros laplacianos suaves (e.g. matriz $5 \mathrm{X} 5 \mathrm{com} 55$ de peso central). 


\subsubsection{Trabalhos de campo}

Os trabalhos de campo compreenderam cerca de 65 dias em 4 etapas de mapeamento geológico na escala 1:50.000 e realização de perfis 1:25.000 perpendiculares às estruturas. Como se dispunha de mapas de detalhe de parte da área de estudos da Companhia Brasileira do Cobre (CBC), os trabalhos de campo visaram preferencialmente o refinamento das informações geológicas obtidas nesses trabalhos. Enfatizou-se a descrição e obtenção de dados de estruturas primárias e sistemas deposicionais para análise de fácies, o levantamento de seções estratigráficas, a coleta sistemática de dados qualitativos e quantitativos de paleocorrentes, proveniência dos clastos e feições tectônicas, e a amostragem litológica para descrição petrográfica posterior.

O estudo estratigráfico (camada a camada) foi implementado através do levantamento de seções estratigráficas tipo Selley (1970) buscando-se sempre a obtenção de dados de paleocorrentes e proveniência nos estratos compativeis, anotando-se o nível correspondente.

A análise estratigráfica de proveniência seguiu as seguintes etapas, conforme as técnicas desenvolvidas por Nilsen (1969), Steel \& Gloppen (1980), Steel \& Aasheim (1978), Steel et al. (1977), Graham (1983), Graham et al. (1986), Miall (1990), Ibbeken \& Schleyer (1991), entre outros:

-Identificação e reconhecimento de fácies por meio da geometria, espessura, estruturas e litologia dos litotipos, procurando-se sempre definir em qual unidade era realizada;

-Análise de proveniência no arcabouço de conglomerados e arenitos conglomeráticos através da contagem de cerca de 100 clastos maiores que $1 \mathrm{~cm}$ por ciclo em afloramentos, ou por afloramentos, ou quando inviabilizada, em regiões com a correlação entre afloramentos;

-Amostragem de clastos para posterior identificação, e de litotipos para laminação e descrição petrográfica; -Estimativa qualitativa dos clastos para interpretação regional em afloramentos de pequena exposição;

$\mathrm{O}$ estudo de paleocorrentes ocorreu concomitantemente à análise de proveniência através de medições em: (i) sentido do mergulho dos estratos frontais das estratificações cruzadas tabulares e acanaladas (em planta e/ou perfil); (ii) marcas ou indicações de corrente como marcas de sola; (iii) marcas onduladas por corrente e climbing ripples; (iv) imbricações de clastos segundo eixos a (maior dimensão ou comprimento) e $b$ (largura) originando o plano $a b$ (Coimbra et al., 1992a); (v) variações de fácies e de granulometria. As medidas dos tipos (i) e (ii) são mais confiáveis estatisticamente e de boa resolução espacial regional e, no entanto, as dos tipos (iii) e (iv) de caráter mais local e de precisão menos confiável.

\section{I.2.1.3 Trabalhos de laboratório e estatísticos}

Para tais atividades utilizou-se dos laboratórios das dependências do Instituto de Geociências da USP (IGc-USP), abaixo mencionados.

Foram realizadas 55 análises petrográficas microscópicas dos sedimentitos no Laboratório Didático de Microscopia Petrográfica (LDMP/DMP). Esse tipo de caracterização abrangeu os seguintes 
parâmetros: descrição preliminar sucinta para a escolha das seções para análise modal; identificação e caracterização da mineralogia; estudos de proveniência; relação entre arcabouço, matriz e cimento, ou seja, a trama das rochas (fabric); presença de minerais instáveis (e.g. feldspatos); maturidade mineral e textural; classificação e contagem de cerca de 400-700 pontos por seção delgada previamente selecionada na descrição preliminar, totalizando 30 lâminas.

Os parâmetros de arredondamento e esfericidade foram calcados na proposta de Powers (1953). Avaliou-se a maturidade das rochas com base em diagramas de Folk (1968), enquanto as porcentagens de maturidade das rochas foram extraídas de Coimbra \& Coutinho (1983). Os parâmetros de seleção seguiram as escalas de Pettijohn et al. (1987). A granulometria foi avaliada com auxílio de escalas granulométricas da PETROBRÁS, por sua vez baseadas em Wentworth (1922). E, finalmente, a classificação dos litotipos baseou-se nas propostas de Dott (1964), Folk (1968) e Dickinson (1988).

Procedeu-se à análise estatística dos dados de proveniência, paleocorrentes e feições estruturais, com a utilização de softwares como Microsoft ${ }^{(1)}$ EXCELL e STEREONET, IPT-TRADE, DIPS, entre outros, no laboratório de computação gráfica (CPD) e sala de computação do DGG/IGc-USP. Nas análises de proveniência implementou-se a elaboração de tabelas de proveniência de cada afloramento amostrado e de cada região para visualização global da variação de área fonte. para as paleocorrentes realizou-se a confecção de diagramas de roseta (rose diagrams) para indicação de vetores de paleocorrentes por afloramento e, por áreas estipuladas segundo a proximidade de pontos (estações);

Foi realizado tratamento digital de imagens de satélite (ver acima) utilizando-se da Análise por Principais Componentes (APC) com o intuito principal de reconhecimento de fácies, estruturas e unidades litoestratigráficas e correlação com os resultados obtidos nas etapas de mapeamento geológico. Estas análises foram realizadas no Laboratório de Imagens e Geoprocessamento (LIG/DGE).

\section{I.2.1.4 Trabalhos finais de gabinete}

Os dados coletados no campo e obtidos em laboratório foram processados em gabinete na forma de tabelas, mapas e perfis para análises de variações laterais e verticais de fácies, procedendo-se a seguir à interpretação dos mesmos. Também foram confeccionados gráficos, blocos-diagrama, figuras, etc, para a apresentação dos dados obtidos nas etapas de campo e de análise laboratorial e estatística. Finalmente, realizou-se a integração de todos os dados para a confecção de um modelo evolutivo para a área estudada.

\section{I.2.2 FUNDAMENTOS DA ANÁLISE ESTRATIGRÁFICA}

A técnica de análise estratigráfica foi empregada para a interpretação ambiental e paleogeográfica das unidades litoestratigráficas da área de estudos. Esta técnica compreendeu as análises de fácies, proveniência, paleocorrentes, petrográfica e sistemas deposicionais. A partir da análise de fácies, 
por intermédio de sua conceituação básica, foram discriminados os diversos litotipos presentes que, posteriormente agrupados em associações de fácies, possibilitaram compor os ambientes deposicionais das rochas sedimentares, para então considerá-las em um contexto de sistemas deposicionais.

\section{I.2.2.1 Análise de fácies sedimentares}

\section{I.2.2.1.1 Introdução}

De acordo com Miall (1990), a análise de fácies compreende o estudo e interpretação de texturas, estruturas sedimentares, assembléias de fósseis e associações litológicas em escala de afloramentos, testemunhos de sondagens ou segmentos de uma bacia. Assim, atribui-se o termo fácies a uma unidade rochosa definida com base em feições, tais como, composição, granulometria, geometria dos corpos e estruturas sedimentares. Cada fácies representa um único evento deposicional, podendo recorrer no tempo $\mathrm{e}$ espaço (Miall, 1990). Fácies podem ser agrupadas em associações de fácies, características de ambientes deposicionais específicos. Estas associações formam a base para definição de um modelo de fácies conforme preconizado por Walker \& James (1992). Tomando-se individualmente cada fácies, esta poderá representar as condições específicas dos processos deposicionais e do ambiente em que foi gerada. Como determinadas fácies podem ter recorrência ou repetição na forma de ciclos em vários ambientes deposicionais, uma fácies isolada não determina satisfatoriamente as condições do sítio de acumulação. Desta feita, é o estabelecimento das relações entre as várias fácies sedimentares, ou seja, a integração das fácies de acordo com as variações laterais intrínsecas e sua correlação que permitirá caracterizar as condições necessárias para a interpretação ambiental.

O propósito de se realizar uma análise de fácies é fornecer uma interpretação ambiental de um grupo de rochas sedimentares (Miall, 1990). Assim, foi elaborado um esquema de fácies com base na composição litológica predominante, textura e granulometria, organização interna, estruturas sedimentares e geometria dos corpos. Cada fácies foi identificada por um código simples de três letras, eventualmente, quatro, de acordo com as classificações originais de Miall $(1977,1978)$ e Eyles et al. (1983). As três litofácies principais compreendem conglomerados $(\mathrm{C})$, arenitos $(\mathrm{A})$ e pelitos (P), estabelecendo-se subfácies destas conforme critérios a seguir expostos. Estabeleceu-se um esquema de fácies preliminar com base nas primeiras boas exposições encontradas na área. Dessa forma, através de comparação, foram descritas as novas seções para alicerçar o esquema final apresentado nas TABELAS III.1-III.4.

\section{I.2.2.1.2 Associações e Modelos de Fácies}

$\mathrm{O}$ conceito de sedimentação cíclica tem como base principal as relações entre fácies. De acordo com Reading (1986), a idéia que fácies sedimentares repetem-se umas após outras (sedimentação cíclica) 
no registro geológico assume um papel fundamental na sedimentologia. A utilização dos ciclos baseia-se na concepção da existência de uma regularidade na sedimentação (chamada ciclicidade), e que esta é um processo estável e normal (steady process) com aparência caótica (eventos casuais periódicos). Entretanto, em alguns processos, eventos aparentemente ao acaso são muito comuns e predominam na sedimentação (e.g. processos de turbidez). Cada fácies (ou associação de fácies) pode então ser comparada com outra encontrada em outro lugar, estabelecendo-se uma correlação estratigráfica. A partir do conceito de ciclicidade deteve-se maior atenção às relações entre fácies, pois se observou que as fácies tendem a ocorrer de modo repetido dentro de um mesmo depósito sedimentar. Desse modo, pode-se organizar as fácies em ciclos sedimentares, nos quais as fácies recorrem muitas vezes em uma seção vertical sem lacuna de tempo (Lei da Correlação de Fácies de Walther).

Agrupamentos de fácies que aparecem na(s) mesma(s) exposição(ões) e estão relacionados geneticamente recebem a denominação de associações de fácies (Reading, 1986). O conceito é fundamental para a interpretação ambiental, desenvolvendo-se a partir da análise da relação entre as fácies. $\mathrm{O}$ termo associações de fácies foi introduzido por Potter (1959) como uma "coleção de atributos sedimentares comumente associados", destacando-se "geometria, continuidade fisica e forma das unidades litológicas, litologia, textura, estruturas sedimentares e fósseis (tipos e abundância)". Uma associação de fácies baseia-se na observação de campo, havendo uma simplificação necessária (Miall, 1984, 1990). É expressa na forma de tabelas, sumário estatístico ou diagramas de seção vertical tipo Selley (1970).

O termo seqüência de fácies é aplicado em sucessões com passagem gradacional entre fácies, podendo ser cíclica ou não. Uma seqüência pode limitar-se no topo e na base erosivamente ou abruptamente, ou por superficie não-deposicional indicada por nível de paleossolo ou diagênese precoce (Reading, 1986).

O conceito de modelo de fácies possui estreita corresponđência com o ambiente deposicional. Inicialmente foi referido por Potter (1959), porém o autor utilizou-o no sentido de assembléia de fácies, termo essencialmente descritivo. Um modelo de fácies implica em elaborar uma interpretação ambiental de uma assembléia de fácies ou associação de fácies (Miall, 1990), cujos processos deposicionais envolvidos conduzem à uma interpretação e uma inferência dos sistemas deposicionais presentes.

Walker (1994) enfatiza os procedimentos a se cumprir na elaboração de um modelo de fácies, definido por ele como "um sumário geral de um ambiente deposicional particular" (turbiditos, no caso retratado pelo autor), e que se norteia como segue:

- será uma norma para fins de comparação entre fácies

- servirá como arcabouço e guia para observações futuras

- atuará na realização de previsões em novas situações geológicas com escassez de dados

- será a base para interpretação ambiental do sistema deposicional

Em regiões carentes em fósseis, ausência de camadas-guia, variações bruscas de fácies, perturbações tectônicas importantes e recorrência de fácies no registro sedimentar, a aplicação do conceito 
de fácies e suas decorrências é fundamental. A análise de fácies permite a identificação dos ambientes geradores dos sedimentos e, tentativamente, a hierarquização dos litotipos e posterior correlação. Através do estudo de fácies e da análise de seus atributos e relações espaciais, pode-se elaborar um modelo faciológico coerente com as observações realizadas. Modelos faciológicos obtidos pelo estudo integrado de sistemas deposicionais e análises de proveniência e paleocorrentes deposicionais, possibilitam a formulação de uma reconstituição paleogeográfica de um sitio deposicional.

\section{I.2.2.2 - Análise de proveniência}

\section{I.2.2.2.1 Introdução}

Estudos de proveniência e paleocorrentes (item I.2.2.3) constituem-se em ferramentas fundamentais na análise e na compreensão da evolução tectônica de bacias em superfície, assim como contribuem significativamente para reconstrução da história tectônica global (Dickinson, 1988; Miall, 1990). Tais técnicas, quando associadas a análises de fácies e sistemas deposicionais, assim como a estudos petrográficos e de diagênese dos sedimentos formadores, permitem caracterizar a área fonte que forneceu detritos para a bacia. Desta forma, as palavras de Earle F. McBride (in Kleinspehn \& Paola, 1988) definem muito bem o significado de tais técnicas: "Provenance concerns the location of the source area from which detritus was derived, identification of the rock types exposed in the source area, and an interpretation of the climate and relief of the source".

A combinação de estudos de proveniência e paleocorrentes possibilta inferências sobre tectônica e clima, os principais fatores controladores da mineralogia sedimentar (Pettijohn et al., 1987).

A análise de proveniência para ser devidamente utilizada deve preceder de um cuidadoso levantamento faciológico por meio de seções estratigráficas tipo Selley, perfis log ou a simples anotação dos locais passiveis de contemplar tal análise. Como salientou Sayeg (1993), a análise de proveniência “... para ser adequadamente explorada, deve ter a composição modal dos (...) produtos sedimentares analisada levando-se em conta o respectivo nível estratigráfico...". No âmbito da própria análise, a composição dos clastos presentes no arcabouço de conglomerados e arenitos deve ser analisada por meio da contagem dos mesmos instituindo-se um valor mínimo de diâmetro a ser considerado (e.g. clastos maiores que $5 \mathrm{~cm}$ ), buscando-se obter um número suficiente estatisticamente representativo, como por exemplo 100. É evidente que nem sempre esse valor pode ser atingido devido à fatores limitantes de exposição, acessibilidade e, não menos importante, o fator tempo. Essas análises costumam demandar algum tempo em sua realização, como também qualquer análise que requeira cuidadosa observação e um número mínimo de medidas a serem efetuadas. Desse modo, o analista pode servir-se de tabelas previamente preparadas como forma de agilizar a contagem. Como auxílio à proveniência, análises 
sedimentológicas de arredondamento, diâmetro máximo, esfericidade e forma dos clastos podem somar para fundamentar a composição dos clastos.

\section{I.2.2.2.2 Descrição do método}

\section{No campo:}

As análises de proveniência foram realizadas em brechas, conglomerados e arenitos conglomeráticos (fácies rudíticas) a nível macroscópico em afloramentos, e na matriz de arenitos e conglomerados, microscopicamente. Nos afloramentos essa análise empreendeu a estimativa dos clastos componentes do arcabouço dessas litologias.

A técnica de análise de proveniência compreendeu diversas etapas. Primeiramente houve o estabelecimento de fácies tendo como parâmetros a geometria e a espessura das camadas, as estruturas e a constituição litológica dos estratos utilizando-se dos conceitos de Reading (1986) e Walker \& James (1992). A análise de proveniência, no arcabouço de conglomerados e arenitos conglomeráticos, foi implementada pela estimativa visual da proporção dos constituintes maiores que $1 \mathrm{~cm}$ e posterior contagem aleatória (random analysis) de 100 clastos em cada localidade analisada (conforme Nilsen, 1969; Graham et al., 1975, por exemplo). Escolheu-se arbitrariamente dimensões superiores a $1 \mathrm{~cm}$ com vistas a abranger a maior variação granulométrica possível. Para tanto, procedeu-se à identificação da litologia dos clastos e sua contagem. Cada porção do estrato ou do afloramento escolhida aleatoriamente era exaustivamente explorada, tentando-se obter um mínimo de 50 clastos pesquisados. Em afloramentos de dimensões reduzidas, ou sem exposições favoráveis, empreendeu-se a contagem sumária aleatória na tentativa de se alcançar o número mínimo. Já em afloramentos mais amplos (pedreiras, cortes de estrada, exposições naturais generosas, encostas de morros) dividiu-se a exposição por ciclos sedimentares (camadas) ou em bancadas (pedreiras) para facilitar a tarefa, procedendo-se à contagem por nível escolhido, respeitando a estratigrafia.

A análise de proveniência foi acompanhada, sempre que possivel, em locais favoráveis, pela obtenção de parâmetros sedimentológicos tais como dimensão, forma, arredondamento e esfericidade dos clastos, textura e relação matriz / arcabouço dos conglomerados. Na aferição das dimensões máximas dos fragmentos podem ser utilizados régua, trena metrada ou paquímetro, este mais adequado. A medida é tomada ao longo do maior comprimento observável, buscando-se sempre que possivel visualização em 3D. $\mathrm{Na}$ estimativa da forma dos clastos foram empregados métodos de estimativa visual baseados em Krumbein (1941), amplamente difundidos desde então.

Recentemente, Dürr (1994) propôs um método de estimativa visual de volumes de clastos no campo através de (i) aproximação da forma do clasto com um elipsóide imaginário (FIGURA I.4); (ii) medição do $\phi_{\max }$ (ou eixo máximo) do elipsóide imaginário e (iii) cálculo do volume aproximado. Os passos (i) e (ii) foram implementados nos afloramentos. Este autor relatou que o método é aplicado com bons 
parâmetros de arredondamento e esfericidade empregou-se as tabelas de estimativa visual de Powers (1953).

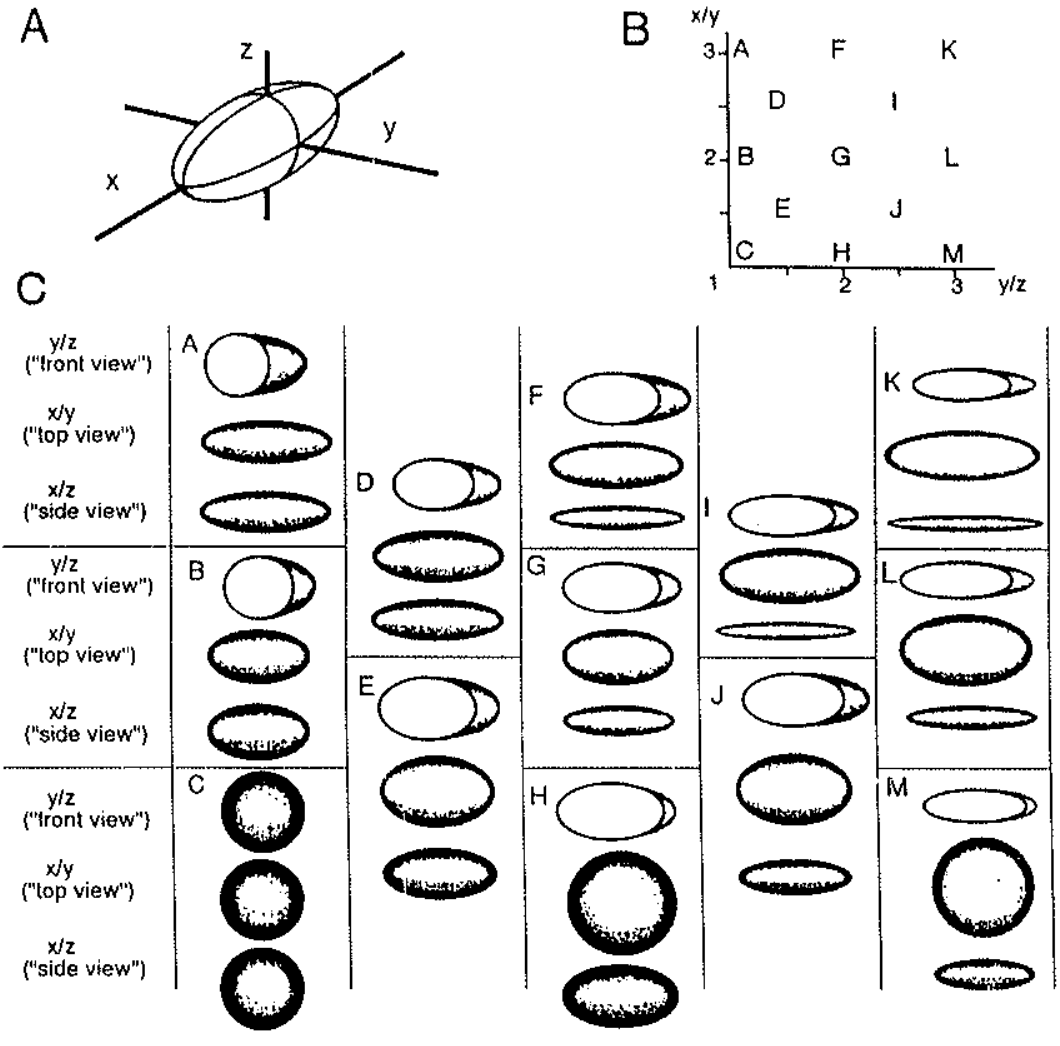

Figura I.4- Método de estimativa visual de volumes de clastos no campo. A) Elipsóide dado por eixos $x, y, z$; B) diagrama binário $x / y$ versus $y / z$ com os 13 elipsóides padrão A-M; C) representação gráfica dos 13 elipsóides padrão de formas A-M. (de Dürr, 1994)

\section{No laboratório:}

Os dados obtidos no campo foram representados em tabelas e histogramas de freqüência em colunas de forma a bem visualizar toda a variação composicional dos clastos, conforme Ibbeken \& Schleyer (1991).

Foram desenvolvidos estudos de proveniência petrográfica com a análise de 55 seções delgadas, das quais 40 tiveram caracterizadas a petrografia e, destas, foram selecionadas 30 para contagem pontual modal (TABELA III.11). A classificação dos litotipos baseou-se nas propostas de Dott (1964) e Folk (1968), sendo que fragmentos de chert e micas foram incluídos como líticos, embora alguns autores incluam Qp (quartzo policristalino) como fragmentos líticos (Basu et al., 1975; Suttner \& Basu, 1985).

A análise de proveniência em seção delgada foi precedida da análise petrográfica convencional no intuito de subsidiar as interpretações de área fonte. 
A descrição petrográfica seguiu, inicialmente, as seguintes etapas (Folk, 1968; Pettijohn et al., 1987): (i) relação entre arcabouço, matriz e cimento; (ii) análise do tamanho dos grãos do arcabouço de arenitos e conglomerados através da contagem de 50 a 100 grãos por lâmina; (iii) análise do arredondamento dos grãos pela contagem de cerca de 100 fragmentos e comparação com a tabela de Powers (1953); (iv) análise da esfericidade dos grãos com a utilização da Tabela Comparativa de Powers (1953) e (v) análise da seleção das rochas por meio das tabelas de Folk (1968) e Pettijohn et al. (1987).

A mineralogia foi avaliada, primeiramente, através da estimativa visual dos componentes e de rápida descrição. A seguir, procedeu-se à atenta descrição dos principais constituintes minerais (quartzo, feldspato, fragmentos líticos, micas) com auxílio de croquis e desenhos. Esta análise fundamentou a análise modal realizada posteriormente. Assim se deu a escolha das seções a serem analisadas modalmente.

$\mathrm{Na}$ análise modal foram estudadas 30 seções delgadas com a contagem de 400 a 700 pontos por seção previamente selecionada, número suficiente para abranger grande parte da variação granulométrica (Pettijohn et al., 1987; Eriksson et al., 1994). A análise modal baseou-se na contagem pontual em separado de variedades de quartzo, feldspato e fragmentos líticos. A título de exemplo, detritos de quartzo foram inicialmente separados em monocristalino $(\mathbf{Q m})$ e policristalino $(\mathbf{Q p})$. Quartzo monocristalino foi dividido em plutônico e vulcânico (segundo divisão de Krynine, 1941). Já o quartzo policristalino foi distinguido nas variedades metamórfica ( $\left(\mathrm{p}_{\mathrm{m}}\right.$ - metamorphic quartz de Krynine, 1941), hidrotermal ou de veio $\left(\mathrm{Q} \mathrm{p}_{\mathrm{s}}\right.$ semi-composto) e deformada ou milonítica $\left(\mathrm{Q} \mathrm{p}_{\mathrm{d}}\right.$ - o chamado sheared quartz na literatura norteamericana), consoante os trabalhos de Blatt (1967), Dickinson (1970), Basu et al. (1975), Young (1976), Mysko \& Hendry (1976), Scholle (1979), Adams et al. (1993), entre outros. Grãos de chert foram considerados separadamente para efeito de área fonte. Essa contagem em separado serviu aos propósitos de análise de área fonte, bem como para a classificação dos litotipos.

Como a finalidade principal da análise petrográfica foi determinar a proveniência dos arenitos e conglomerados por intermédio dos detritos líticos presentes, a contagem modal seguiu os métodos tradicionais de avaliação. Desta feita, não se adotou integralmente o método Gazzi-Dickinson de contagem pontual (Dickinson, 1970; Gazzi et al., 1973; Ingersoll et al., 1984), visto que tal método presume que fragmentos derivados de rochas plutônicas, por exemplo, um granito, sejam enquadrados como grãos de quartzo, feldspato, mica ou acessório compativel, ou seja, de maneira a minimizar as porcentagens de fragmentos líticos (L), muito embora, por outro lado, o efeito do tamanho dos grãos nas modas seja reduzido com esse método, daí sua finalidade. Deste modo, buscou-se contar o número máximo possível de fragmentos em cada lâmina para minimizar tal efeito.

Por último, enfatizamos a correlação entre as técnicas empregadas, de forma a compor um quadro coerente de análise estratigráfica de fácies, proveniência e paleocorrentes. 


\section{I.2.2.3 Análise de paleocorrentes}

Trata-se de uma das técnicas mais utilizadas em análise de bacias em superficie. Henry C. Sorby foi o fundador da sedimentologia e precursor do uso da técnica, obtendo 20.000 medidas de paleocorrentes em sete anos, entre 1852-59, a maioria delas ainda inéditas (Miall, 1984). O estudo de paleocorrentes deposicionais pode fornecer informações valiosas a respeito:

(i) da localização da(s) área(s) fonte(s);

(ii) da reconstituição topográfica e situação inicial dos paleorelevos local e regional;

(iii) de sistemas deposicionais e fácies;

(iv) da geometria e direção preferencial das unidades litoestratigráficas.

Considerando-se estes 4 (quatro) aspectos principais, adiciona-se a importância em elucidar a paleogeografia em áreas nas quais a recorrência de fácies e de litotipos de grande homogeneidade litológica é regra.

Este tipo de análise visou inferir a localização das áreas fontes determinadas na análise de proveniência e, sobretudo, a paleogeografia da bacia e da área fonte quando da época da deposição. Tais análises foram determinadas em estruturas direcionais planares e lineares encontradas preferencialmente em estratificações cruzadas e marcas de corrente (como marcas de sola), respectivamente.

\section{I.2.2.3.1 Principais tipos de indicadores de paleocorrentes}

Potter \& Pettijohn (1977) demonstraram exaustivamente diversos indicadores de paleocorrentes. Uma breve descrição destes faz-se necessária. Em função do estudo aqui desenvolvido, ater-nos-emos a apenas 5 (cinco), quer sejam: estratificações cruzadas, marcas onduladas, marcas de sola (sole marks), arcabouço de ruditos (imbricações de clastos) e variações granulométricas e de fácies.

1) Estratificacões cruzadas: é o atributo de paleocorrentes mais utilizado devido sua ampla disseminação e fácil determinação (Potter \& Pettijohn, 1977). Formas de leito geralmente correspondem ao fluxo dominante de corrente, e difícilmente, são remodeladas por fluxos de baixa, assim estratificações cruzadas tendem a representar o paleodeclive original, ou seja, são bons indicadores de paleocorrentes (FIGURA I.5).

Definição: é uma estrutura planar confinada a uma unidade única de sedimentação (Otto, 1938 apud Potter \& Pettijohn, 1977), consistindo de acamamento interno, denominado de lâmina frontal (foreset), inclinado em relação à principal superfície de acumulação (So). Esta definição não guarda relação com a escala de trabalho, pois estratificações cruzadas podem variar em espessura de $3 \mathrm{~mm}$ a 33m (McKee \& Weir, 1953; Hamblin, 1961; Potter \& Pettijohn, 1977). 


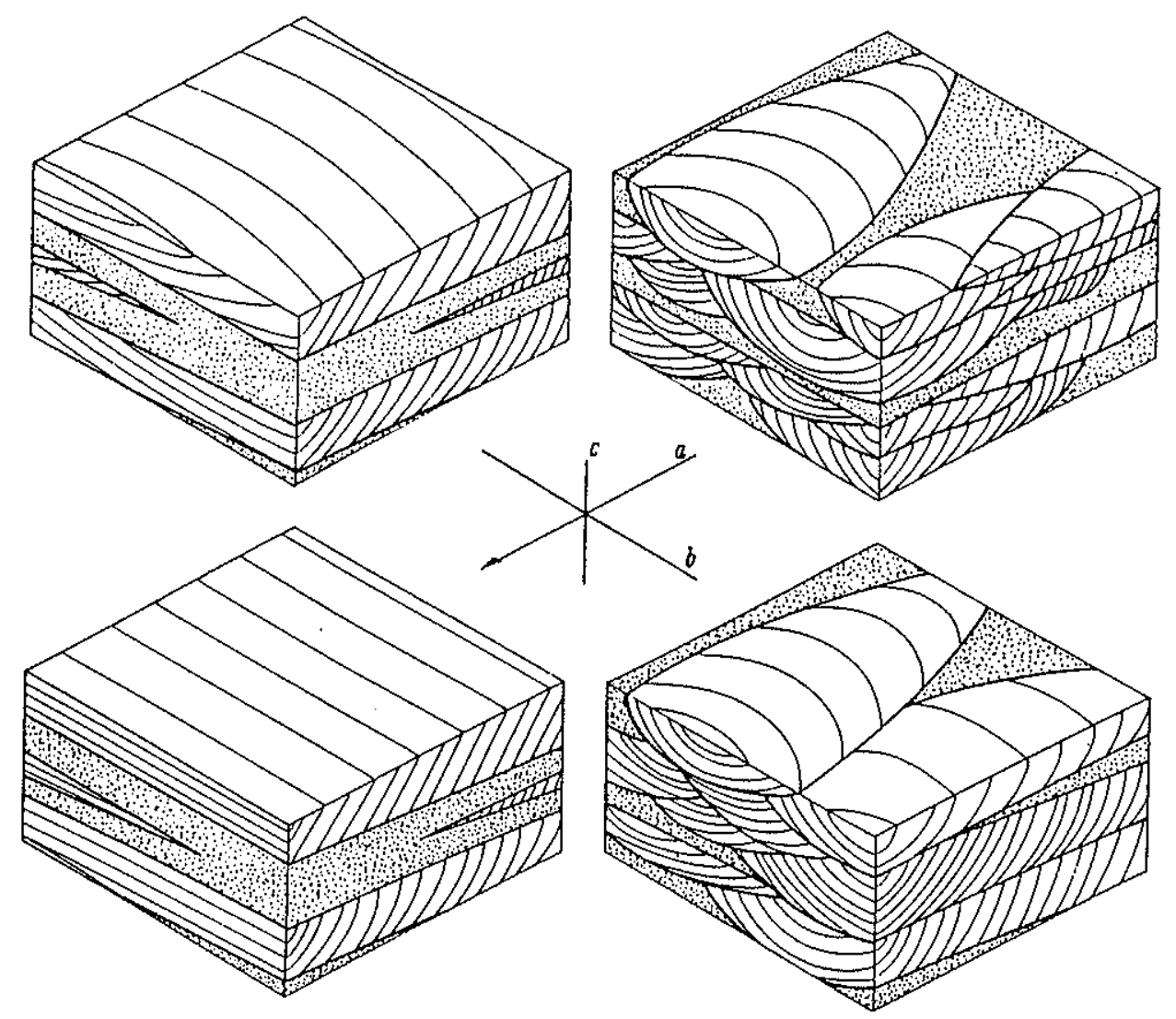

FigURA I.5 - Exemplos de blocos diagramas com os dois tipos extremos de estratificações cruzadas, tabular (à esquerda) e acanalada (à direita). Extraída de Potter \& Pettijohn (1977).

McKee \& Weir (1953) formularam uma proposta de hierarquização de estratificações cruzadas conforme o porte da estrutura: pequeno porte (sets de $<0,3 \mathrm{~m}$ de espessura); médio porte $(0,3 \mathrm{~m} \leq \mathrm{S} \leq 3 \mathrm{~m}$, onde $\mathrm{S}$ é o set da estratificação), grande porte (sets entre $3 \mathrm{~m}$ e $6 \mathrm{~m}$ ) e porte gigante $(>6 \mathrm{~m})$. Recentemente, Fernandes (1992) propôs uma modificação nesta hierarquia, qualificando de $I^{a}$ ordem as estruturas maiores de $3 \mathrm{~m}$ (grande porte a gigantes), de $2^{a}$ ordem as de médio porte e o mesmo para as de pequeno porte. $\mathrm{O}$ autor discutiu a representatividade estatística de medidas de paleocorrentes destas estruturas. Aquelas de $1^{a}$ ordem teriam representatividade regional mesmo quando consideradas pequenas populações (1 a 6 medidas por estação). Os valores de paleofluxo obtidos em estratificações de $2^{\underline{a}}$ e $3^{\mathfrak{a}}$ ordens, preferencialmente, apresentariam consistência estatistica com populações entre 7 e 30 medidas, e maiores que 30 , respectivamente.

Estratificações cruzadas de médio porte fornecem boas indicações do paleofluxo, conquanto exijam grande número de medidas, muitas vezes de dificil obtenção. Alguns autores (Potter \& Pettijohn, 1977; Miall, 1974; Tucker, 1989; Miall, 1990; Assine, 1994) sugerem uma população média de 25 medidas, com extremos de 7 a 30 , de maneira a possibilitar uma confiabilidade e validade do tratamento estatistico indispensáveis (Fernandes, 1992). Essas estruturas afloram praticamente em uma só exposição, facilitando sua visualização e o acúmulo de dados. 
Não é o que acontece com estruturas de grande porte, pois se por um lado necessitam de poucas medidas $(<7)$, a dificuldade reside no fato de não se observar toda a estrutura e, desta forma, reduzir-se a chance de obter dados confiáveis.

Estratificações e laminações cruzadas apresentam limitante no número de medidas, já que o valor mínimo estatístico é alto e muitas vezes a exposição não comporta tal volume de dados.

Como as estruturas planares obtidas nesta investigação são de médio (predominantes) e pequeno portes, foram necessárias várias aferições de estruturas, tarefa nem sempre possível em função da exposição e continuidade dos afloramentos.

2) Marcas onduladas: refere-se às ondulações rítmicas ou periódicas que ocorrem nos planos de acamamento. Normalmente são inferiores a 1 metro de largura. Formam-se preferencialmente em materiais granulares na interface sedimentar como resposta ao movimento de fluidos, sejam subaquáticos ou aéreos. Ocorrem em ambientes fluviais, litorâneos, marinhos ou eólicos de qualquer idade (Potter \& Pettijohn, 1977). São classificadas de diversas formas (Potter \& Pettijohn, 1977; Collinson \& Thompson, 1989): pelo aspecto em planta, sejam cristas retilíneas ou curvas (sinuosas) ou contínuas ou descontínuas; pela simetria das cristas, que podem ser simétricas ou assimétricas; pela relação do arranjo interno dos grãos para a forma externa; ou ainda de acordo com a orientação em relação à corrente. Ondulações com cristas relativamente retilíneas e subparalelas, sejam contínuas ou não, comumente são transversais à direção da corrente. Seções de cristas de marcas onduladas transversais podem ser simétricas, ou assimétricas, se um lado, o sotavento (lee side), é mais íngreme que o outro. Sendo assim, aplica-se o termo de marca ondulada por corrente (current ripple mark). Marcas de corrente apresentam estruturação interna de lâminas cruzadas ou até estratos cruzados, em função das dimensões. Usualmente podem ser encontradas estruturas de ondulações cavalgantes assimétricas (assymmetrical climbing ripples) no perfil da marca de corrente. Marcas onduladas transversas com perfil simétrico são denominadas de marcas de oscilação ou marcas de ondas (oscillation ripples ou wave ripples).

$$
\text { indice de ondulação }=\frac{\text { comprimento de onda }}{\text { amplitude }}=\frac{\lambda}{a}
$$

3) Marcas de sola (sole marks): a parte basal de camadas de arenitos e siltitos pode apresentar estranhas marcas que formam saliências no plano do acamamento, configurando-se em moldes de estruturas originadas no estrato inferior, normalmente formado por argila e silte argiloso, muito plástico. São feições conspícuas em arenitos formados por eventos episódicos de sedimentação, como processos de correntes de turdidez (turbiditos), mas já foram registrados em arenitos interestratificados com 
conglomerados de depositos de sheetflood de fácies de leques aluviais em ambientes semi-áridos, arenitos de depósitos de rompimento de dique marginal em planicies de inundação de fácies fluvial (crevasse-splay) e ambientes atingidos por tempestades em águas rasas (Collinson \& Thompson, 1989).

Marcas de sola são estruturas lineares muito abundantes em seqüências de ritmitos arenopeliticos, pois se constituem em estruturas erosivas onde a camada de material mais fino (argila) é escavada e a depressão formada é posteriormente preenchida por material de granulometria mais grossa (geralmente areia). Como os niveis peliticos podem ser erodidos mais facilmente, o que resta é o "contramolde" da estrutura na base dos estratos de arenito sobrejacentes. Uma das utilidades do estudo da estrutura é o grande potencial como indicador de topo e base ('way-up'). Collinson \& Thompson (1989) dividiram os tipos de marcas de sola em duas classes de acordo com o processo principal de geração: aquelas devido à processos de arraste e atrito (scour marks) e aquelas formadas por objetos movidos por correntes (tool marks). Já Potter \& Pettijohn (1977) separaram em uma variedade de tipos, fugindo ao escopo deste a apresentação de todos.

Scour marks: são distinguidas por sua forma geral e pela aparência de "cauda de cometa". Podem ocorrer como moldes isolados ou em padrões cobrindo a superficie de acamamento. Quatro grupos são importantes de acordo com Collinson \& Thompson (1989): (1) marcas de obstáculos (obstacle scours), (2) marcas de sulcos (flute casts), (3) longitudinal scours e (4) "marcas de escavação" (gutter scours). Destas, interessam-nos mais diretamente apenas (2), em vista de sua ocorrência na área de estudos e da utilidade como indicador de paleocorrentes deposicionais.

Flute casts: caracterizam-se pelas formas arredondadas, embora às vezes, um tanto encurvadas, semelhantes a um "nariz". A parte mais profunda (i.é. de relevo máximo no molde) localiza-se próximo ao "nariz", de cujo ponto a marca alarga-se e desaparece, indicando sentido de corrente para jusante (downstream). Em cada nível as marcas apontam na mesma direção, de forma que basta uma só medida de uma feição para se obter um bom dado de paleocorrente deposicional (Potter \& Pettijohn, 1977).

4) Orientacão e imbricacão de clastos no arcabouco de conglomerados: os clastos passiveis de sofrer orientação preferencial apresentam formas alongadas (em bastonetes), achatadas (discóides) ou tipo disco (disk-like particles), tais como palhetas de micas, seixos de ardósias, sob a ação exclusiva da gravidade (FIGURA I.6).
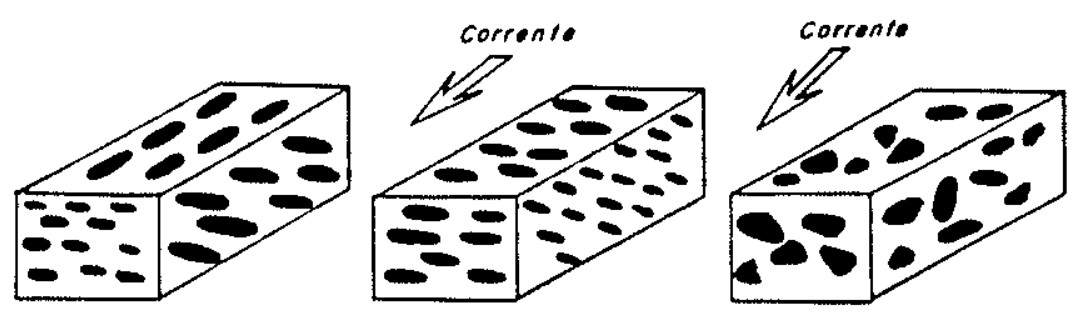

FIGURA I.6 - Exemplo de padrões de orientação espacial preferencial de clastos (petrofábrica) em conglomerados. Modificada de Suguio (1980). 
Quando há a combinação da ação da gravidade + ação de correntes o resultado pode ser a imbricação de clastos. Coimbra et al. (1992a) discutiram o comportamento de clastos quando transportados paralelos ou perpendiculares à corrente fluvial e segundo o caimento do plano $a b$ por ocasião da deposição (FIGURA 1.7). Tais assertivas foram adotadas nas mediçoos de paleocorrentes em depósitos apropriados.
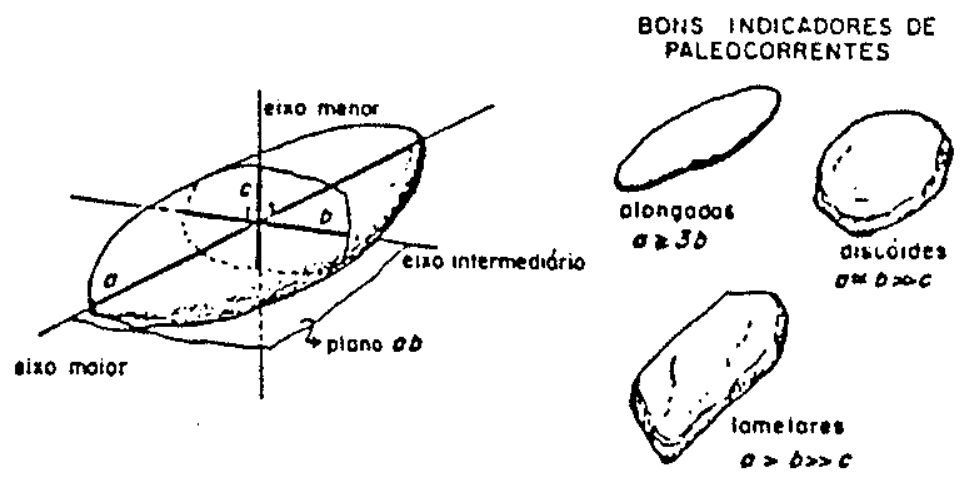

MAUS INDICADORES DE PAL EOCORRENTES
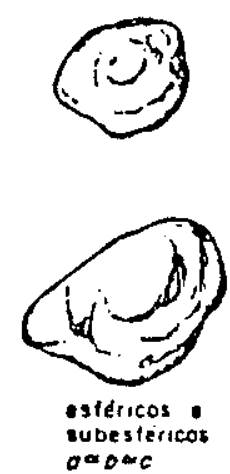

\section{COMPORTAMENTO DOS CLASTOS}

\section{ALONGADOS}

(vieos irtaimunional)

1) em repouso

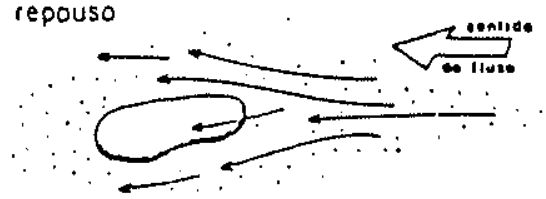

EIXO PARALELO A CORRENTE

Posicionam-se no futido de modo o oferecer menor resisténcio ò passogem do fluxo.

2) em movimento

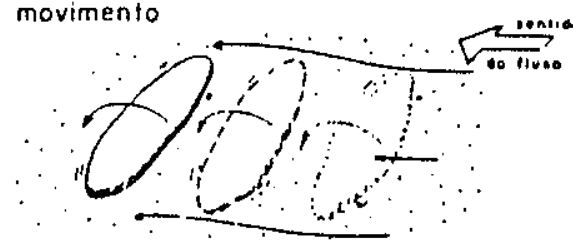

EIXO O PERPENJMCULAR A CORRENTE Iniciodo o movimento, rolom em torno do tixo - da maneiro que exige o menor forco

$3)$ clostos com eixo 0 em posicōes intermedio rios. Sỏo enconircios com menor frequéncio, pois lendem o odulor umo das posicócs an teriores.

\section{DiscóIDES E LAMELARES}

(riodo bidimenoicnal)

1)

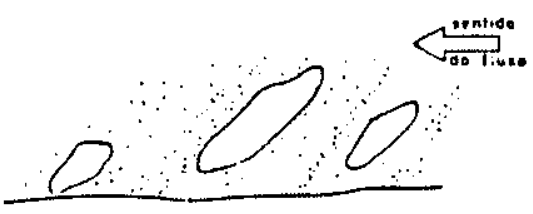

PLANO OD COM CAIMENTO NO SENTIDO DO FLUXO

Clasios deposilajos am motriz, tendem o posiçoo de moiar estabilidode assentorido-se corn o plo no ob paroleto a estrofificoçoo. Furfados ini ciolmeilfe peto colisōo intergranistor, colocom-se em posiçõo de menor resisténcio oo fluxo odjocente.

2)

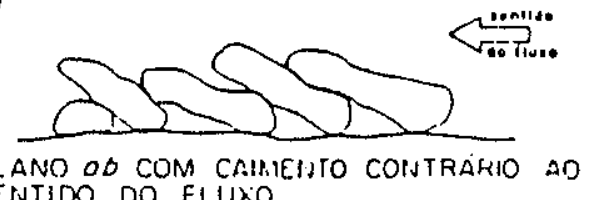
SENTIDO DO FLUXOO

Clustos arrostadas (predominoniemente) ou roto dos eni larno do eixo a. Ao estocionorem nó funco encontram posiçōo mais estovel imbicon do.se ulis scbre outros

FIGURA I.7 - Modelo de comportamento de clastos durante transporte através de arrasto e rolamento por uma corrente fluvial (extraida de Coimbra et al., 1992a). 


\subsection{Procedimentos adotados}

Procedeu-se da forma seguinte, conforme as recomendações de Teixeira (1995):

Nos trabalhos de campo:

- Freqüente medida da atitude do acamamento (So), muitas vezes no mesmo afloramento;

- Atenta observação do sentido de topo e base das camadas passíveis de extração de medidas de paleocorrentes ou não, conforme as estruturas primárias encontradas;

- Descrição pormenorizada da(s) estrutura(s) medida(s), incluindo-se tipo, forma, dimensões, orientação, espessura dos estratos, croqui e localização nele das medidas;

- Sentido do paleofluxo segundo (i) o mergulho da camada, ou o rumo do dip das camadas (notação Clar), tomadas a partir da concavidade dos estratos frontais (foresets) de estratificações cruzadas acanaladas, ou (ii) sentido de caimento das lâminas frontais dos estratos cruzados de estratificações cruzadas tabulares e/ou tangenciais na base, ou ainda (iii) a direção ortogonal à assimetria de cristas de marcas onduladas;

- Estudo de paleocorrentes através de medidas sistemáticas em (1) estratos frontais (foresets) de estratificações cruzadas acanaladas e/ou tabulares (com visualização em 3D, vide FIGURA I.5), com um mínimo de 1 medida por foreset em cada camada, de acordo com Bigarella et al. (1969), Potter \& Pettijohn (1977), Miall (1974; 1977; 1984), Graham (1988), Tucker (1989), Miall (1990) e Assine (1994), tentando-se obter um número $n$ mínimo de 7 medidas por estação (o ideal deve ser $7 \leq n \leq 30$ ) de forma a abranger toda a dispersão e obter um vetor médio estatisticamente representativo, (2) marcas ou indicações de corrente como marcas de sola, bastando 1 (uma) medida por camada conforme Potter \& Pettijohn (1977), (3) marcas onduladas por corrente, (4) imbricações de clastos segundo o caimento dos eixos $b$ (largura) ou a (maior dimensão ou comprimento) de acordo com os métodos de Rust (1972b), Davies \& Walker (1974), Johnson \& Walker (1979), Collinson \& Thompson (1989) e Coimbra et al. (1992a), (5) variações de fácies e de granulometria.

No laboratório e gabinete:

- as medidas obtidas foram reunidas por região, ou estação, de acordo com a proximidade dos pontos de coleta e divididas conforme a associação faciológica e o tipo de dado de paleocorrentes (fluvial, turbidítica);

- para cada estação, as medidas foram ordenadas em classes de $30^{\circ}$, cujas porcentagens foram exprimidas em diagramas circulares de frequiência, as rosetas, de acordo com Assine (1994), permitindo assim a visualização da dispersão dos valores de paleocorrentes;

- plotagem manual dos pólos das lâminas frontais (foresets) dos estratos cruzados em diagrama de igual área SCHMIDT-LAMBERT, projetados no hemisfério inferior;

- plotagem dos pólos de acamamento (So) em diagrama igual ao anterior por processo digital, utilizando-se para isso dos programas Microsoft ${ }^{\circledR}$ STEREONET para Windows; 
- plotagem manual no diagrama acima do pólo médio do acamamento adernado (So) obtido por procedimento igual no computador;

- as medidas obtidas em afloramentos com acamamento adernado tiveram que ser corrigidas do efeito tectônico;

- procedeu-se à horizontalização do acamamento basculado tectonicamente, i.é., mergulhos acima de $10^{\circ}$ (FIGURA I.8). Com os dois pólos médios plotados (de So e paleocorrentes), moveu-se o pólo de So no sentido anti-horário até este coincidir com a reta do equador no diagrama. Desta feita, o pólo da paleocorrente encontrou uma curva do círculo mínimo;
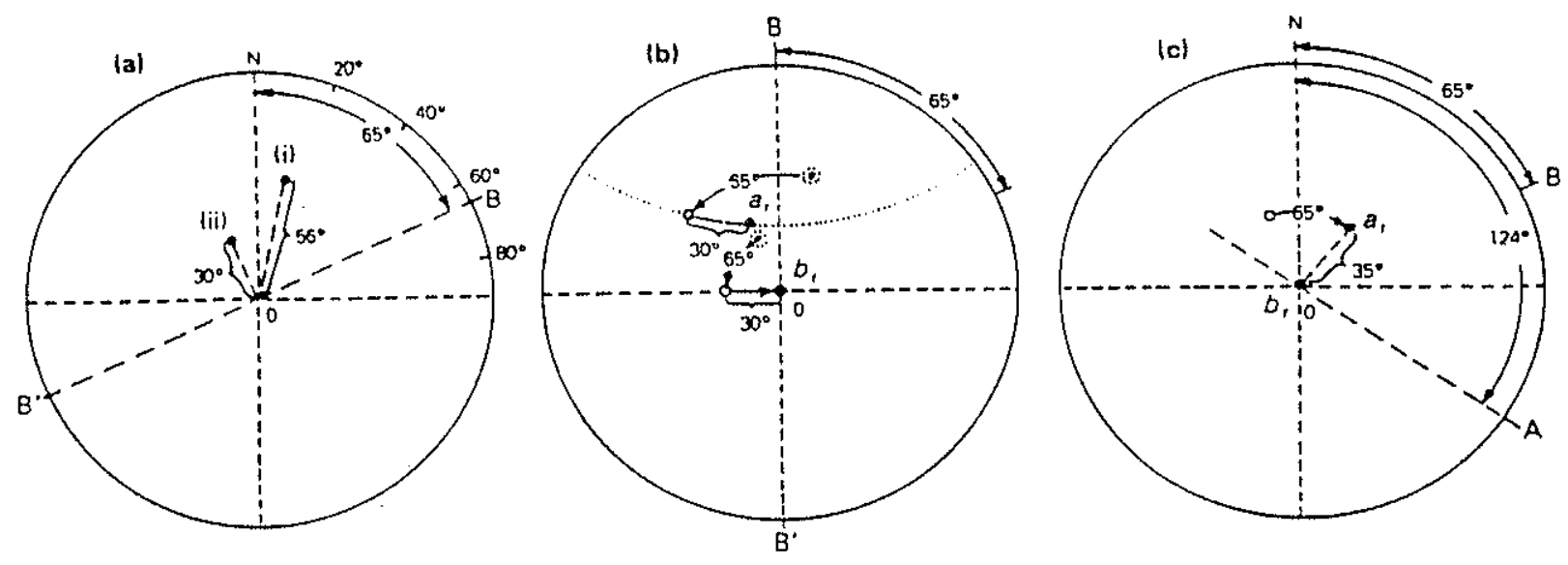

FIGURA I.8 - Procedimentos adotados para a correção de paleocorrentes em camadas basculadas. Plotase os dados como pólos no hemisfério inferior da rede de SCHMIDT. a) So=N65E/30SE; plano de estratificação cruzada $=N 78 \mathrm{~W} / 56 \mathrm{SW}$. B0B' é a direção da camada: i é o pólo da estratificação cruzada e ii o pólo do acamamento. b) Rotação do acamamento e da estratificação cruzada de $65^{\circ}$ afim de que o pólo do acamamento coincida com o círculo máximo; a seguir leva-se o pólo do acamamento por $30^{\circ}$ no círculo mínimo até $\mathrm{a}_{\mathrm{r}}$; c) Procede-se a rotação no sentido horário de $65^{\circ}$, retornando o estereograma à posição original, de forma que $\mathrm{a}_{\mathrm{r}}$ atinja quadrante NE. Resultado: a atitude original do plano da estratificação era N56W/35SW, isto é, a paleocorrente deposicional dirigia-se para SW com mergulhos de $35^{\circ}$. Modificada de Collinson \& Thompson (1989) e Teixeira (1995).

- a seguir levou-se o pólo de So basculado até o centro do diagrama, devolvendo a posição original, horizontalizando-o;

- com o acamamento horizontalizado, a nova posição do pólo das paleocorrentes representa a atitude original do plano da estratificação à época da deposição, ou seja, constitui o sentido do fluxo deposicional local quando da sedimentação;

- de posse dos planos horizontalizados de So contendo os pólos de paleocorrentes, estes foram plotados em diagramas de roseta (rose diagrams) do programa Microsoft ${ }^{\circledR}$ STEREONET para Windows obtendo-se 
toda a variação e trend de paleocorrentes. Também foram obtidos pelo mesmo programa os vetores médios (mean vector) de paleocorrentes, representados por setas.

- os dados individualizados de paleocorrentes por área escolhida (estação) foram representados por seus vetores médios por região, ou conjunto de afloramentos. Os vetores médios foram calculados conforme método estatístico da variância, exposto em Potter \& Pettijohn (1977), Tucker (1989) e Assine (1994), em que cada valor medido de paleocorrente pode ser tratado como um vetor com direção, sentido e magnitude (intensidade). Com os azimutes medidos $(\alpha)$ e do número de medidas efetuadas (n), foram obtidos para cada agrupamento o azimute do vetor médio $(\mathrm{X})$ e o fator de consistência (f.c.), a partir das seguintes equações (Davis, 1986; Tucker, 1989; Assine, 1994):

$$
\begin{aligned}
& \text { (1) } X=\operatorname{arctg}\left(\sum \operatorname{sen} \alpha / \sum \cos \alpha\right) \\
& \text { (2) } f . c=\sqrt{ }\left(\sum \operatorname{sen} \alpha^{2}\right)+\left(\sum \cos \alpha^{2}\right) / \mathrm{n}
\end{aligned}
$$

- calculou-se, ainda, uma média geral para cada associação faciológica individualizada a partir da média aritmética dos vetores médios obtidos em cada grupo de medidas. 


\section{PARTE II}

\section{CONTEXTO GEOLÓGICO REGIONAL}




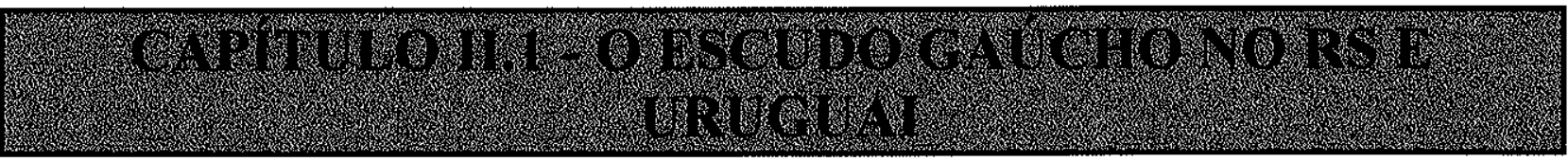

\section{II.1.1 Introdução}

O Escudo Gaúcho é o resultado de uma evolução pretérita bastante peculiar. Conforme as palavras de Jost \& Hartmann (1984) "blocos com grau metamórfico, histórias deformacionais, significados paleogeográficos, ambientes geotectônicos e sedimentares, magmatismo e idades diferentes se justapõem", constituindo um mosaico tectônico recentemente caracterizado como uma colagem de terrenos suspeitos (Fragoso Cesar et al., 1994; Fragoso Cesar \& Machado, 1997), sendo que os depósitos da Bacia do Camaquã situam-se preferencialmente ao longo dos limites destes terrenos (Fragoso Cesar et al., em preparação), condicionados à instalação e reativação de zonas de cisalhamento de direção NE-SW (Oliveira \& Fernandes, 1991; Sayeg et al., 1992). Dada a intima relação entre os depósitos aqui estudados e a estruturação em terrenos do Escudo Gaúcho faremos aqui uma breve discussão sobre estes, precedida por uma sintese sobre os principais modelos geotectônicos já sugeridos para este escudo.

\section{II.1.2 Principais Modelos Geotectônicos}

Issler et al. (1965; in Picada, 1971) tiveram a primazia na tentativa de compartimentar as unidades geotectônicas no Escudo Gaúcho, a saber: (i) “Cráton Dom Feliciano" (complexo granítico-migmatítico da porção leste), e (ii) metamorfitos do Grupo Porongos sensu Goñi et al. (1962), na sua porção centroocidental.

Almeida (1967) promoveu uma integração regional dos conhecimentos geológicos da época em seu seminal trabalho "Origem e Evolução da Plataforma Brasileira", sob a égide da Teoria Geossinclinal, reconhecendo o Grupo Porongos como uma seqüência vulcano-sedimentar "pré-inversão". Já a cobertura foi caracterizada como "pós-inversão". Segundo o autor, "O Grupo Camaquã, por sua litologia, parece constituir vasta espessura de molassa continental vermelha, associada a vulcanismo andesítico pósorogênico."

Em 1969, Almeida estabeleceu uma evolução fanerozóica da Plataforma Brasileira em três estágios: (i) transição, (ii) estabilização e (iii) reativação, interpretando as bacias tidas como molássicas desde Issler et al. (1965) como indicadoras do estágio transicional, relacionando estes espessos depósitos clásticos imaturos ao soerguimento e posterior erosão de cadeias montanhosas do desfecho do Ciclo Brasiliano (Pré-Cambriano superior/Eopaleozóico). Este autor buscou uma correlação com todos os depósitos similares da Plataforma Sul-Americana tais como a Formação Camarinha e o Grupo Guaratubinha, no PR, e o Grupo Itajaí em SC. 
Picada (1971), aprimorando o modelo de Issler et al. (1965), elaborou um quadro evolutivo do Escudo Sul-Riograndense em que se destacam compartimentos separados por grandes sistemas de falhamentos (FIGURA II.I), O autor separou o por ele denominado Geossinclíneo Porongos em intrageossinclinais e intrageoanticlinais do Cráton Dom Feliciano pela Zona de Fraturas Profundas Dorsal do Canguçu.

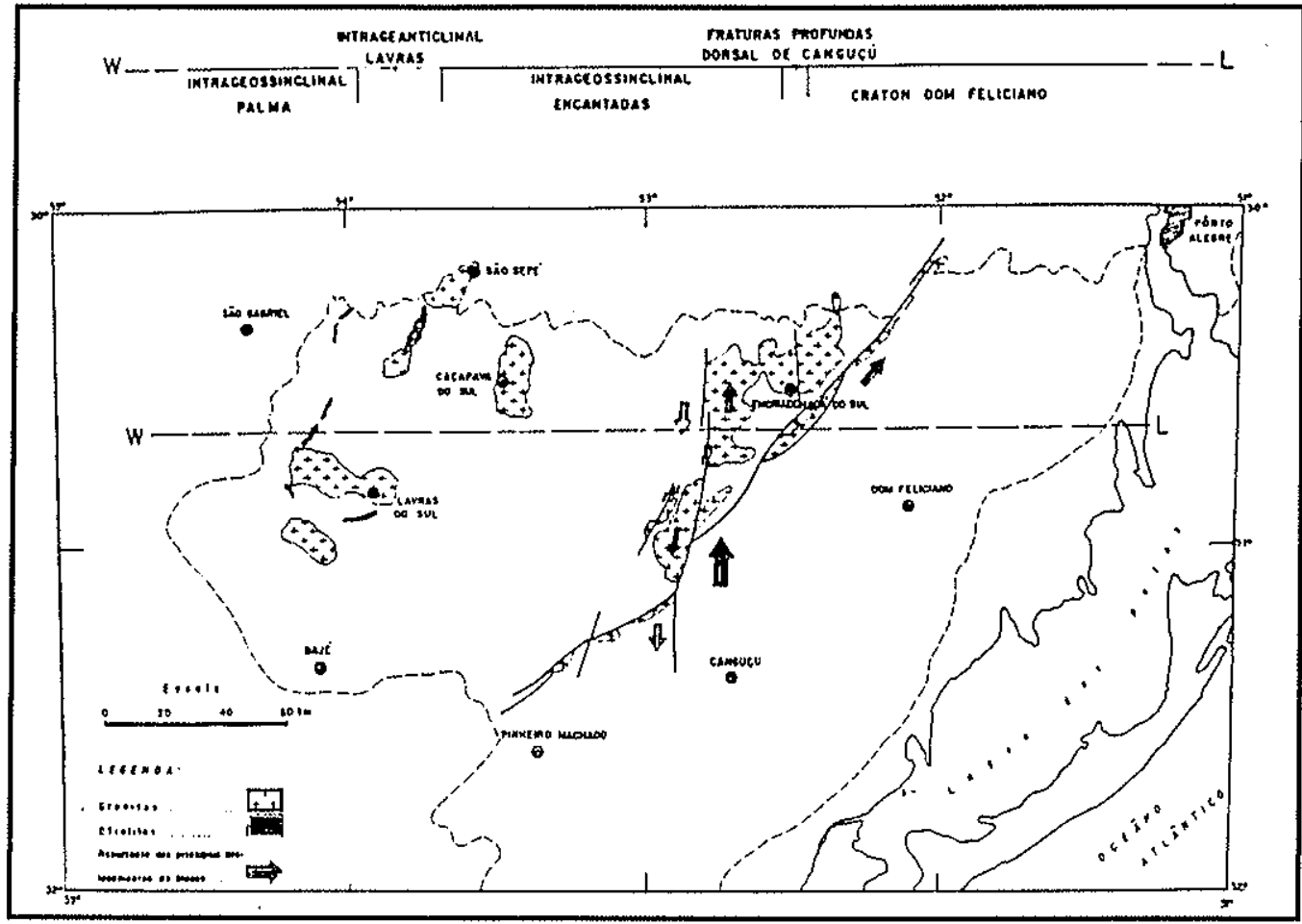

Figura II.1 - Esquema preliminar dos compartimentos tectônicos do Escudo Gaúcho segundo o modelo pioneiro de Picada (1971). Extraída do mesmo.

Ferrando \& Fernandez (1971), defendendo o modelo já desenvolvido por Bossi et al. (1967), compartimentaram o Pré-Devoniano do Uruguai em duas unidades maiores com dados isotópicos K/Ar e $\mathrm{Rb} / \mathrm{Sr}$ : um escudo ocidental e um sudeste. Ao bloco consolidado no Pré-Cambriano Superior da porção ocidental denominaram de "Zócalo Predevoniano de La Cuenca del Rio de La Plata" formado por três faixas de metamorfitos (Arroyo Grande, Paso Severino e Montevideo) intercalados com rochas graníticas e migmatíticas com idades 2100-1670 Ma, comprovando a antiga estabilização deste núcleo. Por outro lado, os autores chamaram de "Zócalo del Este y Sureste" às faixas metamórficas de direção geral NNE do Grupo Lavalleja e Formação Sierra Ballena intercaladas com migmatitos e rochas granitóides de idades variando de 670-490 Ma.

Almeida et al. (1973) denominaram de Cráton Rio de La Plata o terreno consolidado no PréCambriano Superior do Uruguai, limitado a leste pelo Cinturão de Dobramentos Ribeira, de direção preferencial NE, com continuidade para norte ocupando todo o sudeste sul-americano. 
Encerrando essa primeira fase dos modelos geotectônicos sob a influência da Teoria Geossinclinal, Hasui et al. (1975) subdividiram o Cinturão de Dobramentos Ribeira, de NW para SE, em Faixa de Dobramentos Apiá, Maciço Mediano de Joinville, Faixa de Dobramentos Tijucas, Maciço Mediano de Pelotas e Faixa de Dobramentos do Leste do Uruguai.

Somente em 1978 com Ribeiro \& Fantinel inaugurou-se a aplicação da Teoria da Tectônica de Placas no RS. Os autores compartimentaram o Escudo Gaúcho em três zonas de associações petrotectônicas, denominadas de Zona Leste, Zona Mediana e Zona Oeste. As faixas oeste e leste representariam "massas de terra que convergiram" durante o Ciclo Brasiliano, "num regime análogo ao de placas", com o fechamento de uma bacia oceânica cujos restos ofiolíticos situar-se-iam na margem leste da Zona Oeste. A Bacia do Camaquã assentou-se na Zona Mediana intensamente fraturada, após a colisão crustal.

Porada (1979) desenvolveu um modelo para o sudoeste africano considerando que a margem leste sul-americana representaria um arco magmático relacionado à subducção para oeste da margem africana sob a sul-americana e fechamento do pretérito Proto-Oceano Atlântico.

Fragoso Cesar (1980) definiu o Cinturão Dom Feliciano (equivalente redefinido da associação Faixa de Dobramentos Tijucas-Maciço Mediano de Pelotas-Faixa de Dobramentos do Leste do Uruguai de Hasui et al., 1975) como uma faixa móvel de idade proterozóica superior marginal a um núcleo cratônico pré-brasiliano por ele identificado como a continuidade Sul-Riograndense do Cráton Rio de La Plata.

Fragoso Cesar et al. (1982b) correlacionaram o Cinturão Dom Feliciano com os cinturões Damara e Gariep na África, de forma análoga ao modelo de Porada (1979). Estas faixas móveis ter-se-iam originado pela colisão dos Crátons Kalahari e Congo com o Cráton Rio de La Plata, no transcorrer da Orogenia Brasiliana/Pan-Africana, através de subducção para oeste. Os autores definiram, ainda, a Antefossa do Sudeste, entre o Cráton Rio de La Plata e o Cinturão Dom Feliciano, incluindo a Bacia do Camaquã.

Posteriormente, este modelo foi seguido por diversos autores, sendo que Soliani Jr. (1986) expandiu-o incluindo no Cinturão Dom Feliciano parte do que anteriormente era considerado Cráton Rio de La Plata, graças aos inúmeros dados geocronológicos por ele então obtidos.

Brito Neves \& Cordani (1991) destacaram a importância da tectônica de escape nos estágios tardios da aglutinação gondwânica, com reativação de transcorrências em zonas de cisalhamento, formação de bacias pull-apart (dentre as quais a Bacia do Camaquã) e magmatismo bimodal e plutonismo anorogênico alcalino a peralcalino.

O conceito de orogenias superpostas foi introduzido por Fragoso Cesar $(1990,1991)$ no Ciclo Brasiliano, usando como exemplo o Rio Grande do Sul com a pioneira aplicação da definição de terrenos suspeitos (sensu Coney et al., 1980) em áreas pré-cambrianas brasileiras, incluindo a identificação de um terreno exótico tipo arco de ilhas intraoceânico (Terreno Rio Vacacai), inaugurando nova fase de modelos para a evolução geotectônica da região. Em tal modelo, o Escudo Gaúcho originou-se por dois cinturões 
análogos aos de Ribeiro \& Fantinel (1978): Cinturão Dom Feliciano (leste) e Cinturão Ribeira (oeste), este englobando os litotipos referiveis ao Cráton Rio de La Plata do modelo anterior, gerado pela interação do Continente Rio de La Plata com o Oceano Charrua, então definidos.

Na edificação do Cinturão Dom Feliciano concorreram: (i) Orogenia Piratini (845/775 Ma) gerando um arco cálcio-alcalino andinotipo; (ii) Orogenia Porongos (650/620 Ma), onde este arco foi obductado sobre a margem oriental do Continente Rio de La Plata; (iii) Orogenia Serra do Herval (570/530 Ma), caracterizada pela colisão do conjunto anterior com o Cráton Kalahari, pondo termo ao Oceano Adamastor de Hartnady et al. (1985).

A formação do Cinturão Ribeira deveu-se à (i) Orogenia Rio Vacacai (770/650 Ma), onde se desenvolveram arcos de ilhas no interior do Oceano Charrua com provável subducção para oeste; (ii) Orogenia Vila Nova $( \pm 650 \mathrm{Ma})$, onde o sistema de arcos de ilhas foi obductado sobre a margem ocidental do Continente Rio de La Plata. Por fim, durante a (iii) Orogenia Bom Jardim (620/530 Ma), uma subducção com mergulho para leste afetou o conjunto acrescido, gerando o Arco Magmático Bom Jardim e suas coberturas vulcano-sedimentares.

Com base em tal esquema tectônico, Sayeg et al. (1992a) evidenciaram a formação da Antefossa Arroio dos Nobres no vale do Boici concomitantemente à Orogenia Serra do Herval (deposição do Flysch Vale do Piquiri), associada "à instalação de extensas zonas de falha com rejeito levógiro deformando distintos blocos crustais", com polaridade compressional para W-SW. Na etapa tardi-orogênica, bacias pull-apart e altos do embasamento foram superimpostos à antefossa originando os depósitos da Molassa Vargas. Na fase pós-orogênica, instalou-se uma bacia transtensional, a Bacia Intermontana Camaquã, de acordo com Fragoso Cesar et al. (1992).

Oliveira \& Fernandes (1992) propuseram que a sedimentação inicial destas bacias ocorreu nos estágios finais de evolução do Cinturão Dom Feliciano no Rio Grande do Sul, enfatizando que se desenvolveram sob condições transpressivas sinistrais em ambiente intracontinental e que não constituíam molassas.

Dando continuidade aos modelos de Fragoso Cesar et al. (1982b) e Soliani Jr. (1986), Fernandes et al. (1992) elaboraram um modelo evolutivo para a estruturação do Escudo Gaúcho ao longo do Proterozóico Superior/Eopaleozóico a partir da subducção oblíqua da crosta oceânica sob a borda oriental do Cráton Rio de La Plata com o fechamento do Oceano Adamastor. Neste estágio, a Magmatic Arc Assemblage I (MMA I) foi gerada e irrompeu-se uma bacia de retroarco havendo a deposição das seqüências supracrustais Porongos e Vacacai ( $\pm 850 \mathrm{Ma}$ ). Seguiu-se a colisão entre o Cráton Kalahari e a MAA I, originando deformação tangencial com transporte para W e NW. A formação da Magmatic Arc Assemblage II (MMA II), em cerca de $650 \mathrm{Ma}$, deu-se nesta fase com o encerramento da bacia de retroarco através de subducção para W (?). Por fim, a associação Cráton Kalahari-MMA I colidiu com o Cráton Rio de La Plata, cuja deformação alojou-se em zonas de cisalhamento transcorrentes e tangenciais com direção NE. 
O Escudo Gaúcho "é o produto da aglutinação neoproterozóica de fragmentos litosféricos amalgamados" e conseqüente consumo de litosferas oceânicas de acordo com Fragoso Cesar et al. (1994). Sob este prisma mobilista, o Escudo Gaúcho apresentaria uma placa central -referida como Placa Rio de La Plata - que se comportou como um anteparo frente à acresção neoproterozóica do Terreno Piratini (a leste) e do Terreno Rio Vacacai (a oeste), interpretados como restos de duas pequenas placas.

Fruto do aperfeiçoamento recente, Fragoso Cesar \& Machado (1997) consolidaram as bases da estruturação do Escudo Gaúcho em terrenos suspeitos. A FIGURA II.2 esquematiza a distribuição dos terrenos e suas relações com o Cráton Rio de La Plata. Considerando a movimentação tectônica destes terrenos em relação à região cratônica referencial, dois grupos são identificados pelos autores: (1) terrenos transportados de oeste (terrenos Rio Vacacai e Valentines), refletindo o fechamento de um oceano proterozóico ocidental - Oceano Charrua -, e (2) terrenos transportados de sul (terrenos Tijucas, Cerro da Árvore, Serra dos Pereira, Encruzilhada, Pelotas e Rocha), possivelmente relacionados ao fechamento do Oceano Adamastor.

\section{II.1.3 Terrenos do Escudo Gaúcho}

Uma breve resenha sobre os terrenos do Escudo Gaúcho e de seu presumível referencial tectônico, - Cráton Rio de La Plata, faz-se aqui necessária por dois motivos: (i) a distribuição da unidade estudada Grupo Camaquã - é tectonicamente condicionada pela atividade sin-sedimentar dos limites inter-terrenos, e (ii) as unidades destes terrenos e de suas coberturas anteriores à instalação do Grupo Camaquã serviram de áreas fontes.

O Cráton Rio de La Plata representa um pequeno fragmento cratônico (Terreno Cratônico Rio de La Plata sensu Fragoso Cesar et al., 1998) exposto no sudoeste do Uruguai, formado por uma associação tipo granito-greenstone $(\geq 2.0 \mathrm{Ga}$ ) afetado por enxames de diques máficos toléticos indeformados de idade em torno de $1.8 \mathrm{Ga}$ (Bossi et al., 1993).

O Terreno Rio Vacacai é um arco de ilhas neoproterozóico composto basicamente por escamas tectônicas vergentes para leste de complexos máfico-ultramáficos ofiolíticos, supracrustais vulcanogênicas toleíticas de alta $\mathrm{Al}_{2} \mathrm{O}_{3}$ a cálcio-alcalinas de baixa $\mathrm{K}_{2} \mathrm{O}$ (supracrustais Vacacai) e ortognaisses cálcioalcalinos de baixa $\mathrm{K}_{2} \mathrm{O}$ (gnaisses Cambai), tendo sua evolução ocorrida entre 900 e $700 \mathrm{Ma}$.

0 Terreno Valentines é um fragmento continental com embasamento de idade $\geq 2.0$ Ga afetada por plutonismo e vulcanismo neoproterozóico tardio. Junto ao limite com o Terreno Rio Vacacai encontram-se resíduos de uma cobertura carbonática-siliciclástica proterozóica (e.g. mármores de Caçapava do Sul e do Mudador), além de depósitos rítmicos de baixo grau metamórfico (Formação Ibaré) relacionados à obducção do Terreno Rio Vacacai sobre este.

O Terreno Tijucas, no RS, representa uma lasca tectônica de um fold-and-thrust belt transpressivo com vergência para N estruturado em estilo duplex (Mello, 1993), onde o embasamento pré- 




FIGURA II.2 - Mapa tectônico esquemático do Escudo Gaúcho com destaque para seus terrenos e área cratônica referencial. IBSZ - Zona de Cisalhamento de Ibaré; SYSZ - Zona de Cisalhamento Sarandi del Yi. (in Fragoso Cesar \& Machado, 1997).

brasiliano granítico-gnáissico (Complexo Porongos) apresenta falso aspecto metassedimentar devido à intensa milonitização que o afetou e imbrica pequenas escamas tectônicas da cobertura miogeoclinal proterozóica, cujas exposições contínuas e bem preservadas ocorrem apenas no Uruguai (Miogeoclínio Lavalleja). Considerando as distinções e a falta de continuidade física entre as exposições sul-riograndense e uruguaia, mais recentemente Fragoso Cesar et al. (1998) optaram por separá-las em dois terrenos: Terreno Serra das Encantadas (RS) e Terreno Lavalleja (Uruguai).

O Terreno Cerro da Árvore e o Terreno Serra dos Pereira constituem-se essencialmente por escamas tectônicas vergentes para NW de, respectivamente, rochas metavulcânicas cálcio-alcalinas $(\sim 0,8$ $\mathrm{Ga})$ e metassedimentares de idade incerta. 
O Terreno Encruzilhada compõe-se basicamente de um embasamento gnáissico, localmente em fácies granulito (Lima et al., 1997) intrudido por uma variada gama de rochas graníticas neoproterozóicas tardias, localmente greizenizadas, além de sienitos.

O Terreno Pelotas é formado por diversos blocos sigmoidais limitados por zonas de cisalhamento, internamente constituídos por: (i) granitóides e ortognaisses cálcio-alcalinos (Complexo GraníticoGnáissico Pinheiro Machado) com idades Rb/Sr em torno de $800 \mathrm{Ma}$ (Soliani Jr., 1986; Fragoso Cesar, 1991), (ii) leucogranitos peraluminosos com idades $\mathrm{Rb} / \mathrm{Sr}$ em torno $680 \mathrm{Ma}$ (Preciozzi et al., 1993), preferencialmente introduzidos ao longo dos limites deste terreno com terrenos vizinhos formando sheets foliadas (Leucogranitos Cordilheira); (iii) um batólito granítico multi-intrusivo cálcio-alcalino de alta $\mathrm{K}_{2} \mathrm{O}$ variável de isótropo a milonítico e associado a enxames de diques riolíticos sin-plutốnicos de estruturação segundo NW-SE e NE-SW (Diques Riolíticos Asperezas), com idades Rb/Sr e U/Pb situadas entre 640$550 \mathrm{Ma}$ (Soliani Jr., 1986; Preciozzi et al., 1993; Babinski et al., 1996) e, (iv) pequenos corpos de granitos alcalinos pós-tectônicos de idade ainda não defínida.

O Terreno Rocha, limitado ao extremo SE do Uruguai, corresponde a uma seqüência clástica marinha fracamente metamorfizada e deformada como um fold-and thrust belt vergente para SE. 


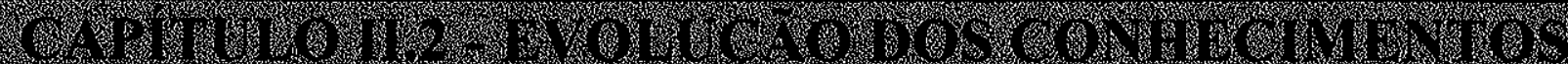
-..1

As ocorrências auriferas e cupriferas motivaram as pioneiras explorações de Gorceix (1875) na região de Lavras do Sul e Caçapava do Sul, consistindo no mais antigo trabalho publicado que tivemos acesso. Seguiram-se o "Mapa Geológico da Zona Mineral do Rio Grande do Sul" realizado por Dahne (1903), referido por Leinz et al. (1941), e o reconhecimento geológico do município de Caçapava executado por Paulino Franco de Carvalho em 1929.

Em seu segundo trabalho, mais conhecido, Carvalho (1932) delineou os grandes grupos de rochas que compõem a estratigrafia do então por ele designado "escudo rio-grandense" na região de Pinheiro Machado-Bagé-Lavras, separando "as rochas do fundamento ou complexo cristalino" em duas grandes unidades. A mais antiga foi referida ao Arqueozóico (Arqueano), composta de "gnaiss, micaxistos, calcáreos dolomíticos, granito, sienito e outros", e as outras, mais jovens, "algonquianas" denominandoas de "Série Porongos", "Filadas de Ibaré" e "Formações Metamórficas das Cabeceiras do Rio Vacacai". Separou, ainda, "Erupções de Andesitos e Tufos Vulcânicos" e a "Série de Camaquan" (ver TABELA II.1), e enquadrou as rochas conhecidas como "formações gondwânicas" na coluna estratigráfica estabelecida por White (1908) em Santa Catarina.

A partir do clássico trabalho de Carvalho (1932), a estratigrafia dos depósitos da "Série de Camaquan" vem sendo paulatinamente revista e modificada. A TABELA II.1 apresenta uma síntese das proposições estratigráficas.

A "Série de Camaquan" deste autor, é constituída por:

1- arenito com palhetas de micas brilhantes na costa do Seival;

2-folhelho argiloso, cerâmico, diversamente colorido, cortado por veios de quartzo;

3- arenito ferruginoso, mais ou menos friável;

4- conglomerados com espessura superior a $100 \mathrm{~m}$, contendo seixos muito variados quanto ao tamanho $e$ origem.

Neste trabalho, Carvalho discutindo o posicionamento estratigráfico da "Série de Camaquan", aponta que "Relações estratigráficas parecem colocar a série no eopaleozóico. Ela é, sem dúvida, posterior às erupções de andesito e, provavelmente, anterior ao permiano. Assim indicam os seus sedimentos bastante movimentados em discordância com os do permiano, largamente ondulados".

Hoje sabemos que, de fato, os sedimentos da "Série de Camaquan" estão sobrepostos aos andesitos e sotopostos à cobertura paleozóica da Bacia do Paraná. Carvalho trabalhou nas regiões a sul do rio Camaquã e a sul do alto de Caçapava e, por esta razão, encontrou somente litologias da sua "Série de Camaquan", não identificando depósitos da Formação Maricá e os derrames riolíticos (ver adiante). Além do mais, não incluiu os depósitos areno-conglomeráticos do Grupo Guaritas, então ainda não definido, possivelmente considerando-os do Permiano. 
No período de 1932 a 1941 destacaram-se trabalhos de cunho econômico, notadamente sobre cobre. Entre estes, encontram-se Carvaiho (1937) sobre os recursos minerais do Rio Grande do Sul, Teixeira (1937) sobre o cobre no Rio Grande do Sul, Barbosa (1939) tratando dos minerais metálicos e Leinz \& Barbosa (1941) a respeito da geologia, mineralização e prospecção da jazida de cobre "Cerro dos Martins", no município de Caçapava do Sul.

Em 1939 Leinz discorreu a respeito do problema geológico do post-Arqueano do Rio Grande do Sul, sobretudo a idade e posição na coluna estratigráfica e a deformação que basculou as camadas da "Série de Camaquam". Neste trabalho, ainda, constatou a presença de unidades sedimentares "em posição horizontal" no caminho para as Minas do Camaquã atribuindo-as à "Serie Camaquan" de Carvalho, contribuindo para a grande confusão estratigráfica que permeou os anos posteriores, atingindo nossos dias.

Leinz et al. (1941), efetuando reconhecimento geológico na região de Caçapava-Lavras do Sul, descobriram seqüências de arcósios com seixos de rochas graníticas e folhelhos subordinados bem representados na Serra do Maricá situada a W de Caçapava do Sul, definindo-as como Formação Maricá, distinta da "Série Camaquan" de Carvalho (1932). Esta última foi redefinida sobreposta à Formação Maricá, compreendendo o resto da cobertura sedimentar pré-gondwânica do Escudo Sul-Riograndense. No topo da estratigrafia foram colocadas as "erupções andesíticas" e o chamado Conglomerado Seival. Leinz e colaboradores assinalaram formalmente a existência do "Camaquã inclinado e Camaquã horizontal", destacando que o último teria sido localmente perturbado pela "erupção andesítica". Apontaram, ainda, "horizontes de arenitos onde poderiam ser descobertos fósseis", o que se verificou logo depois (Dolianiti, 1945; Martins, 1948), então relacionados à Formação Maricá, o que se constituiu em mais um equívoco.

Seguiu-se à descoberta de fósseis, sua identificação e o posicionamento no permo-carbonifero, impelindo alguns pesquisadores a situar a "Série Camaquan" no final do Paleozóico (Martins, 1952; Beurlen et al., 1955; Martins et al., 1955).

Pinto (1955) e Barbosa (1957) resgataram a estratigrafia proposta por Leinz et al. (1941) ao assinalarem a discordância angular existente entre o horizonte fossilífero (então chamado de "afloramento Budó") e a Formação Maricá sotoposta, colocando o mencionado horizonte nos depósitos gondwânicos, encerrando a polêmica.

Trabalhos de reconhecimento geológico regional no período de 1957-1960 na região de Caçapava do Sul-Lavras do Sul, executados por uma equipe mista do DNPM e USGS formada pelo engenheiro Geraldo Conrado Melcher, e pelos geólogos Robert F. Johnson, Henri Mau e Jacques F. Robertson, forneceram subsídios para uma reformulação da estratigrafia da região.

Em 1960, Melcher \& Mau divulgaram o artigo intitulado "Novas observações geológicas na região de Caçapava do Sul", onde propuseram alterações na estratigrafia definida por Leinz et al. (1941). A Formação Maricá passou a ser Série Maricá composta por “...conjunto de folhelhos, grauvacas, conglomerados, pequenas lentes de calcários e vulcânicas básicas e ácidas subordinadas, anteriores à principal fase vulcânica", a erupção de andesitos. Neste trabalho, muito criticado nos posteriores, os 
autores acima incluíram, ainda, na Série Maricá rochas do embasamento cristalino como xistos, filitos e outros metamorfitos circunvizinhos ao stock granítico de Caçapava.

Goñi et al. (1962) redefiniram a Formação Maricá como Grupo Maricá, separando a unidade sedimentar inferior (Formação Maricá de Leinz et al., 1941) da predominantemente vulcânica superior, com as rochas efusivas ácidas (Plateau da Ramada) colocadas na base e as básicas, no topo. Introduziram, ainda, o Grupo Camaquã constituído pelas formações Camaquã e Guaritas, respectivamente, "Camaquã inclinado e Camaquã horizontal" de Leinz et al. (1941), colaborando para a confusão estratigráfica.

Delaney \& Goñi (1963) redefiniram os arenitos fossilíferos das "camadas Budó" como "Fácies Budó", em contato francamente discordante com a Formação Maricá, integrando-os ao Subgrupo Itararé da Bacia do Paraná, encerrando a discussão sobre seu posicionamento estratigráfico.

Considerando as observações de Carvalho (1932) e inconformado com os resultados do levantamento efetuado pela equipe do DNPM/USGS publicado por Melcher \& Mau (1960), Robertson (impresso em 1966 a partir de manuscrito inédito de 1961) redefíniu a "Série Camaquan" como Grupo Camaquã composto pelas formações Santa Bárbara e Guaritas (embora separadas por discordância angular de extensão regional) e o conglomerado Coxilhas, além de preservar a Formação Maricá sensu Leinz et al. (1941), reconhecendo, porém, novas e amplas áreas de ocorrência. Segundo o autor, o Grupo Camaquã assenta-se discordantemente sobre os tufos riolíticos do denominado Riolito da Ramada, em referência ao Plateau da Ramada que se situa a oeste de Caçapava do Sul, onde Almeida (1949) havia reconhecido riolitos e tufos ácidos, e posteriormente Mau $(1959,1962)$ havia identificado ignimbritos. 0 Plateau da Ramada, por sua vez, recobre rochas vulcânicas efusivas de composição básica a intermediária com predomínio de andesitos, designando-as de Andesito Hilário, discordantemente sobrepostos à Formação Maricá. Reconheceu, ainda, a discordância litológica entre os metamorfitos aflorantes no alto de Caçapava do Sul e a Formação Maricá sobrejacente.

Ribeiro et al. (1966) e Tessari \& Picada (1966), efetuando mapeamentos na escala 1:250.000, resgataram a Formação Maricá sensu Leinz et al. (1941) como uma unidade basal sobre a qual repousa discordantemente o que foi por eles denominado Grupo Bom Jardim, dando sua parcela de contribuição para os equivocos estratigráficos. Este grupo foi por estes autores subdividido nas formações Arroio dos Nobres e Crespos (esta composta pelos membros Hilário e Acampamento Velho, equivalentes ao Andesito Hilário e ao Riolito Ramada de Robertson, 1966). A Formação Arroio dos Nobres foi dividida em duas unidades, ainda segundo estes autores: Membro Mangueirão constituído por ritmitos psamo-pelíticos e o Membro Vargas representado por conglomerados e arenitos conglomeráticos. De acordo con estes trabalhos, sobre o Grupo Bom Jardim assenta-se o Grupo Camaquã, incluindo as formações Santa Bárbara (com o Membro Rodeio Velho, equivalente ao "Andesito Martins" de Robertson, 1966, redenominado por Ribeiro et al., 1966) e Guaritas. Estes trabalhos definiram os principais lineamentos NE do Escudo Gaúcho, assim como aqueles NW (perpendiculares ao eixo das bacias do Escudo Gaúcho). 
Ribeiro (1970), executando trabalhos de mapeamento na quadrícula de Bom Jardim, propôs o Grupo Bom Jardim como unidade indiferenciada, argumentando a impossibilidade de sua subdivisão em formações e membros como anteriormente proposta.

Tal reestruturação também foi adotada por Ribeiro \& Carraro (1971). Carraro et al. (1974) porém, restituíram a divisão original do Grupo Bom Jardim.

Cordani et al. (1974) elevaram o Membro Acampamento Velho da Formação Crespos de Ribeiro et al. (1966) à categoria de formação com base em estudos radiométricos $\mathrm{K} / \mathrm{Ar}$ e $\mathrm{Rb} / \mathrm{Sr}$.

Ao elaborarem uma síntese da geologia do Rio Grande do Sul, Ribeiro \& Fantinel (1978) englobaram a Formação Maricá no Grupo Bom Jardim, subdividindo-o em quatro formações: Maricá (basal), Hilário, Vargas e Acampamento Velho. O Grupo Camaquã permaneceu de acordo com a proposta estratigráfica de Ribeiro et al. (1966), isto é, composto pelas formações Santa Bárbara e Guaritas. Ainda neste ano, Ribeiro \& Lichtemberg (1978) agruparam na Formação Santa Bárbara os Andesitos Rodeio Velho e o membro Lanceiros e subdividiram a Formação Guaritas em dois membros: Camadas Guarda Velha (inferior) formadas por unidades rudáceas, e Camadas Varzinha (superior) compostas por arenitos vermelhos e pelitos, dispostas em estratos de grande continuidade lateral.

Em 1978, Santos e colaboradores redefiniram o Grupo Bom Jardim como Grupo Maricá (PréCambriano Superior a Eo-Cambriano), composto pelas formações Pessegueiro (Maricá de Leinz et al., 1941), Cerro dos Martins (com os membros Hilário e Arroio dos Nobres sensu Ribeiro et al., 1966) e Acampamento Velho.

Becker \& Fernandes (1982), estudando depósitos análogos aos do Grupo Camaquã na região do Passo do Tigre, identificaram ambientes de leques aluviais e de planícies aluviais e eólicas, com base na pioneira aplicação do conceito de fácies e utilização de paleocorrentes nestas coberturas.

Em seu modelo de 1982 com base na Tectônica de Placas, Fragoso Cesar e colaboradores instituíram a Associação Molássica Sedimentar como preenchimento da denominada Antefossa do Sudeste, composta pela Formação Arroio dos Nobres (sensu Tessari \& Picada, 1966) e Grupo Camaquã (sensu Robertson, 1966). Os autores englobaram as Formações Hilário (sensu Ribeiro \& Fantinel, 1978 - na base) e Acampamento Velho (sensu Cordani et al., 1974 - no topo), situadas na borda oriental do Cráton Rio de La Plata (sensu Fragoso Cesar, 1980) na Associação Molássica Plutono-Vulcano-Sedimentar (Fragoso Cesar et al., 1982a, b).

Posteriormente, em trabalho de cunho regional e integrador, Fragoso Cesar et al. (1984) propuseram que todo o conjunto molássico fosse informalmente dividido em molassas precoce e tardia por suas distintas características tectônicas e estratigráficas. Neste trabalho, "entendendo que o conjunto molássico deve ser englobado em uma única unidade estratigráfica maior, voltamos à definição original de Carvalho (1932), reunindo-as no Grupo Camaquã ("Série de Camaquan”)”.

Em seguida, promovendo ampla revisão na estratigrafia da cobertura molássica com redefinição e descrição das unidades, Fragoso Cesar et al. (1985) formalmente atribuíram denominações às molassas 
precoce e tardia de Fragoso Cesar et al. (1984), respectivamente, Formação Maricá e Formação Guaritas, mantendo a Formação Acampamento Velho para os vulcanitos ácidos superiores. A Formação Maricá compreendendo os membros Mangueirão, Vargas, Pessegueiro e Hilário, e a Formação Guaritas tendo sido subdividida em associações de fácies e no Membro Rodeio Velho, contribuindo também para aumentar a confusão na estratigrafia das coberturas do Escudo Gaúcho.

Lavina et al. (1985) fizeram um levantamento detalhado dos ambientes formadores da Bacia do Camaquã, enfatizando os processos deposicionais envolvidos e fornecendo os elementos para a elaboração de um quadro paleogeográfico mais pormenorizado da região.

Faccini et al. (1987) valeram-se do mesmo enfoque estratigráfico e sedimentológico de Fragoso Cesar et al. (1985) e Lavina et al. (1985), respectivamente, ao estudarem o contato das duas grandes seqüências referidas anteriormente na região das Minas do Camaquã, utilizando análise de fácies no estudo das coberturas.

Ao mapearem a Folha Passo do Salsinho, a W de Caçapava do Sul, Leites et al. $(1990,1992)$ reconheceram quatro seqüências vulcano-sedimentares despojando-se da estratigrafia formal, através da aplicação dos conceitos de fácies e sistemas deposicionais: (1) Seqüência Vulcano-Sedimentar I, correspondente à Formação Maricá (sensu Leinz et al., 1966) ou à Formação Pessegueiro (sensu Santos et al., 1978) compreende conglomerados a pelitos com vulcânicas riolíticas intercaladas; (2) Seqüência Vulcano-Sedimentar 2, correspondente à Formação Cerro dos Martins (sensu Santos et al., 1978), compõe-se de conglomerados, arenitos grossos a finos e pelitos com intercalações de vulcânicas andesíticas, brechas vulcânicas e tufos; (3) Seqüência Vulcano-Sedimentar 3, de natureza predominantemente vulcânica, correspondendo à Formação Acampamento Velho de Cordani et al. (1966), constitui-se de riolitos, tufos e ignimbritos; (4) Seqüência Vulcano-Sedimentar 4, correspondente ao Grupo Camaquã de Robertson (1966) constitui-se de ortoconglomerados e arenitos grossos mal selecionados na porção SE da área mapeada.

Fragoso Cesar (1991), calcado em estudos de cunho regional, sugeriu uma reinterpretação das sucessões "molássicas" separando-as em função do contexto tectônico e paleogeográfico em que estão inseridas. Esta proposição postulava que existiam duas seqüências molássicas relacionadas a orógenos distintos. A primeira, a leste, mais antiga, estaria relacionada à estruturação do Cinturão Dom Feliciano e representada pela Antefossa Camaquã, cuja evolução acha-se intimamente ligada aos eventos tardicolisionais brasilianos englobados na Orogenia Serra do Herval (570 a $530 \mathrm{Ma})$. A outra sequêencia, a oeste, mais jovem, relacionar-se-ia ao desenvolvimento e estruturação do Cinturão Ribeira e estaria representada pela Bacia de Retro-Arco Santa Bárbara. Este autor, pelos motivos acima expostos, restringiu - Grupo Camaquã apenas às unidades da Antefossa Camaquã, excluindo aquelas situadas a oeste, tanto as da Bacia de Retro-Arco Santa Bárbara como as da borda ocidental da Bacia do Camaquã. O Grupo Camaquã, conforme redefinido pelo citado autor, é constituído por duas formações: Formação Arroio dos 
Nobres (Tessari, 1965), com os membros Flysch Vale do Piquiri e Molassa Vargas, e Formação Guaritas (Robertson, 1966), separadas por discordância angular regional.

Oliveira \& Fernandes (1991) atribuíram à extensa calha sedimentar do Vale do Piquiri uma origem transcorrente sinistral (strike-slip basin) identificando depósitos correlacionados à Formação Arrroio dos Nobres (sensu Ribeiro et al., 1966), como atestam suas palavras: “... representam remanescentes de bacias individualizadas durante o sistema transpressivo responsável pela estruturação final do Cinturão Dom Feliciano".

Paim et al. (1992) apresentaram uma proposta de divisão das coberturas vulcano-sedimentares pré-gondwânicas do Escudo Gaúcho em três seqüências deposicionais baseada nos conceitos de Sloss (1969) e Galloway (1989), individualizadas por eventos transgressivos. A Seqüência Deposicional I corresponderia à Formação Maricá (Leinz et al., 1941), principiando com um sistema fluvial (Ia) seguido de um sistema marinho colmatado por um sistema deltaico-aluvial (Ib). A Seqüência Deposicional II compreenderia, na base, depósitos deltaico-aluviais com vulcânicas intercaladas (Ila), equivalentes ao Grupo Bom Jardim de Ribeiro et al. (1966) e depósitos de leques aluviais progradantes (IIb e IIc), equivalentes à Formação Santa Bárbara de Robertson (1966). Por último, a Seqüência Deposicional III eqüivaleria à Formação Guaritas de Robertson (1966), situando na base um sistema desértico (IIIa) com efusivas andesíticas intercaladas, seguido por depósitos deltaico-aluviais (IIIb). Indubitavelmente, este trabalho é uma grande contribuição à estratigrafia da região por propor um temporário abandono de termos que ultimamente somente vinham semear confusão. Em contrapartida, sugeriram uma divisão a partir de sistemas deposicionais englobados em eventos cíclicos (ou seqüências) separados por discordâncias ou superficies de inundação (flooding surfaces), abundantes na Bacia do Camaquã. Os autores, ainda, reportaram a identificação inédita de traços fósseis na região das Minas do Camaquã e no vale de Santa Bárbara, que Netto et al. (1992) dividiram em associações representativas do Vendiano e Cambriano.

Sayeg et al. (1992a, b) e Machado \& Sayeg (1992) assinalaram uma origem transcorrente sinistral para a Bacia do Vale do Boici em função das características dos depósitos, forma alongada da calha, do padrão de paleocorrentes e, sobretudo, da cinemática dos falhamentos, notadamente os de Torrinhas e Açotéia-Pedras Altas-Passo Real (sensu Tessari \& Giffoni, 1970), que limitam a bacia e, a Falha do Boici, separando os membros Flysch Vale do Piquiri e Molassa Vargas (sensu Fragoso Cesar, 1991).

Paim (1992) apresentou uma visão detalhada sobre os depósitos aluviais da Formação Guaritas na esteira da estratigrafia de seqüências, relacionando as fácies a dois subambientes aluviais desenvolvidos a partir de ambas as bordas: 1- na porção $\mathrm{E}$ da bacia com paleocorrentes perpendiculares ao eixo da bacia $\mathrm{e}$ maior dispersão do padrão; 2- a W mostrando padrão de paleocorrentes longitudinais interpretado como um modelo de trunk river.

Fambrini et al. (1992a, b) realizaram estudos de áreas-fontes da Formação Arroio dos Nobres no Vale do Boici através da aplicação de análises petrográficas e estratigráficas de proveniência e de paleocorrentes. Concluiram que a unidade basal Flysch Vale do Piquiri recebeu suprimento sedimentar de 
rochas supracrustais e de litotipos do Batólito Pelotas situados a leste, com ligeiro predomínio dos últimos para o topo da seqüência, atestando a erosão deste. Análises de paleocorrentes respaldaram tais afirmações. A unidade sobrejacente, Molassa Vargas, caracterizada por sistemas de leques aluviais em ambas as bordas com paleocorrentes para NW-W e E-SE, apresenta carga sedimentar proveniente, respectivamente, em um primeiro momento, do Batólito Pelotas e terrenos supracrustais expostos na base da seqüência e, tardiamente, do terreno Serra das Encantadas exemplificados pelos fragmentos de milonitos e mármores para o topo, marcando a ascensão deste terreno a oeste individualizando a região do Vale do Boici como uma bacia separada por altos do embasamento.

Sayeg (1993) reiterou estas proposições anteriores evidenciando duas distintas etapas da Orogenia Serra do Herval. $O$ autor constatou que "o desenvolvimento destes falhamentos é seguido pela colocação de corpos graníticos da Suíte Dom Feliciano do Batólito de Pelotas gerando uma cadeia de montanhas", cujo soerguimento e erosão sinaliza a inversão da Bacia do Vale do Boici. Esta passa de um contexto deposicional de leques subaquáticos para ambientes transicionais (costeiros) e continentais, por meio de bruscas variações de fácies, representados na Molassa Vargas. Esta compõe-se de sistemas fluviais braided e leques aluviais associados, de caráter autofágico proeminente. A instalação de possantes leques aluviais relacionados à borda NW (Terreno Serra das Encantadas) registra o surgimento da Bacia do Boici como uma bacia individualizada indicando o alçamento dessa serra durante as fases finais da evolução da Orogenia Serra do Herval. O autor concluiu que a Bacia do Boici "pode ser considerada uma bacia transcorrente gerada em uma importante zona de cisalhamento responsável pela instalação das principais entidades do Cinturão Dom Feliciano...", em uma provável zona de sutura da crosta.

Os conceitos de Aloestratigrafia foram pioneiramente introduzidos por Paim (1994) nos depósitos da Bacia do Camaquã onde, através de análises de sistemas deposicionais conjugadas com estudos de paleocorrentes, propôs uma divisão dos pacotes com base na Estratigrafia de Seqüências modificando substancialmente as proposições anteriores, aplicando denominações mais locais aos eventos cíclicos encontrados na bacia.

Caravaca et al. (1995) realizaram estudos de proveniência na sub-bacia Vale do Piquiri, cuja evolução foi similar à região do Arroio Boici, inicialmente com o aporte de detritos dos terrenos metamórficos adjacentes e, com a erosão de níveis crustais mais profundos, clastos de rochas gnáissicas e supracrustais foram carreados, além de intraclastos, com transporte sedimentar para $\mathrm{N}$ paralelo ao eixo principal. Clastos de sienitos e granitos a duas micas, respectivamente, do Sienito Piquiri e do Terreno Encruzilhada do Sul, com paleocorrentes para SW, registram a inversão da bacia na região.

Paim et al. (1995), dando prosseguimento à aplicação da aloestratigrafia ao preenchimento da Bacia do Camaquã, dividiram as exposições em alogrupos Maricá, Bom Jardim, Santa Bárbara e Guaritas.

A TABELA 11.1 apresenta sinteticamente as principais propostas de classificação aplicadas às coberturas do Escudo Gaúcho. 
Fambrini, G.L. = O Grupo Camaquã: análise de fácies, proveniência e paleocorrentes

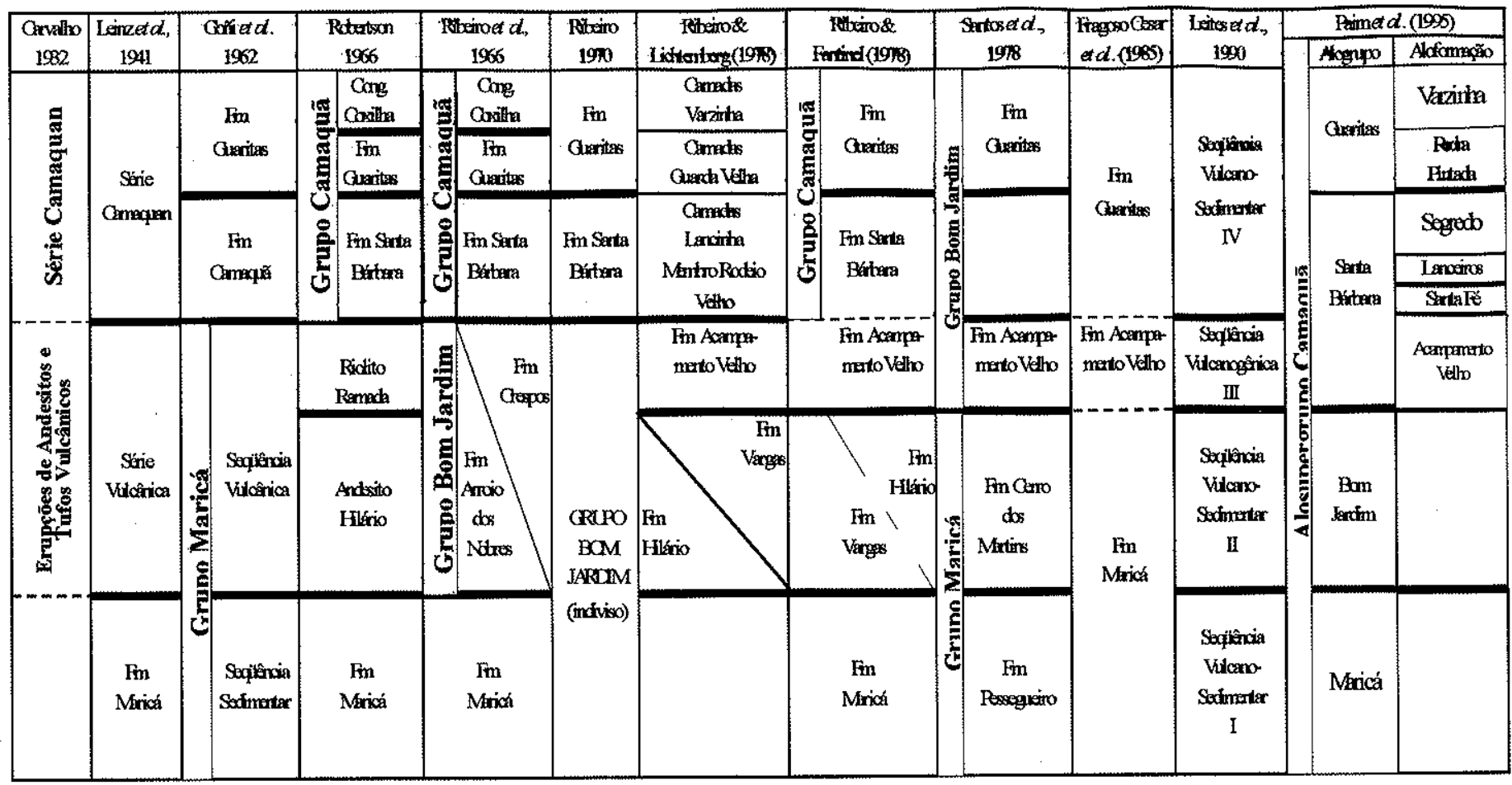

Thpos decontato

\begin{tabular}{|c|c|}
\hline Dasoconâncọa & $\cdots \quad$ Inciscrinimado \\
\hline
\end{tabular}

TABela II.1 - Propostas litoestratigráficas para o empilhamento dos sedimentos das coberturas do Escudo Gaúcho, incluindo-se o Arco Bom Jardim. Modificada a partir de Fragoso Cesar (1984), Sayeg (1993) e Paim et al. (1995).

Considerando, conjuntamente, estes avanços recentes na estratigrafia destas coberturas com os conhecimentos acumulados por nossa equipe, Fragoso Cesar et al. (em preparação) propõem nova coluna litoestratigráfica abaixo discriminada (QUADRO II.1), que será a utilizada na presente dissertação.

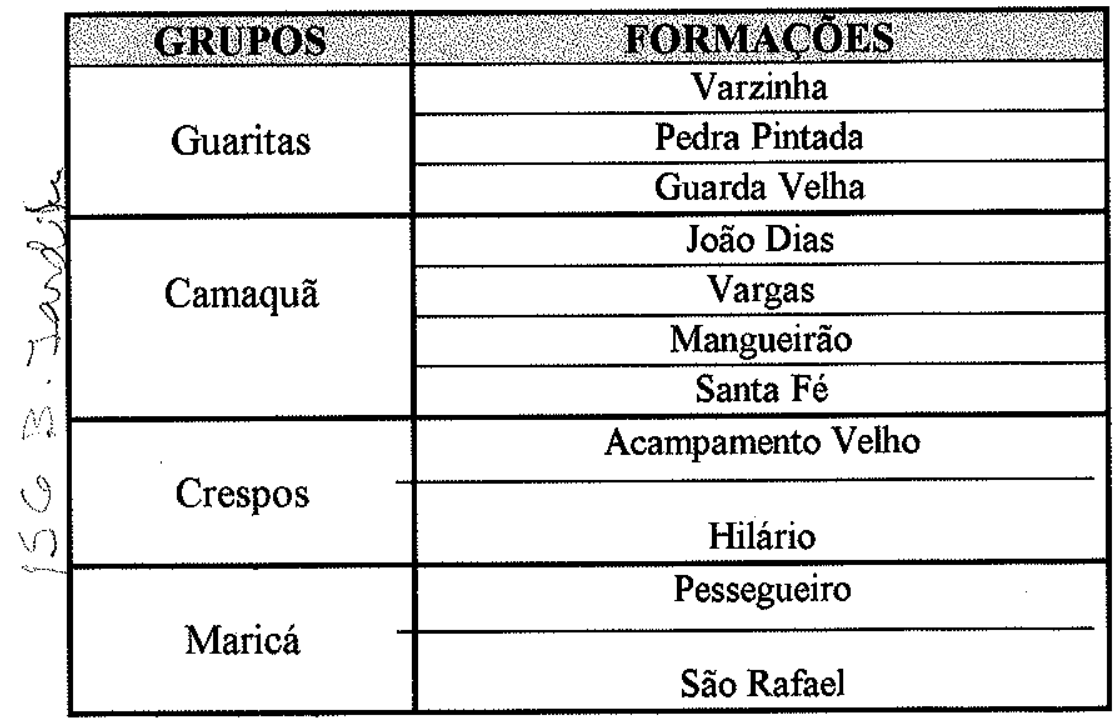

QuADro II.1 - Proposta litoestratigráfica para o empilhamento dos sedimentos das coberturas do Escudo Gaúcho de Fragoso Cesar et al. (em preparą̧ão). 
Na porção Sul-Riograndense do Escudo Gaúcho visualizam-se quatro unidades de cobertura, separadas por discordâncias regionais e limites tectônicos (FIGURA II.3): (i) Grupo Maricá; (ii) Grupo Crespos; (iii) Grupo Camaquã e (iv) Grupo Guaritas (Fragoso Cesar et al., em preparação).

De acordo com esse modelo a distribuição dessas unidades em relação aos terrenos é sintomática de suas evoluções durante os arranjos tectônicos desses: o Grupo Maricá é restrito ao Terreno Rio Vacacai; o Grupo Crespos ocorre sobre os terrenos Rio Vacacai e Valentines; o Grupo Camaquã, distintamente dos anteriores, ocorre sobre todos os terrenos no RS, com suas cunhas clásticas claramente condicionadas aos limites tectônicos desses; o Grupo Guaritas ocorre predominantemente sobre os terrenos Serra das Encantadas e Valentines, porém, localmente, extravasa os limites destes.

Esta distribuição evidencia:

(i) que a evolução do Grupo Maricá afetou apenas o Terreno Rio Vacacai não possuindo ocorrências sobre outros terrenos, sugestiva de que a sedimentação deste grupo precedeu à colagem dele com o Terreno Valentines;

(ii) que a evolução do Grupo Crespos afetou tanto os terrenos Valentines e Rio Vacacai, isto é, nas épocas de suas evoluções esses terrenos já estavam tectonicamente unidos entre si, porém ainda não justapostos aos demais;

(iii) que a evolução do Grupo Camaquã já afetou todos os terrenos, sendo concomitante à justaposição tectônica entre eles, permitindo que o estudo de sua evolução deposicional e tectônica, através de análise de proveniência e paleocorrentes, traga subsídios fundamentais para o entendimento dessa colagem tectônica e,

(iv) que a evolução do Grupo Guaritas foi posterior à colagem tectônica, indicando que a região ocupada pelos terrenos Serra das Encantadas e Valentines foi, parcialmente, nessa época, um baixo deposicional na forma de um gráben.

De acordo com essa estruturação, abaixo faremos uma breve síntese destas unidades de cobertura.

\subsubsection{Grupo Marica}

Os depósitos do Grupo Maricá encontram-se imediatamente em contato com o embasamento granítico e metamórfico do Terreno Rio Vacacai. Leinz et al. (1941) descobriram-nos e os cunharam de Formação Maricá. De acordo com Fragoso Cesar et al. (em preparação), este grupo é composto por duas formações: (i) Formação São Rafael, constituída por arenitos arcoseanos, localmente conglomeráticos, de origem fluvial, cujas medidas de paleocorrentes em seus estratos cruzados indicam transporte sedimentar preferencialmente para E (Paim et al., 1992; Paim, 1994), sobreposta pela (ii) Formação Pessegueiro, constituída por espessos pacotes de turbiditos psamo-pelíticos indicando um episódio de ampla transgressão marinha que, em sentido ao topo, gradam para depósitos deltaicos. Medidas disponiveis de paleocorrentes nas seqüências turbidíticas indicam transporte para $\mathrm{E}$ e, subordinadamente, NE (Leites et al., 1990; Paim et al., 1992; Paim, 1994). 


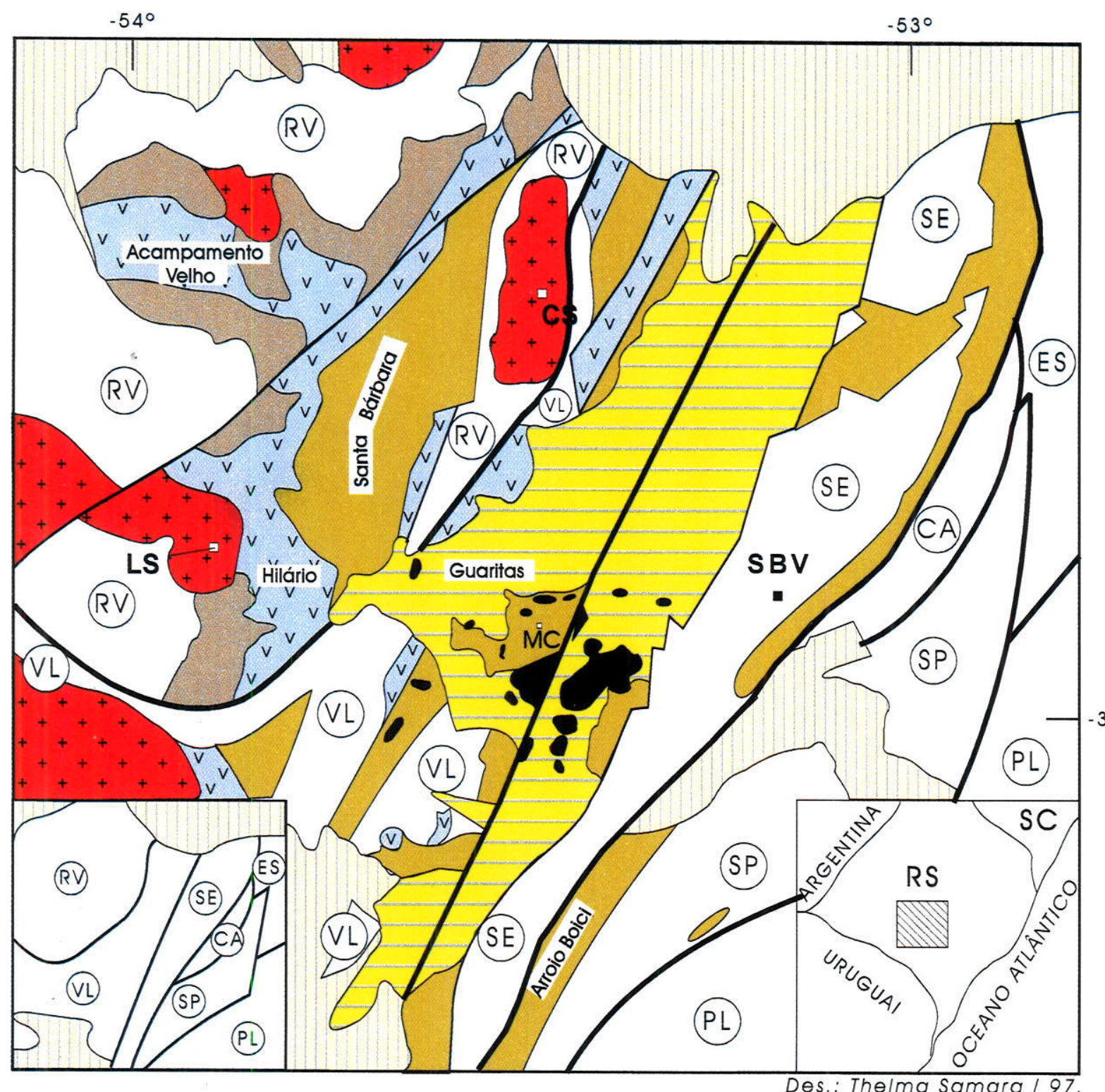

\section{LEGENDA}

BACIA DO PARANÁ

(Neopaleozóico-Mesozóico)

- Sills máficos rodeio Velho (Paleozóico)

\section{BACIA GUARITAS}

(Eopaleozóico)

BACIA CAMAQUÃ

(Limite Neoproterozóico III Cambrianol

\section{ARCO BOM JARDIM}

(Neoproterozóico III - Superior)

BACIA MARICÁ

(Neoproterozóico III)

$-31^{\circ}$

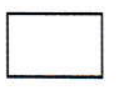

TERRENOS DE EMBASAMENTO

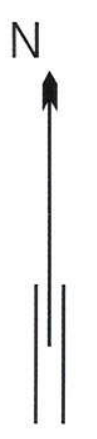

$20 \mathrm{~km}$

Figura II.3 - Mapa tectônico e geológico esquemático do Escudo Gaúcho no Rio Grande do Sul destacando as unidades de cobertura e os limites entre terrenos. Siglas dos terrenos: RV- Rio Vacacai; VL- Valentines; SE- Serra das Encantadas; CA- Cerro da Árvore; ES- Encruzilhada do Sul; SP- Serra dos Pereiras; PL- Pelotas. Localidades: SBV-Santana da Boa Vista, CS- Caçapava do Sul, LS- Lavras do Sul, MC- Minas do Camaquã (de Fragoso Cesar et al., em preparação). 
A ocorrência de assembléias de icnofósseis na seqüência de topo denuncia deposição no Vendiano Superior (Netto et al., 1992). Dados radiométricos obtidos no Granito Lavras do Sul, intrusivo neste grupo, fornecem diversas idades: (i) $568 \pm 6$ Ma pelo método $\mathrm{Rb} / \mathrm{Sr}$ (Vieira Jr. \& Soliani Jr., 1989); (ii) $580 \pm 6$ Ma pelo método SCHRIMP U/Pb em zircão (Leite, 1995); (iii) $592 \mathrm{Ma}$ em isócrona de referência $\mathrm{Pb} / \mathrm{Pb}$ em rocha total (Remus et al., 1997).

Esta unidade dispõe-se discordantemente acima do embasamento metamórfico cuja idade mínima é de $700 \mathrm{Ma}$ e, a SW e W, faz contato com rochas granitóides não metamorfisadas de idades $\mathrm{Rb} / \mathrm{Sr}$ oscilando entre $640 \mathrm{Ma}$ e $620 \mathrm{Ma}$ (Soliani Jr., 1986), cujos fragmentos, juntamente com clastos riolíticos, se encontram em arenitos conglomeráticos da Formação São Rafael

Em suma, considerando o exposto acima, a sedimentação do Grupo Maricá possivelmente teve início após $620 \mathrm{Ma}$ encerrando antes de $590 \mathrm{Ma}$ e, portanto, no Neoproterozóico III.

\subsubsection{Grupo Crespos}

O Grupo Crespos reúne as coberturas vulcânicas situadas entre os grupos Maricá e Camaquã, registrando atividade extrusiva de um suposto arco andinotipo, definido como Arco Bom Jardim (Ribeiro \& Fantinel, 1978; Fragoso Cesar, 1990, 1991). Este grupo é composto pelas formações Hilário, basal, e Acampamento Velho, superior.

A Formação Hilário compreende derrames de andesitos e, subordinadamente, andesi-basaltos, basaltos e lamprófiros, os quais, em direção ao topo, intercalam-se com materiais piroclásticos de natureza distinta (andesitos, riolitos), podendo haver diques de riolito e necks de composição monzonítica cortando a unidade (Nardi \& Lima, 1985; Wildner \& Lima, 1992; Almeida et al., 1993). Possui caráter geoquímico intermediário cálcio-alcalino de alta $\mathrm{K}_{2} \mathrm{O}$ a shoshonítico (Lima \& Nardi, 1992; Almeida et al., 1993; Lima, 1995).

A Formação Acampamento Velho é formada por riolitos porfiríticos, riolitos fluidais e piroclásticas associadas como brechas vulcânicas, tufos e tufos lapílicos, de caráter alcalino (Lima \& Nardi, 1992; Wildner \& Lima, 1992).

Estudos geoquímicos têm apontado caráter comagmático entre a Formação Hilário e o Granito Lavras do Sul (Nardi \& Lima, 1985; Nardi et al., 1992) de tal forma que se tem assumido a mesma idade para estas duas unidades. Datada conjuntamente com o granito pelo método $\mathrm{Pb} / \mathrm{Pb}$ aponta idade de $592 \mathrm{Ma}$ (Remus et al., 1997). Outras datações no granito situam-no no intervalo $580 \pm 6 \mathrm{Ma}$ (método SCHRIMP $\mathrm{U} / \mathrm{Pb}$ em zircão, Leite, 1995) e $568 \pm 6 \mathrm{Ma}$ (método Rb/Sr; Viera Jr. \& Soliani Jr., 1989), compatível com datação pelo método $\mathrm{K} / \mathrm{Ar}$ em comubianito originado pelo metamorfismo de contato do granito com esta formação indicando idade de $560 \pm 25 \mathrm{Ma}$ (Minioli \& Kawashita, 1971). Uma idade bem mais antiga, incompatível com as anteriormente citadas, apontou idade $\mathrm{Rb} / \mathrm{Sr}$ em rocha total de $653 \pm 23,4 \mathrm{Ma}$ (Lima, 
1995). Apesar desta idade, assumimos que o vulcanismo gerador da Formação Hilário possivelmente ocorreu entre 590-560 Ma.

A Formação Acampamento Velho, aparentemente, ainda não foi datada pelo método $\mathrm{U} / \mathrm{Pb} \mathrm{em}$ zircões. Dados recentes $\mathrm{Rb} / \mathrm{Sr}$ têm apontado duas idades: $545 \pm 12,7$ Ma para sills provavelmente correlatos à essa formação que intrudem o Grupo Maricá, e $546 \pm 12,9$ Ma em ignimbritos desta unidade (Almeida et al., 1996).

\subsection{Crupo Camaqua}

As ocorrências do Grupo Camaquã situam-se nos limites entre os terrenos do Escudo Gaúcho no Rio Grande do Sul (FIGURA II.3), tendo sua evolução relacionada à instalação e reativação de zonas de cisalhamento de direção NE-SW (Oliveira \& Fernandes, 1991; Sayeg et al., 1992; Fragoso Cesar et al., em preparação). A Bacia do Camaquã (FIGURA II.3) compreende os depósitos do grupo homônimo, gerados posteriormente à deposição dos sedimentos do Grupo Maricá e ao magmatismo que gerou o Arco Bom Jardim, ambos relacionados a outro contexto tectônico, conforme discutido.

De acordo com Fragoso Cesar et al. (em preparação), a Bacia do Camaquã ocorre em discordância angular sobre os produtos destes eventos orogênicos superpostos, relacionando-se às reativações de sistemas de falhas NE-SW, particularmente daqueles que representam zonas de colagens dos terrenos de seu embasamento. A contínua reativação sin-sedimentar destas zonas de falhas acaba por compartimentar tectonicamente a Bacia do Camaquã nas sub-bacias Santa Bárbara, Mangueirão e Passo do Tigre, a oeste, Rincão dos Mouras, Vale do Piquiri e Arroio Boici, a leste e, internamente, nas sub-bacias Minas do Camaquã, Cerro da Angélica, Casa de Pedra, Arroio Rondina e Arroio Apati. (FIGURA II.3). O Grupo Camaquã separa-se do sobreposto Grupo Guaritas por discordância angular claramente exposta na região das Minas do Camaquã, onde se situa o presente estudo.

Seu limite oriental é formado por extensa e larga zona de falhas entre a bacia e os terrenos metamórficos (Serra dos Pereira e Cerro da Árvore) e graniticos (terrenos Encruzilhada do Sul e Pelotas) situados a leste. Nesse limite, entre os altos do embasamento formados pelos terrenos Serra das Encantadas (a oeste) e Serra dos Pereira e Cerro da Árvore (a leste), instalou-se um sistema de strike slip basins, onde hoje se situam o Vale do Piquiri, a norte, e o Vale do Arroio Boici, a sul, com amplas áreas onde afloram rochas correlacionáveis ao Grupo Camaquã (Oliveira \& Fernandes, 1991, 1992; Sayeg et al., 1992a, b; Sayeg, 1993; Fragoso Cesar et al., em preparação).

Em sua porção central destaca-se a sub-bacia Minas do Camaquã cujo contato com outras exposições ocorre encoberto pelos depósitos do Grupo Guaritas. É condicionada por grandes sistemas de falhas NE e cortado por fraturamentos NW e WNW, destacando-se uma grande estrutura N-NE, a falha Tapera-Emiliano localizada ao longo de sua zona axial, possivelmente limitando em profundidade os terrenos Valentines e Serra das Encantadas. 
Seu limite ocidental é constituído por rochas vulcânicas do Grupo Crespos, granitos associados e metamorfitos aflorantes em altos de embasamento desta região.

Conforme redefinido (Fambrini et al., 1996b; Fragoso Cesar et al., em preparação), o Grupo Camaquã compreende as exposições anteriormente relacionadas à (i) Formação Arroio dos Nobres (sensu Ribeiro et al., 1966), tanto nas sub-bacias Vale do Piquiri, Rincão dos Mouras, e Vale do Boici a leste; na região das Minas do Camaquã, Palmas e das Tocas, na porção central da bacia e (ii) unidades da Formação Santa Bárbara (sensu Robertson, 1966) no vale de Santa Bárbara.

O Grupo Camaquã, segundo nossa atual concepção, é formado pelas seguintes unidades: (i) Formação Santa Fé, aparentemente restrita à sub-bacia Santa Bárbara, constituída por leques conglomeráticos costeiros; (ii) Formação Mangueirão, composta por ritmitos psamo-pelíticos (turbiditos, tempestitos e inunditos) e arenitos costeiros; (iii) Formação Vargas, representada por conglomerados e arenitos conglomeráticos de legues aluviais e costeiros; e (iv) Formação João Dias, aparentemente restrita à região das Minas do Camaquã, formada por arenitos e ritmitos de ambiente marinho raso e deltaico.

As rochas do Grupo Camaquã na região das Minas do Camaquã foram objeto de estudos que as situaram entre o Vendiano Superior e o Cambriano Inferior segundo: (1) duas datações K/Ar na fração fina da Formação Mangueirão indicando idades de $572 \pm 17$ Ma e $535 \pm 16 \mathrm{Ma}$ e duas datações K/Ar em pelitos intercalados nos arenitos finos da Formação João Dias (então considerada como do Grupo Guaritas) fornecendo idades de $529 \pm 11 \mathrm{Ma}$ e $524 \pm 16 \mathrm{Ma}$ (Bonhomme \& Ribeiro, 1983), (2) estudos em icnofósseis mostrando que a base destes pacotes situa-se no Vendiano Superior, enquanto o topo seria tomotiano (Netto et al., 1992). Considerando-se o intervalo 544-531 Ma para o limite entre o Vendiano e o Cambriano (Bowring et al., 1993; Isachsen et al., 1994; Grotzinger et al., 1995; Knoll, 1996), as idades de $535 \pm 16 \mathrm{Ma}, 529 \pm 11 \mathrm{Ma}$ e $524 \pm 16 \mathrm{Ma}$ mostram-se significativas, indicando deposição neste intervalo adentrando o Cambriano. No entanto, a de $572 \pm 17 \mathrm{Ma}$ talvez tenha problemas de argônio primário. De qualquer forma, conciliando as evidências radiométricas com as paleontológicas, admite-se que o Grupo Camaquã depositou-se durante o limite Neoproterozóico-Cambriano.

\section{II.3.4 Grupo Guaritas}

O Grupo Guaritas, discordantemente sobreposto ao Grupo Camaquã, compõe-se basicamente de arenitos e conglomerados representando depósitos continentais formados por sistema fluvial braided gradando para uma planície eólica. Estes são alimentados a partir das bordas por sistemas de leques aluviais, constituindo uma planície aluvial instalada entre os altos do embasamento de Caçapava do Sul, a oeste, e da Serra das Encantadas, a leste (Paim, 1994; 1995; Fragoso Cesar et al., 1996; em preparação). Representaria, de acordo com Paim $(1994,1995)$, um sistema de trunk river entre estes altos do embasamento. 
De acordo com Fragoso Cesar et al. (em preparação), o Grupo Guaritas compreende três formações: (i) Formação Guarda Velha, constituída por arenitos e conglomerados de leques aluviais e planície aluvial entrelaçada, com paleocorrentes predominantes para SW e W (Paim et al., 1992; Paim, 1992, 1994, 1995; Silva Filho, 1997; Fragoso Cesar et al., no prelo); (ii) Formação Pedra Pintada, formada por arenitos médios e finos bem selecionados com estratificações cruzadas acanaladas de grande porte caracterizando planícies eólicas que localmente apresentam depósitos de wadis e de interdunas úmidas interdigitando-se, junto à serra das Encantadas, com arenitos fluviais e brechas de depósitos de fluxos de detritos (Fácies Pedra das Torrinhas) (Fragoso Cesar et al., 1984; Lavina et al., 1985; Faccini et al., 1987; Paim et al., 1992; Fragoso Cesar, 1991; Paim, 1994, 1995, 1996; Silva Filho, 1997); (iii) Formação Varzinha, composta por arenitos e conglomerados fluviais superpostos por arenitos e ritmitos psamo-pelíticos flúvio-deltaicos (Paim, 1994, 1995).

A idade do Grupo Guaritas ainda não está definida, nem paleontológica nem radiometricamente. Recentemente, nossa equipe (Fragoso Cesar et al., 1998 no prelo) levantou a possibilidade de que esta unidade represente depósitos da seqüência mais basal da Bacia do Paraná, supostamente correlata ao Grupo Caacupé do Paraguai, de idade neo-ordoviciana a eo-siluriana. 


\section{PARTE III}

\section{O GRUPO CAMAQUÃ NA REGIÃO DAS MINAS DO CAMAQUÃ}




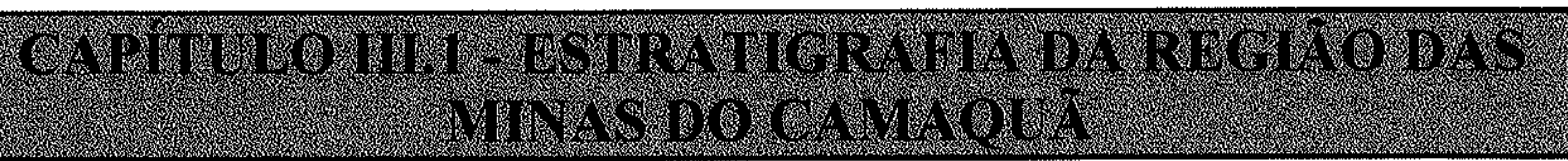

\section{III.1.1 Introdução}

A região das Minas do Camaquã situa-se na porção central da Bacia do Camaquã, tendo sido conhecida por muito tempo como um dos maiores distritos cupríferos do país. Possivelmente foi nesta região que Carvalho (1932) reconheceu rochas sedimentares distintas da então "Série Tubarão" de White (1908), cunhando-as de "Série Camaquan", em alusão ao rio homônimo que atravessa o segmento meridional da área de estudos. São as melhores exposições do Grupo Camaquã na bacia homônima e estão sendo eleitas como a localidade-tipo da unidade (Fragoso Cesar et al., em preparação).

As rochas sedimentares da região das Minas do Camaquã foram reunidas em duas unidades maiores, a saber: Grupo Camaquã (Vendiano Superior-Cambriano) e Grupo Guaritas (NeoOrdoviciano?) sensu Fragoso Cesar et al. (em preparação), além dos corpos ígneos Rodeio Velho. Estas unidades maiores encontram-se separadas por discordância angular de caráter regional, claramente exposta na região das Minas do Camaquã, sobretudo a norte e a noroeste das Minas do Camaquã. A sul (ponto MC-306), registramos a ocorrência de conglomerado basal do Grupo Guaritas em nítido contato erosivo com os arenitos finos e médios castanhos do Grupo Camaquã, sotoposto. A espessura estimada para o Grupo Camaquã na região, conforme a seção levantada (e.g. ao longo do perfil do Passo da Mina), é de cerca $2500 \mathrm{~m}$. Já o Grupo Guaritas em sua localidade-tipo (região das Guaritas), parcialmente aflorante na área mapeada, teria uma espessura de aproximadamente $500 \mathrm{~m}$, segundo dados de sondagens da CBC.

\section{III.1.2 GRUPO CAMAQUÃ}

\section{III.1.2.1 Histórico das Minas do Camaquã}

As ocorrências cupriferas das Minas do Camaquã foram descobertas em 1865 por mineiros ingleses que garimpavam ouro na região (in Teixeira et al., 1978b). O mais antigo trabalho publicado sobre a região deve-se às pioneiras explorações de Gorceix (1875). A partir dessa época as minas do Camaquã alternaram períodos de intensa exploração com fases de inatividade.

Ao longo das últimas décadas, a região das Minas do Camaquã foi palco de intensas pesquisas e explorações minerais em função das ocorrências de cobre, chumbo, zinco, prata e ouro presentes nos conglomerados e arenitos do Grupo Camaquã (Ribeiro et al., 1966; Bettencourt, 1972; Bettencourt \& Damasceno, 1974; Ribeiro, 1978; Teixeira, 1978; Teixeira et al., 1978a; Gonzalez \& Teixeira, 1980; Ribeiro et al., 1980; Badi \& Gonzalez, 1980; Veigel \& Dardenne, 1990; Ribeiro, 1992). Deste modo, inúmeros trabalhos de pesquisa foram desenvolvidos, valendo-se das excelentes exposições proporcionadas pela atividade mineira (Robertson, 1966; Ribeiro et al., 1966; Bettencourt, 1972; Teixeira et al., 1978b; 
Gonzalez \& Teixeira, 1980; Lavina et al., 1985; Faccini et al., 1987; Ribeiro, 1992; Veigel \& Dardenne, 1990; Beckel, 1990, 1992; Veigel, 1992; Paim, 1994; Fambrini et al., 1995; Silva Fillio et al., 1996b; Silva Filho, 1997).

Dentre estes trabalhos destacam-se os de Bettencourt (1972), que desenvolveu estudos relativos à mineralização de cobre do Distrito das Minas do Camaquã, cuja gênese por magmato-hidrotermalismo deveu-se à controle estrutural; Teixeira et al. (1978a) que interpretaram os minérios como sedimentares; Gonzalez \& Teixeira (1980) que consideraram uma origem diagenética dos sulfetos "obedecendo ao controle paleogeográfico" e Veigel \& Dardenne (1990) que relacionaram as mineralizações de cobre às várias fases diagenéticas que afetaram os conglomerados e arenitos do Grupo Camaquã.

\section{III.1.2.2 Trabalhos Anteriores na Região das Minas do Camaquã}

Carvalho (1932) definiu a "Série de Camaquan". Embora o autor não apontasse claramente uma localidade-tipo para a unidade, possivelmente o nome foi inspirado nas sucessões de rochas que abrigam as Minas do Camaquã junto às margens do rio Camaquã.

Leinz (1939) percorreu a região das Minas do Camaquã assinalando a frase que tanto nos inspirou: "Um estudo detalhado dos seixos deste conglomerado devia dar grandes esclarecimentos à litologia da superficie post-algonquiana". Este autor constatou a existência de duas "séries de Camaquan". $\mathrm{O}$ autor reconheceu a ocorrência de camadas horizontais na "Série de Camaquan" além daquelas fortemente inclinadas já identificadas por Carvalho (1932), adicionando uma unidade à "série".

Durante os trabalhos de mapeamento regional conduzidos pela equipe mista do USGS/DNPM, em 1961, Robertson (apud Ribeiro et al., 1966) deixou um manuscrito, publicado somente em 1966, onde redefiniu a "Série de Camaquan" de Carvalho (1932) como Grupo Camaquã, constituída pelas formações Santa Bárbara, basal, de camadas inclinadas, que hospeda os minérios das Minas do Camaquã, e Guaritas, sobrejacente, com camadas de atitude horizontal. Este autor foi o primeiro a descrever a natureza do contato discordante entre os sedimentos horizontalizados da Formação Guaritas, por ele definida, e as unidades inclinadas mais antigas da sua Formação Santa Bárbara, aflorante a NW das Minas do Camaquã na estrada que conduz à Caçapava do Sul, apesar de reuní-las em uma mesma unidade litoestratigráfica maior.

Posteriormente, Ribeiro et al. (1966) ali identificaram conglomerados e arenitos relacionados à parte da Formação Santa Bárbara de Robertson (1966) como Formação Arroio dos Nobres, constituida pelos membros Mangueirão e Vargas. A Formação Arroio dos Nobres, segundo estes autores, formaria o núcleo de uma estrutura anticlinal, enquanto a Formação Santa Bárbara, discordantemente sobreposta, ocorreria estruturada em homoclinal. Os autores reiteraram o contato discordante "claramente visivel" entre as formações Santa Bárbara e Guaritas diagnosticado por Robertson (1966).

Ribeiro (1978) incluiu no Membro Vargas sensu Ribeiro et al. (1966) a unidade mapeada como Santa Bárbara por estes mesmos autores, sendo seguido por Teixeira et al. (1978a, b) e Gonzalez \& 
Teixeira (1980), dividindo informalmente esta sucessão clástica em 5 níveis reconhecíveis na região das Minas do Camaquã, mapeáveis na escala 1:25.000, a saber: Arenito Inferior, Conglomerado Inferior, Arenito Intermediário, Conglomerado Superior e Arenito Superior. O Arenito Inferior foi caracterizado por depósitos de arenitos finos e médios, micáceos, com espessura da ordem de $350-400 \mathrm{~m}$. O Conglomerado Inferior compõe-se de conglomerados de seixos, predominantemente, e arenitos conglomeráticos exibindo variações laterais na granulometria bem como na composição dos seixos, com espessura em torno de 80$100 \mathrm{~m}$. O Arenito Intermediário, formado por arenitos finos, com espessura de $20-25 \mathrm{~m}$, possui grande extensão lateral e serviu de camada-guia para individualização dos conglomerados. O Conglomerado Superior, com espessura estimada de $200-300 \mathrm{~m}$, é representado por conglomerados com seixos e calhaus e intercalações de arenitos médios a grossos, destacando-se pela variedade de composição e tamanho dos clastos. Estes corpos foram relacionados ao desenvolvimento de leques aluviais que invadem um corpo d'água, ou seja, leques deltaicos (Teixeira et al., 1978b; Gonzalez \& Teixeira, 1980; Ribeiro et al., 1980).

Depois dos pioneiros trabalhos na aplicação do conceito de fácies lato sensu na região das Minas do Camaquã (Teixeira et al., 1978b; Gonzalez \& Teixeira, 1980; Ribeiro et al., 1980), Della Fávera (1984) pioneiramente reconheceu fácies strictu sensu de inunditos na região. Em seguida, Lavina et al. (1985) vincularam os inunditos com a progradação dos leques em corpos d'água rasos. Logo depois, Faccini et al. (1987) identificaram diversas fácies com base na geometria dos corpos, feições internas e distribuição, a saber: (1) ritmitos psamo-pelíticos representando depósitos de tempestitos marinhos e de turbiditos gerados na desembocadura de distributários deltaicos; (2) arenitos sigmoidais associados a depósitos de lobos de frentes deltaica; (3) arenitos com climbing ripples críticas a supercríticas relacionados à fluxos hiperpicnais sob ação de correntes de turbidez de frentes deltaicas; (4) arenitos com estratificação cruzada acanalada representativos de um sistema fluvial braided do tipo Donjek de Miall (1977) desenvolvido em uma planície deltaica e, (5) ruditos tabulares vinculados a porções medianas de leques aluviais (depósitos de sheet floods). Posteriormente, Fambrini et al. (1995) aplicaram a esses depósitos análises estratigráficas de fácies, proveniência e paleocorrentes, temas da presente dissertação.

Retomando a definição de "Série Camaquan" de Carvalho (1932), Fragoso Cesar et al. (em preparação) admitem para o empilhamento das rochas da região duas unidades maiores separadas pela discordância já apontada por Robertson (1966): grupos Camaquã e Guaritas. Assim, de acordo com tal proposição litoestratigráfica, o Grupo Camaquã consiste nas formações Mangueirão, Vargas e João Dias, tendo esta última sua localidade-tipo definida e descrita na presente dissertação (FIGURA III.1). A Formação Mangueirão compreende espessas sucessões psamo-pelíticas onde na base há o predomínio de litologias pelíticas, e em direção ao topo, dominam os arenitos (QUADRO III.1). A Formação Vargas compõe-se de conglomerados grosseiramente acamadados, cujo arcabouço é repleto de clastos angulosos a subangulosos de granulometria seixo a matacão, e arenitos conglomeráticos de matriz arcoseana portando estratificação cruzada tabular ou acanalada. A Formação João Dias, equivalente ao Arenito Superior de 
Ribeiro (1978), constitui-se de arenitos médios a finos, arcoseanos, com estruturas como laminações cruzadas cavalgantes, laminações cruzadas por migração de marcas onduladas, fendas de ressecação e estratificações cruzadas tabulares, subordinadamente, acanaladas e, possivelmente, estratificações cruzadas tipo Hummocky. Os pelitos representam finas interestratificações nos pacotes arenosos.

\begin{tabular}{|c|c|c|}
\hline \multicolumn{3}{|c|}{ GRUPO CAMAQUÃ } \\
\hline $\begin{array}{l}\text { Fragoso Cesar et al. (em } \\
\text { preparação) }\end{array}$ & Litologia & Este trabalho \\
\hline Formação João Dias & $\begin{array}{l}\text { arenitos médios e finos maciços, vermelhos, localmente grossos, com lami- } \\
\text { nações cavalgantes, marcas onduladas assimétricas, laminações cruzadas } \\
\text { truncadas por ondas e fendas de ressecação em delgada película argilosa }\end{array}$ & $\begin{array}{l}\text { CS3 } \\
\text { CS2 } \\
\text { CS1 }\end{array}$ \\
\hline Formação Vargas & $\begin{array}{l}\text { conglomerados grosseiramente a bem estratificados, de seixos até matacões, } \\
\text { matriz média a grossa com grânulos, em pacotes bem individualizados ou } \\
\text { de distribuição caótica (sem orientação) }\end{array}$ & $\begin{array}{l}\text { CM3 } \\
\text { CM2 } \\
\text { CM1 }\end{array}$ \\
\hline Formação Mangueirão & $\begin{array}{l}\text { intercalações de arenitos finos a muito finos, micáceos, localmente médios a } \\
\text { grossos, e siltitos e argilitos de colorações castanha, vermelha a bordô, cinza } \\
\text { e esverdeadas, subordinadas, em pacotes tabulares rítmicos, com estrutura } \\
\text { maciça, fina estratificação plano-paralela, laminação cruzada por ondas e } \\
\text { acamamentos heterolíticos }\end{array}$ & $\begin{array}{l}\text { CI5 } \\
\text { CI4 } \\
\text { CI3 } \\
\text { CI2 } \\
\text { CI1 }\end{array}$ \\
\hline
\end{tabular}

QUADRO III.1 - Litoestratigrafia do Grupo Camaquã na região das Minas do Camaquã segundo Fragoso Cesar et al. (em preparação). São apresentados, também, os conjuntos de associações de fácies sedimentares separadas internamente a cada formação neste trabalho.

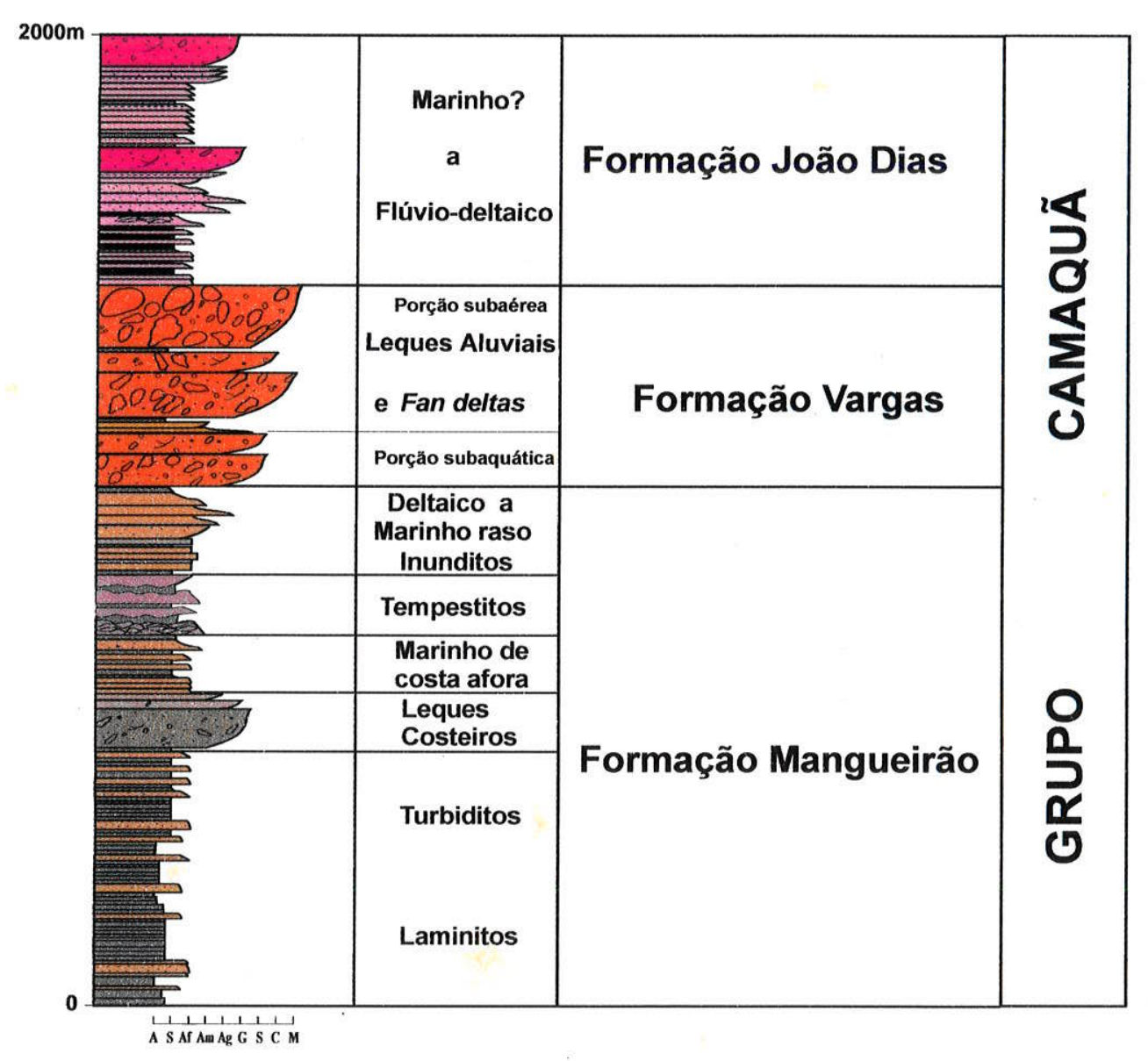

FIGURA III.1 - Coluna estratigráfica composta do Grupo Camaquã na região das Minas do Camaquã. 
As rochas do Grupo Camaquã foram separadas em fácies sedimentares de acordo com parâmetros de composição litológica, geometria, estruturas primárias, paleocorrentes e proveniência, exemplificadas pelas fácies adiante discriminadas. Estas basearam-se nas propostas de Miall (1978, TABELA III.1) e Eyles et al. (1983), para sedimentos psamíticos e, para rochas psefiticas, nas proposições de Schultz (1984), Ghibaudo (1992) e Blair \& McPherson (1994b). Secundariamente, para o Grupo Guaritas também foram discriminados os litotipos, adotando-se as fácies individualizadas por Paim (1994), visto que nesse estudo foi focalizado, prioritariamente, o Grupo Camaquã. Posteriormente, as fácies sedimentares individualizadas foram agrupadas em associações de fácies, segundo relações conspícuas entre processos geradores de ambientes deposicionais.

\begin{tabular}{|c|c|c|c|}
\hline $\begin{array}{l}\text { Código } \\
\text { de Fácies }\end{array}$ & Litofácies & Estruturas Sedimentares & Interpretação \\
\hline$G m s$ & $\begin{array}{l}\text { conglomerados sustentados pela } \\
\text { matriz, maciços }\end{array}$ & nenhuma & depósitos de fluxo de detritos \\
\hline$G m$ & $\begin{array}{l}\text { conglomerados maciços ou grossei- } \\
\text { ramente acamadados }\end{array}$ & $\begin{array}{l}\text { acamamento horizontal, } \\
\text { imbricação de clastos }\end{array}$ & $\begin{array}{l}\text { barras longitudinais, depósitos resi- } \\
\text { duais de canais (lag), depósitos } \\
\text { de peneiramento (sieve) }\end{array}$ \\
\hline$G t$ & conglomerados, estratificados & estratificações cruzadas acanaladas & preenchimento de canais \\
\hline$G p$ & conglomerados, estratificados & estratificações cruzadas planares & $\begin{array}{l}\text { barras linguóides ou migração delta- } \\
\text { ica sobre antigas barras }\end{array}$ \\
\hline$S t$ & $\begin{array}{l}\text { arenitos médios a muito grossos, } \\
\text { por vezes com seixos }\end{array}$ & $\begin{array}{l}\text { estratificações cruzadas acanaladas } \\
\text { solitárias }(\theta) \text { ou agrupadas }(\pi)\end{array}$ & $\begin{array}{l}\text { dunas subaquáticas (regime de fluxo } \\
\text { inferior) }\end{array}$ \\
\hline$S p$ & $\begin{array}{l}\text { arenitos médios a muito grossos, } \\
\text { por vezes com seixos }\end{array}$ & $\begin{array}{l}\text { estratificações cruzadas planares } \\
\text { solitárias }(\alpha) \text { ou agrupadas }(o)\end{array}$ & $\begin{array}{l}\text { barras transversais, linguóides e du- } \\
\text { nas (regime de fluxo inferior) }\end{array}$ \\
\hline Sr & arenitos muito finos a grossos & marcas onduladas de todos os tipos & $\begin{array}{l}\text { ondulações (regime de fluxo } \\
\text { inferior) }\end{array}$ \\
\hline$S h$ & $\begin{array}{l}\text { arenitos (areia muito fina a muito } \\
\text { grossa, podendo conter seixos) }\end{array}$ & $\begin{array}{l}\text { laminação horizontal, lineação de } \\
\text { partição ou de fluxo }\end{array}$ & $\begin{array}{l}\text { fluxo acamadado planar (regimes } \\
\text { de fluxo inferior e superior) }\end{array}$ \\
\hline$S l$ & arenitos finos & $\begin{array}{l}\text { estratificações cruzadas de baixo } \\
\text { ângulo }\left(<10^{\circ}\right)\end{array}$ & $\begin{array}{l}\text { preenchimento de sulcos, rompi- } \\
\text { mento de diques marginais (cre- } \\
\text { vasse splays), antidunas }\end{array}$ \\
\hline Se & $\begin{array}{l}\text { arenitos com intraclastos e sulcos } \\
\text { erosivos }\end{array}$ & estratificações cruzadas incipientes & preenchimento de sulcos \\
\hline Ss & arenitos finos a grossos, $\mathrm{c} /$ seixos & $\begin{array}{l}\text { sulcos rasos amplos incluindo } \\
\text { estratificações cruzadas tipo } \eta\end{array}$ & preenchimento de sulcos \\
\hline Sse, She e Spe & arenitos & análogos a $S s, S h$ e $S p$ & depósitos eólicos \\
\hline$F l$ & $\begin{array}{l}\text { arenitos pelíticos, pelitos arenosos } \\
\text { e pelitos }\end{array}$ & $\begin{array}{l}\text { laminação fina, ondulações de pe- } \\
\text { quena amplitude }\end{array}$ & $\begin{array}{l}\text { depósitos de transbordamento ou de } \\
\text { decantação de enchentes }\end{array}$ \\
\hline Fsc & pelitos (silte e lama) & laminada a maciça & $\begin{array}{l}\text { depósitos de pântanos ou de planície } \\
\text { de inundação }\end{array}$ \\
\hline Fcf & pelitos (lama) & maciça,com moluscos de água doce & depósitos pantanosos inundáveis \\
\hline$F m$ & pelitos (lama, silte) & maciça, com fendas de ressecação & depósitos de transbordamento \\
\hline$F r$ & pelitos (silte e lama) & marcas de raizes & níveis pelíticos \\
\hline$C$ & carvão, lamas carbonosas & plantas, filmes de lama (argila) & depósitos de pântanos \\
\hline$P$ & carbonatos & feições pedogenéticas & solos \\
\hline
\end{tabular}

TABELA III.1 - Classificação de litofácies sedimentares de ambientes fluviais de Miall (1978). 
Miall (1978) elaborou um código de classificação de litofácies com base em ambientes fluviais, amplamente aplicado e difundido. Mais tarde, Eyles et al. (1983) adaptaram essa proposta de litofácies fluviais para fácies de ambiente glacial. Tal nomenclatura é muito simples e de fácil aplicação, pois considera a litologia, a geometria e as principais estruturas sedimentares. É representada por letras maiúsculas (G-conglomerados, D-diamictitos, S-arenitos e F-pelitos) seguida de uma ou duas minúsculas, representativas das estruturas sedimentares presentes ( $\mathbf{m}$-maciço, g-estratificação gradacional, testratificação cruzada tabular e a-estratificação cruzada acanalada). Deste modo, disseminou-se por completo o emprego das classificações de fácies sedimentares para (1) turbiditos e fácies relacionadas (Howell \& Normark, 1982; Pickering et al., 1986; Ghibaudo, 1992; Boiano, 1997), (2) leques aluviais (Schultz, 1984; Feyter \& Molenaar, 1984; Blair \& McPherson, 1992a, b; Blair \& McPherson, 1994b), (3) fan deltas (Gloppen \& Steel, 1981); (4) lacustrinas (Horton \& Schmitt, 1996), entre outros.

Abaixo encontram-se as fácies sedimentares individualizadas neste trabalho com base nas propostas discutidas acima (TABELAS III.2-III.4).

\begin{tabular}{|c|c|c|c|}
\hline & \multicolumn{3}{|c|}{ PSEFITOS } \\
\hline Cms & $\begin{array}{c}\text { Conglomerados sustentados por matriz, } \\
\text { desorganizados, compostos por seixos } \\
\text { e calhaus, por vezes até matacठes }\end{array}$ & $\begin{array}{l}\text { Pacotes de espessura métrica, } \\
\text { maciços a estratificados e } \\
\text { geometria lenticularizada }\end{array}$ & $\begin{array}{l}\text { Depósitos de fluxo de detritos de leques } \\
\text { aluviais proximais. Fluxos gravitacionais de } \\
\text { massa }\end{array}$ \\
\hline Ccs & $\begin{array}{c}\text { Conglomerados sustentados por } \\
\text { clastos, organizados, compostos por } \\
\text { seixos e calhaus. Matriz composta por } \\
\text { areia média a grossa a muito grossa e } \\
\text { grânulos }\end{array}$ & $\begin{array}{l}\text { Corpos decimétricos a métricos, } \\
\text { de geometria tabular e de grande } \\
\text { extensáo lateral, estratificação } \\
\text { plano-paralela muito conspicua. } \\
\text { Imbricaçao comum } \\
\end{array}$ & $\begin{array}{c}\text { Depositos de fluxos canalizados (stream } \\
\text { channel flow) e de enchentes em lençol } \\
\text { (she日t foods) de sistema de leques aluviais } \\
\text { medianos }\end{array}$ \\
\hline $\mathrm{Cmm}$ & $\begin{array}{l}\text { Conglomerados de calhaus e seixos } \\
\text { angulosos, sustentados pela matriz de } \\
\text { argila a areia grossa com grânulos }\end{array}$ & $\begin{array}{l}\text { Pacotes de espessura métrica, } \\
\text { maciços, de geometria lenticular. } \\
\text { Imbricaçăo de clastos ocasional }\end{array}$ & $\begin{array}{l}\text { Depósitos de fluxo de detritos de leques } \\
\text { proximais. Fluxos gravitacionais de massa de } \\
\text { alta viscosidade }\end{array}$ \\
\hline Cmg & $\begin{array}{l}\text { Conglomerados de seixós a matacáo } \\
\text { pouco organizados, com matriz de areia } \\
\text { grossa e grânulos, gradaçáo inversa }\end{array}$ & $\begin{array}{l}\text { Pacotes de espessura métrica, } \\
\text { maciços a estratificados (gradaçăo } \\
\text { inversa), de geometria tabular }\end{array}$ & $\begin{array}{l}\text { Depósitos de fluxo de detritos (debris fow) de } \\
\text { sistema de leques proximais. Fluxos } \\
\text { gravitacionais de massa de alta viscosidade }\end{array}$ \\
\hline $\mathrm{Cp}$ & $\begin{array}{c}\text { Conglomerados de seixos a matacoes, } \\
\text { organizados, matriz de areia fina a } \\
\text { grossa }\end{array}$ & $\begin{array}{l}\text { Pacotes de espessura métrica e } \\
\text { geometria tabular, com conspicua } \\
\text { estratificaçáco plano-paralela }\end{array}$ & $\begin{array}{l}\text { Depósitos de fluxos canalizados e de } \\
\text { enchentes em lençol (sheet foods) de } \\
\text { sistema de leques aluviais medianos }\end{array}$ \\
\hline $\mathrm{Ca}$ & $\begin{array}{l}\text { Conglomerados de gránulos e de seixos } \\
\text { e matriz de areia média a grossa com } \\
\text { estratificaçరes cruzadas acanaladas de } \\
\text { médio e pequeno portes }\end{array}$ & $\begin{array}{c}\text { Pacotes lenticulares de espeșsura } \\
\text { métrica }(1-2 \mathrm{~m}) \text {. Seixos } \\
\text { demarcando os foresets das } \\
\text { estratificaçסes. Imbricaçáo de } \\
\text { clastos segundo plano ab }\end{array}$ & $\begin{array}{l}\text { Depositos de fluxos canalizados (stream } \\
\text { channel fiow) e de enchentes em lençol } \\
\text { (sheet floods) de sistema de leques aluviais } \\
\text { medianos a distais. Lateralmente associam- } \\
\text { se com arenitos Aca e Acp de outros pulsos }\end{array}$ \\
\hline Ct & $\begin{array}{l}\text { Conglomerados de seixos e calhaus e } \\
\text { matriz de areia média a grossa com } \\
\text { estratificaçסes cruzadas tabulares de } \\
\text { médio e pequeno portes }\end{array}$ & $\begin{array}{l}\text { Pacotes lenticulares de espessura } \\
\text { métrica. Estratificaçסes cruzadas } \\
\text { tabulares com seixos nos foresets. } \\
\text { Gradaçăo normal. Imbricaçăo de } \\
\text { clastos segundo plano ab }\end{array}$ & $\begin{array}{l}\text { Depósitos de fluxos canalizados (stream } \\
\text { channel flow) e de enchentes em lençol } \\
\text { (sheot floods) de sistema de leques aluviais } \\
\text { medianos a distais. Lateralmente associam- } \\
\text { se com arenitos Aca e Acp de outros pulsos }\end{array}$ \\
\hline Aca & $\begin{array}{c}\text { Arenitos médios a grossos, } \\
\text { conglomeráticos de seixos e de } \\
\text { gránulos, com estratificaçðes cruzadas } \\
\text { acanaladas e tabulares de pequeno } \\
\text { porte }\end{array}$ & $\begin{array}{c}\text { Geometria lenticular dos corpos de } \\
\text { espessura métrica }(\sim 1 \mathrm{~m}) \\
\text { Imbricação de clastos segundo } \\
\text { plano } a b\end{array}$ & $\begin{array}{l}\text { Depósitos de fluxos canalizados (stream } \\
\text { channel flow) e de enchentes em lençol } \\
\text { (sheet floods) de sistema de leques aluviais } \\
\text { distais adentrando planicie aluvial braided. } \\
\text { Migraçăo de dunas (fluxo inferior) }\end{array}$ \\
\hline Acp & $\begin{array}{l}\text { Arenitos médios a grossos, } \\
\text { conglomeráticos de seixos, com } \\
\text { estratificaçăo plano-paralela }\end{array}$ & $\begin{array}{l}\text { Corpos lenticulares de espessura } \\
\text { decimétrica e abundantes } \\
\text { estruturas hidrodinâmicas }\end{array}$ & $\begin{array}{l}\text { Porçoes distais de leques aluviais atingindo } \\
\text { planicie aluvial entrelaçada (braided), onde o } \\
\text { suprimento d'áqua era maior }\end{array}$ \\
\hline
\end{tabular}

TABELA III.2 - Descrição das fácies de psefitos do Grupo Camaquã com ênfase na geometria e estruturas sedimentares encontradas. Modificada da proposta de Ghibaudo (1992) e das classificações originais de Miall (1978) e Eyles et al. (1983) e adaptada para nosso idioma com base em Coimbra et al. (1992b) e Riccomini \& Coimbra (1993). 


\begin{tabular}{|c|c|c|c|}
\hline \multicolumn{4}{|c|}{ PSAMITOS } \\
\hline AfS, AmH & $\begin{array}{l}\text { Arenitos finos e médios, de base e topo } \\
\text { ondulados, bem selecionados, com } \\
\text { laminaçסes cruzadas truncadas por } \\
\text { ondas cujo topo comumente ostenta } \\
\text { marcas onduladas simétricas nos } \\
\text { pacotes decimétricos. Nas camadas } \\
\text { métricas pode ocorrer estratificaçáo } \\
\text { cruzada Hummocky }\end{array}$ & $\begin{array}{l}\text { Corpos granodecrescentes } \\
\text { decimétricos a métricos de geometria } \\
\text { tabular. Megaondulaçסes de } \\
\text { comprimento de onda de, no mínimo, } \\
0.80-1 \mathrm{~m} \mathrm{e} \text {, máximo de } 5 \mathrm{~m}\end{array}$ & $\begin{array}{c}\text { Processos esporádicos de transporte e } \\
\text { acumulaçăo de material arenoso sob a } \\
\text { açăa combinada de fluxos de corrente } \\
\text { oscilatória de alta energia e comprimento } \\
\text { de onda sob influência de ondas de } \\
\text { tempestades (tempestitos sensu Seilacher, } \\
\text { 1982a) }\end{array}$ \\
\hline $\begin{array}{l}\text { Afm, } \\
\text { Amm }\end{array}$ & $\begin{array}{c}\text { Arenitos finos e médios, maciços, com } \\
\text { marcas onduladas no topo das } \\
\text { camadas e estruturas convolutas }\end{array}$ & $\begin{array}{c}\text { Pacotes tabulares de grande extensăo } \\
\text { lateral }\end{array}$ & $\begin{array}{l}\text { Fluxos gravitacionais de alta viscosidade } \\
\text { gerados por correntes de turbidez e fluxos } \\
\text { de alta densidade }\end{array}$ \\
\hline $\begin{array}{l}\text { Afh, Amh, } \\
\text { Agh }\end{array}$ & $\begin{array}{c}\text { Arenitos finos com laminação } \\
\text { horizontal, lineaçăo de partiçăo ou de } \\
\text { fluxo e delgada pelicula de argila com } \\
\text { fendas de ressecaçåo } \\
\end{array}$ & $\begin{array}{l}\text { Corpos tabulares decimétricos. Fendas } \\
\text { de ressecação e parting lineation }\end{array}$ & $\begin{array}{l}\text { Fluxo acamadado planar sob regimes de } \\
\text { fluxo superior (laminação horizontal) e de } \\
\text { fluxo inferior }\end{array}$ \\
\hline Afc & $\begin{array}{l}\text { Arenitos finos a muito finos } \\
\text { moderadamente selecionados com } \\
\text { laminaçסes cruzadas cavalgantes }\end{array}$ & $\begin{array}{l}\text { Pacotes métricos de arranjo interno } \\
\text { dado pela superposiçăo de ondulaçð̄es } \\
\text { unidirecionais cavalgantes criticas a } \\
\text { supercriticas. Extensăo variável }\end{array}$ & $\begin{array}{c}\text { Fluxos hiperpicnais oriundos da entrada de } \\
\text { grande carga de material em regime de } \\
\text { traçåo e suspensâo sob a açâo de } \\
\text { correntes de turbidez }\end{array}$ \\
\hline Afoa & $\begin{array}{l}\text { Arenitos finos com marcas onduladas } \\
\text { assimétricas }\end{array}$ & $\begin{array}{l}\text { Geometria tabular e climbing ripples } \\
\text { associadas com as ripples }\end{array}$ & Fluxos de corrente. Regime de fluxo inferior \\
\hline Afos & $\begin{array}{c}\text { Arenitos finos com marcas onduladas } \\
\text { simétricas }\end{array}$ & Camadas decimétricas & Fluxos de oscilaçăo \\
\hline Afl & $\begin{array}{l}\text { Arenitos finos a muito finos com } \\
\text { delgadas låminas de argila no topo dos } \\
\text { estratos, originando laminaçáo plano- } \\
\text { paralela ou ondulada }\end{array}$ & $\begin{array}{l}\text { Pacotes tabulares de espessura } \\
\text { decimétrica a métrica, com intraclastos } \\
\text { pelíticos }\end{array}$ & $\begin{array}{l}\text { Alternåncia de fluxos trativos sob regime de } \\
\text { fluxo superior e inferior, e episódios de } \\
\text { decantação do material fino em suspensão }\end{array}$ \\
\hline Afid & $\begin{array}{c}\text { Arenitos finos a médios com laminaçăo } \\
\text { cruzada por migração de marca } \\
\text { ondulada }\end{array}$ & $\begin{array}{c}\text { Corpos granodecrescentes de } \\
\text { geometria tabular e de porte métrico (1- } \\
1,5 \mathrm{~m}) \text { e extensão variada }\end{array}$ & $\begin{array}{l}\text { Fluxos oscilatórios de pequeno porte } \\
\text { associados a perturbaçoes na zona de off- } \\
\text { shore }\end{array}$ \\
\hline Ams & $\begin{array}{c}\text { Arenitos médios a finos } \mathrm{cl} \\
\text { estratificaçăo cruzada sigmoidal de } \\
\text { médio porte }\end{array}$ & $\begin{array}{l}\text { Corpos métricos granocrescentes de } \\
\text { geometria sigmoidal a lenticular }\end{array}$ & $\begin{array}{l}\text { Lobos deltaicos progradantes associados a } \\
\text { fan-deltas que colmatam um corpo raso }\end{array}$ \\
\hline Affr & $\begin{array}{l}\text { Arenitos finos, mal selecionados, } \\
\text { maciços a grosseiramente laminados, } \\
\text { de matriz pelítica com clastos } \\
\text { (grânulos e areia grossa) esparsos }\end{array}$ & $\begin{array}{l}\text { Corpos métricos tabulares de } \\
\text { continuidade lateral restrita }\end{array}$ & $\begin{array}{c}\text { Fluxos gravitacionais (correntes de turbidez } \\
\text { de alta densidade) }\end{array}$ \\
\hline $\begin{array}{c}\text { Afp, Amp, } \\
\text { Agp }\end{array}$ & $\begin{array}{c}\text { Arenitos finos, médios ou grossos com } \\
\text { estratificaçấo plano-paralela }\end{array}$ & $\begin{array}{c}\text { Pacotes tabulares de espessura } \\
\text { variável }\end{array}$ & $\begin{array}{l}\text { Fluxos sob condiçres trativas (regime de } \\
\text { fluxo superior) }\end{array}$ \\
\hline Amc & $\begin{array}{c}\text { Arenitos finos a médios com } \\
\text { laminaçסes cavalgantes (climbing } \\
\text { nipples) e marcas onduladas por } \\
\text { corrente associadas (current ripples) e } \\
\text { estratificaçăo ondulada (wavy } \\
\text { beddding) }\end{array}$ & $\begin{array}{l}\text { Pacotes decimétricos tabulares de } \\
\text { continuidade fisica lateral grande e } \\
\text { superficie de separaçăa entre as } \\
\text { camadas arenosas com predomínio de } \\
\text { sedimentos finos }\end{array}$ & $\begin{array}{l}\text { Fluxos sob condiçб̃es trativas (migração de } \\
\text { leito ondulado em regime de fluxo inferior) }\end{array}$ \\
\hline Amt & $\begin{array}{c}\text { Arenitos finos e médios de seleçãoe } \\
\text { arredondamento bons e estratificaçסes } \\
\text { cruzadas tabulares e espinha-de-peixe } \\
\text { de médio e pequeno portes }\end{array}$ & $\begin{array}{l}\text { Pacotes granodecrescentes de } \\
\text { espessura métrica e grande } \\
\text { continuidade lateral. Marcas onduladas } \\
\text { lingubides associadas e gretas }\end{array}$ & $\begin{array}{l}\text { Fluxos trativos por migração de ondulaçóes } \\
\text { de dunas subaquáticas, provavelmente de } \\
\text { fundo de leito de rio (regime de fluxo } \\
\text { inferior) ou praial sob influência de marés }\end{array}$ \\
\hline Ama & $\begin{array}{l}\text { Arenitos médios a finos com seleçåo } \\
\text { moderada a boa exibindo } \\
\text { estratificaçסes cruzadas acanaladas de } \\
\text { porte médio a pequeno com granulos } \\
\text { demarcando os sets frontais }\end{array}$ & $\begin{array}{l}\text { Geometria lenticular dos pacotes de } \\
\text { espessura métrica onde sobressaem } \\
\text { termos mais grossos (lentes de } \\
\text { conglomerados a grânulos e seixos). } \\
\text { Estruturas de corte e preenchimento } \\
\text { são comuns } \\
\end{array}$ & $\begin{array}{l}\text { Fluxos trativos relacionados a migraçסes } \\
\text { de ondulaçбes de leitos. Dunas } \\
\text { subaquáticas desenvolvidas em sistema } \\
\text { fluvial entrelaçado (braided river system) }\end{array}$ \\
\hline Agt & $\begin{array}{c}\text { Arenitos grossos a médios com } \\
\text { estratificaçбes cruzadas tabulares de } \\
\text { médio a pequeno porte, seleçăo pobre } \\
\text { a moderada } \\
\end{array}$ & $\begin{array}{c}\text { Camadas lenticulares de espessura } \\
\text { decimétrica a métrica, apresentando } \\
\text { freqüentes intraclastos argilosos e } \\
\text { marcas onduladas }\end{array}$ & $\begin{array}{l}\text { Migraçăo de ondulaçбes de fundo de leito } \\
\text { de barras linguoides transversais geradas } \\
\text { por fluxos trativos. Dunas subaquáticas } \\
\text { que se associam às barras longitudinais }\end{array}$ \\
\hline 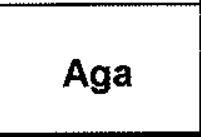 & $\begin{array}{l}\text { Arenitos grossos, de seleção } \\
\text { moderada a pobre, localmente } \\
\text { conglomeráticos, com estratificação } \\
\text { cruzada acanalada de médio porte }\end{array}$ & $\begin{array}{l}\text { Pacotes granodecrescentes } \\
\text { lenticulares, métricos, em camadas } \\
\text { decimétricas. Feiçסes de corte e } \\
\text { preenchimento conspicuas }\end{array}$ & $\begin{array}{l}\text { Fluxos trativos (migração de dunas } \\
\text { subaquáticas) }\end{array}$ \\
\hline
\end{tabular}

TABELA III.3 - Descrição das fácies psamíticas do Grupo Camaquã com ênfase na geometria e estruturas sedimentares observadas. Modificada a partir das classificações originais de Miall (1978) e Eyles et al. (1983). Adaptada de Gesicki (1996) e, para nosso idioma, com base em Coimbra et al. (1992b) e Riccomini \& Coimbra (1993). 


\begin{tabular}{|c|c|c|c|}
\hline \multicolumn{4}{|c|}{ PELITOS } \\
\hline Prl & $\begin{array}{l}\text { Ritmitos psamo-pelfiticos com laminaçסes } \\
\text { cruzadas truncadas por ondas }\end{array}$ & $\begin{array}{l}\text { Pacotes tabulares de espessura } \\
\text { variável (decimetrica a métrica) }\end{array}$ & $\begin{array}{l}\text { Rápida ressedimentaçăo de sedimentos ainda } \\
\text { inconsolidados sob condicoes plásticas }\end{array}$ \\
\hline Prc & $\begin{array}{l}\text { Ritmitos formados por gradação de niveis } \\
\text { decimimétricos de arenitos muito finos com } \\
\text { laminação plano-paralela a ondulada e } \\
\text { laminaçбes cavalgantes e estratos }(1-2 \mathrm{~cm}) \\
\text { de siltitos e argilitos maciços a laminados }\end{array}$ & $\begin{array}{c}\text { Camadas centimétricas a } \\
\text { decimétricas. Geometria tabular } \\
\text { de continuidade lateral grande } \\
\text { compondo espessas associaçóes } \\
(\sim 10-15 \mathrm{~m}) \text {. }\end{array}$ & $\begin{array}{l}\text { Correntes de turbidez de baixa densidade } \\
\text { (razâo carga em suspensão / velocidade do } \\
\text { fluxo baixa) associando-se a leques costeiros } \\
\text { distais em porçбes de maior aporte de } \\
\text { material detrítico }\end{array}$ \\
\hline Prh & $\begin{array}{l}\text { Ritmitos formados por intercalação } \\
\text { gradacional centimétrica de arenitos finos a } \\
\text { muito finos portando laminaçăo plano- } \\
\text { paralela e de siltitos e argilitos }\end{array}$ & $\begin{array}{l}\text { Camadas tabulares de espessura } \\
\text { centimétrica a decimétrica de } \\
\text { grande continuidade lateral. } \\
\text { Estrutura maciça (arenitos) a } \\
\text { finamente laminada (pelitos) }\end{array}$ & $\begin{array}{l}\text { Correntes de turbidez de baixa densidade } \\
\text { (razăo carga em suspensáo / velocidade do } \\
\text { fluxo baixa) }\end{array}$ \\
\hline Prd & $\begin{array}{l}\text { Ritmitos psamo-pelíticos deformados } \\
\text { (dobras convolutas, slumps, ball and pillow) }\end{array}$ & $\begin{array}{l}\text { Pacotes lenticulares de espessura } \\
\text { variável (decimétrica a métrica) }\end{array}$ & $\begin{array}{l}\text { Rápida ressedimentaçåo de sedimentos ainda } \\
\text { inconsolidados sob condiçðes plásticas }\end{array}$ \\
\hline $\begin{array}{l}\text { Psh, } \\
\text { Psm }\end{array}$ & $\begin{array}{c}\text { Siltitos argilo-arenosos com laminaçăo } \\
\text { plano-paralela a maciços. Fendas de } \\
\text { ressecaçăo podem ocorrer }\end{array}$ & $\begin{array}{l}\text { Camadas decimétricas tabulares. } \\
\text { Associam-se a Prh e Prc }\end{array}$ & $\begin{array}{l}\text { Segmentos distais de correntes de turbidez } \\
\text { de densidade baixa dominadas por processos } \\
\text { de decantaçăo. Exposiçăo eventual }\end{array}$ \\
\hline
\end{tabular}

TABELA III.4 - Descrição das fácies pelíticas do Grupo Camaquã com ênfase na geometria e estruturas sedimentares observadas. Modificada das classificações originais de Miall (1978) e Eyles et al. (1983). Adaptada de Gesicki (1996) e, para nosso idioma, com base em Coimbra et al. (1992b) e Riccomini \& Coimbra (1993).

\section{III.2.1 Associações de Fácies Sedimentares}

O Grupo Camaquã na região das Minas do Camaquã, provisoriamente eleita como seção-tipo por apresentar uma das melhores exposições do grupo e a coluna estratigráfica mais completa, compõe-se de rochas predominantemente areno-conglomeráticas separadas preliminarmente por Fambrini et al. (1995) em três conjuntos de associações de fácies parcialmente correlacionadas àquelas de Paim et al. $(1992,1995) \mathrm{e}$ Paim (1994) que, em última instância, refletem diferentes condições tectônicas e deposicionais. Na litoestratigrafia formal, tais conjuntos equivalem, da base para o topo, às formações Mangueirão, Vargas e João Dias de Fragoso Cesar et al. (em preparação). O Grupo Camaquã pôde ser dividido em três conjuntos de associações de fácies: Inferior, Média e Superior (Anexo 01). As rochas sedimentares de cada unidade (conjunto de fácies) foram individualizadas em Associações de Fácies - unidades menores que definem o empilhamento estratigráfico e sua distribuição na área de estudos, sendo equiparáveis na litoestratigrafia ao rank de membros -, representadas, respectivamente, pela sigla $\mathrm{C}$ de conjunto, seguida da inicial maiúscula da posição estratigráfica (se inferior, média ou superior) e de um número relativo à hierarquia da associação. $O$ Anexo 02 traz a localização dos pontos citados no texto. 


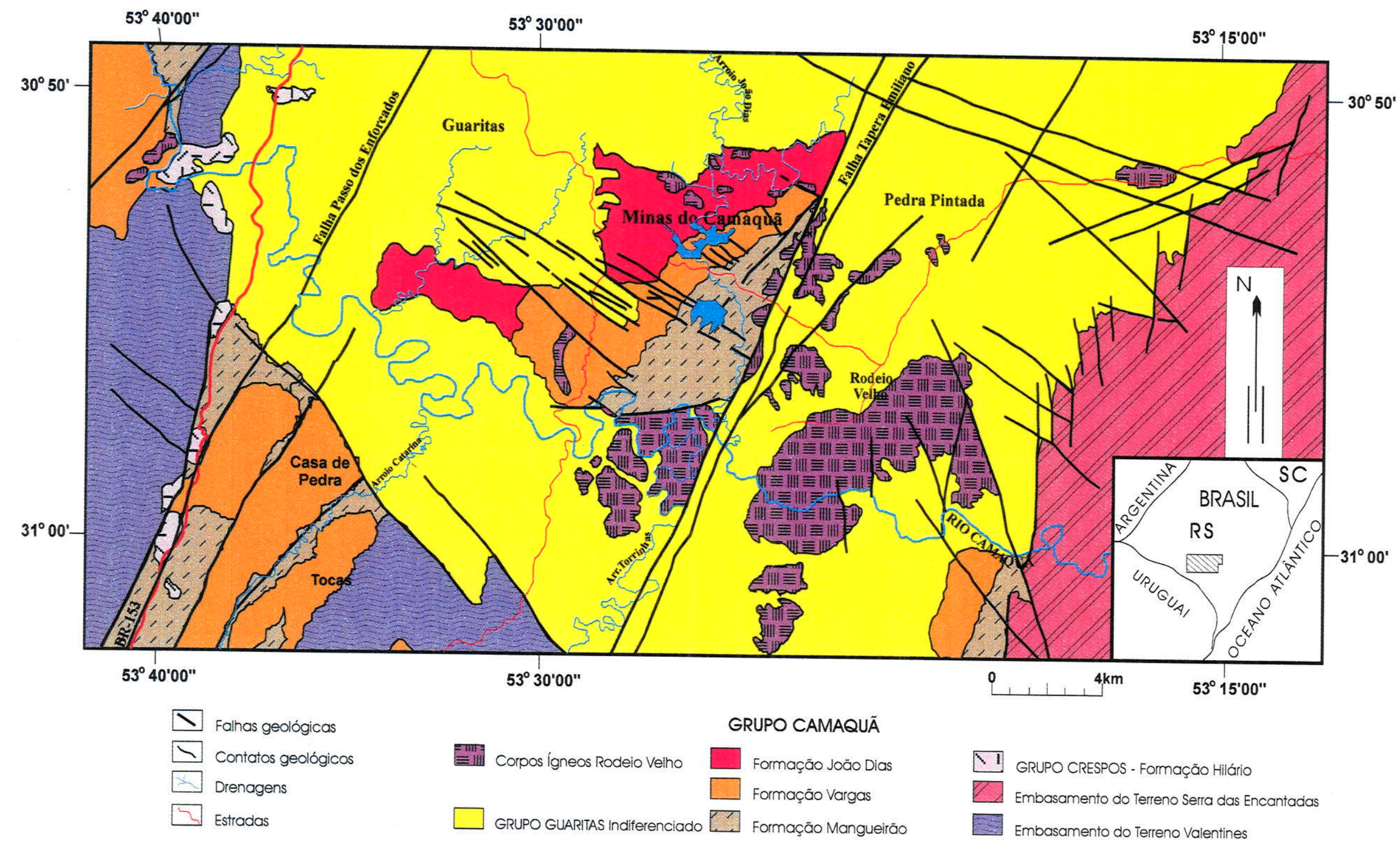

FIGURA III.2 - Mapa geológico regional da porção central da Bacia do Camaquã. Compilado de Ribeiro et al. (1966), Tessari \& Giffoni (1970), Ribeiro \& Carraro (1971), Teixeira et al. (1978b), Gonzalez \& Teixeira (1980), Camozzato et al. (1984), Santos et al. (1986), Paim (1994), Silva Filho (1997), Ribeiro \& Carraro mapas diversos da Companhia Brasileira do Cobre (CBC) nas escalas de 1:10.000 a 1:50.000 de 1978 a 1983. Utilizou-se como apoio imagens digitais TMLandsat nas escalas de 1:50.000 e de 1:150.000. O Grupo Guaritas não está individualizado, pois temos controle de suas unidades apenas a N do rio Camaquã 


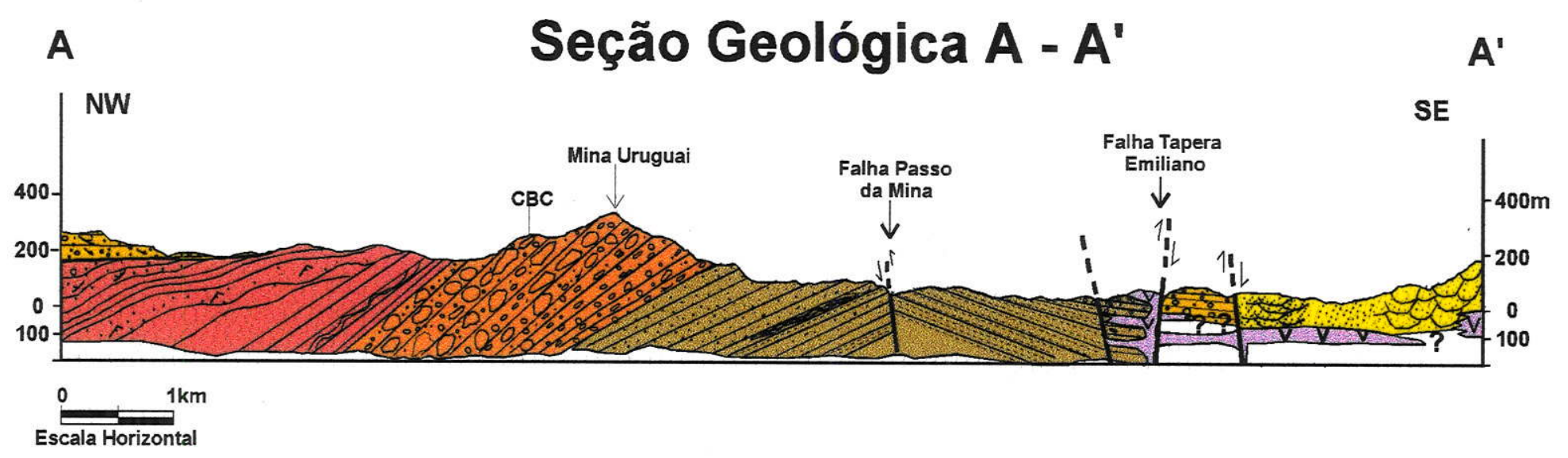

\section{LEGENDA}

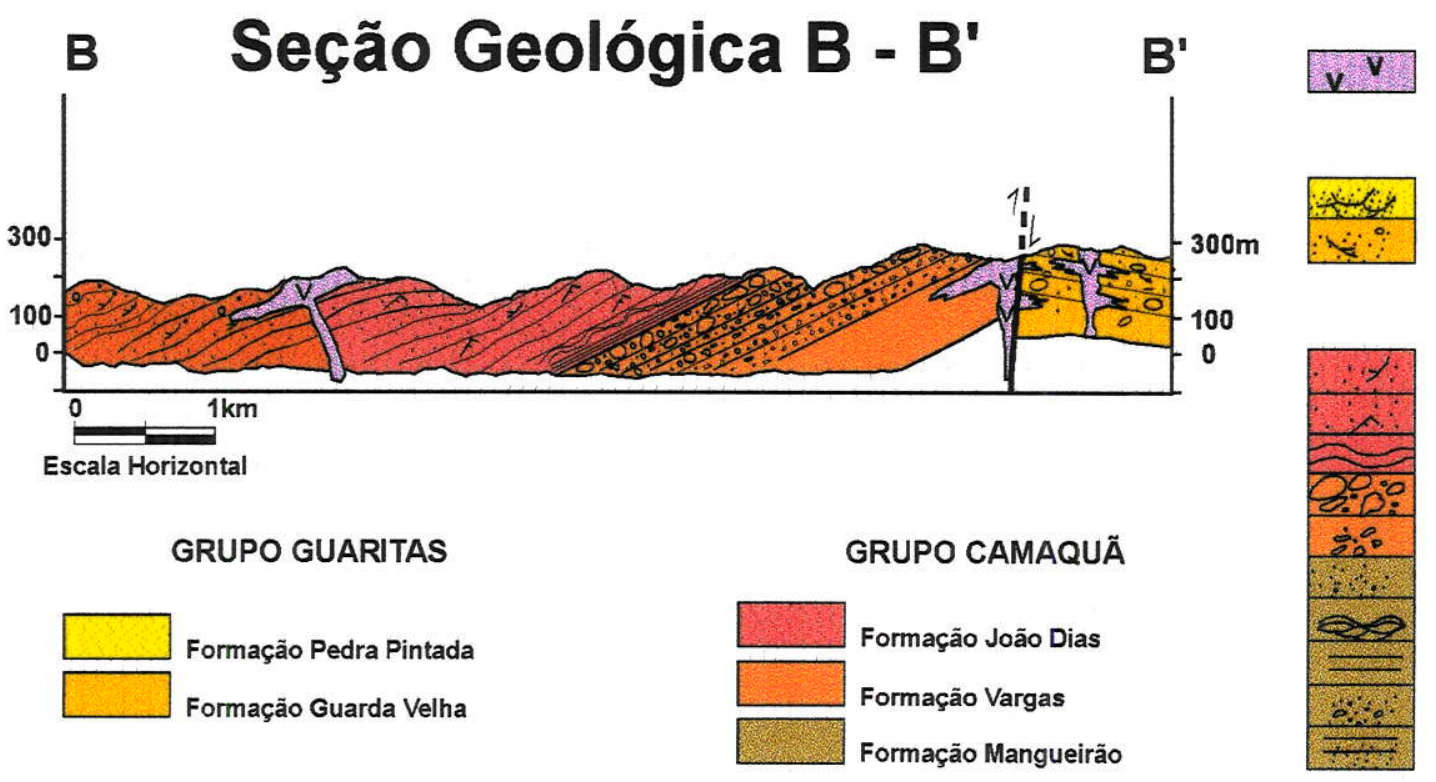

Corpos Ígneos Rodeio Velho

\section{GRUPO GUARITAS}

Arenitos $\mathrm{c} /$ estratificações cruzadas de grande porte Arenitos grossos $\mathrm{c} /$ estratificaçōes acanaladas

\section{GRUPO CAMAQUÃ}

Arenitos médios $\mathrm{c} /$ estratificaçöes acanaladas Arenitos médios a finos $\mathrm{c} /$ laminações cavalgantes Arenitos finos ondulados

Ortoconglomerados e arenitos conglomeráticos Conglomerados e arenitos de arcabouço anguloso Arenitos médios $\mathrm{c} /$ estratificações sigmoidais

Arenitos médios $\mathrm{c} /$ laminaçöes truncadas por ondas Intercalações de ritmitos psamo-pelíticos

Conglomerados e arenitos de arcabouço anguloso Arenitos finos maciços a laminados 


\section{III.2.1.1 CONJUNTO INFERIOR (CI) - FORMAÇÃO MANGUEIRÃO}

O termo Mangueirão foi primeiramente empregado por Ribeiro et al. (1966), então definido na categoria de membro, para designar "uma seqüência de sedimentos rítmicos" caracterizados pela alternância de horizontes finos de arenitos e siltitos argilosos aflorantes no arroio homônimo a leste da cidade de Caçapava do Sul. Os autores estimaram a espessura da unidade em cerca de $3000 \mathrm{~m}$.

A Formação Mangueirão, na região estudada, é constituída por sucessões, ora granodecrescentes ora granocrescentes para o topo da coluna, constituindo ciclos de arenitos médios e finos passando para siltitos e, subordinadamente, argilitos, compondo a Associação CI1, tendo localmente a ocorrência de termos conglomeráticos de caráter predominantemente granocrescente para o topo englobados na Associação CI2. A espessura máxima foi estimada em cerca de 2000 metros (FIGURA III.4)

As exposições da fácies conglomerática da Formação Mangueirão (Associação Cl2) eram reunidas na unidade sobreposta (Formação Vargas), tendo em vista a possível presença de uma dobra anticlinal no flanco NE da área, e também por se tratar de depósitos de conglomerados, classicamente englobados na unidade mencionada. Em mapa, essa fácies apresenta forma lenticular (FIGURA III.5), enquanto em seção interdigita-se com os arenitos da Associação CI1 (FIGURA III.6). A Falha do Passo da Mina soergueu o bloco a leste onde se situa a fácies conglomerática da Formação Mangueirão, dando a falsa impressão de uma dobra (vide Anexo 01).

\section{III.2.1.2 ASSOCIAÇÕES DE FÁCIES DA FORMAÇÃO MANGUEIRÃo}

As fácies sedimentares da Formação Mangueirão foram mapeadas na planície do vale do João Dias a norte do rio Camaquã, ao longo da estrada que cruza as Minas do Camaquã e une a BR392 à BR153 no trecho a oeste da Falha Tapera Emiliano e a leste do Cerro da Cruz, e em trecho da estrada que conduz para a Serra dos Apertados. Este conjunto de fácies é consituído pelas associações de fácies CI1, CI2, CI3, CI4 e CI5.

A Associação CI1 é formada predominantemente por corpos tabulares de ritmitos finos compostos por horizontes de arenitos médios e finos que gradam para siltitos no topo dos ciclos. A deposição se deu abaixo do nível de ação das ondas de tempestade.

A Associação Cl2 é composta de conglomerados de seixos e arenitos intercalados em pacotes de até $1,50 \mathrm{~m}$ de espessura acumulados também abaixo do nível das ondas de tempestade. A passagem da Associação CI1 para esta associação é gradual de modo a se constituir em um megaciclo dominantemente granocrescente para o topo ( $\geq 10 \mathrm{~m}$ ), embora localmente apresente contato erosivo (Local MC-109).

A Associação CI3 é formada por corpos de geometria tabularizada de ritmitos psamo-pelíticos com laminações plano-paralelas nos pelitos e cruzadas truncadas por ondas nos níveis arenosos sedimentadas no nível de ação de ondas de tempestade. 


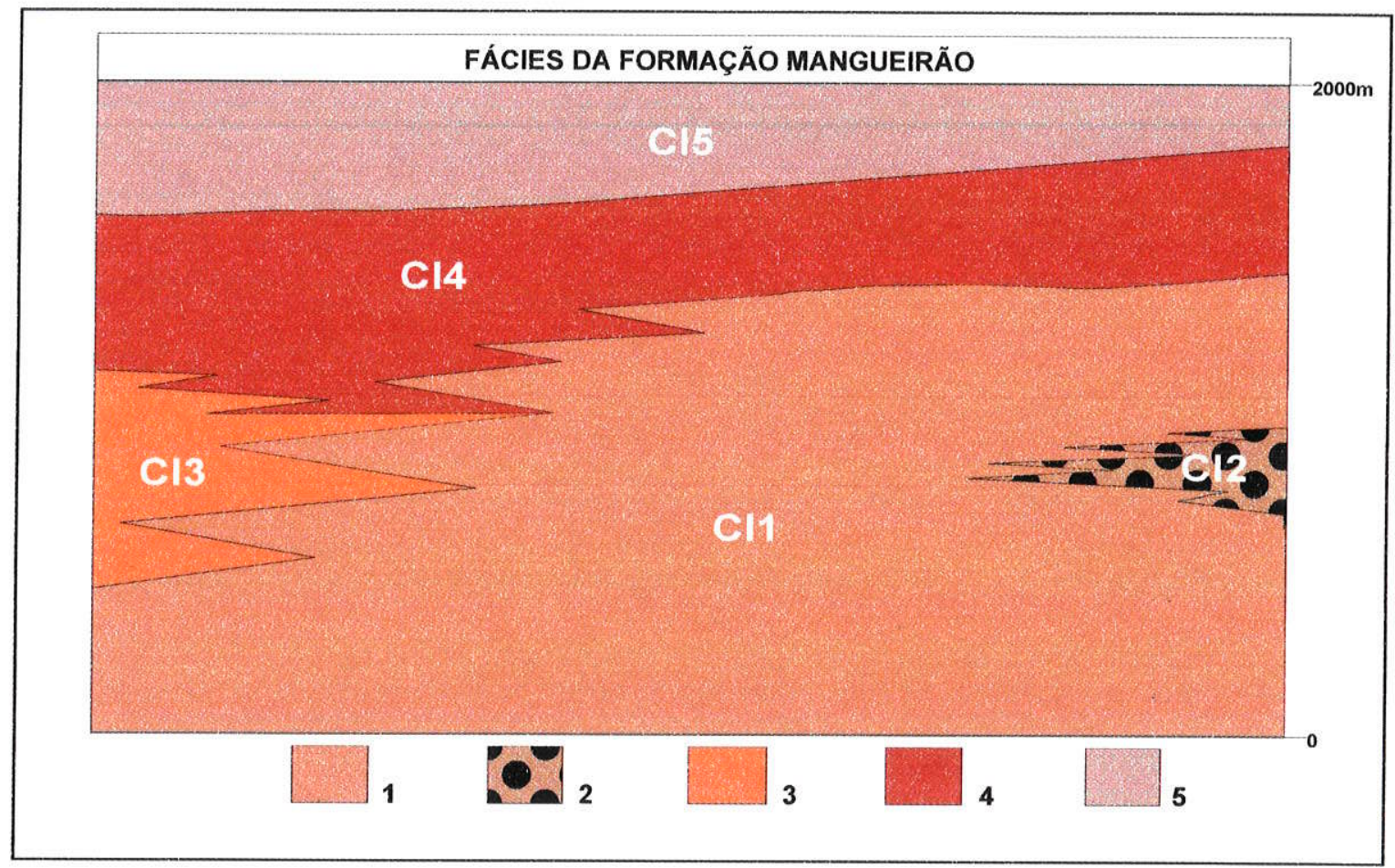

FIGURA III.4 - Esquema da distribuição de fácies sedimentares da Formação Mangueirão na região das Minas do Camaquã. 1- embasamento; 2- Fácies CI1 de ritmitos psamo-pelíticos; 3- fácies CI2 rudácea; 4- fácies CI3 de arenitos médios e finos com laminações cruzadas truncadas por ondas; 5- fácies CI4 de arenitos finos e médios com fendas de ressecação; 6- fácies CI5 de arenitos médios com estratificação cruzada sigmoidal.

A Associação CI4 compreende corpos tabulares de arenitos médios e finos acumulados sob a ação das ondas normais e constantemente com exposição subaérea. Interdigita-se com as associações CI3 e CI5.

Por fim, a Associação CI5 constitui-se de arenitos médios com estratificações cruzadas dos tipos sigmoidal e tabular de baixo ângulo, intercalados com arenitos finos maciços amalgamados.

\begin{tabular}{|c|c|l||}
\hline \multicolumn{2}{|c|}{ ASSOCIAÇÃo CI1 } \\
\hline \hline ASSOCIAÇÃO & FÁCIES & \multicolumn{1}{|c|}{ DESCRIÇÃO SUMÁRIA } \\
\hline \multirow{2}{*}{ CI1 } & Psm & Siltitos maciços \\
\hline & Prh & Pelitos rítmicos com laminação plano-paralela \\
\hline & Prd & Pelitos rítmicos deformados \\
\hline & Prc & Pelitos rítmicos com laminações cruzadas cavalgantes \\
\hline & Afc, Amc & Arenitos finos e médios com laminações cruzadas cavalgantes \\
\hline & Afm, Amm & Arenitos médios e finos maciços \\
\hline & Afr & Arenitos médios e finos, maciços, com fragmentos líticos \\
\hline
\end{tabular}

A Associação CI1 aflora na porção oriental da área de estudos na estrada que cruza as Minas do Camaquã e une a BR392 à BR153 no trecho do Passo da Mina-Rodeio Velho a oeste da Falha Tapera 
Emiliano e a leste do Cerro da Cruz, em trecho da estrada que conduz para a Serra dos Apertados e na planície a sul da Falha do Cemitério.

Esta associação de fácies é formada por pacotes métricos (1-1,50m) tabulares com grande persistência lateral nos afloramentos de ritmitos psamo-pelíticos, por sua vez constituídos por gradação normal de níveis centimétricos da base para o topo de: (i) arenitos médios a finos com fragmentos esparsos pela matriz (grânulos e pequenos seixos), por vezes de granulometria grossa, maciços a grosseiramente laminados (Afr); (ii) arenitos médios a finos maciços dispostos em camadas amalgamadas (Amm, Afm); (iii) arenitos médios a finos internamente portando laminação cruzada cavalgante (Afc, Prc); (iv) pelitos deformados em camadas lenticulares decimétricas (Prd) e (v) siltitos e argilitos maciços a laminados (laminação plano-paralela), estes de espessura decimétrica (Psm) (FIGURA III.5). Localidades MC-35, 36, $37,124,98,97,169,191$, entre outras.

\section{Descrição}

Na Fácies Afr estão os arenitos médios a finos castanhos de matriz silto-argilosa de geometria tabular, pouco micáceos, maciços a grosseiramente laminađos, com grânulos e pequenos seixos esparsos $(<$ $2 \mathrm{~cm}$ em diâmetro). Fina estratificação plano-paralela aparece como estrutura primária principal. Localmente, intercalam-se gradacionalmente com niveis conglomeráticos de grânulos e pequenos seixos, cuja matriz compõe-se de areia grossa, iniciando novo ciclo (Local MC-109). A base das camadas arenosas, sobrepondo-se às lâminas pelíticas do ciclo anterior, apresenta contramoldes de marcas erosivas de corrente (tipo flute casts). (Localidades MC-35, 37, 98, 109, entre outras).

As fácies Afm e Amm são formadas por arenitos finos e médios acastanhados, micáceos, maciços, organizados em camadas bem tabulares de espessura decimétrica (FIGURA III.5) expostos nas localidades MC-37, 97, 125, 305, 306. Quando diretamente em contato com camadas pelíticas de outras fácies, podem apresentar contra-moldes de marcas de sola (MC-35, 37).

As fácies Afc e Amc constituem-se de arenitos médios a finos, castanhos, micáceos, internamente portando laminações cruzadas cavalgantes (climbing ripples). As camadas apresentam espessura decimétrica, extensão variável e arranjo interno dado pela superposição de ondulações unidirecionais cavalgantes críticas a supercríticas. (Localidades MC-37, 97, 98, 101, 109).

A Fácies Prc compõe-se de intercalações rítmicas de niveis centimétricos de arenitos finos a muito finos, micáceos, e camadas decimétricas de pelitos laminados. Os arenitos apresentam internamente laminações cruzadas cavalgantes que se associam a marcas onduladas assimétricas no topo dos estratos. A geometria dos corpos é tabular com grande persistência lateral nos afloramentos. Essa fácies ocorre intimamente relacionada com as fácies Prh e Prd, e, subordinadamente, à Fácies Afr. Localidades MC$35,36,37,124,98,97,169,191$, entre outras. 

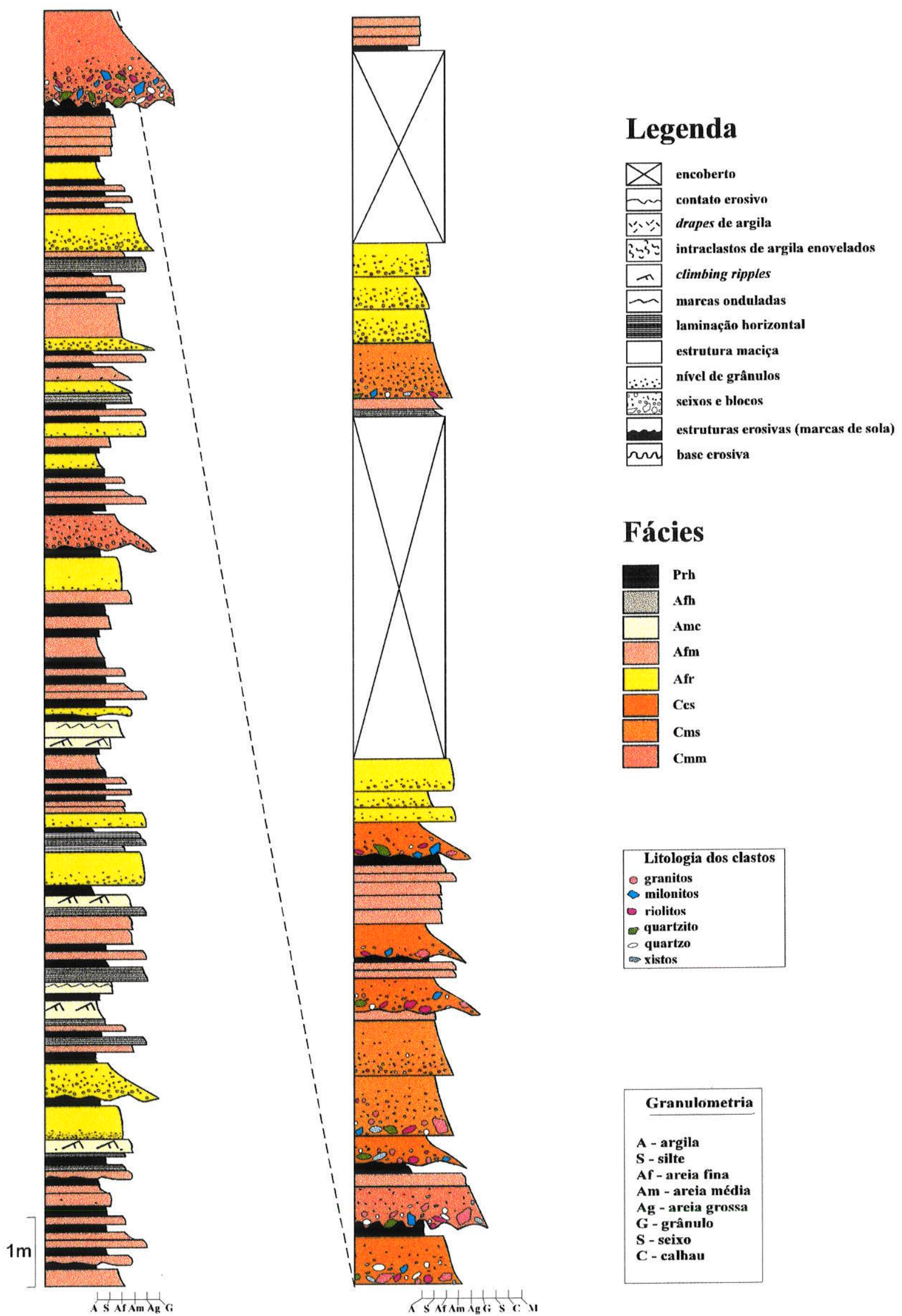

\section{Fácies}

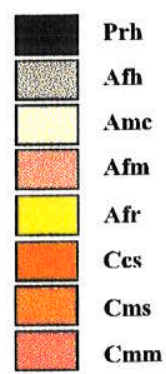

\begin{tabular}{|l|}
\hline Litologia dos clastos \\
granitos \\
gralonitos \\
miolitos \\
ruartzito \\
0 quartzo \\
xistos \\
\hline
\end{tabular}

\begin{tabular}{|l|}
\hline Granulometria \\
A - argila \\
S - silte \\
Af - areia fina \\
Am - areia média \\
Ag - areia grossa \\
G - grânulo \\
S - seixo \\
C - calhau \\
\hline
\end{tabular}

FIGURA III.5 - Seção estratigráfica de detalhe das Associações CI1 e CI2 na localidade MC-37. Note o caráter granocrescente do megaciclo $(\sim 10 \mathrm{~m})$ na exposição e os microciclos granodecrescentes (cerca de $1 \mathrm{~m}$ ). 
A Fácies Prd engloba pacotes lenticulares de espessura variável (centimétrica a métrica) formados por ritmitos psamo-pelíticos deformados por estruturas tais como dobras convolutas, slumps e ball and pillow (FIGURA III.7) (Localidades MC-97, 98, 125, 305, 306).

A Fácies Prh guarda sucessões de pacotes tabulares de grande continuidade lateral (FIGURA III.6) de ritmitos formados por intercalações centimétricas de arenitos finos a muito finos de coloração acastanhada e siltitos laminados, que gradam para corpos de siltitos e argilitos arroxeados, maciços a laminados portando laminação plano-paralela da Fácies Psm (Localidades MC-35, 36, 37, 124, 98, 192, 97).

\section{Interpretação}

As fácies de ritmitos psamo-pelíticos e arenitos finos da Associação CI1, estes localmente apresentando grânulos e pequenos seixos (1-2cm) na base dos ciclos, poderiam vincular-se à atuação de correntes de turbidez de baixa e alta densidades, respectivamente, em um corpo aquoso, provavelmente de grande extensão lateral.

As fácies mais arenosas Afm e Afr são sugestivas da atuação de correntes de turbidez de alta densidade como mecanismo da rápida deposição do material detrítico. A participação de esporádicos intraclastos pode ser vinculada à ação de fluxos viscosos. Deste modo, as fácies Afm e Afr formaram-se por processos de fluxos gravitacionais de viscosidade e densidade mais altas gerados por correntes de turbidez. Elas seriam representativas da seqüência $T_{A}$ do modelo de Bouma (1962) que, mais recentemente, vêm sendo interpretados como depósitos oriundos de processos de correntes de turbidez de alta densidade nos trabalhos de Lowe $(1979,1982)$.

Em seus trabalhos, Lowe teceu algumas considerações a respeito dos processos de correntes de turbidez. As correntes turbidíticas de baixa densidade compreenderiam fluxos pouco viscosos (até $20 \%$ de sedimentos), nos quais a turbulência inerente ao processo seria responsável pela movimentação da massa sobretudo quando esta contivesse sedimentos finos (areia fina + lama). A deposição ocorreria com a desaceleração da corrente, com a carga de fundo sendo sedimentada por tração (as areias de maior densidade) e a carga de suspensão (lama) por acréscimo vertical, resultando em uma sucessão granodecrescente ascendente típica, correlata à seqüência $T_{B C D(E)}$ de Bouma (1962). No entanto, as correntes de turbidez de alta densidade dependem da concentração do fluxo, por definição. Assim, quanto maior a concentração granular do fluxo maior será a competência deste de transportar carga detrítica de granulometria grossa (areia + cascalho).

As Fácies Prh e Prc podem ser explicadas pela ação de correntes de turbidez de baixa densidade (baixa razão de carga em suspensão / velocidade de fluxo). Essas fácies correlacionar-se-iam às seqüências $T_{A B D(E)}$ e $T_{B C D(E)}$ do modelo de turbiditos definido originalmente por Bouma (1962). A Fácies Prd vinculase à rápida ressedimentação de sedimentos finos ainda inconsolidados sob condições hidroplásticas. 
$\underline{\text { Fambrini, }} \underline{\text { G.L. }}=\underline{\text { o }} \underline{\text { Grupo Camaquã: }} \underline{\text { análise de fácies, proveniência e paleocorrentes }}$

A
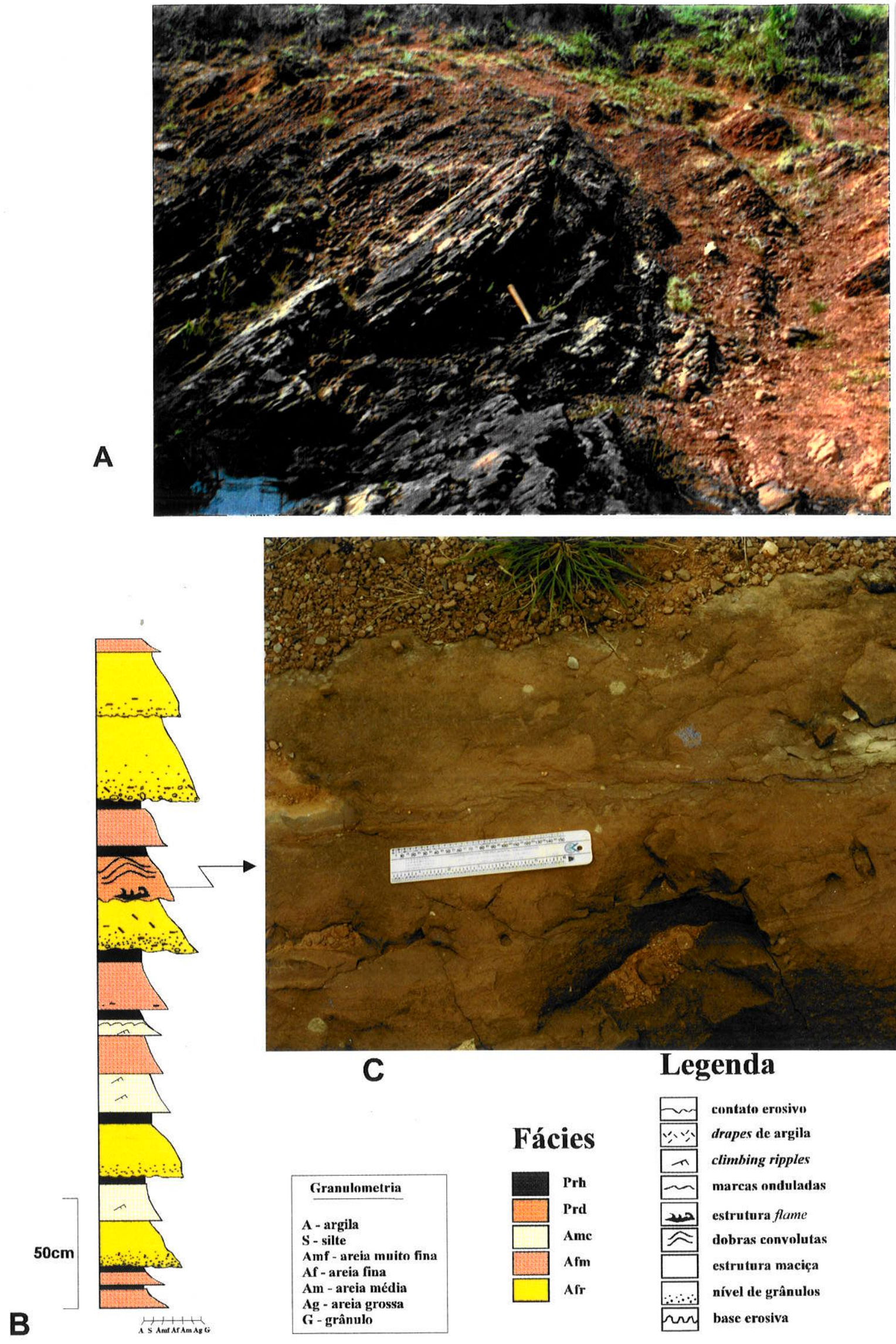

FIGURA III.6 - Associação CI1 na localidade MC-98 (A) Visão geral dos depósitos de ritmitos, (B) seção estratigráfica de detalhe tipo Selley (1970) (C) Foto de detalhe de estrutura em chama (flame). 
A relação das fácies Prh, Prc e Prd com as fácies arenosas acima descritas deve refletir contextos sucessivamente mais distais para a sedimentação das correntes de turbidez de baixa densidade. A deposição efetuou-se mediante pulsos das correntes de alta densidade que, simultaneamente, foram o mecanismo alimentador principal dos detritos das correntes turbidíticas de densidade mais baixa. A Fácies Prc, onde se destacam climbing ripples supercríticas tipo A de Joplin \& Walker (1968), indicaria prováveis condições de deposição mais distais, em um contexto de energia de fluxo substancialmente inferior, ligado à participação de grande conteúdo de sedimentos finos em suspensão. Howel \& Normark (1982) sugeriram que, nessa situação, tal associação pode representar depósitos de leque mediano ou franja de leque, devido à predominância de sedimentos finos. Ainda, com base nestes autores, a preponderância de ciclos granodecrescentes permite relacionar a associação com um contexto deposicional retrogradacional.

Nestas associaçães de fácies verificou-se que a sedimentação processou-se basicamente por fluxos gravitacionais não confinados de baixa densidade, provavelmente alimentados por fluxos mais densos e viscosos provindos dos diversos aportes sucessivos de correntes impregnadas de detritos. Tais correntes, ao atingir o corpo aquoso, comportar-se-iam como fluxos hiperpicnais sensu Bates (1953), devido à elevada carga detrítica que promoveria a geração de depósitos turbidíticos gradualmente mais finos para o interior da bacia.

Portanto, essas fácies representariam fluxos gravitacionais de baixa e alta viscosidades relacionados a processos esporádicos de transporte e sedimentação. A Associação de Fácies CI1 foi interpretada como depósitos de turbiditos clássicos representados por ciclos rítmicos granodecrescentes com os intervalos definidos a partir de Bouma (1962). Inicia-se com arenitos médios a grossos, maciços, com fragmentos (Fácies Afr), representativos da divisão $T_{A}$, ou arenitos médios a fínos, portando laminação plano-paralela (divisão $T_{B}$ ) e exibindo marcas de sola ou de objetos (Ponto MC-35), que gradam em direção ao topo para arenitos finos com laminação cruzada cavalgante (divisão $T_{C}$ ), e terminando com níveis pelíticos (divisão $\mathrm{T}_{\mathrm{DE}}$ ) com laminação plano-paralela incipiente. Esta interpretação condiz com outras anteriores para a região estudada (Faccini et. al., 1987; Fambrini et. al., 1995; Fambrini, et al., 1996c) e também para acumulações similares na bacia como um todo (Lavina et al., 1985; Fragoso Cesar, 1991; Sayeg, 1993; Paim et. al., 1992; Paim, 1994; Fambrini et. al., 1996b).

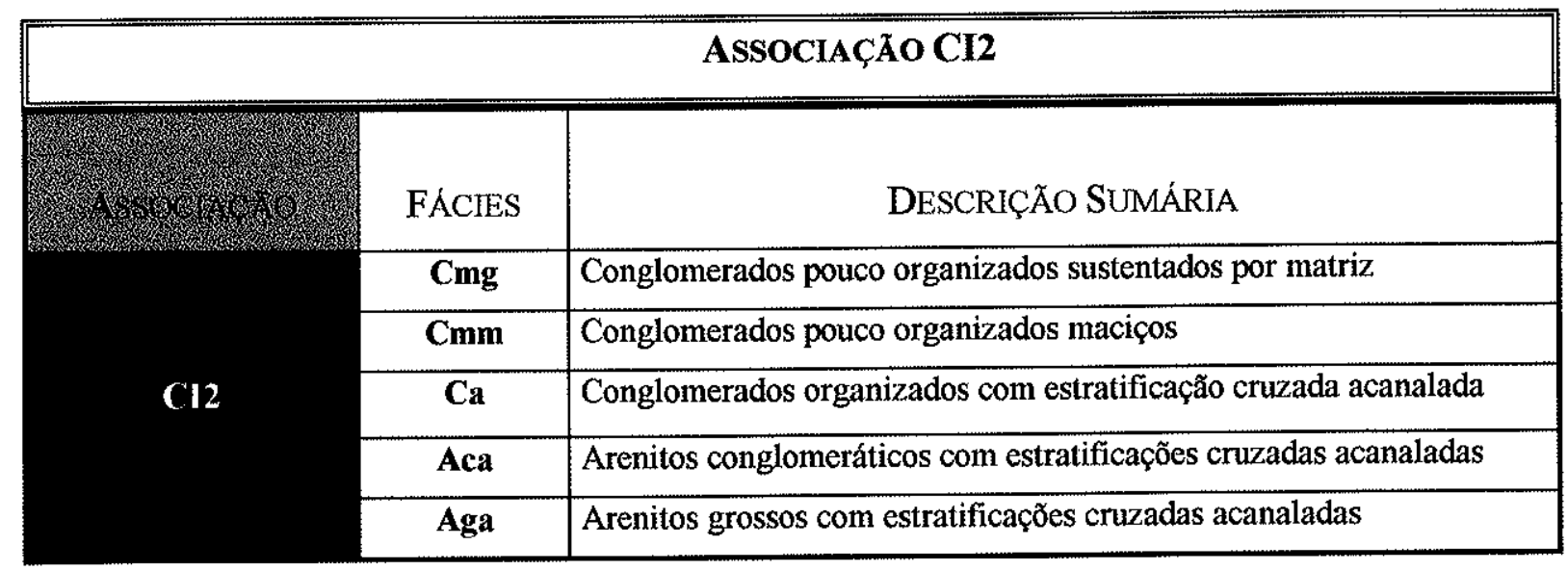


A Associação CI2 ocorre na borda oriental de ocorrência do Grupo Camaquã na área de estudos em contato com a Falha Tapera Emiliano, em bloco soerguido provavelmente pela atuação da mesma e da Fallha Passo da Mina.

Esta associação constitui-se de fácies conglomeráticas de geometria tabular em escala de afloramento formadas por intercalações de paraconglomerados maciços de espessura variando de $50 \mathrm{~cm}$ a Im (Fácies Cmm) e paraconglomerados grosseiramente gradados em camadas de até 1,5m (Fácies Cmg), alternados em contato brusco com niveis de arenitos grossos a finos com grânulos (Fácies Aga) ou com arenitos conglomeráticos com seixos esparsos $(2 \leq \phi \leq 5,5 \mathrm{~cm})$ da Fácies Aca que gradam bruscamente para niveis centimétricos de pelitos, podendo, ocasionalmente, apresentar camadas lenticulares pouco espessas $(10-30 \mathrm{~cm})$ de ortoconglomerados com estratificações cruzadas acanaladas (Fácies Ca), conforme as FIGURAS III.7 e III.8. A rigor, os termos rudíticos desta associação de fácies variam de paraconglomerados bimodais a polimodais (mais freqüentes) a arenitos com seixos de matriz grossa segundo as propostas de Walker (1975) e Collinson \& Thompson (1989).

\section{Descrição}

A Fácies Cmg constitui-se de pacotes tabulares de espessura métrica (FIGURA III.7) de conglomerados pouco organizados suportados por matriz, estratificados muito grosseiramente (com gradação inversa MC-38). Os clastos são de granulometria seixo, com alguns calhaus dispersos. A matriz compõe-se de areia fina a média com grânulos, apresentando ocasional imbricação de clastos. As estratificações presentes são do tipo plano-paralelo e, principalmente, gradacional; esta originada pela gradação normal e inversa dos clastos. Apesar das poucas estratificações presentes que conferem certa organização ao depósito, a disposição dos clastos é caótica a pseudo-organizada (algumas imbricações), como se os fragmentos tivessem sido lançados e precipitados conforme a perda de energia de transporte, sem maiores indicações de organização. O fenômeno é melhor observado em planta que em perfil, conforme comprovado pela presença comum de fragmentos de granulometria seixo e calhau colocados lado a lado na matriz fina a média com grânulos, por exemplo. A matriz desses depósitos os envolve no geral, podendo ocorrer contatos pontuais a planares entre os fragmentos, os últimos ocasionando imbricação (Localidades MC-38, 110, 364, 365, 128, 129, 130, 331, 332).

A Fácies Cmm é formada por pacotes de espessura métrica e geometria tabular, de paraconglomerados polimíticos maciços desorganizados com calhaus e seixos angulosos imersos em matriz de areia grossa com grânulos (FIGURA III.7). Embora seja caótica e apresente estrutura maciça, por vezes a deposição seguiu uma gradação normal compondo ciclos granodecrescentes, onde cada novo ciclo possui limite erosivo com o anterior (Localidades MC-38, 364, 365, 331, 332). 

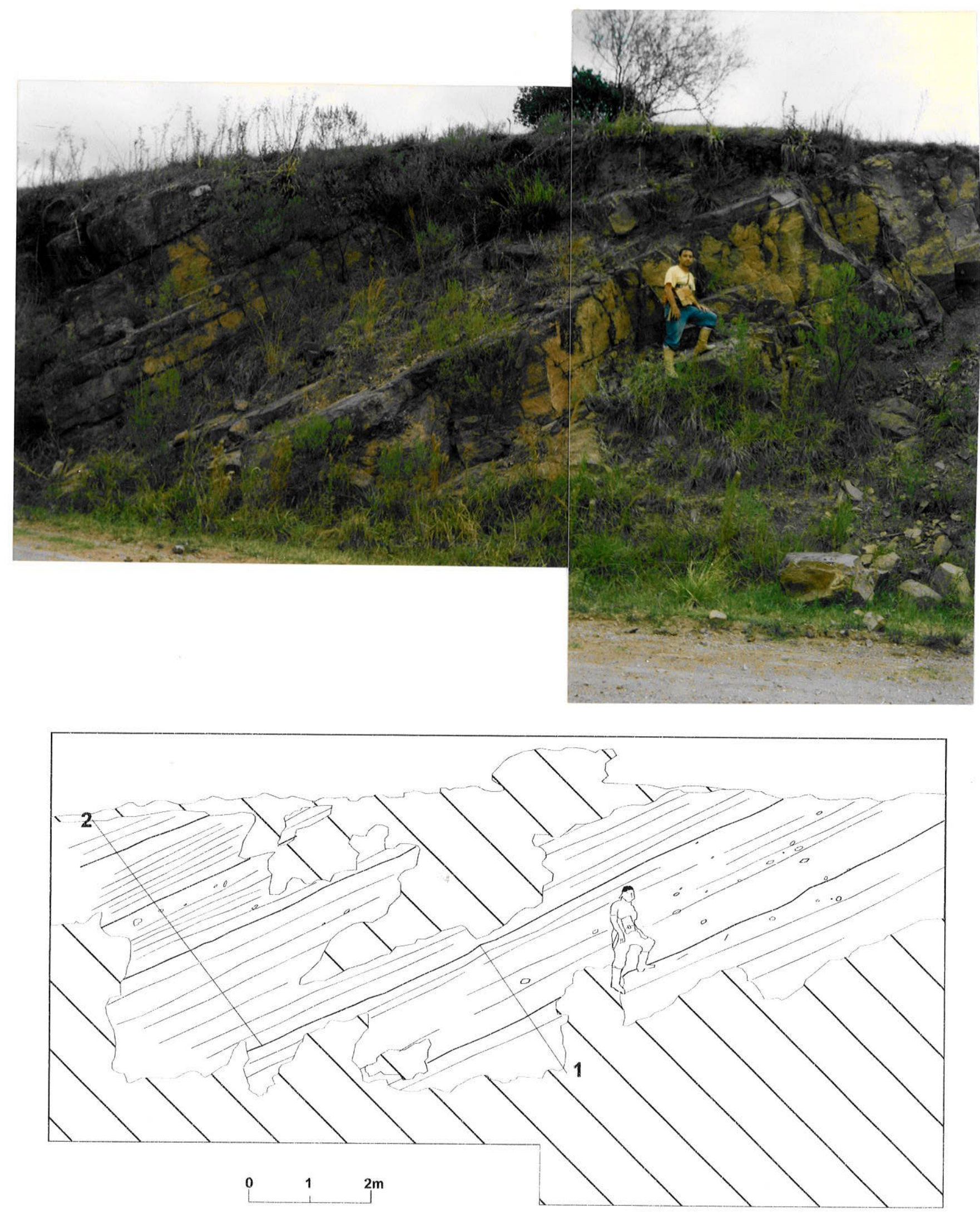

FIGURA III.7 - Aspecto geral da Associação CI2 no ponto MC-38 salientando depósitos de conglomerados sustentados pela matriz e arenitos conglomeráticos. Foto gentilmente cedida por Heitor S. Sayeg. 


\section{PALEOCORRENTES $\quad \phi$ MÁXIMO}

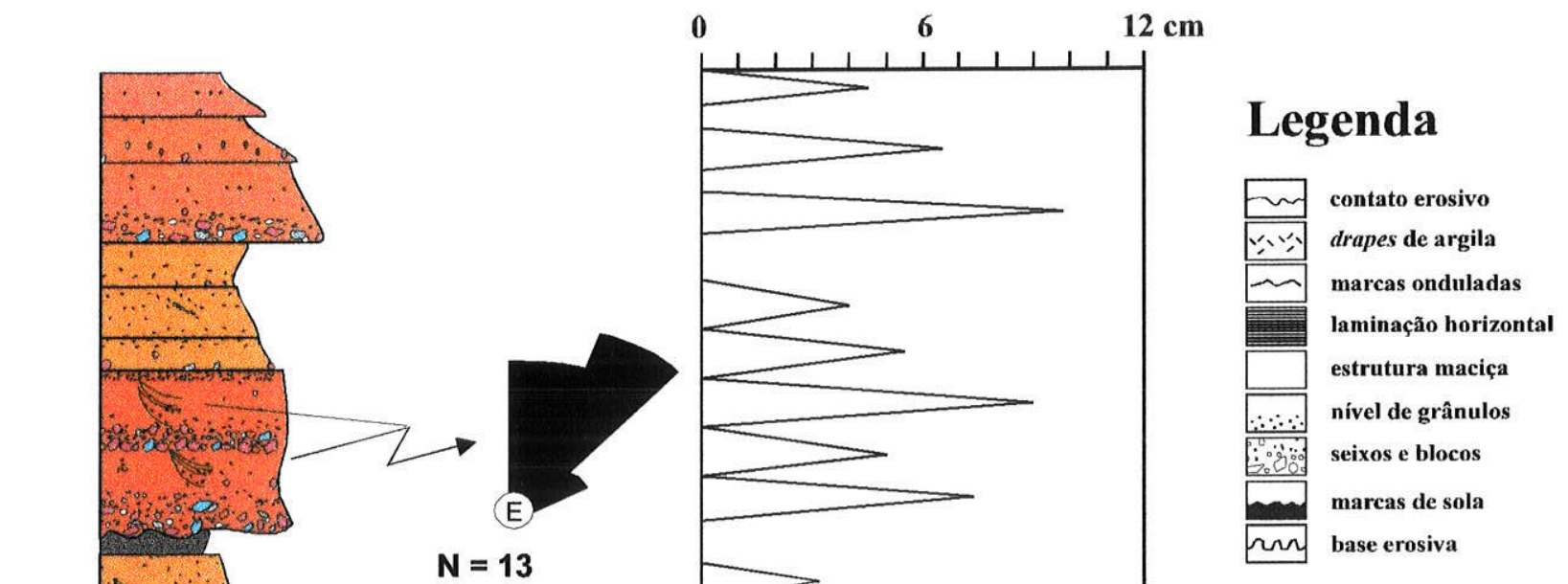

\section{Fácies}
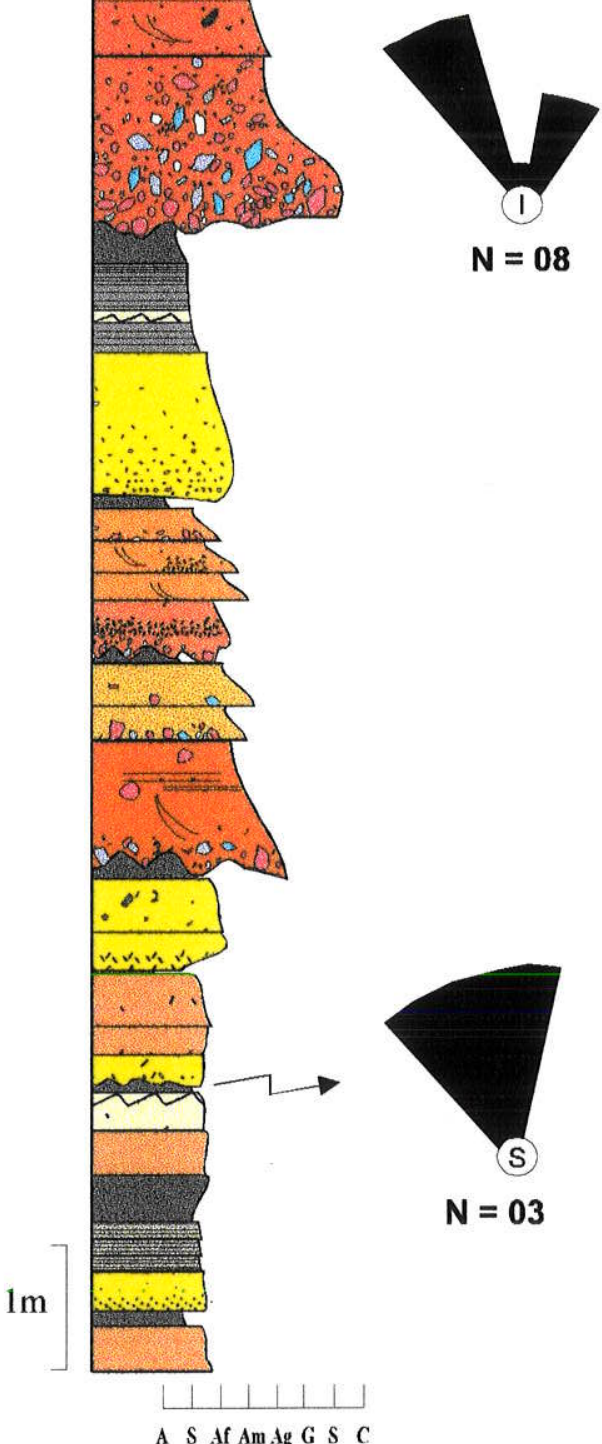

$\mathbf{N}=08$

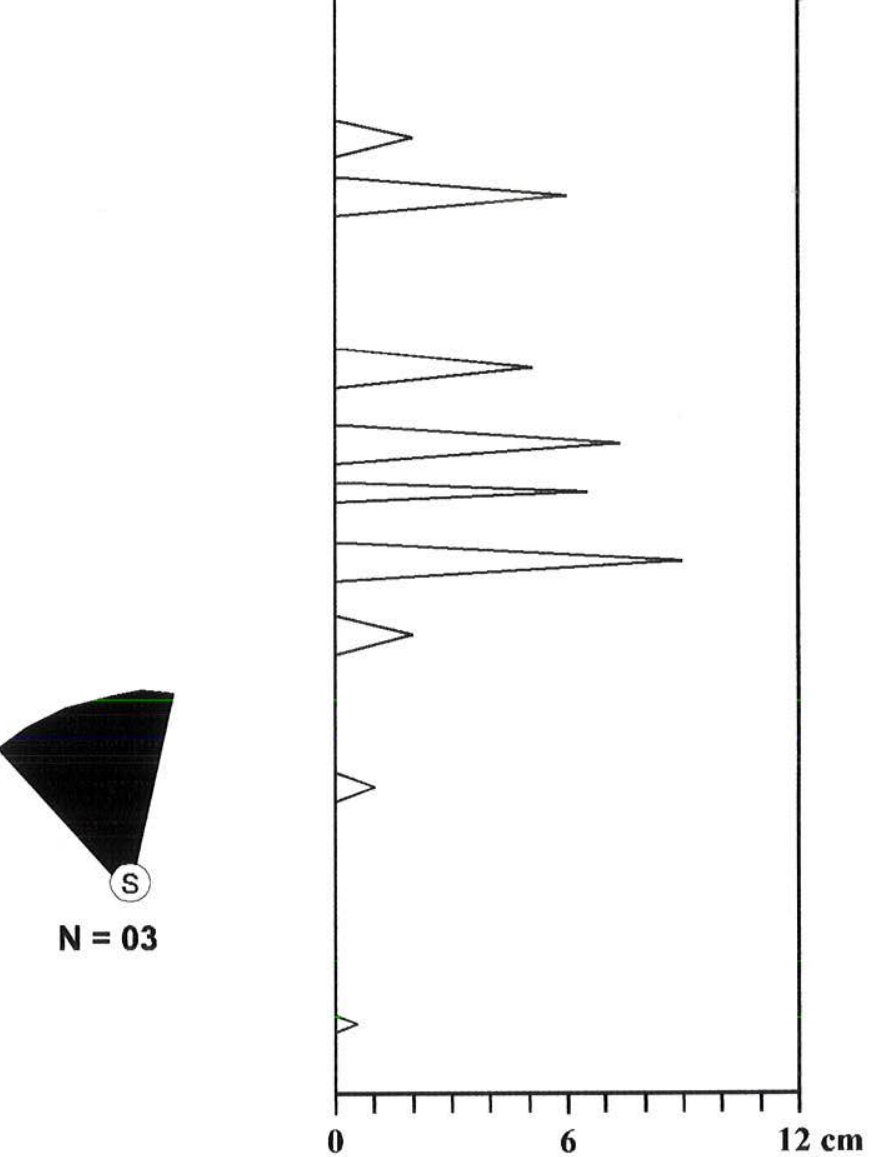

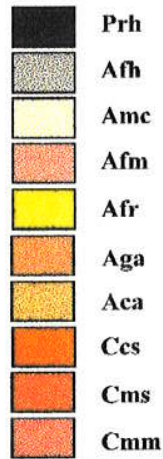

\begin{tabular}{|l|}
\hline \multicolumn{1}{|c|}{ Litologia dos clastos } \\
granitos \\
milonitos \\
r riolitos \\
quartzito \\
quartzo \\
quistos \\
\hline
\end{tabular}

FIGURA III.8 - Seção estratigráfica de detalhe da Associação CI2 na localidade MC-38. Vide localização na figura anterior. Atentar para diâmetro máximo de clastos $\left(\phi_{\text {maxx }}\right)$ nos níveis conglomeráticos. 
de feldspato e quartzo e fragmentos líticos variados. Os fragmentos são no geral subangulosos, variando desde angulosos até bem arredondados. As poucas estratificações presentes são do tipo gradacional, originada pela gradação normal e inversa dos clastos. Apesar das poucas estratificações presentes que conferem certa organização ao depósito, a disposição dos clastos é caótica a pseudo-organizada (algumas imbricações), como se os fragmentos tivessem sido lançados e precipitados conforme a perda de energia de transporte, sem maiores indicações de organização. $O$ fenômeno é melhor observado em planta que em perfil, conforme comprovado pela presença comum de fragmentos de granulometria seixo e calhau colocados lado a lado na matriz fina a média com grânulos, por exemplo. A matriz desses depósitos os envolve no geral, podendo ocorrer contatos pontuais a planares entre os fragmentos, os últimos ocasionando imbricação (Localidades MC-38, 110, 364, 365, 128, 129, 130, 331, 332).

Os ortoconglomerados (Fácies Ccs) subordinam-se aos conglomerados sustentados pela matriz (Fácies $\mathbf{C m g}, \mathbf{C m m}$ ), restringindo-se a níveis decimétricos (10-30 cm de espessura) intercalados nestes ou separando níveis areno-conglomeráticos, onde localmente os pacotes atingem espessuras da ordem de 60$70 \mathrm{~cm}$ (MC-110). A Fácies Ces é constituída por pacotes de geometria lenticular de ortoconglomerados polimíticos de calhaus e seixos angulosos a subarredondados $(\phi \operatorname{mix}=10 \mathrm{~cm})$. Os clastos caracterizam-se por contatos planares a côncavo-convexos. A matriz é de areia média a grossa com grânulos. Os ortoconglomerados apresentam estratificações cruzadas acanaladas de baixo ângulo e médio porte. Imbricação de clastos é feição comum (MC-38, 130, 331). No MC-110, ocorre imbricação de clastos bem formada, segundo caimento do plano $a b$ no sentido inverso do fluxo (Localidades MC-38, 110, 331, 130, 128).

A Fácies Aga encerra arenitos grossos, muito mal selecionados, com grânulos e seixos, e até alguns calhaus dispersos $(\phi$ máx $=9,0 \mathrm{~cm}$ ). Os arenitos apresentam gradação dos clastos ocasionando incipiente estratificação plano-paralela e, por vezes, estratificações cruzadas tabulares e acanaladas de pequeno porte, possuindo, ainda, tênue imbricação de clastos. As lâminas frontais das estratificações cruzadas tabulares, não raro, aparecem demarcadas por seixos e grânulos que se acumularam durante o processo. Há, também, feições de corte e preenchimento (scour and fill, MC-195). (Localidades MC-100, $101,102,110,128,129,130$ ).

\section{Interpretação}

A Associação CI2 pode ser interpretada como depósitos subaquáticos devido à vinculação com a Associação de Fácies CI1 e consoante as características: (i) geometria tabular; (ii) espessura superior a $50 \mathrm{~m}$; (iii) clastos variando de grânulos a calhaus angulosos a subangulosos imersos em (iv) matriz formada por pelitos a arenitos grossos e (v) baixa organização dos depósitos. De acordo com Howell \& Normark (1982), fácies de leques subaquáticos são aquelas definidas com base nas principais características como: tamanho dos grãos e outros atributos texturais, razão areia / lama, espessura das camadas e geometria, organização interna das camadas, estruturas sedimentares dinâmicas, trama dos litotipos e composição. 
Rochas análogas à Associação CI2 em outras regiões da Bacia do Camaquã foram consideradas como produtos da deposição em meio subaquático desde os estudos pioneiros de Tessari \& Picada (1966) e de Tessari \& Giffoni (1970) nos vales do Piquiri e do Arroio Boici. O excelente trabalho de Lavina et al. (1985) apresentou um modelo de leques costeiros para estes depósitos. Os autores propuseram-no com base em características como "grandes espessuras dos estratos, geometria e relações de contato com as demais unidades". Assim, em depósitos correlatos do vale do Boici, Sayeg et al. (1992a, b) e Sayeg (1993) interpretaram o contexto deposicional formado por leques subaquáticos com variação de águas mais profundas (seqüências de Bouma) a rasas (fácies de inunditos), com passagem para ambientes costeiros, em processo de colmatação de um grande corpo d'água, possivelmente um mar epicontinental. As seqüências incompletas de Bouma $\left(T_{A E}, T_{C E}, T_{D E}, T_{B D E}\right)$ foram relacionadas a porções distais de leques subaquáticos, constituindo depósitos de turbiditos grossos originados abaixo do nível de ação de ondas de tempestades, de acordo com critérios estabelecidos por Lowe (1982).

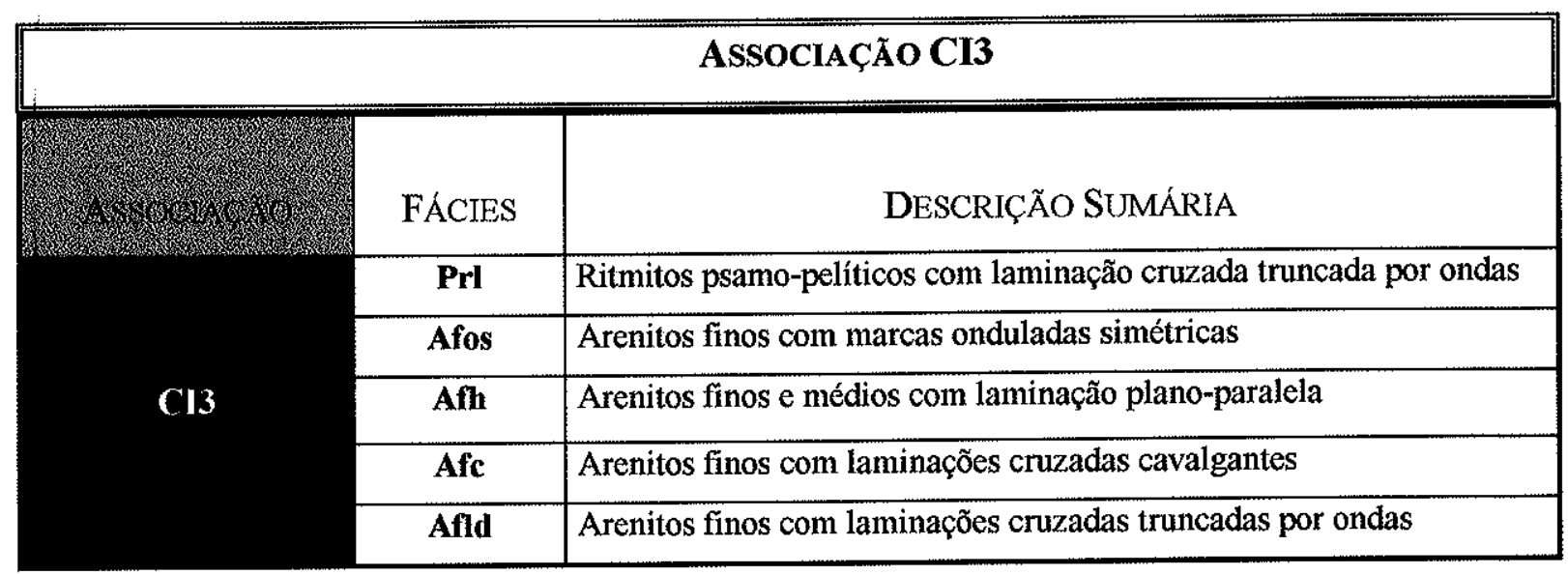

A Associação Cl3 possui exposições na planície a sul das Minas do Camaquã (e.g. no caminho que leva ao rio Camaquã) (Anexo 01).

A Associação CI3 consiste em corpos tabulares de espessura entre $50-80 \mathrm{~cm}$, atingindo fortuitamente até $1,0 \mathrm{~m}$, formados por ritmitos psamo-pelíticos constituídos, da base para o topo, pela alternância brusca de camadas decimétricas de arenitos médios a finos acastanhados bem selecionados com laminação cruzada truncada por ondas de porte centimétrico (Fácies Afld), laminação cruzada cavalgante (Fácies Afc), laminação plano-paralela (Fácies Afh) e marcas onduladas simétricas (Fácies Afos), e lâminas de pelitos (siltitos arenosos esverdeados) de espessura centimétria $(5-10 \mathrm{~cm})$ de estrutura laminada da Fácies Prl (Localidades MC-169, 124).

\section{Descrição}

A Fácies Afld constitui-se de arenitos finos a muito finos, bem selecionados, com palhetas de muscovita nos planos das estratificações, distribuídos em camadas tabulares ( 2 a $8 \mathrm{~cm}$ de espessura) cujo 
topo e cuja base encontram-se ondulados. Internamente, possuem estruturas sedimentares como laminações cruzadas truncadas por migração de marcas onduladas (ripple drift cross lamination) ou microhummockies sensu Dott \& Bougeois (1982), laminação plano-paralela e ondulada (wavy bedding) (Localidades MC-169, 124, 125).

A fácies Afc compõe-se de arenitos médios a finos, castanhos, micáceos, dispostos em camadas de espessura decimétrica, extensão variável e internamente portando laminações cruzadas cavalgantes (climbing ripples) desenvolvidas por ondas de comprimentos de onda centimétricos $(3-6 \mathrm{~cm})$ (Localidades MC-169, 124).

Já a Fácies Afh apresenta corpos tabulares decimétricos de arenitos finos acastanhados, micáceos, contendo laminação plano-paralela e lineação de partição (parting lineation) (Localidades MC-124).

A Fácies Afos destaca-se por arenitos médios a finos ondulados formando camadas centimétricas a decimétricas que, no topo dos estratos, exibem marcas onduladas de perfil simétrico com comprimentos de onda oscilando entre 8 e $12 \mathrm{~cm}$ e cristas de ápice arredondado ou em cúspide.

Por fim, no topo da associação ocorrem as Fácies Prl e Psm. A Fácies Prl é representada por ritmitos formados por intercalações de arenitos finos a muito finos argilosos, arroxeados, micáceos e camadas de pelitos (siltitos arenosos esverdeados) de espessuras centimétricas $(5-15 \mathrm{~cm})$. Os pacotes apresentam laminação plano-paralela como estrutura primária observada (Localidades MC-169, 124).

Psm é a fácies composta por intercalações de corpos tabulares decimétricos de siltitos esverdeados maciços e níveis centimétricos de argilitos maciços (Localidades MC-124, 171).

\section{Interpretação}

Os depósitos da Associação CI3 distinguem-se pela tabularidade dos estratos, granodecrescência ascendente, alternância de camadas de arenitos finos de topo e base ondulados com níveis centimétricos de pelitos. Internamente, estruturas como: (i) laminação plano-paralela; (ii) laminação cruzada truncada por migração de ondas (ripple drift cross lamination) ou micro-hummocky, quando o comprimento de onda é inferior a $1 \mathrm{~m}$; (iii) laminações cruzadas cavalgantes e, no topo das camadas arenosas, (iv) marcas onduladas simétricas com comprimento de onda variando de 1 a $6 \mathrm{~cm}$, indicando oscilação, permitem sugerir que estes depósitos foram gerados por ondas abaixo do nível de ação das ondas normais e dominados por processos de oscilação, possivelmente uma região costeira assolada por ondas de tempestade originando tempestitos sensu Seilacher (1982a).

A Associação CI3 assinala a ocorrência de depósitos gerados sob a influência de processos esporádicos de transporte e acumulação de material arenoso sob a ação combinada de fluxos de correntes oscilatórias de alta energia e alto comprimento de onda e unidirecional (Cheel \& Leckie, 19.92) sob influência de ondas de tempestades (micro-hummockies), sedimentados em ambiente marinho raso, configurando tempestitos. 
Por outro lado, a Fácies Afh vincula-se a processos formados por fluxo acamadado planar sob regimes de fluxo superior e de fluxo inferior. Associa-se com Afld sempre para o topo do perfil. A Fácies Afh deve representar a deposição de sedimentos finos por suspensão durante períodos de tempo firme ou estável (fairweather) na zona de praia, sujeitos à exposição subaérea (fendas de ressecação), e introdução e retrabalhamento de silte grosso por movimentos oscilatórios de ondas de tempestade os quais tocam a superficie dos sedimentos durante novas tempestades (Reading, 1986).

\begin{tabular}{|c|c|c|}
\hline & & ASSOCIAÇÃo CI4 \\
\hline & FÁCIES & DESCRIÇÃO SUMÁRIA \\
\hline \multirow{8}{*}{ CI4 } & Prh & Ritmitos psamo-pelíticos com laminação plano-paralela \\
\hline & Pre & Ritmitos psamo-pelíticos com laminações cruzadas cavalgantes \\
\hline & Afh & Arenitos finos com laminação plano-paralela \\
\hline & Amep & Arenitos médios com estratificação cruzada tipo espinha-de-peixe \\
\hline & Amt & Arenitos médios com estratificações cruzadas tabulares de baixo ângulo \\
\hline & Amc & Arenitos médios com climbing ripples e estratificação ondulada \\
\hline & Amp, Afp & Arenitos médios e finos com estratificação plano-paralela \\
\hline & Afm, Amm & Arenitos finos e médios maciços \\
\hline
\end{tabular}

A Associação CI4 apresenta exposições ao longo da estrada que cruza as Minas do Camaquã e une a BR392 à BR153 no trecho do trevo de acesso à vila das Minas do Camaquã-Passo da Mina, na planície a sul das Minas do Camaquã (e.g. no caminho que leva ao rio Camaquã), bem como nas lavras subterrâneas e a céu aberto da extinta Companhia Brasileira do Cobre (CBC) (vide Anexo 01).

A Associação CI4 compreende pacotes tabulares de espessura variável (decimétricos a métricos, atingindo ocasionalmente até $2,0 \mathrm{~m}$ ) de ritmitos psamo-pelíticos formados internamente pela alternância brusca, da base para o topo (FIGURA III.9), de arenitos médios maciços de colorações variadas (Fácies Afm, Amm); arenitos médios e finos castanhos dispostos em camadas decimétricas, micáceos, bem selecionados, com estratificação plano-paralela, lineação primária de fluxo (parting lineation) da fácies Amp, Afp; arenitos médios com estratificações cruzadas tabulares de baixo ângulo (Fácies Amt); arenitos médios a finos acastanhados com laminação cruzada cavalgante e estratificação ondulada (wavy bedding) dispostos em camadas milimétricas a centimétricas (Fácies Amc), com lâminas milimétricas a centimétricas de pelitos (siltitos e argilitos) entre as camadas arenosas (Fácies Prc); laminação planoparalela (Fácies Afh) e lâminas de ritmitos pelíticos (siltitos arenosos esverdeados) de espessura centimétria $(5-10 \mathrm{~cm})$ de estrutura laminada da Fácies Prh (Localidades MC-43, 313, 124, 125, 169, 124). 


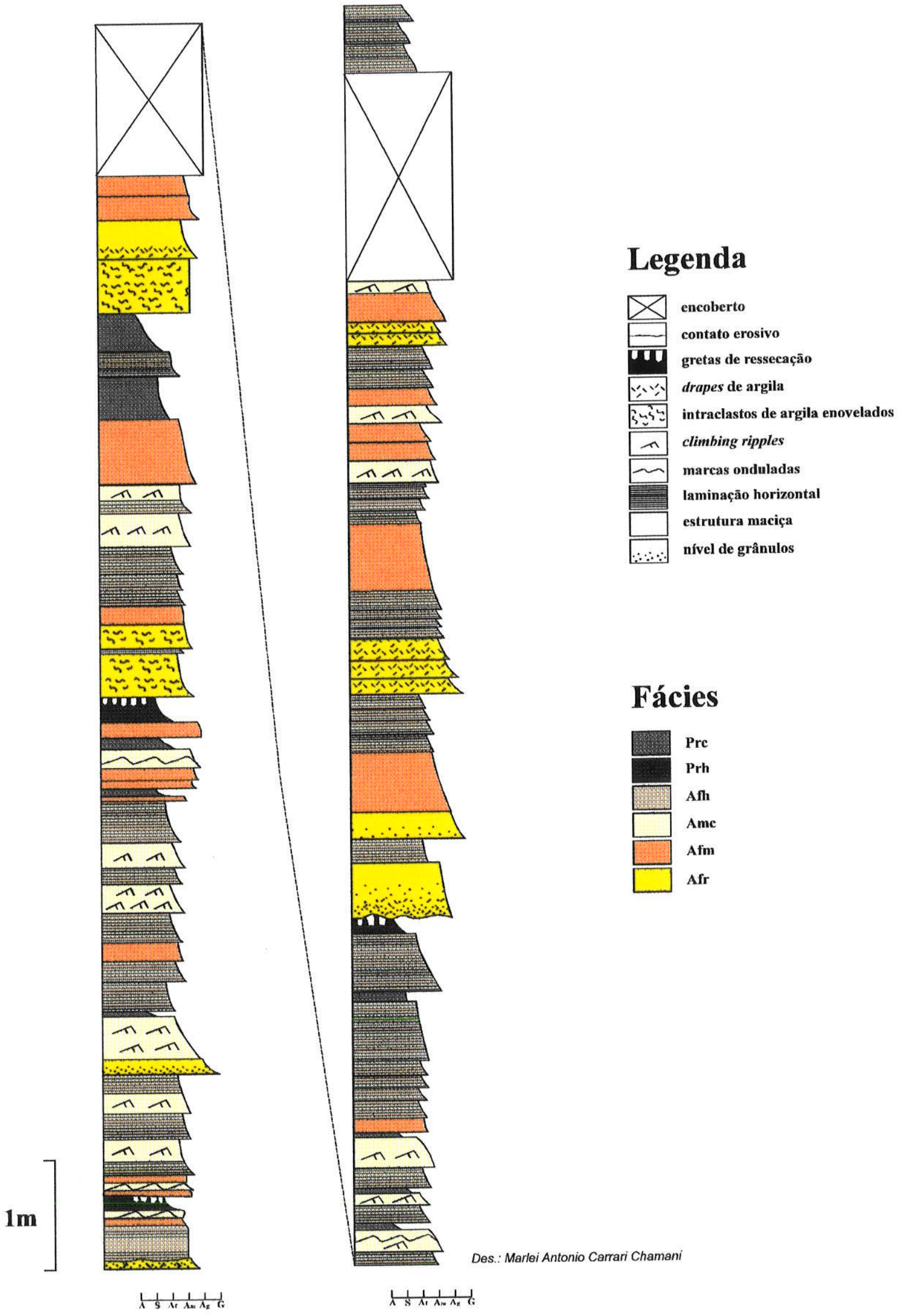

FIGURA III.9 - Seção estratigráfica de detalhe da localidade MC-313 onde se destacam arenitos finos a muito finos de regime de fluxo superior da Associação CI4. Estrada Minas do Camaquã-BR-392. 


\section{Descrição}

As fácies (Amp, Afp) compõem-se de arenitos médios e finos com estratificação plano-paralela denotada por níveis de grãos bem selecionados dispostos em camadas decimétricas $(10-30 \mathrm{~cm})$ alternadas com a fácies de arenitos maciços em cuja base expõe-se marcas erosivas basais (FIGURA III.10) (Localidades MC-43, 313, 124, 125).

A Fácies Amc é definida por pacotes tabulares de espessura variável formados por arenitos médios a finos de coloração castanha dispostos em camadas milimétricas a centimétricas, com laminações cruzadas cavalgantes (climbing ripples) e marcas onduladas por corrente associadas (current ripples) (Figura III.11) e estratificação ondulada (wavy bedding) (Ponto MC-43). Por vezes a estratificação ondulada é originada por lentes de argila em meio às camadas arenosas constituindo estratificação flaser. Esta fácies associa-se com Prc e Prh, possivelmente em porção distal, e em escala de afloramento com as fácies Afh e Afm (FIGURA III.9) (Localidades MC-43, 313, 124, 125).

A Fácies Amt é formada por corpos de geometria tabular de arenitos finos e médios, pobremente selecionados, acastanhados, muito micáceos, laminados, com variações bruscas na granulometria. Ocorrem filmes de argila (drapes). As estruturas presentes são laminação e estratificação plano-paralela, estratificações cruzadas tabulares de médio porte e baixo ângulo $\left(\theta \leq 10^{\circ}\right)$ (Localidades $\mathrm{MC}-184,185$, 176,177 e 178).

A Fácies Amep é formada por corpos de geometria bem tabular de arenitos médios predominantes, mas também por termos mais finos e mais grossos de coloração acastanhada a ocre, bem selecionados por estrato, formando sucessões granodecrescentes para o topo das camadas. Ocorrem estratificações cruzadas tabulares de baixo ângulo $\left(\theta=5^{\circ}-8^{\circ}\right)$ de caráter bimodal (sentidos opostos de mergulho dos foresets das estratificações), por vezes chegando a constituir estratificação espinha-de-peixe (hering bone stratification) de porte pequeno a médio, no ponto MC-176. (Localidades MC-176, 196, 197, entre utras).

A Fácies Afh é constituída por corpos tabulares decimétricos a métricos de arenitos finos castanhos, micáceos, com laminação plano-paralela, lineação de partição ou de fluxo (parting lineation), e delgada película de argila na interface das camadas arenosas, apresentando fendas de ressecação. Associase com a Fácies Afm (Localidades MC-35, 36, 215, 109).

A Fácies Prc compõe-se de ritmitos tabulares constituídos por gradação de níveis decimétricos de arenitos finos a muito finos de aspecto maciço, micáceos, internamente portando incipiente laminação plano-paralela e laminações cruzadas cavalgantes, a estratos centimétricos de siltitos e argilitos maciços a laminados (laminação plano-paralela a ondulada) e acamamento lenticular (estruturas linsen e flaser). 0 topo dos estratos arenosos possui marcas onduladas (FIGURA III.11A) (Localidades MC-35, 36, 37, 98, $169,191)$. 


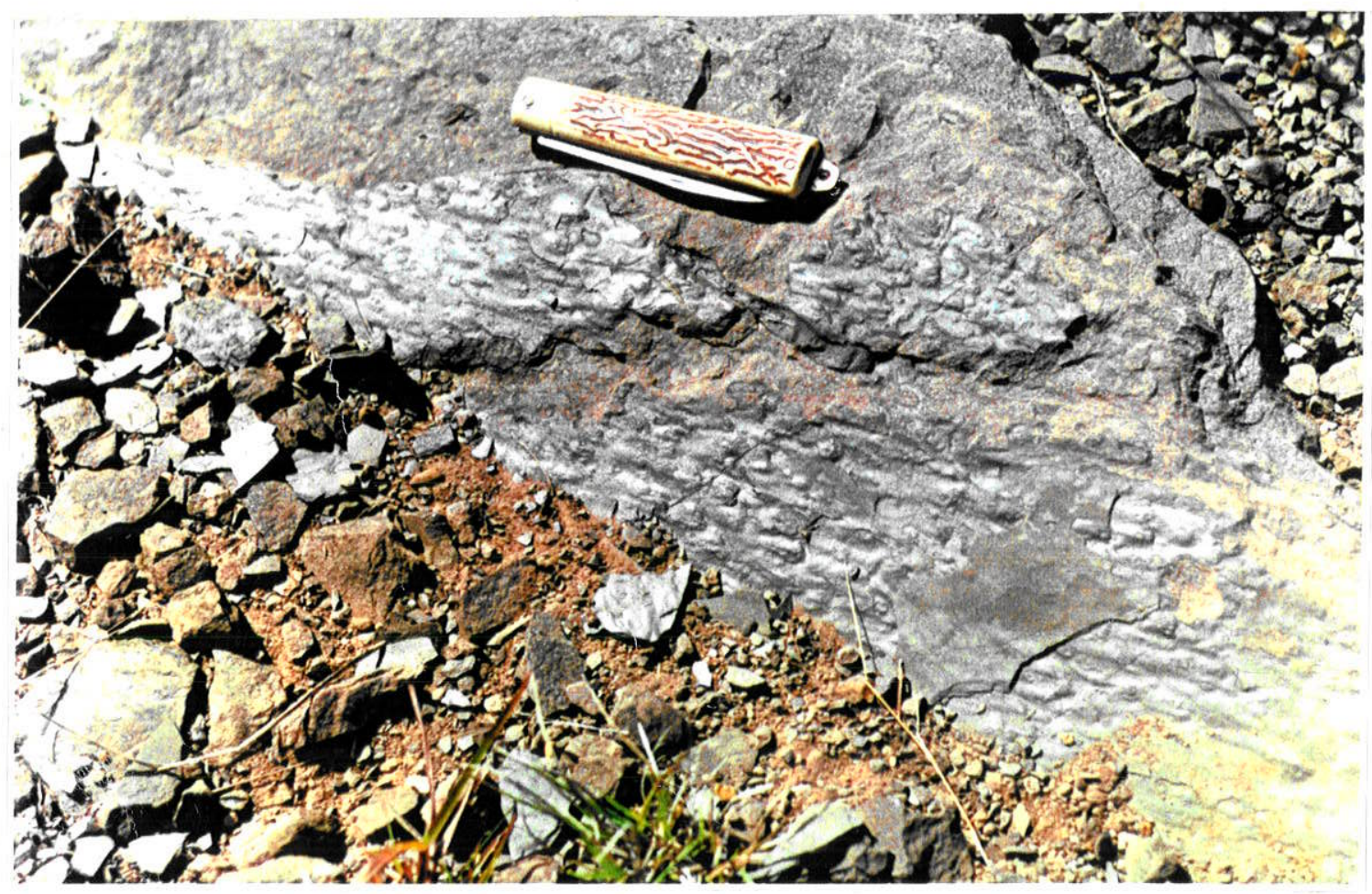

FIGURA III.10 - Contra-molde de marcas erosivas basais encontradas em arenitos finos maciços da Fácies Afm da Associação CI4 na localidade MC-124 (às margens do lago de decantação no vale do arroio João Dias). Fotografia gentilmente cedida pelo Prof. Wellington Ferreira da Silva Filho (UFC).

A Fácies Prh compreende sucessões de ritmitos formados por intercalação centimétrica de arenitos finos a muito finos de coloração acastanhada, contendo laminação plano-paralela, formando estratificação lenticular (linsen), ou em meio a siltitos e argilitos arroxeados com fendas de ressecação poliédricas irregulares de tamanho milimétrico a centimétrico no topo (FIGURA III.11B), internamente mostrando-se maciços ou com laminação plano-paralela A geometria do conjunto é tabular, de grande continuidade lateral. Esta fácies ocorre na planície formada pelo arroio João Dias a norte da Falha do Cemitério (Localidades MC-43, 313, 124, 125).

\section{Interpretação}

As fácies Prh e Prc designam depósitos gerados por correntes de turbidez de baixa densidade (baixa razão de carga em suspensão / velocidade do fluxo) adentrando um corpo d'água raso, localmente com feições de ressecação. A Fácies Afh representa sedimentação por fluxo acamadado planar sob regimes de fluxo superior (laminação plano-paralela) e inferior, freqüentemente sujeita a exposição subaérea. A presença de acamamentos heterolíticos (flaser, linsen, wavy) pode ser explicada por correntes semipermanentes cuja superimposição da ação de ondas carece de efeito construtivo de forma a preservá-los (Raaf et al., 1977; Reineck \& Singh, 1980; Visser, 1980). A presença comum de fendas de ressecação vincula-se à variações constantes no nível do corpo d'água onde chegam a expor seu substrato. Já os arenitos das fácies Amc e Afm indicam condições de geração por atividade considerável de ondas em ambiente de águas muito rasas. Podem representar depósitos de uma planície de maré. 


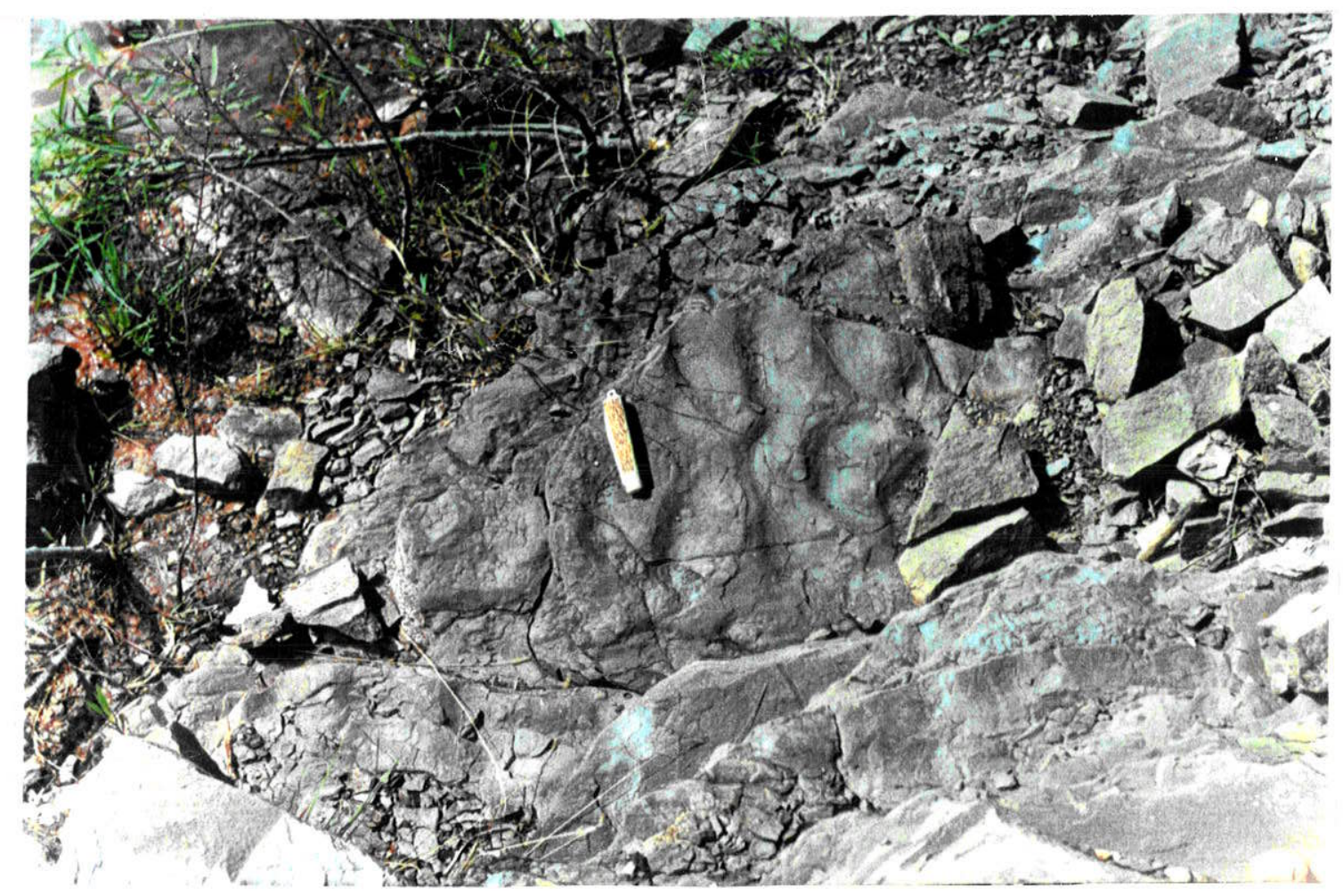

A

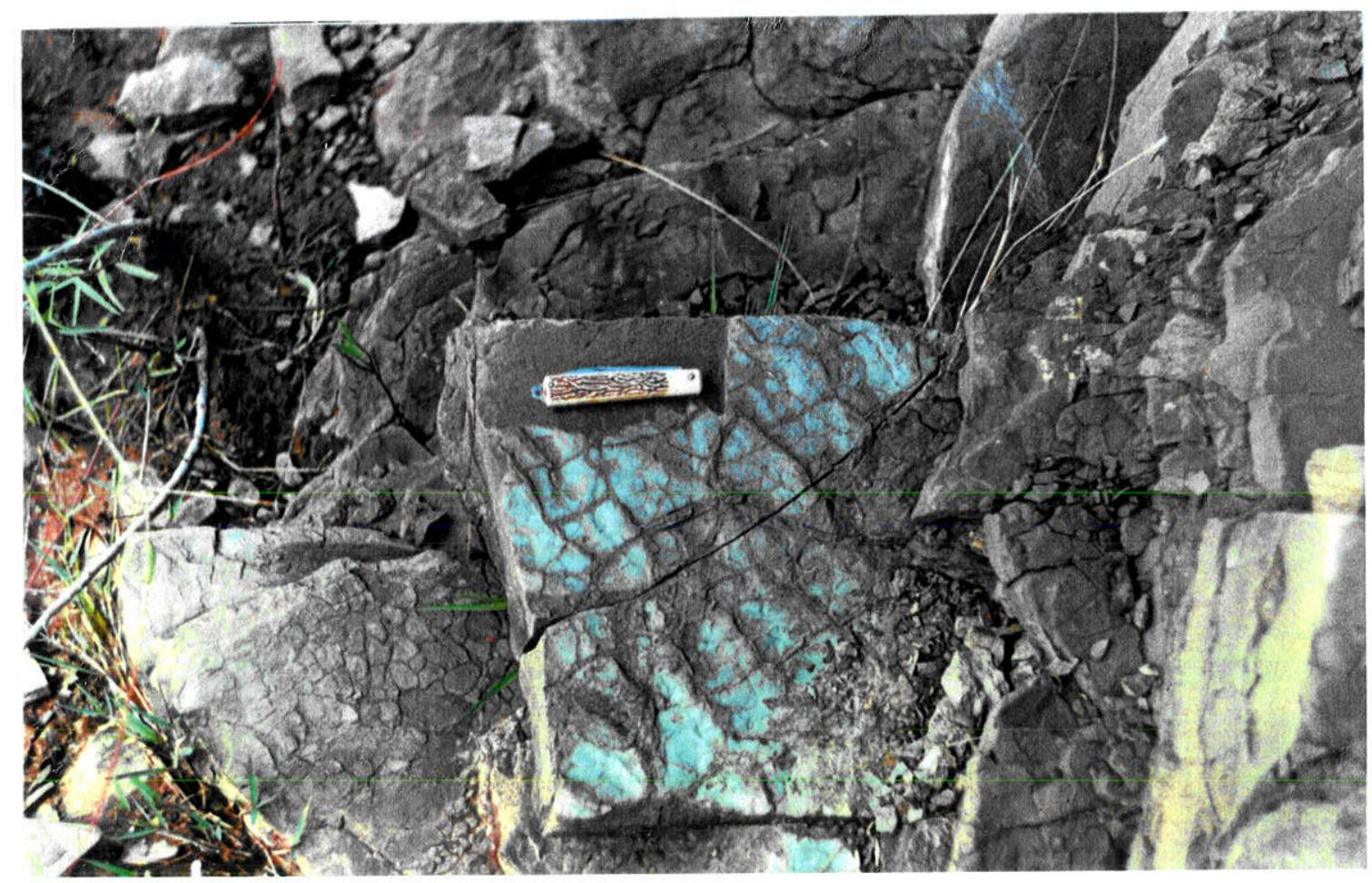

B 
Estas fácies de planície de maré compreendem intercalações de arenitos e pelitos em camadas tabulares de espessura oscilando entre 2 e $10 \mathrm{~cm}$, onde os níveis arenosos exibem boa seleção, cuja base e topo encontram-se ondulados portando estruturas típicas de ambiente transicional de lâmina d'água rasa em ambiente de planície de maré. Caracterizam-se pelas sub-fácies de (a) infra-maré, localizadas abaixo da ação de ondas normais, destacando-se feições como laminação cruzada truncada por ondas (microhummocky), linsen nas camadas pelíticas e presença de pelitos no topo dos pacotes, sobretudo siltitos esverdeados, (b) inter-maré, onde se individualizam arenitos médios arcoseanos portando estruturas sedimentares como flaser, ripple drift cross lamination, climbing ripples e de (c) supra-maré, onde são abundantes as feições de marcas onduladas assimétricas e mesmo simétricas no topo das camadas arenosas, e de fendas de ressecação na parte superior das lâminas de pelitos cobrindo os estratos de arenitos. Nesse ambiente, a deposição de sedimentos finos ocorre nas interrupções de maré alta vindo a acumular-se nas calhas formadas pelas marcas onduladas, originando o acamamento tipo flaser, típico dela, podendo ser erodidos com o refluxo da maré (Raaf et al., 1977; Visser, 1980). Possivelmente foi nessa associação de fácies que Netto et al. (1992) reportaram a ocorrência de traços fósseis (icnofósseis) representados pelos icnogêneros Intrites e Planolites (na base), Cochlichnus, Didymanlichnus, Cruziana?, Planolites, Gyrolithes, Skolithos? e Rusophycus (para o topo). Tal icnofauna, segundo os mesmos autores, refletiria um ambiente de águas rasas, de moderada energia e relativa estabilidade, possivelmente um corpo d'água restrito sob influência de marés e contribuição deltaica. A descoberta de icnofósseis em depósitos da Formação Mangueirão na região das Minas do Camaquã (Paim et al., 1992; Netto et al., 1992) e de estruturas típicas de fácies de borda de um grande corpo d'água indica que este corpo aguoso apresenta características de um mar epicontinental.

As características mencionadas acima, associadas com a ausência de intercalações pelíticas mais importantes e a associação com arenitos sigmoidais da Associação CI5 (Fácies Ams) e com fácies aluviais da unidade superposta (CM) sugerem que a deposição dessa fácies se deu sob o domínio da ação das ondas normais, de pequena magnitude, em águas muito rasas com períodos intermitentes de emergência subaérea eventual. Desse modo, esses sedimentos indicam condições deposicionais em ambiente costeiro, margem de um corpo d'água marinho. A presença de estratificações com sentidos de paleofluxo opostos sugere a ação de marés.

De fato, como sugerem alguns autores sobre este ponto. Della Fávera (1984) afirmou que muitos dos depósitos desta associação de fácies ter-se-iam originado pelo rápido aporte de grande carga sedimentar em águas rasas a muito rasas, com exposição subaérea, definindo-os como inunditos. Lavina et al. (1985) interpretaram esses depósitos como produtos de ambientes transicionais, cuja deposição foi promovida predominantemente por fluxos densos em águas rasas, com exposição subaérea eventual, caracterizando tais depósitos como inunditos de Seilacher (1982b). Sayeg (1993) também apontou depósitos de inunditos associados com leques costeiros na região do vale do Boici, sugerindo que estes pudessem representar as margens de um mar epicontinental que se fixara naquela região. 
depósitos de inunditos associados com leques costeiros na região do vale do Boici, sugerindo que estes pudessem representar as margens de um mar epicontinental que se fixara naquela região.

\begin{tabular}{|c|c|c|}
\hline \multicolumn{2}{|c|}{ ASSOCIAÇÃo CI5 } \\
\hline \multirow{3}{*}{ CI5 } & FÁCIES & DESCRIÇÃo SUMÁRIA \\
\hline & Ams & Arenitos finos a médios com estratificação cruzada sigmoidal \\
\hline & Amt & Arenitos médios com estratificações cruzadas tabulares \\
\cline { 2 - 4 } & Afm & Arenitos finos maciços com exposição subaérea \\
\hline & Afh & Arenitos finos com laminação plano-paralela \\
\hline
\end{tabular}

A Associação CI5, equivalente ao Arenito Inferior de Ribeiro (1978) e Gonzalez \& Teixeira (1980), é encontrada na estrada que cruza as Minas do Camaquã e une a BR392 à BR153 no trecho do trevo de acesso à vila das Minas do Camaquã-Passo da Mina, mas a Fácies Ams somente foi identificada em um corte às margens dessa estrada, abaixo do Cerro da Cruz (local MC-145).

\section{Descrição}

A Fácies Afm compreende arenitos finos acastanhados, micáceos, maciços, formando pacotes centimétricos de geometria tabular. Intraclastos pelíticos são comuns (Localidades MC-125, 145).

A Fácies Amt caracteriza-se por arenitos médios portando estratificações cruzadas tabulares de baixo ângulo e pequeno porte em camadas centimétricas (Localidades MC-125, 145).

A Fácies Ams encerra corpos métricos granocrescentes de geometria tipo sigmoidal a lenticular de arenitos finos a médios acastanhados, amalgamados ou com delgada lâmina de pelitos na interface e marcas onduladas assimétricas no topo dos estratos arenosos (FIGURA III.12A). Dentre as estruturas internas presentes destacam-se estratificação cruzada sigmoidal de médio porte (FIGURA III.12B), estratificações cruzadas acanaladas na parte superior dos estratos. Intraclastos pelíticos são abundantes. Esta fácies está relacionada com a Fácies Amt (Localidades MC-145).

Afh é uma fácies composta de arenitos finos com laminação plano-paralela e delgada lâmina de argila na interface das camadas arenosas, apresentando fendas de ressecação (Localidade MC-145).

\section{Interpretação}

A Fácies Ams, em vista da geometria dos corpos e estruturas internas e sua associação comum com as fácies de tempestitos, inunditos e de planície de maré do Conjunto Inferior (CI3 e CI4) e aluviais do Conjunto Médio (Formação Vargas), pode estar relacionada com lobos de frente deltaica em condições de fluxo homopicnal (sensu Bates, 1953). As fácies Afm e Afh subordinam-se à Ams e representariam 
Figura III.12- Arenitos médios e finos sigmoidais (Fácies Ams) e maciços (Fácies Afm) da Associação CI5 na localidade MC-145, estrada vicinal Minas do Camaquã - BR-392 que conecta a área de estudos aos municípios de Santana da Boa Vista e Pelotas. A - Geometria sigmoidal dos corpos amalgamados de arenito (ao lado do homem de escala), por vezes separados por delgada lâmina de siltitos ou, mais raramente, argilitos que podem exibir fendas de ressecação. Notar forte mergulho das camadas (cerca de $40-45^{\circ}$ de inclinação). B - Detalhe da estruturação interna mostrando a amalgamação dos arenitos maciços (Fácies Afm) e arenitos com provável estratificação sigmoidal (Fácies Ams). Estas fácies relacionam-se com a Associação CM1, superior, podendo representar corpos deltaicos da porção emersa do corpo aquoso do Conjunto Inferior de Associaçðes de Fácies (CI). 
$\underline{\text { Fambrini, }} \underline{\text { G.L. }}=\underline{\text { O Grupo Camaquã: }} \underline{\text { análise de fácies, proveniência e paleocorrentes }}$




possivelmente depósitos de rompimento de diques marginais de distributários deltaicos (Faccini et al., 1987). A presença de arenitos com estratificações cruzadas tabulares com pelitos para o topo reforçam tal suposição, pois podem evidenciar a deposição rápida dos distributários deltaicos após o rompimento dos diques, assemelhando-se à depósitos de crevasse-splays.

\section{III.2.1.3 SISTEMAS DEPOSICIONAIS DA FORMAÇÃO MANGUEIRÃO}

A unidade evidencia a presença de depósitos de um corpo aquoso representado por diversas faciologias representativas das várias batimetrias desse corpo.

A Associação de Fácies CI1 vincular-se-ia à depósitos de turbiditos significando as porções proximais e distais desse corpo aquoso que se achava sob a ação de perturbações tectônicas gerando correntes de turbidez.

Na Associação de Fácies CI2 encontramos depósitos conglomeráticos relacionados aos turbiditos, podendo significar as porções de granulometria grossa dos mesmos, mas já evidenciando batimetrias possivelmente mais rasas, dentro de contexto de leques costeiros.

A Associação de Fácies C13 representa depósitos formados abaixo do nível de ação das ondas normais, possivelmente vinculados à atuação de tempestades, onde mecanismos de ondulação com esporádicas exposições subaéreas insinuam fortemente que os sedimentos precedentes sofreram retrabalhamento por ondas e, ocasionalmente, ondas de tempestade, culminando com o acúmulo de depósitos de tempestitos. A associação evidencia, assim, contexto deposicional mais próximo das margens do corpo aquoso.

A Associação de Fácies CI4 pode associar-se à borda do corpo d'água, provavelmente sob a ação de marés, mas inequivocamente em contexto deposicional mais raso que os anteriores em vista das abundantes feições subaéreas encontradas. Desse modo, representaria ambiente de planície de marés desse corpo aquoso.

A Associação de Fácies CI5 já representaria a porção predominantemente emersa desse corpo d'água vinculada a depósitos de lobos de frentes delataicas em ambiente transicional.

A presença de sistemas de turbiditos distais e proximais (Associações CIl e Cl2), passando coluna acima para depósitos de borda de corpo aquoso (fácies de planícies de marés), sugere que houve um corpo d'água na região, provavelmente um sistema deposicional marinho-transicional, ou que apresentou alguma conexão marinha precedente, em vista da provável presença de fácies de tempestitos, fácies costeiras e, principalmente, a ocorrência de assembléias de icnofósseis nos estratos desta formação (Netto et al., 1992).

Dessa maneira, a Formação Mangueirão na área de estudos originou-se em um corpo marinho possivelmente raso, um mar de características epicontinentais. 


\section{III.2.1.2 Conjunto Médio (CM) - Formação Vargas}

O Conjunto Médio de Associações de Fácies (CM) - Formação Vargas - compreende as sucessões psefito-psamíticas normalmente descritas na literatura como Membro Vargas da Formação Arroio dos Nobres de Ribeiro et al. (1966), ou seqüência IIb de Paim et al. (1992). Constitui-se na principal unidade conglomerática aflorante na região perfazendo espessura de cerca de $500 \mathrm{~m}$, incluindo-se as amplas e generosas exposições da cava a céu aberto da Mina Uruguai (CBC). Sobrepõe-se ao Conjunto Inferior de Associações de Fácies (CI) por contato gradacional constituindo-se em ciclos progradantes (granocrescentes). Ribeiro (1978), Teixeira et al. (1978b) e Gonzalez \& Teixeira (1980) referiram-na como: Conglomerado Inferior, Arenito Intermediário e Conglomerado Superior.

\section{III.2.1.2.1 Associações de Fácies da Formação Vargas}

Na cava a céu aberto da Mina Uruguai da extinta Companhia Brasileira do Cobre afloram possantes conglomerados da Formação Vargas. Nesse local foi possível distinguir duas unidades equivalentes aos Conglomerado Inferior e Superior de Ribeiro (1978) e Gonzalez \& Teixeira (1980), onde foram definidas duas associações de fácies: CM1, de conglomerados polimíticos de matriz de areia média a grossa intercalados com arenitos conglomeráticos e arcoseanos grossos compondo níveis de $1,5-2,0 \mathrm{~m}$ e CM2, onde se destacam ortoconglomerados polimíticos organizados dispostos em camadas tabulares de um metro de espessura separados por níveis de arenitos grossos conglomeráticos. A Associação CM3, aflorante apenas no extremo nordeste da área da Formação Vargas, é composta de brechas oligomíticas sustentadas tanto por clastos como por matriz (Fácies Bmm) de depósitos de brechas de fluxos de detritos.

\begin{tabular}{|c|c|c|}
\hline \multicolumn{3}{|c|}{ Equivalente ao Conglomerado Inferior de Ribeiro (1978) e Gonzalez \& Teixeira (1980). } \\
\hline AssociacAo & FACIES & DESCRIÇÃO SUMÁRIA \\
\hline & $\mathbf{C a}$ & Conglomerados organizados com estratificação cruzada acanalada \\
\hline Cyi & $\mathbf{C m m}$ & Conglomerados sustentados pela matriz, clastos angulosos \\
\hline & $\mathbf{C p}$ & Conglomerados sustentados pelos clastos c/ estratificação plano-paralela \\
\hline$=$ & Aga & Arenitos grossos a muito grossos com fragmentos \\
\hline
\end{tabular}

A Associação CM1 ocorre como uma faixa estreita entre a Formação Mangueirão e a Associação CM2. A espessura medida é de cerca de 80 metros na cava a céu aberto da Mina Uruguai. 
Esta associação congrega fácies conglomeráticas de geometria lenticularizada em mapa e tabular na escala de afloramento formadas por intercalações de camadas decimétricas de paraconglomerados polimiticos de seixos e, subordinadamente, calhaus (Fácies Ca); estratificados muito grosseiramente em camadas de até 1,5m (Fácies Aca); paraconglomerados maciços de geometria lenticular de espessura variando de $50 \mathrm{~cm}$ a $\mathrm{lm}$ (Fácies $\mathbf{C m m}$ ), alternados em contato brusco com níveis de arenitos finos a grossos com grânulos (Fácies Aga) ou conglomeráticos com seixos esparsos da Fácies Aca que gradam bruscamente para niveis centimétricos de pelitos com fendas de ressecação.

\section{Descrição}

A Fácies Ca comporta paraconglomerados pouco organizados em pacotes de espessura média em torno de $50 \mathrm{~cm}$ e máxima de até $\operatorname{lm}$ (FIGURA III.13), com seixos e, subordinadamente, calhaus ( $\phi$ máx $=15$ $\mathrm{cm}$ ). A matriz compõe-se de areia média a muito grossa, mal selecionada, com grânulos e possui coloração esverdeada. Os fragmentos são subangulosos (50\%), mas podendo ser angulosos (30\%) a subarredondados (15\%) a bem arredondados (5\%). Já os clastos de granulometria maior são melhor arredondados, porém preservando a angulosidade característica típica da unidade. A matriz os envolve, podendo ocorrer contatos pontuais a planares entre os clastos, os últimos ocasionando imbricação. É curiosa a presença de clastos de leucogranito róseo com textura Rapakivi (ver análise de proveniência adiante). Embora seja caótica e apresente estrutura maciça, por vezes a deposição seguiu uma gradação normal compondo ciclos granodecrescentes, onde cada novo ciclo possui limite erosivo com o anterior. As estruturas presentes são estratificações plano-paralela e cruzadas acanaladas de médio porte e baixo ângulo. No topo dos pacotes, ou mesmo de cada ciclo, pode haver delgada película de finos (arenito muito fino argiloso e até siltito marrom) com fendas de ressecação (FIGURA III.14). Localidades MC-40 (principal), 195, 44 (Cerro da Cruz).

A Fácies Cmm constitui-se de pacotes de 60-70 cm de espessura máxima com geometria lenticular formados por paraconglomerados polimíticos desorganizados de callaus e seixos angulosos imersos em matriz de areia grossa com grânulos, maciços, de coloração cinza esverdeada, com ocasional imbricação de clastos.

Os ortoconglomerados (Fácies $\mathbf{C p}$ ) subordinam-se aos conglomerados sustentados pela matriz (Ca, $\mathbf{C m m})$, restringindo-se a níveis centimétricos $(10-30 \mathrm{~cm}$ de espessura) intercalados nestes ou separando níveis areno-conglomeráticos, onde localmente os pacotes atingem espessura métrica (MC-40). São compostos por seixos e grânulos e, muito esporadicamente, alguns calhaus $\left(\phi_{\operatorname{mix}}=10 \mathrm{~cm}\right.$, riolito) (FIGURA III.13). São maciços a estratificados e apresentam geometria lenticularizada. As estratifícações presentes são do tipo plano-paralelo e gradacional, esta originada pela gradação normal dos clastos. Caracterizam-se por contatos planares a côncavo-convexos, deste modo tomando a matriz subordinada. Imbricação de clastos é feição comum. Localidades MC-40, 195, 44, 394. As estruturas presentes são, além da estrutura 
maciça e da gradação normal dos clastos, estratifícação plano-paralela evidenciada pelos planos de acamamento dos estratos e imbricação de clastos.

A Fácies Aga compõe-se de níveis de arenitos finos a grossos com grânulos, muito mal selecionados, localmente com esporádicos seixos (FIGURA III.13). Os arenitos estão bem estratificados, apresentando acamamentos plano-paralelos e estratificações cruzadas dos tipos tabular e acanalado, possuindo, ainda, tênue imbricação de clastos. A geometria em afloramentos é tabular, mas parece ser lenticular em escala menor.

A Fácies Aca corresponde a pacotes lenticulares decimétricos de arenitos grossos, muito mal selecionados por estrato, matriz arcoseana, com grânulos e seixos, e até calhaus dispersos $\left(\phi_{\max }=9,0 \mathrm{~cm}\right)$. Os fragmentos colocam-se nos foresets das estratificações cruzadas. As estratificações cruzadas são do tipo acanalado, dado pela terminação côncava para o topo dos estratos individuais, truncando os foresets das estratificações subjacentes (vide FIGURA III.15). As lâminas frontais, não raramente, aparecem demarcadas por seixos e grânulos que se acumularam durante o processo, salientando os planos das estratificações cruzadas (FIGURA III.16). Há, também, feições de corte e preenchimento (scour and fill) (MC-195, 217). Associa-se às fácies Ca e Ccs. Localidades MC-40 (principal), 195, 219, 220, 218, 394, 217,392 .

\section{Interpretação}

As fácies Ca, Cp, Cmm e Aga relacionam-se a processos de transporte em regime de tração e deposição na forma de barras longitudinais (predominantes) e dunas subaquáticas em ambiente aluvial, possivelmente um corpo de fan delta. Teixeira et al. (1978b) foram os primeiros a admitir geração através de fan deltas para tais depósitos, no que estamos de pleno acordo.

Podem representar depósitos de fluxos de detritos subaquáticos. Segundo Holz (1987), tais depósitos geralmente são mais finos que os subaéreos, formando conglomerados suportados pela matriz, com freqüência imbricados em virtude do movimento clasto-a-clasto e podendo apresentar gradação inversa. Normalmente encontram-se intercalados com os depósitos da própria bacia de acumulação, tais como intercalações de finos de origem marinha ou marinho-deltaica com as fácies de fluxo de detritos subaquáticas (Gloppen \& Steel, 1981). 
FIGURA III.13 - Arenitos conglomeráticos (Fácies Aga), de geometria tabular, da Associação CM1. Notar fragmentos subangulosos a angulosos do tamanho seixo, predominantemente, na base dos pacotes. Por sua vez, esses apresentam granodecrescência ascendente, definindo ciclos granodecrescentes. Localidade MC-40 (cava a céu aberto da Mina Uruguai, $C B C$ ).

FIGURA III.14 - Fendas de ressecação em delgada película de argila na interface entre dois ciclos conglomeráticos da Associação CM1. O nível refere-se à interface entre os dois pacotes da Figura III.13, imediatamente acima da escala (martelo). A feição revela o topo de um ciclo e indica exposição subaérea para esses depósitos. Localidade MC-40 (cava a céu aberto da Mina Uruguai, $\mathrm{CBC}$ ). 
$\underline{\text { Fambrini, }} \underline{\text { G.L. }}=\underline{\text { O Grupo Camaquã: }} \underline{\text { análise de fácies, }} \underline{\text { proveniência e paleocorrentes }}$

NW

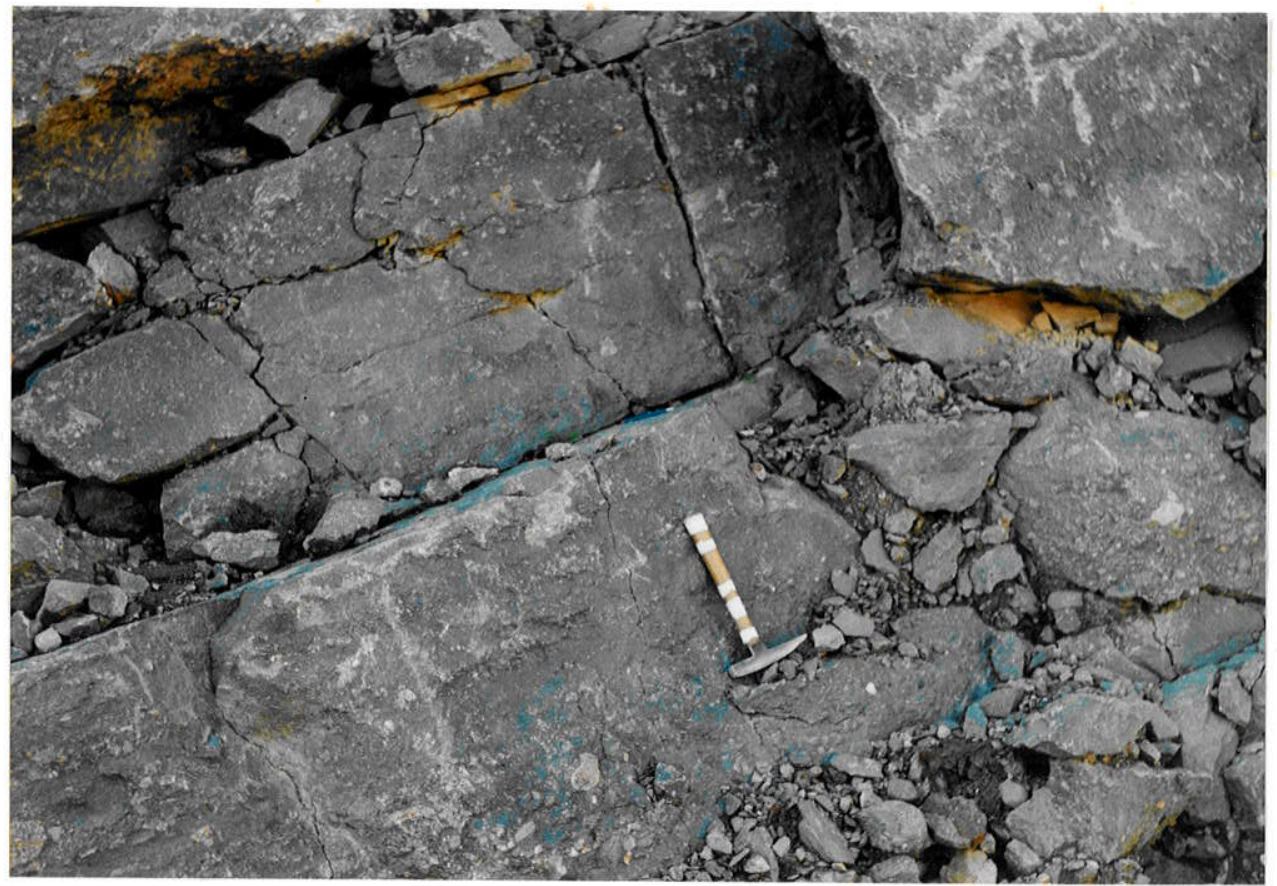

SE

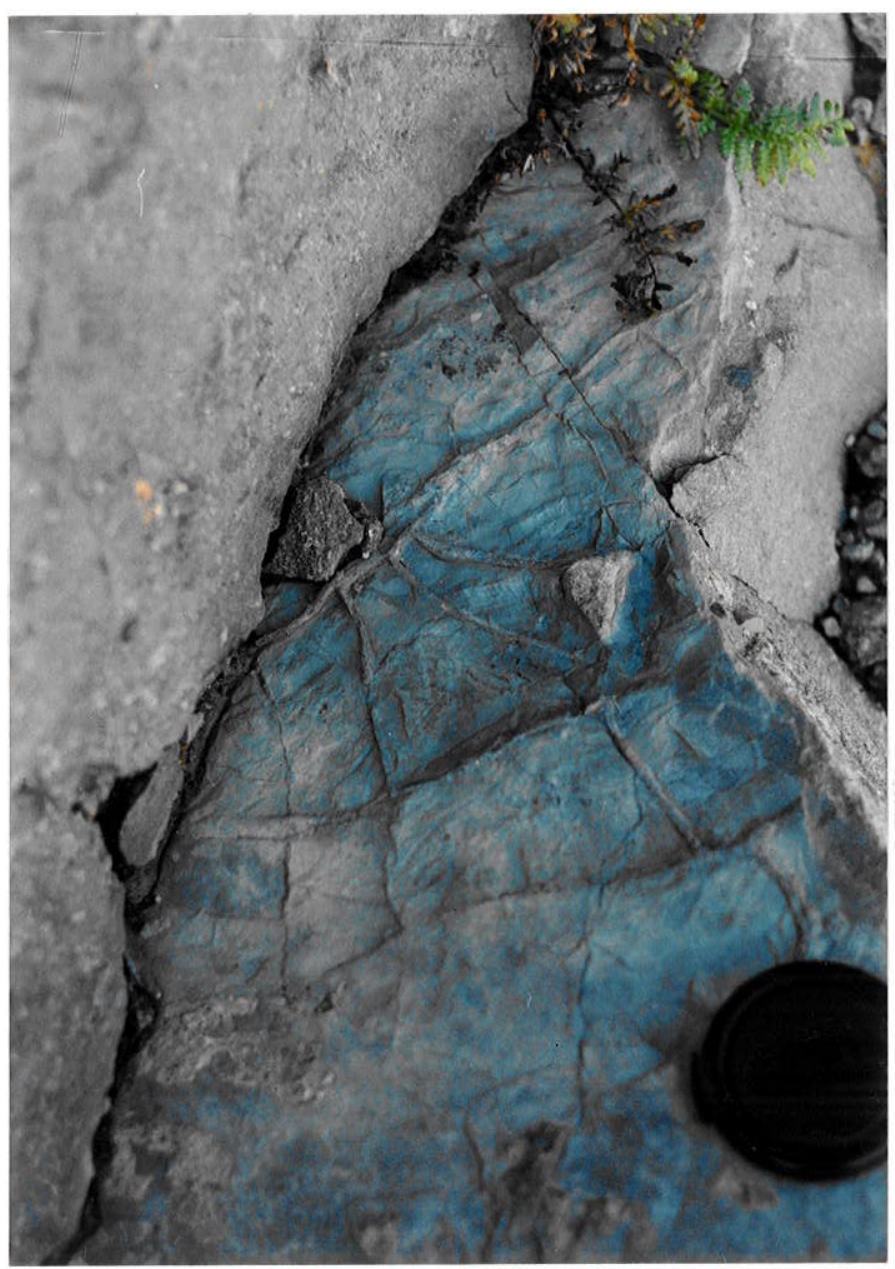


FIGURA III.15 - Arenitos conglomeráticos da Fácies Aca da Associação CM1 mostrando peculiar estratificą̧ão cruzada de pequeno porte. Notar fragmentos subangulosos a angulosos do tamanho seixo na base dos ciclos. Topo dos pacotes em posição normal. Localidade MC-40 (cava a céu aberto da Mina Uruguai, $\mathrm{CBC}$ ).

FIGURA III.16 - Conglomerados estratificados (Fácies Cp) da Associação CM1 apresentando níveis de clastos e níveis mais arenosos que definem a estratificação. Notar fragmentos subangulosos a angulosos do tamanho seixo, predominantemente, na base dos pacotes, sendo alguns subarredondados. Localidade MC-40 (cava a céu aberto da Mina Uruguai, $\mathrm{CBC}$ ). 


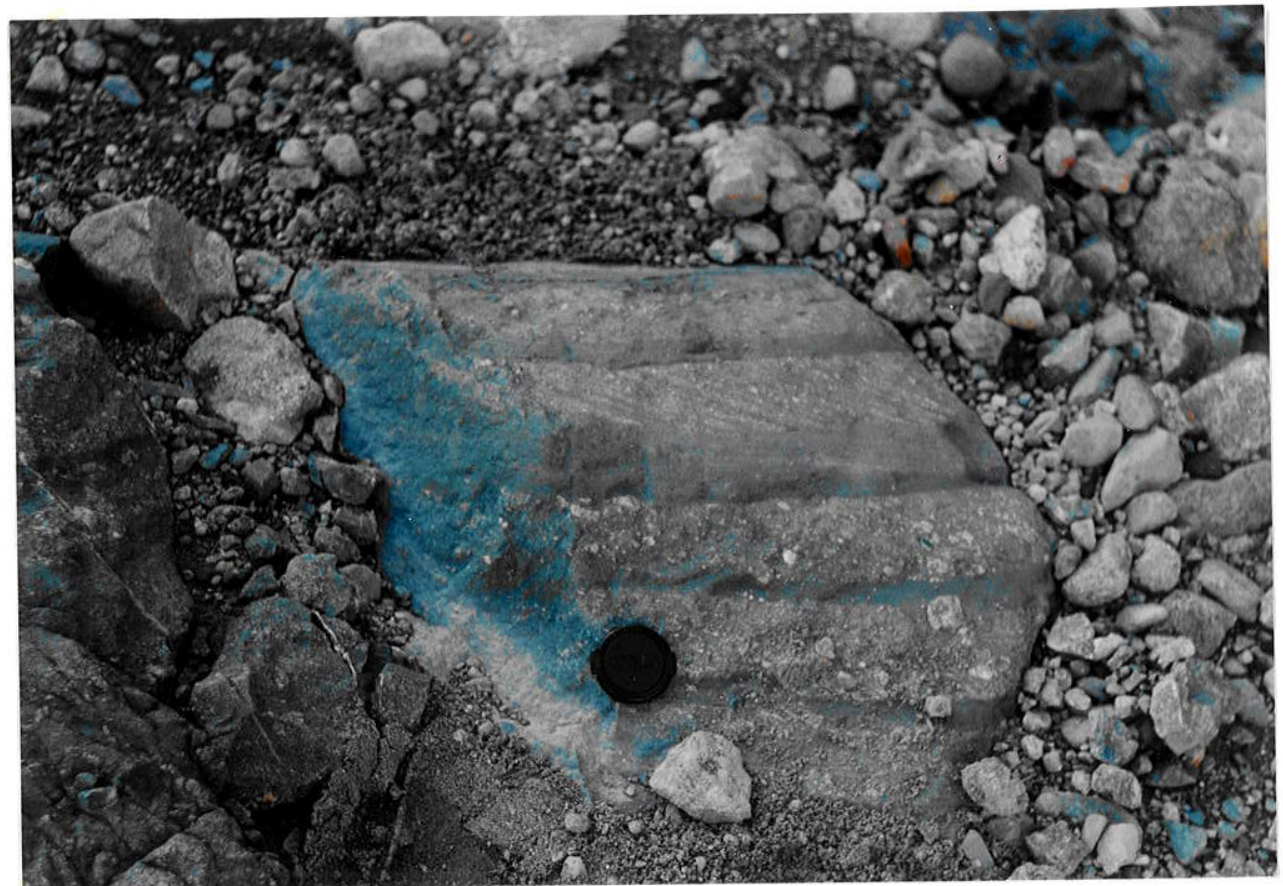

NW

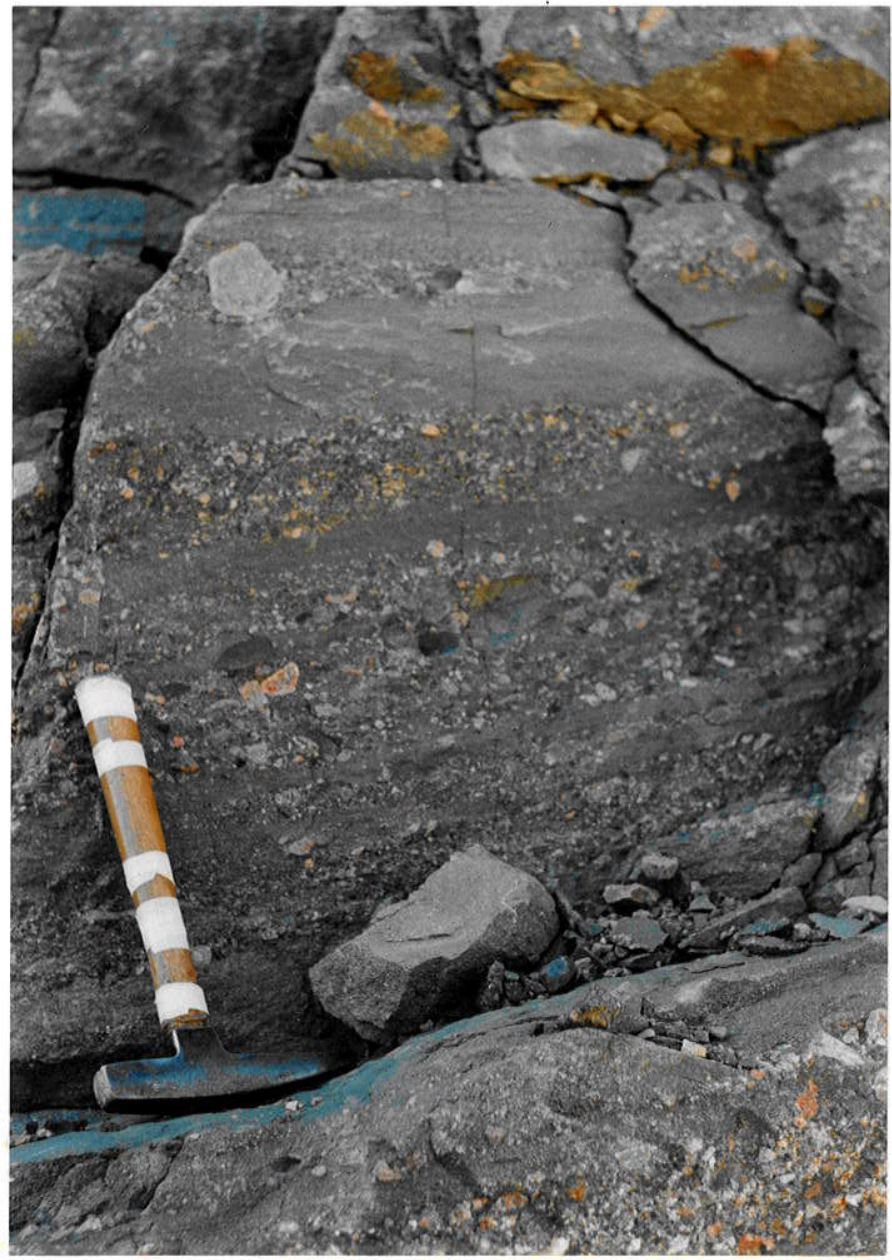




\begin{tabular}{|c|c|c|}
\hline \multicolumn{3}{|c|}{$\begin{array}{l}\text { AssoCIAÇão CM2 } \\
\text { Equivalente aos Arenito Intermediário e Conglomerado Superior de Ribeiro (1978) }\end{array}$} \\
\hline & FACIES & DESCRIÇÃO SUMÁRIA \\
\hline \multirow{6}{*}{$\mathrm{CM} 2$} & Ces & Ortoconglomerados organizados de geometria tabular \\
\hline & Cmg & Paraconglomerados desorganizados a gradados \\
\hline & $\mathbf{C t}$ & Conglomerados com estratificações cruzadas tabulares \\
\hline & $\mathbf{C a}$ & Conglomerados com estratificações cruzadas acanaladas \\
\hline & Aca & Arenitos conglomeráticos c/ estratificações cruzadas acanaladas \\
\hline & Aga & Arenitos grossos a muito grossos com fragmentos \\
\hline
\end{tabular}

A Associação de Fácies CM2 apresenta excelentes exposições ao longo da estrada que cruza as Minas do Camaquã e une a BR392 à BR153 no trecho do Passo da Mina-Estrada do Passo do Cação, em trecho da estrada que conduz para a Serra dos Apertados e passa pela Pedra do Bagual e, principalmente, nas minas subterrânea e a céu aberto da Companhia Brasileira do Cobre (CBC). Constituem camadas tabulares de grande persistência lateral de espessura máxima estimada em 400m (vide Anexo 01).

Esta associação abrange camadas centimétricas a decimétricas formando pacotes métricos de fácies de ortoconglomerados polimíticos tabulares gradados (Fácies Ces) a estratificados (Fácies Ct, Ca); arenitos grossos (Fácies Aga) e arenitos conglomeráticos (Fácies Aca) e paraconglomerados gradados de seixos (Fácies Cmg), como ilustram as FIGURAS III. 17 e III.18.

Os ortoconglomerados tabulares dominam esta associação de fácies (FIGURA III.20), envolvendo estratos de 1 a $2 \mathrm{~m}$ de espessura, compondo ciclo granocrescente, notadamente para o topo da coluna (thickenuing upward cycle). Os níveis de ortoconglomerados, sejam gradados ou estratificados, dispõem-se em alternância com os de arenitos grossos e arenitos conglomeráticos (Fácies Aga e Aca) e de paraconglomerados, perfazendo contatos bruscos, predominantemente. 
A
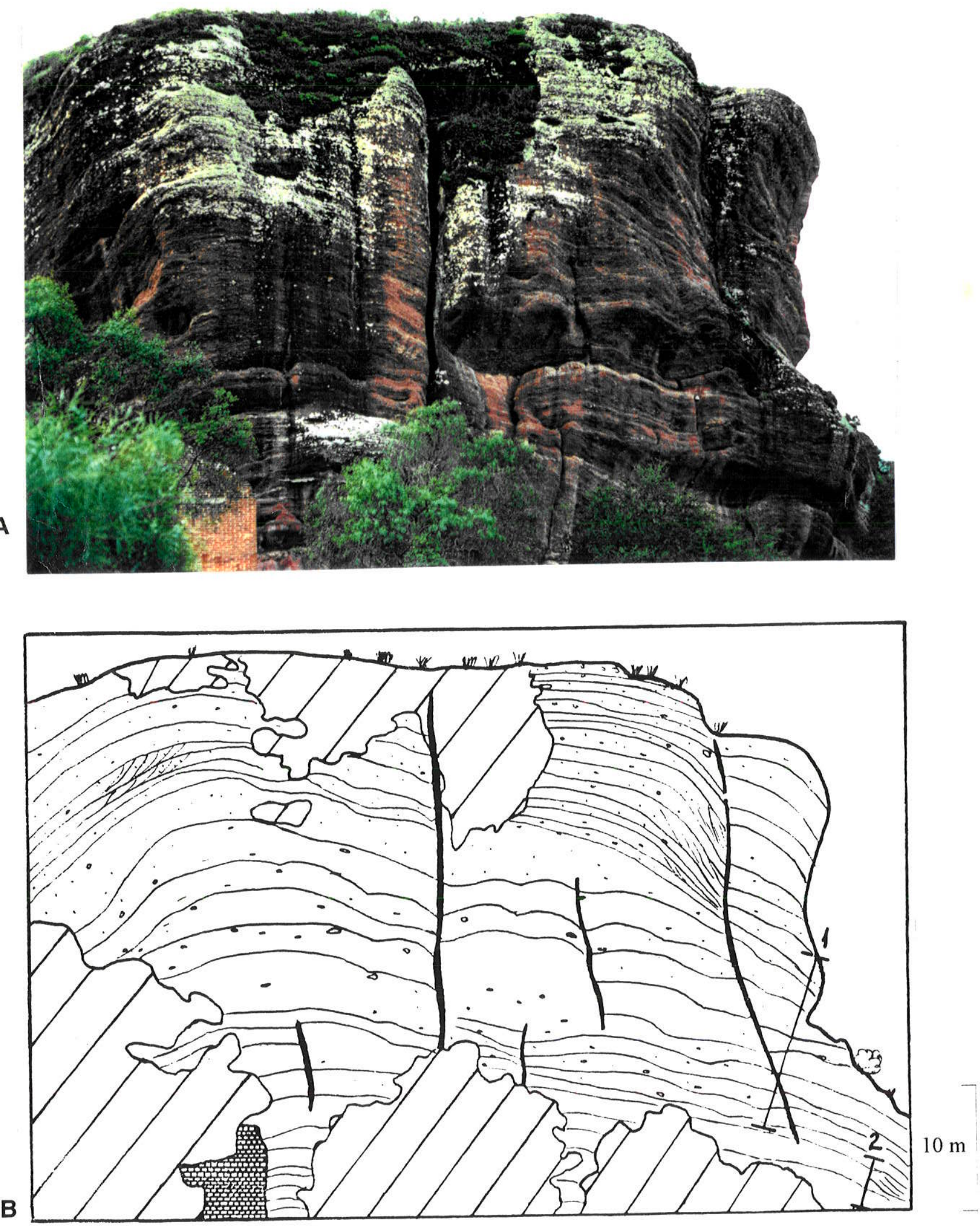

FIGURA III.17 - Associação CM2 no local MC-195. A- Visão geral dos pacotes de arenitos e conglomerados da AM3; B- Croqui de A denotando as principais feições sedimentares. 

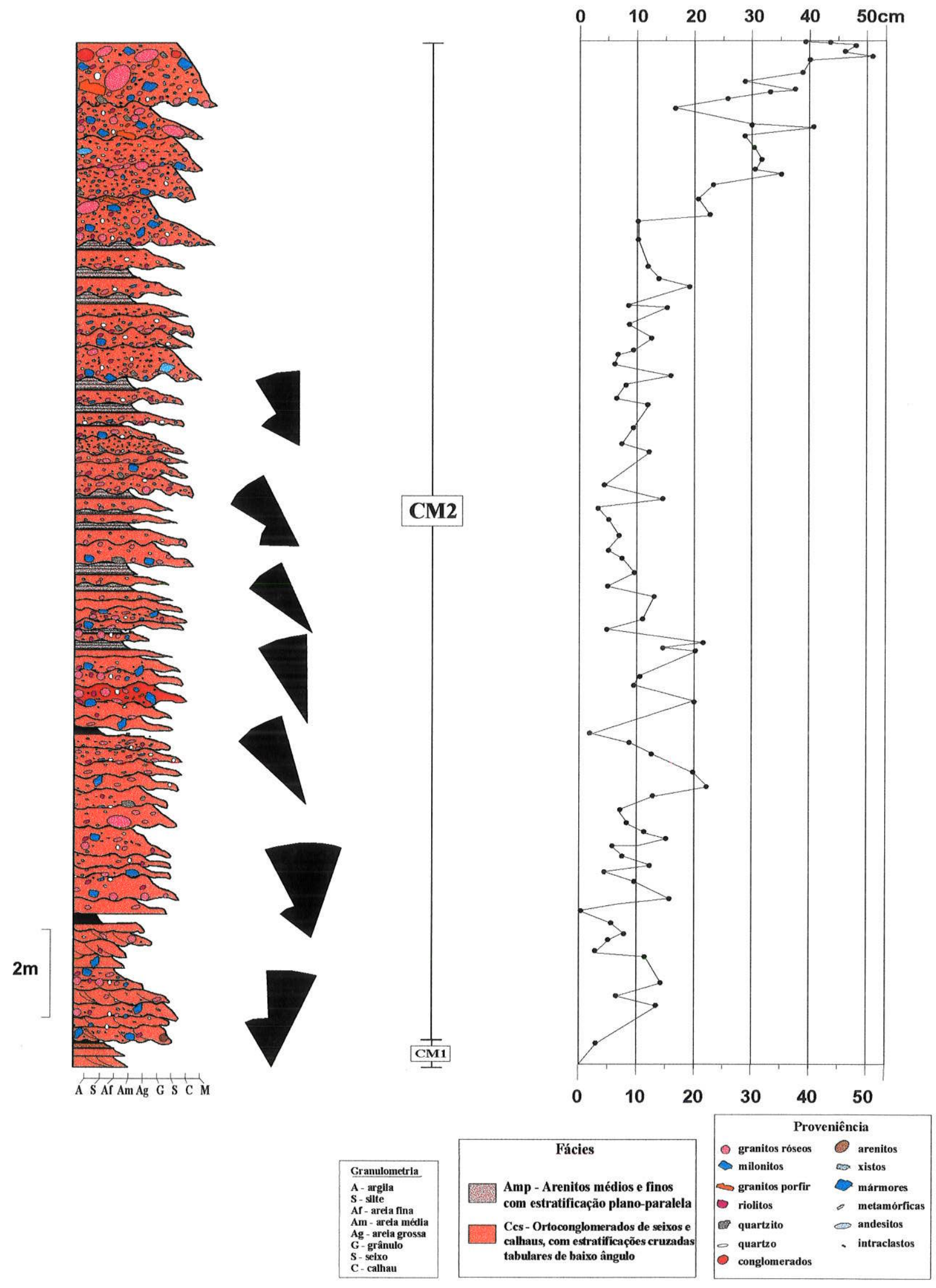

FIGURA IIII.18 - Seção estratigráfica da base da Associação CM2 no local MC-195. Destaque também para as paleocorrentes medidas por nível e os diâmetros máximos ( $\phi$ máx) tomadas em cada camada investigada. 

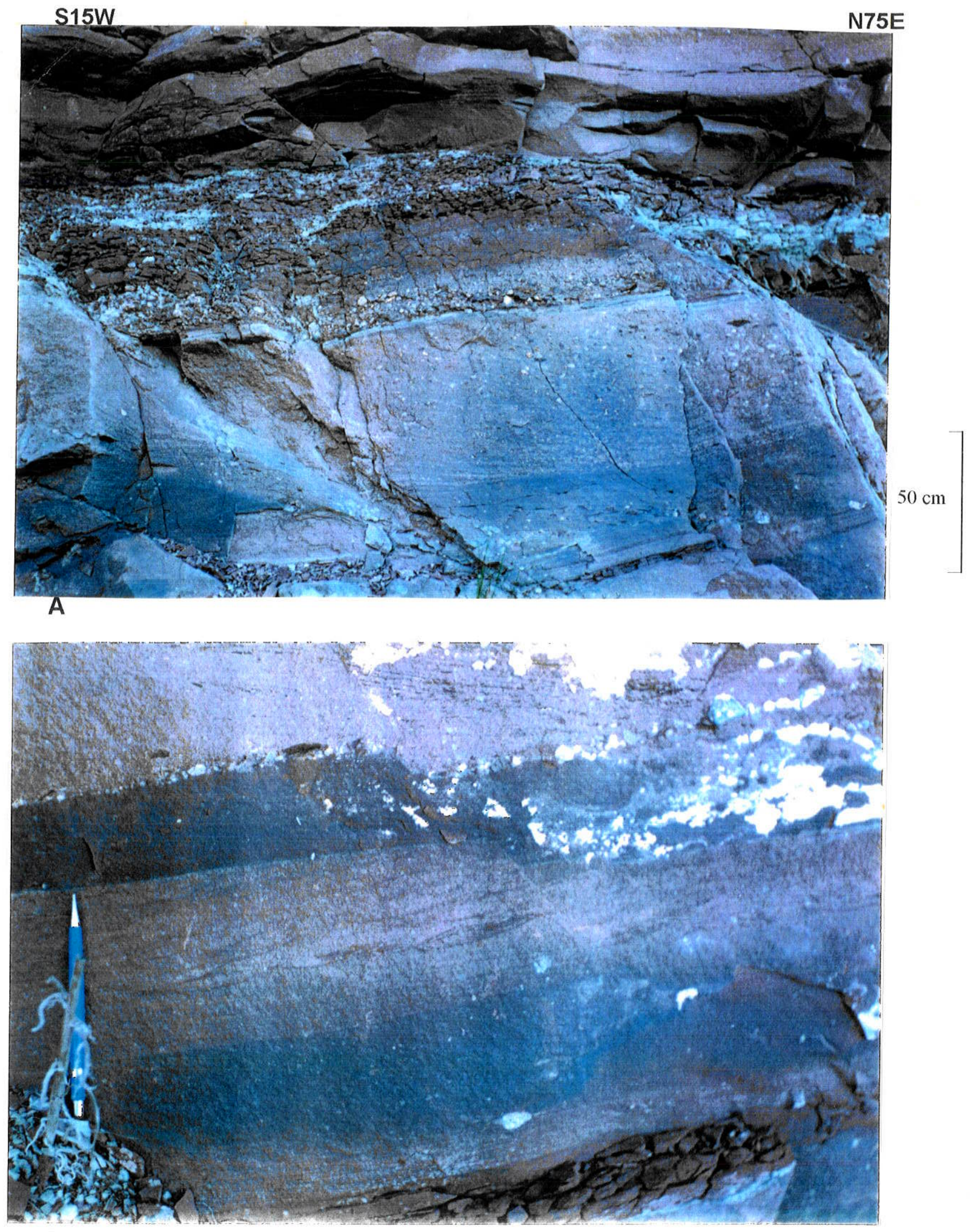

B

FiguRA III.19 - Fácies Aca da base da Associação CM2 no local MC-195. A- Arenitos basais da Associação CM2 mostrando ciclo granodecrescente. Paleocorrentes da esquerda para a direita da foto; B- Detalhe de laminações cavalgantes em nível arenoso fino. 


\section{Descrição}

As Fácies Aga e Aca caracterizam-se por arenitos grossos (Aga), muito mal selecionados por estrato, matriz arcoseana, conglomeráticos de grânulos e seixos (Aca), e até calhaus dispersos ( $\phi$ máx $=9,0$ $\mathrm{cm}$ ). Os fragmentos colocam-se nos foresets das estratificações cruzadas. As estratificações cruzadas são do tipo acanalado, dado pela terminação côncava para o topo dos estratos individuais, truncando os foresets das estratificações subjacentes. Há, também, feições de corte e preenchimento (MC-195), mas muito esporádicas. Pode ser uma barra arenosa ou duna subaquática de rios entrelaçados (braided) retrabalhada. Localidades MC-40 (principal), 195, 219, 220,

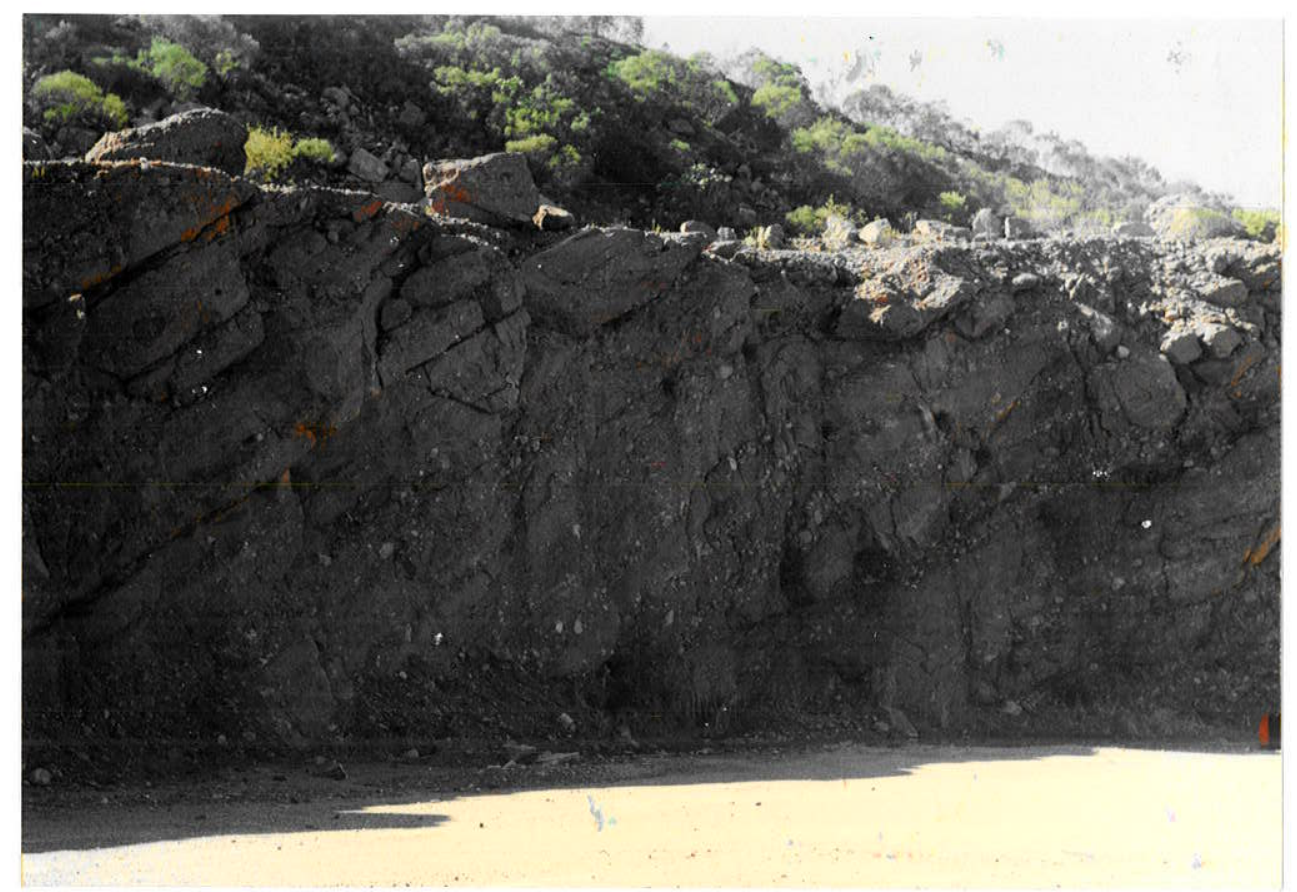

FIGURA III.20 - Vista parcial de exposição de conglomerados da Associação CM2 na cava a céu aberto da Mina Uruguai da extinta Companhia Brasileira do Cobre (CBC). Observar a variação no tamanho dos clastos, a tabularidade conspícua das camadas, a estratificação evidenciada pela gradação dos clastos de depósitos tipo sheet flood da porção subaérea de fan deltas da Formação Vargas. Notar escala (mochila vermelha) no canto inferior direito da fotografia (local MC-40).

Conglomerados de seixos e calhaus e matriz de areia média a grossa com estratificações cruzadas tabulares de médio e pequeno portes compõem a Fácies Ct. Os pacotes são lenticulares de espessura métrica (cerca de $3 \mathrm{~m}$ ). Exibem estratificações cruzadas tabulares com seixos demarcando as lâminas frontais dos estratos (foresets), gradação normal e imbricação de clastos segundo caimento do plano $a b$. Localidades MC-195, 144, 40.

A Fácies Ca é representada por ortoconglomerados de seixos e calhaus e de matriz de areia média a grossa com grânulos e esporádicos matacões em meio à matriz e os seixos. Como estruturas ocorrem estratificações cruzadas acanaladas de médio e pequeno portes, feições de escavação e preenchimento, estratificação plano-paralela e imbricação de clastos muito comum. Localidades MC-133, 220, 238, 239, $240,241,242,144$. 
A Fácies Ccs compreende corpos de estratos de geometria tabular e de extensão lateral grande, de espessura decimétrica $(30-70 \mathrm{~cm})$ a esporadicamente métrica, formados por conglomerados polimíticos organizados, sustentados pelos clastos ( $50-60 \%$ do arcabouço), compostos por seixos a matacões angulosos a arredondados, com o predomínio de fragmentos da granulometria calhau ( $\phi$ méd $\cong 12,0 \mathrm{~cm})$. A matriz é composta por areia média a grossa a muito grossa e grânulos, predominantemente, e areia média ou fina em cuja superfície delgados níveis marcam estratificações. Em delgadas películas de argila separando estratos de conglomerados, por ventura, encontram-se fendas de ressecação. A coloração das camadas varia de róseo-avermelhada ou ferruginosa a esverdeada, de acordo com a cimentação preponderante. Internamente, os pacotes podem exibir gradação normal e estratificação plano-paralela muito conspícua nos níveis mais organizados, e incipiente naqueles onde a organização é baixa. Imbricação de clastos é rara, mas ocorre. Os níveis de ortoconglomerado dominam a fácies com intervalos de 3,5 a 4,0 metros, mas aparecem intercalações areno-conglomeráticas a arenosas $(\sim 1,5-2,0 \mathrm{~m})$ como ilustra a FIGURA III.21. A passagem é brusca e irregular, sugestiva de feições erosivas. Localidades MC-40 (principal), 133, 195, 220, 238, 239, 240, 241, 242, 144 (Cerro da Cruz).

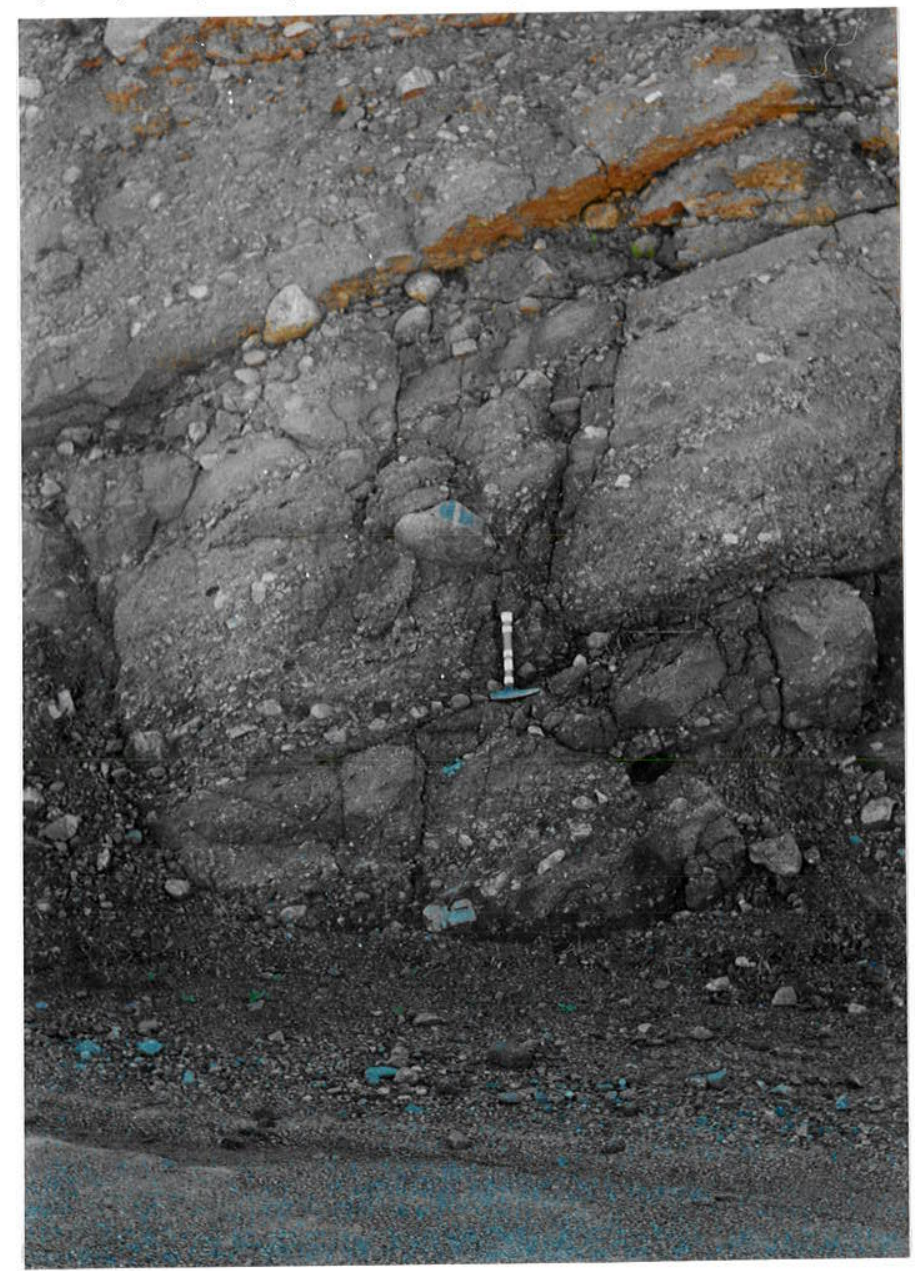

FIGURA III.21 - Camadas de ortoconglomerados estratificados da Fácies Ces da Associação de Fácies CM2 da Formação Vargas na cava a céu aberto da Mina Uruguai. Internamente às camadas, aparecem níveis decimétricos intercalados de arenitos conglomeráticos da Fácies Aca. A estratificação fica evidente pela gradação dos clastos e por certo arranjo por tamanho. O clasto imediatamente acima da escala mede $39,6 \mathrm{~cm}$ de eixo maior (local MC-40). 
A Fácies Cmg comporta pacotes tabulares métricos (1-4m) de conglomerados pouco organizados (gradados) sustentados pela matriz de seixos e calhaus e matriz de argila a areia média a grossa, assemelhando-se a paraconglomerados. As camadas apresentam internamente acamadamento gradacional dos tipos normal e inverso (este mais comum).

\section{Interpretação}

A Associação de Fácies CM2 evidencia mecanismos deposicionais pela ação de fluxos inicialmente confinados (fácies arenosas e areno-conglomeráticas Aga e Aca) da carga sedimentar que, ao atingirem o corpo d'água, sofreram desaceleração e desconfinamento. A sucessão vertical de fácies seguidamente mais grossas para o topo da coluna, chegando a conglomerados com matacões, testemunham o caráter progradacional desta associação, culminando com a substituição gradual de fácies subaquáticas por aquelas desenvolvidas em ambiente subaéreo.

As fácies Ca e Aca podem representar depósitos de fluxos canalizados (stream channel flow) e de enchentes em lençol (sheet floods) de sistema de leques aluviais distais a medianos, respectivamente.

As fácies Cp e Ces, organizadas e de geometria tabular, apresentando gradação inversa (mais comumente), mas também normal, e estratificação plano-paralela bem marcada, podem representar porções medianas a proximais de depósitos de leques subaéreos. A variação no tamanho dos clastos ( $\Delta$ variação do diâmetro) não é muito pronunciada por estrato, embora exista, $(9<\phi<45 \mathrm{~cm})$, sendo no máximo 4 a 5 vezes. É notável a grande persistência lateral das camadas desta fácies. As superfícies de estratificação são realçadas por delgados níveis de areia média ou fina $(30-40 \mathrm{~cm})$ contendo laminação plano-paralela ou estratificação cruzada tabular, encerrando um ciclo granodecrescente ou, por vezes, marcando o início de um pulso granocrescente (coarsening-upward cycle). Esse fato se deve à: (i) uma taxa de sedimentação rápida (episódica) situada nas porções médias de leques aluviais (Blair \& McPherson, 1994b) ou mid-fan (Nilsen, 1982), imediatamente abaixo do ponto de intersecção do leque, onde o desconfinamento simultâneo de canais dos fluxos aquosos torrenciais associado a uma rạpida deposição impediria o desenvolvimento mais significativo de superficies de corte, refletindo processo de enchentes em lençol (sheet-floods), tal como sugerido anteriormente por Faccini et al. (1987); (ii) a tabularidade das camadas indica condições de deposição a partir de fluxos subaquosos desconfinados, o que favorece uma vinculação com depósitos de enchentes em lençol.

A falta de intercalações pelíticas mais pronunciadas e evidências de retrabalhamento por correntes sob regime de fluxo inferior (trativas) de alta energia (fácies Ca, Aca e Aga) insinuam fortemente a existência de um contexto deposicional continental (subaéreo), ou ao menos transicional. A estruturação interna das fácies Ccs e $\mathbf{C p}$ coadunam com as feições características de depósitos de fluxos aquosos de leques aluviais (depósitos de sheet flood e stream channel), tal como discutidas em Nilsen (1982) e Blair \& McPherson (1994): (i) deposição relativamente próxima à área fonte (rochas a SE da Falha Tapera 
Figura III.22 - A- Visão de parte do Cerro da Cruz (Figura III.23) e localização de B; BDetalhe da passagem brusca da Fácies CI5 para a Fácies CM1do Conjunto Médio de Associaçães de Fácies. Local MC-144, Cerro da Cruz, Minas do Camaquã. Vide localização no croqui da figura anterior. 


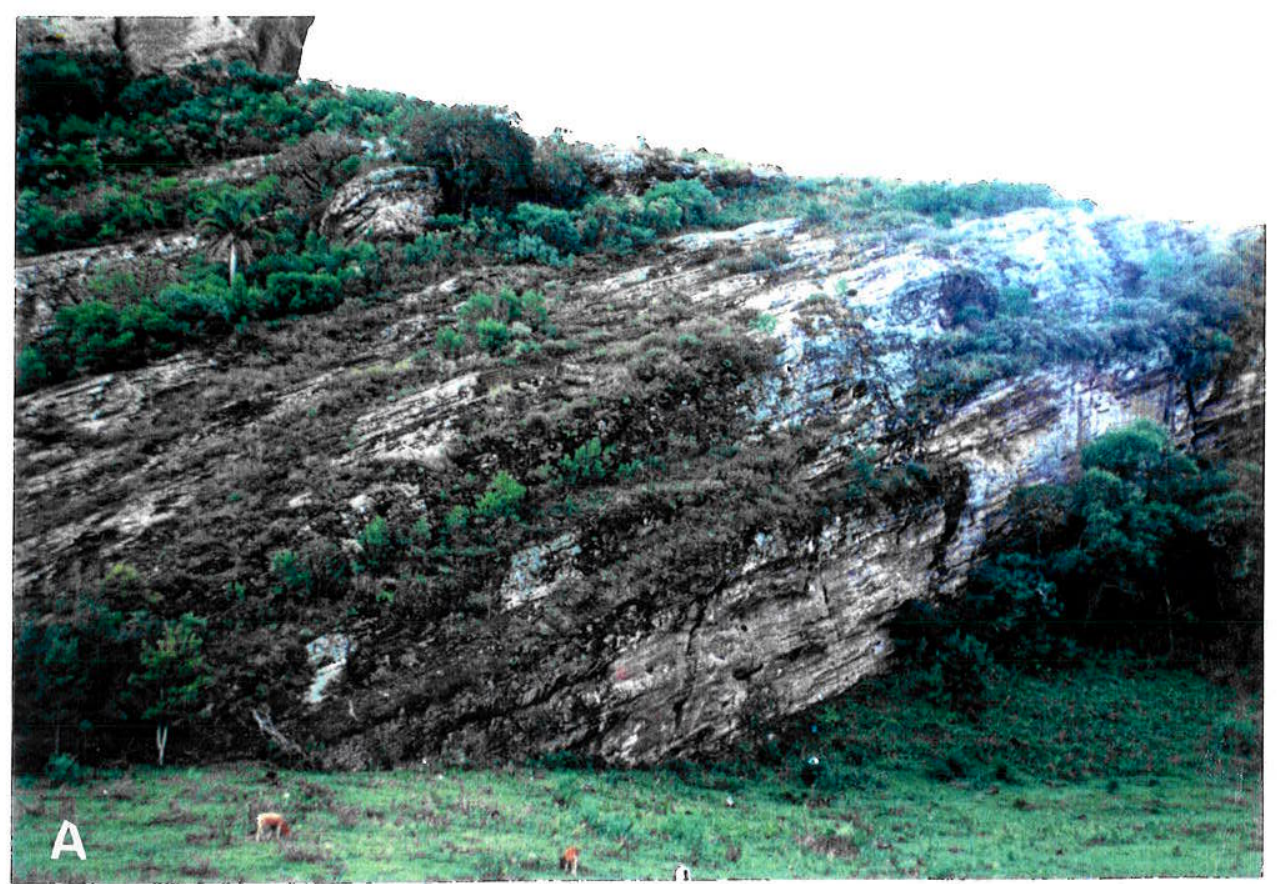

w

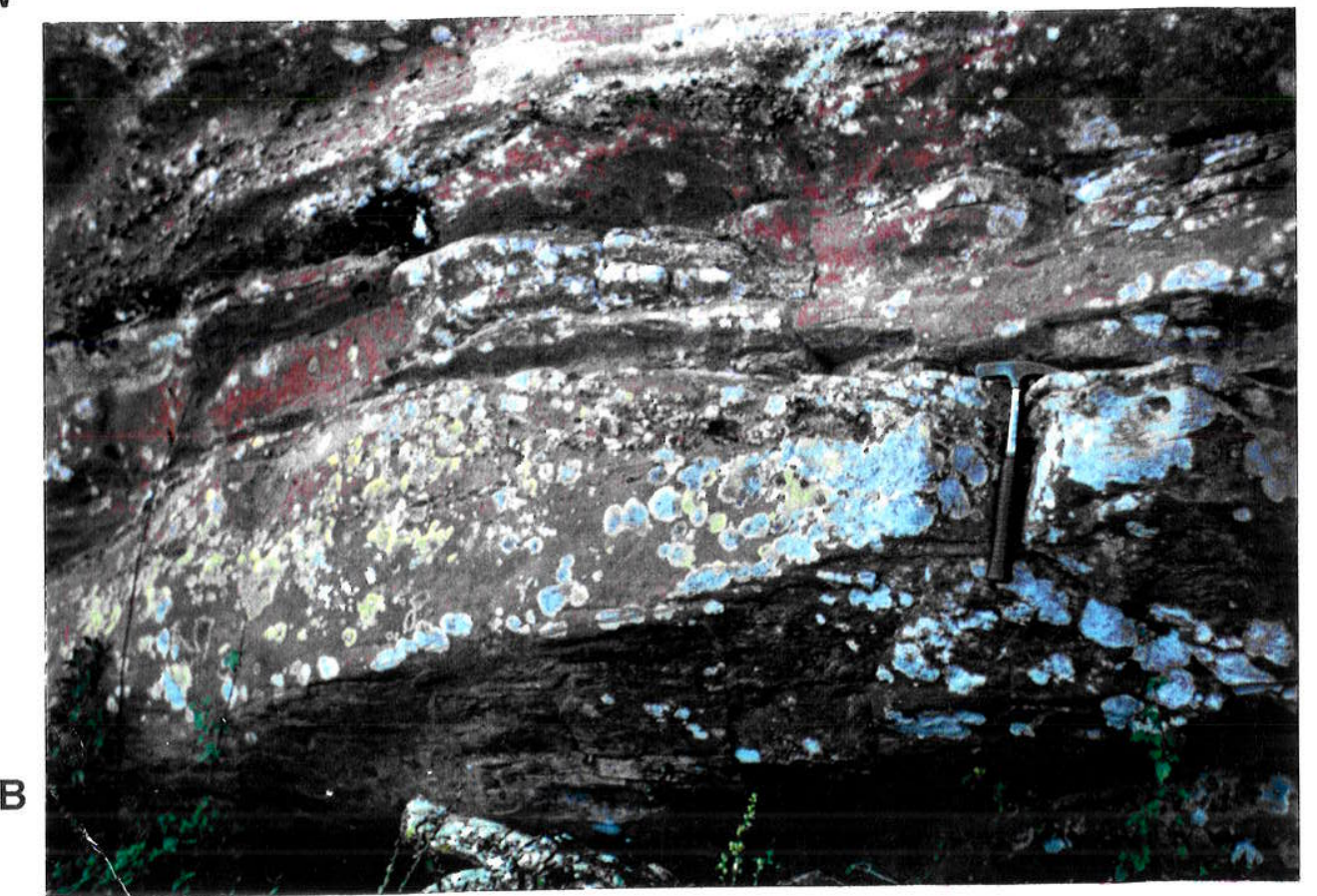



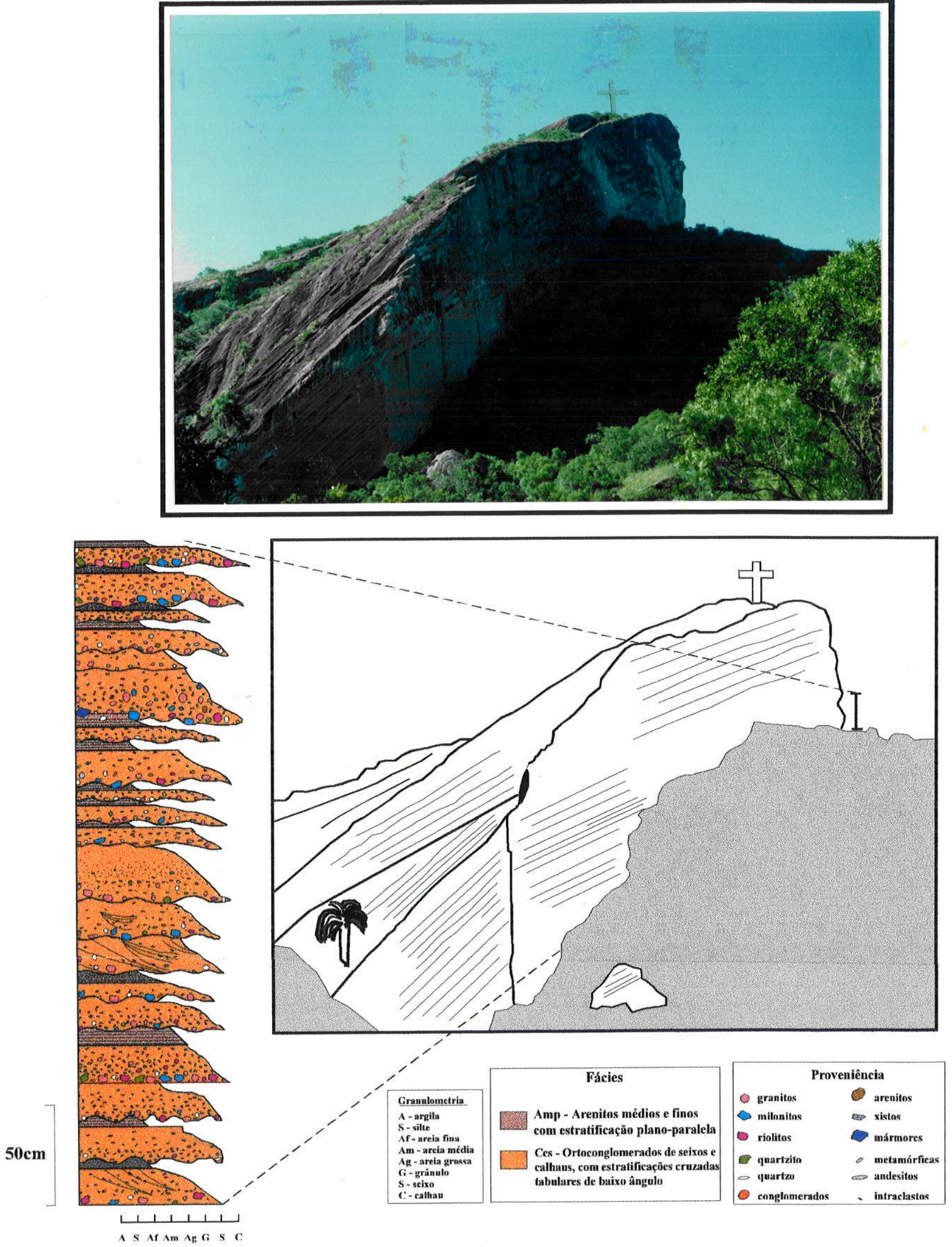

FIGURA III.23 - Seção estratigráfica de detalhe da parte inferior da Associação CM2 no ponto MC-144, Cerro da Cruz, Minas do Camaquã, modificada de Paim (1994). Vide localização na foto anexa e no croqui. 
Emiliano); (ii) maior organização dos depósitos com referência àqueles mais proximais, embora preservando a imaturidade textural e mineralógica dos depósitos; (iii) depósitos canalizados e com estratificações cruzadas acanaladas e tabulares de pequeno e médio portes; (iv) granodecrescência ascendente; (v) imbricação dos clastos. Mas a feição mais importante é a ocorrência de fendas de ressecação nas películas de argila recobrindo níveis arenosos intercalados indicando condições subaéreas de deposição, após o espraiamento do leque na planície aluvial.

\begin{tabular}{|c|c|c|}
\hline \multicolumn{3}{|r|}{ ASSOCIAÇÃO CM3 } \\
\hline Associacio & FÁCIES & DESCRIÇÃo SUMÁRIA \\
\hline CM3 & Bmm & Brechas oligomíticas sustentadas por matriz, maciças \\
\hline & Bg & Brechas oligomíticas sustentadas por clastos com gradação normal \\
\hline
\end{tabular}

A Associação de Fácies CM3, de ocorrência muito restrita, aflora apenas no extremo nordeste de exposições da Formação Vargas, ao longo de afloramentos na estrada que vai ter na serra dos Apertados.

A associação supra citada compõe-se de brechas oligomíticas sustentadas tanto por clastos como por matriz (Bmm). O arcabouço de tais litologias é formado principalmente de seixos e calhaus, embora matacões possam ser encontrados (FIGURA III.24). A matriz é areno-lamítica a arenosa com grânulos.

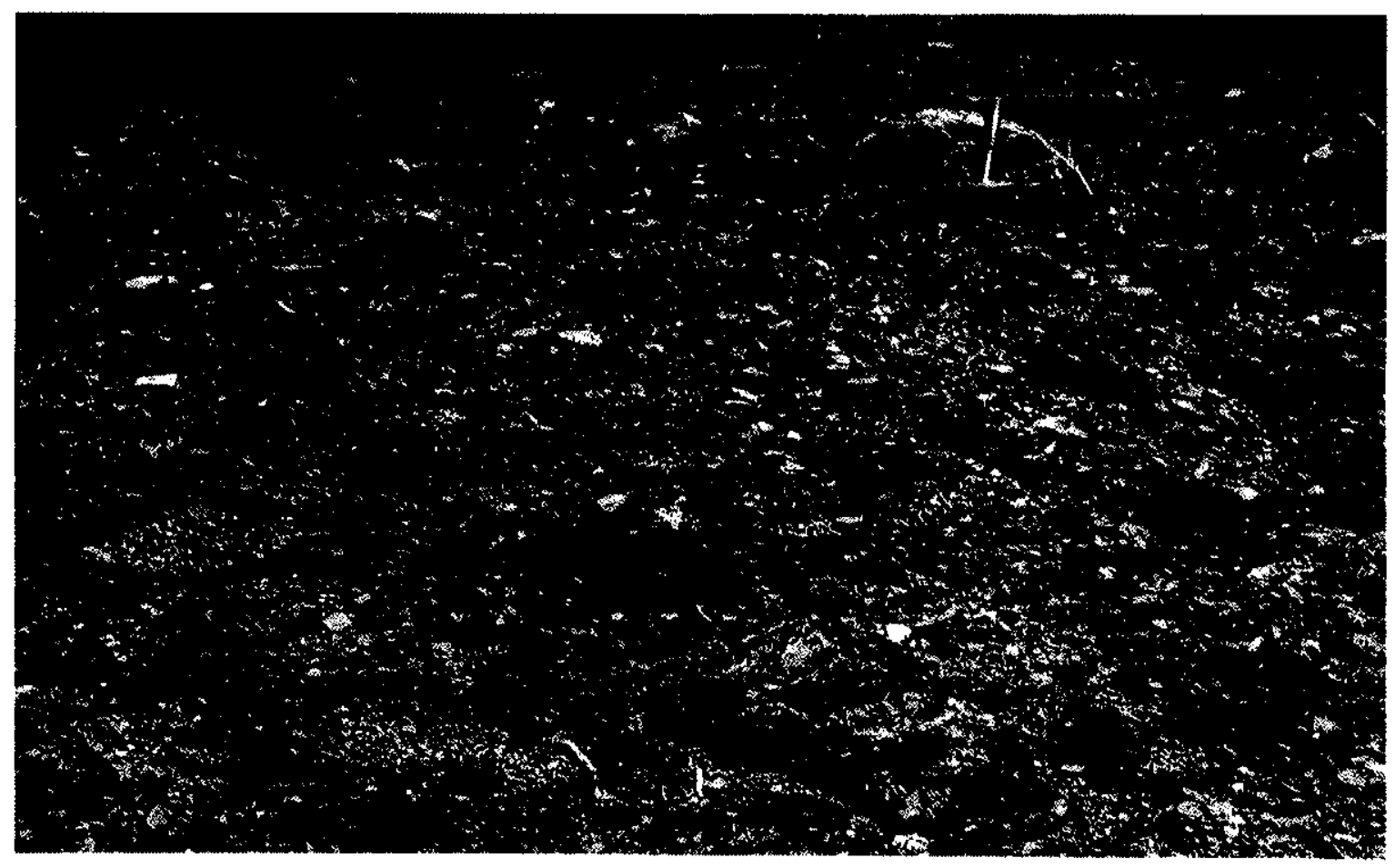

FigURA III.24 - Brechas da Associaçăo CM3 no ponto MC-224, compostas principalmente de seixos e calhaus, mas também clastos da granulometria matacão $(\phi=53 \mathrm{~cm}$, centro da foto) ou bloco possam ocorrer. Fragmentos são basicamente angulosos com formas tendendo a poligonais, imersos na matriz de composição psamo-pelítica (hoje clorita e cimentada por limonita) com grânulos e areia grossa, mas também podendo vir a ser arenosa. 
A situação estratigráfica precisa desta associação é de dificil caracterização, pois nos principais perfís executados esta não foi reconhecida. No perfil mencionado ao longo da estrada de chão para a região dos Apertados, o contato inferior observado com a Associação CM2 apresenta rápida transição, recobrindo arenitos médios a grossos distais desta associação, enquanto o contato de topo com o Grupo Guaritas se faz por falha (Falha Tapera Emiliano). Essa porção das exposições do Grupo Camaquã foi submetida a falhamentos intensos, obliterando parte da coluna estratigráfica, de sorte que o posicionamento estratigráfico da Associação de Fácies CM3 não é evidente. Tendo em vista as observações de campo, presume-se que se situe na porção superior da Formação Vargas, o que parece coerente devido ao caráter progradante dos depósitos de fan deltas.

\section{Descrição}

A Fácies Bmm comporta camadas de espessura decimétrica a métrica $(0,4-4 \mathrm{~m})$, de geometria supostamente tabular, formadas por brechas oligomíticas mal selecionadas sustentadas por clastos angulosos a subangulosos derivados de fragmentos de rochas essencialmente metamórficas encontradas no Complexo Porongos (FIGURA III.25). São desprovidas de qualquer organização ou estruturação. O arcabouço das brechas compõe-se principalmente de seixos e calhaus, muito embora comumente clastos da granulometria matacão $(\phi=50 \mathrm{~cm})$ ou bloco possam ocorrer (FIGURA III.25). Os fragmentos são basicamente angulosos com formas tendendo a poligonais, imersos na matriz de composição psamo-pelítica (hoje clorita e cimentada por limonita) com grânulos e areia grossa, mas também podendo vir a ser arenosa com grânulos (Localidades MC-318, 319, 320, 322, 323, 324).

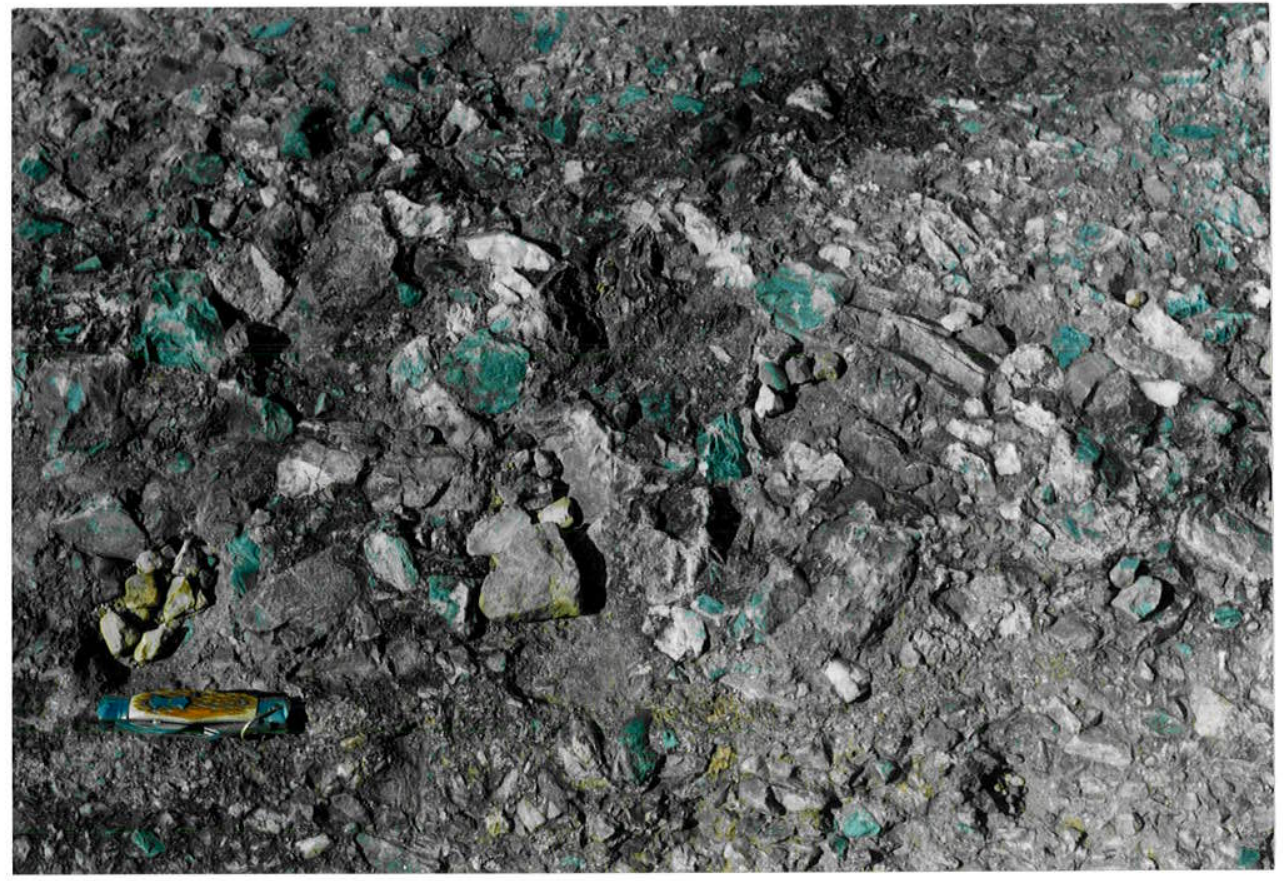

FIGURA IIII.25 - Detalhe do arcabouço das brechas da Associação CM3 no ponto MC-224. Fragmentos da granulometria seixo e calhau são basicamente angulosos com formas tendendo a poligonais derivados de fragmentos de rochas essencialmente metamórficas, imersos na matriz de composição psamo-pelítica com grânulos e areia grossa de coloração esverdeada. 
A Fácies Bmg comporta pacotes tabulares métricos $(1-4 \mathrm{~m})$ de brechas oligomíticas sustentadas por matriz composta de matriz de pelito a arenito médio a grosso, assemelhando-se a paraconglomerados. $O$ arcabouço é formado de seixos e calhaus e alguns matacões esporádicos. As camadas apresentam internamente acamadamento gradacional dos tipos inverso e normal (este mais comum), dado pela diminuição na granulometria dos clastos para o topo da seção. Os clastos podem ocorrer eventualmente imbricados (Localidades MC-320, 322, 323, 324, 325).

\section{Interpretação}

A Associação de Fácies CM3 evidencia mecanismos deposicionais regidos por fluxos gravitacionais de massa, exemplificados pelos depósitos de brechas gerados por fluxos de detritos em sua maioria, sedimentados em ambiente subaéreo, a julgar pelo processo de rebaixamento geral do nível d'água que o corpo aquoso vinha sofrendo (Associações CM1 e CM2) e pela posição inferida na coluna. A associação caracteriza-se por níveis de alta energia, baixa seleção do material e densidade e coesão altas, exemplificados por clastos de diferentes granulometrias e provável matriz originalmente areno-argilosa. Representa o topo de um perfil progradante do sistema de fan deltas da Formação Vargas.

\section{III.2.1.2.2 Sistemas Deposicionais da Formação Vargas}

A Formação Vargas evidencia mecanismos deposicionais pela ação de fluxos inicialmente confinados (Associação de Fácies CM1) da carga sedimentar que, ao atingirem o corpo d'água, sofreram desaceleração e desconfinamento. A sucessão vertical de fácies seguidamente mais grossas para o topo da coluna, chegando a conglomerados com matacões (Associação de Fácies CM2) e depósitos de brechas de fluxos de detritos (Associação de Fácies CM3), testemunham o caráter progradacional da unidade, culminando com a substituição progressiva de fácies subaquáticas por aquelas desenvolvidas em ambiente subaéreo.

Sugerimos que os espessos depósitos da Associação CM2 da Formação Vargas representem fácies subaéreas típicas de leques aluviais, notadamente um sistema formado predominantemente por processos de sheet flood (enchentes em lençol), tal como enunciado por Blair \& McPherson (1994b), restringindo a Associação CM1 às feições subaquáticas. Nesse ponto, nossas observações conduzem a um modelo de fan deltas progradantes sobre um corpo d'água marinho (e.g. coarse grained deltas de Wescott \& Ethridge, 1980; McPherson et al., 1987; Nemec, 1990).

Entretanto, McPherson et al. (1987) elaboraram um modelo de "deltas grossos" em que distinguem fan deltas de braid deltas (termo por eles definido), este para designar a progradação de corpos deltaicos grossos formados pela progradação de sistema fluvial entrelaçado sobre um corpo aquoso marinho ou lacustrino, e o outro para indicar a progradação de leques aluviais em corpos d'água, salientando que "as principais diferenças entre fan-deltas e braid deltas residem na componente subaérea, já que a porção 
subaquática é praticamente similar", esta presente em todos os deltas grossos. Em nossa compreensão, a porção subaérea dos leques das Minas do Camaquã ajusta-se com os modelos de leques aluviais disponíveis (e.g. Blissenbach, 1954; Hooke, 1967; Nilsen, 1969; Bull, 1972, 1977; Nilsen, 1982; Rust \& Koster, 1984; Blair, 1987; Blair \& McPherson, 1994, entre outros), constituindo no todo uma sucessão vertical típica de um fan delta progradante sobre um corpo d'água. Esta compreende fácies finas marinhas na base, exemplifícadas pela Formação Mangueirão, sendo recobertas concordantemente por fácies grossas de leques aluviais (conglomerados e arenitos de depósitos de sheet flood, fluxos canalizados e fluxo de detritos), tais como sugeridas por McPherson et al. (1987) com o modelo de fan deltas de granulometria grossa definido por estes autores.

Deste modo, o conjunto de fácies da Formação Vargas representaria pacotes de fan deltas sensu McPherson et al. (1987). Faccini et al. (1987) foram os primeiros a apresentar um modelo subaéreo para os leques da região. Os autores argumentaram sobre a origem subaérea dos leques com base na estruturação interna das camadas e associação com leques e planícies aluvial e deltaica. $\mathrm{Na}$ opinião destes autores, o contexto deposicional seria progradante, destacando-se fácies de pró-delta até aluviais de alta energia, representando corpos de fan deltas. Opinião constante também em Paim et al. (1992) e Paim (1994). O modelo de fan deltas implica na reavaliação dos modelos de evolução paleogeográfica da Bacia do Camaquã, como sustentado por Fambrini et al. (1996b).

Heward (1978 a, b) demonstrou para uma seqüência de leques aluviais do Carbonífero do norte da Espanha que grandes seqüências granodecrescentes com adelgaçamento das camadas (thinning-and fining upward megasequences) assinalam a posição média canalizada de leques aluviais, e doutro modo, seqüências granocrescentes com aumento na espessura dos estratos evidenciam as partes mais distais dos leques. Esta em parte é o que se verifica na Associação CM2, notadamente nas porções superiores dos pacotes.

Nossas observações conduzem a uma interpretação contrária com outras anteriormente formuladas (Teixeira et al., 1978b; Ribeiro et al., 1980; Gonzalez \& Teixeira, 1980; Lavina et al., 1985; Fragoso Cesar et al., 1985), pois estas consideravam todos os leques da região das Minas do Camaquã como oriundos de correntes subaquáticas. As bases de sustentação destas formulações foram a tabularidade dos estratos, transporte predominante por mecanismos de suspensão (fluxos gravitacionais de massa subaquáticos) e associação com fácies turbidíticas.

Essa associação de fácies foi responsável pela colmatação dos depósitos anteriores subaquosos, propiciando a continentalização de parte da região.

\section{III.2.1.3 Conjunto Superior (CS) - Formação João Dias}

O Conjunto Superior de Associações de Fácies (CS) - Formação João Dias, aqui definida -, correlato ao Arenito Superior de Ribeiro (1978) e à seqüência IIc de Paim et al. (1992), é exposto na 
porção norte e noroeste/oeste da área de estudo. É a unidade de maior expressão areal na região das Minas do Camaquã, limitando-se por discordância angular com os arenitos e arenitos conglomeráticos róseoavermelhados do Grupo Guaritas. Abaixo, o contato de arenitos finos e siltitos desta unidade com conglomerados do topo da Formação Vargas é brusco e nítido, refletindo evento de afogamento da região Como seus depósitos seguem por baixo do Grupo Guaritaș, a espessura mínima estimada encontra-se em torno de $1500 \mathrm{~m}$. No perfil de detalhe na estrada principal ligando as minas à BR-153, a espessura medida resultou em cerca de 1000 metros (FIGURA III.3).

\section{III.2.1.3.1 Associações de Fácies da Formação João Dias}

As fácies sedimentares da Formação João Dias ocorrem ao longo do arroio homônimo a norte das Minas do Camaguãa, na estrada que liga as Minas do Camaquã à BR153 no trecho entre o trevo da CBC e o acesso para o Passo do Cação; na estrada para Capão do Cedro a norte; e em trecho da estrada que passa pelo Capão do Salso rumo ao Passo dos Enforcados. Este conjunto de fácies inclui as associações de fácies CS1, CS2 e CS3.

A Associação CS1 possui boas exposições naturais na região de campos do Capão do Salso. Esta associação abarca pacotes tabulares de arenitos médios e finos, bem selecionados, de coloração vermelha a acastanhada, com estratificações cruzadas tipo Hummocky (Fácies AmS, Ams) que gradam para arenitos finos maciços (Fácies Afm) e ritmitos com laminação plano-paralela no topo (Fácies Prh), configurando granodecrescência ascendente (FIGURA III.26). A associação limita-se ao bordo oeste da ocorrência do Grupo Camaguã, na região do Capão do Salso, não tendo sido observadas relações de contato com as demais fácies, assim como, devido à proibição de acesso do proprietário à área, o contato inferior com a Formação Vargas. Desta forma, o mesmo foi extraido de mapas da CBC conforme registrado no Anexo 01. De acordo com Paim (1994) este contato é brusco.

A Associação CS2, também em contato brusco com a Formação Vargas, apresenta amplas exposições a norte das Minas do Camaquã, principalmente ao longo da estrada que parte do posto de gasolina para a localidade de Capão do Cedro e nas imediações da estrada principal que liga as minas à BR153. A associação encerra intercalações de camadas decimétricas de arenitos médios e finos para o topo, maciços, com fendas de ressecação (Fácies Amm), com laminações cruzadas truncadas por migração de marcas onduladas (Fácies Afld) e laminações cruzadas cavalgantes e marcas onduladas associadas (Fácies Afc e Afoa).

A Associação CS3 marca o topo da Formação João Dias, situando-se entre a Associação CS2 e a discordância com o Grupo Guaritas, compreende intercalações arenosas de granulometria variada (Ag, Am e Af) contendo estruturas sedimentares como estratificações cruzadas tabulares (Fácies Agt) e acanaladas (Fácies Ama), laminações cruzadas cavalgantes e marcas onduladas associadas (Fácies Afc e Afoa), e estrutura maciça (Fácies Amm). 


\begin{tabular}{|c|c|l||}
\hline \multicolumn{2}{|c|}{ ASSOCIAÇÃo CS1 } \\
\hline \hline \multirow{2}{||c|}{} & \multirow{2}{|c|}{} & \\
\hline ASSOCIAÇÃo & FÁCIES & DESCRIÇÃO SUMÁRIA \\
\hline \multirow{2}{*}{ CS1 } & Prh & Ritmitos com laminação plano-paralela \\
\hline & Afm & Arenitos finos maciços \\
\hline & AfS, AmS & Arenitos finos e médios com estratificação cruzada Hummocky \\
\hline
\end{tabular}

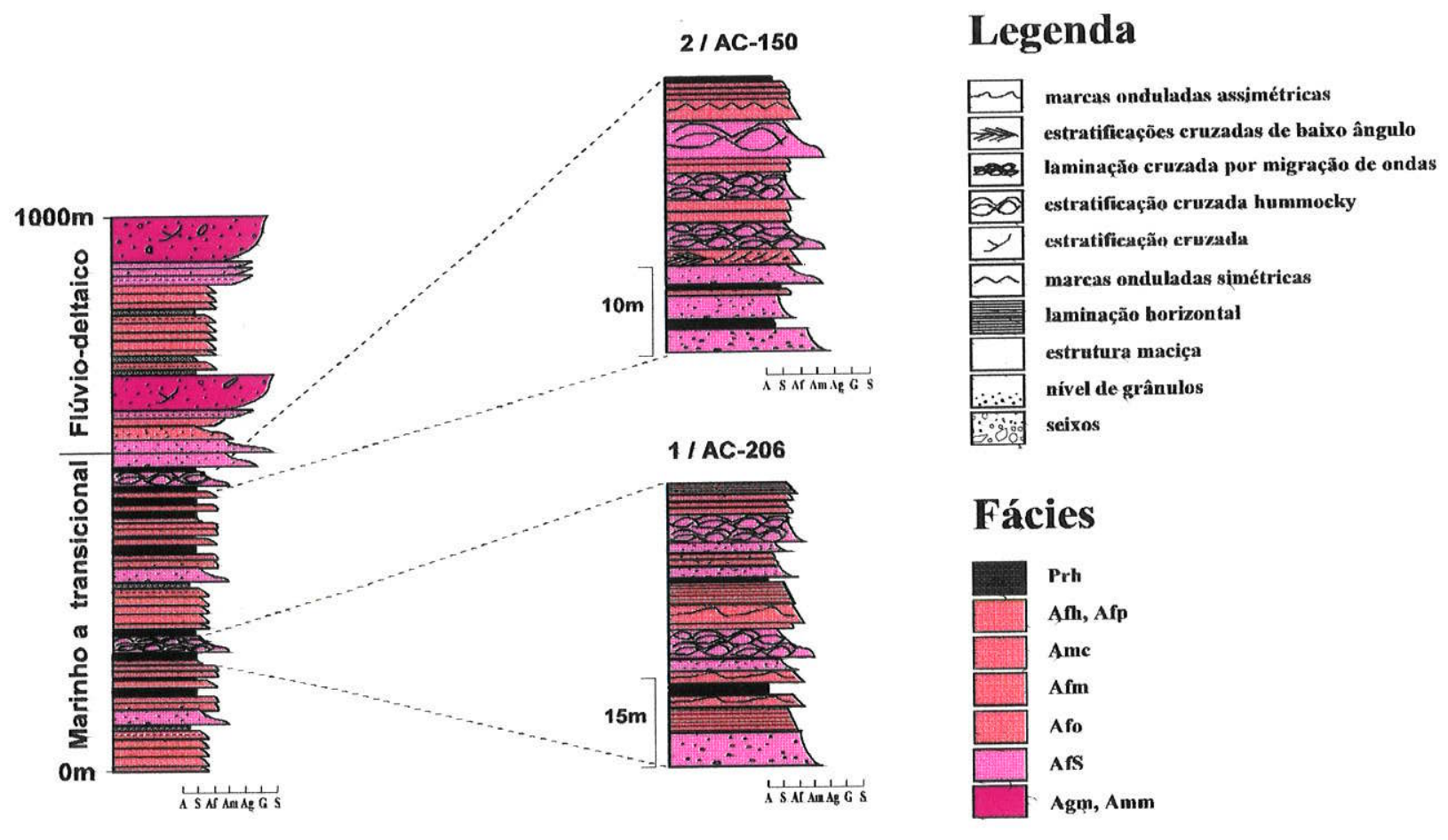

FIGURA III.26 - Seção estratigráfica completa da Formação João Dias mostrando depósitos progradantes de marinho-transicional a flúvio-deltaico e seções de detalhe levantadas (1/AC-206 em porção média da coluna da mesma associação e 2/AC-150, 165 no topo da Associação CS1).

\section{Descrição}

Esta associação restringe-se à porção ocidental da área de estudos (vide Anexo 01). Os pacotes tabulares da fácies (AfS, AmS) são compostos por camadas granodecrescentes, decimétricas a métricas, de geometria tabular de grande expressividade lateral, constituídas de arenitos finos e médios com laminação cruzada truncada por ondas nos pacotes centimétricos, mais abundantes, cujo topo comumente ostenta marcas onduladas de perfil simétrico (ondulação) nos pacotes tabulares decimétricos. Nas camadas métricas encontram-se megaondulações de comprimento de onda de, no mínimo, 0,8m e no máximo de $3 \mathrm{~m}$, provavelmente estratificações cruzadas tipo Hummocky (sensu Harms et al., 1975; Hamblin \& Walker, 1979) (localidades AC-165, 167, 168). Fendas de ressecação nas lâminas pelíticas associam-se às marcas simétricas de ondulação nos pacotes centimétricos (Localidades AC-165, 167, 168, MC-169, 170, 171, 172). 


\section{Interpretạ̧ão}

O conjunto de fácies da Associação CS1 pode retratar um novo evento de rebaixamento do nível de base da bacia ou de soerguimento do nível do mar. Assim, sedimentos finos correriam para o interior dela, possivelmente um mar raso de características epicontinentais, suprindo as fácies acima.

\begin{tabular}{|c|c|c|}
\hline & & ASSOCIAÇÃo CS2 \\
\hline AssoctacAo & FÁCIES & DESCRIÇÃO SUMÁRIA \\
\hline \multirow{5}{*}{ CS2 } & Psm & Pelitos maciços com fendas de ressecação \\
\hline & Afoa & Arenitos finos com marcas onduladas assimétricas \\
\hline & Afc & Arenitos finos com laminações cruzadas cavalgantes \\
\hline & Afld & Arenitos finos com laminações cruzadas truncadas por ondas \\
\hline & Amm, Afm & Arenitos médios e finos maciços \\
\hline
\end{tabular}

\section{Descrição}

A Fácies (Amm, Afm) constitui-se de corpos arenosos de geometria tabular (continuidade lateral nos afloramentos) abrangendo arenitos médios, mal selecionados, com porçőes finas a grossas alternandose, avermelhados, de aspecto maciço (sem estruturação interna, MC-233), maciços (MC-231, 49), micáceos,com presença de grânulos e seixos muito dispersos (Localidades MC-228, 231, 233, 236, 200, 57).

A Fácies Afld compõe-se de arenitos finos de coloração vermelha, micáceos, de boa seleção granulométrica constituindo camadas de geometria tabularizada em afloramento. Internamente mostram laminações cruzadas truncadas por migração de marcas onduladas (ripple drift cross lamination) de tamanho decimétrico (até $20 \mathrm{~cm}$ ), mas, localmente, apenas com laminação plano paralela,.

A Fácies Psm possui siltitos cinza-esverdeados com fendas de ressecação no topo (Localidades MC-228, 231, 233, 236, 200, 57).

A Fácies Afl comporta pacotes centimétricos de arenitos muito finos siltosos de cor vermelho tijolo com laminação plano-paralela (MC-49, 233, 230).

A Fácies Afc contém arenitos finos a muito finos com laminações cruzadas cavalgantes (climbing ripple cross-lamination) possuindo superficies de divisão entre as camadas arenosas com predomínio de sedimentos finos. Os pacotes têm espessura métrica, extensão variável e arranjo interno dado pela superposição de ondulações unidirecionais cavalgantes críticas a supercríticas. (Localidades MC-124, 43, 171, 227, 273, AC-150). 
A Fácies Afoa apresenta arenitos finos avermelhados, micáceos, com marcas onduladas assimétricas. Os corpos arenosos possuem geometria tabular e laminações cruzadas cavalgantes associadas com as marcas onduladas. Por vezes, são observadas superficies com lineação primária de corrente, que podem ser sucedidas por marcas onduladas com interferência de fase (FIGURA III.27). No topo das camadas arenosas, delgadas películas de argila exibem fendas de ressecação de formas poligonal a irregular de tamanho centimétrico (MC-225, 227, 272). (Localidades MC-272, 273, 225, 227, 45, 47, 237, AC-150, 153, 155, 205, 206, 214).

\section{Interpretação}

Esses depósitos podem representar inunditos clássicos como produtos de corrida de material durante um evento de inundação fluvial, cuja deposição foi promovida predominantemente por fluxos densos penetrando em águas rasas, com exposição subaérea eventual. Faccini et al. (1987) interpretaram tais pacotes como gerados através da influência de fluxos hiperpicnais oriundos da chegada de grande carga de material em regime de tração/suspensão sob a ação de correntes de turbidez. Os autores argumentaram que a relação desta com fácies de arenitos sigmoidais, bem como pela características internas do depósito, permitiram vinculá-la a depósitos de frente deltaica.

Uma outra interpretação possivel para a associação seria a existência de corpos d'água de dimensões reduzidas, exemplificados pela fácies Afm (arenitos finos a muito finos cor de tijolo do MC-49) freqüentemente expostos à radiação solar, suprindo uma planície deltaica entrelaçada (braid-delta plain sensu McPherson et al., 1987) com eventuais períodos de pluviosidade torrencial gerando processos de correntes de turbidez, pois relaciona-se com a Associação CS3, tipicamente fluvial. Estes corpos d'água poderiam ser um mar raso ou resquícios de lagos da colmatação ocorrida durante a sedimentação da Formação Vargas.

\begin{tabular}{|c|c|c|}
\hline & & ASSOCIAÇÃO CSB \\
\hline AssOelacAO & FÁCIES & DESCRIÇÃO SUMÁRIA \\
\hline \multirow{6}{*}{ CS3 } & Afoa & Arenitos finos com marcas onduladas assimétricas \\
\hline & Afe & Arenitos finos com laminações cruzađas cavalgantes \\
\hline & Afp & Arenitos finos e médios com laminação plano-paralela \\
\hline & {$[\mathbf{A g}, \mathbf{A m}, \mathbf{A f}] \mathbf{a}$} & Arenitos finos a grossos com estratificação acanalada \\
\hline & Agt & Arenitos grossos com estratificaçóes tabulares \\
\hline & Agm, Amm & Arenitos grossos a médios maciços \\
\hline
\end{tabular}




\section{Descrição}

A Fácies Afc compreende arenitos finos cujo arranjo interno é dado pela superposição de ondulações unidirecionais cavalgantes críticas a supercríticas.

A Fácies Afoa apresenta arenitos finos avermelhados, micáceos, com marcas onduladas assimétricas. A FIGURA III.28 mostra os vários tịpos de marcas onduladas presentes (MC-225). Os corpos arenosos possuem geometria tabular, laminações cruzadas cavalgantes associadas com as marcas onduladas, abundantes intraclastos de argila marrom escura e siltitos cinza-esverdeados (MC-229) (FIGURA III.29 e III.30) que chegam a formar níveis de brechas intraformacionais (MC-273, 229) e estruturas tipo ripple drift cross lamination sensu Walker (1963). Em delgada película de argila no topo das camadas arenosas, encontram-se fendas de ressecação de formas poligonal a irregular e tamanho centimétrico (MC-225, 227, 272). Localidades MC-272, 273, 225, 227, 45, 47, 237, AC-150, 153, 155, 205, 206, 214.

Amm é a fácies constituída de arenitos médios mal selecionados, avermelhados, alternando-se porções finas a grossas, de matriz arcoseana, de aspecto maciço (MC-233) ou laminado (MC-231), micáceos, com presença de grânulos e de seixos muito dispersos (MC-200). Como estruturas sedimentares principais aparecem estratificação plano-paralela muito sutil a laminação plano-paralela (MC-233, 230), fendas de ressecação em níveis pelíticos delgados, e abundantes intraclastos de argila marrom escura e siltitos cinza-esverdeados (MC-229). A geometria dos corpos é bem tabular, embora em função das variações granulométricas verificadas localmente ocorra geometria lenticular. Localidades MC-228, 231, 233, 236, 200, 57.

Arenitos médios, maciços a estratificados (MC-235), micáceos, pouco ou mal selecionados, com porções finas a grossas, alternando-se bruscamente, constituem a Fácies Ama. A matriz é arcoseana, de coloração vermelha ou acastanhada. Há presença de grânulos e seixos muito dispersos arranjados caoticamente, ou demarcando foresets das estratificações cruzadas. Como estruturas sedimentares aparecem estratificações cruzadas do tipo acanalado de médio e pequeno portes (cerca de 1,0-2,0m) (MC232, 234, 229, 235, 42), estratificações cruzadas tabulares (MC-222, 234, 229), estratificação planoparalela conspícua a sutil e/ou laminação plano-paralela (MC-232, 233) e cruzada (MC-232), intraclastos argilosos (MC-273, 229). Localmente (MC-234), ocorre estratificação cruzada tabular de baixo ângulo ( $\theta$ $=5^{\circ}$ ) de caráter bimodal. A geometria dos corpos é bem tabular (continuidade lateral nos afloramentos), muito embora em função das estratificações acanaladas e das variações granulométricas verificadas localmente ocorra geometria lenticular. Localidades MC-272, 273, 229, 233, 234, 235, 222, 232, $230,42$.

As fácies (Ag, Am, Af)a comportam arenitos finos a grossos muito mal selecionados por estrato, matriz arcoseana com grânulos e seixos. Os fragmentos colocam-se nos foresets das estratificações cruzadas. Estas são do tipo acanalado, truncando os foresets das estratificações subjacentes, difícultando a medida devido à falta de continuidade física mínima dos estratos. Há, também, feições de escavação e preenchimento. Localidades MC-223 (principal), 235. 
A Fácies Agt compreende camadas lenticulares de espessura decimétrica a métrica de arenitos grossos a médios, seleção pobre a moderada, apresentando estratificações cruzadas tabulares de médio a pequeno porte, freqüentes intraclastos argilosos e marcas onduladas. Localidades MC-223, 58.

\section{Interpretação}

A Fácies Agt originou-se de processos de migração de ondulações de fundo de leito de barras linguóides transversais geradas por fluxos trativos. Evidencia a supremacia de dunas subaquáticas que se associavam às barras longitudinais (lentes de conglomerados) em ambiente de moderada a alta energia (estratificações cruzadas do tipo acanalado de médio e pequeno portes, i.é., cerca de 1,0-2,0 m). Nesse contexto, as fácies (Ag, Am, Af)a representariam as barras arenosas ou dunas subaquáticas de rios entrelaçados (braided), retrabalhadas.

A associação de fácies CS3, superior, é interpretada como uma planície deltaica retrogradante, alimentada por sedimentos praiais e costeiros (Fácies CS1 e CS2), gradando para sistema fluvial braided. Outros autores associaram-na com depósitos progradantes de uma planície deltaica (Faccini et al., 1987; Paim et al., 1992; Paim, 1994). Esta associação é identificada por sucessivos pacotes de arenitos médios a finos, localmente conglomeráticos de grânulos e pequenos seixos esparsos, possuindo estruturas tipo ripple drift cross lamination com evidências claras de exposição subaérea (fácies de inunditos), e estratificações cruzadas acanaladas e tabulares de pequeno porte (fácies fluvial). A passagem brusca, porém gradacional, destas para a associação CS1 indica gue os leques aluviais sofreram um novo evento de afogamento.

\section{III.2.1.3.2 Sistemas Deposicionais da Formação João Dias}

A Formação João Dias representa evento de ingressão marinha alternando-se com depósitos de uma planície flúvio-deltaica.

A Associação de Fácies CS1 compreende depósitos marinhos que afogaram as sucessões conglomeráticas de fan delta sotopostas. Representa depósitos formados abaixo do nível de ação das ondas normais, onde mecanismos de ondulação com esporádicas exposições subaéreas insinuam fortemente que os sedimentos sofreram retrabalhamento por ondas onde, por vezes, ondas de tempestade atuavam, culminando com o acúmulo de depósitos de tempestitos. A associação apresentou alguma conexão oceânica precedente, em vista da ocorrência de assembléias de icnofósseis nos estratos desta formação (Netto et al., 1992).

A Associação de Fácies CS2 compreende depósitos de frente deltaica. Embora a relação no campo com a Associação CS1 não tenha sido observada, possivelmente deva ter sido variação de nível mais rasas, dentro de contexto de uma planície deltaica.

A Associação de Fácies CS3 representa depósitos ligeiramente mais grossos internamente formando ciclos granodecrescentes vinculados a ambiente fluvial que se associa com depósitos 


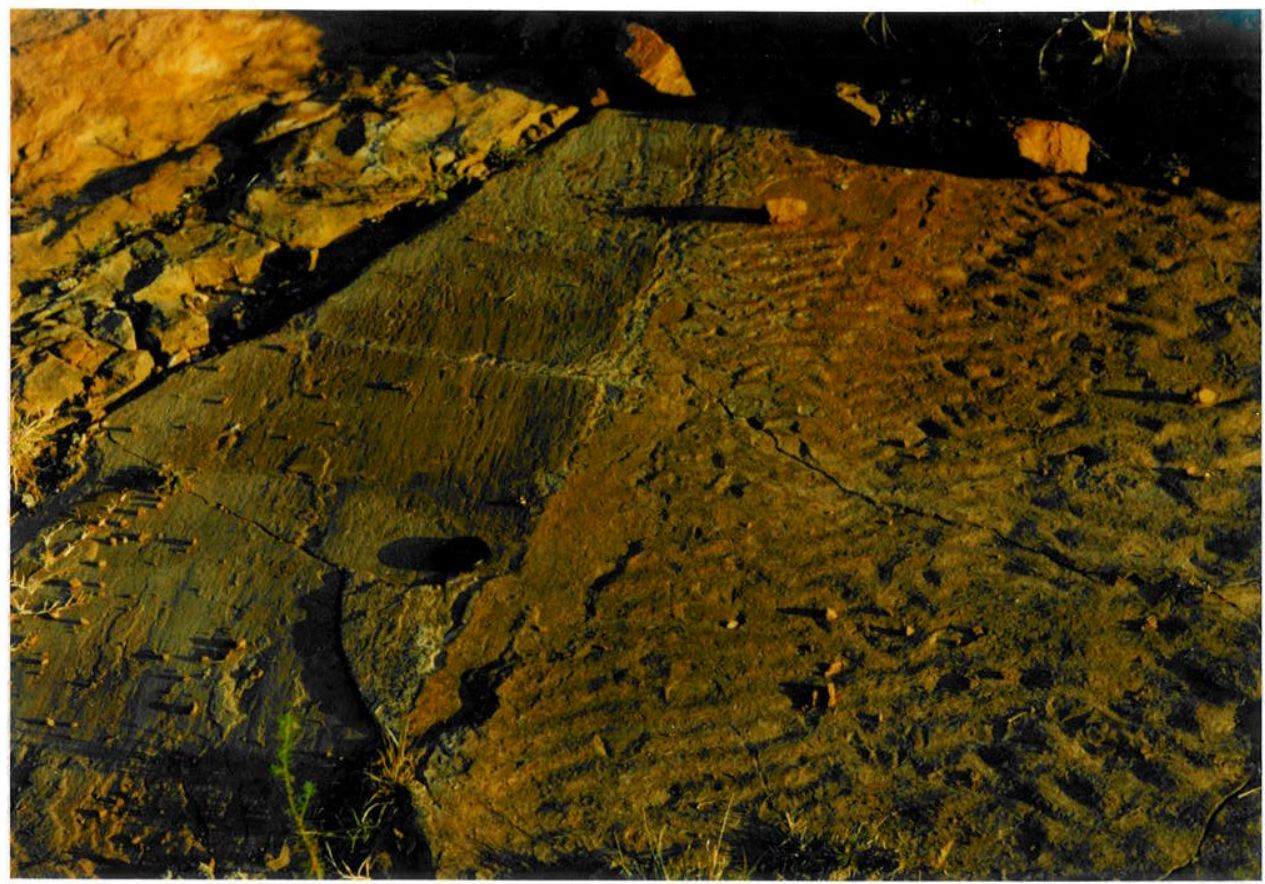

FIGURA III.27 - Pavimento exibindo marcas onduladas por corrente com interferência de fase da Fácies Afoa da Associação CS1 e, ao lado, superfície alguns centímetros acima com lineação primária de fluxo segundo a direção N-S. Local MC-214.

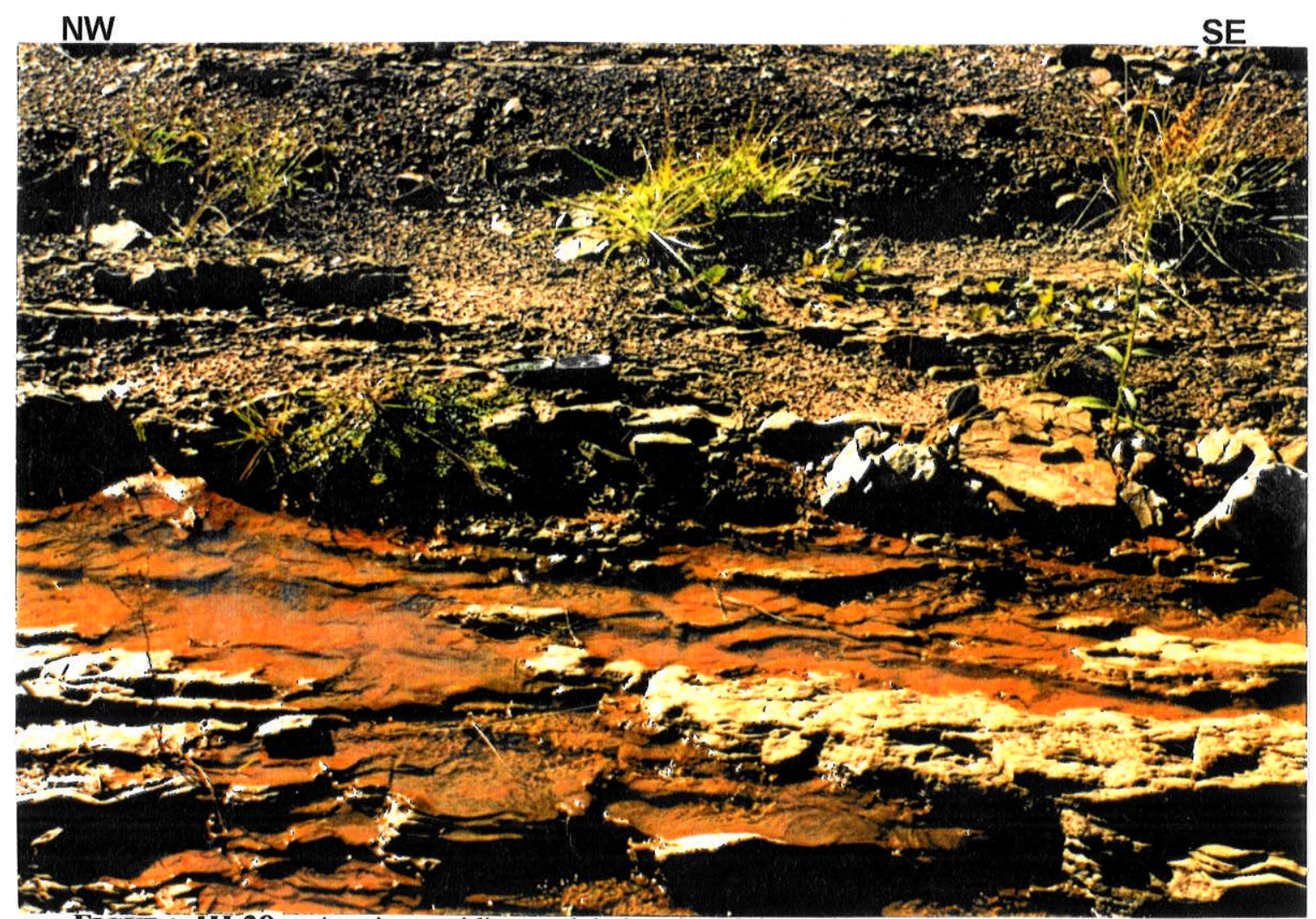

FIGURA III.28 - Arenitos médios ondulados da Fácies Afoa (Associação CS3) gerados por diversas superfícies de marcas onduladas assimétricas de cristas sinuosas em sua maioria. Local MC-225, estrada vicinal ligando as Minas do Camaquã à rodovia federal BR-153. 
FIGURA III.29 - Arenitos finos avermelhados da Fácies Afoa da CS3 apresentando em: A- pavimento com intraclastos argilosos que chegam a formar niveis de brechas intraformacionais. Acima (nivel com escala) marcas onduladas de perfil assimétrico (por corrente) indicando fluxo para a parte superior da foto (no sentido apontado pela lapiseira); B- Detalhe da brecha intraformacional de $\mathbf{A}$. Os clastos argilosos concentram-se e possuem tênue orientação segundo $E$ (direita da foto). Local MC-272 (estrada para Capão do Cedro).

FIGURA III.30 - Marcas onduladas de perfil assimétrico (por corrente) indicando fluxo para a direita da foto (no sentido apontado pela lapiseira). Local MC-272 (estrada para Capão do Cedro). 


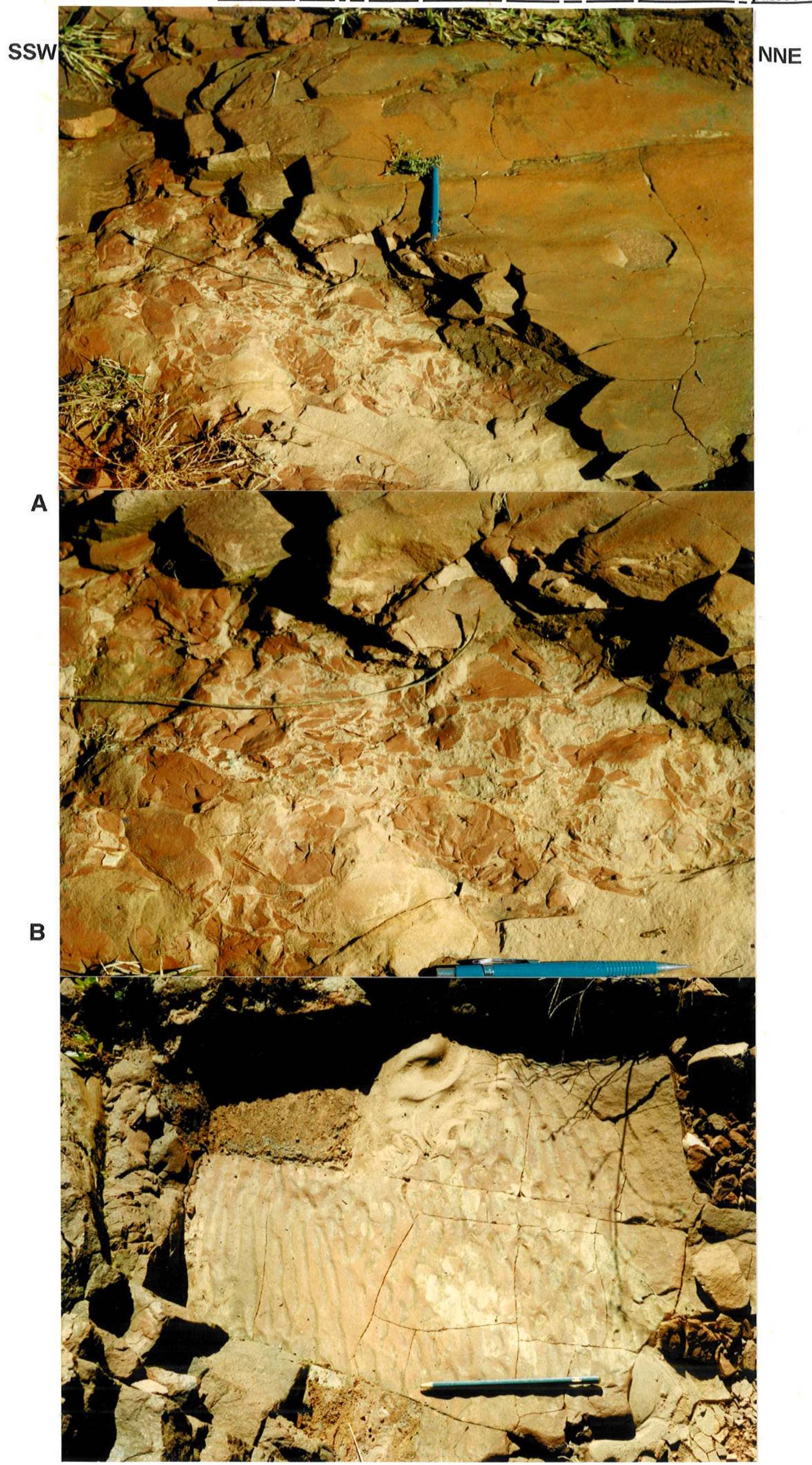


progradantes de uma planície deltaica (CS2).

Em síntese, a Formação João Dias compreende uma sucessão granocrecente para o topo a partir de depósitos finos marinhos (Associação CI1) passando coluna acima para depósitos de frentes deltaicas de uma planície flúvio-deltaica (Associação CI2) culminando com depósitos mais grossos fluviais no topo.

\section{III.2.1.4 Grupo Guaritas}

O Grupo Guaritas ocorre em discordância angular com o Grupo Camaquã bem exposta na região das Minas do Camaquã (FIGURA III.31). O Grupo Guaritas é formado por arenitos e conglomerados róseos avermelhados aflorantes em torno do Grupo Camaquã, sobretudo a NW das Minas do Camaquã.

As associações de fácies seguem a divisão de Silva Filho (1997) e, internamente, as fácies representadas refletem a separação feita por Paim (1994). A TABELA III.5 ilustra sumariamente as fácies do Grupo Guaritas. Não cabe aqui uma apresentação pormenorizada em vista do tema deste trabalho.

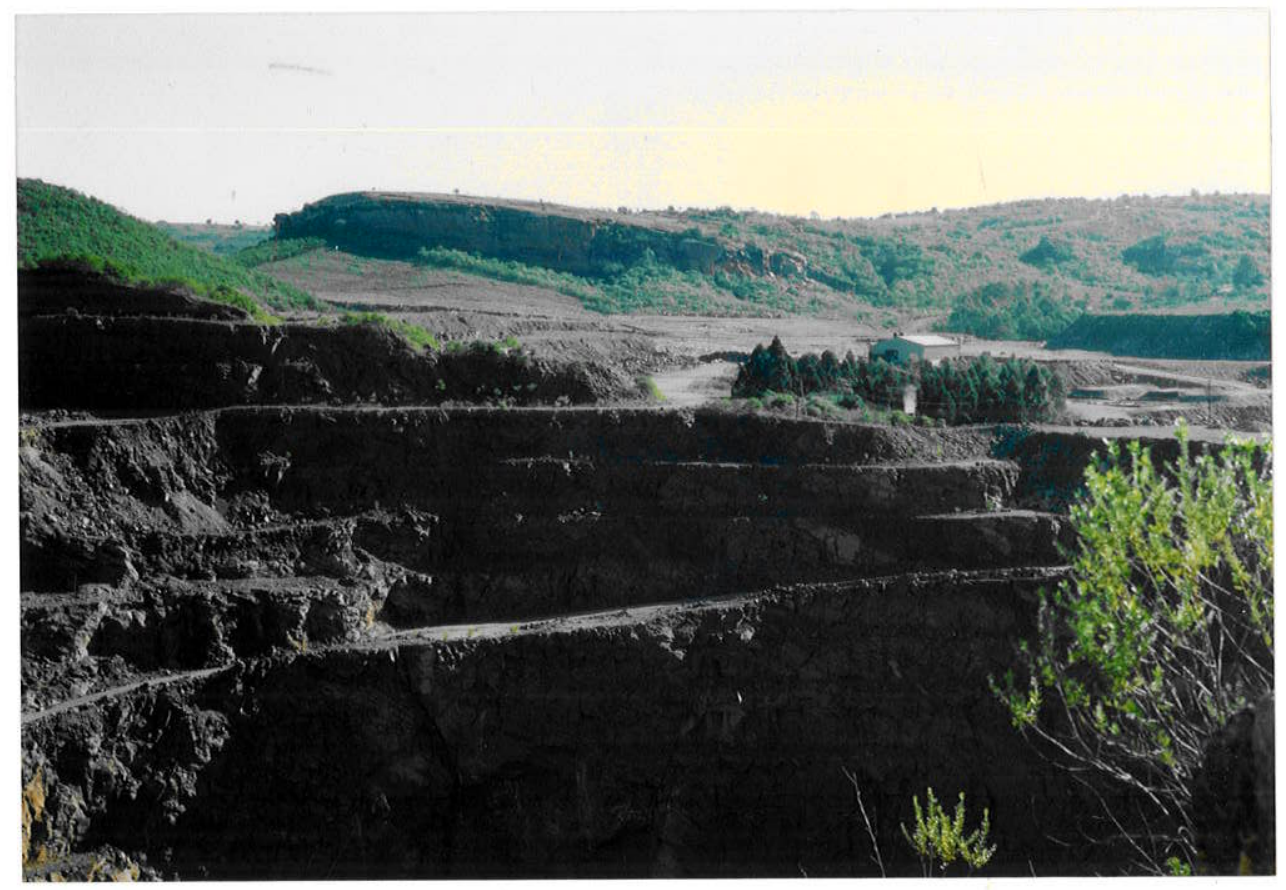

FIGURA III.31 - Discordância angular entre o Grupo Guaritas (morro tabular ao fundo) com o Grupo Camaquã (Formação João Dias) vista a partir da cava a céu aberto da CBC, Minas do Camaquã.

\section{III.2.1.4.1 Formação Guarda Velha}

A Formação Guarda Velha ocorre em discordância angular com a Formação João Dias. A unidade apresenta conglomerados suportados por seixos e calhaus bem arredondados de litologias ígneas (riolitos, leucogranitos róseos, quartzo leitoso, leucogranitos a duas micas), de matriz de areia grossa, com estratificações cruzadas acanaladas e tabulares de pequeno a grande porte, que se intercalam com arenitos médios a grossos, conglomeráticos de seixos e de grânulos arredondados, com estratifícações cruzadas 
acanaladas e tabulares de pequeno a médio porte por vezes demarcada por seixos e grânulo. Para o topo tem-se arenitos finos a grossos, maciços, com calhaus, seixos e grânulos esparsos.

\section{III.2.1.4.2 Formação Pedra Pintada}

Compõe-se de arenitos finos e médios, bem selecionados, sem micas, com estratificações cruzadas acanaladas de grande porte, com truncamentos refletindo paleoambientes eólicos. Aparecem na margem oriental da área de estudos. Aparecem conglomerados suportados por seixos e grânulos bem arredondados, matriz de areia grossa, com estratificações cruzadas tabulares de pequeno a médio porte e acanaladas, de matriz arenosa com quartzo e feldspato com intercalações de arenitos finos micáceos com laminação planoparalela congregando ambientes fluviais de deserto, os chamados wadis.

\section{III.2.1.5 Corpos Intrusivos Rodeio Velho}

Trata-se do principal corpo ígneo da região. A ocorrência mais importante arealmente aparece a $\mathrm{E}$ e SE das Minas do Camaquã (donde originou a denominação) e, portanto, fora dos limites da área deste estudo. Sua colocação, aparentemente, se deu em várias superfícies anisotrópicas dentro do sistema eólico do Membro Pedra Pintada (Grupo Guaritas) e ao longo da discordância entre o Grupo Camaquã, sotoposto, e o Grupo Guaritas, sobreposto (Silva Filho et al., 1996a; Silva Filho, 1997). Pequenas ocorrências bordejam a Zona de Falha Tapera Emiliano no limite leste da área de estudos, situando-se entre os conglomerados do Grupo Camaquã e os arenitos conglomeráticos da base do Grupo Guaritas. Essas rochas compõem-se, basicamente, de rochas petrograficamente classificadas tanto no campo como em laboratório como andesitos. Orientação por fluxo magmático é freqüente (Lima et al., 1995; Silva Filho et al., 1996a). Correspondem aos Andesitos Rodeio Velho sensu Ribeiro et al. (1966) ou Seqüência Vulcânica IV de Lima et al. (1995). Foram reconhecidos três tipos de rochas: amigdaloidais, maciços de textura afanítica a muito fina e vesiculares porfiríticos.

As rochas ígneas amigdaloidais são as predominantes na região das Minas do Camaquã, sobretudo quando se aproveitam das descontinuidades das encaixantes nas quais se inserem, incluindo corpos de pequena extensão da porção norte da área nas proximidades do contato entre os grupos Camaquã e Guaritas. Constituem-se de rochas cinza escuras contendo amígdalas (predominante) e vesículas de diâmetros mili a centimétricos, formato esférico a achatado e preenchimento de calcita, calcedônia e quartzo. Petrograficamente formam-se de fenocristais de até 3,5mm de plagioclásio (andesina-oligoclásio), pseudomorfos de piroxênio (agora com clorita predominantemente) e opacos em matriz composta por plagioclásio, piroxênio e material vítreo intersticial alterado. Normalmente observa-se maior volume de amigdalas nas bordas do corpo, ou seja, próximo do contato com a encaixante (Silva Filho et al., 1996a). Localidades MC-175, 176, 177, 328, 329, 325, 376. Também aparecem rochas maciças de textura afanítica a fanerítica muito fina sempre nas porções internas dos corpos. Localidades MC-325, 376, 177. 
As rochas ígneas vesiculares porfiriticas são de coloração púrpura, matriz fanerítica de granulação fina a média e mineralogia, segundo Almeida et al. (1993), formadas por fenocristais de plagioclásio de hábito ripiforme de disposição caótica, piroxênio (pseudomorfos), biotita e opacos com plagioclásio, piroxênio e material vítreo na matriz. Restringem-se à borda oriental da área mapeada, junto à Zona de Falha Tapera Emiliano. Localidades MC-104, 128,129, 329, 333, 332, 334.

\section{Interpretação}

A partir de Ribeiro et al. (1966) vários pesquisadores que se ocuparam do magmatismo "andesítico" no Escudo Gaúcho têm enfatizado o caráter efusivo dos Andesitos Rodeio Velho (Almeida et al., 1993; Paim, 1994; Lima et al., 1995; Wildner et al., 1997). Entretanto, Silva Filho et al. (1996a) contestaram esse "caráter efusivo" com base nas feições de contato de topo dos andesitos com os sedimentos na área-tipo (Passo do Moinho), levando-os à redefinição de sua colocação, como uma intrusão rasa. C. Riccomini (comunicação pessoal, 1990) já havia apontado o caráter intrusivo dessas rochas na área-tipo.

De acordo com Silva Filho et al. (1996a), a gênese das rochas Rodeio Velho pode dever-se a: "(i) aumento da pressão dos fluidos intersticiais pela transferência de calor da intrusão; (ii) cisalhamento do contato do magma andesítico com a encaixante, ocasionando a abertura de fraturas; (iii) estabelecimento de um gradiente de pressão levando à súbita descompressão do arenito aquecido; (iv) fluidificação (sensu Reynolds, 1954) e injeção do material nas fraturas, em processo análogo ao descrito por Walton \& O'Sullivan (1950)". Processos de elutriação podem explicar a estratificação das injeções e da zona alimentadora (Reynolds, 1954). É digno de nota a inexistência tanto de produtos piroclásticos quanto de retrabalhamento fluvial do topo dos "derrames" (Silva Filho et al., 1996a).

Outra argumentação favorável à natureza intrusiva é a sua colocação preferencial em anisotropias importantes da pilha sedimentar. Em nosso estudo, observamos que esses corpos preenchem fraturas de direções preferenciais WNW-ESE da Formação João Dias, de caráter eminentemente discordante. Isso é verificado no local MC-176 onde as vesículas e amigdalas apresentam-se alongadas segundo N30-40W, ocupando cerros orientados segundo essa mesma direção. Os limites do corpo na localidade seguem o mesmo trend (ver mapa geológico). Essas evidências contrariam mapas geológicos da CBC onde estes corpos aparecem concordantes com as camadas sedimentares circunjacentes, configurando "derrames".

Por outro lado, feições como zonas amigdaloidais, texturas e estruturas que indicam fluxo em estado plástico e matriz vítrea podem ocorrer tanto em magmas extrusivos como intrusivos rasos.

Em vista do exposto acima, consideramos que os corpos ígneos Rodeio Velho, pelo menos na área enfocada neste trabalho, são intrusivos rasos. Esta descoberta implica na revisão dos modelos tectonosedimentares atuais para o eopaleozóico do Rio Grande do Sul, como os de Paim (1994), Lima et al. (1995), Paim et al. (1995) e Wildner et al. (1997), tal como sugeriram Silva Filho et al. (1996a). 


\section{III.3.1 Introdução}

Imagens digitais de satélite Landsat 5 Thematic Mapper foram utilizadas e processadas para identificar e delimitar unidades de mapeamento, fácies sedimentares, principais lineamentos e estruturas regionais. Destarte foi utilizada a imagem TM-Landsat WRS 222/81, adquirida junto ao Instituto Nacional de Pesquisas Espaciais (INPE), com as bandas 2, 3, 4, 5 e 7. Optou-se pelas mesmas em função de custos e disponibilidade no ato da aquisição. A banda TM6 (termal) não interessou nesta abordagem. A pouca espessura de solo ou mesmo sua inexistência, associada às respostas da vegetação em relação às variedades litológicas, propiciou a utilização de imagens de sensores orbitais multiespectrais, tipo Landsat, no mapeamento de respostas espectrais estatisticamente correlacionadas com o arcabouço geológico (Ver TABELA III.5). A composição dos pixels (picture elements) mistos das imagens resulta de ponderação entre o conteúdo e tipo de biomassa e de rocha exposta. Resultados pioneiros de tal investigação naregião podem ser encontrados em Ohara (1982) e Ribeiro de Almeida et al. (1995, 1996, 1997).

\section{III.3.2 Processamento Digital de Imagens}

Cada pixel possui um valor de radiação para cada uma das sete bandas espectrais. Bandas individuais podem ser relacionadas a cores primárias diferentes (vermelho, verde e azul, ou seja, o espaço RGB), e assim combinadas para produzir imagens coloridas para facilitar a interpretação geológica. Dentre as combinações possíveis destacam-se imagens falsa-cor das bandas originais ou combinações de imagens produzidas por processamentos aritméticos ou matemáticos, tais como a Análise por Principais Componentes (APC).

A escolha das combinações coloridas falsa-cor baseou-se na análise de suas correlações (bandas 425 e 457 mostraram-se as menos correlacionadas) e na qualidade final das imagens. A combinação colorida 425 (RGB), teoricamente interessante, não discriminou bem os litotipos, cujos resultados foram inferiores àqueles da combinação 457 (RGB), assumindo-se a combinação 457 como a ideal, seguindo-se 435 e 472 (RGB). A banda 4, devido à alta reflectância da vegetação (a qual se correlaciona com a geologia nesta área), foi fixada como a componente $\mathrm{R}$ do espaço $\mathrm{RGB}$, em vista da boa habilidade do aparelho visual humano em distinguir suas tonalidades. A escolha das demais bandas deu-se através de tentativa e erro, culminando-se com as combinações 435 e 457 (RGB). 
$\mathrm{Na}$ tentativa de separar a resposta espectral relativa à vegetação daquela das rochas expostas, bem como realçar as diferentes fácies sedimentares, foi aplicada a técnica de Análise por Principais Componentes (APC). Ohara (1982) a utilizou no processamento digital de imagens da região das Minas do Camaquã, conseguindo realce diferenciado dos membros inferior e superior do Grupo Guaritas, como entendidos neste trabalho, nas PC3 e PC4 geradas por APC das quatro bandas MSS-Landsat.

\begin{tabular}{|c|c|c|c|c|}
\hline $\begin{array}{l}\text { UNIDABES LTOLOCICASI } \\
\text { ATRIBUTOS DO TERRENO }\end{array}$ & Vegetacáo & $\begin{array}{l}\text { Cobertura do } \\
\text { Solo }\end{array}$ & Relevo & Rocha exposta \\
\hline $\begin{array}{c}\text { Corpos gneos RODEIO } \\
\text { VELHO }\end{array}$ & $\begin{array}{l}\text { Densa, } \\
\text { formada por } \\
\text { arbustos e } \\
\text { árvores }\end{array}$ & $\begin{array}{l}\text { Espessa, } \\
\text { horizontes A e C } \\
\text { argilosos }\end{array}$ & $\begin{array}{l}\text { Relevo alto, } \\
\text { plateau, irregular }\end{array}$ & $\begin{array}{l}\text { Em pequenas } \\
\text { áreas (topos de } \\
\text { colinas no centro } \\
\text { e SE da regiã́o) }\end{array}$ \\
\hline GRUPO GUARITAS & & 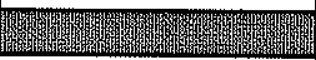 & 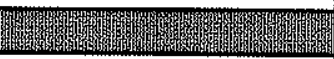 & 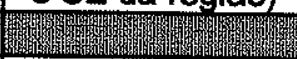 \\
\hline Formagáo Pedra Pintada & $\begin{array}{c}\text { Ausente, } \\
\text { rocha exposta }\end{array}$ & Ausente & $\begin{array}{l}\text { Alto, plateaus } \\
\text { tabulares }\end{array}$ & Disseminada \\
\hline Formaçáo Guarda Velha & $\begin{array}{c}\text { Gramineas e } \\
\text { arbustos }\end{array}$ & $\begin{array}{l}\text { Delgada, } \\
\text { horizonte C } \\
\text { arenoso }\end{array}$ & $\begin{array}{l}\text { Baixo, padrão } \\
\text { dendrítico de } \\
\text { drenagem }\end{array}$ & $\begin{array}{l}\text { Algumas áreas } \\
\text { nos plateaus de } \\
\text { arenitos }\end{array}$ \\
\hline GRUPO CAMACUA & & 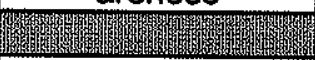 & 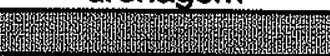 & 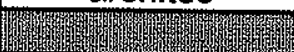 \\
\hline $\begin{array}{l}\text { Arenitos } \\
\text { Conjunto Superior (CS) }\end{array}$ & $\begin{array}{c}\text { Gramineas, } \\
\text { ávores } \\
\text { esparsas } \\
\end{array}$ & $\begin{array}{l}\text { Delgada a } \\
\text { ausente }\end{array}$ & $\begin{array}{l}\text { Plano, irregular } \\
\text { (colinas, vales } \\
\text { encaixados) }\end{array}$ & $\begin{array}{l}\text { Pouca, nas } \\
\text { encostas das } \\
\text { colinas }\end{array}$ \\
\hline $\begin{array}{l}\text { Arenitos Conglomeráticos } \\
\text { e Conglomerados } \\
\text { Conjunto Medlo (CM) }\end{array}$ & $\begin{array}{c}\text { Cobertura de } \\
\text { árvores e } \\
\text { arbustos }\end{array}$ & $\begin{array}{l}\text { Rasa a ausente } \\
\text { (horizonte C fino } \\
\text { de cascalho) }\end{array}$ & $\begin{array}{c}\text { Colinas, cotas mais } \\
\text { altas na regiăo, } \\
\text { padrăo retilíneo de } \\
\text { drenagem }\end{array}$ & $\begin{array}{c}\text { Em topos de } \\
\text { colinas e nas } \\
\text { encostas dos } \\
\text { morros }\end{array}$ \\
\hline $\begin{array}{l}\text { Ritmitos psamo politicos } \\
\text { Conlunto linforior (C) }\end{array}$ & $\begin{array}{l}\text { Grama, } \\
\text { arbustos } \\
\text { esparsos }\end{array}$ & $\begin{array}{c}\text { Delgada, } \\
\text { horizontes A (fino) } \\
\text { eC (espesso) }\end{array}$ & $\begin{array}{l}\text { Plano, baixo, } \\
\text { grandes campos } \\
\text { abertos }\end{array}$ & $\begin{array}{c}\text { Alguns blocos in } \\
\text { situ }\end{array}$ \\
\hline ENBASAMENTO & & (25) & 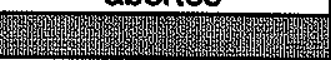 & \\
\hline Quartzo-milonitos & Ausente & Nenhuma & $\begin{array}{l}\text { Alto, cristas de } \\
\text { quartzo-milonitos }\end{array}$ & $\begin{array}{c}\text { Grandes } \\
\text { exposiços }\end{array}$ \\
\hline Rochas granitóides & $\begin{array}{c}\text { Arbustos, } \\
\text { árvores e } \\
\text { grama }\end{array}$ & Delgada & $\begin{array}{l}\text { Baixo, vales em } \\
\text { forma de } V\end{array}$ & $\begin{array}{l}\text { Poucas } \\
\text { exposiçб̋́es }\end{array}$ \\
\hline
\end{tabular}

TABELA III.5- Relação dos atributos do terreno das imagens processadas com as características fisiográficas naturais da regiåo (modificada de Ribeiro de Almeida et al., 1997).

Segundo Davis (1977, in Loughlin, 1991), a APC é uma técnica estatística que seleciona sucessivas combinações lineares não correlacionadas de um conjunto de variáveis, de tal modo que cada combinação linear, ou Principal Componente (PC), tem uma variância menor que a da sua predecessora. A variância estatística em imagens multi-espectrais relaciona-se com a resposta espectral dos vários materiais superficiais como solos, vegetação e rochas, bem como da resolução radiométrica do sensor. 
Nesse trabalho, a interpretação das PCs fundamentou-se genericamente no método denominado Feature-oriented Principal Component Selection-FPCS (Crosta \& Moore, 1989), o qual "baseia-se em modelos espectrais de alvos específicos e na relação quantitativa existente entre o conjunto original de bandas multiespectrais e o de bandas PCs dele derivado" (Crosta, 1990).

Esta técnica compreende três etapas (Crosta, 1990):

(i) Aplicação da APC com o cálculo dos parâmetros estatísticos de transformação;

(ii) Modelamento do comportamento espectral dos materiais de interesse e;

(iii) Seleção das PCs contendo a informação desejada, baseada na resposta dos materiais de interesse e nos módulos e sinais dos auto-vetores.

Ribeiro de Almeida et al. $(1995,1997)$ determinaram empiricamente que a resposta espectral característica de muitas das unidades litológicas da região das Minas do Camaquã deve-se à fatores físiográficos e litológicos. Silva Filho (1997) demonstrou o mesmo para as fácies sedimentares do Grupo Guaritas. Com base nisso, o modelo espectral assentou-se na fisiografia da cena (TABELA III.5). Utilizando-se de uma amostragem de 100 pixels em cada uma das bandas, em áreas sombreadas ou não, para cada tipo de rocha representativo das unidades geológicas individualizadas nos trabalhos de mapeamento regional, obteve-se um padrão diferenciado do comportamento espectral das amostras (TABELA III.6) que serviu na análise de cada PC. Foram calculadas a média e variância de cada banda original (TABELA III.7).

\begin{tabular}{l|lrrrccc}
\hline & \multicolumn{7}{c}{ MÉDIAS } \\
\hline & LITOTIPOS & \multicolumn{1}{c}{ TM2 } & TM3 & TM4 & TM5 & TM7 \\
GRUPO & Fm. Man- & Ritmitos & $13,9 \pm 0,9$ & $20,0 \pm 1,1$ & $50,0 \pm 3,7$ & $76,6 \pm 6,8$ & $22,5 \pm 2,1$ \\
CAMAQUÃ & gueira & Arenito & $9,9 \pm 1,6$ & $12,7 \pm 2,1$ & $42,2 \pm 6,0$ & $58,6 \pm 7,1$ & $16,1 \pm 2,0$ \\
& Fm. Vargas & $9,2 \pm 0,7$ & $12,7 \pm 1,1$ & $36,8 \pm 3,3$ & $55,9 \pm 5,1$ & $16,5 \pm 2,0$ \\
& Fm. João Dias & $12,6 \pm 1,0$ & $17,8 \pm 1,0$ & $44,7 \pm 4,8$ & $70,9 \pm 8,6$ & $20,9 \pm 2,3$ \\
\hline \multirow{2}{*}{ GRUPO } & Fm. Guarda Velha & $11,6 \pm 2,7$ & $18,1 \pm 3,1$ & $38,6 \pm 5,6$ & $72,0 \pm 11,0$ & $23,3 \pm 4,8$ \\
GUARITAS & Fm.. Pedra Pintada & $10,4 \pm 2,5$ & $15,3 \pm 4,3$ & $33,8 \pm 4,1$ & $60,9 \pm 13,4$ & $19,5 \pm 5,9$ \\
\hline & Rodeio Velho & $7,8 \pm 1,2$ & $9,8 \pm 1,9$ & $37,0 \pm 3,0$ & $46,1 \pm 8,5$ & $12,4 \pm 3,4$ \\
\hline
\end{tabular}

TABELA III.6- Médias aritméticas dos valores de nível de cinza (DN) de 100 amostras representativas dos litótipos diferenciados na cena (Ribeiro de Almeida et al., 1997).

$\begin{array}{llllll}\text { Banda } & \text { TM2 } & \text { TM3 } & \text { TM4 } & \text { TM5 } & \text { TM7 } \\ \text { Média } & 10 & 15 & 39 & 66 & 18 \\ \text { Variância } & 10 & 28 & 86 & 298 & 44\end{array}$

TABELA III.7- Média e variância das amostras coletadas para a APC

A APC foi aplicada para as cinco bandas disponíveis sem qualquer pré-processamento. As PCs resultantes foram submetidas à aumento linear de contraste e à filtragem laplaciana com kernel 5 X 5 .

Os auto-valores e auto-vetores de cada imagem PC gerada são mostrados na TABELA III.8. 
$\underline{\text { Fambrini, }}$ G.L. $=\underline{O}$ Grupo Camaquã: $\underline{\text { análise de fácies, proveniência e paleocorrentes }}$

\begin{tabular}{lcccccr}
\multicolumn{1}{c}{ Bandas } & TM2 & TM3 & TM4 & TMS & TM7 \\
PC & Auto-valor (\%) & \multicolumn{4}{c}{ Auto-vetor (\%) } \\
PC1 & 85 & 7,7 & 12,6 & 16,5 & 46,7 & 16,5 \\
PC2 & 12 & 2,0 & $-7,2$ & 60,8 & $-13,7$ & $-16,3$ \\
PC3 & 02 & 22,5 & 45,5 & 2,2 & $-20,8$ & 9,0 \\
PC4 & 01 & $-5,9$ & $-16,0$ & 8,9 & $-16,6$ & 52,6 \\
PC5 & 00 & 63,1 & $-30,0$ & $-5,6$ & 0,0 & $-0,7$
\end{tabular}

TABELA III.8- Auto-vetores e autovalores das PCs geradas pela APC.

As PCs foram então combinadas em tripletes com aumento linear de contraste (ALC). Os tripletes em RGB foram interpretados com base nos auto-valores, auto-vetores e feições conhecidas do terreno.

\section{III.3.3 Discussão}

Na curva espectral da vegetação (Drury, 1987), as zonas de menor reflectância correspondem, em ordem crescente, às bandas $1,3,2$ e 7. Já as zonas de maior reflectância correspondem às bandas 4 e 5 . Segundo Ribeiro de Almeida et al. (1995), para a região estudada, a maior parte da informação da banda 5 concentra-se na PCl que é regida pelo albedo (TABELA III.8). A PC2 é rica em informações da vegetação, como a participação da banda 4. As PCs restantes possuem contribuição das bandas 3,7 e 2 (PC3, PC4 e PC5, respectivamente). Teoricamente, têm a maior probabilidade de concentrar a informação relativa à componente litológica dos pixels mistos.

A PCl apresenta informações correlacionadas positivamente de todas as bandas, a qual se deve às diferenças de iluminação da cena (sombreamento topográfico) e ao albedo natural das superficies. A maior contribuição na $\mathrm{PC} 1$ se deve à banda $5(46,7 \%)$, de maior contraste, cuja variância (298) é a maior de todas as bandas originais (TABELA III.8). Na PC1 (FIGURA III.32), pixels claros representam (i) áreas de rocha exposta, como no topo dos morros e colinas da Associação Superior do Grupo Guaritas, a NW das Minas do Camaquã, (ii) áreas com pouca ou nenhuma vegetação nos conglomerados da Associação Média do Grupo Camaquã e (iii) setores da Formação Guarda Velha do Grupo Guaritas, imediatamente a ESE da Falha Tapera-Emiliano (Ribeiro de Almeida et al., 1995, 1996, 1997; Silva Filho, 1997). Áreas com predomínio de cobertura vegetal herbácea e relevo plano ou pouco irregular, respectivamente, nos ritmitos psamo-pelíticos e arenitos do Grupo Camaquã, também apresentam pixels claros porque a grama comporta-se como uma superficie homogênea de reflexão. A TABELA III.9 sumariza estas informações com base nos atributos do terreno.

Pixels escuros na PCl (TABELA III.9) relacionam-se à exposições dos corpos ígneos Rodeio Velho. Estas superfícies são cobertas por vegetação arbórea e são irregulares. Pixels escuros ocorrem também em áreas de afloramentos dos conglomerados do Grupo Camaquã, em virtude da cobertura arbórea e da textura naturalmente rugosa do litotipo, em razão das fraturas e patamares de acamamento. Pixels intermediários ocorrem na Formação Guarda Velha, onde a relação vegetação arbórea/herbácea é maior. 
A contribuição mais importante para a PC2 vem da banda $4(60,8 \%)$, possivelmente devido ao realce da resposta espectral da vegetação. Uma comparação da $\mathrm{PC} 2$ com a razão entre as bandas $4 / 3$ (FIGURA III.33) indica que elas são análogas. A FIGURA III.33, divisão entre bandas TM4/TM3, apresenta a mesma resposta espectral da PC4, só que com menor correlação. Na PC2, pixels claros relacionam-se às exposições de: (i) corpos ígneos Rodeio Velho, (ii) ritmitos psamo-pelíticos da Formação Mangueirão e arenitos da Formação João Dias do Grupo Camaquã, e (iii) algumas áreas do Complexo Porongos a SW (TABELA III.9). Pixels escuros aparecem em áreas de rocha exposta, como topos de morros da Formação Pedra Pintada. Pixels intermediários ocorrem sobre exposições da Formação Guarda Velha e em conglomerados do Grupo Camaquã.

Na PC4, a maior contribuição deve-se à banda TM7 (52,6\%), seguida da TM5 (-16,6\%) e, TM3 ($16,0 \%$ ). Observa-se que pixels claros ocorrem no topo dos morros da Formação Varzinha, realçando as ocorrências na porção centro-norte da cena e em algumas zonas imediatamente a leste da Falha TaperaEmiliano da Formação Guarda Velha, onde ocorrem as maiores espessuras de arenitos eólicos desta associação. Pixels médios a claros indicam o topo de muitos dos morros de conglomerados e arenitos do Grupo Camaquã e da Formação Varzinha, no bloco a W da Falha Tapera-Emiliano, e o topo das cristas do embasamento do Terreno Valentines a oeste. Pixels de intensidade média definem áreas de exposição dos corpos Rodeio Velho, a sul e sudeste da cena.
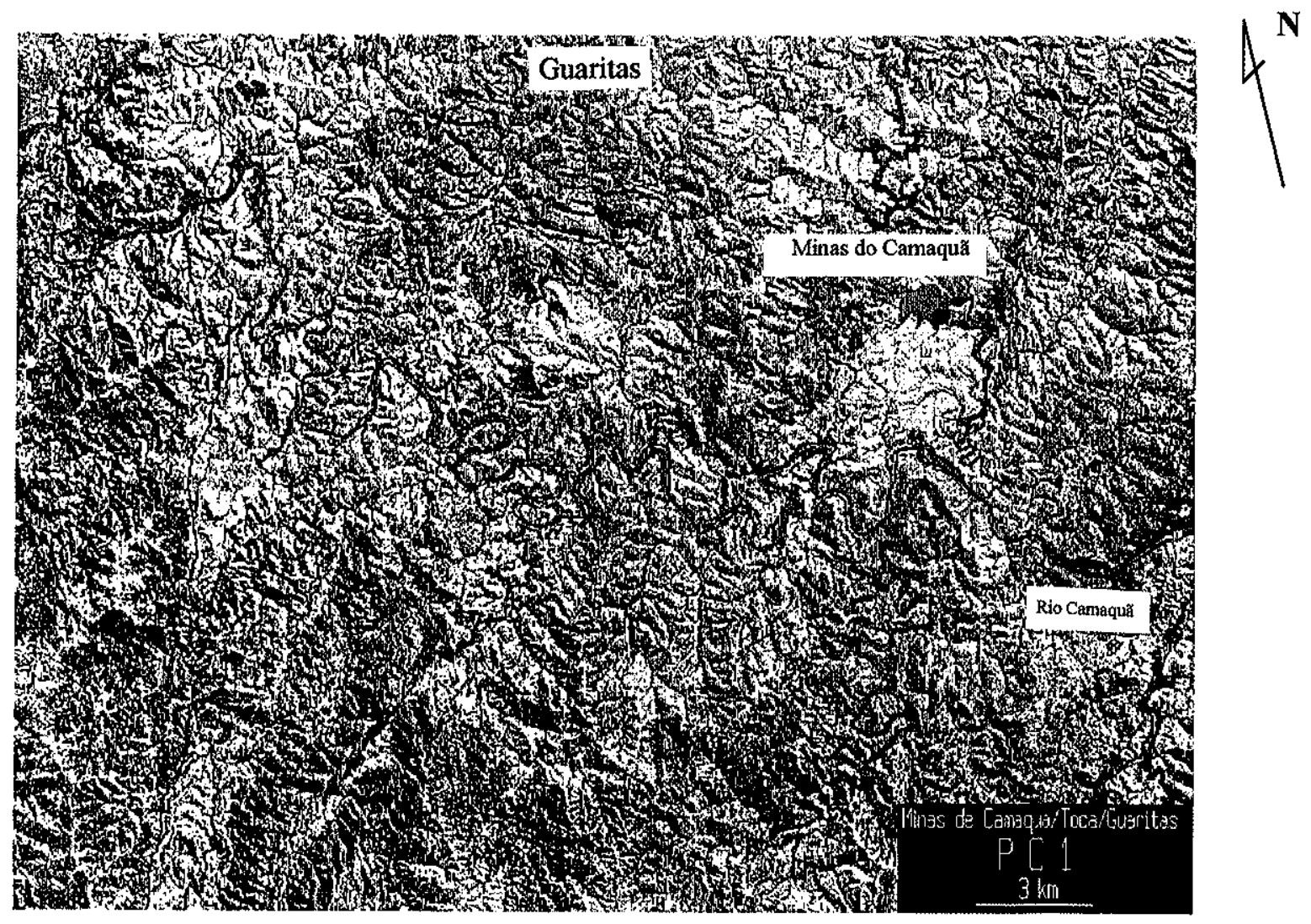

FIGURA III.32- Imagem PC1 mostrando os vários padrões texturais das superficies e os lineamentos (foliaçðes, acamamentos, falhas e fraturas). 


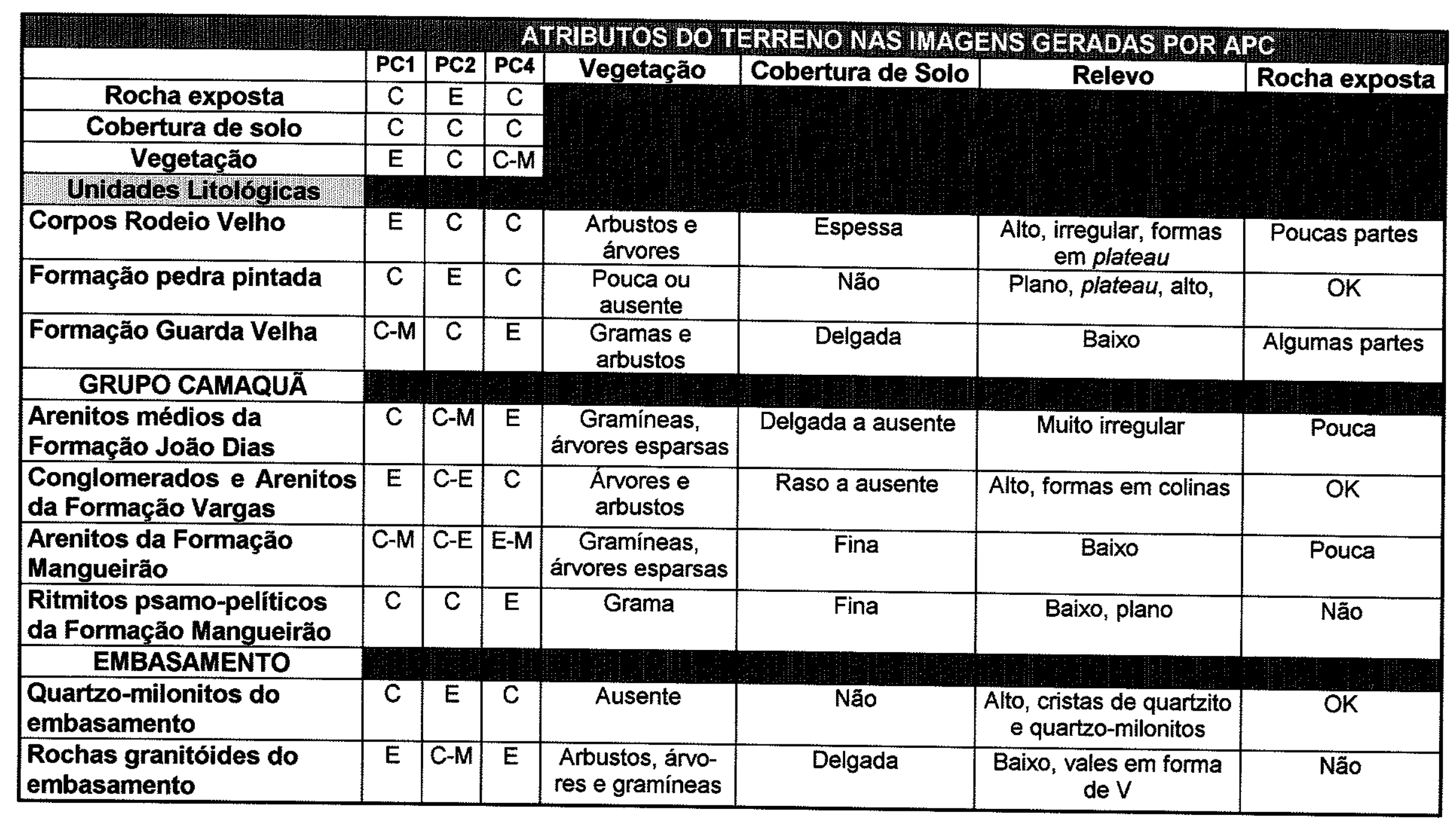

TABELA III.9- Atributos do terreno nas imagens processadas por Análise por Principais Componentes (APC). Foram relacionados atributos das PC1, PC2, e PC4 frente a cada unidade investigada. Siglas: E- pixels escuros; C- pixels claros; M- pixels médios ou intermediários 
Pixels predominantemente escuros indicam áreas ocupadas por: (i) ritmitos psamo-pelíticos da Formação Mangueirão e arenitos da Formação João Dias, (ii) ocorrências da fácies eólica do Grupo Guaritas (Formação Pedra Pintada) nas porções NE, centro- SE e SE da imagem. Excetuando-se as áreas de ocorrência do Rodeio Velho, na PC4 o comportamento geral da intensidade dos pixels é inverso àquele da PC2. O conhecimento da físiografia da região permite considerar que as áreas mais claras representem pixels com pequena contribuição de vegetação, tanto nas ocorrências de quartzo-milonitos do embasamento e da Formação Varzinha quanto em setores de ocorrência do Rodeio Velho (sobretudo na ocorrência a S da região das Mina do Camaquã).

As composições coloridas falsa-cor 457 e 472 em RGB (FIGURAS III.34 e III.35) são apresentadas para comparação com a FIGURA III.36, onde se distinguem algumas das unidades litoestratigráficas, no entanto sem a riqueza de informações espectrais da combinação de PCs. $O$ triplete 457 (RGB), com aumento de contraste, mostra predominância de tons cyan, vermelho e magenta. Este associa-se com a resposta espectral da cobertura vegetal que cobre partes dos conglomerados do Grupo Camaquã, do embasamento e, principalmente, os corpos ígneos Rodeio Velho. Tons de cyan puro relacionam-se aos morros tabulares dos arenitos do Grupo Guaritas, muito pobres em vegetação, o mesmo ocorrendo nas cristas de quartzo-milonito do Complexo Porongos. A forte contribuição de cyan na cena pode se dever ao predomínio de gramíneas nas porções mais baixas do relevo que não possuem biomassa suficiente para refletir os comprimentos de onda no infra-vermelho muito próximo, pois a resposta espectral da banda 4 tem sido utilizada como um índice de densidade de biomassa (Sabins, 1986).

Tendo em vista o exposto acima, o exame visual dos tripletes mostrou que a combinação PCIPC2PC4 (FIGURA III.36) é a mais apropriada para realçar feições estruturais e, principalmente, unidades litológicas que, em última instância, refletem diferentes unidades ou fácies sedimentares.

A composição mencionada permitiu a fácil individualização das várias unidades presentes na área enfocada. $O$ triplete possui riqueza de texturas e de brilhos, mas a principal característica da imagem é sua resposta espectral diferenciada para cada litotipo. $O$ comportamento das diferentes unidades em cada uma das PCs é descrito abaixo. A combinação dessas PCs pode ser explicada pela teoria das cores. Em geral o embasamento aparece em tons verde claros e apresenta uma textura muito rugosa em função das estruturas presentes (fraturas + foliações), sendo que as cristas quartzíticas de direção $\mathrm{N}$ apresentam tons magenta devido à exposição de rocha. As duas unidades sedimentares também foram facilmente separadas em subunidades que correspondem a fácies sedimentares dessas unidades.

O Grupo Camaquã pôde ser individualizado em três unidades como segue: (i) ritmitos psamopelíticos da Formação Mangueirão ocorrem com tons amarelos e amarelo-avermelhados e textura lisa; (ii) conglomerados e arenitos da Formação Vargas aparecem em verde intenso ou, onde a vegetação é pouco expressiva ou mesmo ausente, em tons magenta. PC1 e PC4 têm grande peso na unidade, enquanto a baixa contribuição da $\mathrm{PC} 2$ reflete cobertura de gramíneas. A textura é muito rugosa; (iii) arenitos finos da Formação João Dias têm cores amarelas a amarelo-avermelhadas, diferindo dos ritmitos por possuírem textura mais rugosa (FIGURA III.36). 


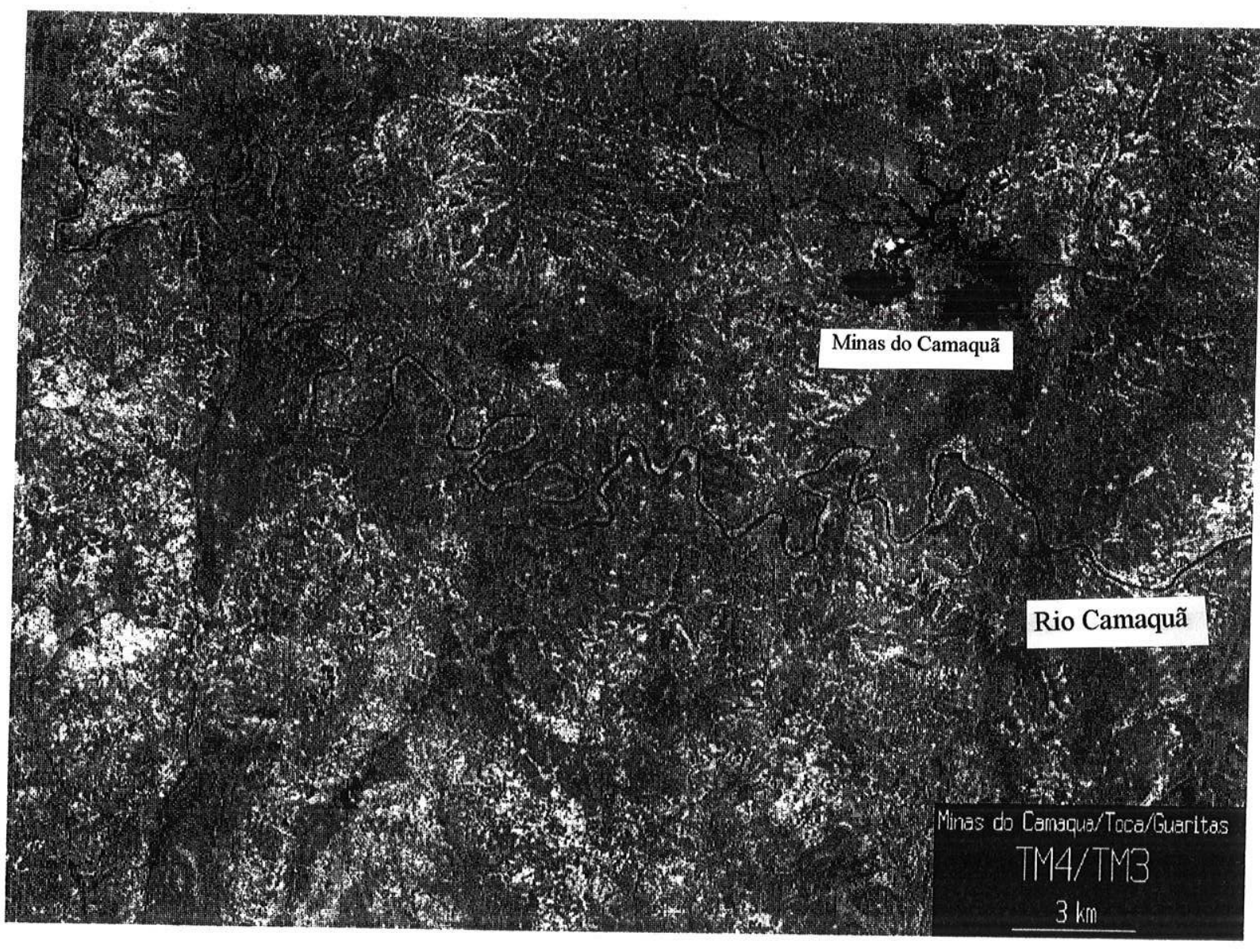

FIGURA III.33- Divisão entre as bandas TM4/TM3. O DN dos pixels é diretamente proporcional à quantidade de biomassa vegetal que recobre a cena. Análoga à PC2.

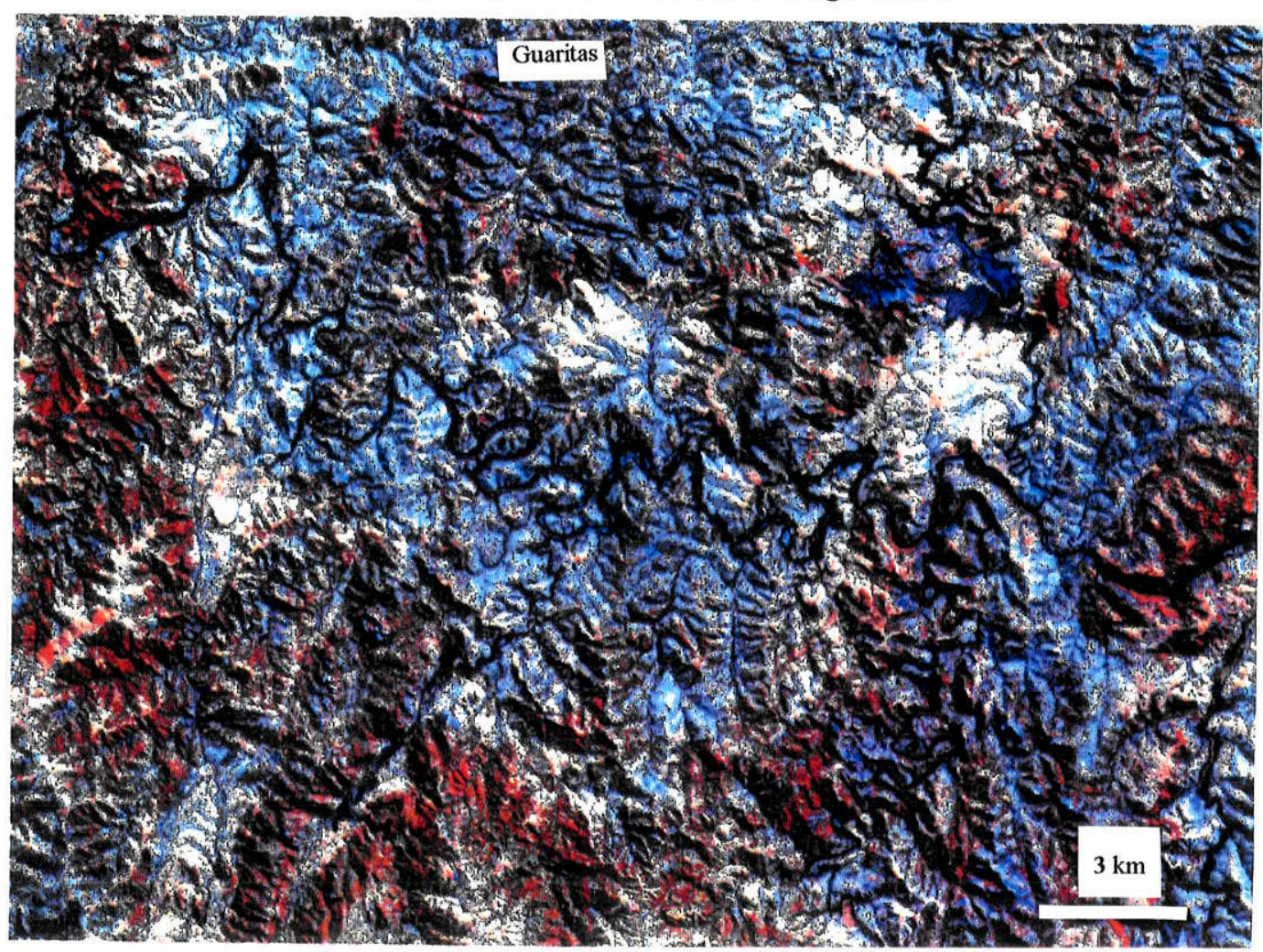

FIGURA III.34- Triplete falsa-cor com a combinação das bandas 457 (RGB). 
O Grupo Guaritas foi separado basicamente em duas unidades principais: (i) Formação Guarda Velha e (ii) Formação Pedra Pintada. A Formação Guarda Velha apresenta tons magenta com grande contribuição da PC4 e albedo muito alto na PC1 como resultado das exposições de rocha dos arenitos desta associação, enquanto que (ii) aparece, preponderantemente, em tonalidades de vermelho intenso, com albedo alto como conseqüência de vegetação rasa ou esparsa, delgadas espessuras de solo e relevo suave.

Finalmente, os corpos ígneos Rodeio Velho saltam aos olhos na imagem em decorrência do verde vivo e da textura bem suave, resultado da cobertura vegetal arbórea, maiores espessuras de solo e litologia mais homogênea (Silva Filho, 1997; Ribeiro de Almeida et al., 1997).

O triplete PC1PC2PC4 (RGB) representa a interação das três componentes principais das feições físiográficas do terreno que são influenciadas pelo arcabouço geológico da área de estudos, respectivamente, a saber: o relevo, o tipo de cobertura vegetal e a proporção entre área de cobertura vegetal e rocha exposta, bem como a resposta espectral dos litotipos.

As bandas originais permitiram a individualização de áreas mais vegetadas daquelas mais ralas ou mesmo ausente. $O$ triplete 472 (RGB) aparece como de grande valia possibilitando a individualização da unidade de conglomerados de áreas de embasamento, de similar resposta espectral, baseando-se só na textura. 
$\underline{\text { Fambrini, }} \underline{\text { G.L. }}=\underline{\text { O Grupo Camaquã: análise de fácies, proveniência e paleocorrentes }}$

z
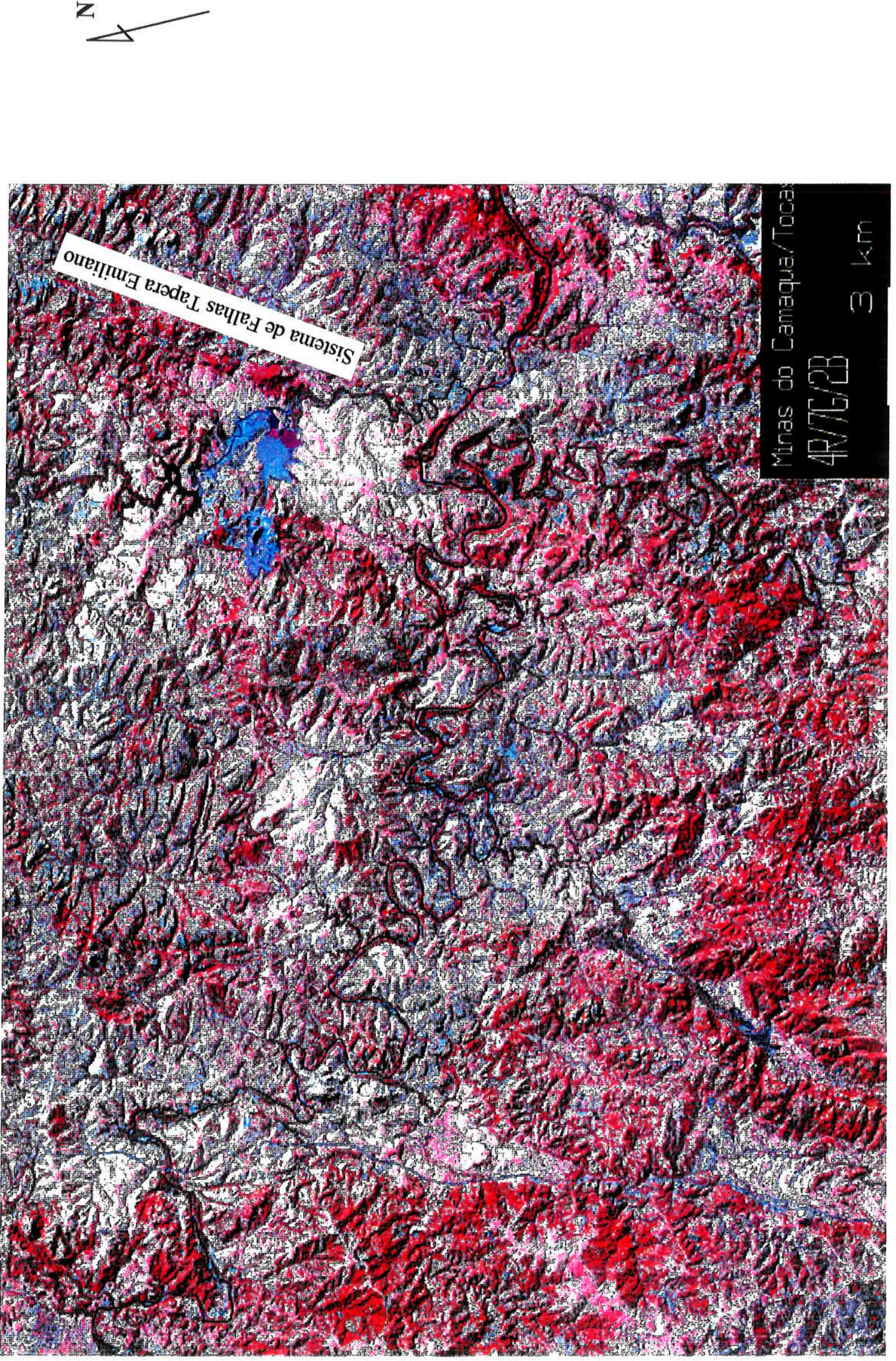

 


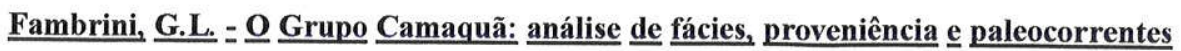
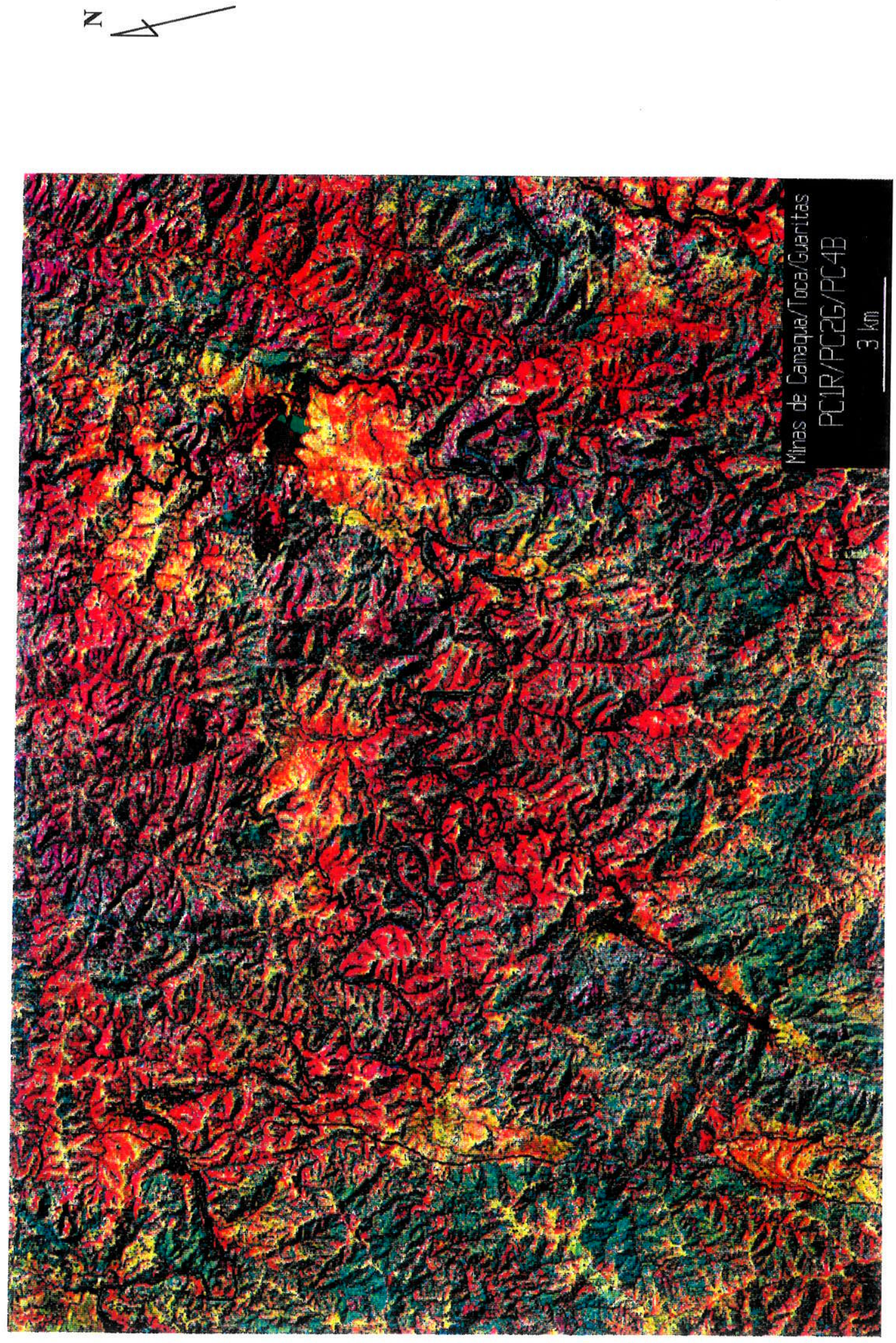

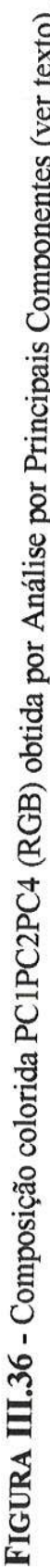




\section{III.4.1 Introdução}

O estudo de paleocorrentes foi realizado através de medidas em fácies aluviais, fluviais e turbidíticas. As duas primeiras foram tomadas a partir do sentido do mergulho dos (1) estratos frontais de estratificações cruzadas tabulares e/ou acanaladas (estruturas do rank 5 de Miall, 1974) de acordo com Potter \& Pettijohn (1977), Miall (1974; 1990) e Graham (1988); (2) marcas ou indicações de corrente como marcas de sola e de objetos (tool-marks), conforme metodologias de Potter \& Pettijohn (1977) e Collinson \& Thompson (1989); (3) imbricações de clastos com base no sentido do caimento do plano $a b$ e a posição dos eixos b ("largura" ou eixo intermediário) ou a (eixo paralelo à maior dimensão ou comprimento do clasto) quanto à corrente segundo Rust (1972a, b), Davies \& Walker (1974), Johnson \& Walker (1979), Collinson \& Thompson (1989) e Coimbra et al. (1992a) e, (4) variações de fácies e de granulometria. Adicionalmente, foram coletadas medidas em marcas onduladas por corrente (current-ripples) e laminações cavalgantes associadas, sendo necessário um mínimo de 30 medidas por exposição, às vezes nem sempre possível.

Nas fácies aluviais, diversas medidas foram obtidas em estratos cruzados tabulares de pequeno e médio portes (mais abundantes), sendo algumas em estratos acanalados de preenchimento de canais de depósitos de sheet flood e de fluxos canalizados. Estas tendem a oferecer menor variância que os estratos tabulares (Miall, 1974). Procurou-se obter um mínimo de 25 medidas em cada estação investigada, número mínimo recomendado para análises estatísticas (Miall, 1990; Assine, 1994) e capaz de prover um vetor médio com erro máximo de $\pm 30^{\circ}$ (Assine, 1994). Tal número mínimo muitas vezes não foi atingido em decorrência de limitações de exposição e acesso.

\section{III.4.2 Paleocorrentes da Formação Mangueirão}

O Conjunto Inferior de Associações de Fácies do Grupo Camaquã (CI), Formação Mangueirão, apresenta paleocorrentes dirigindo-se para (1) para E e NE nas porções inferior e mediana da sub-unidade; (2) NNE (azimute $20^{\circ}$ ) com pequena dispersão para NW na porção superior da coluna (FIGURA III.37). As do tipo (1), tomadas em imbricações de clastos das lentes conglomeráticas de seixos, refletem grande variação no padrão. As do tipo (2) foram obtidas de marcas de sola e climbing-ripples em turbiditos e de estratos cruzados de pequeno porte em arenitos intercalados nos conglomerados e arenitos grossos da fácies conglomerática $\left(T_{A}\right)$ mostrando coerência com as marcas de sola. Nos níveis silto-arenosos ocorrem abundantes marcas onduladas assimétricas $\left(\mathrm{T}_{\mathrm{c}}\right)$, com comprimento de onda centimétrico, e sentido geral de paleocorrente para NNE, enquanto nos níveis argilosos $\left(\mathrm{T}_{\mathrm{DE}}\right)$ ocorrem gretas de ressecação. 


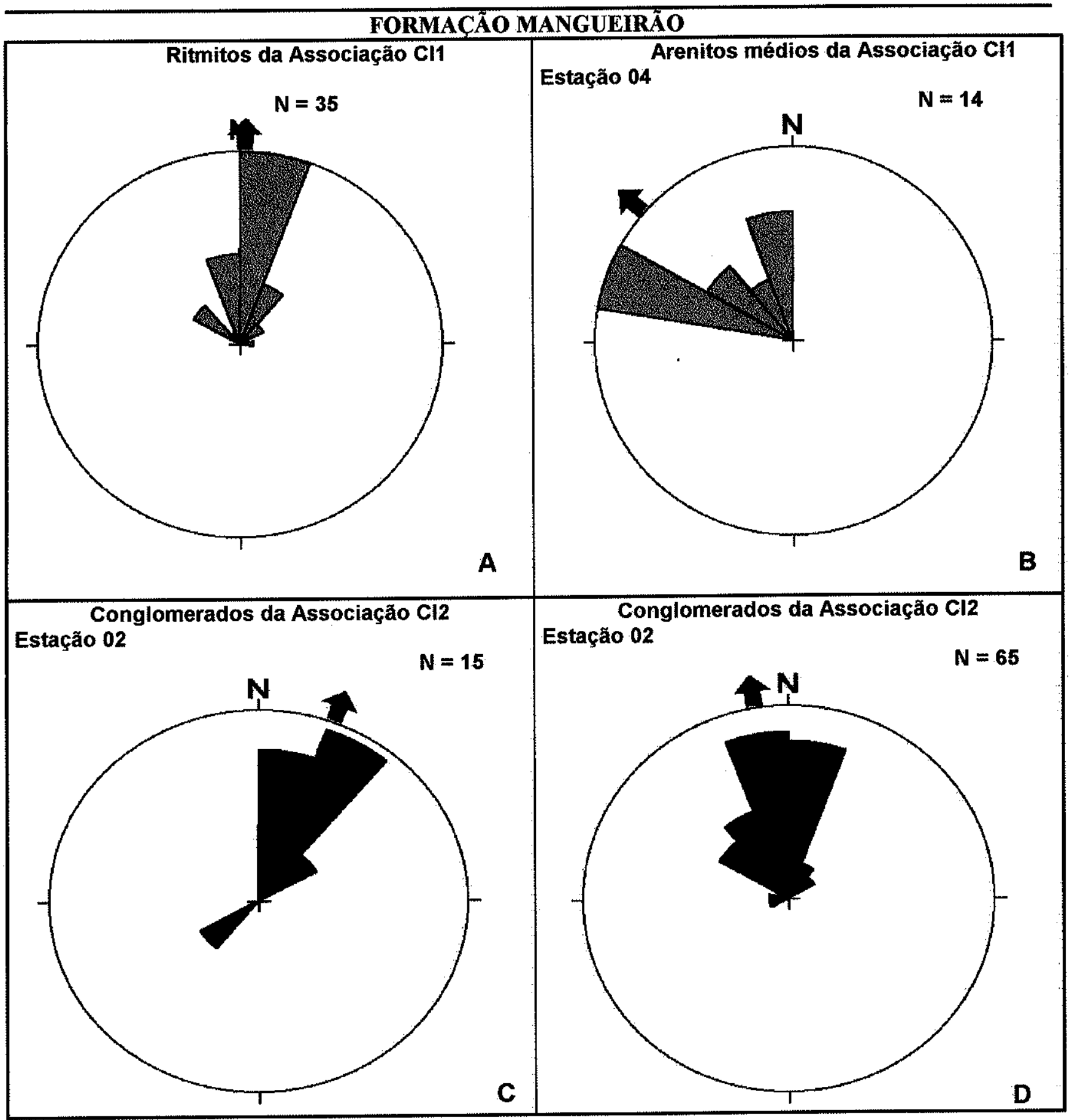

Figura III.37 - Diagramas de roseta mostrando padrão de dispersão de paleocorrentes e respectivos vetores médios (seta) da Formação Mangueirão em A- ritmitos tomadas em laminações cavalgantes $(\mathrm{N}=35)$ de várias exposições da Associação CI1; B- arenitos médios coletadas em estratificações cruzadas tabulares e acanaladas de pequeno porte $(\mathrm{N}=14)$ da estação 04 (pontos 184/185); $\mathbf{C}$ - estratificações cruzadas tabulares e acanaladas de pequeno porte $(\mathrm{N}=15)$ de conglomerados e arenitos conglomeráticos lenticulares da estação 02 da Associação CI2 (pontos 38, 110, 362 e 369); $\mathbf{D}$ - imbricações de clastos dos ruditos na estação $02(\mathrm{~N}=65$ ).

As medidas de paleocorrentes deposicionais na fácies de turbiditos indicam um padrão consistente para N/N20E (FIGURA III.37 A/C). A dispersão desse padrão varia de correntes dirigindo-se para leste (2 
medidas) e para N60W (6 medidas), tendo-se obtido um vetor médio para norte aproximadamente $(\mathrm{X}=02$, $\mathrm{N}=35$ ) (FIGURA III.37A).

A fácies de arenitos finos e médios mostra vetores de paleocorrentes para $\mathrm{NE}$ e $\mathrm{NW}$, com grande consistência $(n=12)$ (vide FIGURA III.38). A Associação CI1 apresenta paleocorrentes para NE, longitudinais ao eixo da sub-bacia na região. A fácies de conglomerados lenticulares possui padrão de paleocorrentes transversal ao eixo da sub-bacia, em função de sua localização junto às bordas, possivelmente.

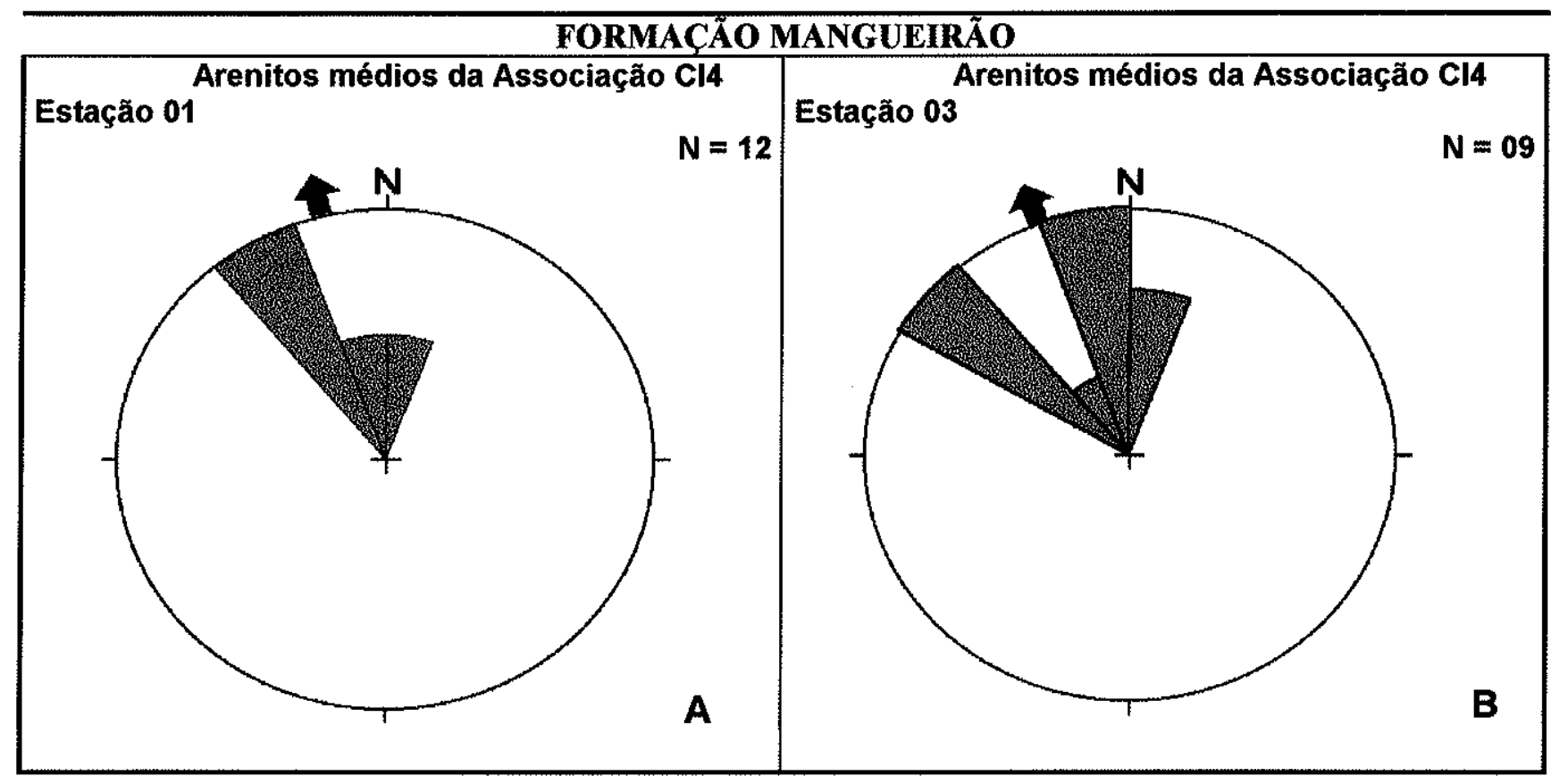

Figura III.38 - Diagramas de roseta mostrando padrão de paleocorrentes de arenitos médios da Associação Cl4 tomadas em A- estratificações cruzadas tabulares e acanaladas de pequeno porte $(\mathrm{N}=12)$; $\mathbf{B}$ - climbig ripples.

\section{III.4.3 Paleocorrentes da Formação Vargas}

O Conjunto Médio de Associações de Fácies do Grupo Camaquã (Formação Vargas) recebeu tratamento especial de paleocorrentes, tendo em vista as boas exposições e abundância de estruturas sedimentares. Esta associação, em função das características deposicionais dos depósitos (arenitos e conglomerados de leques aluviais) possui gama maior e variada de estruturas sedimentares passíveis de medidas de paleocorrentes deposicionais. As medidas de paleocorrentes foram coletadas na maioria das unidades aqui referidas, em (1) estratos cruzados tangenciais e acanalados em arenitos e arenitos conglomeráticos fluviais e intercalados nos conglomerados (de acordo com os métodos de Rust, 1972a; Miall, 1981) e (2) imbricações de clastos nas porções organizadas de conglomerados de leques aluviais (conforme Rust, 1972b; Collinson \& Thompson, 1989; Coimbra et al., 1992a).

As paleocorrentes dirigem-se para NNE (azimute $0-20^{\circ}$ ) na base da Associação CM1. As paleocorrentes medidas e disponíveis na literatura indicam transporte para NNE, com pequena dispersão para E e para W, predominando aquelas para NNE (e.g. N15E) conforme ilustra a FIGURA III.39. O vetor médio 
calculado resultou $X=12$, tendo extremos em 80 e 260 (notação azimutal). A FIGURA III.39A mostra o padrão de paleocorrentes da Associação CM1 com base em medidas em estratificações cruzadas acanaladas e tabulares de pequeno porte, enquanto que em III.39B verificamos o padrão decorrente de medidas de imbricação de clastos, principalmente, mas também de estratificações cruzadas tabulares.

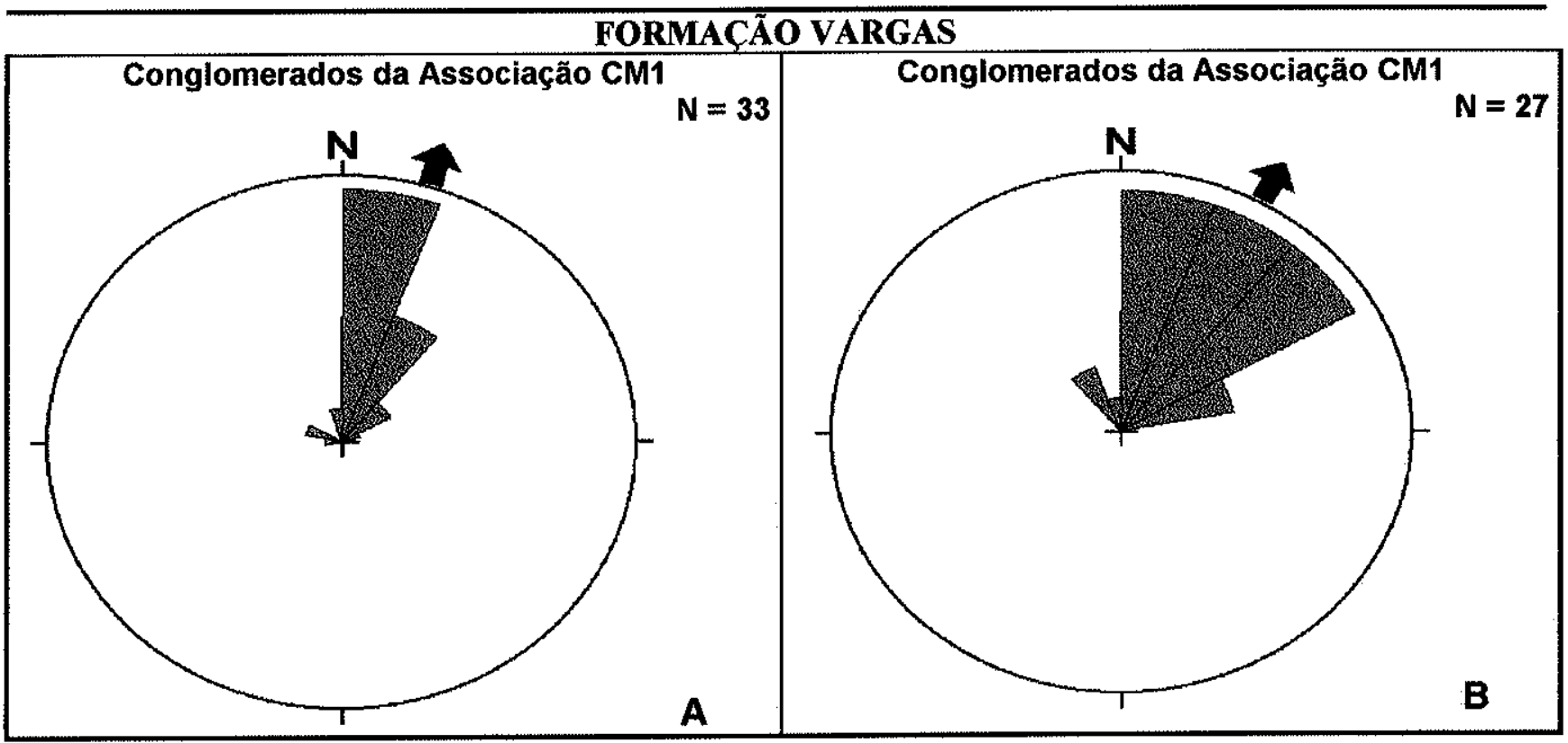

Figura III.39 - Diagramas de roseta mostrando padrão de paleocorrentes da Formação Vargas na Associação CM1 (Conglomerado Inferior) medidas em $\mathbf{A}$ - estratificações acanaladas e tabulares de pequeno porte; $\mathbf{B}$ estratificações acanaladas e tabulares de pequeno porte e imbricações de clastos. Cava a céu aberto da Mina Uruguai (CBC), estação 05.

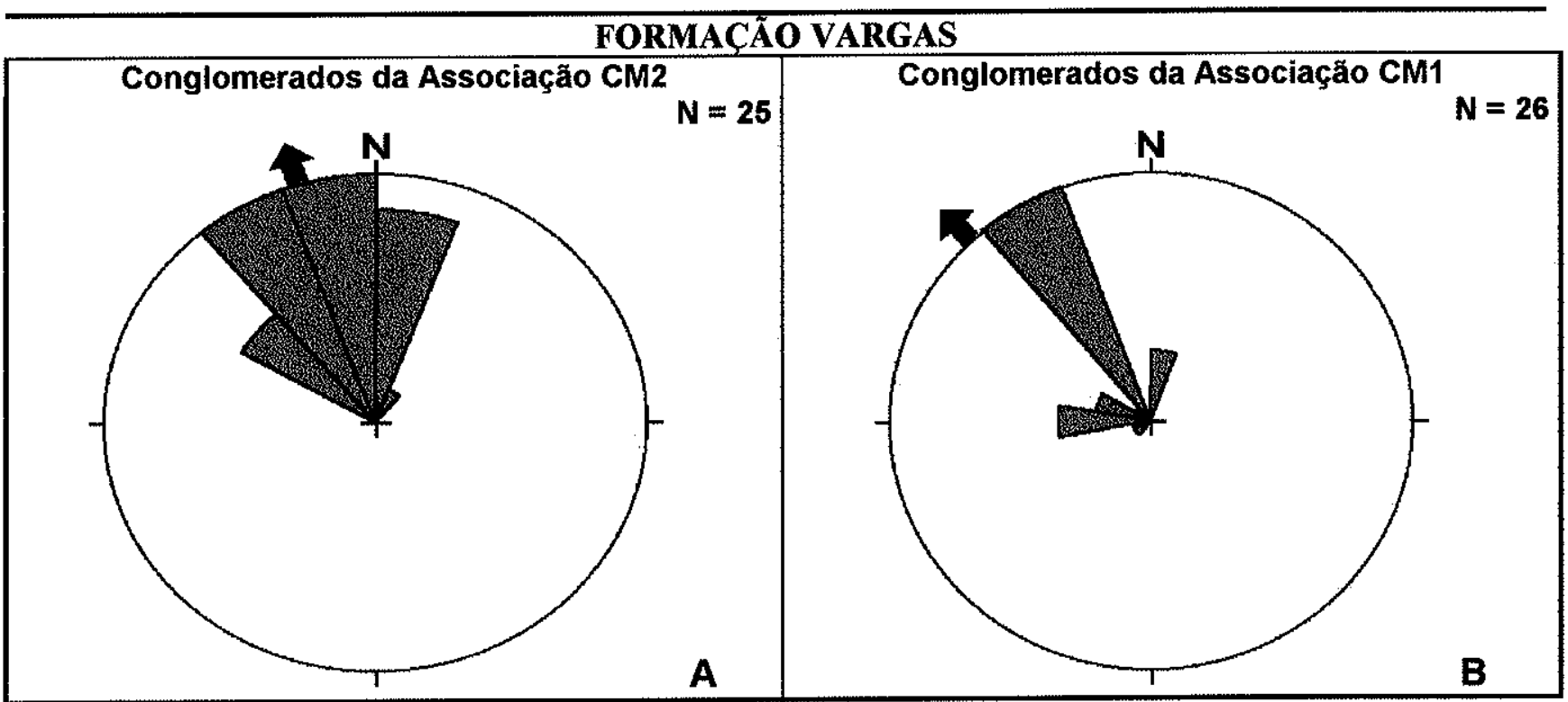

Figura III.40 - Diagramas de roseta mostrando padrão de paleocorrentes na Associação CM2 (Conglomerado Superior) da Formação Vargas medidas em A- estratificações acanaladas e tabulares de pequeno porte em nível areno-conglomerático intercalado nos pacotes tabulares de ortoconglomerados; B- imbricações de clastos segundo caimento do plano $a b$. Cava a céu aberto da Mina Uruguai (CBC), estação 05. 
A Associação CM2 da Formação Vargas possui o maior número de medidas $(n=81)$ evidenciando boa distribuição na unidade (FIGURAS III.40 e III.41). O padrão de paleocorrentes mostra consistência em (1) arenitos conglomeráticos tabulares cujos vetores médios são para NW ( $\mathrm{X}=353$ e $\mathrm{X}=344)$; (2) conglomerados tabulares com vetores médios para $\mathrm{N}(\mathrm{X}=04)$ e para $\mathrm{NW}(\mathrm{X}=325)$ e para $\mathrm{NE}(\mathrm{X}=28)$, mostrando o domínio de clastos derivados do TSE situado a E, SE e S da região das Minas do Camaquã. Quando se analisa somente as medidas de estratificações cruzadas acanaladas e tabulares planares e tangenciais na base dos estratos, obtém-se vetor médio para $\mathrm{N} 15 \mathrm{~W}$ aproximadamente $(\mathrm{X}=353)$, mas paleocorrentes com sentido para N20-40E ocorrem também (FIGURA III.40A).

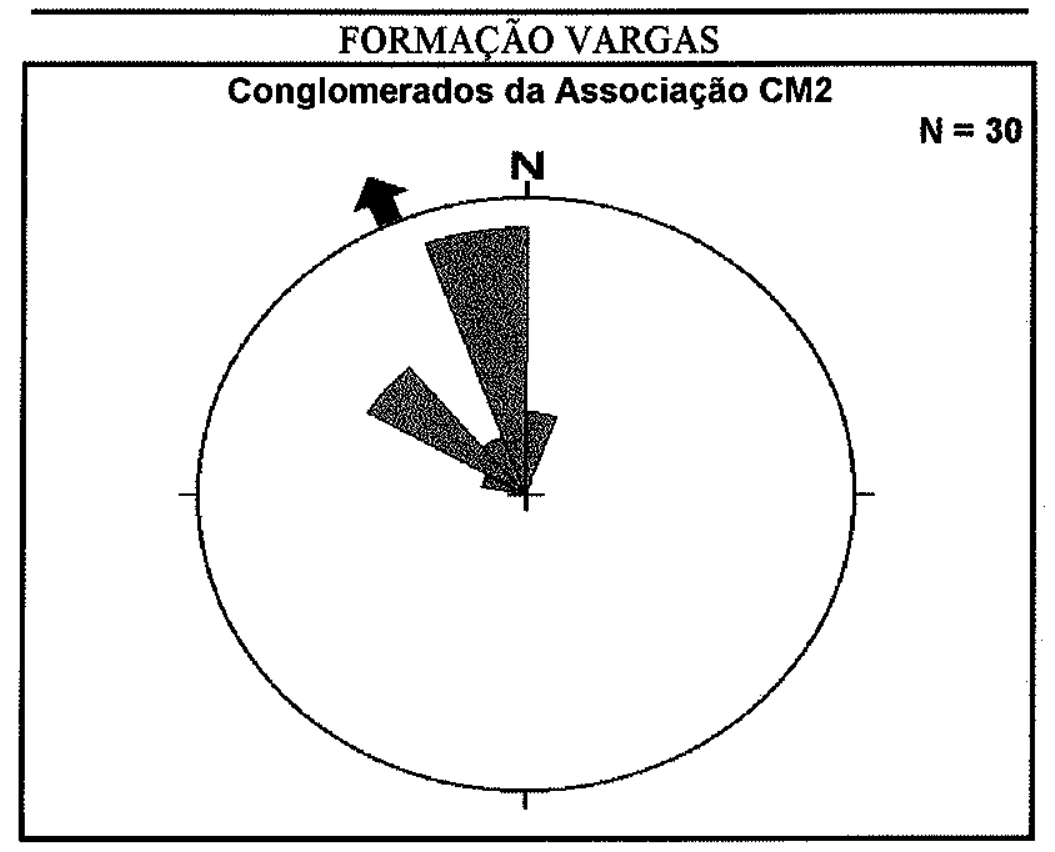

Figura III.41- Diagrama de roseta mostrando padrão de paleocorrentes e respectivos vetores médios (setas) da Associação CM2 tomadas em estratificações cruzadas tabulares e acanaladas de médio e pequeno portes na Estação 06 (MC-195).

\section{III.4.4 Paleocorrentes da Formação João Dias}

Por fim, o Conjunto Superior de Associações de Fácies do Grupo Camaquã (Formação João Dias) possui padrão diverso de paleocorrentes (FIGURA III.42). Na Associação (CS2) (fácies transicionais) os vetores indicam um paleotransporte para NE (estações 01, 02 e 04), paralelo ao eixo da sub-bacia e semelhante ao Conjunto Inferior na fácies de turbiditos. Nas fácies flúvio-deltaicas desta associação (porções de topo) o padrão de paleocorrentes indica transporte pa WNW (Estação 03) extraídas de estratificações cruzadas tabulares de médio porte de boa representatividade. 


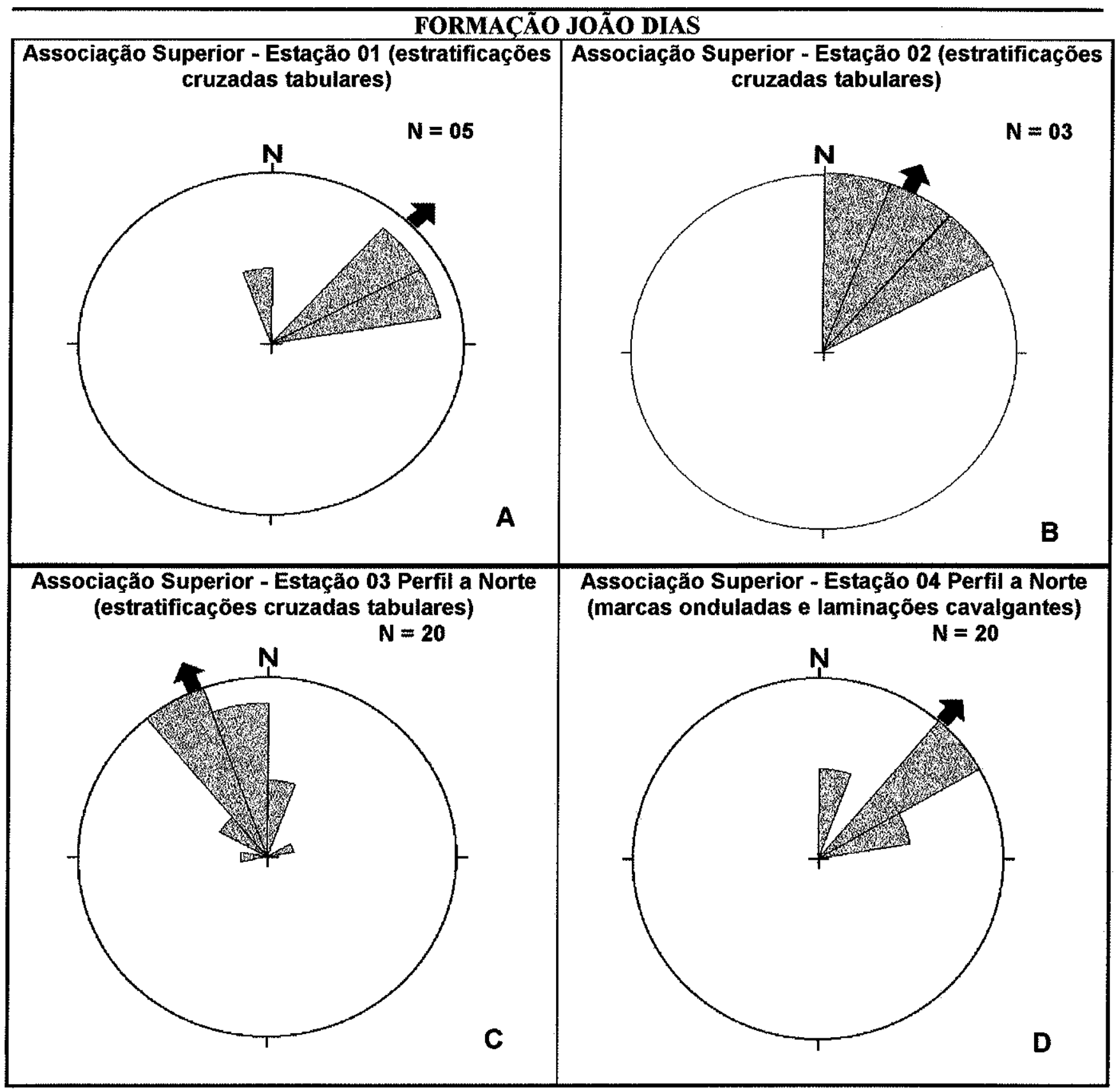

Figura III.42- Diagramas de roseta mostrando padrão de paleocorrentes na associação de arenitos finos e médios tomadas em estratificaç̋̃es cruzadas tabulares e acanaladas de médio e pequeno portes (A, B e C), e marcas onduladas e laminações cavalgantes (D).

Segundo Silva Filho (1997), junto à borda do Alto Estrutural das Minas do Camaquã a Formação Guarda velha do Grupo Guaritas apresenta padrão de paleocorrenrtes centrífugo, sugerindo que este alto já se encontrava soerguido ou em processo de ascensão durante a deposição dessa associação. Esta assertiva encontra respaldo nas análises de proveniência realizadas neste trabalho nas fácies do Grupo Guaritas, as quais indicam forte contribuição das rochas do Grupo Camaquã. 


\section{III.5.1 Introdução}

As rochas do Grupo Camaquã na área de estudos foram objeto de análise petrográfica, efetuada a nível macroscópico e microscópico. Foram analisadas amostras selecionadas de arenitos e da matriz de conglomerados com o intuito principal da determinação mineralógica e textural para fins de estudos de proveniência, e adequada classificação dos litotipos. Assim, optou-se pelo método tradicional de contagem de clastos, mais adequado para investigações dessa natureza (e.g. Erikson et al., 1994)., e por não se adotar o Método Gazzi-Dickinson de contagem tal como preconizado por Ingersoll et al. (1984), Aalto (1989) e Critelli \& Ingersoll (1994), entre outros, A história diagenética das rochas da região das Minas do Camaquã foi alvo de investigações de Veigel \& Dardenne (1990) e Veigel (1992) que, certamente, trouxeram contribuição inestimável neste assunto. Conclusões mais apuradas destes autores foram aqui contempladas. As principais características petrográficas podem ser observadas na TABELA III.6.

\section{III.5.2 Descrição Petrográfica}

\section{III.5.2.1 Formação Mangueirão}

Os arenitos da Formação Mangueirão são em sua maioria classificados como arcóseos e arenitos líticos (Folk, 1968). O arcabouço dos arenitos constitui-se de detritos de quartzo dos tipos monocristalino $(\mathrm{Qm})$ e policristalino $(\mathrm{Qp})$, ortoclásio, plagioclásio, microclínio, fragmentos líticos (granitos, quartzitos, chert, intraclastos de argila, xistos), acessórios como muscovita e biotita, minerais pesados (TABELA III.6).

Grãos de quartzo ( $\cong 40 \%$ - estimativa visual) incluem os tipos policristalino (Qp), abundante e (Qm) quartzo monocristalino, também abundante, mas subordinado ao $Q p(Q m=35 \%$ e $Q p=7 \%$ da rocha). O Qm, majoritariamente, é o tipo ígneo plutônico de Krynine (1940). Predominam aqueles grãos com extinção alternando-se de fortemente ondulante (40\%) e ondulante (30\%), mas simultânea ou reta também aparecem (30\%). Possuem diversas inclusões e micrólitos dispersos pelo grão, e crescimentos secundários comuns (<10\%). Quartzo monocristalino vulcânico (Krynine, 1940) é raro e, quando presente, possui hábito euedral e extinção reta, com bordas corroídas. Distinguem-se o hábito xenomórfico típico (anédrico) e formas subedrais e equidimensionais. Entretanto, grãos formados de cristais de hábito tendendo a euedral, com predomínio daqueles ondulantes, também surgem, derivados possivelmente de fontes hidrotermais (de veio) ou mesmo metamórficas, embora careçam de feições de recristalização. Tipos 
vacuolizados destacam-se também, assim como quartzo tipo leitoso com abundantes inclusões, ambos sugestivos de fontes hidrotermais (o chamado quartzo de veio). Grãos subangulosos perfazem cerca de $50 \%$ dos arenitos, conquanto subarredondados (35\%), arredondados ( $8 \%$ ) e angulosos ( $10 \%)$ ocorram.

Detritos de quartzo policristalino (Qp) atingem até $\sim 20 \%$, destacando-se os tipos composto metamórfico (Cm) de Krynine (1940), semi-composto e/ou de veio (Csc) e estirado, milonítico ou deformado $(\mathrm{Cd})$. O tipo policristalino metamórfico apresenta vários cristais com evidências de recristalização, quais sejam: (i) extinções diferentes por cristal (ora um está extinto, o outro está não extinto) e (ii) contatos bem formados entre os cristais (retos e poliedrais), onde por vezes chega a ser poligonal perfeito. $O$ tipo composto estirados ou deformado também é formado por vários cristais com feições de recristalização, mas difere substancialmente em dois quesitos: (i) quanto ao contato intercristais e (ii) orientação interna no grão dos cristais individuais. $O$ primeiro mostra contatos amplamente irregulares e contorcidos, em um grau mais avançado nos grãos suturados, onde se sobressaem alguns cristais "intactos" em meio à massa deformada. Quanto à orientação, todos os cristais encontram-se estirados, orientados e alongados segundo uma orientação preferencial (eixo $c$ orientado). Os grãos de $Q p$ normalmente estão melhor arredondados que os monocristalinos. Como exemplo tomemos a amostra FMC109 (Fácies Afr da Associação CI1) onde o arredondamento de Qp segue segundo: anguloso (6\%), subanguloso (40\%), subarredondado (40\%), arredondado (22\%), muito anguloso (2\%).

Os arenitos são ricos em feldspatos em geral (TABELA III.6), cujos picos de abundância atingem até $25 \%$ da composição total (matriz + cimento). Os feldspatos alcalinos dominam e, destes, o ortoclásio é o mais comum atualmente.

Convivem grãos frescos (límpidos) e alterados (sujos), provavelmente refletindo processos originados ainda nas áreas fonte em razão de retrometamorfismo (De Ros, 1986). Os K-feldspatos, de maneira geral, encontram-se alterados para sericita e caulinita e sofreram, também, processos de saussuritização (calcita + epídoto + sericita + muscovita), este muito provavelmente na fonte original. Em geral, apresentam formas tabulares e pouco arredondadas. Alguns plagioclásios encontram-se com zonação e, outros, com extinção análoga à ondulante. Esta deve refletir processos diagenéticos então em curso, dada a composição heterogênea das bordas para o núcleo dos grãos.

Ortoclásio ( 10\%, Dim: $0,4 \mathrm{~mm} \leq \mathrm{D} \leq 0,75 \mathrm{~mm})$ aparece com predomínio de grãos alterados (pelo menos os identificáveis). Constituem-se em grãos mantendo a forma próxima à original e outros arredondados, freqüentemente alterados para sericita (sericitização) e uma mistura de calcita + epídoto + sericita + muscovita (saussuritização), talvez já na área fonte provocada por retrometamorfismo. $O$ hábito é tabular típico, mas formas mais alongadas também ocorrem. Normalmente aparecem "sujos" sob luz natural.

Microclínio ( 5\%, Dim: 0,6 mm $\leq \mathrm{D} \leq 1,35 \mathrm{~mm}$ ) ocorre subordinadamente, apresentando as típicas maclas de geminação em grade ou xadrez. Os grãos frescos superam os alterados $(7: 1)$. Ocorrem 
também tipos com uma triclinicidade intermediária ou geminações em grade mal geradas (spindle twinning). Possuem formas mais equidimensionais.

No caso do plagioclásio predominam grãos subarredondados, mas muitos são quase euédricos (e portanto, angulosos e subangulosos). São frescos (maioria) e alterados. $O$ hábito é equidimensional subhédrico a tabular (nas formas euédricas). Composição andesina (6 grãos), oligoclásio ( 3 grãos), albita (5 grãos), labradorita (1 grão). Teor $\mathrm{An}_{10-20} \leq \mathrm{An} \leq \mathrm{An}_{30-40}=\mathrm{An}_{10-30}$ (albita- andesina). A alta porcentagem de plagioclásio talvez se deva aos granodioritos, onde se destacam intercrescimentos mirmequíticos.

Muito significativa é a presença de fragmentos líticos (4-12\%) disseminados no arcabouço dos arenitos e lentes de conglomerados, provavelmente guardando relação com a granulometria das rochas (média a grossa). Aparecem, principalmente, clastos de chert, vulcânicas, xistos, quartzitos, milonitos, granodioritos, e intraclastos. Chert apresenta-se sempre subarredondado a arredondado, com dimensões entre 0,5 e $0,75 \mathrm{~mm}$. Prováveis fragmentos de granodioritos (granitos com cristais de plagioclásio $\gg \mathrm{F}-\mathrm{K}$ ) são os de maiores dimensões $(0,7 \mathrm{~mm}<\mathrm{Dm} \leq 1,5 \mathrm{~mm})$. Litoclastos vulcânicos estão representados dominantemente por ácidas (riolitos, riodacitos), de texturas felsíticas e vítreas, e ignimbritos, mas incluindo-se ainda termos intermediários/básicos de texturas porfiríticas e traquíticas (e.g. andesitos).

Litoclastos metamórficos (xistos, quartzitos, ardósias, filitos) disseminam-se nos arenitos e conglomerados. As composições médias ( $<1-10 \%)$ podem estar subestimadas, pois grande parte da pseudomatriz destas rochas é formada por fragmentos compactados de rochas metamórficas micáceas. Muitos orientam-se favoravelmente à estratificação da rocha, segundo o alongamento dos grãos.

Entre os minerais acessórios destacam-se as micas, cujas porcentagens médias refletem pouca abundância $\left(\mathrm{N}_{\max }=10 \%\right.$ ). Biotita supera ligeiramente a muscovita em abundância (TABELA III.6), quase sempre em adiantado grau de alteração para clorita e/ou óxidos de Fe (ilita). Muscovita mostra-se mais preservada e geralmente em dimensões menores que a primeira. Normalmente ajustam-se com o acamamento da rocha. Minerais pesados tais como zircão, turmalina, apatita e opacos aparecem disseminados pela matriz ou formando níveis finos onde se concentram. É notável a ocorrência de níveis de magnetita retrabalhada (e portanto, detrítica) salientando o plano de acamamento (Veigel, 1992), muito embora este mineral possa ser encontrado bem formado sugerindo caráter autigênico.

A Associação Cl1 é formada por detritos de quartzo monocristalino $(\mathrm{Qm}=35 \%)$, plagioclásio sódico $(12,0 \%)$, quartzo policristalino $(\mathrm{Qp}=7 \%)$, ortoclásio $(10,0 \%)$, microclínio $(4,6 \%)$, fragmentos líticos (7\%) representados por rochas vulcânicas, metamórficas argilosas indiferenciadas (filitos, ardósias?), quartzitos, chert, intraclastos de argila, xistos, granitos), acessórios como muscovita e biotita e minerais pesados. Matriz, minerais autigênicos e cimento somam cerca de $20 \%$.

A Associação CI2 é composta de detritos de quartzo monocristalino ( $\mathrm{Qm} \cong 30 \%$, quartzo policristalino $(\mathrm{Qp} \cong 20 \%$ ), feldspato alcalino $(12,6 \%)$ dominantemente ortoclásio $(9,7 \%)$, plagioclásio dominantemente sódico (10,5\%), fragmentos líticos (10\%) representados por rochas vulcânicas, quartzitos, chert, intraclastos de argila, xistos, granitos, milonitos) e rochas metapelíticas indiferenciadas (filitos, 
ardósias?), e minerais acessórios como biotita e muscovita, além de pesados (turmalina, zircão, apatita). Matriz, minerais autigênicos e cimento somam cerca de $15 \%$.

As Associações CI3 e CI4 são formadas por detritos de quartzo monocristalino (Qm $\cong 31 \%)$, quartzo policristalino $(\mathrm{Qp}=12 \%)$, ortoclásio $(9,5 \%)$, microclínio $(2,5 \%)$, plagioclásio essencialmente sódico $(8,0 \%)$, fragmentos líticos $(6 \%)$ representados por rochas vulcânicas, metamórficas argilosas indiferenciadas (filitos, ardósias?), quartzitos, chert, intraclastos de argila, xistos, granitos), acessórios como muscovita e biotita $(6,0 \%)$ e minerais pesados $(5 \%)$. Matriz, minerais autigênicos e cimento somam cerca de $20 \%$.

\section{III.5.2.2 Formação Vargas}

$\mathrm{O}$ arcabouço da matriz dos ruditos constitui-se de quartzo monocristalino e policristalino, $\mathrm{K}$ feldspato, plagioclásio, fragmentos líticos (entre estes chert, quartzito, rochas vulcânicas, arenitos, conglomerados, pelitos e granitos), acessórios como muscovita, biotita, opacos e minerais pesados (turmalina, zircão e apatita). Predomina granulometria fina a grossa (de $0,15 \mathrm{~mm}$ a $0,9 \mathrm{~mm}$ ) até muito grossa, incluindo também grânulos (em torno de 3,0-4,0mm). Assim, a seleção é de muito pobre a moderada, onde os grãos são de angulosos a arredondados, predominando aqueles subarredondados, de esfericidade sobretudo média (segundo classificação de Powers, 1953). Os litotipos possuem pouquíssimos espaços intergranulares, com predomínio de contatos dos tipos côncavo-convexo e planar, evidenciando alta compactação e, conseqüentemente, com evidente redução da porosidade das rochas. Observa-se comumente cimento carbonático e ferruginoso (limonita), em proporções nunca superiores a $5 \%$. É comum a presença de cutículas hematíticas envolvendo, por vezes, totalmente grãos de quartzo, principalmente, mas também de feldspatos. Nestes, freqüentemente a hematita interpenetra o grão através das maclas de geminação e/ou por meio de fraturas e deficiências do cristal original. Pseudo-matriz ocorre disseminada nos interstícios e entre os grãos maiores do arcabouço.

O quartzo (em torno de 40-45\%) é o principal componente detrítico destas rochas. A variedade policristalina predomina em relação à monocristalina, provavelmente como causa direta da granulometria mais grossa das rochas desta associação, tal qual sugerido por diversos autores para arenitos grossos em várias partes do mundo (Blatt, 1967; Pittman, 1969; Basu et al., 1975; Misko \& Hendry, 1979; Ingersoll et al., 1984; Pettijohn et al., 1987; entre outros). O quartzo monocristalino ou simples (Qm) é anguloso e subanguloso até subarredondado e de esfericidade média a baixa, cujos grãos exibem extinção ondulante a fortemente ondulante indicativa de esforço (stress). $\mathrm{O}$ hábito xenomórfico, associado com a presença abundante de vacúolos, micrólitos e inclusões de muscovita e sericita, constituindo o tipo plutônico de Krynine (1940), sugere caráter intrusivo (Blatt, 1967; Misko \& Hendry, 1979).

Entretanto, é o quartzo policristalino $(\mathrm{Qp})$ o mais importante devido às implicações deste quanto à: proveniência, transporte, retrabalhamento e deformação. A variedade policristalina ocorre em 
quantidades de cerca de 2:1 em relação à monocristalina, e, por vezes, pode atingir até 4,0mm de diâmetro. Dentre os tipos policristalinos, destacam-se semi-composto, composto metamórfico e compostodeformado (sheared-quartz) de acordo com Blatt (1967) e Scholle (1979). O tipo semi-composto ou de veio consiste em grãos onde não se distingue nitidamente cristais individuais. Esta variedade caracteriza-se por apresentar grãos com extinção ondulante, contatos "intercristais" irregulares (na verdade um efeito decorrente da extinção dos diversos pseudo-cristais) e ausência de orientação preferencial. $O$ tipo semicomposto fornece boas indicações de fonte de veios e filões hidrotermais (o chamado quartzo leitoso), principalmente e, também, plutônicas e metamórficas. $O$ tipo composto metamórfico (metamorphic quartz de Krynine, 1940) é o predominante (cerca de 12-14\% das rochas), constituindo-se de um mosaico de vários cristais que, dependendo do caráter e dos limites intercristais, podem fornecer boas indicações de proveniência. Apresentam evidente individualização dos cristais e exibem contornos irregulares e suturados intercristais. Os cristais são desorientados, porém mostram-se recristalizados. São subangulosos a subarredondados, de esfericidade baixa (normalmente aqueles alongados). Sugerem proveniência de terrenos metamórficos de alto grau (Blatt, 1967; Basu et al., 1975; Young, 1976; Scholle, 1979) e curto transporte, pois se desagregam em conseqüência da abrasão sofrida pelos grãos com o transporte (Pettijohn et al., 1987). O tipo composto deformado, milonítico ou estirado (sheared quartz, de acordo com Scholle, 1979) caracteriza-se por evidente orientação e estiramento dos cristais individuais (singlecristals), contornos irregulares e suturados intercristais (Adams et al., 1993). Os cristais individuais mostram-se alongados e, por vezes, estirados segundo uma orientação preferencial. Cada cristal exibe diferentes orientações de eixo ótico, podendo um cristal individual apresentar extinção leve a fortemente ondulante (esta predominante). Em vários casos, cada cristal individual constitui-se, por sua vez, em um cristal semi-composto. Em geral, mostram-se subarredondados e podem representar fonte que sofreu alto grau de deformação e/ou metamorfismo. Grãos de quartzo policristalino deformados indicam fontes que sofreram alto grau de deformação e metamorfismo.

O feldspato alcalino presente nestas litologias é essencialmente o microclínio, aparecendo também o ortoclásio. 0 primeiro ocorre em percentagens em torno de 20-22\%. A dimensão média gira por volta de 1,5-2,5mm. Constituem grãos bem maiores que os de plagioclásio. A maior parte possui geminação indicativa de uma triclinicidade intermediária, perfazendo intercrescimentos pertíticos. Mostram-se parcialmente arredondados, porém ainda preservam a forma euédrica e $\circ$ hábito prismático originais. Alguns acham-se parcialmente sericitizados. Inclusões de quartzo, muscovita, biotita e plagioclásio são freqüentes.

Plagioclásio $(0,5-1,0 \mathrm{~mm})$ ocorre tanto fresco como alterado, em proporção nunca superior a $10 \%$ nos conglomerados, mas alcançando até $20-22 \%$ nos arenitos (vide TABELA III.6). Os grãos apresentam bom arredondamento e dimensões reduzidas se comparados com o microclínio. Os grãos frescos possuem forma euédrica a subédrica, tendo composição sódica (oligoclásio) e mostram evidências de deformação rúptil (brittle-grains), pois deslocam as maclas de geminação da albita, sendo, inclusive, uma das causas 
da alteração destes feldspatos. Já os grãos alterados evidenciam saussuritização (calcita + epídoto + muscovita + sericita) e sericitização, esta última a alteração mais comum, cuja evolução chega a mascarar as maclas de geminação polissintética, dificultando a identificação.

É importante a presença de fragmentos líticos, sobretudo nos arcósios líticos e matriz de conglomerados da Associação CM2. Compõem-se de fragmentos de rochas vulcânicas ácidas, sobretudo de riolitos, onde se destacam fenocristais de quartzo e de microclínio em meio à matriz fina a muito fina, já alterada, composta por feldspato alcalino e quartzo, e com estruturas fluidais, sendo possivelmente ignimbritos; conglomerados; prováveis fragmentos de xistos; leucogranitos (3A do diagrama de Strekeisen); vulcânicas intermediáriaslbásicas, com ripas de plagioclásio em matriz afanítica alterada e ausência de quartzo; milonitos, quartzitos e chert são também freqüentes.

Estas rochas em função da disposição dos grãos do arcabouço, ausência de matriz fina (<5\%) e presença de minerais instáveis como feldspato, podem ser designadas de imaturas a submaturas mineralógica e submaturas texturalmente.

A Associação CM1 possui um predomínio de quartzo monocristalino e menor variedade de fragmentos líticos, destacando-se rochas vulcânicas ácidas porfiríticas e com estruturas fluidais, estas provavelmente litoclastos de ignimbritos, e quartzitos.

Já a Associação CM2 apresenta abundância de quartzo policristalino, notadamente dos tipos metamórfico e deformado (milonítico) e de fragmentos líticos (até 20\%). É digno de nota a presença de litoclastos de granitos (até 4,0\% em volume normalizado), intraclastos pelíticos e de feldspato alcalino

\section{III.5.2.3 Formação João Dias}

De forma geral, os arenitos finos e médios são formados por grãos de quartzo monocristalino do tipo plutônico de extinção simultânea predominante e hábito xenomórfico, raros fragmentos de policristalino hidrotermal (mais resistentes) e ainda mais escassos, vulcânicos. Dos feldspatos comparecem plagioclásio e, ao menos nas seções descritas, subordinadamente, feldspato alcalino. $O$ plagioclásio detrítico é de composição sódica (andesina-oligoclásio), hábito euedral destarte tratar-se de arenitos parcialmente de sistema fluvial. Plagioclásios albitizados foram relacionados à diagênese submetida a essas rochas. $\mathrm{O}$ ortoclásio ocorre tanto alterado (saussuritização) quanto fresco. Microclínio está subordinado aos anteriores e em dimensões menores.

Fragmentos líticos são pouco comuns $(\cong 5 \%)$, provavelmente relacionado à granulometria mais fina dos litotipos. Destacam-se detritos de vulcânicas intermediária (andesitos), quartzitos, metamórficas micáceas (xistos), chert e intraclastos pelíticos.

Acessórios comuns são a muscovita detrítica e autigênica?, biotita cloritizada e minerais pesados como zircão. 
Composição Modal (\%) de arenitos finos e médios e lentes de conglomerados da Formação Mangueirão
Composição Modal (\%) de conglomerados e arenitos conglomeráticos da Formação Vargas

\begin{tabular}{|c|c|c|c|c|c|}
\hline Mineralogia & Média (\%) & Máxima & & Média (\%) & Máxima \\
\hline Quartzo detrítico & 38.50 & 43.20 & Quartzo detritico & 36.55 & 45.69 \\
\hline Quartzo Monocristalino & 27.97 & 36.80 & Quartzo Monocristalino & 15.36 & 19.20 \\
\hline$Q_{z M p}$ (plutonico) & 27.61 & 36.80 & $\widetilde{Q}_{z M p}$ (plutônico) & 14.81 & 18.51 \\
\hline QzMp extinção reta & 9.21 & 11.74 & QzMp extinção reta & 6.01 & 7.51 \\
\hline QzMp ext. ondulante & 18.41 & 21.01 & QzMp ext. ondulante & 8.81 & 11.01 \\
\hline$Q z M v$ & 0.48 & 1.20 & $Q z M v$ & 0.54 & 0.68 \\
\hline Quartzo Policristalino & 10.46 & 14.46 & Quartzo Policristalino & 21.20 & 26.50 \\
\hline QzP metamórfico & 7.70 & 10.87 & QzP metamórfico & 11.86 & 14.82 \\
\hline QzPsc & 1.58 & 2.69 & QzPsc & 4.05 & 9.50 \\
\hline QzP hidrotermal & 0.76 & 1.46 & QzP hidrotermal & 2.72 & 6.59 \\
\hline $\mathrm{Q} z \mathrm{Pd}$ & 0.88 & 2.00 & $\mathrm{QzPd}$ & 4.22 & 5.28 \\
\hline$F-K$ detritico & 13.35 & 18.20 & $F-K$ detritico & 14.40 & 18.00 \\
\hline Mcl Detrítico & 4.20 & 7.40 & Mcl Detrítico & $4 . .66$ & 5.83 \\
\hline $\mathrm{Mcl}$ fresco & 2.68 & 6.00 & $\mathrm{Mcl}$ fresco & 3.18 & 3.52 \\
\hline Mcl alterado & 1.51 & 2.20 & Mcl alterado & 1.48 & 1.85 \\
\hline Ort Detritico & 10.40 & 12.90 & Ort Detritico & 9.74 & 12.17 \\
\hline Ort fresco & 3.60 & 5.00 & Ort fresco & 4.17 & 4.87 \\
\hline Ort alterado & 6.79 & 8.73 & Ort alterado & 5.57 & 7.38 \\
\hline Plagiocl detrítico & 11.29 & 14.24 & Plagiocl detritico & 7.83 & 9.79 \\
\hline Pl fresco & 6.43 & 7.68 & Pl fresco & 4.41 & 6.90 \\
\hline Pl alterado & 5.48 & 6.60 & Pl alterado & 3.42 & 4.38 \\
\hline Bt detritica & 4.07 & 4.78 & Bt detritica & 2.07 & 2.59 \\
\hline$M v$ detritica & 2.60 & 4.80 & $M v$ detritica & 1.47 & 1.84 \\
\hline Minerais pesados & 3.80 & 5.44 & Minerais pesados & 1.76 & 3.26 \\
\hline Fragmentos liticos & 6.29 & 7.94 & Fragmentos líticos & 15.86 & 19.87 \\
\hline Rvulc. & 0.69 & 1.63 & Rvulc. & 1.92 & 4.38 \\
\hline Vulc. Ácidas & 0.40 & 1.20 & Vulc. Ácidas & 1.20 & 2.81 \\
\hline Vulc. Interm. & 0.37 & 1.00 & Vulc. Interm. & 0.72 & 1.50 \\
\hline Chert & 1.94 & 2.91 & Chert & 2.00 & 2.50 \\
\hline Intracl. pel. & 1.18 & 1.68 & Intracl. pel. & 2.63 & 2.88 \\
\hline Qzito. & 1.17 & 1.68 & Qzito. & 1.80 & 2.24 \\
\hline Xistos & 0.42 & 0.65 & Xistos & 0.44 & 1.12 \\
\hline Gran. & 0.26 & 0.65 & Gran. & 3.12 & 3.90 \\
\hline Aren. & 0.14 & 0.32 & Aren. & 1.03 & 1.29 \\
\hline Congl. & - & - & Congl. & 0.68 & 0.94 \\
\hline Metam. & 0.20 & 0.48 & Metam. & 0.62 & 1.06 \\
\hline Milon. & 0.04 & 0.20 & Milon. & 0.99 & 1.28 \\
\hline Calced. \Silex & 0.08 & 0.40 & Calced. $\backslash$ Silex & 0.18 & 0.23 \\
\hline n & 561.667 & 736 & & 583.429 & 712 \\
\hline Arcabouço detrítico & 80 & 85 & Arcabouço detrítico & $80-90$ & 90 \\
\hline Matriz & 15 & 15 & Matriz & $5-10$ & 10 \\
\hline Cimento & 5 & 7 & Cimento & $5-10$ & 12 \\
\hline
\end{tabular}

TABELA III.10 - Análise Petrográfica Modal de 30 amostras de arenitos e conglomerados do Grupo Camaquã (cerca de 400 a 700 pontos por lâmina contados) com a norma máxima verificada em alguns exemplares. Normalizadas para o arcabouço total $=100 \%$ (matriz + cimento). Siglas: QzM- quartzo monocristalino, QzMp- plutônico; QzMv- vulcânico, QzP- quartzo policristalino, QzPsc- quartzo policristalino semicomposto, QzPd- quartzo policristalino deformado, estirado, milonítico; F-K- feldspato potássico, Mclmicroclínio, Ort- ortoclásio; Pl- plagioclásio; Bt- biotita, Mv- Muscovita; Rvulc- rochas vulcânicas em geral, incluindo-se brechas, piroclásticas, etc, Vulc Ácida- vulcânica de composição ácida, Vulc Interm.vulcânica de composição intermediária; Intracl pel.- intraclasto pelítico; Qzito- quartzito; Gran- granito isótropo, Aren- arenito; Cong- conglomerado; Metam- metamórficas não diferenciadas como filitos, ardósias, metamargas, metavulcânicas, etc; Milon- milonitos; Calced- calcedônia, opala. 


\section{III.5.1 Introdução}

Este capítulo visa apresentar as análises de proveniência efetuadas na área de estudos e elaborar um quadro paleogeográfico da região com base neste e nos capítulos precedentes de fácies sedimentares (CAPÍTULO III.2), paleocorrentes (CAPÍTULO III.4) e análise petrográfica (CAPÍTULO III.5).

As análises de proveniência foram realizadas a nível macroscópico na fração maior que grânulo e microscopicamente na matriz dos arenitos e conglomerados. Buscou-se a contagem ao acaso de 100 clastos por área selecionada e, no caso da Associação CM2 da Formação Vargas, analisou-se 10 estações bem espalhadas na área enfocada neste estudo, conforme métodos desenvolvidos por Nilsen (1969), Graham et al. (1986) e Ibbeken \& Schleyer (1991) e adaptado para as condições encontradas. Os fragmentos escolhidos apresentaram tamanhos maiores que $1 \mathrm{~cm}$, de forma a abranger a maior variação granulométrica possível. Paralelamente, alguns clastos tiveram mensurados parâmetros sedimentológicos tais como: dimensões máxima ( $\phi_{\text {maxx }}$ ) e mínima $\left(\phi_{\text {min }}\right)$, arredondamento, esfericidade e forma. Tal análise serviu de suporte para as aferições de área fonte e condições de transporte. A análise foi feita estratigraficamente, i.é., da base para o topo das camadas, bem como buscando-se obter variações laterais (mais de um local da mesma camada).

\section{III.5.2 Proveniência da Formação Mangueirão}

Dados de petrografía sedimentar apontam que o arcabouço dos arenitos finos e médios da Associação de Fácies CI1 da Formação Mangueirão é bem arcoseano e moderadamente selecionado, predominando grãos subangulosos e subarredondados, de baixa esfericidade, constituído de fragmentos de guartzo, feldspato, líticos, opacos, muscovita e biotita. Devido à granulometria destes termos, a principal inferência de área-fonte veio da análise petrográfica, salvo raros grãos e fragmentos esparsos no arcabouço dos arcóseos e arcóseos líticos compostos de quartzo, feldspato rosa, leucogranito róseo médio, metamórficas, milonitos e intraclastos, principalmente de argila. $\mathrm{O}$ quartzo monocristalino $(\mathrm{Qm})$ do tịpo comum plutônico domina com extinção simultânea a ondulante. Detritos de quartzo policristalino $(\mathrm{Qp})$ são abundantes, destacando-se os tipos composto metamórfico ( $\mathrm{Cm}$ ) de Krynine (1940) e semi-composto e/ou de veio ( $\mathrm{Sc}$ ), este sugestivo de fontes hidrotermais. O predomínio de quartzo monocristalino, plagioclásio sódico e muscovita, associado a fragmentos líticos de quartzitos, chert, vulcânicas e intraclastos, sugere derivação de terrenos granitognáissicos e metamórficos de baixo grau.

A fácies conglomerática (C12) possui clastos de leucogranitos róseos médios, riolitos, xistos, milonitos, guartzo, feldspato e quartzitos (FIGURA III.43A, B). A matriz compõe-se de areia média a muito grossa, mal selecionada, com grânulos de feldspato rosa (abundantes), quartzo branco leitoso, quartzo vítreo e variedades cinza de forma ameboidal e castanha pseudo-prismática (vulcânico?), fragmentos líticos variados (leucogranitos róseos médios, vulcânicas ácidas, xistos, milonitos e quartzitos). Os fragmentos são no geral 
subangulosos, podendo ser angulosos (notadamente feldspato rosa e quartzo vítreo), subangulosos (quartzo leitoso e cinza, riolitos) a bem arredondados (granitos).

\section{LEGENDA DOS HISTOGRAMAS DE PROVENIÊNCIA}

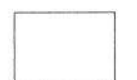

qzo/qzo saca

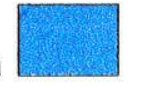

leucrómo

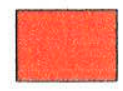

ultramil

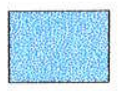

xisto/xist esv

calc

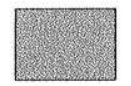

leucci/leuccepg

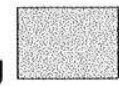

leuccg

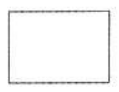

leuccevg
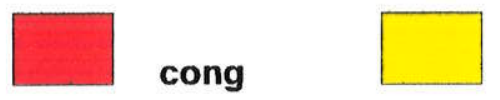

leucróg
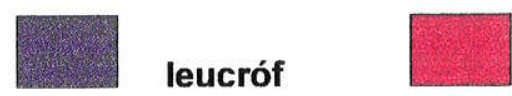

feld

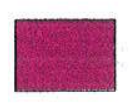

vacida
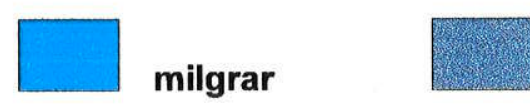

mesogra

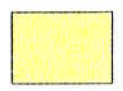

intr
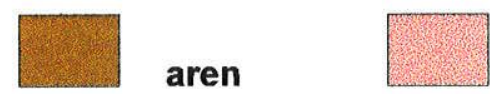

leuccarn

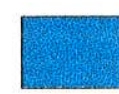

qzomil

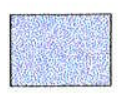

brecha

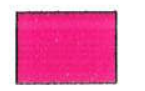

leucróm

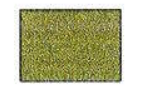

leucrópg

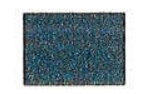

metam

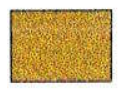

silex
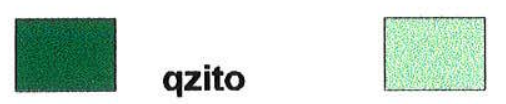

hleucrópg

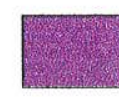

andes
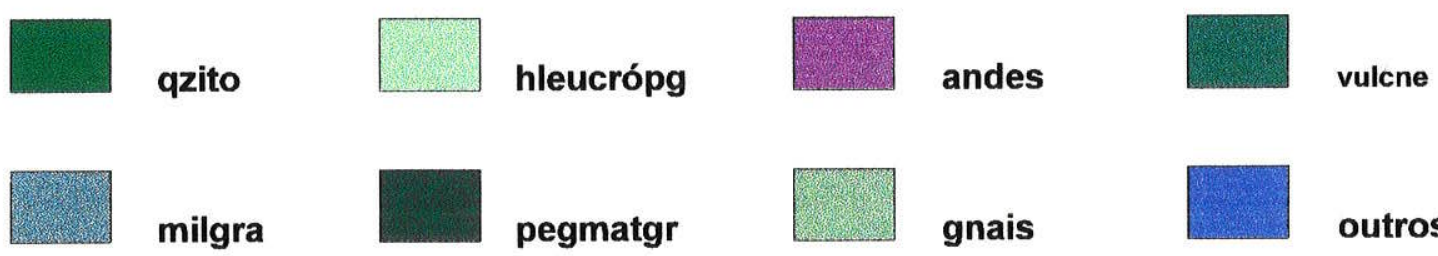

pegmatgr

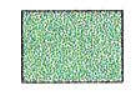

gnais

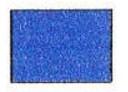

outros

mil

\section{Sigla das legendas dos clastos}

LEGENDA: qzo, qzo saca $=$ quartzo, quartzo sacaroidal; calc $=$ mármore; cong $=$ conglomerado; vácida $=$ vulcânica ácida (riolitos, ignimbritos, riodacitos); $\mathbf{a r e n =}$ arenito; leucróm= leucogranito róseo granulação média; $\mathbf{q z i t o}=$ quartzito; milgra $=$ milonito granitos diversos; leucrómo $=$ leucogranito róseo granulação média orientado; leucci= leucogranito cinza grosso; leucróg= leucogranito róseo granulação grossa; milgrar= milonito leucogranito róseo; leuccarn= leucogranito coloração carne a sienogranitos; leucrópg= leucogranito róseo porfirítico granulação grossa; hleucróg= hololeucogranito róseo porfirítico granulação grossa; pegmatgr $=$ pegmatito granito; ultramil $=$ ultramilonitos; leucróf $=$ leucogranito róseo granulação fina; mesogra $=$ granito mesocrático porfirítico; qzomil= quartzo milonito; metam= metamórfica indiferenciada; andes $=$ andesito; gnais $=$ gnaisse porfiroblástico; xisto $=$ xisto, clorita xistos; leuccevg $=$ leucogranito cinza esverdeado grosso a porfirítico; feld= feldspato; intrcl= intraclastos; brecha= brecha vulcânica; sílex= sílex, opala 


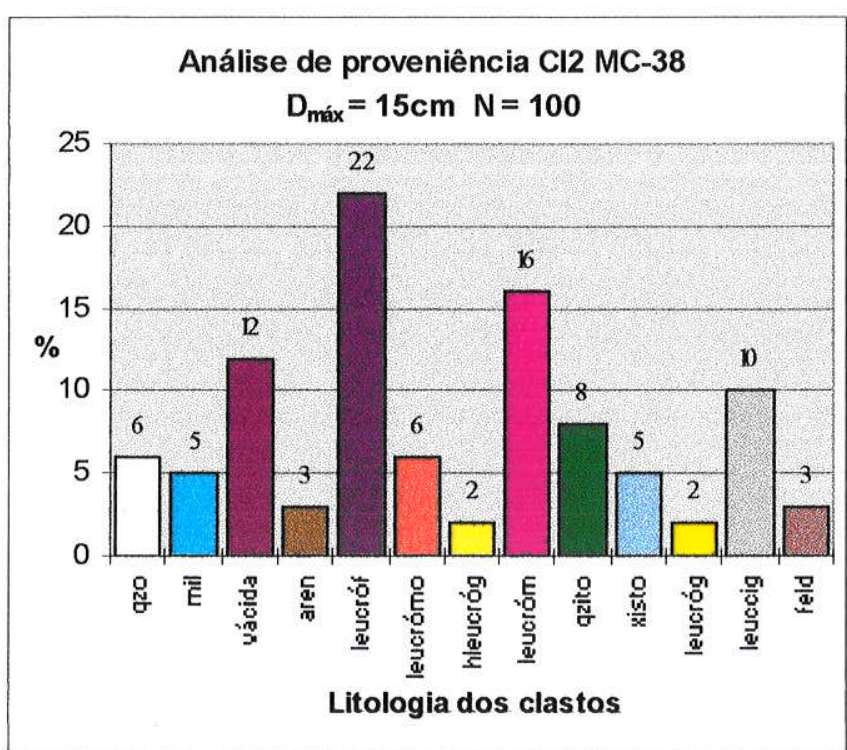

A

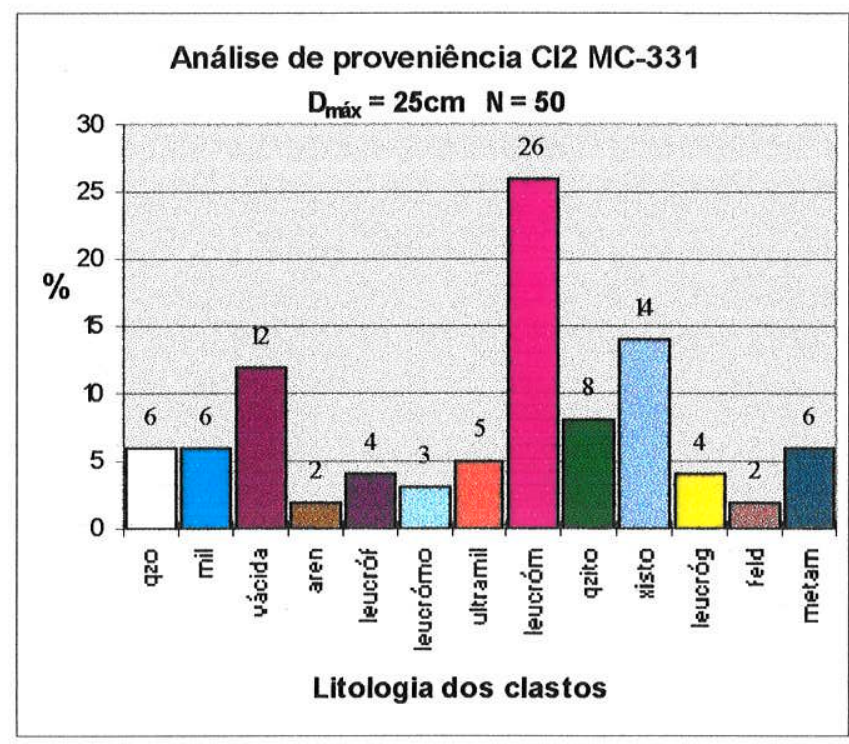

B

FIGURA III.43 A e B- Histogramas de freqüência de clastos da Associação (CI2) da Formação Mangueirão. Os clastos maiores que $1 \mathrm{~cm}$ de diâmetro foram contados aleatoriamente, buscando-se obter 100 medidas por nível investigado, número nem sempre alcançado. Notar predomínio de fragmentos de leucogranitos róseos de matriz fanerítica média em todas as bancadas e a alta porcentagem de clastos de rochas vulcânicas ácidas.

As associações de fácies CI3, CI4 e CI5 da Formação Mangueirão apresentam arcabouço petrograficamente constituído de litoclastos de quartzo monocristalino plutônico, quartzo policristalino metamórfico e semi-composto e/ou de veio, plagioclásio sódico, líticos, ortoclásio, opacos, muscovita e biotita. Da mesma forma que a Associação CI1, os fragmentos esparsos no arcabouço dos arcóseos são compostos de quartzo, feldspato rosa, leucogranito róseo médio, metamórficas, milonitos e intraclastos, principalmente de argila. O predomínio de quartzo monocristalino, plagioclásio sódico e muscovita, associado a detritos de quartzo policristalino metamórfico e de veio, e a fragmentos líticos de quartzitos, chert, vulcânicas básicas a intermediárias e intraclastos, sugere derivação de terrenos granito-gnáissicos e metamórficos de baixo grau e de regiões com cobertura vulcano-sedimentar.

As paleocorrentes obtidas na Associação CI1 apresentam dispersão para NNE, indicando que a associação proveio de sul e sudoeste. $\mathrm{Na}$ Associação CI2 as paleocorrentes indicam que seus detritos vieram de sudoeste e, nas associações de fácies CI3, CI4 e CI5 os dados de paleocorrentes sugerem que os clastos detríticos tiveram centro irradiador a sul da área de estudos.

A possibilidade de áreas fontes que se apresenta é o Terreno Valentines, situado a sul e a sudoeste da região das Minas do Camaquã (vide FIGURA II.3 do CAPÍTULO II.3, pág. 40). Neste terreno ocorrem litologias como granulitos, gnaisses e granitóides de idade paleoproterozóica $(>2.0 \mathrm{Ga})$, com restos de cobertura carbonática e clástica associada. Esse terreno é intrudido por batólitos graníticos e parcialmente recoberto por rochas vulcânicas básicas a intermediárias (Formação Hilário) e ácidas (Formação Acampamento Velho) do Grupo Crespos. 


\section{III.6.3 Proveniência da Formação Vargas}

A Formação Vargas (Conjunto Médio de Associações de Fácies) foi o alvo principal das análises de proveniência efetuadas no arcabouço de seus ruditos - conglomerados e arenitos conglomeráticos. Dada sua importância para este estudo, as associaçoes de fácies CM1 e CM2 serão tratadas separadamente. Também foram realizadas análises petrográficas a nível microscópico para consubstanciar as análises macroscópicas em afloramentos. As principais análises de proveniência provieram do estudo da cava a céu aberto da Mina Uruguai (CBC), a melhor exposição da área de estudos. Nesta, foi possível individualizar duas sucessões conglomeráticas com proveniência de áreas distintas preferenciais (Associações de Fácies CM1 e CM2) designadas por Ribeiro (1978), respectivamente, de Conglomerado Inferior e Conglomerado Superior.

\section{Proveniência da Associação de Fácies CM1}

De forma a possibilitar ligação com a análise petrográfica descrita no capítulo anterior (vide CAPÍTULO III.5), inicialmente retomaremos as principais inferências da referida análise. Petrograficamente, esta associação possui abundância em quartzo policristalino $(\mathrm{Qp})$ que exibe as variedades (i) semi-composta (o chamado quartzo leitoso, de veio, vacuolizado) sugestiva de fontes de veios e filões hidrotermais; (ii) compostacomum ou metamórfica (metamorphic quartz de Krynine, 1940) formada por vários cristais que podem exibir contatos poligonais e suturados intercristais, sugerindo proveniência de terrenos metamórficos de alto grau (Basu et al., 1975; Young, 1976; Scholle, 1979; Adams et al., 1993); (iii) composta-deformada (sheared quartz, de acordo com Scholle, 1979) constituída por cristais orientados de contornos irregulares, suturados e estirados indicando derivação de rochas de alto grau de metamorfismo e/ou deformação. Feldspatos atingem até $50 \%$ da composição do arcabouço, mas segundo Veigel (1992) “é dificil precisar a composição detritica original dos feldspatos, pois eles foram extensivamente substituidos e regenerados durante a diagênese". Destacam-se ortoclásio (predominante), plagioclásio (muitos regenerados e albitizados) e microclínio. Fragmentos líticos ocorrem e se compõem de chert, granitos, milonitos, quartzitos, xisto, intraclastos e rochas vulcânicas básicas a intermediárias. Muscovita e biotita aparecem também

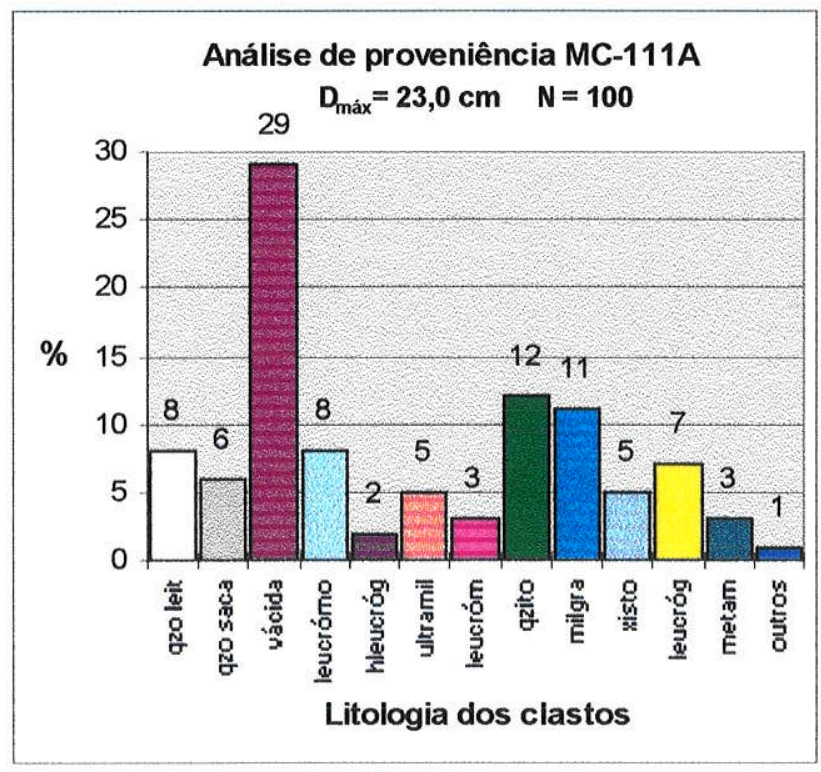

FIGURA III.44 - Histograma de freqüência de clastos da Associação CM1 da Formação Vargas no ponto $\mathrm{MC}-111$. Os clastos maiores que $1 \mathrm{~cm}$ de diâmetro foram contados aleatoriamente em dois níveis investigados, buscando-se obter 100 medidas. 


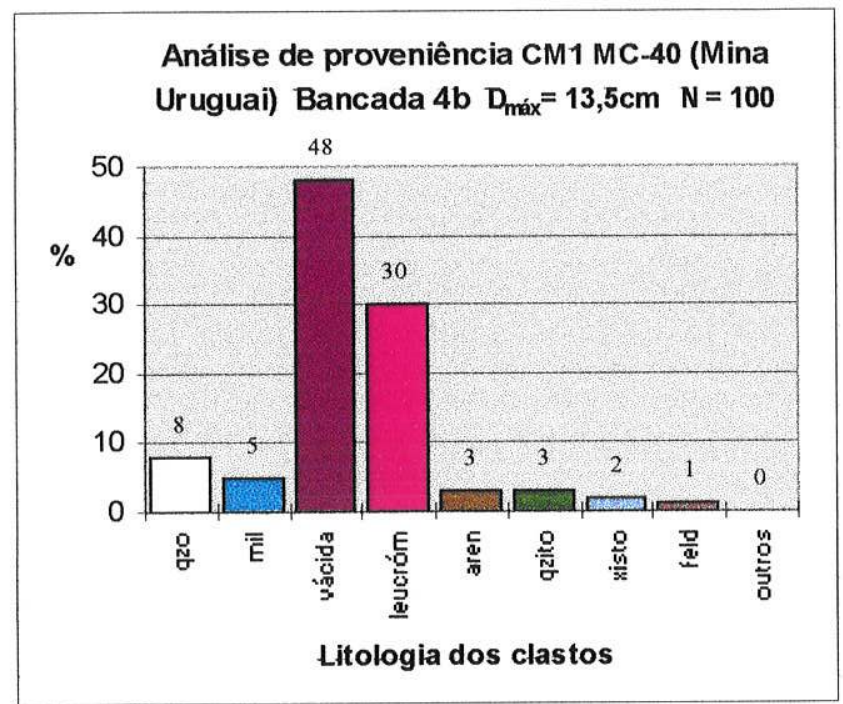

A

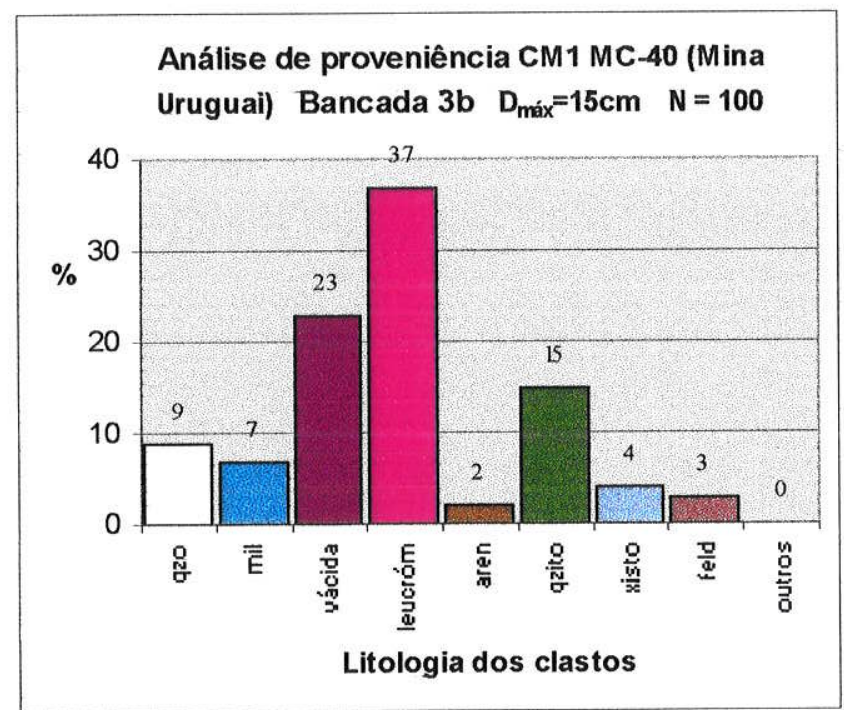

B

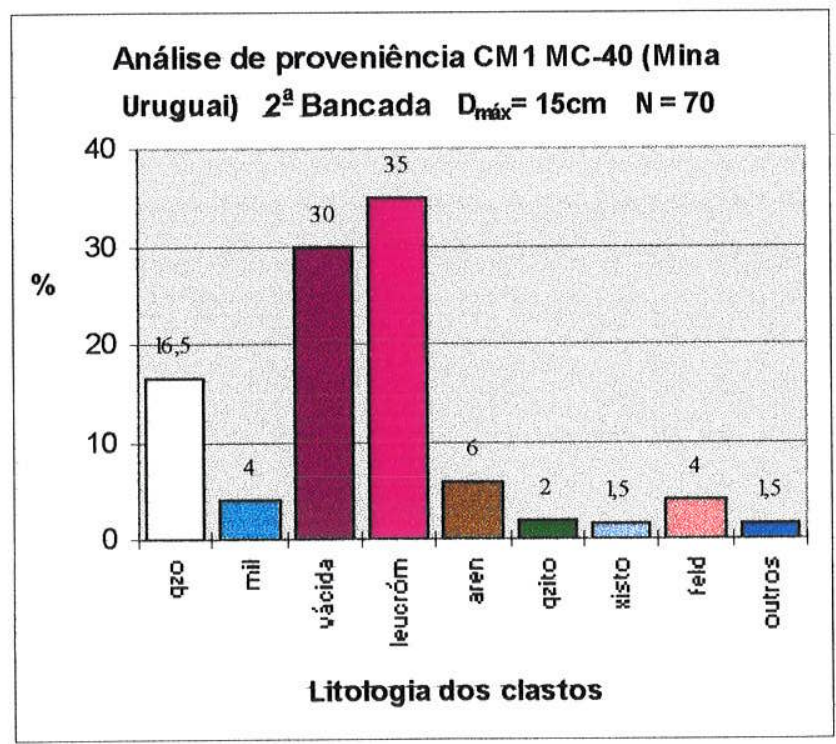

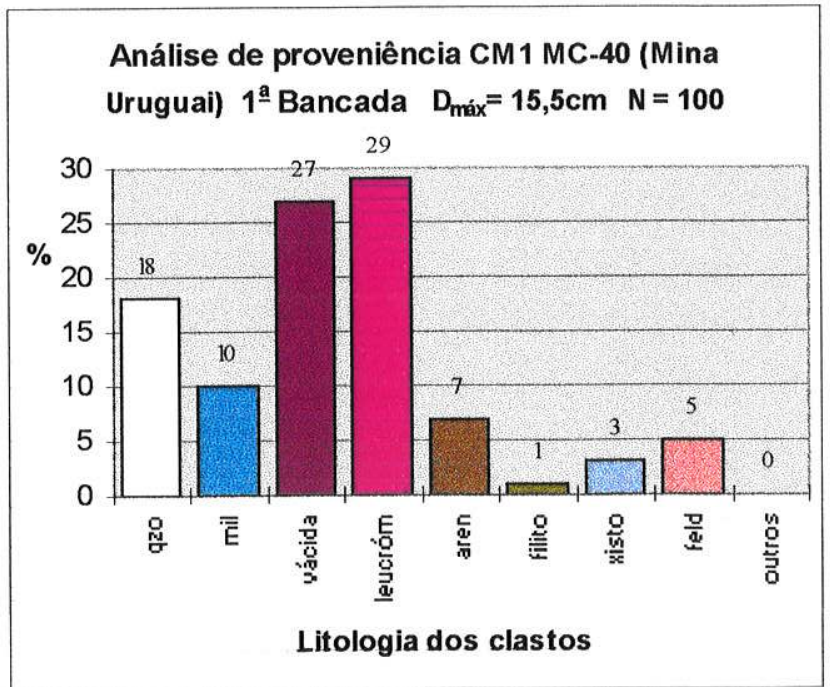

D

FIGURA 45- Histogramas de frequiência de clastos Associação CM1 da Formação Vargas. Os clastos maiores que $1 \mathrm{~cm}$ de diâmetro foram contados aleatoriamente, buscando-se obter 100 medidas por nível investigado. Notar predomínio de fragmentos de leucogranitos róseos de matriz fanerítica média em todas as bancadas e a alta porcentagem de clastos de rochas vulcânicas ácidas (A e B). Na base há o predomínio de vulcânicas ácidas (A) e é grande a freqüência de clastos de quartzitos, e para o topo é expressiva a quantidade de quartzo (C e D). Outros em C inclui clastos de rochas andesíticas. Na classe leucróm (leucogranitos róseos médios) incluímos aqueles de várias granulações (fina, média, grossa, porfirítica), mas em virtude do amplo predomínio da granulação média, optou-se por tal designação.

\section{Macroscopicamente, a Associação CM1}

da Formação Vargas apresenta clastos de diversas proveniências. Na FIGURA III.45 A, B, atestam-se alguns dos clastos presentes. $\mathrm{Na}$ base sobressaem-se fragmentos subangulosos de rochas vulcânicas de composição ácida (riolitos, dacitos e riodacitos), havendo, em contrapartida, clastos de leucogranitos róseos de granulação média, por vezes exibindo textura rapakivi, bem como de granulação mais grossa e mais fina, clastos de rochas metamórficas (quartzitos, xistos, milonitos,

C 
ultramilonitos, não determinadas), quartzo e feldspato (FIGURA III.44).

Os resultados para CM1 (FIGURA III.45) apontam para o predomínio de rochas vulcânicas ácidas ( $30-35 \%$ ), como riolitos e riodacitos, podendo atingir até $\sim 50 \%$ (FIGURA III.45A), e leucogranitos róseos médios e finos $(\sim 30 \%)$, incluindo-se aqueles de textura rapakivi, além de fragmentos de rochas vulcânicas básicas a intermediárias. Quartzo, milonitos, quartzitos e xistos finos também ocorrem. No geral os clastos são angulosos a subangulosos, notadamente os fragmentos de quartzo e de vulcânicas ácidas. Na base há um ligeiro predomínio de fragmentos de quartzitos e xistos. Para o topo prevalecem os clastos de vulcânicas ácidas e leucogranitos róseos.

As paleocorrentes da Associação CM1 (CAPÍTULO III.4) mostram dispersão para $\mathrm{N}$ e NE, com boa consistência de dados, indicando que as áreas fontes situar-se-iam a S e SW da região das Minas do Camaquã. Atualmente, a sul e a sudoeste da área de estudos encontra-se o Terreno Valentines.

Este terreno apresenta litologias de baixo a alto grau de metamorfismo e deformação, como xistos, quartzitos e milonitos, rochas intrusivas, como leucogranitos róseos, por vezes exibindo textura rapakivi, e rochas extrusivas ácidas e básicas a intermediárias, como as pertencentes ao Grupo Crespos. Por outro lado, embora atualmente a oeste, o Terreno Rio Vacacai também mostra as mesmas associações de rochas, com maior predomínio das rochas vulcânicas, pois as maiores manifestações vulcânicas encontram-se nos arredores da região de Lavras do Sul.

A Associação CM1 exibe clastos de rochas vulcânicas correlatas ao Grupo Crespos - sendo majoritariamente de rochas ácidas da Formação Acampamento Velho e, subordinadamente, básicas a intermediárias da Formação Hilário - e leucogranitos róseos, que se acham tanto no Terreno Valentines, a sul e sudoeste das Minas do Camaquã, como no Terreno Rio Vacacai, a oeste. Da mesma forma, leucogranitos róseos exibindo textura rapakivi aparecem tanto no Granito Lavras do Sul, a oeste (Nardi \& Lima, 1985; Lima \& Nardi, 1992), de idade neoproterozóica, pertencente ao Terreno Rio Vacacai, como em batólito intrusivo no Terreno Valentines no Uruguai, na região de Nico Perez, de idade paleoproterozóica (Bossi \& Campal, 1992). Deste modo, as áreas fontes da Associação CM1 poderiam situar-se, principalmente, no Terreno Valentines, a sul da região, de acordo com os dados de paleocorrentes e a análse de proveniência, ou no Terreno Rio Vacacai, atualmente a oeste da região das Minas do Camaquã, devido à presença nesse terreno de associações de rochas semelhantes às encontradas no arcabouço dos conglomerados da Associação CM2, com destaque para leucogranitos róseos, alguns portando textura rapakivi, e rochas vulcânicas ácidas, ou mesmo de ambos. As demais litologias encontradas ocorrem em quase todos os terrenos a sul (Valentines, Terreno Serra das Encantadas, Pelotas), não podendo ser utilizadas para averiguar área fonte.

Assim, visualiza-se uma paleogeografia distinta da atual, onde o Terreno Rio Vacacai situar-se-ia mais a sul. Estudos detalhados de análises estruturais das zonas de cisalhamento que ocorrem a oeste das Minas do Camaquã poderão elucidar melhor a questão. 


\section{Proveniência da Associação de Fácies CM2}

A Associação CM2 propiciou as principais análises de proveniência deste trabalho em vista da qualidade e abundância das exposições. Assim, 10 localidades foram analisadas macroscopicamente buscando-se obter a contagem de 100 clastos ao acaso por nível investigado. Secundariamente, as rochas dessa associação também foram analisadas ao microscópio. Entretanto, devido à magnificência de algumas exposições (a cava da Mina Uruguai, os morros dos pontos MC-195, MC-219 e MC-220), foi necessário ponderar estas análises, em função de sua maior representatividade (TABELA III.7). Inicialmente os dados da petrografia microscópica serão enfócados, prosseguindo-se com a análise macroscópica e, por fim, uma discussão a respeito das possibilidades de fontes será feita.

Petrograficamente, a associação constitui-se predominantemente de fragmentos de quartzo policristalino $(\mathrm{Qp})$, quartzo monocristalino $(\mathrm{Qm})$, ortoclásio, plagioclásio, fragmentos líticos (entre estes milonitos, granitos, quartzitos, rochas vulcânicas ácidas e básicas a intermediárias, arenitos, pelitos, conglomerados, prováveis fragmentos de xistos, milonitos, chert), muscovita e biotita. $\mathrm{O}$ quartzo policristalino compreende os tipos (i) composto metamórfico indicativo de fontes metamórficas de médio a alto grau e (ii) composto deformado (sheared quartz, de acordo com Scholle, 1979), sugestivo de fonte que sofreu alto grau de deformação e metamorfísmo; além de quartzo monocristalino plutônico $\left(\mathrm{Qm}_{\mathrm{p}}\right)$ de hábito xenomórfico característico, sugerindo fontes intrusivas (Misko \& Hendry, 1979) como granitos. As áreas fontes seriam terrenos granito-gnáissicos deformados e metamórficos, corpos graníticos intrusivos e coberturas vulcanosedimentares.

Na cava da Mina Uruguai (CBC), o estudo detalhado de proveniência propiciou uma completa visão da distribuição vertical dos clastos da Associação CM2 (FIGURA III.46). Da mesma forma, as outras localidades investigadas possibilitaram a visão pontual da proveniência (FIGURAS III.46 a III.57) e da distribuição geral dos clastos (TABELA III.7). Esta análise indicou que a associação possui gama variada de litologias, destacando-se em todo o conjunto leucogranitos róseos de granulação média ( 30\%).

$\mathrm{Na}$ base da Associação CM2 predominam, além dos leucogranitos róseos médios, termos correspondentes mais grossos e mais finos (leucogranitos grossos e finos, este mais abundante), fragmentos de quartzo, quartzitos róseos a esverdeados, leucogranitos foliados, xistos, arenitos finos achocolatados, vulcânicas ácidas, andesitos, conglomerados e milonitos (FIGURA III.46A, B).

Para o topo há o progressivo predomínio de milonitos destes granitóides e de termos mais granodioríticos e/ou mesocráticos (FIGURA III.47A), rochas granitóides porfiríticas e grossas (FIGURA III.47B), turmalina granitos, granitos greizenizados, conglomerados e arenitos das unidades inferiores e mármores, concomitante ao aumento na granulometria (FIGURA III.46C, III.46D. III.47A,B).

A análise dos tamanhos dos clastos ( $\phi_{\text {maxx }}$ ) destes conglomerados sugerem que o depósito transportou carga de granulometria calhau e seixo 
$\underline{\text { Fambrini, }} \underline{\text { G.L. }}=\underline{\text { o Grupo Camaquã: análise de fácies, proveniência e paleocorrentes }}$

TABELA 111.11 - Análise de proveniência da Associação CM2 da Formação Vargas mostrando valores médios (em por local investigado. Litologia de 100 clastos contados aleatoriamente por nível estratigráfico em 10 locais.

\begin{tabular}{|c|c|c|c|c|c|c|c|c|c|c|c|}
\hline & & & & & & & & & & & \\
\hline Lilologla dos clastos & 40 & 111 & 195 & 219 & 220 & 238 & 239 & 245 & 269 & 392 & Média* \\
\hline quartzo & 6,6 & 9 & 7 & 7 & 6 & 8 & 8 & 6 & 24 & 6 & 5,52 \\
\hline mármore & 0 & 0 & 1 & 1 & 2 & 0 & 0 & 0 & 0 & 3 & 0,75 \\
\hline conglomerado & 2,75 & 0 & 3 & 6 & 6 & 5 & 4 & 4 & 4 & 5 & 3,75 \\
\hline vulcânica ácida & 3,6 & 18 & 8 & 3,5 & 6 & 5 & 7 & 16 & 2 & 6 & 6,77 \\
\hline arenito & 4,2 & 2 & 5 & 6,5 & 8 & 5 & 4 & 6 & 6 & 8 & 5,34 \\
\hline leucogranito róseo médio orientado & 0 & 6 & 2,5 & 6 & 3 & 0 & 1 & 0 & 0 & 0 & 1,95 \\
\hline hololeucogranito róseo fino isótropo & 0,63 & 0 & 2,5 & 1 & 3 & 0 & 0 & 0 & 0 & 3 & 1,43 \\
\hline hololeucogranito róseo grosso porfir. & 0,63 & 4 & 3,5 & 6 & 0 & 0 & 5 & 0 & 0 & 0 & 2,23 \\
\hline ultramilonito & 5,5 & 6 & 1,5 & 1,5 & 3 & 0 & 7 & 4 & 2 & 3 & 3,10 \\
\hline mesogranito grosso porfirítico cesv & 3,75 & 0 & 1,5 & 4 & 1 & 5 & 2 & 0 & 10 & 1 & 2,50 \\
\hline leucogranito róseo médio isótropo & 23,6 & 12 & 17 & 12 & 8 & 15 & 11 & 28 & 32 & 12 & 17,32 \\
\hline quartzito & 10,3 & 10 & 5 & 8,5 & 8 & 10 & 11 & 6 & 0 & 8 & 7,46 \\
\hline milonito granito diversos & 16,4 & 12 & 7 & 2 & 7 & 12 & 9 & 12 & 6 & 7 & 9,20 \\
\hline intraclastos & 0 & 0 & 0,5 & 0 & 0 & 5 & 0 & 0 & 0 & 0 & 0,40 \\
\hline leucogranito róseo grosso porfirítico & 1,9 & 8 & 12 & 13 & 17 & 2 & 9 & 0 & 8 & 16 & 8,63 \\
\hline leucogranito grosso cinza & 3,13 & 0 & 2 & 1,5 & 1 & 2 & 0 & 4 & 0 & 0 & 1,68 \\
\hline milonito mesogranito grosso cesv & 0,5 & 0 & 3 & 13,5 & 11 & 2 & 2 & 6 & 0 & 11 & 4,35 \\
\hline xisto, xisto esverdeado & 3,13 & 6 & 1,5 & 2,5 & 0 & 5 & 1 & 2 & 0 & 2 & 2,08 \\
\hline leucogranito carne porfirítico & 9,25 & 0 & 4 & 0 & 0 & 1 & 0 & 0 & 0 & 2 & 3,05 \\
\hline feldspato & 0,25 & 1 & 1 & 0 & 0 & 0 & 0 & 0 & 0 & 0 & 0,40 \\
\hline leucogranito róseo fino isótropo & 0 & 0 & 0,5 & 0 & 5 & 0 & 0 & 2 & 0 & 4 & 0.95 \\
\hline andesito & 0,38 & 1 & 2 & 3,5 & 1 & 6 & 0 & 0 & 0 & 0 & 1,48 \\
\hline metamórfica indiferenciada & 0,25 & 5 & 1,5 & 0,5 & 0 & 10 & 6 & 4 & 4 & 0 & 2,00 \\
\hline vulcânica básica & 0 & 0 & 0,25 & 0 & 0 & 0 & 2 & 0 & 0 & 0 & 0,07 \\
\hline hololeucogranito róseo médio & 0 & 0 & 1 & 0 & 0 & 0 & 0 & 0 & 0 & 0 & 0,30 \\
\hline quartzo milonito & 0 & 0 & 1 & 0 & 2 & 0 & 4 & 0 & 0 & 3 & 0,85 \\
\hline gnaisse & 0,75 & 0 & 1 & 0 & 0 & 0 & 1 & 0 & 0 & 0 & 0,45 \\
\hline pematito granitóide & 0 & 0 & 1 & 0 & 1 & 0 & 0 & 0 & 0 & 0 & 0,30 \\
\hline leucogranito cinza esverdeado grosso & 0,33 & 0 & 3 & 0,5 & 0 & 0 & 4 & 0 & 0 & 0 & 1,02 \\
\hline brecha & 0 & 0 & 0,25 & 0 & 1 & 2 & 4 & 0 & 0 & 0 & 0,45 \\
\hline sílex & 0 & 0 & 0 & 0 & 0 & 0 & 0 & 0 & 2 & 0 & 0,10 \\
\hline & 100 & 100 & 100 & 100 & 100 & 100 & 100 & 100 & 100 & 100 & \\
\hline
\end{tabular}

Tendo em vista a maior representatividade estatística de certas exposições na obtenção da média geral por litologia, foi feita uma ponderação em relação ao valor de cada local investigado. A título de exemplo, o local MC-195 apresentou um fator 6, pois nesse local foi realizada a contagem de 100 clastos em 6 niveis diferentes e, no ponto 392 onde se coletou uma amostra com população igual a 100, o fator computado foi 1. 


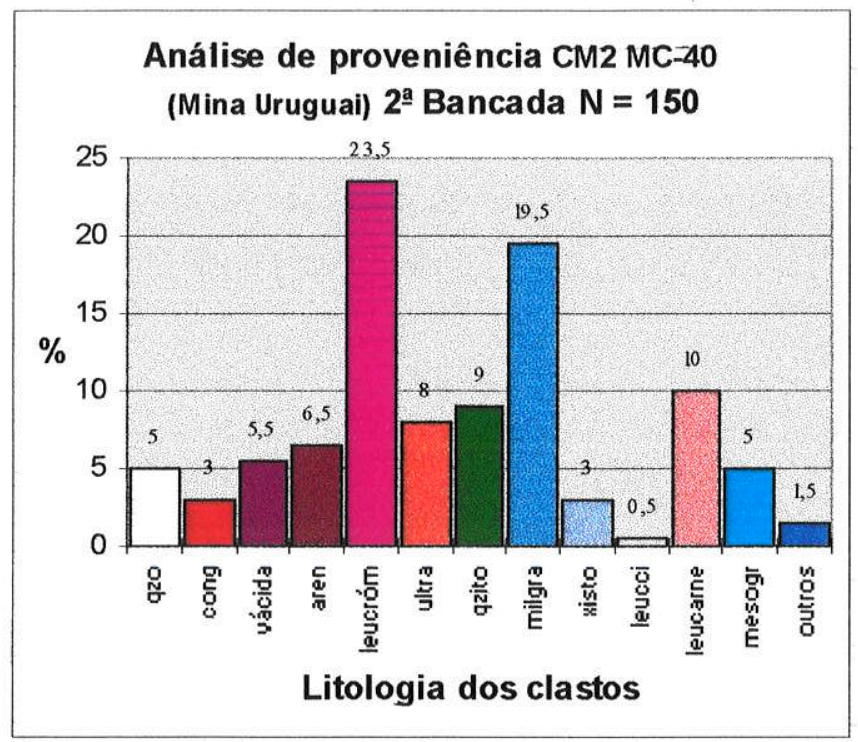

A

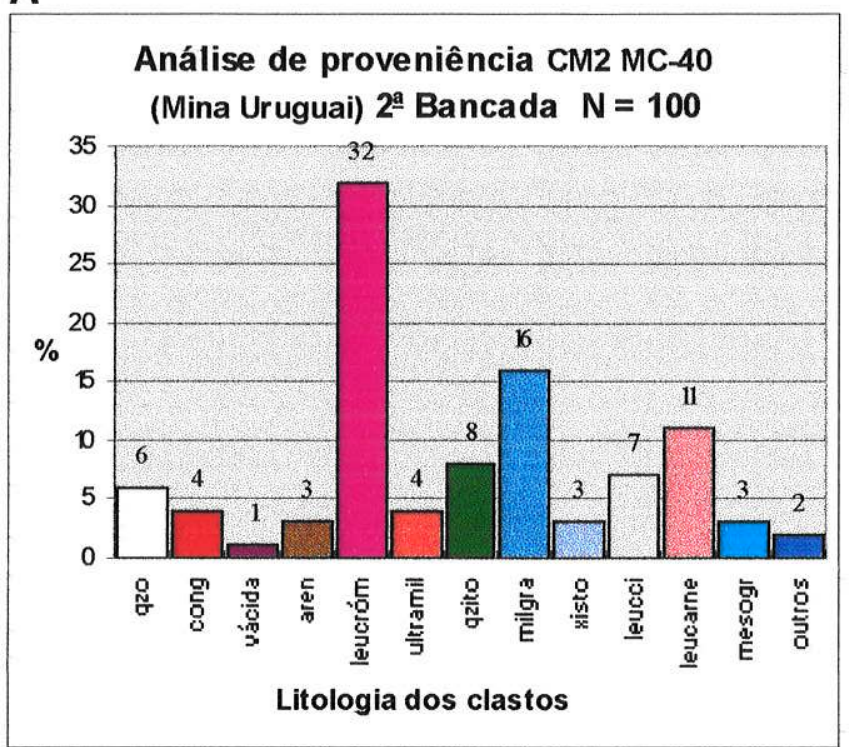

B

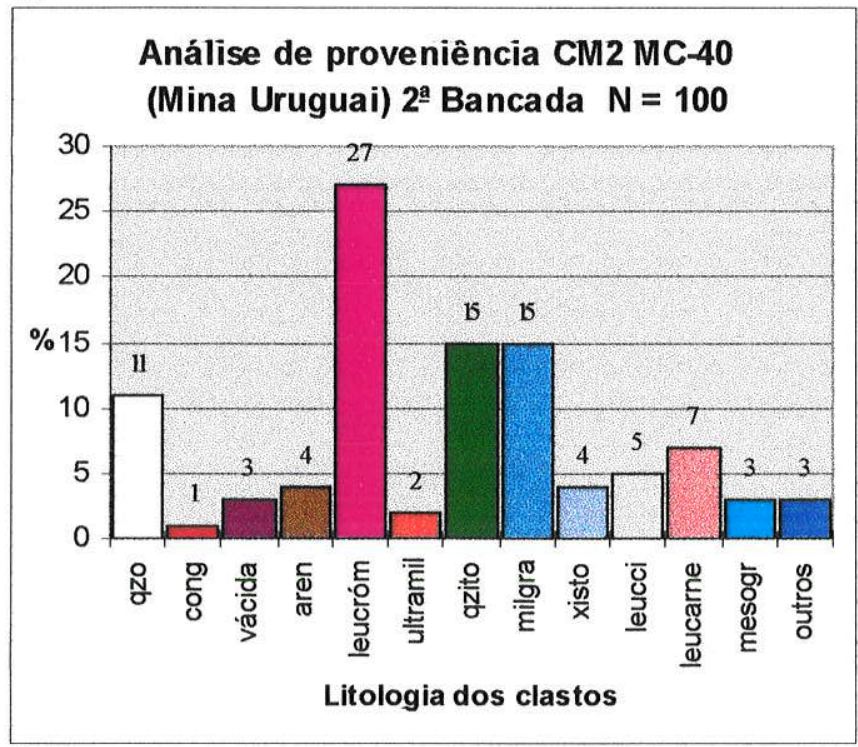

Análise de proveniência CM2 MC-40 (Mina Uruguai) 1 ${ }^{\mathrm{a}}$ Bancada

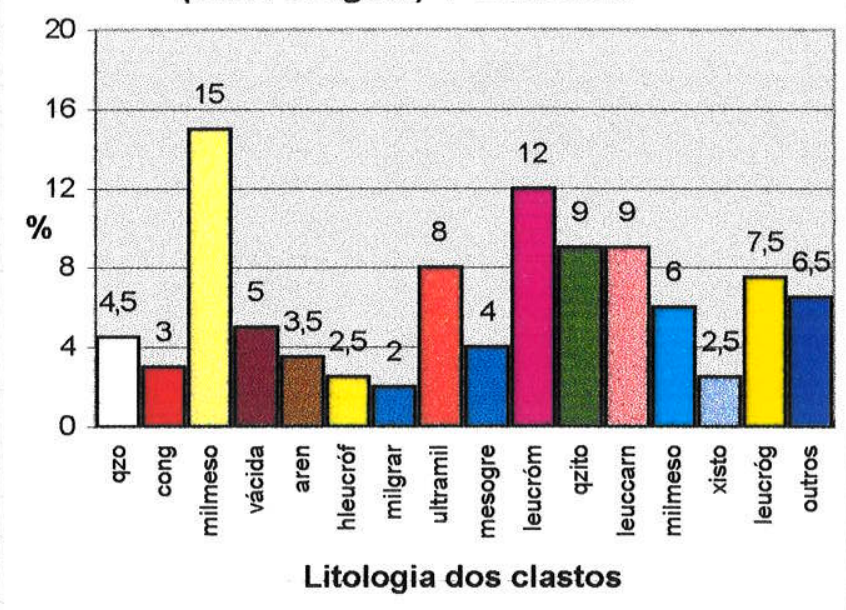

D

FIGURA 46- Histogramas de frequiência de clastos da Associação CM2 da Formação Vargas. Os clastos maiores que $1 \mathrm{~cm}$ de diâmetro foram contados aleatoriamente, buscando-se obter 100 medidas por nível investigado. Nesta subunidade há o predomínio de fragmentos da granulometria calhau a matacão, que foram selecionados para a contagem. Notar predomínio de fragmentos de leucogranitos róseos de matriz fanerítica média em todas as bancadas, em 17A e 17B a alta porcentagem de clastos de rochas miloníticas na $2^{\underline{a}}$ bancada (i.é. para o topo da sub-unidade) e em $17 \mathrm{C} \mathrm{a}$ grande porcentagem de clastos de quartzitos na $2^{\mathrm{a}}$ bancada. 17D - freqüência de clastos do topo da Associação CM2. Atentar para predomínio de litologias miloníticas Cava a céu aberto da Mina Uruguai ( $\mathrm{CBC}$ ), ponto MC-40.

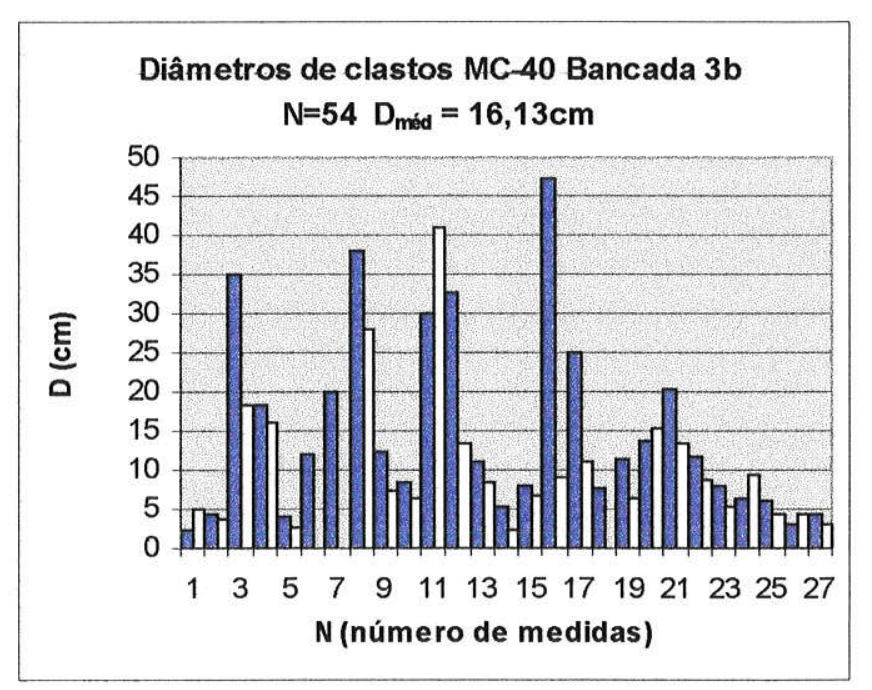


$\underline{\text { Fambrini, }} \underline{\text { G.L. }}=\underline{\text { o }} \underline{\text { Grupo Camaquã: }} \underline{\text { análise de fácies, proveniência e paleocorrentes }}$

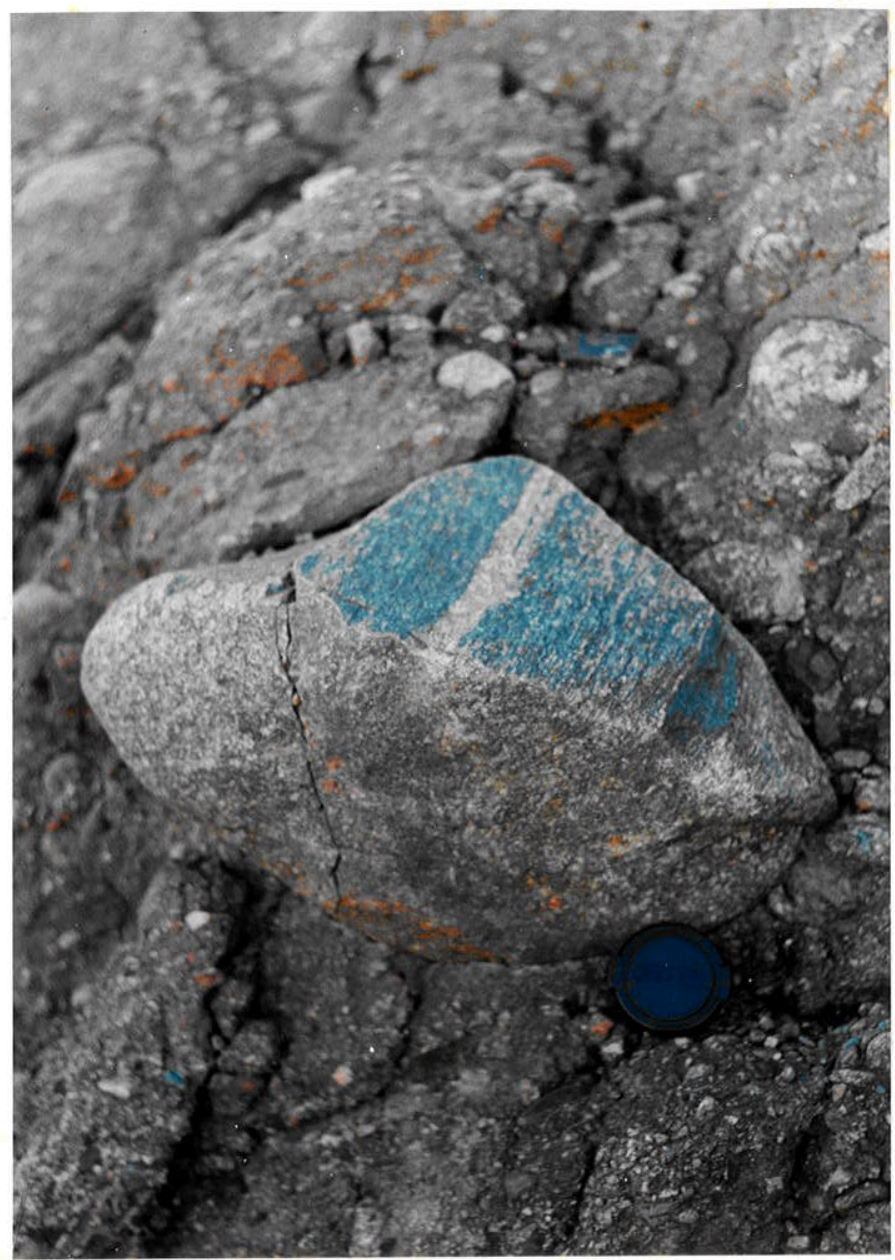

FIGURA III.47A - Detalhe de matacão subarredondado (39,6cm de diâmetro) de granitóide milonítico com estrutura gnáissica presente em conglomerados da Associação CM2 da Formação Vargas. Cava a céu aberto da Mina Uruguai, Companhia Brasileira do Cobre (CBC).

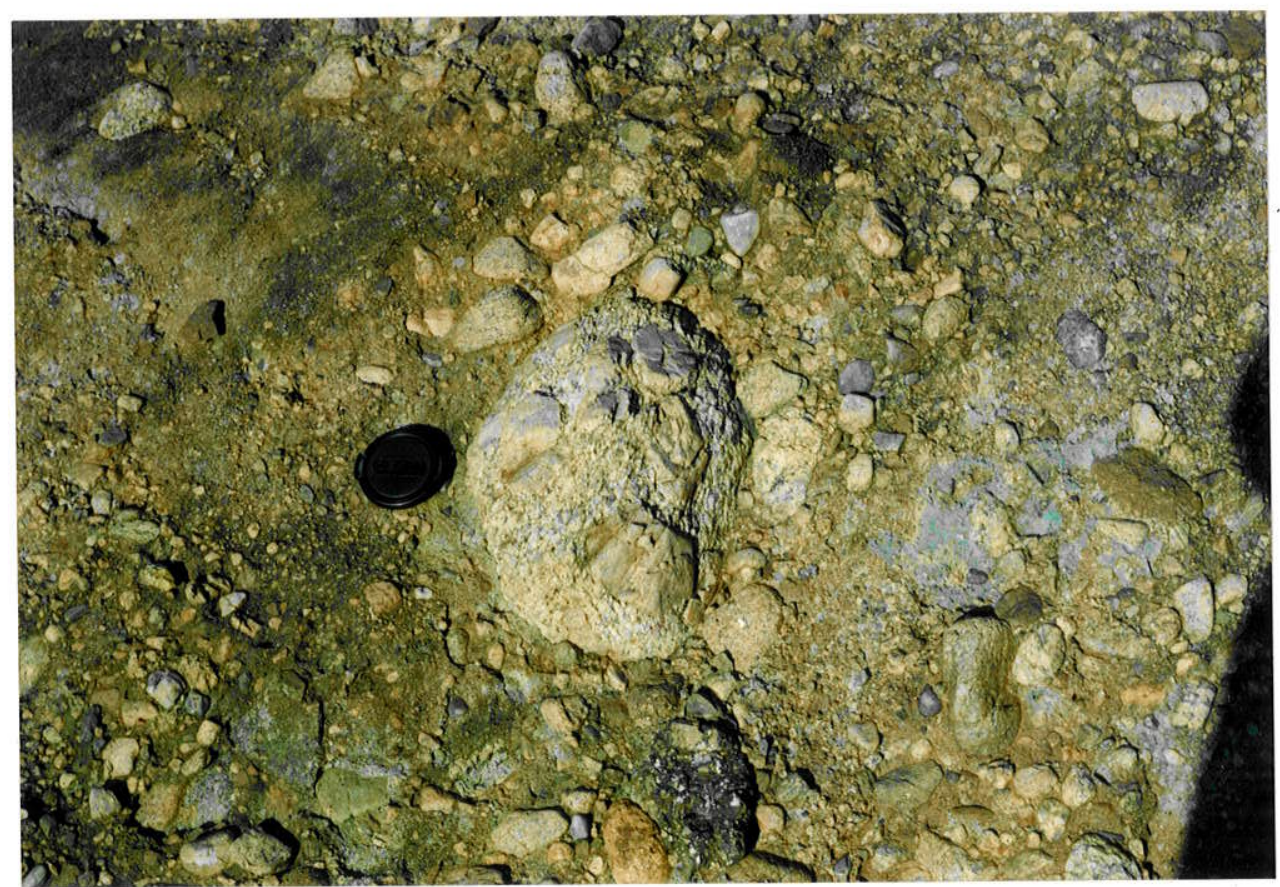

FIGURA III.47B - Detalhe de matacão arredondado de rocha granitóide porfirítica de matriz grossa $(40,1 \mathrm{~cm}$ de diâmetro). Topo da Associação CM2 da Formação Vargas. Localidade MC-195, junto à antiga barragem da Companhia Brasileira do Cobre (CBC). 
A análise dos tamanhos dos clastos ( $\phi$ máx) destes conglomerados sugerem que o depósito transportou carga de granulometria calhau e seixo (ver $\left.\phi_{\text {méd }}\right)$ com freqüentes matacões em meio à matriz, de tal modo que a energia do meio fosse grande o suficiente para carregá-los (FIGURAS III.489B, III.49B).

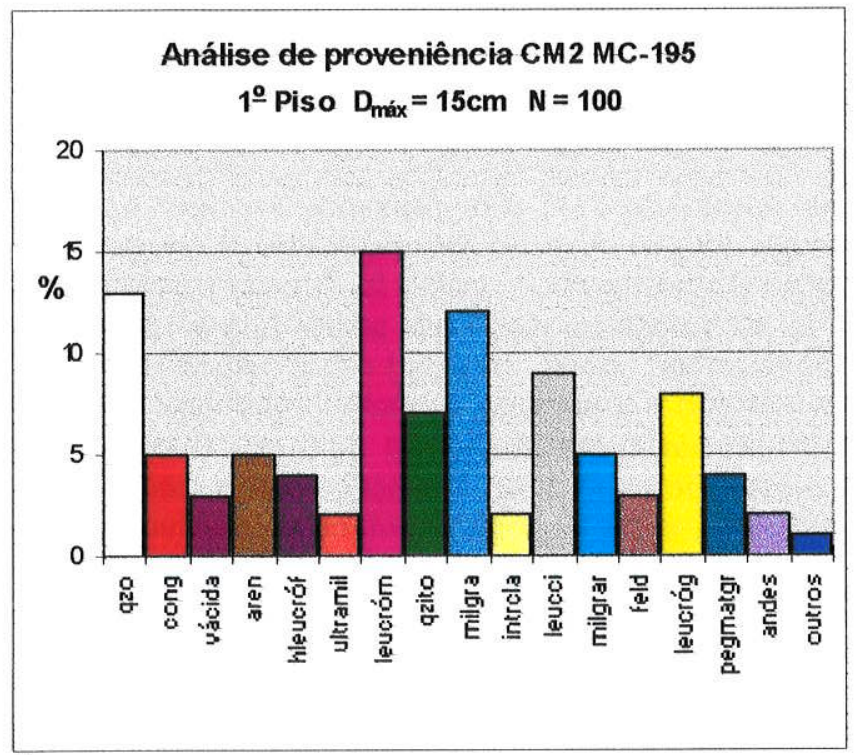

\section{A}

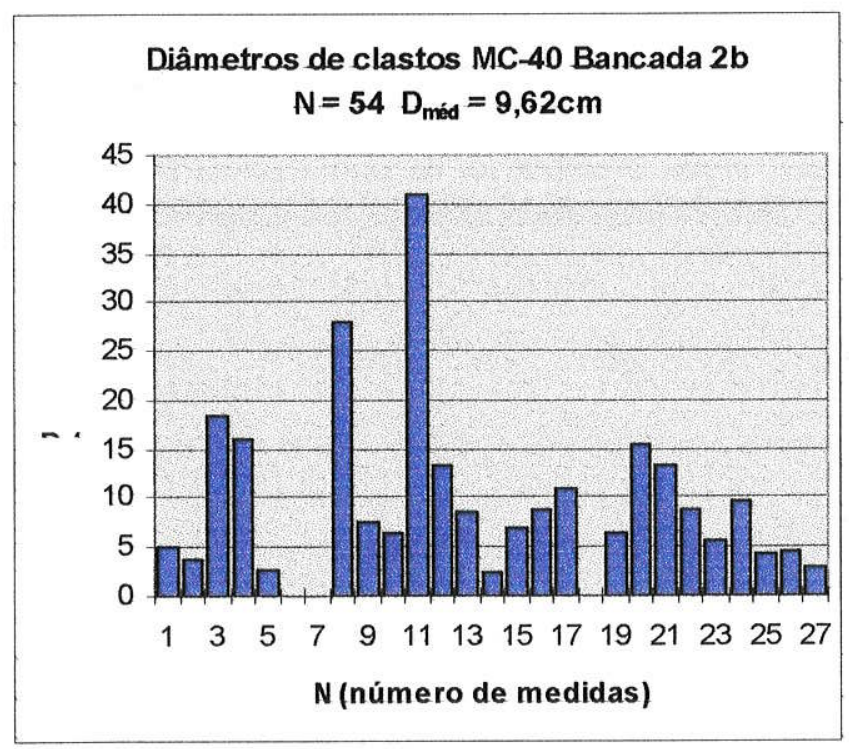

B

FIGURA 48- Histogramas de freqüência de clastos (A) e de diâmetros máximos (B) da base da Associação CM2 da Formação Vargas.

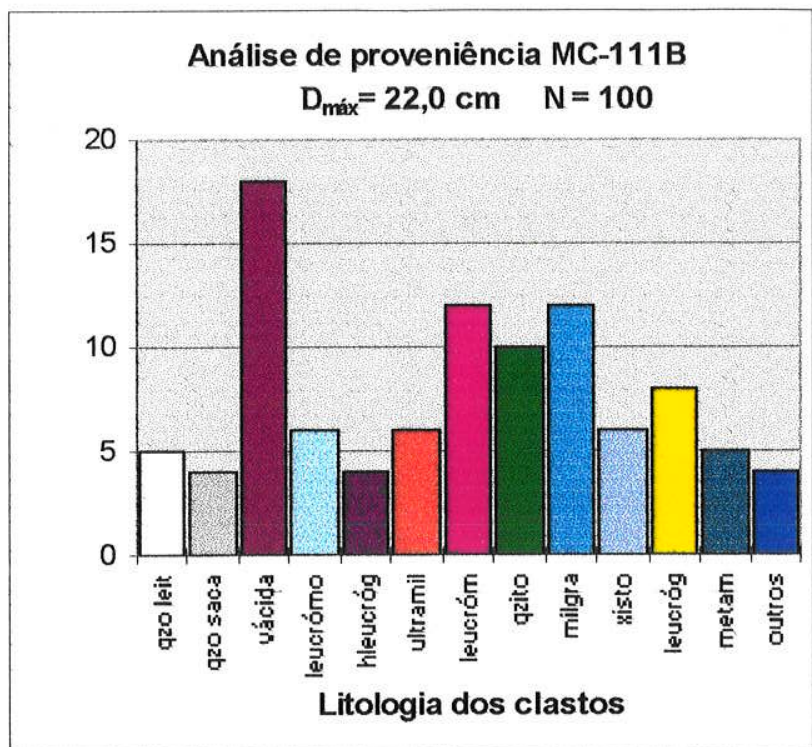

A

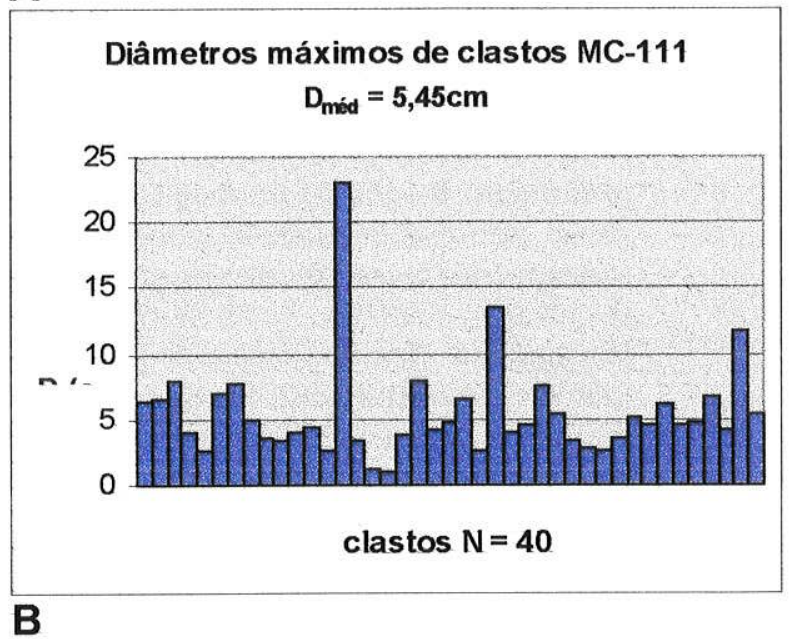

FigURA IHI.49 - Histogramas do ponto MC-111 da Associação CM2 da Formação Vargas. Os clastos maiores que $1 \mathrm{~cm}$ de diâmetro foram contados aleatoriamente, buscando-se obter 100 medidas por nível investigado. A- Histograma de freqüência de clastos em nível basal dela. BHistograma do diâmetro máximo dos clastos da Associação CM1.

As exposições pela região das Minas do Camaquã mantém as relações estabelecidas na Mina Uruguai (TABELA III.7). $\mathrm{Na}$ base predominam clastos de rochas vulcânicas ácidas, metamórficas e granitos diversos (FIGURA III.48A) e predomínio de seixos $\left(D_{\text {méd }}=5-7 \mathrm{~cm}\right)$, correlacionável à exposição de CM2 na Mina Uruguai. 
$\underline{\text { Fambrini, }} \underline{\text { G.L. }}$ = $\underline{\text { O Grupo }} \underline{\text { Camaquã: }} \underline{\text { análise de fácies, proveniência e paleocorrentes }}$

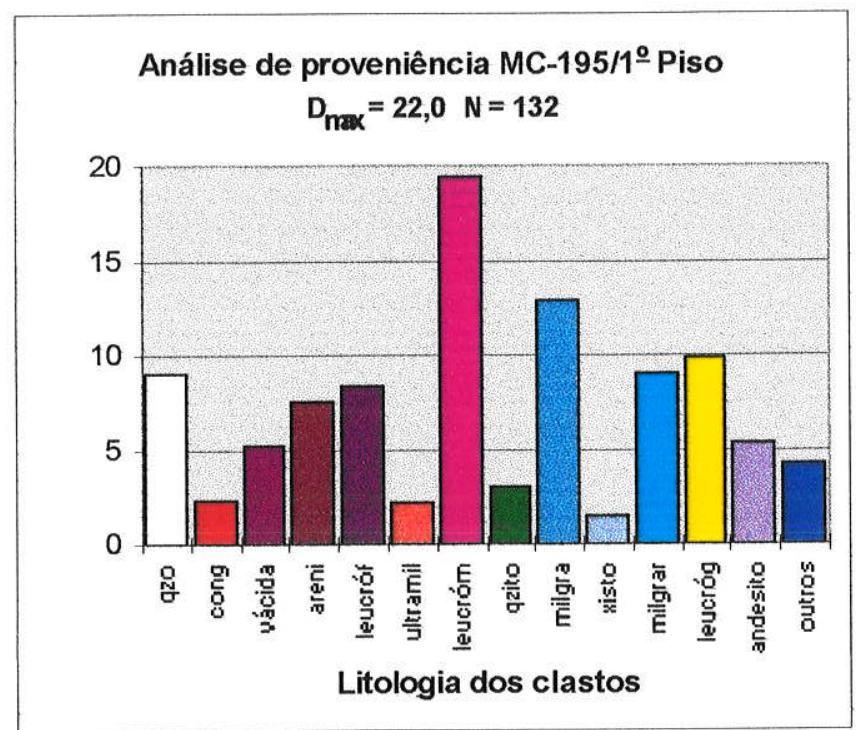

A

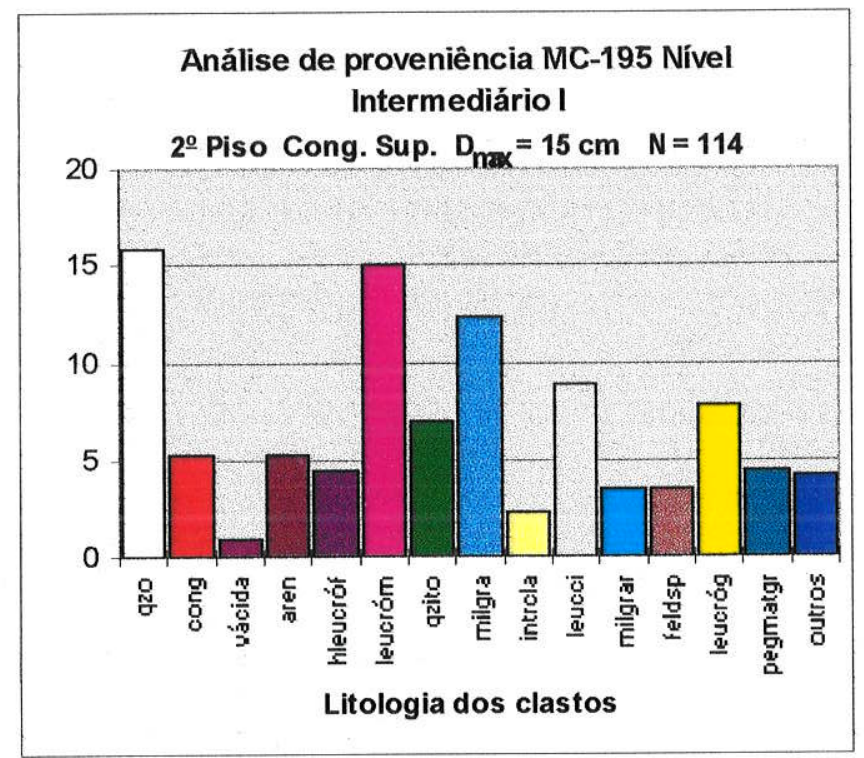

B

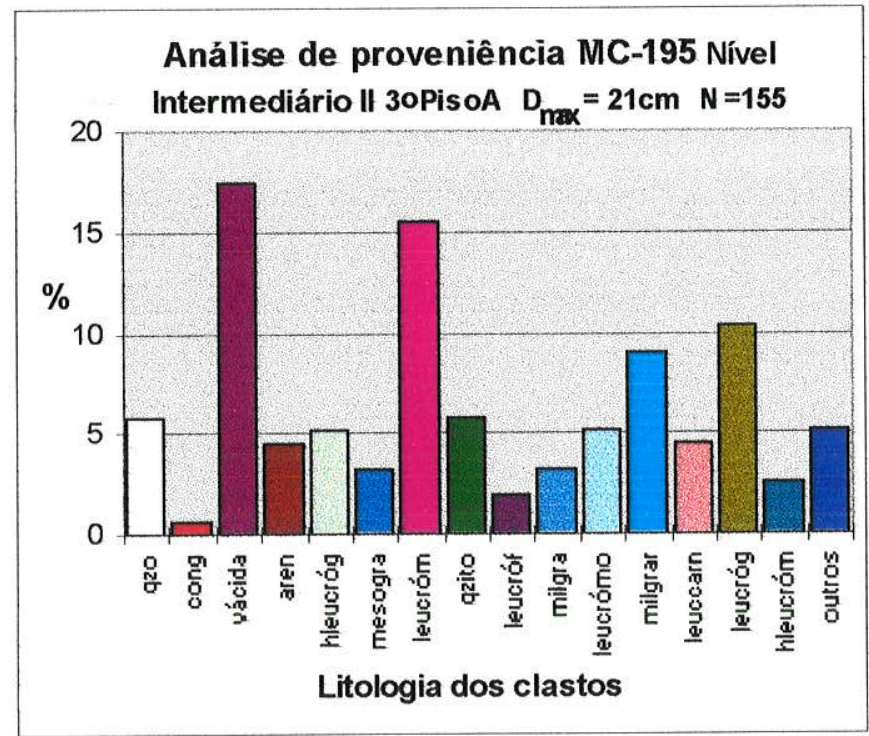

C

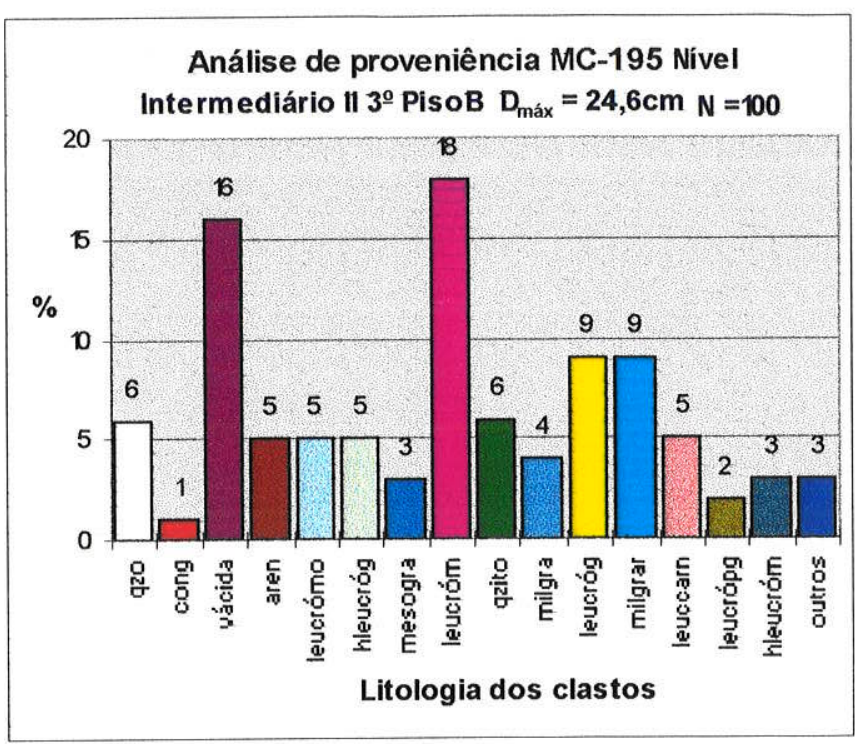

D

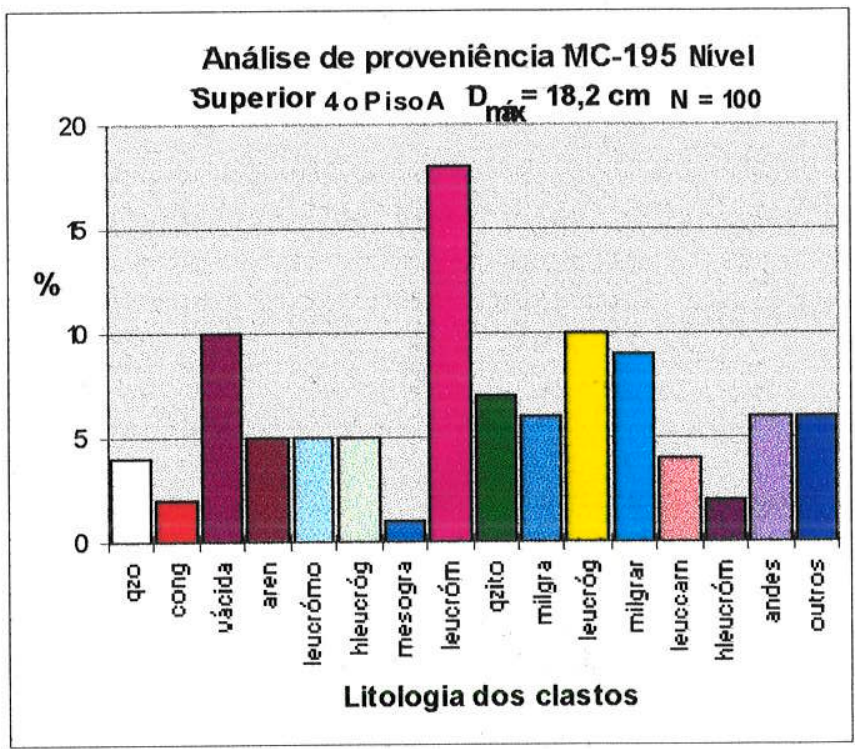

E

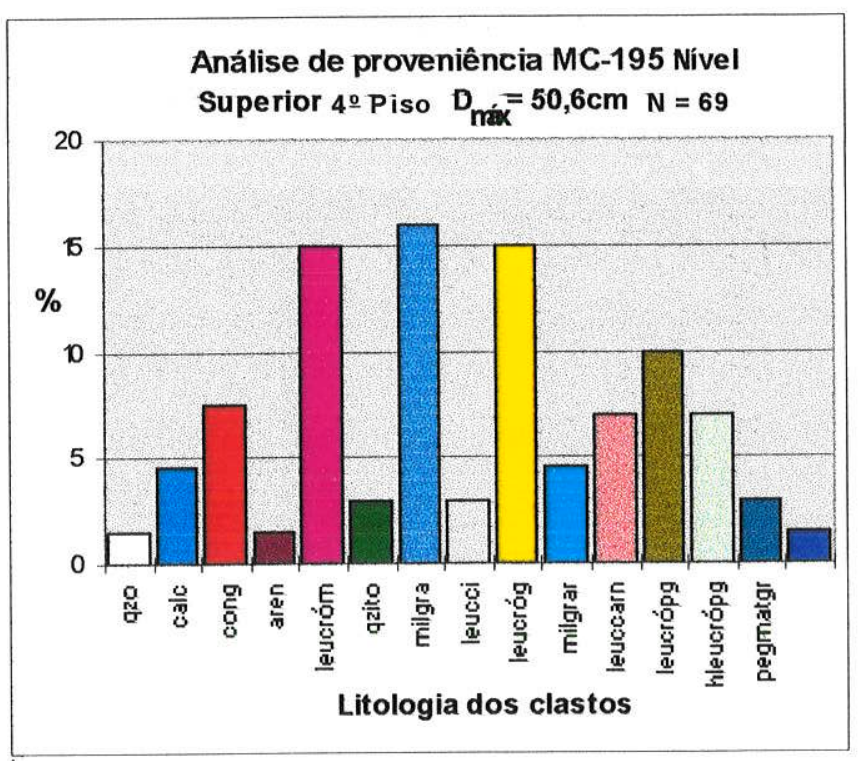

F 


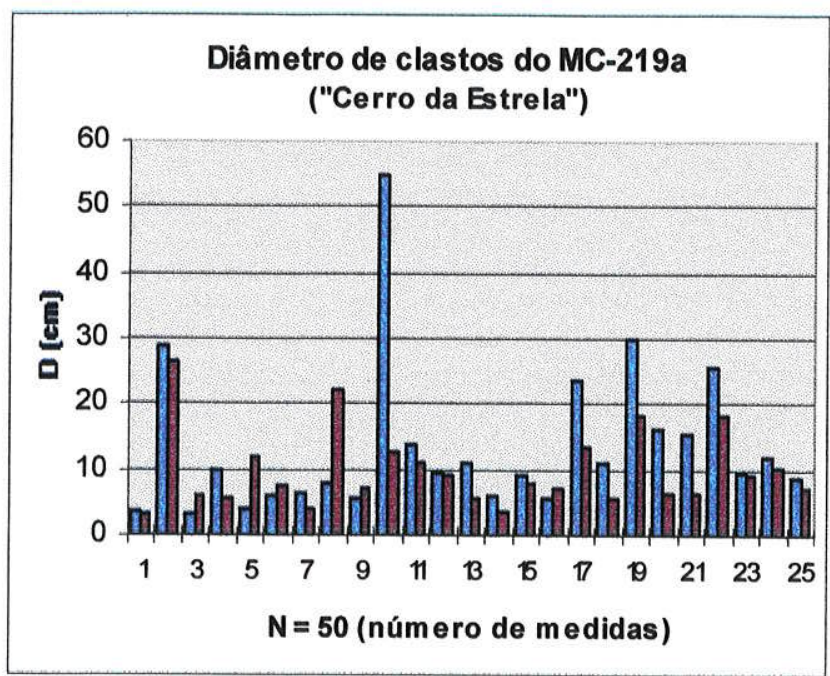

\section{A}

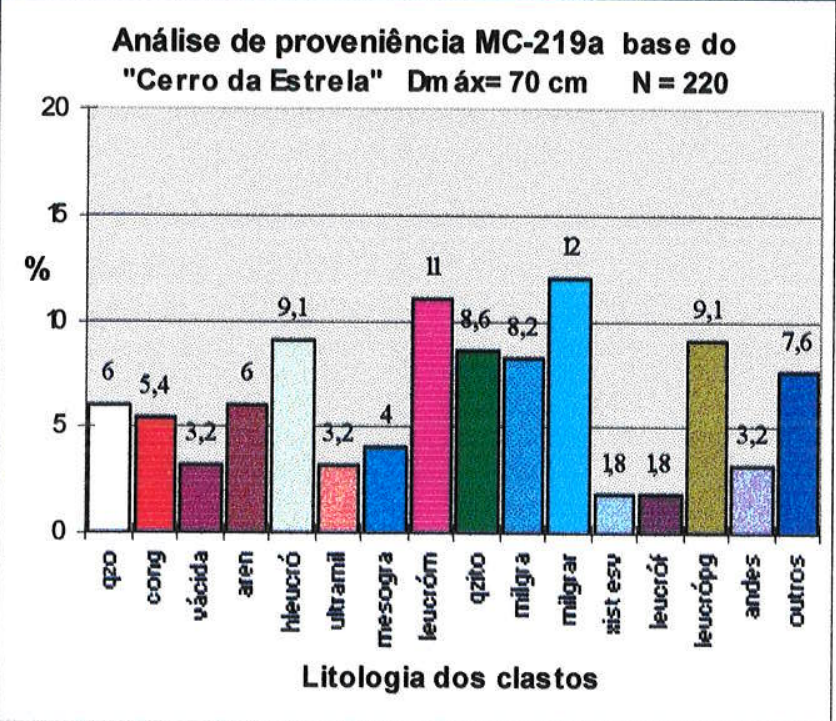

$\mathbf{A}^{\prime}$

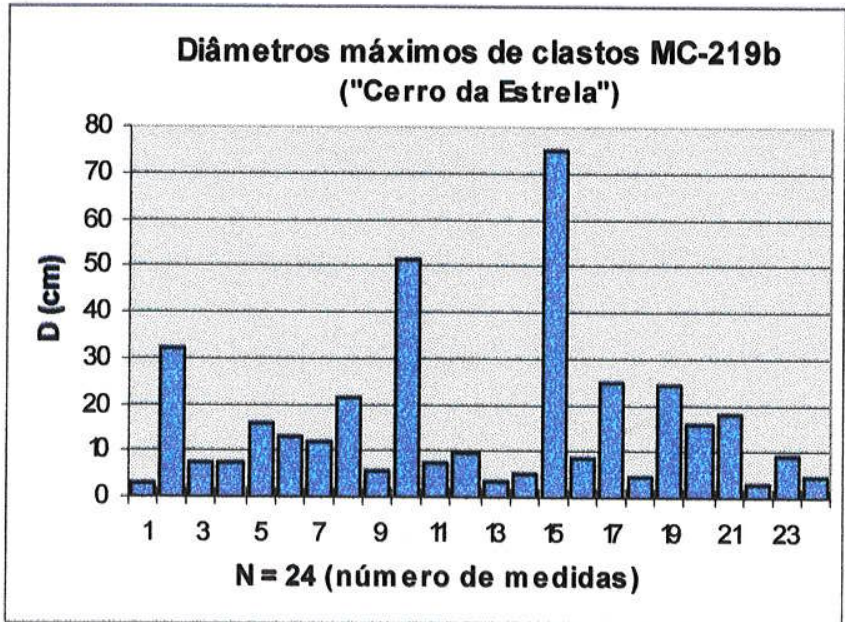

B

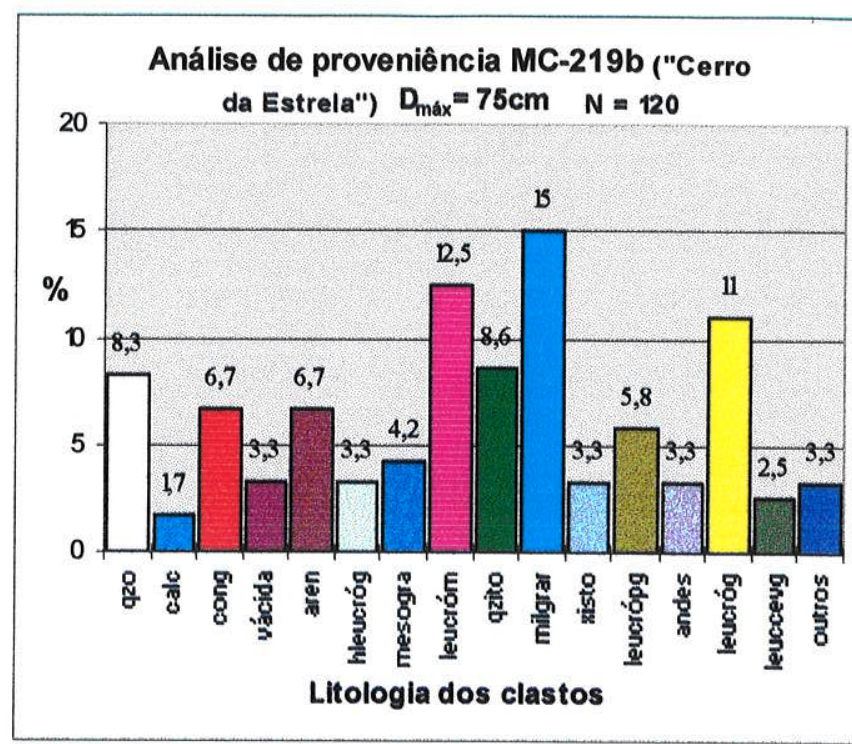

B'

FIGURA III.51 - Histogramas de freqüência de clastos e respectivo de frequêencia do diâmetro máximo dos clastos do ponto MC-219 da Formação Vargas na Associação CM2 em A- nível basal dela e B- topo da associação no local investigado. Os clastos maiores que $1 \mathrm{~cm}$ de diâmetro foram contados aleatoriamente, buscando-se obter pelo menos 100 medidas por nível investigado.

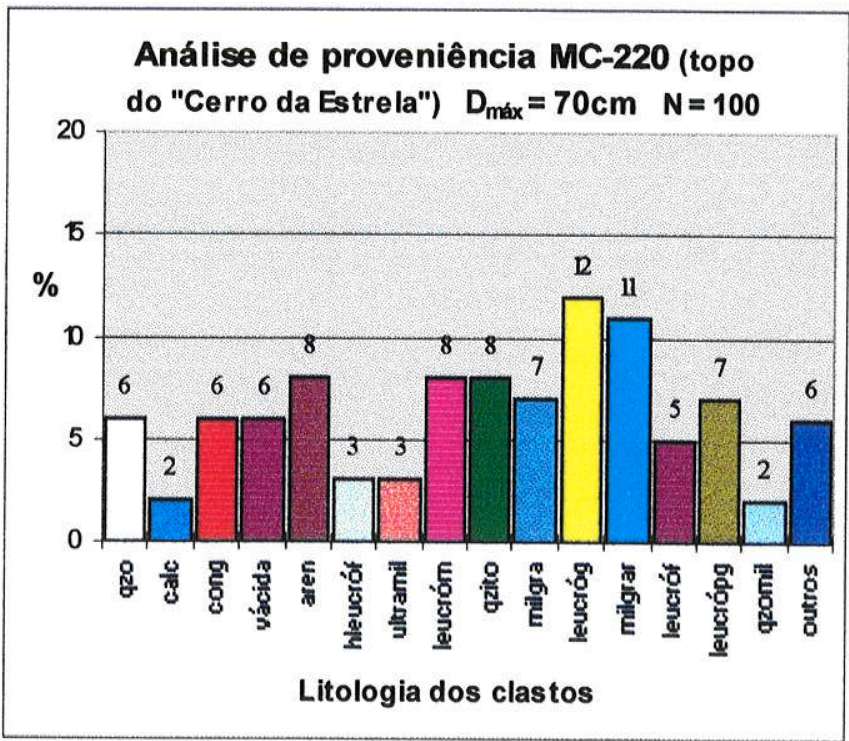

FIGURA III.52 - Histogramas de freqüência de clastos do ponto MC-220 da Formação Vargas na Associação CM2 em nível intermediário entre 219a e $219 \mathrm{~b}$ no local investigado. Os clastos maiores que $1 \mathrm{~cm}$ de diâmetro foram contados aleatoriamente, buscando-se obter 100 medidas no nível analisado. 


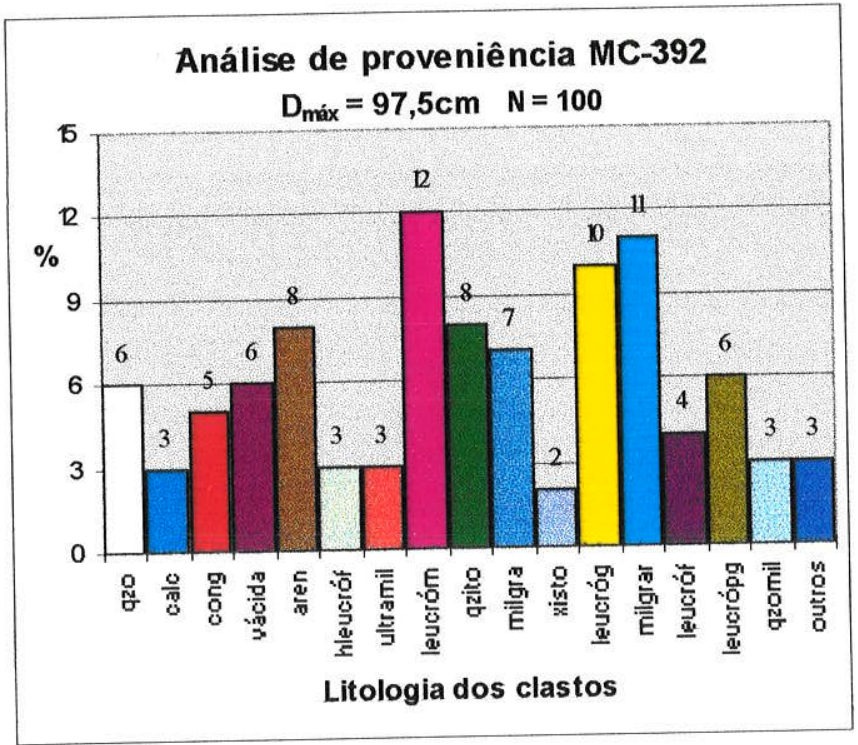

FIGURA III.53 - Histogramas de freqüência de clastos do ponto MC-392 da Formação Vargas na Associação CM2. Os clastos maiores que $1 \mathrm{~cm}$ de diâmetro foram contados aleatoriamente, buscandose obter 100 medidas no nível analisado.

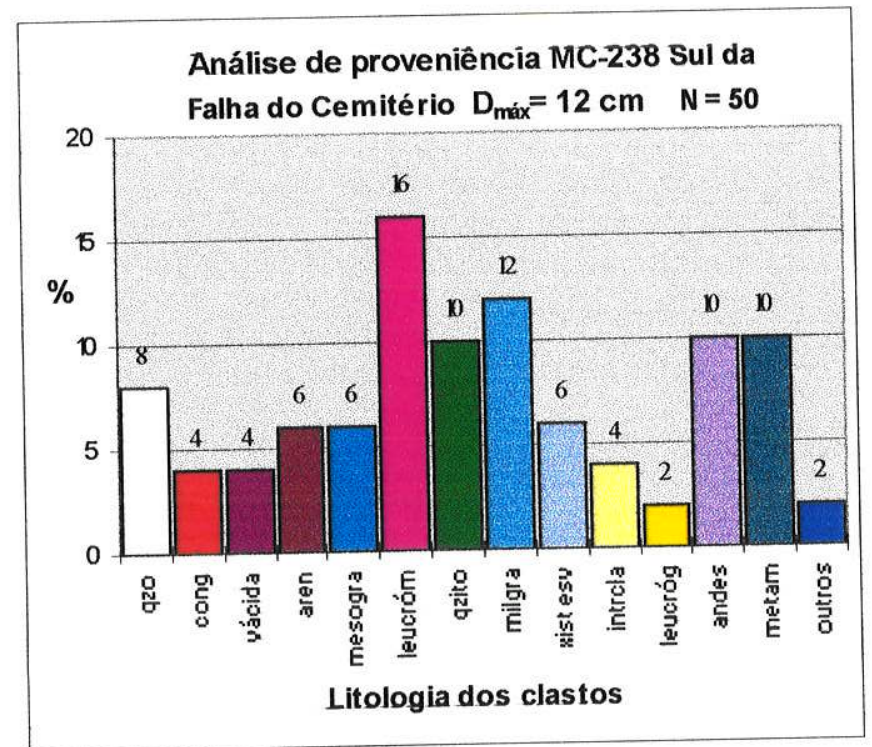

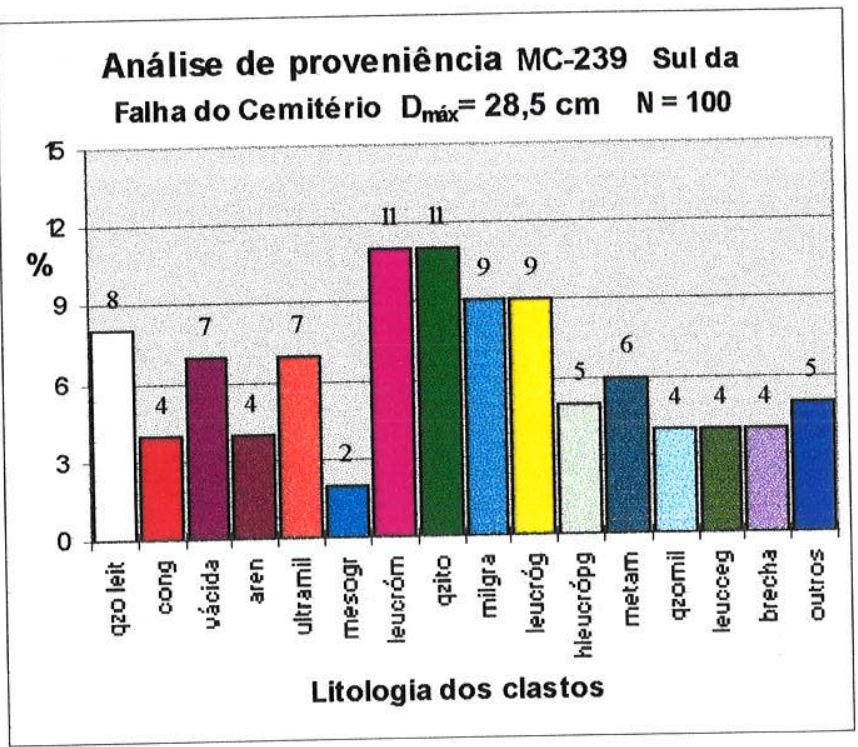

FIGURA III.54 - Histogramas de freqüência de clastos do ponto MC-238 e 239 da Associação CM2 da Formação Vargas. Os clastos maiores que $1 \mathrm{~cm}$ de diâmetro foram contados aleatoriamente, buscandose obter 100 medidas no nível analisado.

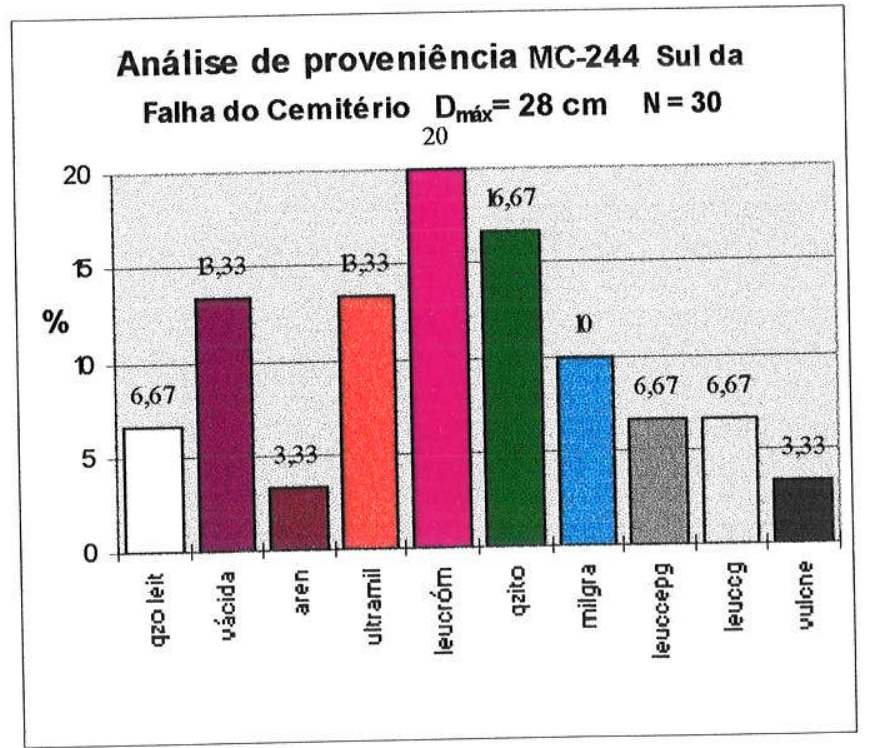

FIGURA III.55 - Histogramas de freqüência de clastos do ponto MC-244 da Associação CM2 da Formação Vargas a sul da Falha do Cemitério. Os clastos maiores que $1 \mathrm{~cm}$ de diâmetro foram contados aleatoriamente, buscando-se obter 100 medidas no nível analisado. 


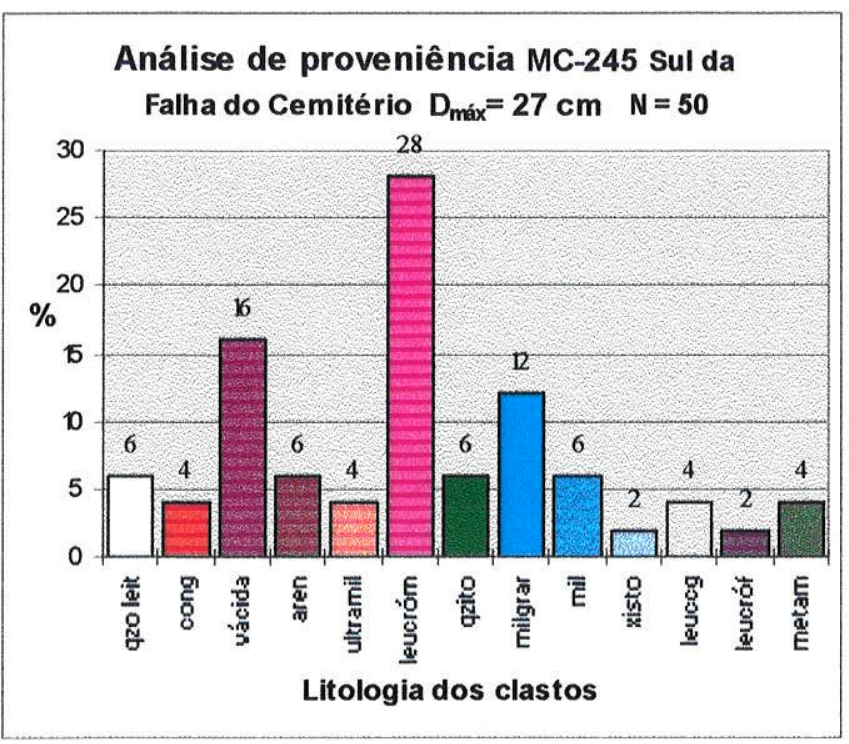

FIGURA III.56 - Histograma de freqüência de clastos do ponto MC-245 da Formação Vargas na Associação CM2.

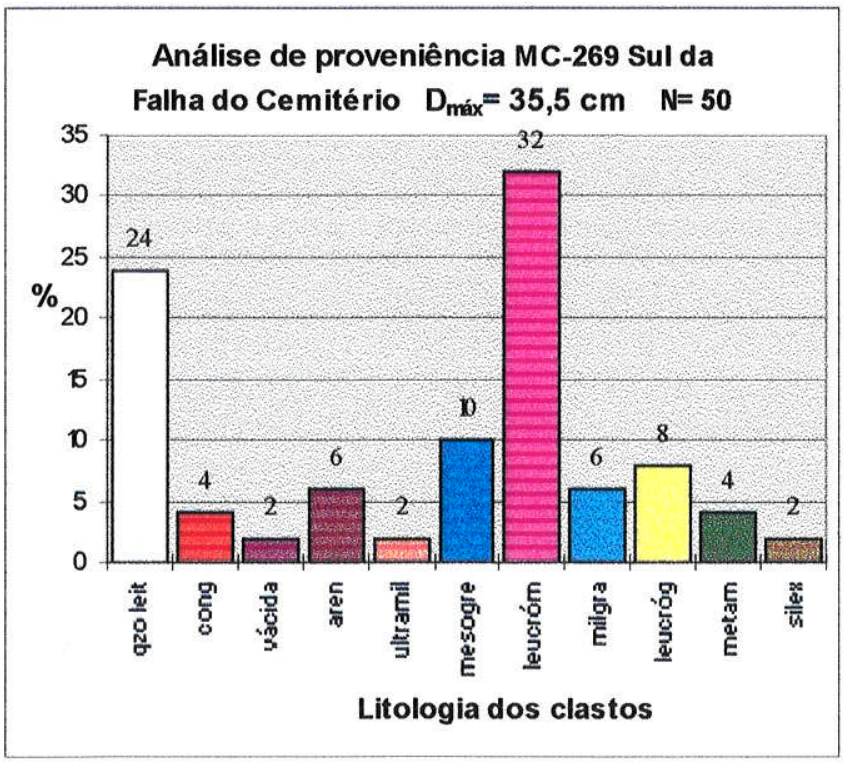

Figura III.57 - Histograma de freqüiência de clastos do ponto MC-269 da Formação Vargas na Associação CM2.

Em direção ao topo há progresivamente o incremento de clastos de milonitos, de rochas granodioríticas e/ granitos mesocráticos grossos, rochas granitóides porfiríticas e grossas (FIGURA III.50E,F), turmalina granitos, granitos greizenizados, conglomerados e arenitos das unidades inferiores e mármores, concomitante ao aumento na granulometria (FIGURA III.51).
A Associação CM2 aponta para o predomínio de leucogranitos róseos médios em toda a unidade podendo atingir até $\sim 30 \%$ (FIGURAS III.56, III.57). Na base há um ligeiro predomínio de fragmentos metamórficos (quartzitos, xistos, milonitos) e de vulcânicas ácidas. Para o topo dominam clastos de rochas granitóides grossas a porfíríticas, onde são abundantes fragmentos intrabacinais (arenitos e conglomerados) e, sobretudo nas porções superiores, de granitos miloníticos diversos e mármores.

As medidas de paleocorrentes da Associação CM2 refletem consistentemente paleotransporte para NW revelando áreas fontes a $\mathrm{S}$ e, principalmente, SSE (vide CAPÍTULO III.4). A distribuição de fácies (vide Anexo 01) enfatiza as medidas de paleocorrentes obtidas. A FIGURA III.58 também torna patente origem de detritos a sudoeste da área de estudos através de mapa de distribuição dos valores dos diâmetros máximos declastos.

A análise de proveniência realizada permite tecer algumas comparações entre os clastos encontrados e as litologias adjacentes à região de estudos. Leucogranitos médios róseos e leucogranitos avermelhados (coloração carne) dominam a unidade, sendo estes análogos àqueles encontrados na Suíte Dom Feliciano do Terreno Pelotas. A base da Associação CM2 possui predomínio de clastos de leucogranitos róseos médios e finos e de vulcânicas ácidas, estas possivelmente ressedimentadas de CM1. Progressivamente para o topo há o incremento de fragmentos de (i) rochas graníticas mais grossas (leucogranitos róseos porfiríticos), (ii) milonitos variados, com destaque para aqueles derivados de 
rochas granitóides, (iii) mesogranitos grossos, (iv) gnaisses porfiroblásticos, (v) granitos greizenizados, (vi) mármores róseos e (vii) conglomerados e arenitos médios a grossos inequivocamente das unidades subjacentes, demonstrando o ávido canibalismo que dominou o processo de sedimentação dos conglomerados da Associação CM2. O conjunto de litologias ígneas e metamórficas ocorrem na porção oriental do escudo Gaúcho no RS, a saber: (i) aparece tanto no Terreno Serra das Encantadas como no terreno Pelotas, (ii), (iv) e (vi) são abundantes no TSE, (v) ocorrem no Terreno Encruzilhada do Sul.

Por outro lado, os fragmentos de rochas metamórficas e deformadas (quartzitos, xistos, quartzo milonitos, milonito granitos, milonito xistos) são análogos aos encontrados no Terreno Serra das Encantadas a ESE.

A presença importante de clastos de arenitos finos acastanhados e conglomerados intraformacionais revela que a bacia sofreu retrabalhamento de unidades anteriores.

As áreas fontes que se apresentam diretamente como possíveis fornecedoras de suprimento detrítico a SSE e a S estão representadas pelo Terreno Serra das Encantadas (TSE) e outros mais orientais. De acordo com Mello (1993) no TSE dominam milonitos de vários tipos (quartzo milonitos, milonito leucogranitos róseos, milonito xistos, filonitos), rochas granitóides isótropas (leucogranitos róseos, turmalina granitos) e mármores róseos, entre outros. No Terreno Pelotas, situado a ESE das Minas do Camaquã, aparece uma associação granítica formada por leucogranitos de coloração rósea intensa a carne (vermelha) e granulação média, típicos da Suíte Dom Feliciano, muscovita leucogranitos, riolitos, granitóides grossos a porfiríticos. Granitos estaníferos (greizens) são abundantes no Terreno Encruzilhada do Sul (TES), a nordeste da área de estudos. No Terreno Cerro da Árvore (TCA) dominam metavulcanogênicas e Terreno Serra dos Pereira (TSP) dominam metarritmitos e quartzitos. Entretanto, estes terrenos a leste acham-se hoje separados pelo TSE, exemplificado pelo alto da serra das Encantadas, que separa a atual área de estudos dos depósitos correlatos do Vale do Boici. Nesta região ocorrem unidades correlatas ao Grupo Camaquã, com as formações Mangueirão e Vargas, nas quais realizamos estudos de proveniência e paleocorrentes (Fambrini et al., 1992a, b; Sayeg et al., 1992a; Sayeg, 1993).

Será feita aqui uma comparação entre os depósitos da Associação CM2 com aqueles aflorantes no Vale do Boici. As análises indicaram que a Formação Mangueirão apresenta predomínio de clastos de vulcânicas ácidas e leucogranitos de coloração rósea intensa a carne (vermelha) vindos de leste e sudeste (Terreno Pelotas), além de quartzitos, quartzo, xistos, metassedimentos. Na Formação Vargas, a base possui, além dos clastos leucogranitos de coloração rósea intensa a carne (vermelha) e riolitos, litologias mais variadas como muscovita leucogranitos, greizens, milonitos e arenitos. Em direção ao topo, aumenta significativamente a proporção de milonitos e granitos deformados, surgindo clastos de mármores e cálciossilicáticas, todos oriundos de NW, ou seja, do Terreno Serra das Encantadas. Estes dados conduziram à interpretação de que o alto da serra das Encantadas teve seu alçamento durante a evolução da sub-bacia Vale do Boici, -cuja cobertura da Formação Mangueirão e da base Formação Vargas ali exposta foi erodida e sedimentada no topo da Formação Vargas -, e com o avanço do soerguimento níveis mais 
profundos desse terreno eram erodidos até culminar com a denudação de seu embasamento milonítico granítico, evidenciado pela abundância de clastos de milonitos no topo da unidade. Esta unidade possivelmente é correlata à Associação CM2 (Conglomerado Superior de Ribeiro, 1978) da região das Minas do Camaquã, o que se correto, poderá ser elemento de correlações estratigráficas.

Com a ascensão do TSE, sua cobertura foi erodida e ressedimentada tanto a oeste como a leste da serra das Encantadas. Desta feita, muitos dos clastos de leucogranitos de coloração rósea e carne encontrados nas Minas do Camaquã, muito semelhantes aos da Suíte Dom Feliciano do Terreno Pelotas, poderiam ter vindo deste terreno desta forma. O mesmo pode ser extrapolado para os granitos greizenizados do Terreno Encruzilhada do Sul.

\section{III.6.4 Proveniência da Formação João Dias}

A proveniência da Formação João Dias, em virtude da praticamente ausência de corpos de rochas rudíticas, foi realizada na matriz de arenitos ao microscópio e embasada pelas paleocorrentes. Petrograficamente, esta associação possui grãos de (i) quartzo monocristalino do tipo plutônico; (ii) plagioclásio sódico (andesina-oligoclásio); (iii) fragmentos líticos como rochas vulcânicas básicas a intermediárias (andesitos), quartzitos, metamórficas micáceas (xistos), chert e intraclastos pelíticos; (iv) ortoclásio. A composição mineralógica sugere proveniência de terrenos graníticos e coberturas vulcanosedimentares (Grupo Crespos), bem como de ressedimentação da própria bacia. As paleocorrentes obtidas sobretudo na Associação CS3 da unidade indicam derivação de fontes situadas a SW e S.

Deste modo, as possíveis áreas fontes para a Formação João Dias poderiam ser o Terreno Valentines.

\section{III.6.5 Discussão}

A análise de proveniência, coerente com os dados sedimentológicos, propiciou a individualização de duas unidades de conglomerados, dividindo a sucessão que os contém em conglomerados Inferior e Superior, com proveniências distintas. A seqüência do Conglomerado Inferior apresenta detritos oriundos da erosão de um arco magmático, a oeste (Arco Bom Jardim), representada por fragmentos de vulcânicas ácidas e intermediárias e das rochas encaixantes (quartzitos e xistos). A análise de proveniência efetuada na seqüência do Conglomerado Superior mostra claramente contribuição de distintas fontes de terrenos ígneos e metamórficos, caracterizando áreas fontes mistas para esses conglomerados, compatível com leques gerados no centro de uma bacia. $O$ bom arredondamento e o predomínio de seixos e calhaus em depósitos bem organizados, associados à presença de clastos de sedimentos da própria bacia (e.g. arenitos fínos achocolatados e conglomerados) e derivados do Terreno Pelotas, permitem sugerir que estes depósitos originaram-se da erosão e retrabalhamento de unidades inferiores. A presença de fragmentos de granitóides 
grossos a porfiríticos, isótropos, bem foliados e fraturados, oriundos de sul, indica fonte do Terreno Serra das Encantadas e do Terreno Pelotas. Por outro lado, fragmentos de milonitos e granitóides podem estar relacionados ao soerguimento do embasamento da bacia, com posterior erosão, sendo depositados na porção superior desta seqüência, configurando uma estratigrafía invertida.

Assim, fica configurada a inversão estratigráfica de áreas fontes.

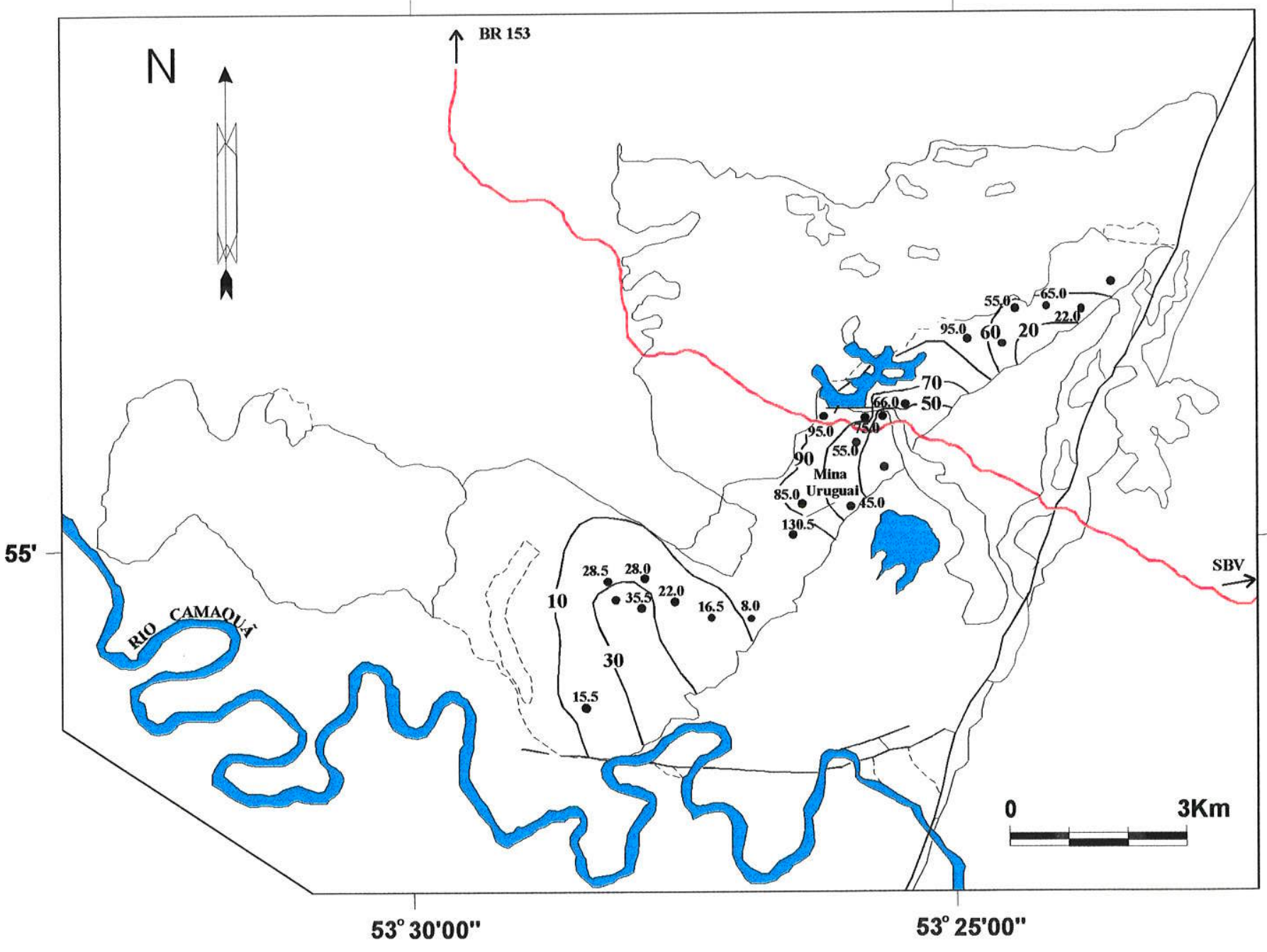

Figura III.58 - Mapa de distribuição dos valores máximos de clastos de fácies rudíticas da Associação CM2 da Formação Vargas. Notar tendência da distribuição para NW. Os valores aumentam em função das características progradantes dos depósitos. 
PARTE IV

CONSIDERAÇÕES FINAIS 


\section{CAPÍTULO IV.1 - EVOLUÇÃO PALEOGEOGRÁFICA} DA BACIA DO CAMAQUÃ

\section{IV.1.1 Introdução}

O objetivo deste capitulo é esboçar tentativamente a evolução paleogeográfica da região das Minas do Camaquã consoante as informações obtidas nos capitulos precedentes.

Segundo H. G. Reading (1986) a tectônica é um dos fatores fundamentais para o controle da sedimentação. De acordo com o autor o tectonismo opera diretamente na espessura dos conjuntos de rochas sedimentares, fácies e seus padrões, influindo indiretamente sobre o clima local, variações do nível do mar e a composição química das fontes sedimentares.

Com base nessas assertivas, será abaixo discutida a influência dos fatores clima, área fonte, tectonismo, variação do nível do mar e idade de forma a compor a evolução do preenchimento sedimentar da região considerada, procurando-se correlacionar com as demais ocorrências sempre que possivel.

\section{IV.1.2 Clima}

O clima atuante durante a deposição do Grupo Camaquã deve ter sido árido e/ou semi-árido, considerando-se os seguintes elementos: (i) abundância relativa de minerais e rochas suscetíveis ao intemperismo químico, tais como: inúmeros fragmentos de feldspatos (plagioclásio e K-feldspato) bem formados de tamanho até centimétrico; biotitas, litoclastos vulcânicos de composições básicas a intermediárias e fragmentos de calcários frescos a pouco alterados, indicativos do predomínio de intemperismo fisico; (ii) supremacia de material desagregado de granulometria areia a blocos, sugerindo longos períodos de desintegração mecânica das rochas e eventos esporádicos de chuvas torrenciais de forma a acumular elevada quantidade de material detrítico na bacia; (iii) domínio da fração silte com baixíssima proporção de argila nos níveis de granulometria fina, da mesma forma indicando o predomínio do intemperismo físico sobre o limitado - ou mesmo ausente - intemperismo químico (hidrólise); (iv) cimentação carbonática e ferruginosa (películas de hematita), sendo esta última responsável pelo caráter de red beds desta unidade; (v) presença de depósitos de fan deltas e leques aluviais de caráter proximal com relação à área fonte, típicos de sedimentação em ambientes áridos e/ou semi-áridos e (vi) transformações diagenéticas, como exemplificado pelo fenômeno de albitização de feldspatos caracterizados por Veigel (1992) na região de estudo. 
Portanto, o clima tanto nas áreas fontes como na bacia apresentava condições de aridez e/ou semi-aridez durante a sedimentação, e mesmo no transcorrer das transformações diagenéticas que se efetuaram nas fácies do Grupo Camaquã na região das Minas do Camaquã, conclusão praticamente consensual entre os diversos pesquisadores que estudaram esta unidade (e.g. Becker \& Fernandes, 1982; Fragoso Cesar, 1984; Fragoso Cesar et al., 1984, 1985; Lavina et al., 1985; Faccini et al., 1987; Veigel \& Dardenne, 1989; Veigel, 1992; Paim, 1994).

\section{IV.1.3 Área fonte}

Estudos de proveniência (Capítulo III.6) no Grupo Camaquã indicam variações de áreas fontes durante sua deposição, sugerindo a participação como fontes de diversos terrenos do Escudo Gaúcho, tentativamente aqui esboçadas com estudo estratigráfico de proveniência aliado ao de paleocorrentes.

A Formação Mangueirão recebeu inicialmente contribuição de áreas situadas a S e SW, exemplificada por fragmentos de leucogranitos róseos, quartzitos, xistos, vulcânicas básicas a intermediárias e, subordinadamente, riolitos e milonitos. Petrograficamente, a combinação de fragmentos de (i) quartzo simples do tipo plutônico, aliados a plagioclásio sódico (oligoclásio, principalmente) e microclínio, levam-nos a supor derivação de terrenos granito-gnáissicos; (ii) quartzitos, xistos, muscovitas e chert permitem considerar terrenos metamórficos de baixo grau e (iii) rochas vulcânicas básicas a ácidas, indicam a presença de coberturas vulcânicas na área fonte. Essas associações de rochas ocorrem nos terrenos Valentines e Rio Vacacai. De acordo com os dados de paleocorrentes o Terreno Valentines deve ter sido a principal área produtora de detritos, não descartando a possível participação do Terreno Rio Vacacai, pois ainda não estão claras as movimentações tectônicas que podem ter ocorrido, durante e após a sedimentação, entre a região estudada e a atual posição deste terreno.

A Associação de Fácies CM1 da Formação Vargas exibe clastos de rochas vulcânicas correlatas ao Grupo Crespos - sendo majoritariamente de rochas ácidas da Formação Acampamento Velho, além de andesitos da Formação Hilário - e leucogranitos róseos, particularmente alguns com textura rapakivi. As paleocorrentes indicam sentido de transporte de áreas fontes situadas a $\mathrm{S}$ e $\mathrm{SW}$, regiões dominadas pelo Terreno Valentines que contém todas estas associações de rochas. A ocorrência distintiva de granitos com textura rapakivi reforça esse terreno como área fonte, pois um grande batólito paleoproterozóico desta litologia o intrude na região de Nico Perez no Uruguai (Bossi \& Campal, 1992). No entanto, no RS também registra-se um granito com essa textura (Granito Lavras do Sul; Neoproterozóico, vide Nardi \& Lima, 1985), porém intrusivo no Terreno Rio Vacacai, podendo estar relacionado ao problema estrutural acima mencionado. Portanto, as áreas fontes da Associação CM1 poderiam situar-se no Terreno Valentines, a sul da região, ou no Terreno Rio Vacacai, atualmente a oeste da região das Minas do Camaquã, ou mesmo de ambos. 
A Associação de Fácies CM2 da Formação Vargas, de acordo com as medidas de paleocorrentes, exibe clastos oriundos de terrenos situados a SE e S. De fato, os litoclastos analisados podem ser referidos aos terrenos Serra das Encantadas (TSE), Serra dos Pereira (TSP), Cerro da Árvore (TCA), Encruzilhada do Sul (TES) e Pelotas (TPL). No entanto, suspeitamos que sua principal área fonte foi o Terreno Serra das Encantadas durante seu soerguimento contemporâneo à sedimentação desta unidade, pois os clastos oriundos dos outros terrenos representam ressedimentação, enquanto os clastos mais superiores na coluna, claramente juvenis, são basicamente derivados do embasamento milonítico deste terreno.

A Formação João Dias recebeu contribuição detritica de áreas situadas dominantemente a SW. Devido à dificuldades de estudos macroscópicos de área fonte nessa unidade em virtude de sua granulometria preponderantemente fina, baseamo-nos apenas em análises petrográficas. As mesma indicam proveniência predominantemente de terrenos granito-gnáissicos exemplificados por grãos de quartzo policristalino dos tipos metamórfico e milonítico, além de litoclastos de milonitos e de vulcânicas básicas a ácidas. Estes tipos de fontes, aliados às medidas de paleocorrentes, sugerem que a principal área fonte deve ter sido o Terreno Valentines.

\section{IV.1.4 Tectonismo}

A tectônica reinante na área de estudos pode ser resumida a três eventos principais através da relação entre taxas de subsidência e soerguimento na área fonte.

Inicialmente, o abatimento de blocos do embasamento, possivelmente controlado pelo sistema de falhamentos Tapera Emiliano, a leste, condicionou a deposição inicial da bacia na região enfocada, representada por sedimentos finos da Formação Mangueirão. Com a subsidência, espessa sucessão clástica imatura (cerca de $2000 \mathrm{~m}$ ) pôde ser empilhada, marcando o primeiro e talvez mais importante evento tectono-sedimentar da região. De acordo com Blair \& Bilodeau (1988), depósitos espessos de sedimentos finos bacinais atestariam a principal carga detrítica de uma bacia evidenciando atividade tectônica mais intensa, pois estes autores consideraram a subsidência como o fator tectônico determinante da deposição de sedimentos em uma calha estrutural. Tal fenômeno, segundo os autores, processa-se tipicamente em bacias do tipo rift, de afastamento (pull-apart) e de antepaís. Assim, a espessa sedimentação basal marinha do Grupo Camaquã pode ser explicada como reflexo de uma atividade tectônica inicial mais intensa na bacia, ocasionando abatimento e formação da calha e posterior subsidência com o peso da carga sedimentar.

A presença de depósitos de fan deltas da Formação Vargas, com recorrência no interior da bacia, relacionados aqui a um segundo evento tectono-sedimentar da região, sugere a existência de um paleorrelevo com forte desnível, indicando soerguimento relativo da área fonte, provavelmente por ação de falhamentos. Autores como Steel et al. (1977), Steel \& Gloppen (1980), Crowell (1982), Aspler \& Donaldson (1985), McPherson et al. (1987), Blair \& McPherson (1992), Blair \& McPherson (1994b), entre tantos outros, sustentaram que a presença de depósitos de leques aluviais, fan deltas ou mesmo leques 
costeiros seriam condicionados por relevo escarpado originado por ação de falhamentos. Não é meritória a discussão sobre o caráter da movimentação desses falhamentos em vista da insuficiência de dados até o momento. Dificil é estimar o porte desse paleorrelevo vigoroso pretérito, mas é altamente sugestiva sua influência nos depósitos da bacia. $O$ relevo das áreas fontes sofreu soerguimento durante esta fase traduzido nas fácies progressivamente proximais de depósitos de fan deltas para o topo. Segundo Blair \& Bilodeau (1988), a presença de depósitos de leques refletiria tão somente período de quiescência tectônica na bacia, de tal sorte que chuvas torrenciais pudessem propiciar o aporte de sedimentos na forma de enxurradas e fluxos de detritos.

Nova fase de subsidência intensa da região está registrada nos depósitos finos marinhotransicionais da Formação João Dias que afogaram os depósitos rudáceos da Formação Vargas. Inicialmente, os depósitos de arenitos finos basais da Formação João Dias marcam depocentro a oeste representados por sedimentação marinha-transicional, provavelmente como conseqüência de ingressão marinha de NW para SE. Acima, nova mudança do depocentro da bacia está registrada nas acumulações flúvio-deltaicas que se dirigiram para $\mathrm{N}$ e NW.

A bacia sofreu também perturbações que a elevaram à categoria de "área fonte" marcando a inversão dos depósitos do Grupo Camaquã, i.é., o que era depressão e acumulava sedimentos passou a ser fonte, refletido na importante discordância angular entre esta unidade e ० Grupo Guaritas. Leques aluviais da Formação Guarda Velha, basal do grupo, formados por intensa ressedimentação de depósitos anteriores só se justificam se esses estivessem com desnível considerável, de modo a gerar erosão e transporte.

\section{IV.1.5 Variações do nível do mar}

Os sistemas deposicionais geradores do Grupo Camaquã na região das Minas do Camaquã podem ser relacionados à variações do nível do mar epicontinental ali instalado na transição do Vendiano para o Cambriano, compreendendo (i) turbiditos representando a primeira incursão do mar reconhecida na região que passam para depósitos de tempestitos e de planície de maré (ii) leques aluviais costeiros que invadem um corpo marinho raso (faciologias), possivelmente com conexão oceânica (icnofósseis), retrabalhados por ondas (tempestitos); (iii) leques deltaicos e costeiros que transicionam para depósitos litorâneos encerrando com sedimentação transicional marcando evento de regressão do nível desse mar epicontinental; (iv) leques aluviais que invadem o corpo marinho configurando fan deltas progradantes entulhando a bacia na região e, finalmente (v) nova ingressão marinha registrada nos depósitos marinhos e transicionais da Formação João Dias (icnofósseis e fácies de tempestitos), afogando os depósitos aluviais sotopostos, que transicionam para uma planície aluvial entrelaçada (braided alluvial plain) com pequenos corpos d'água rasos, e grada para sistema flúvio-deltaico de topo registrando importante evento progradante. 
Em essência, na região das Minas do Camaquã temos depósitos marinhos (Formação Mangueirão) que transicionam para depósitos continentais (Formação Vargas) culminando com outra ingressão marinha registrada na Formação João Dias. A questão, no momento ainda não definida, é se essas variações de nível do mar refletem variações globais (climáticas) ou locais (tectônicas). A importância da atividade das zonas de cisalhamento que condicionaram a Bacia do Camaquã como um todo, com atividade sin-sedimentar de soerguimentos e abatimentos de blocos durante sua evolução, favorecem a hipótese de que as variações de nível do mar nessa bacia deveram-se fundamentalmente à atividade tectônica.

\section{IV.1.6 Idade}

Em fácies correlatas à Associação de Fácies CI4 da Formação Mangueirão, Netto et al. (1992) reportaram a ocorrência de traços fósseis representados pelos icnogêneros Didymanlichnus, Intrites e Planolites. Na base da Formação Vargas os mesmos autores registraram a ocorrência dos icnogêneros Cochlichnus, Didymanlichnus, Cruziana?, Planolites, Gyrolithes, Skolithos? e Rusophycus. Intrites sugere idades limitadas ao Vendiano, enquanto que Rusophycus e Gyrolithes indicam icnofósseis que surgiram no Tomotiano (base do Cambriano). Os demais icnogêneros representam pistas que apareceram no Vendiano Superior e se estenderam Fanerozóico adentro; portanto, na Transição NeoproterozóicoFanerozóico.

As rochas psamo-pelíticas da Formação Mangueirão, basal na região das Minas do Camaquã, foram objeto de estudos radiométricos que as situaram no intervalo Vendiano Superior e Cambriano Inferior de acordo com: (1) duas datações K/Ar na fração fina da Formação Mangueirão indicando idades de $572 \pm 17 \mathrm{Ma}$ e $535 \pm 16 \mathrm{Ma}$ e (2) duas datações K/Ar em pelitos intercalados nos arenitos finos da Formação João Dias (então considerada como do Grupo Guaritas) fornecendo idades de $529 \pm 11$ Ma e $524 \pm 16 \mathrm{Ma}$ (Bonhomme \& Ribeiro, 1983). As idades de $535 \pm 16 \mathrm{Ma}, 529 \pm 11 \mathrm{Ma}$ e $524 \pm 16 \mathrm{Ma}$ mostram-se compatíveis com os dados estratigráficos e paleontológicos, indicando deposição neste intervalo. No entanto, a de $572 \pm 17 \mathrm{Ma}$ é incompatível.

Considerando-se o intervalo de 544-530 Ma para o limite entre o Vendiano e o Cambriano (Bowring et al. 1993; Isachsen et al., 1994; Grotzinger et al., 1995; Knoll, 1996), evidências radiométricas e paleontológicas sugerem uma deposição durante a transição Neoproterozóico-Cambriano.

\section{IV.1.7 Evolução do preenchimento sedimentar}

A Formação Mangueirão registra o início da sedimentação do Grupo Camaquã através da instalação de um mar de características epicontinentais representado por fácies de turbiditos que passam a depósitos de tempestitos e, em sentido ao topo, gradam para depósitos de águas rasas formados por fácies de planície de maré que transicionam para corpos deltaicos, refletindo o enérgico entulhamento que sofreu a 
bacia na região. Ou nas palavras de Sayeg (1993) “...o contexto deposicional formado por leques subaquáticos com variação de águas mais profundas (seqüencias de Bouma) a rasas (fácies de inunditos), com passagem para ambientes costeiros, em processo de colmatação de um grande corpo d'água, possivelmente um mar epicontinental".

Este corpo marinho raso ou pouco profundo foi invadido por fan deltas da Formação Vargas, alimentados inicialmente (Associação CM1, “Conglomerado Inferior') pela erosão da cobertura vulcânica do Grupo Crespos, que aflora tanto sobre o Terreno Valentines como o Terreno Rio Vacacai. Seguiu-se um breve periodo de quiescência tectônica representada pela deposição dos arenitos basais da Associação CM2. A retomada do processo deu-se com a enérgica deposição da Associação CM2 como resultado do soerguimento regional mais intenso a S e SE do Terreno Serra das Encantadas e a denudação de sua cobertura então erodida e ressedimentada. $O$ progressivo incremento da evolução do soerguimento deste terreno resultou na erosão de seu embasamento milonítico, configurando uma estratigrafía invertida de área fonte.

Posteriormente, a região foi possivelmente abatida permitindo uma nova ingressão marinha e conseqüente deposição da Formação João Dias

Assim, imagina-se a seguinte paleogeografia para a região estudada:

(i) Instalação de um mar epicontinental como resposta à uma subsidência intensa do embasamento. Os ritmitos da Formação Mangueirão registram os depósitos basais expostos do Grupo Camaquã na região.

(ii) Leques costeiros invadem corpos d'água de ambiente marinho raso isolados por altos do embasamento então em ascensão, cujos sedimentos são retrabalhados por ondas de tempestade e afetados por eventos episódicos de inundação, com grande carreamento de material arenoso e síltico.

(iii) Um processo de continentalização generalizado, promovido pelo avanço dos sistemas de leques aluviais e a colmatação do corpo marinho. Isso se verifica através da passagem de sedimentos subaquáticos silto-arenosos para depósitos aluviais e deltaicos da Formação Vargas.

(iv) Novo evento de abatimento da região registrado pelos depósitos marinho-transicionais da Formação João Dias. 


\section{(iv)}

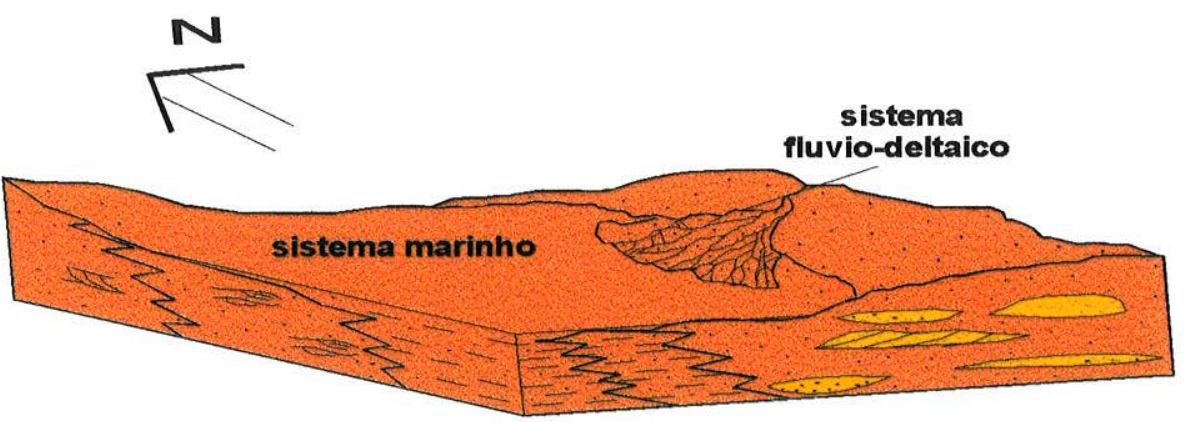

FORMAÇÃO

JOÃO DIAS

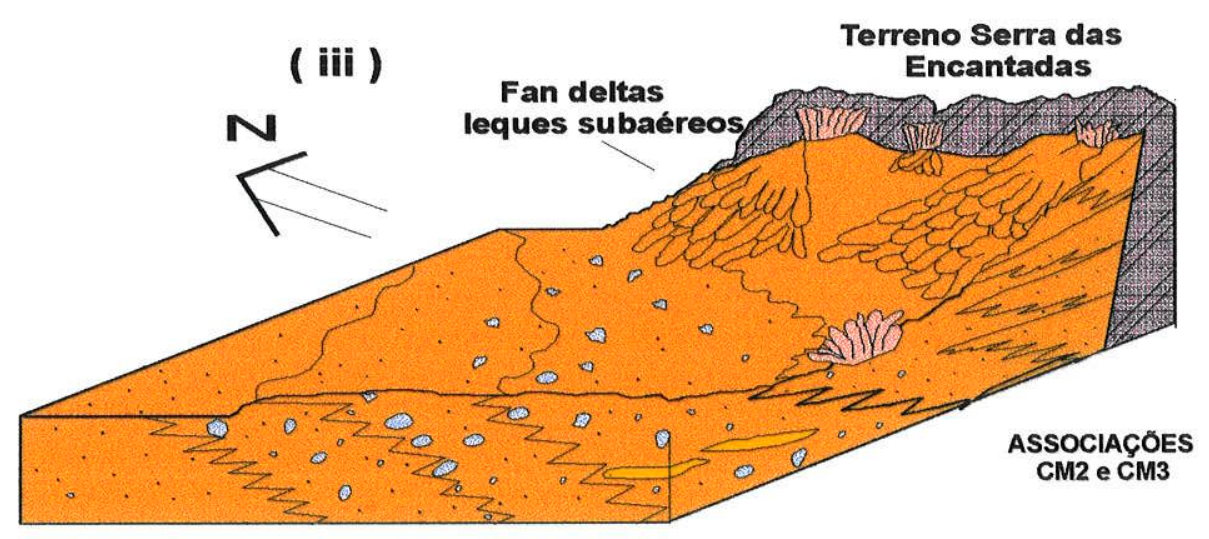

transição

\section{(ii)}

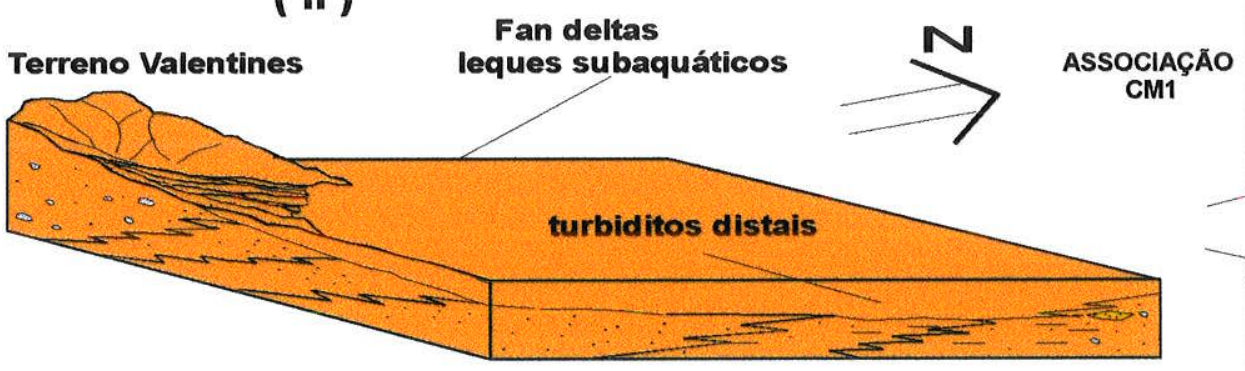

(i)

\section{Terreno Valentines}

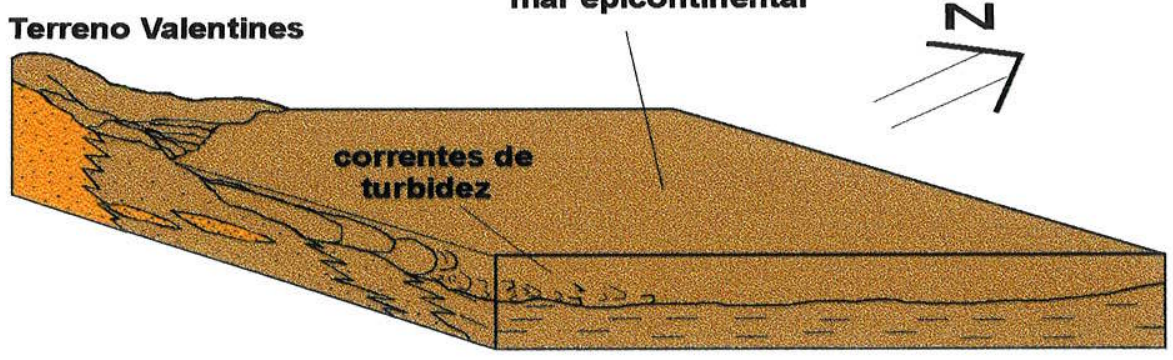

transição

\section{FORMAÇÃO VARGAS}

\section{FORMAÇÃO MANGUEIRÃO}

FIGURA IV.1 - Esquema de evolução paleogeográfica do Grupo Camaquã na região das Minas do Camaquã. (i) instalação de um mar epicontinental como resposta à uma subsidência intensa do embasamento registrada pelos ritmitos da Formação Mangueirão, depósitos basais expostos do Grupo Camaquã na região, cujos sedimentos são retrabalhados por ondas de tempestade e freqüentemente expostos; (ii) leques subaquáticos da Associação CM1 invadem os depósitos marinhos sotopostos, isolando altos do embasamento, provindos de SSW; (iii) um processo de continentalização generalizado, promovido pelo avanço dos sistemas de fan deltas e a colmatação do corpo marinho. Isso se verifica através da passagem dos leques subaquáticos da Associação CM1 para depósitos de leques aluviais das Associações CM2 e CM3 da Formação Vargas, marcando mudança de área fonte (de SSE); (iv) novo evento de abatimento da região registrado pelos depósitos marinho-transicionais a flúvio-deltaicos de planície aluvial entrelaçada da Formação João Dias. 


\section{CAPÍTULO IV.2 - DISCUSSÃO FINAL}

Com base na integração dos dados estratigráficos de fácies, proveniência e paleocorrentes e de mapeamento geológico obtidos neste trabalho, descritos nos capítulos anteriores, combinados com aqueles encontrados na literatura vigente, permite-se considerar a seguinte evolução para o Grupo Camaquã na região clássica das Minas do Camaquã.

Os depósitos do Grupo Camaquã na área de estudos situam-se entre duas das principais zonas de cisalhamento que recortam o Escudo Gaúcho - o Sistema Tapera-Emiliano, a leste, e o Sistema Passo dos Enforcados, a oeste, integrantes do Sistema de Falhas Irapuá de Ribeiro et al. (1966). Essas feições provavelmente condicionaram a sedimentação das litologias da Bacia do Camaquã na região considerada.

Nas fases precoces da Bacia do Camaquã em sua porção central, o soerguimento e erosão do Terreno Valentines (granitos com textura rapakivi, gnaisses polideformados, milonitos, anfibolitos e mármores da fácies anfibolito), a oeste e sudoeste, e do Terreno Rio Vacacai (metavulcânicas máficas, metassedimentos, ortognaisses) forneceram detritos para os depósitos marinhos da Formação Mangueirão.

Nova fase de preenchimento foi responsável pela modificação do depocentro da bacia na região. Estudos de fácies e paleocorrentes sugerem que o depocentro migrou paulatinamente para NW, em função de reativação do sistema de falhas Tapera-Emiliano registrando soerguimento mais intenso do embasamento da bacia a SE e E (Terreno Serra das Encantadas - TSE), e da cobertura sedimentar então existente. Com a erosão de ambos foram gerados possantes coarse-grained fan deltas (sensu McPherson et al., 1987) da Formação Vargas, culminando com a colmatação deste corpo marinho epicontinental. A variação nas taxas de deposição versus taxas de subsidência ocasionou flutuações no nível d'água. $O$ grande afluxo de sedimentos entulhou a bacia, de tal sorte que houve um importante incremento da subsidência da bacia, mas por si só não explicaria a permanência de altas taxas de sedimentação com deposição em águas relativamente rasas, com freqüentes emersões dos sedimentos.

Outra evidência para a alteração do sítio deposicional devido a mudanças no embasamento da bacia adveio do estudo de proveniência efetuado. Um soerguimento mais intenso das rochas do TSE adjacentes à bacia do lado leste é postulado aqui. As evidências disso são: (i) a existência de paleocorrentes NNW, com dispersão secundária para $W$, (ii) variações de fácies no sentido NW e, sobretudo, (iii) a presença, no arcabouço dos conglomerados, de clastos derivados de litologias metamórficas nitidamente relacionadas ao terreno acima mencionado, tais como de milonito granitos, milonito xistos, quartzomilonitos e filonitos do Complexo Porongos, mármores róseo-avermelhados e cinza finos e quartzitos da cobertura desse complexo, e (iv) uma fácies de brechas oligomíticas formadas por fragmentos de xistos, quartzo leitoso, milonito xistos e quartzo-milonitos (semelhantes às encontradas nas bordas das sub-bacias do Arroio Boici e do Vale do Piquiri com o TSE). Tais evidências só se explicam se, no sítio deposicional onde se encontram os depósitos horizontalizados do Grupo Guaritas, houvesse um alto do embasamento 
(ou série deles) proporcionando suprimento detrítico abundante para a Formação Vargas.

As rochas das unidades enfocadas receberam contribuição detrítica de (i) inicialmente áreas metamórficas postadas a SW das Minas do Camaquã; (ii) erosão da cobertura vulcânica e de áreas graníticas e deformadas (milonitos e gnaisses) a S e SW da região; (iii) retrabalhamento das unidades inferiores e (iv) áreas metamórficas e deformadas do Terreno Serra das Encantadas a SE e E .

Com relação à estratigrafia, duas considerações se fazem necessárias. Em primeiro lugar a impossibilidade de acomodar em um único grupo (no caso Grupo Camaquã) unidades litologicamente diferentes e que contenham internamente uma discordância angular de caráter regional, além de mudanças sensiveis nos paleoambientes, levaram-nos a sugerir o desmembramento desse grupo, formado então pelas formações Guaritas e Santa Bárbara de Robertson (1966), elevando-as à categoria de grupo. Por outro lado, desmembramos da unidade Vargas a aqui definida Formação João Dias em virtude das marcantes diferenças litológicas - a primeira constituída por conglomerados e esta formada por arenitos médios e finos - e também diante da possibilidade de mapeamento da unidade João Dias na escala 1:25.000.

A análise estratigráfica de fácies, proveniência e paleocorrentes aplicada ao Grupo Camaquã na região das Minas do Camaquã possibilitou a identificação de duas sequiências rudíticas com áreas fontes e história evolutiva distintas na Formação Vargas, evidenciadas por leques com características deposicionais e composicionais diferentes. A primeira associada a CM1, de feições subaquáticas, e a outra correlata a CM2 e CM3, cuja deposição ocorreu em condições subaéreas. Este último conjunto de leques, devido à composição mista, inclusive com fragmentos da própria bacia, e aos detritos com bom grau de arredondamento, são interpretados como produto da ressedimentação das unidades predecessoras. Variação de paleocorrentes é regra.

Os depósitos de fan deltas da região das Minas do Camaquã encontram-se intimamente relacionados à tectônica dos fallhamentos, em especial aqueles que originaram os altos do embasamento a SW, S e, principalmente, SE da região. Dentre estes, destaca-se o Sistema de Falhas Tapera Emiliano - ou outros mais orientais e hoje encobertos pelos depósitos do Grupo Guaritas -, que possivelmente controlou a deposição dos sedimentos, particularmente as Associações CM2 e CM3 da Formação Vargas, e parece ter sido em boa dose responsável pela configuração atual da região.

Este conjunto de eventos vincula-se à instalação de sub-bacias separadas por altos do embasamento que então ocorriam por conta das reativações de antigos falhamentos, moldando a configuração atual da bacia, proporcionando a erosão progressiva da cobertura e do embasamento, configurando uma estratigrafia invertida de área fonte. 


\section{REFERÊNCIAS BIBLIOGRÁFICAS}

AALTO, K.R. (1989) Sandstone petrology and tectonostratigraphic terranes of the northwest California and southwest Oregon Coast Ranges. Journal of Sedimentary Petrology, v. 59, n. 4, p. 561-571.

ADAMS, A.E.; MACKENZIE, W.S.; GUILFORD, C. (1993) Atlas of sedimentary rocks under the microscope. Harlow Longman, Essex. 108 p.

AGIRRENZABALA, L.M.; GARCIA-MONDEJAR, J. (1994) A coarse-grained turbidite system with morphotectonic control (Middle Albian, Ondarroa, Northern Iberia). Sedimentology, v. 41, n. 3, p. 383-407.

ALLEN, J.R.L. (1965) A review of the origin and characteristics of recent alluvial sediments. Sedimentology, v. 5, n. 2, p. 89-191.

ALMEIDA, D. del P.M.; PAIM, P.S.G.; VIEIRA Jr., N. (1992) Petrologia do vulcanismo Eo-Paleozóico das bacias do Camaquã e Santa Bárbara, RS. In: WORKSHOP SOBRE AS BACIAS MOLÁSSICAS BRASILIANAS, 1. São Leopoldo. 1992. Boletim de Resumos Expandidos. São Leopoldo, SBG/UNISINOS, p. 23-27.

ALMEIDA, D. del P.M.; PAIM, P.S.G.; VIEIRA Jr., N. (1993) Caracterização petrográfica e geoquímica do vulcanismo eo-paleozóico das bacias do Camaquã e Santa Bárbara (RS). Acta Geologica Leopoldensia, v. 16, n. 37 , p. $159-189$.

ALMEIDA, D. del P.M.; ZERFASS, H.; BASEI, M.A.S. (1996) Mineralogia, geoquímica e novas idades para o vulcanismo ácido da Bacia do Camaquã, RS. In: CONGRESSO BRASILEIRO DE GEOLOGIA, 39., Salvador, 1996. Anais.... Salvador, SBG, v. 2, p. 19-21.

ALMEIDA, F.F.M. (1949) Novo campo de riólitos e tufos no sul do Brasil. Mineração e Metalurgia, v. 14, p. 101103.

ALMEIDA, F.F.M. (1967) Origem e evolução da Plataforma Brasileira. Boletim da Divisão de Geologia $e$ Mineralogia DNPM, n. 241, p. 1-36.

ALMEIDA, F.F.M. (1969) Diferenciação tectônica da Plataforma Brasileira. In: CONGRESSO BRASILEIRO DE GEOLOGIA, 23., Salvador, 1969. Anais.... Salvador, SBG, v. 1, p. 29-46.

ALMEIDA, F.F.M. (1971) Geochronological division of the South America. Revista Brasileira de Geociências, v. 1, n. 1, p. 13-21.

ALMEIDA, F.F.M.; AMARAL, G.; CORDANI, U.G.; KAWASHITA, K. (1973) The Precambrian evolution of the South American Cratonic Margin South of the Amazonas river. In: NAIRN, A.E.M.; STEILI, F.G. (eds) The Oceans Basins and Margins. New York, Plenum, p. 411-446.

ALMEIDA, F.F.M.; HASUI, Y.; BRITO NEVES, B.B. (1976) The Upper Precambrian of South America. Boletim IG-USP, n. 7, p. 45-80.

ANGELIER, J.; MECHLER, P. (1977) Sur une méthode graphique de recherche des contraintes principales également utilisable en tectonique et en séismologie: la méthode des dièdres droits. Bullettin de la Societe Geólogique de France, v. 19, n. 6, p. 1309-1318.

ANGELIER, J.; COLLETA, B.; ANDERSON, R.E. (1985) Neogene paleostress changes in the Basin \& Range: A case study at Hoover Dam, Nevada-Arizona. Geological Society of America Bullettin, v. 96, n. 3, p. 347-361.

ARTHAUD, F. (1969) Méthode de détermination graphique des directions de raccourcissment, d'allongement et intermédiaire d'une population de failles. Bulletin de la Societe Geólogique de France, v. 11, n. 5, p. 729-737. 
ASPLER, L.B.; DONALDSON, J.A. (1985) The Nonacho Basin (Early Proterozoic), Northwest Territories, Canada: Sedimentation and deformation in a strike-slip setting. In: BIDDLE, K. T.; CHRISTIE-BLICK, N (eds.) Strikeslip deformation, basin formation and sedimention. Tulsa, SEPM, p. 1-34. (Society of Economic Paleontologists and Mineralogists. Special Publication, n. 37)

ASSINE, M.L. (1994) Paleocorrentes e paleogeografia na Bacia do Araripe, nordeste do Brasil. Revista Brasileira de Geociências, v. 24, n. 4, p. 223-232.

AZEVEDO, A (1980) Geografia do Brasil: bases fisicas, vida humana e vida econômica. $9^{\text {ed }}$. São Paulo, Editora Nacional, $325 \mathrm{p}$.

BABINSKI, M.; CHEMALE Jr., F.; HARTMANN, L.A.; VAN SCHMUS, W.R.; SILVA, L.C. (1996) Juvenile accrection at 750-700 Ma in southern Brazil. Geology, v. 24, n. 5, p. 439-442.

BADI, W.S.R.; GONZALEZ, A.P. (1980) Jazida Santa Maria Pb e Zn no membro Vargas -RS. In: CONGRESSO BRASILEIRO DE GEOLOGIA, 31., Camboriú, SC, Anais.... Camboriú, SBG, v. 3, p. 1360-1372.

BALLANCE. P.F. (1984) Sheet-flow-dominated gravel fans of the nonmarine middle Cenozoic Simmler Formation, central California. Sedimentary Geology, v. 38, n. 1-4, p. 337-359.

BARBOSA, O. (1939) Jazidas de minerais metálicos no Rio Grande do Sul. Mineração e Metalurgia, v. 4, n. 22, p. 194.

BARBOSA, A.F. (1957) A série Maricá e sua posição na coluna geológica do estado do Rio Grande do Sul. Boletim da Sociedade Brasileira de Geologia, v. 6, n. 2, p. 5-19.

BASEI, M.A.S.; BRITO NEVES, B.B. (1992) Características geológicas da transição Proterozóico-Fanerozóico no Brasil. In: MARCO GUTIERREZ, J.G.; SAAVEDRA, J.; RÁBANO, I. (eds.). Paleozbico Inferior de IberoAmerica. Madrid, Universidad de Extremadura, p. 331-342.

BASEI, M.A.S.; KAWASHITA, K.; SIGA Jr., O. (1987) Idade, características litoestratigráficas e estruturais do Grupo Itajaí. In: SIMPÓSIO SUL-BRASILEIRO DE GEOLOGIA, 3., Curitiba, 1987. Atas... Curitiba, SBG, v. 1, p. 93-106.

BASU, A.; YOUNG, S.W.; SUTTNER, L.J; JAMES, W.C.; MACK, G.H. (1975) Re-evaluation of the use of undulatory extinction and polycristallinity in detrital quartz for provenance determination. Journal of Sedimentary Petrology, v. 45, n. 4, p. 873-882.

BATES, C.C. (1953) Rational theory of delta formation. American Association of Petroleum Geologists Bulletin, v. 37 , n. 9 , p. $2119-2162$.

BEATY, C.B. (1963) Origin of alluvial fans, White Mountains, California and Nevada. American Association of Geographers Annals, v. 53, n. 4, p. 516-535.

BECKEL, J. (1992) Evolução geotectônica da Bacia do Camaquã, RS: proposta de classificação dentro de um conceito mobilista. In: WORKSHOP SOBRE AS BACIAS MOLÁSSICAS BRASILIANAS, 1. São Leopoldo. 1992. Boletim de Resumos Expandidos. São Leopoldo, SBG/UNISINOS, p.1-5.

BECKEL, J. (1992) Características físico-químicas do fluido hidrotermal formador das mineralizaçôes de cobre das Minas de Camaquã, RS. In: WORKSHOP SOBRE AS BACIAS MOLÁSSICAS BRASILIANAS, 1. São Leopoldo. 1992. Boletim de Resumos Expandidos. São Leopoldo, SBG/UNISINOS, p. 6-11.

BECKER, R; FERNANDES, L.A.D. (1982) Caracterização faciológica de uma sequência vulcano-sedimentar eopaleozoica na Folha Passo do Tigre (RS). Acta Geologica Leopoldensia, v. 6, n. 13, p. 287-322.

BETTENCOURT, J.S. (1972) A mina de cobre de Camaquã, RS. São Paulo, SP, 176 p. (Tese - Doutorado)- Instituto de Geociências, Universidade de São Paulo. 
BETTENCOURT, J.S.; DAMASCENO, E.C. (1974) Análise tectônica e controles de mineralização no distrito cuprífero de Camaquã, RS. In: CONGRESSO BRASILEIRO DE GEOLOGIA, 28., Porto Alegre, 1974. Anais... Porto Alegre. SBG, v. 1, p. 85-106.

BEURLEIN, K.; MARTINS, E.A. (1953) A idade da "Série Camaquã" e dos Conglomerados do Seival, R. G. Sul. Engenharia, Mineração e Metalurgia, v. 28, n. 108, p. 307-308.

BEURLEIN, K.; SENA SOBRINHO, M; MARTINS, E.A. (1955) Formações Gondwânicas do Rio Grande do Sul. Boletim do Museu Nacional. série Geologia, n. 22, 55 p.

BIGARELLA, J.J.; BECKER, R.D.; DUARTE, G.M. (1969) Coastal dune structures from Paraná (Brazil). Marine Geology, v. 7, n. 1, p. 5-55.

BLAIR, T.C. (1987) Sedimentary processes, vertical stratification sequenes, and geomorphology of the Roaring River alluvial fan, Rocky Mountain National Park, Colorado. Journal of Sedimentary Petrology, v. 57, p. 1-18.

BLAIR, T.C.; BILODEAU, W.L. (1987) Development of tectonic cyclothems in rift, pull-apart, and foreland basins: Sedimentary response to episodic tectonism. Geology, v. 16, p. 517-520.

BLAIR, T.C.; McPHERSON, J.G. (1992 $\left.{ }^{a}\right)$ The Trollheim alluvial fan and facies model revisited. Geological Society of America Bullettin, v. 104, p. 762-769.

BLAIR, T.C.; McPHERSON, J.G. $\left(1992^{\mathrm{b}}\right)$ The Trollheim alluvial fan and facies model revisited. Reply to R.L. Hooke. Geological Society of America Bulletin, v. 105, p. 564-567.

BLAIR, T.C.; McPHERSON, J.G. (1994ª) Alluvial fan process and forms. In: ABRAHAMS, A D.; PARSONS, A (eds) Geomorphology of Desert Environments. London, Chapman Hall, p. 354-402.

BLAIR, T.C.; McPHERSON, J.G. (1994) The natural distinction of alluvial fans from rivers based on morphology, hydraulic processes, sedimentary processes, and facies. Journal of Sedimentary Research. Section A, v. 64 , n. 3 , p. $450-489$.

BLATT, H. (1967) Original characteristics of clastic quartz grains. Journal of Sedimentary Petrology, v. 37, p. 401-424.

BLISSENBACH, E. (1954) Geology of alluvial fans in semi-arid regions. Geological Society of America Bulletin, v. 65 , n. 2 , p. $175-190$.

BLUCK, B.J. (1964) Sedimentation of an alluvial fan in southern Nevada. Journal of Sedimentary Petrology, v. 34, p. $395-400$.

BOCCHI, P.R. (1970) Geologia da Folha de Caçapava do Sul, Rio Grande do Sul. Boletim da Divisão de Geologia e Mineralogia DNPM, Rio de Janeiro, n. 245, p. 1-83.

BOIANO, U. (1997) Anatomy of a siliciclastic turbidite basin: the Gorgoglione Flysch, Upper Miocene, southern Italy: physical stratigraphy, sedimentology and sequence-stratigraphic framework. Sedimentary Geology, v. 107, n. 1 , p. 231-262.

BONHOMME, M.E.; RIBEIRO, M.J. (1983) Datações K-Ar das argilas associadas a mineralizações de cobre da Mina Camaquã e de suas encaixantes. In: SIMPÓSIO SUL-BRASILEIRO DE GEOLOGIA, 1., Porto Alegre, 1983. Atas.... Porto Alegre, SBG, v. 1, p. 82-88.

BOSSI, J.; CAMPAL, N. (1992) Magmatismo y tectónica transcurrente durante el Paleozoico Inferior en Uruguay. In: MARCO GUTIERREZ, J.G.; SAAVEDRA, J.; RÁBANO, I. (eds.). Paleozóico Inferior de lbero-America. Madrid, Universidad de Extremadura, p. 343-356.

BOSSI, J.; CAMPAL, N.; CIVETTA, L.; GIRARDI, V.A.V.; MAZZUCCHELLI, M.; NEGRINI, L.; RIVALENTI, G.; FRAGOSO CESAR, A.R.S.; SINIGOI, S.; TEIXEIRA, W.; PICCIRILLO, E.M.; MOLESINI, M. (1993) Early 
Proterozoic dike swarms from western Uruguay: geochemistry, $\mathrm{Sr}-\mathrm{Rb}$ isotopes and petrogenesis. Chemical Geology, v. 106, n. 3-4, p. 263-277.

BOSSI, J.; FERRANDO, L.; ALBANEL, H. (1967) Basamento cristalino del Sureste del Uruguay. Bol. 78, Facultad de Agronomia. Montevideo - Uruguay.

BOUMA, A.H. (1962) Sedimentology of some flysch deposits. Amsterdam, Elsevier. 168 p.

BOWEN, A.J.; STOW, D.A.V. (1980) A physical model for the transport and sorting of fine grained sediment by turbidity currents. Sedimentology, v. 27, n. 1, p. 31-46.

BOWRING, S.A.; GROTZINGER, J.P.S.; ISACHSEN, C.E.; KNOLL, A.H.; PELECHATY, S.M.; KOLOSOV, P. (1993) Calibrating rates of early cambrian evolution. Science, v. 261, n. 3, p. 1293-1298.

BRENCHLEY, P.J.; NEWALL, G.; STANISTREET, I.G. (1979) A storm surge origin for sandstone beds in an epicontinental platform sequence (Ordovician, Norway). Sedimentary Geology, v. 22, n. 3-4, p. 185-217.

BRITO NEVES, B.B.; CORDANI, U.G. (1991) Tectonic evolution of South America during the Late Proterozoic. Precambrian Research, v. 53, p. 23-40.

BULL, W.B. (1963) Alluvial-fan deposits in Western Fresno County, California. Journal of Geology, v. 71, p. 243251.

BULL, W.B. (1964) Alluvial fans and near-surface subsidence in Western Fresno County, California. United States Geological Survey. Professional Paper 437A, 70 p.

BULL, W.B. (1972) Recognition of alluvial-fan deposit in the stratigraphic record. In: RIGBY, J K; HAMBLIN, W.K. (eds) Recognition of Ancient Sedimentary Environments. Tulsa, SEPM, p. 63-83. (Society of Economic Paleontologists and Mineralogists. Special Publication, n. 16)

BULL, W.B. (1977) The alluvial-fan environment. Progress in Physical Geography, v. 1, p. 222-270.

BUSBY, C.J.; INGERSOLL, R.V. (1995) Tectonics of sedimentary basins. Cambridge, Blackwell Science. 579 p.

CAMOzZATO, E. (1984) Cachoeira do Sul Folha SH.22-Y-A - Texto e Mapas. In: Projeto Mapas Metalogenéticos e de Previsão de Recursos Minerais (Coordenação de L.C. SILVA e D.R. TRAININI), CPRM/DNPM.

CANT, D.J;; WALKER, R.G. (1976) Development of a braided-fluvial facies model for the Devonian Battery Point Sandstone, Quebec. Canadian Journal of Earth Sciences, v. 13, n. 1, p. 102-119.

CANT, D.J;; WALKER, R.G. (1978) Fluvial process and facies sequences in the sandy braided South Saskatchewan River, Canada. Sedimentology, v. 25, n. 5, p. 625-648.

CARAVACA, G.; FERNANDES, L.A.D.; MENEGAT, R.; SCHERER, C.M.S. (1995) Proveniência dos conglomerados da Formação Arroio dos Nobres e implicações tectônicas na região de Encruzilhada do Sul, RS. In: SIMPÓSIO NACIONAL DE ESTUDOS TECTÔNICOS, 5., Gramado, RS, 1995, Boletim de Resumos Expandidos, Gramado, SBG, Núcleo RS, p. 272-273.

CARRARO, C.C.; GAMERMANN, N.; EICK, N.C.; BORTOLUZZI, C.A.; JOST, H.; PINTO, J.F. (1974) Mapa geológico do estado do Rio Grande do Sul. Escala 1:000.000, Porto Alegre, UFRGS/FAPERGS/GERGS, 1 folha.

CARVALHO, P.F. (1929) Reconhecimento geológico effectuado no município de Caçapava, Rio Grande do Sul, Brasil. Boletim do Serviço Geologico e Mineralogico do Brasil, Relatorio Annual do Director, 1928, p. 41-55.

CARVALHO, P.F. (1932) Reconhecimento Geológico no Estado do Rio Grande do Sul. Boletim.Serviço Geologico e Mineralogico, n. 66, p.1-72.

CARVALHO, P.F. (1937) Recursos minerais do estado do Rio Grande do Sul. Boletim do Serviço Geologico e Mineralogico do Brasil, n. 72, p. 1-72. 
CHAVEZ, M. (1975) Atmospheric, solar and MTF corrections of ERTS digital imagery. In: AMERICAN SOCIETY OF PHOTOGRAMMETRY FALL CONVENTION. Proceedings. Phoenix, p. 69-69a.

CHEEL, R.J.; LECKIE, D.A. (1992) Coarse-grained storm beds of the Upper Cretaceous Chungo Member (Wapiabi Formation), southern Alberta, Canada. Journal of Sedimentary Petrology, v. 62, n. 6, p. 933-945.

CHEMALE Jr., F.; COSTA, A.F.U.; LESSA DIAS, N.; MAGRO, L.F. (1994) Gravimetria e geologia estrutural da Bacia do Camaquã, RS: resultados preliminares. In: CONGRESSO BRASILEIRO DE GEOLOGIA, 38., Balneário Camboriú, 1994. Boletim de Resumos Expandidos. Balneário Camboriú, SBG, v.1, p. 572.

CHEMALE Jr., F.; HARTMANN, L.A.; BABINSKI, M.; WILDNER, W.; VAN SCHMUS, W.R. (1994) Evolução tectônica do Bloco São Gabriel, RS. In: CONGRESSO BRASILEIRO DE GEOLOGIA, 38., Balneário Camboriú, 1994. Boletim de Resumos Expandidos. Balneário Camboriú, SBG, v. 1, p. 232-233.

CHRISTIE-BLICK, N.; BIDDLE, K.T. (1985) Deformation and basin formation along strike-slip faults. Tulsa, SEPM.

p. 1-34. (Society of Economic Paleontologists and Mineralogists. Special Publication, n. 37)

CIGUEL, J.H.G.; GÓIS, R. (1989) O Paleozóico Inferior das regiões sul-sudeste do Brasil. Correlácion Geológica, v. 5 , p. $165-178$.

CIGUEL, J.H.G.; GÓIS, R.; ACEÑOLAZA, F.G. (1991) Ocorrência de icnofósseis em depósitos molássicos da Formação Camarinha (Neoproterozóico III - Cambriano Inferior), no estado do Paraná, Brasil. Correlácion Geologica, v. 9, p. 157-158.

COIMBRA, A.M.; FERNANDES, L.A.; MORAES, M.C.; MELO, M.S. (1992ª) Métodos de estudos de litologias e paleocorrentes de cascalhos em terraços do baixo Ribeira do Iguape (SP). Anais da Academia Brasileira de Ciências, v. 64, n. 3, p. 253-267.

COIMBRA, A.M.; GÓES, A.M.; HACHIRO, J.; SANT'ANNA, L.G.; HELlMEISTER Jr., Z.; CABRAL Jr., M.; MORAES, M.C.; STEFANI, F.L.; VIEIRA, P.C. $\left(1992^{b}\right)$ Proposta de classificação integrada de rochas sedimentares clásticas. In: CONGRESSO BRASILEIRO DE GEOLOGIA, 37., São Paulo, 1992. Boletim de Resumos Expandidos. São Paulo, SBG, v. 2, p. 419-421.

COLLINSON, J.D.; THOMPSON, D.B. (1989) Sedimentary structures. London, Unwin Hyman, 207 p.

CONDIE, W.F. (1989) Plate tectonics and crustal evolution. Oxford, Pergamon Press, 476 p.

CONEY, P.J.; JONES, D.L.; MONGER, J.W.H. (1980) Cordilleran suspect terranes. Nature, v. 288, n. 5789, p. 329333.

CORDANI, U.G.; HALPERN, M.; BERENHOLC, M. (1974) Comentários sobre as determinações geocronológicas na Folha Porto Alegre. In: Carta Geologica do Brasil ao Milionésimo, Texto explicativo das Folhas Porto Alegre e Lagoa Mirim. DNPM, Brasília, p. 70-85.

COSTA, A.F.U.; CHEMALE Jr., F.; MAGRO, L.F.; LESSA DIAS, N. (1994) Modelagem gravimétrica da Bacia do Camaquã, RS. In: SIMPÓSIO NACIONAL DE ESTUDOS TECTÔNICOS, 5., Gramado, 1995. Boletim de Resumos Expandidos. Gramado, SBG- Núcleo RS, p. 234-235.

COUTINHO, J.M.V.; COIMBRA, A.M. (1988) Tabela de identificação óptica de minerais transparentes em sedimentos. Departamento de Paleontologia e Estratigrafia, IG-USP.

CRIMES, T.P. (1987) Trace fossils and correlation of late Precambrian and early Cambrian strata. Geological Magazine, v. 124 , n. 2, p. 97-119.

CRIMES, T.P.; ANDERSON, M.M. (1986) Trace fossils from late Precambrian-early Cambrian strata of southeastern Newfoundland (Canada): temporal and environmental implications. Journal of Paleontology, v. 59 , n. 2, p. 310-343. 
CRIMES, T.P.; GERMS, G.J.B. (1982) Trace fossils from the Nama Group (Precambrian-Cambrian) of southeastern Africa (Namibia). Journal of Paleontology, v. 56 , n. 6, p. 890-907.

CRITELLI, S. (1991) Evoluzione delle mode detritiche delle sucessioni arenitiche terziarie dell'Appennino Meridionale. Memorie della Società Geologica Italiana, v. 47, p. 55-93.

CRITELLI, S.; INGERSOLL, R.V. (1994) Sandstone petrology and provenance of the Siwalik Group (northwestern Pakistan and western-southeastern Nepal). Journal of Sedimentary Research. Section A, v. 64, n. 4, p. 815-823.

CROSTA, A.P. (1990) Discriminação de Principais Componentes com base em relações quantitativas e espectrais. In: SIMPÓSIO DE QUANTIFICAC̨ÃO EM GEOCIÊNCIAS, 4., Rio Claro, 1990. Boletim de Resumos. Rio Claro, IGCE-UNESP.

CROSTA, A.P. (1992) Processamento Digital de Imagens de Sensoriamento Remoto. Campinas, IG/UNICAMP. 170 p.

CROSTA, A.P.; MOORE, J.MCM. (1989) Enhancement of Landsat Thematic Mapper Imagery for Residual Soil Mapping in SW Minas Gerais State, Brazil: A Prospecting Case History in Greenstone belt Terrain. In: THEMATIC CONFERENCE: REMOTE SENSING FOR EXPLORATION GEOLOGY, 7., Calgary, 1989. Proceedings. Calgary, p. 1173-1187.

CROWELL, J.C. (1974) Origin of late cenozoic basins in southern California. In: DICKINSON, W.R. (ed.) Tectonics and sedimentation. Tulsa, SEPM, p. 190-204. (Society of Economic Paleontologists and Mineralogists. Special Publication, n. 22)

CROWELL, J.C. (1982) The Violin Breccia, Ridge Basin, southern California. In: CROWELL, J.C.; LINK, M.H. (eds) Geology of the Ridge Basin, Southern California. Los Angeles, SEPM, Pacific Section, p. 89-98.

DAVIES, I.C.; WALKER, R.G. (1974) Transport and deposition of resedimented conglomerates: the Cap Enragé Formation, Gaspe, Quebec. Journal of Sedimentary Petrology, v. 44, n. 4, p. 1200-1216.

DAVIS, W.M. (1930) Rock floors in arid and humid climates. Journal of Geology, v. 38, p. 1-27.

DAVIS, W.M. (1938) Sheetfloods and streamfloods. Geological Society of America Bulletin, v. 49, p. 1337-1416.

DECKER, J.; HELMOND, K.P. (1985) The effect of grain size in detrital modes: a test of Gazzi-Dickinson pointcounting method - Discussion. Journal of Sedimentary Petrology, v. 55, n. 4, p. 618-620.

DELANEY, P.J.V.; GOÑI, J.C. (1963) Correlação preliminar entre as formações Gondwânicas do Uruguai e do Rio Grande do Sul, Brasil. Boletim Paranaense de Geografia, n. 8 - 9, p. 3-21.

DELLA FÁVERA, J.C. (1984) Eventos de sedimentação episódica nas bacias brasileiras. Uma contribuição para atestar o caráter pontuado do registro sedimentar. In: CONGRESSO BRASILEIRO DE GEOLOGIA, 33., Rio de Janeiro, 1984. Anais. Rio de Janeiro, SBG, v. 1, p. 489-501.

DE ROS, L.F. (1986) Petrologia e características do reservatório da Formação Sergi (Jurássico) no Campo de Sesmaria, Bacia do Recôncavo, Brasil. Ciência-Técnica-Petróleo, Seção Exploração de Petróleo, n. 19, p. 1-107.

DE ROS, L.F.; MORAD, S.; PAIM, P.S.G. (1994) The role of detrital composition on the diagenetic evolution of continental molasses: evidences from the Cambro-Ordovician Guaritas Sequence, southern Brazil. Sedimentary Geology, v. 92, p. 197-228.

DE ROS, L.F.; MORAES, M.A.S. (1984) Sequiência diagenética em arenitos: uma discussão inicial. In: CONGRESSO BRASILEIRO DE GEOLOGIA, 33., Rio de Janeiro, 1984. Anais... Rio de Janeiro, SBG, v. 2, p. 894-904.

DICKINSON, W.R. (1970) Interpreting detrital modes of graywacke and arkose. Journal of Sedimentary Petrology, v. 40, p. $695-707$. 
DICKINSON, W.R. (1980) Plate tectonics and petrologic associations. In: STRANGWAY, D.W. (ed.) The Continental Crust and its mineral deposits. Toronto, Geological Association of Canada, p. 341-360. (Geological Association of Canada. Special Paper, v. 20)

DICKINSON, W.R. (1988) Provenance and Sediment Dispersal in Relation to Paleotectonics and Paleogeography of Sedimentary Basins. In: KLEINSPEHN, K.L.; PAOLA, C. (eds.) New Perspectives in Basin Analysis. New York, Springer Verlag, p. 3-25.

DICKINSON, W.R.; SUCZEK, C.A. (1979) Plate tectonics and sandstone composition. American Association of Petroleum Geologists Bulletin, v. 63, n. 12, p. 2164-2182.

DOLIANITI, E. (1945) Descoberta de fósseis na Formação Maricá, estado do Rio Grande do Sul. Mineração $e$ Metalurgia, v. 9, n. 51, p. 110.

DOTT Jr., R.H. (1964) Wacke, graywacke and matrix - What approach to immature sandstone classification. Journal of Sedimentary Petrology, v. 34, n. 3, p. 625-632.

DOTT Jr., R.H.; BOURGEOIS, J. (1982) Hummocky stratification: significance of its variable sequences. Geological Society of America Bullettin, v. 93, n. 8, p. 663-680.

DRURY, S.A. (1987) Image Interpretation in Geology. London, Allen \& Unwin, 243 p.

DÜRR, S.B. (1994) Quick estimation of pebble volumes. Journal of Sedimentary Research. Section A, v. 64, n. 3 , p. $677-679$.

ENOS, P. (1977) Flow regimes in debris flow. Sedimentology, v. 24, n. 1, p. 133-142.

ERIKSSON, P.G.; SCHREIBER, U.M.; RECZKO, B.F.F.; SNYMAN, C.P. (1994) Petrography and geochemistry of sandstones interbedded with the Rooiberg Felsite Group (Transvaal Sequence, South Africa): implications for provenance and tectonic setting. Journal of Sedimentary Research. Section A, v. 64, n. 4, p. 836-846.

EYLES, N.; EYLES, C.H.; MIALL, A.D. (1983) Lithofacies types and vertical profile models: an alternative approach to the description and environmental interpretation of glacial diamict and diamictite sequences. Sedimentology, v. 30 , n. 2 , p. 393-410.

FACCINI, U.F.; PAIM, P.S.G.; FRAGOSO CESAR, A.R.S. (1987) Análise faciológica das molassas brasilianas na região das Minas do Camaquã, Eo-paleozóico do RS. In: SIMPÓSIO SUL-BRASILEIRO DE GEOLOGIA, 3., Curitiba, 1987. Atas.... Curitiba, SBG, v. 1, p. 75-91.

FAMBRINI, G.L. (1992) Petrografia da cunha molássica brasiliana da regiao do Vale do Arroio Boici, RS. Relatório final de Iniciação Científica, CNPq, Processo № 802340/88-1, São Paulo, 104 p. (inédito)

FAMBRINI, G.L.; FRAGOSO CESAR, A.R.S.; SILVA FILHO, W.F.; TEIXEIRA, G.; SAYEG, H.S.; MACHADO, R. (1995) Aplicação da análise estratigráfica de proveniência e paleocorrentes à Formação Santa Bárbara na região das Minas do Camaquã, RS. In: SIMPÓSIO SUL-BRASILEIRO DE GEOLOGIA, 6/ ENCONTRO DE GEOLOGIA DO CONE SUL,1, Porto Alegre, 1995. Boletim de Resumos Expandidos. Porto Alegre, SBGNúcleo RS, p. 187-191.

FAMBRINI, G.L.; FRAGOSO CESAR, A.R.S.; SILVA FILHO, W.F.; TEIXEIRA, G.; SAYEG, H.S.; MACHADO, R. (em preparação) Aplicação da análise estratigráfica de fácies, proveniência e paleocorrentes do Grupo Camaquã (transição Proterozóico-Cambriano) na Mina Uruguai e suas implicações na evolução tectonosedimentar da Bacia do Camaquã, RS. Boletim IG-USP, Série Científica, n. 29 (admitido para publicação).

FAMBRINI, G.L.; MARTIN, M.A.B.; FRAGOSO CESAR, A.R.S.; McREATH, I.; CHIARINI, A.; SILVA FILHO, W.F.; SAYEG, H.S.; MACHADO, R.; RIBEIRO DE ALMEIDA, T.I. (1996 ${ }^{\mathrm{a}}$ ) Registro preliminar sobre o vulcanismo Bom Jardim na borda sudoeste da Bacia do Camaquã, RS: evidências de atividade piroclástica 
subaquática sob a ação de ondas e correntes de turbidez. In: CONGRESSO BRASILEIRO DE GEOLOGIA, 39., Salvador, 1996. Boletim de Resumos Expandidos. Salvador, SBG - Núcleos Bahia/Sergipe, v. 5, p. 379-381. FAMBRINI, G.L.; SAES, G.S.; FRAGOSO CESAR, A.R.S.; SILVA FILHO, W.F.; SAYEG, H.S.; TEIXEIRA, G.;

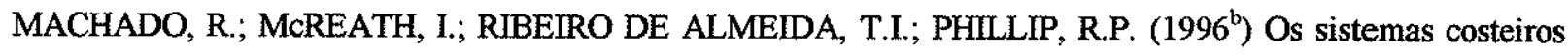
da Formação Santa Bárbara, Bacia do Camaquã, RS (transição Proterozóico-Fanerozóico): registro preliminar da sedimentação em ambiente de águas rasas dominado por ondas. In: CONGRESSO BRASILEIRO DE GEOLOGIA, 39., Salvador, 1996. Boletim de Resumos Expandidos. Salvador, SBG - Núcleos Bahia/Sergipe, v. 2, p. 204-206.

FAMBRINI, G.L.; SAYEG, H.S.; FRAGOSO CESAR, A.R.S. (1992ª) Variação de áreas-fonte da Formação Arroio dos Nobres (Cambriano) no Vale do Arroio Boici, RS: análise estratigráfica de proveniência e de paleocorrentes. In: CONGRESSO BRASILEIRO DE GEOLOGIA, 37., São Paulo, 1992. Boletim de Resumos Expandidos. São Paulo, SBG, v. 2, p. 441.

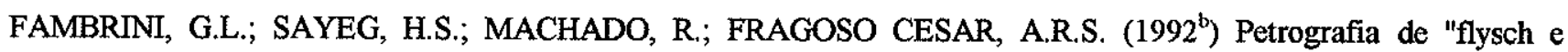
molasse" cambrianos da região do Vale do Arroio Boici, RS. In: WORKSHOP SOBRE AS BACIAS MOLÁSSICAS BRASILIANAS, 1., São Leopoldo,1992. Boletim de Resumos Expandidos. São Leopoldo, SBG/UNISINOS, p. 23-27.

FAMBRINI, G.L.; SAYEG, H.S.; MACHADO, R.; SILVA FILHO, W.F.; TEIXEIRA, G.; SALES, F.F.; RIBEIRO DE ALMEIDA, T.I.; McREATH, I. ; FRAGOSO CESAR, A.R.S. $\left(1996^{\circ}\right)$ Provenance and paleocurrents of the Santa Bárbara Formation, Camaquã Basin, RS (Proterozoic-Phanerozoic transition): examples from the Arroio Boici and the Minas do Camaquã regions. Anais da Academia Brasileira de Ciências, v. 68, n. 4, p. 599-600.

FEDO, C.M.; COOPER, J.D. (1990) Braided fluvial to marine transition: the basal Lower Cambrian Wood Canyon Formation, southern Marble Mountains, Mojave Desert, California. Journal of Sedimentary Petrology, v. 60, p. $220-234$.

FERNANDES, L.A. (1992) A cobertura suprabasáltica no Paraná e Pontal do Paranapanema (SP): os grupos Bauru $e$ Caiuá. São Paulo, 129 p. ( Dissertação - Mestrado) - Instituto de Geociências, Universidade de São Paulo.

FERNANDES, L.A.D.; TOMMASI, A.; PORCHER, C.C.; MARQUES TOIGO, M.; GUERRA SOMMER, M.; PICCOLI, A. M. (1988) Mapa Geologico 1:50.000 de Parte das Folhas Quitéria e Várzea do Capivarita. IGUFRGS. (inédito).

FERNANDES, L.A.D.; TOMMASI, A.; PORCHER, C.C. (1990) Esboço estrutural de parte do Batólito Pelotas -região de Quitéria-Capivarita. Acta Geologica Leopoldensia, v. 30, n. 2, p. 117-138.

FERNANDES, L.A.D.; TOMMASI, A;; PORCHER, C.C. (1992) Deformation patterns in the southern Brazilian branch of the Pan-African Dom Feliciano Belt: a reappraisal. Journal of South American Earth Sciences, v. 5 , n. 1, p. 77-96.

FERNANDES, L.A.D.; TOMMASI, A.; VAUCHEZ, A.; PORCHER, C.C.; MENEGAT,R.; KOESTER, E. (1993) Zona de cisalhamento transcorrente Dorsal do Canguçu: caracterização e importância na compartimentação tectônica do Cinturão Dom Feliciano. Revista Brasileira de Geociências, v. 2, n. 2, p. 257-266.

FERRANDO, L.A.; FERNANDEZ, A.N. (1971) Esquema tectonico-cronoestratigráfico del Pré-Devoniano en Uruguay. In: CONGRESSO BRASILEIRO DE GEOLOGIA, 25., São Paulo, 1971. Anais... São Paulo, SBG, v. 1, p. $199-210$

FOLK, R.L. (1954) The distinction between grain size and mineral composition in sedimentary rock nomenclature. Journal of Geology, v. 62, p. 344-359. 
FOLK, R.L. (1968) Petrology of Sedimentary Rocks. Austin, Hemphill's Publication, $170 \mathrm{p}$.

FRAGOSO CESAR, A.R.S. (1980) O Craton Rio de La Plata e o Cinturão Dom Feliciano no Escudo Uruguaio-SulRiograndense. In: CONGRESSO BRASILEIRO DE GEOLOGIA, 31., Camboriú, 1980. Anais.... Camboriú, SBG, v. 5, p. 2879-2892.

FRAGOSO CESAR, A.R.S. (1984) Evolução Paleoambiental e tectônica da Bacia do Camaquã: uma introdução. Porto Alegre, 103 p. (Dissertação - Mestrado) - Curso de Pós-Graduação em Geociências, Universidade Federal do Rio Grande do Sul.

FRAGOSO CESAR, A.R.S. (1990) Tectônica de Placas no Bloco São Gabriel (RS) em base nos dados geológicos, geocronológicos e geoquímicos. In: "WORKSHOP" GEOQUÍMICA ISOTÓPICA E LITOQUÍMICA DAS REGIÕ̃ES SUL E SUDESTE DO BRASIL. São Paulo, 1990. Boletim de Resumos. São Paulo, SBGq -IG-USP, p. 8-16.

FRAGOSO CESAR, A.R.S. (1991) Tectônica de Placas no Ciclo Brasiliano: as orogenias dos Cinturóes Dom Feliciano e Ribeira no Rio Grande do Sul. São Paulo, 366 p. (Tese - Doutorado) - Instituto de Geociências, Universidade de São Paulo.

FRAGOSO CESAR, A.R.S. (1992) A aplicação do conceito de orogenia no Ciclo Brasiliano com exemplos do Rio Grande do Sul. Boletim. IG-USP, n. 12, p. 41-43. (Série Publicação Especial)

FRAGOSO CESAR, A.R.S. (1993) As placas brasilianas do Sul e Sudeste da Plataforma Sul-Americana. In: SIMPÓSIO NACIONAL DE ESTUDOS TECTÔNICOS, 4., Boletim Resumos Expandidos, SBG, Núcleo MG, p. $183-188$.

FRAGOSO CESAR, A.R.S.; FACCINI, U.F.; PAIM, P.S.G.; LAVINA, E.L.; ALTAMIRANO, J.A.F. (1985) Revisão na Estratigrafia das Molassas do Ciclo Brasiliano no Rio Grande do Sul. In: SIMPÓSIO SUL-BRASILEIRO DE GEOLOGIA, 2., Florianópolis, 1985. Anais.... Florianópolis, SBG, p. 477-491.

FRAGOSO CESAR, A.R.S.; FAMBRINI, G.L.; SAYEG, H.S.; SILVA FILHO, W.F. da; MACHADO, R.; ALMEIDA, T.I.R. de; McREATH, I. (em preparação) As coberturas sedimentares do Escudo Gaúcho no Rio Grande do Sul: uma revisão. Revista Brasileira de Geociências, n. 29. (a ser submetido)

FRAGOSO CESAR, A.R.S; FAMBRINI, G.L.; SILVA FILHO, W.F. da; SAYEG, H.S.; MACHADO, R.; ALMEIDA, T.I.R.; McREATH, I. (1996) Grupo Camaquã: registro sedimentar e significado geotectônico da transição Vendiano-Cambriano no Rio Grande do Sul. Anais da Academia Brasileira de Ciências, v. 68, n. 4, p. 599.

FRAGOSO CESAR, A.R.S.; FIGUEIREDO, M.C.H.; SOLIANI Jr.; FACCINI, U.F. (1986) O Batólito Pelotas (Proterozóico Superior/ Eo-Paleozóico) no Escudo do Rio Grande do Sul. In: CONGRESSO BRASILEIRO DE GEOLOGIA, 34., Goiânia, 1986. Anais.... Goiânia, SBG, v. 4, p. 1322-1342.

FRAGOSO CESAR, A.R.S.; LAVINA, E.L.; PAIM, P.S.G.; FACCINI, U.F. (1984) A Antefossa Molássica do Cinturão Dom Feliciano no Escudo do Rio Grande do Sul. In: CONGRESSO BRASILEIRO DE GEOLOGIA, 33., Rio de Janeiro, 1984. Anais... Rio de Janeiro, SBG, v. 7, p. 3272-3283.

FRAGOSO CESAR, A.R.S.; MACHADO, R. (1997) Neoproterozoic terranes of the Gaúcho Shield (southern Brazil and Uruguay). In: SOUTH AMERICAN SIMPOSIUM ON ISOTOPE GEOLOGY, Campos de Jordão, 1997. Extended Abstrats. Campos do Jordão, FAPESP/CNPq/CPRM. p. 65-68.

FRAGOSO CESAR, A.R.S.; MACHADO, R.; MELLO, F.M.; SAYEG, H.S.; FAMBRINI, G.L.; PINTO, R.F. (1993 ${ }^{a}$ ) As placas proterozóicas do Escudo Gaúcho. In: SIMPÓSIO INTERNACIONAL DEL NEOPROTEROZOICOCAMBRICO DE LA CUENCA DEL PLATA., 1., La Paloma-Minas, 1993. Resumenes Extensos. La Paloma, DINAMIGE/Facultad de Agronomia, v. 1, part. 3. 
FRAGOSO CESAR, A.R.S.; MACHADO, R.; MELLO, F.M.; SAYEG, H.S.; PINTO, R.F.; FAMBRINI, G.L. (1993 ) As placas, oceanos e orogenias do Ciclo Brasiliano no Rio Grande do Sul. In: SIMPÓsIO SUL-BRASILEIRO DE GEOLOGIA, 5., Curitiba, 1993. Boletim de Resumos e Programa. Curitiba, SBG-Núcleos PR/SC/RS, p. 25-26.

FRAGOSO CESAR, A.R.S.; MACHADO, R.; MELLO, F.M. de; SAYEG, H. S.; SILVA FILHO, W.F. da ; FAMBRINI, G.L. (1994) Acresção Neoproterozóica no sul do Brasil e Uruguai: A Placa Rio de La Plata e os Terrenos Piratini e Rio Vacacai. In: CONGRESSO BRASILEIRO DE GEOLOGIA, 38., Balneario Camboriú, 1994. Boletim de Resumos Expandidos. Balneário Camboriú, SBG, v. 1, p. 206-207.

FRAGOSO CESAR, A.R.S.; MACHADO, R.; MONTEIRO, R.L.; SALLET, R. (1990) Nappes e estruturas correlatas do Cinturão Dom Feliciano no Escudo Uruguaio-Sulriograndense: uma introdução ao problema. Acta Geologica Leopoldensia, v. 30, n. 13, p. 75-92.

FRAGOSO CESAR, A.R.S.; MACHADO, R.; PHILLIP, R.P.; MELLO, F.M. de; ENDO, I.; NUMMER, A.R.; PRECIOZZI, F.P.; FAMBRINI, G.L.; SAYEG, H.S. (1998) Terrenos suspeitos a sul da Placa Sanfranciscana (SE da Plataforma Sul-Americana). In: CONGRESO URUGUAYO DE GEOLOGIA, 2., Punta del Este, 1998. Actas.... Punta del Este, SUG/Facultad de Ciencias, p. 1-6.

FRAGOSO CESAR, A.R.S.; MACHADO, R.; SAYEG, H.S.; FAMBRINI, G.L. (1992) Bacias orogênicas do Ciclo Brasiliano no Rio Grande do Sul e Uruguai. In: WORKSHOP SOBRE AS BACIAS MOLÁSSICAS BRASILIANAS, 1., São Leopoldo, 1992. Boletim de Resumos Expandidos. São Leopoldo, SBG/UNISINOS, p. 47-53.

FRAGOSO CESAR, A.R.S.; MACHADO, R.; WERNICK, E.; McREATH, I.; PHILLIP, R.P.; SALLET, R.; ENDO, I.; MELLO, F.M. de; ALMEIDA, T.I.R. de; SAYEG, H.S.; FAMBRINI, G.L.; SILVA FILHO, W.F. da; DEHLER, N.M.; TEIXEIRA, A.L. (1995) The Brasiliania plate, the western Paranaides and eastern Atlantides and Africanides accreted terranes: a model for the Neoproterozoic tectonic collage of southeastern South America. In: SIMPÓSIO SUL-BRASILEIRO DE GEOLOGIA, 6/ ENCONTRO DE GEOLOGIA DO CONE SUL, 1., Porto Alegre, 1995. Boletim de Resumos Expandidos. Porto Alegre, SBG - Núcleo RS, p. 20-26.

FRAGOSO CESAR, A.R.S.; SILVA FILHO, W.F. da; FAMBRINI, G.L.; SAYEG, H.S.; MELLO, F.M.; MACHADO, R.; ALMEIDA, T.I.R. de; McREATH, I. (no prelo) The Proterozoic-Phanerozoic transition in Rio Grande do Sul state, southern Brazil: the Maricá basin, the Bom Jardim magmatic arc and the Camaquã basin. In: AMOS, A.J.; ROCHA CAMPOS, A.C.; GAMUNDI, O.L. (Eds.) The Sedimentary Basins of South America. Amsterdam, Elsevier.

FRAGOSQ CESAR, A.R.S.; SOLIANI Jr., E. (1984) Compartimentação Tectônica do Cráton Rio de La Plata. In: CONGRESSO BRASILEIRO DE GEOLOGIA, 33., Rio de Janeiro, 1984. Anais... Rio de Janeiro, SBG, v. 5, p. 2426-2434.

FRAGOSO CESAR, A.R.S.; WERNICK, E.; SOLIANI Jr., E. (1982ª) Associaçoes petrotectônicas do Cinturão Dom Feliciano (SE da Plataforma Sul-Americana). In: CONGRESSO BRASILEIRO DE GEOLOGIA, 32., Salvador, 1982. Anais.... Salvador, SBG, v. 1, p. 1-12.

FRAGOSO CESAR, A.R.S.; WERNICK, E.; SOLIANI Jr., E. $\left(1982^{b}\right.$ ) Evolução geotectônica do Cinturão Dom Feliciano- Uma contribuição através da aplicação do modelo da Tectônica de Placas. In: CONGRESSO BRASILEIRO DE GEOLOGIA, 32., Salvador, 1982. Anais.... Salvador, SBG, v. 1, p. 13-23. 
FUCK, R.A.; MARINI, O.J.; TREIN, E. (1967) A Formação Guaratubinha. In: BIGARELLA, J.J.; SALAMUNI, R.; PINTO, V.M. (eds.). Geologia do Pré-Devoniano e intrusivas subsequientes da porção oriental do Estado do Paraná. Boletim Paranaense de Geociências, Curitiba, v. 23-25, p. 237-255.

FULFARO, V.J.; SAAD, A.R.; ETCHEBEHERE, M.L. de C.; CIGUEL, J.H.G. (in memorian) (1992) Paleozóico Inferior do Brasil. In: MARCO GUTIERREZ, J.G.; SAAVEDRA, J.; RÁBANO, I. (eds.) Paleozóico Inferior de Ibero-America. Universidad de Extremadura, p. 317-330.

GALLOWAY, W.E. $\left(1989^{\mathrm{a}}\right)$ Genetic stratigraphic sequences in basin analysis I: architecture and genesis of floodingsurface bounded deposicional units. American Association of petroleum Geologists Bulletin, v. 73, n. 2, p. $125-142$.

GALLOWAY, W. E. $\left(1989^{\mathrm{b}}\right)$ Genetic stratigraphic sequences in basin analysis II: aplication to Northwest Gulf of Mexico Cenozoic Basin. American Association of petroleum Geologists Bulletin, v. 73, n. 2, p. 143-154.

GAZZI, P.; ZUFFA, G.E.; GANDOLFI, G.; PAGANELLI, L. (1973) Provenienza e dispersione litoranea delle sabbie delle spiagge addriatiche fra le foci dell'Isonzo e del Foglia: inquadramento regionale. Memorie della Società Geologica Italiana, v. 12, p. 1-37.

GESICKI, A.L.D. (1996) Geologia da Formação Aquidauana (Neopaleozóico, Bacia do Paraná) na porção centro* norte do estado de Mato Grosso do Sul. São Paulo, 126 p. (Dissertação - Mestrado) - Instituto de Geociências, Universidade de São Paulo.

GHIBAUDO, G. (1992) Subaqueous sediment gravity flow deposits: practical criteria for their field description and classification. Sedimentology, v. 39, n. 3, p. 423-454.

GLOPPEN, T.G.; STEEL, R.J. (1981) The deposits, internal structure and geometry in six alluvial fan-delta bodies (Devonian-Norway) - a study in the significance of bedding sequence in conglomerates. In: ETHRIDGE, F.G.; FLORES, R.M. (eds.) Recent and Ancient Depositional Environments: models for exploration. Tulsa, SEPM, p. 49-69. (Society of Economic Paleontologists and Mineralogists. Special Publication, n. 39)

GOÑI, J.C. (1961) O Rapakivi de Lavras. Jazidas Metálicas associadas. Lavras do Sul, Rio Grande do Sul, Brasil. Boletim da Escola de Geologia, Universidade do RGS, n. 7, Porto Alegre, p. 1-107.

GOÑI, J.C.; GOSO, H.; ISSLER, R.S. (1962) Estratigrafia e Geologia Econômica do Pré-Cambriano e Eo-Paleozóico Uruguaio e Sul-Rio-Grandense. Avulso da Escola de Geologia, Universidade do RGS, Porto Alegre, v. 3, p. 1105 .

GONZALEZ, M; 'TEIXEIRA, G. (1980) Consideraçб̃es sobre a estratigrafia e ambientes de sedimentação da região das minas de Camaquã e jazida Santa Maria-RS. In: CONGRESSO BRASILEIRO DE GEOLOGIA, 31., Camboriú, 1980. Anais.... Camboriú, SC, SBG, v. 3, p. 1513-15-24.

GORCEIX, H. (1875) Résultat d'une première exploration de La Province du Rio Grande do Sul (Brésil). Bullettin de la Societe Geólogique de France, v. 3, Serv. III, Paris.

GRAHAM, J. (1988) Collection and analysis of field data. In: TUCKER, M. (ed.) Techniques in sedimentology. Blackwell Scientific Publications. p. 5-62.

GRAHAM, S.A. (1983) Evolving concepts and teaching approaches in tectonic and sedimentation. Journal of Geological Education, v. 31, p. 266-276.

GRAHAM, S.A.; INGERSOLL, R.V.; DICKINSON, W.R. (1975) Common provenance for lithic grains in carboniferous sandstones from Ouachita Mountains and Black Warrior basin. Journal of Sedimentary Petrology, v. 46, p. 620-632. 
GRAHAM, S.A.; TOLSON, R.B.; DECELLES, R.V.; INGERSOLL, R.V.; BARGAR, E.; CALDWELL, M.; CAVAZZA, W.; EDWARDS, D.P.; FOLLO, M.F.; HANDSCHY, J.F.; LEMKE, L.; MOXON, I.; RICE, R.; SMITH, G.A.; WHTTE, J. (1986) Provenance modelling as a technique for analysing source terrane evolution and controls on foreland sedimentation. In: ALLEN, P.A.; HOMEWOOD, P. (eds.) Foreland Basins. p. $425-$ 436 (International Association of Sedimentologists Special Publication n. 8)

GRESSE, P.G.; CHEMALE Jr., F.; SILVA, L.C.; WALRAVEN, F.; HARTMANN, L.A. (1996) Late- to post-orogenic basins of the Pan-African-Brasiliano collision orogen in southern Africa and southern Brazil. Basin Research, v. 8 , n. 2 , p. 157-171.

GROTZINGER, J.P.S.; BOWRING, S.A.; SAYLOR, B.Z.; KAUFMAN, A.J. (1995) Biostratigraphic and geochronologic constraints on early animal evolution. Science, v. 270, n. 2, p. 598-604.

HAMBLIN, W.K. (1961) Micro-cross-lamination in Upper Keweenawan sediments of northern Michigan. Journal of Sedimentary Petrology, v. 31, p. 390-401.

HAMBLIN, A.P.; WALKER, R.G. (1979) Storm-dominated shallow marine deposits: The Fernie-Kootenay (Jurassic) transition, southern Rocky Mountains. Canadian Journal of Earth Sciences, v. 16, n. 9, p. 1673-1690.

HAMPTON, M.A. (1979) Buoyancy in debris flows. Journal of Sedimentary Petrology, v, 49, n. 5, p. 753-758.

HANCOCK, P.L. (1994) Continental Deformation. Oxford, Pergamon Press, 421 p.

HARDING, T.P. (1985) Seismic characteristics and identification of negative flower structures, positive flower structures, and positive structural inversion. American Association of Petroleum Geologists Bulletin, v. 69, n. 4, p. 582-600.

HARMS, J.C.; SOUTHARD, J.B.; SPEARING, D.R.; WALKER, R.G. (1975) Depositional environments as interpreted from primary sedimentary structures and stratification sequences. SEPM Short Course n. 2, 161 p. (Society of Economic Paleontologists and Mineralogists).

HARMS, J.C.; SOUTHARD, J.B.; WALKER, R.G. (1982) Structures and sequences in clastic rocks. SEPM Short Course n, 9, 249 p. (Society of Economic Paleontologists and Mineralogists).

HARTNADY, C.; JOUBERT, P.; STOWE, C. (1985) Proterozoic crustal evolution in Southeastern Africa, Episodes, v. 8, n. 4 , p. $236-244$.

HASUI, Y.; CARNEIRO, C.D.R.; COIMBRA, A.M. (1975) The Ribeira Folded Belt. Revista Brasileira de Geociências, v. 5, n. 4, p. 257-266.

HENDRY, H.E. (1976) The orientation of discoidal clasts in resedimented conglomerates, Cambro-Ordovician, Gaspe, eastern Quebec. Journal of Sedimentary Petrology, v. 46, p. 48-55.

HEWARD, A.P. $\left(1978^{\mathrm{a}}\right)$ Alluvial fan and lacustrine sediments from the Stephanian A and B (La Magdalena, Cifiera Matallana and Sabero) coalfields, northern Spain. Sedimentology, v. 25, p. 451-488.

HEWARD, A.P. $\left(1978^{\mathrm{b}}\right)$ Alluvial fan sequence and megasequence models: with examples from Westphalian D Stephanian B coalfields, Northern Spain. In: MIALL, A.D. (ed.) Fluvial Sedimentology. Calgary, Canadian Society of Petroleum Geologists. p. 669-702. (Canadian Society of Petroleum Geologists Memoir n. 5)

HEWARD, A.P. (1981) A review of wave-dominated clastic shoreline deposits. Earth Science Review, v. 17, n. 2, p. 223-276.

HOLZ, M. (1987) Leques aluviais -faciologia e ocorrência em sedimentitos do Supergrupo Tubarão (Eo-Permiano) da Bacia do Paraná no Rio Grande do Sul. Acta Geologica Leopoldensia, v. 11, n. 25, p. 65-104.

HOOKE, R.L. (1967) Processes in arid-region alluvial fans. Journal of Geology, v. 75, p. 438-460. 
HORTON, B.K.; SCHMITT, J.G. (1996) Sedimentology of a lacustrine fan-delta system, Miocene Horse Camp Formation, Nevada, USA. Sedimentology, v. 43, n. 1, p. 133-155.

HOWARD, J.L. (1992) An evaluation of shape indices as palaeoenvironmental indicators using quartzite and metavolcanic clasts in Upper Cretaceous to Palaeogene beach, river and submarine fan conglomerates. Sedimentology, v. 39, n. 3, p. 471-486.

HOWELL, D.G.; NORMARK, W.R. (1982) Sedimentology of submarine fans. In: SCHOLLE, P.A.; SPEARING, D. (Eds.) Sandstone Depositional Environments. Tulsa, AAPG, p. 365-404. (American Association of petroleum Geologists Memoir n. 31)

IBBEKEN, H.; SCHLEYER, R. (1991) Source and Sediment - A case study of provenance and mass balance at an active plate margin (Calabria, southern Italy). Springer-Verlag, Berlin Heidelberg, $286 \mathrm{p}$.

INGERSOLL, R.V. (1990) Atualistic sandstone petrofacies: discriminating modern and ancient source rocks. Geology, v. 18 , p. $733-736$.

INGERSOLL, R.V.; BULLARD, T.F.; FORD, R.L.; GRIMM, J.B.; PICKLE, J.D.; SARES, S.W. (1984) The effect of grain size on detrital modes: a test of the Gazzi-Dickinson point-counting method. Journal of Sedimentary Petrology, v. 54 , n. 1, p. 103-116.

ISACHSEN, C.E.; BOWRING, S.A.; LANDING, E.; SAMSON, S.D. (1994) New constraint on the division of Cambrian time. Geology, n. 22, p. 496-498.

ISSLER, R.S. (1982) Evento geodinâmico brasiliano - fechamento de oceanos e colisão continental dos cratons Rio de La Plata e Dom Feliciano: granito a duas micas e ofiolitos. In: CONGRESSO BRASILEIRO DE GEOLOGIA, 32., Salvador, 1982. Anais.... Salvador, SBG, v. 1, p. 24-38.

JOHNSON, B.A.; WALKER, R.G. (1979) Paleocurrents and depositional environments of deep water conglomerates in the Cambro-Ordovician Cap Enragé Formation, Quebec Appalachians. Canadian Journal of Earth Sciences, v. 16 , n. 9 , p. 1375-1387.

JOPLING, A.V.; CLIFTON, H.E. (1982) Cyclic deposits and hummocky cross-stratification of probable storm origin on Upper Cretaceous rocks of Cape Sebastian area, southwestern Oregon. Journal of Sedimentary Petrology, v. 52, n. 1, p. $127-143$.

JOPLING, A.V.; WALKER, R.G. (1968) Morphology and origin of ripple drift cross-lamination, with examples from the Pleistocene of Massachusetts. Journal of Sedimentary Petrology, v. 38, n. 4, p. 971-984.

JOST, H. (1981) Geology and metallogenesis of the Santana da Boa Vista region, South Brazil. PhD. Thesis. The University of Georgia Athens, $208 \mathrm{p}$.

JOST, H. (1984) Sedimentação e vulcanismo durante o Ciclo Brasiliano no Rio Grande do Sul: uma revisão. In: CONGRESSO BRASILEIRO DE GEOLOGIA, 33., Rio de Janeiro, 1984. Anais... Rio de Janeiro, SBG, v. 7, p. 3241-3257.

JOST, H.; BITENCOURT, M.F. (1980) Estratigrafia e tectônica de uma fração da Faixa de Dobramentos Tijucas no Rio Grande do Sul. Acta Geologica Leopoldensia, v. 4, n. 9, p. 27-60.

JOST, H.; FRANTZ, J.C.; BROD, J.A. (1984) Revisão da tipologia, cronologia e significado geotectônico dos falhamentos do Escudo Sul-Riograndense. In: CONGRESSO BRASILEIRO DE GEOLOGIA, 33., Rio de Janeiro, 1984. Anais.... Rio de Janeiro, SBG, v. 4, p. 1707-1720.

JOST, H.; HARTMANN, L.A. (1984) Provincia Mantiqueira - Setor Meridional. In: ALMEIDA, F.F.M; HASUI, Y., (coords.) O Pré-Cambriano do Brasil. São Paulo, Editora Edgard Blücher, 378 p. 


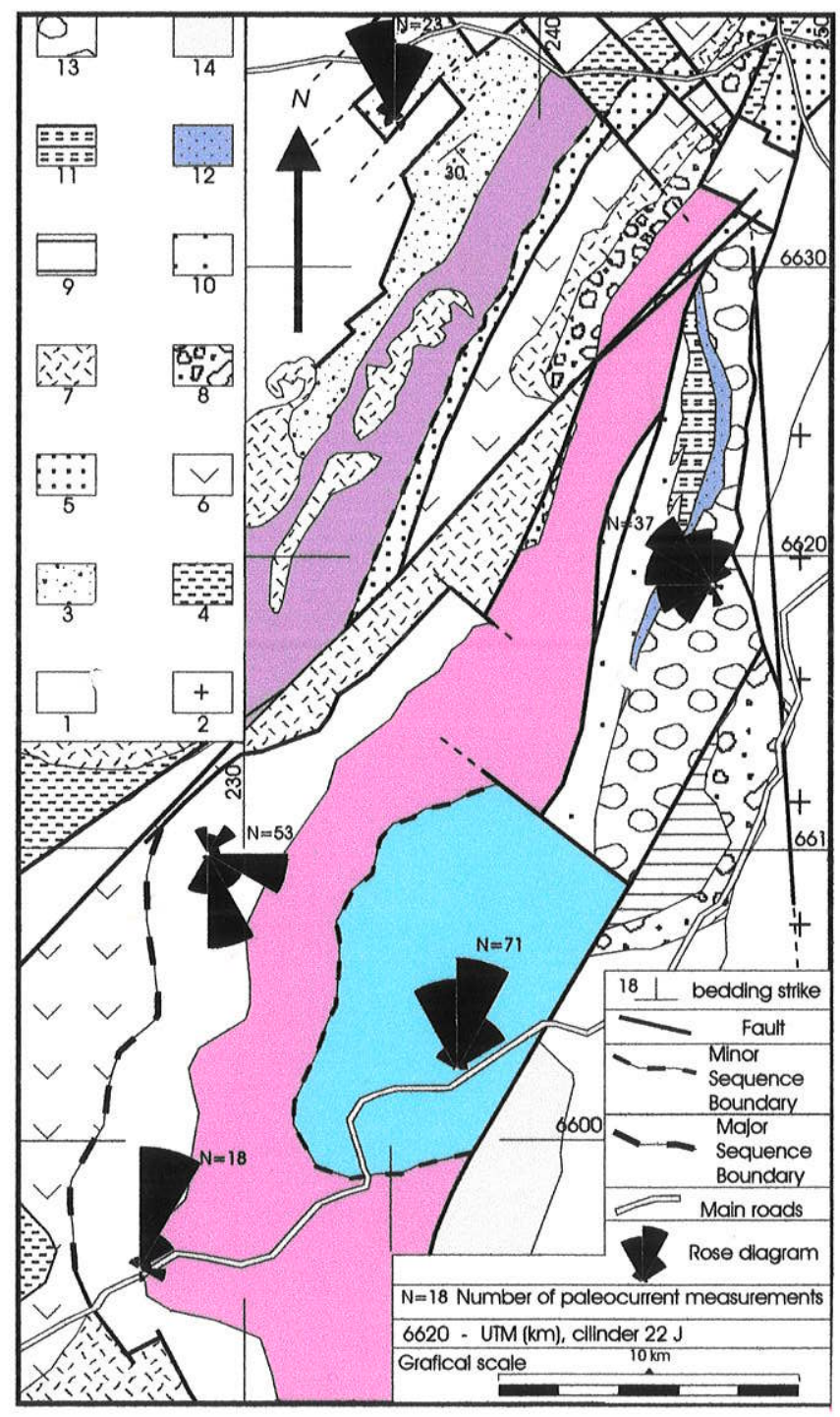


JULIANI, C.; RICCOMINI, C.; BARROS, E.J.; BATISTUCCI, N.L.N. (1990) Proterozoic storm-dominated sedimentation in the Pico de Itapeva Formation (São Paulo State, Brazil). Anais da Academia Brasileira de Ciências, v. 62, n. 1, p. 105.

KNOLL, A.H. (1996) Daughter of time. Paleobiology, v. 22, n. 1, p. 1-7.

KLEINSPEHN, K.L.; PAOLA, C. (1988) New Perspectives in Basin Analysis, Springer-Verlag, New York, 3-26 p.

KRAUS, M.J. (1992) Alluvial response to differential subsidence: sedimentological analysis aided by remote sensing,

Willwood Formation (Eocene), Bighorn Basin, Wyoming, USA. Sedimentology, v. 39, n. 3, p. 455-470.

KRUMBEIN, W.C. (1941) Measurement and geological significance of shape and roundness of sedimentary particles. Journal of Sedimentary Petrology, v. 11, n. 1, p. 61-72.

KRYNINE, P.D. (1940) Petrology and genesis of the Third Bradford Sand. Pennsylvania State College Bulletin, v. 29, $134 \mathrm{p}$.

LANG, H.R.; ADAMS, S.L.; CONEL, J.E.; McGUFFIE, B.A.; PAYLOR, E.D.; WALKER, R.E. (1987) Multiespectral remote sensing as stratigraphic and structural tool, Wind River Basin and Big Horn Basin areas, Wyoming. American Association of petroleum Geologists Bulletin, v. 71, p. 389-402.

LAVINA, E.L. (1984) Consideraçð̃es sobre o paleoambiente da Formação Sanga do Cabral (Eotriássico - Grupo Rosário do Sul) na região da Folha de Catuçaba -RS. In: CONGRESSO BRASILEIRO DE GEOLOGIA, 33., Rio de Janeiro, 1984. Anais.... Rio de Janeiro, SBG, v. 2, p. 792-804.

LAVINA, E.L.; FACCINI, U.F.; PAIM, P.S.G.; FRAGOSO CESAR, A.R.S. (1985) Ambientes de sedimentação da Bacia do Camaquã, Eo-Paleozóico do Rio Grande do Sul. Acta Geologica Leopoldensia, v. 21, n. 9, p. 185-227.

LEINZ, V. (1939) Problema geológico do Post-Arqueano no Rio Grande do Sul. Mineração e Metalurgia, v. 4, n. 22 , Rio de Janeiro, p. 203-206.

LEINZ, V.; BARBOSA, A.F. (1941) A jazida de cobre "Cerro dos Martins", Caçapava, Rio Grande do Sul, sua geologia, mineralização e prospecção. Mineração e Metalurgia, v. 5, n. 30, Rio de Janeiro.

LEINZ, V;; BARBOSA, A.F.; TEIXEIRA, G.A. (1941) Mapa Geológico Cacapava-Lavras. Boletim da Divisão de Produção Mineral da Secretaria de Agricultura, Industria e Commercio, Porto Alegre, RS, v. 90, p. 1-39.

LEIPNITZ, I.I.; PAIM, P.S.G.; ROSA, A.A.S. da; ROSA, A.I.Z.; NOWATSKI, C.H. (1997) Primeira ocorrência de Chanceloriidae no Brasil. In: CONGRESSO BRASILEIRO DE PALEONTOLOGIA, 15., São Pedro, Boletim de Resumos Expandidos. São Pedro, SBP, p. 1.

LEITE, J.A.D. (1995) Datação Schrimp U/Pb em zircões e o exemplo de dois corpos graníticos contrastantes no Escudo Sul-Riograndense. In: SIMPÓSIO SUL-BRASILEIRO DE GEOLOGIA, 6/ ENCONTRO DE GEOLOGIA DO CONE SUL,1, Porto Alegre,1995. Boletim de Resumos Expandidos. Porto Alegre, SBGNúcleo RS, p. 5-12.

LEITES, S.R.; LOPES, R.C.; WILDNER, W.; PORCHER, C.A.; SANDER, A. (1990) Divisão litofaciológica da Bacia do Camaquã na Folha Passo do Salsinho, Caçapava do Sul -RS, e sua interpretação paleoambiental. In: CONGRESSO BRASILEIRO DE GEOLOGIA, 36., Natal, 1990. Anais.... Natal, SBG, v.1, p. 300-312.

LIMA, E.F. (1995) Petrologia das rochas vulcânicas e hipabissais da Associação Shoshonitica de Lavras do Sul ASLS. Porto Alegre, 338 p. (Tese - Doutorado) - Universidade Federal do Rio Grande do Sul.

LIMA, E.F. de; NARDI, L.S.V. (1992) O magmatismo shoshonítico no estado do Rio Grande do Sul. Uma revisão. Pesquisas, v. 19, n. 2, p. 190-194.

LIMA, E.F. de; PORCHER, C.A.; WLDNER, W. (1997) Identificação de rochas granulíticas da porção leste do estado do Rio Grande do Sul, região da Várzea do Capivarita - Brasil. SEMANA DE GEOQUíMICA, 10./ 
CONGRESSO DE GEOQUÍMICA DOS PAÍSES DE LÍNGUA PORTUGUESA, 4., Braga, 1997. Actas... Braga, Portugal, Universidade do Minho, p. 73-76.

LIMA, E.F. de; WILDNER,'W.; LOPES, R.C.; SANDER, A.; SOMMER, C.A. (1995) Vulcanismo neoproterozóico associado às bacias do Camaquã e Santa Bárbara-RS: uma revisão. In: SIMPÓSIO SUL-BRASILEIRO DE GEOLOGIA, 6/ ENCONTRO GEOLÓGICO DO CONE SUL, 1., Porto Alegre, 1995. Boletim de Resumos Expandidos. Porto Alegre, SBG, p. 197-199.

LOPES, R. da C.; WILDNER, W.; SANDER, A.; CALDASSO, A.L. (1994) Correlação entre as sequências vulcanosedimentares da Bacia do Camaquã na Folha Passo do Salsinho (Caçapava do Sul), Passo do Tigre (Bagé) e Aberto do Cerro (Piratini) - RS. In: CONGRESSO BRASILEIRO DE GEOLOGIA, 38., Balneário Camboriú, Boletim de Resumos Expandidos. Balneário Camboriú, SBG, v. 3, p. 245-247.

LOUGHLIN, W. (1991) Principal component analysis for alteration mapping. Photogrametry, Engineering and Remote Sensing, v. 57, n. 9, p. 1163-1169.

LOWE, D.R. (1979) Sediment gravity flows: their classification and some problems of application to natural flows and their deposits. In: DOYLE, L.A.; PILKEY Jr., O.H. (eds.) Geology of continental slopes. SEPM, Tulsa. p. 7582. (Society of Economic Paleontologists and Mineralogists. Special Publication, n. 27)

LOWE, D.R. (1982) Sediment gravity flows: II. Depositional models with special reference to the deposits of highdensity turbidity currents. Journal of Sedimentary Petrology, v. 52, n. 1, p. 279-297.

MACHADO, N.; KOPPE, J.C.; HARTMANN, L.A. (1988) Upper Proterozoic zircon age from the Bossoroca Complex, RS. INTERNATIONAL CONFERENCE ON GEOCHEMISTRY AND EVOLUTION OF CONTINENTAL CRUST, Abstracts, Poços de Caldas, Brasil. p. 305.

MACHADO, R.; FRAGOSO CESAR, A.R.S. (1987) Deformações brasilianas do Cinturão Dom Feliciano no Uruguai. In: SIMPÓSIO SUL-BRASILEIRO DE GEOLOGIA, 3., Atas.... v. 2, p. 911-919.

MACHADO, R.; FRAGOSO CESAR, A.R.S.; FACCINI, U.F. (1987) O Domo de Santana (RS): domo manteado ou figura de interferência tipo domo e bacia? In: SIMPÓSIO SUL-BRASILEIRO DE GEOLOGIA, 3., Curitiba, 1987. Atas... Curitiba, SBG, v. 1, p. 167-182.

MACHADO, R.; SAYEG, H.S. (1992) Aplicação da análise geométrica e cinemática nos falhamentos que condicionaram a bacia molássica do Arroio Boici, RS. In: WORKSHOP SOBRE AS BACIAS MOLÁSSICAS BRASILIANAS, 1., São Leopoldo, 1992. Boletim de Resumos Expandidos. São Leopoldo, SBG/UNISINOS, p. 73-76.

MARTINS, E.A. (1952) Uma hipótese sobre o Gonduana do Rio Grande do Sul. Engenharia, Mineração e Metalurgia, v. 17, n. 103, Rio de Janeiro, p. 47.

MARTINS, E.A.; SENA SOBRINHO, M. (1948) Novos fósseis e a idade da Formação Maricá no Rio Grande do Sul. Boletim do Museu Nacional, série Geologia, Rio de Janeiro, n. 8.

MARTINS, E.A.; SENA SOBRINHO, M. (1955) Novos reconhecimentos geológicos no Rio Grande do Sul. Boletim do Museu Nacional, série Geologia, Rio de Janeiro, n. 19, 21 p.

MAU, H. (1959) "Ignimbritos" na região de Caçapava do Sul, Rio Grande do Sul. Engenharia, Mineração $e$ Metalurgia, v. 19, n. 1, Rio de Janeiro, p. 13-14.

MAU, H. (1960) Vale pré-glacial ao norte de Lavras do Sul, RGS. Boletim da Sociedade Brasileira de Geologia, v. 9, n. 2, p. $79-82$. 
MAU, H. (1962) Atividades magmáticas na região de Caçapava-Lavras, Estado do Rio Grande do Sul. Boletim da Faculdade de Filosofia, Ciências e Letras da Universidade de São Paulo, São Paulo, Brasil, n, 64, Geologia, n. 19 , p. $5-64$.

McBRIDE, E.F. (1962) The term graywacke (discussion). Journal of Sedimentary Petrology, v. 32, p. 614-615.

MCLAUGHLIN, R.J.; NILSEN, T.H. (1982) Neogene nonmarine sedimentation and tectonics in small pull-apart basins of the San Andreas Fault System, Sonoma County, California. Sedimentology, v. 29, p. 865-876.

McKEE, E.D.; WEIR, G.W. (1953) Terminology for stratification and cross-stratification in sedimentary rocks. Geological Society of America Bulletin, v. 64, p. 381-390.

McPHERSON, J.G.; SHANMUGAM, G.; MOIOLA, R.J. (1987) Fan-deltas and braid deltas: varieties of coarsegrained deltas. Geological Society of America Bulletin, v. 99, p. 331-340.

MEDEIROS, R.A.; SCHALLER, H.; FRIEDMAN, G.M. (1971) Fácies sedimentares, análise e critérios para o reconhecimento de ambientes deposicionais. Ciência-Técnica-Petróleo, Seção Exploração de Petróleo, n. 5, p. $1-123$.

MELCHER, G.C.; MAU, H. (1960) Novas observaçб̃es geológicas na região de Caçapava do Sul, Rio Grande do Sul. Anais da Academia Brasileira de Ciências, v. 32, n. 2, p. 43-50.

MELLO, F.M. (1993) Contribuição à geologia estrutural da Unidade Porongos na sua localidade tipo: região de Pinheiro Machado, Rio Grande do Sul. São Paulo, 122 p. (Dissertação - Mestrado) - Instituto de Geociências, Universidade de São Paulo.

MELLO, F.M.; MACHADO, R. (1992) A estruturação em duplex dos gnaisses, granitos miloníticos e metassedimentos da região do Cerro dos Porongos, RS. Boletim IG-USP, n. 12, p. 79-80. (Série Publicação Especial)

MIALL, A.D. (1974) Palaeocurrent analysis of alluvial sediments: a discussion of directional variance and vector magnitude. Journal of Sedimentary Petrology, v. 44, n. 4, p. 1174-1185.

MIALL, A.D. (1977) A review of the braided-rivers depositional environment. Earth Science Review, v. 13, n. 1, p. $11-62$.

MIALL, A.D. (1978) Lithofacies types and vertical profile models in braided-rivers deposits: a summary. In: MIALL, A.D. (ed.) Fluvial Sedimentology. Calgary, Canadian Society of Petroleum Geologists. p. 597-604. (Canadian Society of Petroleum Geologists Memoir n. 5)

MIALL, A.D. (1981) Analysis of fluvial depositional systems. AAPG Educational Course Note Series, p. 1-75. (American Association of petroleum Geologists. Special Publication n. 20)

MIALL, A.D. (1984) Principles of sedimentary basin analysis. Springer-Verlag, Berlim, $490 \mathrm{p}$.

MIALL, A.D. (1990) Principles of sedimentary basin analysis. $2^{\text {nd }}$ ed., New York, Springer-Verlag, 668 p.

MIDDLETON, G.V.; HAMPTON, M.A. (1973) Sediment gravity flows: mechanics of flow and deposition. In: .DOYLE, L.J.; PILKEY Jr., O.H. (eds.) Turbidites and Deep-WaterSedimentation. SEPM, Pacific Section, Short Course Lecture Notes, p. 1-38 (Society of Economic Paleontologists and Mineralogists. Special Publication)

MINIOLI, B.; KAWASHITA, K. (1971) Contribuição à estratigrafia do Eo-paleozóico do "Escudo Riograndense". In: CONGRESSO BRASLEIRO DE GEOLOGIA, 25., São Paulo, 1971. Anais.... São Paulo, SBG, v. 1, p.193-198.

MISKO, R.M.; HENDRY, H.E. (1979) The petrology of sands in the uppermost Cretaceous and Paleocene of southern Saskatchewan: a study of composition influenced by grain size, source area, and tectonics. Canadian Journal of Earth Sciences, v. 16, n. 1, p. 38-49.

MORO, R.P.X. (1993) A Bacia ordoviciana do Grupo Castro -PR. Rio Claro, 210 p. (Dissertação - Mestrado) IGCE-UNESP, 
MORO, R.P.X.; BONACIM, E.A.; SOARES, P.C. (1992) Grupo Castro: uma bacia transtensional pós-orogênica no Cambro-Ordoviciano do Estado do Paraná. In: WORKSHOP SOBRE AS BACIAS MOLÁSSICAS BRASILIANAS, 1., São Leopoldo, 1992. Boletim de Resumos Expandidos. São Leopoldo, SBG/UNISINOS, p. $77-81$.

MORO, R.P.X.; BONACIM, E.A.; SOARES, P.C. (1994) Geologia da Bacia de Castro - PR. Boletim Paranaense de Geociências, v. 42, p. 43-58.

MURATORI, A.; FUCK, R.A.; BIGARELLA, J.J. (1967) Contribuição ao estudo da Formação Camarinha. In: BIGARELlA, J.J.; SALAMUNI, R.; PINTO, V.M. (eds.). Geologia do Pré-Devoniano e intrusivas subsequientes da porção oriental do Estado do Paraná. Boletim Paranaense de Geociencias, Curitiba, v. 23-25, p. 221-235.

MUTTI, E.; RICCI-LUCCHI, F. (1972) Le turbiditi dell'Appennino settentrionale: Introduzione all'analisi di facies. Memorie della Società Geologica Italiana, v. 11, p. 336-357.

NARDI, L.S.V.; BITENCOURT, M.F. (1989) Geologia, petrologia e geoquímica do Complexo Granítico de Caçapava do Sul, RS. Revista Brasileira de Geociências, v. 19, n. 2, p. 153-169.

NARDI, L.S.V; LIMA, E.F (1985) A Associação Shoshonítica de Lavras do Sul, RS. Revista Brasileira de Geociências, v. 15, n. 2, p. 139-146.

NARDI, L.S.V.; LIMA, E.F.; GASTAL, M.C.P. (1992) Magmatismo no Grupo Bom Jardim: afinidade geoquímica e significado geotectônico. In: WORKSHOP SOBRE AS BACIAS MOLÁSSICAS BRASILIANAS, 1., São Leopoldo, 1992. Boletim de Resumos Expandidos. São Leopoldo, SBG/UNISINOS, p. 82-89.

NEMEC, W. (1990) Aspects of sediment movement on steep delta slopes. In: COLLELA, A.; PRIOR, D.B. (eds.) Coarse grained deltas, p. 29-73. (International Association of Sedimentologists. Special Publication n. 10)

NEMEC, W.; STEEL, R.J. (1984) What is a fan delta and how do we recognize it? In: NEMEC, W.; STEEL, R.J. (eds.) Sedimentology and Tectonic Settings. London, Blackie and Son, p. 3-13.

NETTO, R.G.; PAIM. P.S.G.; ROSA, C.L.M. (1992) Registro Preliminar da ocorrência de traços fósseis em sedimentos das Bacias do Camaquã e Santa Bárbara. In: WORKSHOP SOBRE AS BACIAS MOLÁSSICAS BRASILIANAS, 1., São Leopoldo, 1992. Boletim de Resumos Expandidos. São Leopoldo, SBG/UNISINOS, p. 90-96.

NILSEN, T.H. (1969) Old red sedimentation in the Buelandet-Vaerlandet Devonian District, western Norway. Sedimentary Geology, v. 3, p. 35-57.

NILSEN, T.H. (1981) Upper Devonian and Lower Mississipian Redbeds, Brooks Range, Alaska. In: MIALL, A.D. (ed.) Sedimentation and Tectonics in Alluvial Basins, p. 187-219. (Geological Association of Canada. Special Paper n. 23)

NLSEN, T.H. (1982) Alluvial fans. In: SCHOLLE, P.A.; SPEARING, D. (eds.) Sandstone Depositional Environments. Tulsa, AAPG, p. 2-84. (American Association of petroleum Geologists. Memoir n. 31)

NLSEN, T.H. (1985) Modern and ancient allwvial fan deposits, New York, Van Nostrand Reinhold, 372 p.

OHARA, T. (1982) Aplicação do Programa Realce pelas Componentes Principais na Região das Minas do Camaquã RS. In: SIMPÓSIO BRASILEIRO DE SENSORIAMENTO REMOTO, 1., Brasilia, 1982. Anais.... Brasília, SBG, v. 1, p. 34-37.

OKADA, H. (1971) Inverted grading in gravels and conglomerates. Geological Society of Japan Bulletin, v. 74, $\mathbf{n}$. 11 , p. 589-594. 
OLIVEIRA, J.M.M.T. (1992) Formação Arroio dos Nobres: depósitos marinhos ou continentais? Uma discussão. In: WORKSHOP SOBRE AS BACIAS MOLÁSSICAS BRASILIANAS, 1., São Leopoldo, 1992. Boletim de Resumos Expandidos. São Leopoldo, SBG/UNISINOS, p. 106-112.

OLIVEIRA, J.M.M.T.; FERNANDES, L.A.D. (1991) Estágios finais da evolução do Cinturão Dom Feliciano: Tectônica e sedimentação da Formação Arroio dos Nobres. In: SIMPÓSIO NACIONAL DE ESTUDOS TECTÔNICOS, 3., Rio Claro, 1991. Boletim de Resumos Extensos, Rio Claro, SBG, p. 58-59.

OLIVEIRA, J.M.M.T.; FERNANDES, L.A.D. (1992) Bacias molássicas brasilianas: mito ou realidade? In: WORKSHOP SOBRE AS BACIAS MOLÁSSICAS BRASILIANAS, 1., São Leopoldo, 1992. Boletim de Resumos Expandidos. São Leopoldo, SBG/UNISINOS, p. 97-105.

PAIM, P.S.G. (1990) Report Thesis: Oxford (inédito).

PAIM, P.S.G. (1992) Alluvial paleogeography of Guaritas depositional sequence (Cambrian of Southern Brazil). In: WORKSHOP SOBRE AS BACIAS MOLÁSSICAS BRASILIANAS, 1., São Leopoldo, 1992. Boletim de Resumos Expandidos. São Leopoldo, SBG/UNISINOS, p. 113-119.

PAIM, P.S.G. (1994) Depositional Systems and Paleogeographical Evolution of the Camaquã and Santa Bárbara Basins, Brazil. Philosofer Doctor Thesis, University of Oxford. v.I, 277 p. (inédito)

PAIM, P.S.G. (1995) Fluvial paleogeography of Guaritas depositional sequence of southern Brazil. In: PLINT, A.G. (ed.) Sedimentary Facies Analysis, p. 3-16. (International Association of Sedimentologists. Special Publication n. 22)

PAIM, P.S.G. (1996) O sistema desértico úmido Pedra Pintada (cambro-ordoviciano do RS). In: CONGRESSO BRASILEIRO DE GEOLOGIA, 39., Salvador, 1996. Boletim de Resumos Expandidos. Salvador, SBG Núcleos Bahia/Sergipe, v. 2, p. 207-209.

PAIM, P.S.G.; FACCINI, U.F.; FRAGOSO CESAR, A.R.S.; LAVINA, E.L. (1986) Modelo submarino para a Formação Maricá no Vale do Piquiri (RS): Leques Submarinos X "Debris Apron". In: CONGRESSO BRASILEIRO DE GEOLOGIA, 34., Goiânia, 1986. Anais.... Goiânia, SBG.

PAIM, P.S.G.; FACCINI, U.F.; NETTO, R.G.; NOWATZKI, C.H. (1992) Estratigrafia de sequêencias e sistemas deposicionais das bacias do Camaquã e Santa Bárbara, Eopaleozóico do RS (Brasil). Universidad Nacional de Tucumán, Serie Correlácion Geologica, v. 9, p. 41-45.

PAIM, P.S.G.; LOPES, R.C.; CHEMALE Jr., F. (1995) Aloestratigrafia, sistemas deposicionais e evolução paleogeográfica da Bacia do Camaquã -Vendiano Superior/ Ordoviciano Inferior do RS. In: SIMPÓSIO SULBRASILEIRO DE GEOLOGIA, 6/ ENCONTRO GEOLOGIA DO CONE SUL,1., Porto Alegre, 1995. Boletim de Resumos Expandidos. SBG- Núcleo RS, p. 39-50.

PAZOS, P.J.; TÓFALO, R.O.; SÁNCHEZ, L.B. (1998) Procesos sedimentarios e indicadores paleoclimáticos en la sección inferior de la Formación Playa Hermosa, Cuenca Playa Verde, Piriápolis, Uruguay. In: CONGRESO URUGUAYO De GeOlOGIA, 2., Punta del Este, 1998. Actas... Punta del Este, SUG/Facultad de Ciencias, p. 64-69.

PETIT, J.P. (1987) Criteria for the sense of movement on fault surfaces in brittle rocks. Journal of Structural Geology, v. 9 , n. $5 / 6$, p. $597-608$.

PETTIJOHN, F.J. (1975) Sedimentary Rocks. Harper \& Raw, 718 p.

PETTIJOHN, F.J.; POTTER, P.E.; SIEVER, R. (1987) Sand and Sandstone. $2^{\text {ed. }}$ New York, Springer-Verlag, 553 p. PHILIPP, R.P. (1990) Geologia e geoquímica dos granitóides da região de Monte Bonito, Pelotas, RS. Porto Alegre, 231 p. (Dissertação - Mestrado) - Universidade Federal do Rio Grande do Sul. 
PICADA, R.S. (1971) Ensaio sobre a tectônica do Escudo Sul-Riograndense. Caracterização dos sistemas de falhas. In: CONGRESSO BRASILEIRO DE GEOLOGIA, 25., São Paulo, 1971. Anais.... São Paulo, SBG, v.1, p. 167-191.

PICKERING, K.T.; STOW, D.A.V.; WATSON, M. \& HISCOTT, R.N. (1986) Deep-water facies, process and models: a review and classification scheme for modern and ancient sediments. Earth Science Review, v. 23, p. 75-174.

PINTO, I.D. (1947) Novos fósseis na Formação Maricá. Boletim da Faculdade de Ciências e Letras da Universidade do Rio Grande do Sul, Porto Alegre, v. 1, n. 1.

PINTO, I.D. (1955) Série Maricá e Formação Teixeira Soares no Rio Grande do Sul, histórico, idade e correlação. Descoberta de fósseis na Formação Palermo no Rio Grande do Sul. Boletim do Instituto de Ciências Naturais, v. 2, p. 1-18.

PITMAN, E.D. (1969) Destruction of plagioclase twins by stream transport. Journal of Sedimentary Petrology, v. 39, p. $1432-1437$.

PITMAN, E.D. (1970) Plagioclase feldspar as an indicator of provenance in sedimentary rocks. Journal of Sedimentary Petrology, v. 40, p. 591-598.

PORADA, H. (1979) The Damara-Ribeira Orogen of the Pan African-Brazilian Cycle in Namibia (southwest Africa) and Brazil as interpreted in terms of continental collision. Tectonophysics, v. 57, p. 237-265.

POSTMA, G.; NEMEC, W.; KLEINSPEHN, K.L. (1988) Large floating clasts in turbidites: a mechanism for their emplacement. Sedimentary Geology, v. 58, n. 1, p. 47-61.

POTTER, P.E. (1959) Facies models conference. Science, v. 129, p. 1292-1294.

POTTER, P.E.; PETTIJOHN, F.J (1977) Paleocurrents and basin analysis. $2^{\text {nd }}$ ed., New York, Springer-Verlag, 425 p.

POWERS, M.C. (1953) A new roundness scale for sedimentary particles. Journal of Sedimentary Petrology, v. 23, p. $117-119$.

PRECIOZZI, F.; MASQUELIN, H.; SÁNCHEZ, L. (1993) Guia de Excursiones. In: PRIMER SIMPOSIO INTERNACIONAL DEL NEOPROTEROZOICO CAMBRICO DE LA CUENCA DEL PLATA, 1. La PalomaMinas, 1993. DINAMIGE/Facultad de Agronomia, v. 2, p. 1-39.

PRICE, N.; COSGROVE, J.W. (1990) Analysis of Geological Structures. Cambridge University Press. 502 p.

RAAF, J.F.M.; BOERSMA, J.R.; van GELDER, A. (1977) Wave-generated structures and sequences from a shallow marine succession, Lower Carboniferous, County Cork, Ireland. Sedimentology, v. 24, p. 451-483.

RADAM, PROJETO (1986) Folhas SH.22 - Porto Alegre, SI.22 - Lagoa Mirim e SH.21 - Uruguaiana. Levantamento de recursos naturais. Texto explicativo e 1 mapa geológico escala 1:1.000.000, Projeto RADAMBRASIL, Florianópolis. (FUNDAÇÃO IBGE, v. 33)

READING, H.G. (1986) Sedimentary facies and environments. $2^{\text {nd }}$ ed. Oxford, Blackwell Scientific, Oxford, p. 4-19.

REINECK, H.E.; SINGH, I.B. (1972) Genesis of laminated sand and graded thythmites in storm-sand layers of shelf mud. Sedimentology, v. 18, p. 123-128.

REINECK, H.E.; SINGH, I.B. (1980) Depositional Sedimentary Environments, $2^{\text {nd }}$ ed., Berlin, Springer-Verlag, 549 p. REMUS, M.V.D.; McNAUGHTON, N.J.; HARTMANN, L.A.; GROVES, D.L.; REISCHL, J.L. (1997) Pb and S isotope signature of sulphides and constraintes on timing and sources of $\mathrm{Cu}$ (Au) mineralisation at the Camaquã and Santa Maria Mines, Caçapava do Sul, southern Brazil. In: SOUTH AMERICAN SIMPOSIUM ON ISOTOPE GEOLOGY, Campos de Jordão, 1997. Extended Abstrats. Campos do Jordão, FAPESP/CNPq/CPRM. p. 253-255.

REYNOLDS, D.L. (1954) Fluidization as a geological process and its bearing on the problem of intrusive granites. American Journal of Sciences, v. 252, p. 577-614. 
RIBEIRO, M.J. (1978) Mapa previsional do cobre no Escudo Sul-Rio-Grandense. Nota explicativa. Série Geologia, $n$. 3 - Seção Geologia Econômica, DNPM, Brasília, n. 1, p. 1-104.

RIBEIRO, M.J. (1992) Síntese sobre os minérios estratiformes da "Bacia do Guaritas". In: WORKSHOP SOBRE AS BACIAS MOLÁSSICAS BRASILIANAS, 1., São Leopoldo, 1992. Boletim de Resumos Expandidos. São Leopoldo, SBG/UNISINOS, p. 120-123.

RIBEIRO, M.J.; BADI, W.S.E.; GONZALEZ, A.P.; GONZALEZ, M.A.; LICHT, O.A.B.; TEIXEIRA, G. (1980) Jazida Santa Maria, chumbo e zinco estratiformes no grupo Bom Jardim, Rio Grande do Sul. In: CONGRESSO

BRASILEIRO DE GEOLOGIA, 31., Camboriú, SC, 1980, Anais.... Camboriú, SBG, v. 3, p. 1725-1742. RIBEIRO, M. (1983) Informes sobre a Formação Maricá. Inheringia, Série Geologia, Porto Alegre, v. 7, p. 1-50. RIBEIRO, M. (1970) Geologia da Folha de Bom Jardim, Rio Grande do Sul, Brasil. Boletim da Divisáo de Geologia e Mineralogia DNPM, Rio de Janeiro, n. 247, p. 1-142.

RIBEIRO, M.; BOCCHI, P.R.; FIGUEIREDO FILHO, P.M.; TESSARI, R.I. (1966) Geologia da Quadrícula de Caçapava do Sul, Rio Grande do Sul. Boletim da Divisão de Fomento da Produção Mineral DNPM, Rio de Janeiro, n. 127, p. 1-232.

RIBEIRO, M.; CARRARO, C.C. (1971) Geotectonic map of the Caçapava do Sul region, Rio Grande do Sul, Brasil. Porto Alegre, UFRGS, Instituto de Geociências. 1 mapa. Escala 1:100.000.

RIBEIRO, M.; FANTINEL, L.M. (1978) Associaç̋̃es petrotectônicas do Escudo Sul-Riograndense: I Tabulação e distribuição das associações petrotectônicas do Escudo do Rio Grande do Sul. Inheringia, Série Geologia, Porto Alegre, v. 5, p. 19-54.

RIBEIRO, M.; LICHTEMBERG, E. (1978) Síntese da geologia do Rio Grande do Sul. In: CONGRESSO BRASILEIRO DE GEOLOGIA, 30., Recife, 1978. Anais.... Recife, SBG, v. 6, p. 2451-2463.

RIBEIRO, M.; TEIXEIRA, C.A.S. (1970) Datações de rochas do Rio Grande do Sul e sua influência nos conceitos estratigráficos e geotectônicos locais. Inheringia, Série Geologia, Porto Alegre, v. 3, p.109-120.

RIBEIRO DE ALMEIDA, T.I.; FAMBRINI, G.L.; BRANCO, F.C.; SILVA FILHO, W.F. da; SAYEG, H.S.; FRAGOSO CESAR, A.R.S.; MACHADO, R.; McREATH, I. (1996) Processamento digital e interpretação geológica de imagens TM-Landsat da região das Minas do Camaquã, Estado do Rio Grande do Sul. Anais da Academia Brasileira de Ciências, v. 68, n. 4, p. 598.

RIBEIRO DE ALMEIDA, T.I.; SILVA FILHO, W.F. da; FAMBRINI, G.L.; SAYEG, H.S.; McREATH, I.; FRAGOSO CESAR, A.R.S.; MACHADO, R. (1997) Digital processing and geological interpretation of TM-Landsat images of the area east of the Camaquã Mines in Rio Grande do Sul State, southern Brazil. Boletim IG-USP, n. 28, p. 101-118. (Série Científica)

RIBEIRO DE ALMEIDA, T.I.; SILVA FILHO, W.F. da; SAYEG, H.S.; FAMBRINI, G.L.; MACHADO, R.; FRAGOSO CESAR, A.R.S. (1995) Procesamiento digital e interpretación geológica de imágenes TMLANDSAT del área al este de la Mina de Camaquã (límite Proterozoico/Fanerozoico), estado do Rio Grande do Sul, Brasil. In: CONGRESSO LATINO AMERICANO DEL PERCEPCIÓN REMOTA, 7., Puerto Vallarta, 1995. Memorias Puerto Vallarta, p. 457-469.

RICCOMINI, C. (1993) Origem, evolução e inversão da Bacia do Pico de Itapeva, Neoproterozóico-Cambriano, São Paulo, Brasil. In: SIMPÓSIO INTERNACIONAL DEL NEOPROTEROZOICO-CAMBRICO DE LA CUENCA DEL PLATA, 1., La Paloma-Minas, 1993. Resumenes Extensos. La Paloma, DINAMIGE/Facultad de Agronomia, v. 1, part. 16. 
RICCOMINI, C.; COIMBRA, A.M. (1993) Sedimentação em rios entrelaçados e anastomosados. Boletim IG-USP, $\mathbf{n}$. 6, p. 1- 44. (Série Didática)

ROBERTSON, J.F. (1966) Revision of stratigraphy and nomenclature of rock units in Caçapava Lavras Region. Notas e Estudos, IG-UFRGS, Porto Alegre, v. 1, n. 2, p. 41-54.

ROSTIROLLA, S.P.; ALKMIN, F.F.; SOARES, P.C. (1992帛) O Grupo Itajaí, Estado de Santa Catarina, Brasil: exemplo de sedimentação em uma bacia flexural de antepaís. Boletim de Geociências da PETROBRÁS, Rio de Janeiro, v. 6, n. 3-4, p. 109-122, JUL/DEZ. 1992.

ROSTIROLLA, S.P.; SOARES, P.C.; ALKMIN, F.F. $\left(1992^{b}\right)$ Análise estrutural da tectônica deformadora da Bacia do Itajaí, SC. Boletim de Geociências da PETROBRÁS, Rio de Janeiro, v. 6, n. 3-4, p. 123-147, JUL/DEZ. 1992. RUST, B.R. (1972 $)$ Structure and process in a braided river. Sedimentology, v. 18, p. 221-245.

RUST, B.R. (1972 ${ }^{\mathrm{b}}$ ) Pebble orientation in fluvial sediments. Journal of Sedimentary Petrology, v. 42, n. 4, p. 384-388. RUST, B.R. (1981) Sedimentation in arid-zone anastomosing fluvial system: Cooper's Creek, Central Australia. Journal of Sedimentary Petrology, v. 51, n. 3, p. 745-755.

RUST, B.R.; KOSTER, E.H. (1984) Coarse alluvial deposits. In: WALKER, R.G. (ed.) Facies models. $5^{\text {th }}$ ed., Geoscience Canada, Reprint Series, p. 53-69.

SADOWSKI, G.R.; MACHADO, R.; FRAGOSO CESAR, A.R.S.; GRESSE, P.; HOFFMAN, K.H.; STANISTREET, I.; UNRUG, R.; SULTAN, M. (1998) Plates and terranes of the Neoproterozoic of the southeastern South America. In: McNIALL, M. (ed.) Proceedings volume on Proterozoic Crust \& Metallogenetic Evolution. Geological Society of Namibia (no prelo).

SANTOS, E.L.; BECKEL, J.; MACEDO, P.M.; GONZALES FILHO, F.; CHABAM, M. (1978) Divisão litoestratigráfica do Eo-Cambriano-Pré-Cambriano Superior do Escudo Sul-Riograndense. In: CONGRESSO BRASILEIRO DE GEOLOGIA, 30., Recife, 1978. Anais... Recife, SBG, v. 2, p. 670-684.

SANTOS, E.L.; RAMGRAB, G.E.; MACIEL, L.A.; MOSMANN, R. (1989) Mapa geológico do estado do Rio Grande do Sul (escala 1:1.000.000) e parte do Escudo Sul-Rio-Grandense (escala 1:600.000). Ministério das Minas e Energia/DNPM.

SARTORI, P.L.P. (1978) Petrologia do Complexo Granitico de São Sepé, RS: modelo evolucional de granitos do sul do Brasil. São Paulo, 196 p. (Tese - Doutorado) - Instituto de Geociências, Universidade de São Paulo.

SARTORI, P.L.P.; KAWASHITA, K. (1985) Petrologia e geocronologia do batólito granítico de Caçapava do Sul, RS. In: SIMPÓSIO SUL-BRASILEIRO DE GEOLOGIA, 2., Florianópolis, SC, 1985. Atas.... Florianópolis, SBG, v. 1, p. 102-115.

SARTORI, P.L.P.; KAWASHITA, K. (1989) Petrologia e geocronologia do stock granítico Santos Ferreira e sua correlação com o Batólito de Caçapava do Sul, RS. Acta Geologica Leopoldensia, v. 12, n. 29, p. 125-142.

SAYEG, H.S. (1993) Evolução geologica brasiliana da Bacia do Arroio Boici, RS. São Paulo. 103 p. (Dissertação Mestrado) - Instituto de Geociências, Universidade de São Paulo.

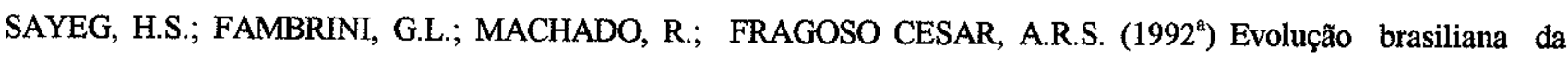
bacia transcorrente do Arroio Boici, RS. In: WORKSHOP SOBRE AS BACIAS MOLÁSSICAS BRASILIANAS, 1., São Leopoldo, 1992. Boletim de Resumos Expandidos. São Leopoldo, SBG/UNISINOS, p. 129-132.

SAYEG, H.S.; FRAGOSO CESAR, A.R.S.; MACHADO, R.; COIMBRA, A.M.; MELLO, F.M.; FAMBRINI, G.L. (1993) Evolução da região do Arroio Boici (RS) durante a Orogenia Serra do Herval. In: SIMPÓSIO 
INTERNACIONAL DEL NEOPROTEROZOICO-CAMBRICO DE LA CUENCA DEL PLATA, 1. La PalomaMinas, 1993. Resumenes Extensos. La Paloma, DINAMIGE/Facultad de Agronomia, v. 1, part. 9.

SAYEG, H.S.; FRAGOSO CESAR, A.R.S.; MACHADO, R.; FAMBRINI, G.L. (1992 $2^{\text {b }}$ A bacia transcorrente brasiliana do Vale do Arroio Boici no contexto da Antefossa Arroio dos Nobres, RS. Boletim IG USP, n. 12, p. 103-104. (Série Publicação Especial)

SCHOLLE, P.A. (1979) A color ilustrated guide to constituents, textures, cements, and porosity of sandstones and associated rocks. AAPG Memoir, Tulsa, Oklahoma, p. 1-202. (American Association of petroleum Geologists. Memoir n. 28)

SCHULTZ, A.W. (1984) Subaerial debris-flow deposition in the Upper Paleozoic Cutler Formation, western Colorado. Journal of Sedimentary Petrology, v. 54, n. 5, p. 759-772.

SHEPARD, A. (1954) Nomenclature based on sand-silt-clay ratios. Journal of Sedimentary Petrology, v. 24, n. 3, p. 151-158.

SEILACHER, A. $\left(1982^{8}\right)$ Distinctive features of sandy tempestites. In: EINSELE, G.; SEILACHER, A. (eds.) Cyclic and event stratification. Berlin, Springer-Verlag, p. 333-349.

SEILACHER, A. $\left(1982^{b}\right)$ General remarks about event deposits. In: EINSELE, G.; SEILACHER, A. (eds.) Cyclic and event stratification. Berlin, Springer-Verlag, p. 161-174.

SELLEY, R.C. (1970) Ancient sedimentary environments. $3^{\text {rd }}$ ed., 1985, Chapman \& Hall, London, 237 p.

SILVA FILHO, W.F. da (1997) A Formação Guaritas na porção centro-sudeste da Bacia do Camaquã-RS. São Paulo, 121 p. (Dissertação - Mestrado) - Instituto de Geociências, Universidade de São Paulo.

SILVA FILHO, W.F. da; FRAGOSO CESAR, A.R.S.; MACHADO, R.; SAYEG, H.S.; FAMBRINI, G.L. ; RIBEIRO DE ALMEIDA, T.I. (1996') O magmatismo Rodeio Velho e a Formação Guaritas no eopaleozóico do Rio Grande do Sul: Uma revisão. In: CONGRESSO BRASILEIRO DE GEOLOGIA, 39., Salvador, 1996. Boletim de Resumos Expandidos. Salvador, SBG - Núcleos Bahia/Sergipe, v. 5, p. 433-435.

SILVA FILHO, W.F. da; MACHADO, R.; TEIXEIRA, G.; DORNELLES, N.; FAMBRINI, G.L.; SAYEG, H.S.; SALES, F.F.; RIBEIRO DE ALMEIDA, T.I.; FRAGOSO CESAR, A.R.S. $\left(1996^{\mathrm{b}}\right)$ Caracterização geométrica e cinemática dos falhamentos na região das Minas do Camaquã, Bacia do Camaquã, RS. Anais da Academia Brasileira de Ciências, v. 68, n. 4, p. 600-601.

SILVA FILHO, W.F. da; RIBEIRO DE ALMEIDA, T.I.; SAYEG, H.S.; FAMBRINI, G.L.; SAES, G.S.; MACHADO, R.; FRAGOSO CESAR, A.R.S. $\left(1996^{\circ}\right)$ A análise por principais componentes de imagens TM-Landsat em mapeamento geológico: um estudo de caso na porção centro-sudeste da Bacia do Camaquã, Eopaleozóico do Rio Grande do Sul. In: CONGRESSO BRASILEIRO DE GEOLOGIA, 39., Salvador, 1996. Boletim de Resumos Expandidos. Salvador, SBG-Núcleos Bahia/Sergipe, v. 5, p. 97-99.

SLOSS, L.L. (1963) Sequences in the cratonic interior of North America. Geological Society of America Bulletin, v. 74, n. 2, p. 93-114.

SNEH, A. (1979) Late Peistocene fan-deltas along the Dead Sea rift. Journal of Sedimentary Petrology, v. 49, n. 5, p. 541-552.

SOARES, P.C. (1987) Seqüências tecto-sedimentares e tectônica deformadora no centro-oeste do Escudo Paranaense. In: SIMPÓSIO SUL-BRASILEIRO DE GEOLOGIA, 3., Curitiba, 1987. Atas... Curitiba, SBG, v. 2, p.743-771.

SOARES, P.C.; FIORI, A.P.; CARVALHO, S.G. (1990) Tectônica colisional obliqua entre o Bloco Paraná e a margem sul do Cráton São Francisco, no Maciço de Guaxupé. In: CONGRESSO BRASILEIRO DE GEOLOGIA, 36., Natal, 1990. Anais.... Natal, SBG, v. 6, p. 2723-2734. 
SOLIANI Jr., E. (1986) Os dados geocronologicos do Escudo Sul-Riograndense e suas implicações de ordem geotectónica. São Paulo. 425 p. (Tese - Doutorado) - Instituto de Geociências, Universidade de São Paulo.

STEEL, R.J.; AASHEIM, S. (1978) Alluvial sand deposition in a rapidly subsiding basin (Devonian, Norway). In: MIALL, A.D. (ed.) Fluvial Sedimentology. Calgary, Canadian Society of Petroleum Geologists. p. 385-413. (Canadian Society of Petroleum Geologists Memoir n. 5)

STEEL, R.J.; GLOPPEN, T.G. (1980) Late Caledonian (Devonian) basin formation, western Norway: signs of strikeslip tectonics during infilling. In: BALLANCE, P.F.; READING, H.G. (eds.) Sedimentation in Oblique-slip mobile zones, p. 79-103. (International Association of Sedimentologists. Special Publication n. 4)

STEEL, R.J.; MAEHLE, S.; NILSEN, H.; RøE, S.L.; SPINNANGR, $\AA$. (1977) Coarsenig-upward cycles in the alluvium of Hornelen Basin (Devonian), Norway: sedimentation response to tectonic events. Geological Society of America Bulletin, v. 88, p. 1124-1134.

STOW, D.A.V. (1986) Deep clastic seas. In: READING, H.G. (ed.) Sedimentary facies and environments. $2^{\text {nd }}$ ed. Oxford, Blackwell Scientific, Oxford, p. 399-444.

SUTTNER, L.J.; BASU, A. (1985) The effect of grain size on detrital modes: a test of the Gazzi-Dickinson pointcounting method - Discussion. Journal of Sedimentary Petrology, v. 55, n. 4, p. 616-627.

SUGUIO, K. (1980) Rochas sedimentares: propriedades, gênese, importancia economica. Editora Edgard Blücher/EDUSP, São Paulo, $500 \mathrm{p}$.

TEIXEIRA, A.L. (1995) Ambientes geradores dos sedimentos da Bacia Eleutério. São Paulo. 122 p. (Dissertação Mestrado) - Instituto de Geociências, Universidade de São Paulo.

TEIXEIRA, A.L.; PETRI, S. (1993) Tectônica e sedimentação da Bacia Eleutério (Eopaleozóico ?), Sudeste do Brasil. In: SIMPÓSIO INTERNACIONAL DEL NEOPROTEROZOICO-CAMBRICO DE LA CUENCA DEL PLATA, 1. La Paloma-Minas, 1993. Resumenes Extensos. La Paloma, DINAMIGE/Facultad de Agronomia, v. 1, part. 17.

TEIXEIRA, E. (1937) Cobre no Rio Grande do Sul. Avulso do Servico de Fomento da Produção Mineral, n. 22, Rio de Janeiro.

TEIXEIRA, G. (1978) Conteúdo da prata e ouro no minério de cobre das Minas do Camaquã. In: CONGRESSO BRASILEIRO DE GEOLOGIA, 30., Recife, 1978. Anais..., Recife, SBG, v. 4, p. 1633-1643.

TEIXEIRA, G., GONZALEZ, A.P., GONZALEZ, H.; LICHT, O.A.B. (1978) Contribuição ao estudo de mineralizações cupriferas disseminadas no distrito Minas do Camaquã. In: CONGRESSO BRASILEIRO DE GEOLOGIA, 30., Recife, 1978. Anais..., Recife, SBG, v. 4, p. 1644-1654.

TEIXEIRA, G.; GONZALEZ, A.P.; GONZALEZ, M.A.; LICHT, O.A.B. (1978 ) Situação das Minas do Camaquã, Rio Grande do Sul. In: CONGRESSO BRASILEIRO DE GEOLOGIA, 30, Recife, 1978. Anais..., Recife, SBG, v. 4, p. 1893-1905.

TEIXEIRA, W. (1982) Folhas SH.22 - Porto Alegre, SI.22 - Lagoa Mirim e SH.21 - Uruguaiana. Interpretação dos dados radiométricos e evolução geocronológica. Projeto RADAMBRASIL, Florianópolis (relatório interno).

TESSARI, R.I.; GIFFONI, L.E. (1970) Geologia da região de Piratini, Pinheiro Machado e Bagé, Rio Grande do Sul. Boletim da Divisão de Geologia e Mineralogia DNPM, Rio de Janeiro, n. 246, p. 1-122.

TESSARI, R.I.; PICADA, R.S. (1966) Geologia da Quadrícula Encruzilhada do Sul, Rio Grande do Sul, Brasil. Boletim da Divisão de Fomento da Produção Mineral DNPM, Rio de Janeiro, n. 124, p. 1-147.

TUCKER, M. (1989) The field description of sedimentary rocks. Geological Society of London, Handbook Series, $p$. 91-97. 
VIEIRA Jr., N.; SOLIANI Jr., E. (1989) Um novo modelo genético-evolutivo para o Maciço Granítico de Lavras do Sul, RS. Acta Geologica Leopoldensia, v. 12, n. 29, p. 143-160.

VEIGEL, R. (1992) Diagênese de rochas siliciclásticas: o exemplo do Membro Vargas, Eopaleozóico da Bacia do Camaquã -RS. Acta Geologica Leopoldensia, v. 15, n. 35, p. 27-154.

VEIGEL, R.; DARDENE, M.A. (1990) Paragênese e sucessão mineral nas diferentes etapas da evolução da mineralização de $\mathrm{Cu}-\mathrm{Pb}-\mathrm{Zn}$ do Distrito de Camaquã, RS. Revista Brasileira de Geociências, v. 20, n. 1-4, p. 55-67.

VISSER, M.J. (1980) Near-spring cycle reflected in Holocene subtidal large-scale bedform deposits: A preliminary note. Geology, v. 8, p. 543-546.

WALKER. R.G. (1963) Distinctive types of ripple drift cross-lamination. Sedimentology, v. 2, n. 2, p. 173-188.

WALKER. R.G. (1969) Geometrical analysis of ripple drift cross-lamination. Canadian Journal of Earth Sciences, v. 6 , n. 3, p. 383-391.

WALKER, R.G. $\left(1975^{\mathrm{a}}\right)$ Conglomerate: sedimentary structures and facies models. In: HARMS, J.C.; SOUTHARD, J.B.; SPEARING, D.R.; WALKER, R.G. (eds.) Depositional environments as interpreted from primary sedimentary structures and stratification sequences. SEPM Short Course 2, Dallas, p. 133-161 (Society of Economic Paleontologists and Mineralogists).

WALKER. R.G. $\left(1975^{\mathrm{b}}\right)$ Generalized facies models for resedimented conglomerates of turbidite association. Geological Society of America Bulletin, v. 86, p. 737-748.

WALKER, R.G. (1984) Facies models. $5^{\text {th }}$ ed., Geoscience Canada, Reprint Series, 211 p.

WALKER, R.G.; JAMES, N.P. (1992) Facies models. Response to sea level changes. Geological Association of Canada, $212 \mathrm{p}$.

WALTON, M.S.; O'SULLIVAN, R.B. (1950) The intrusive mechanics of a clastic dyke. American Journal of Sciences. v. 248, n. 1, p. 1-21.

WENTHWORTH, C.K. (1922) A scale of grade and class terms for clastic sediments. Journal of Sedimentary Petrology, v. 30, p. 377-392.

WESCOTT, W.A.; ETHRIDGE, F.G. (1980) Fan-delta sedimentology and tectonic setting -Yallahs fan-delta, southeast Jamaica. American Association of petroleum Geologists Bulletin, v. 64, p. 374-399.

WHITE, I.C. (1908) Relatório final sobre as "Coal Measures"e rochas associadas do sul do Brasil, parte 1: Brasil. Comissão de Estudos das minas de carvão de pedra, p. 1-201.

WILDNER, W.; LIMA, E.F. (1992) Considerações sobre os depósitos vulcanogênicos do Grupo Bom Jardim nas regiões de Lavras do Sul e Caçapava do Sul, RS. In: WORKSHOP SOBRE AS BACIAS MOLÁSSICAS BRASILIANAS, 1., São Leopoldo, 1992. Boletim de Resumos Expandidos. São Leopoldo, SBG/UNISINOS, p. 137-142.

WILDNER, W.; LIMA, E.F.; CAMOZZATO, E.; LOPES, R. da C. (1997) Vulcanismo Neoproterozóico-Cambriano no Rio Grande do Sul: estratigrafia e aspectos texturais. A Terra em revista, v. 3, p. 19-27.

WILLIAMS, H.; HATCHER Jr., R.D. (1982) Suspect terranes and accretionary history of the Appalachian orogen. Geology, v. 10, p. 530-536.

YOUNG, S.W. (1976) Petrographic texture of detrital polycrystalline quartz as an aid to interpreting crystalline source rocks. Journal of Sedimentary Petrology, v. 46, n. 3, p. 595-603.

ZUFFA, G.G. (1980) Hybrid arenites: their composition and classification. Journal of Sedimentary Petrology, v. 50, n. 1, p. 21-29. 


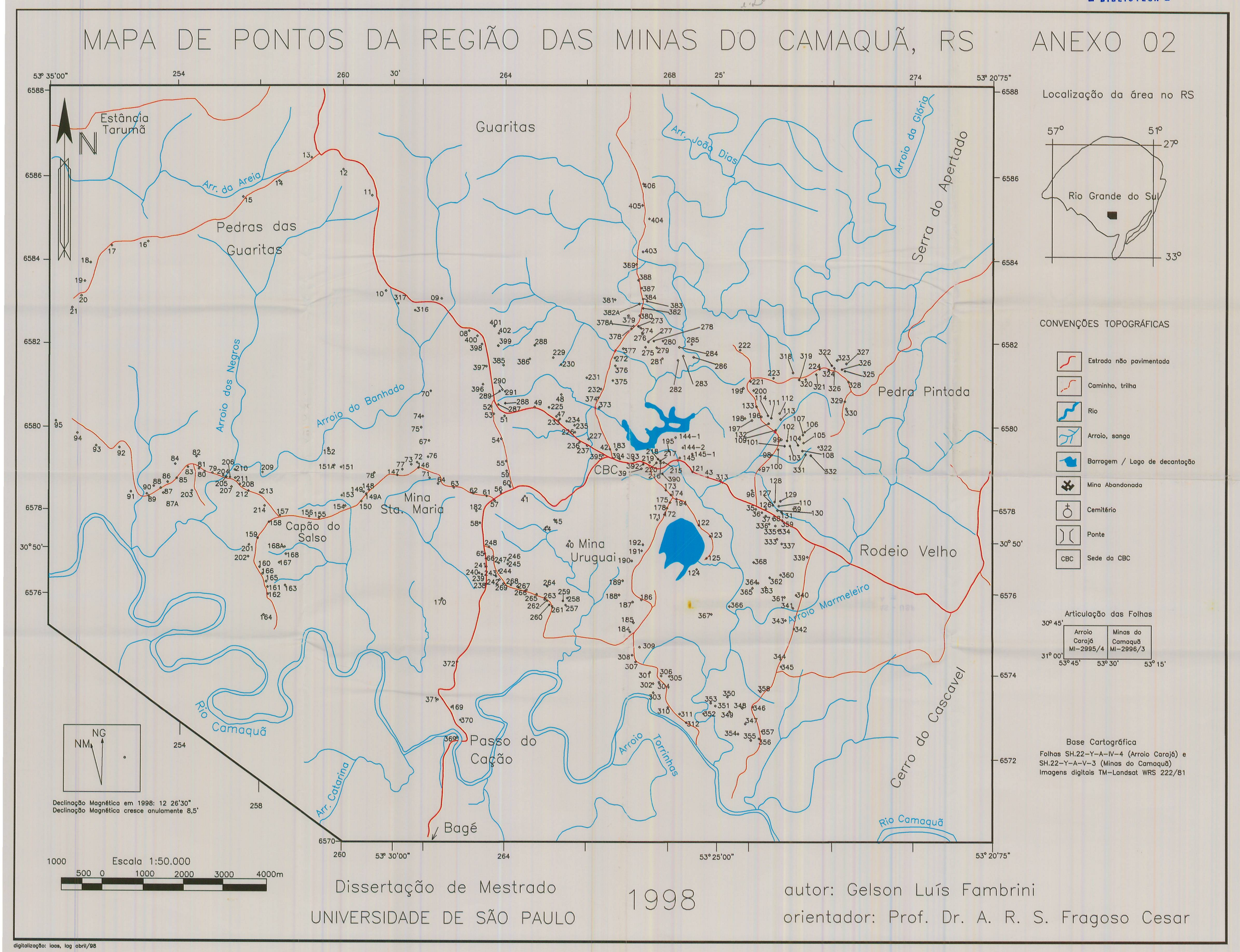

